JOSÉ EDUARDO BERTO GALDIANO

\title{
TÉCNICA DE JULGAMENTO DE RECURSOS REPETITIVOS PELO SUPREMO TRIBUNAL FEDERAL E PELO SUPERIOR TRIBUNAL DE JUSTIÇA
}

MESTRADO EM DIREITO

ORIENTADOR: PROFESSOR DOUTOR ANTONIO CARLOS MARCATO

FACULDADE DE DIREITO DA UNIVERSIDADE DE SÃO PAULO SÃO PAULO - 2014 
JOSÉ EDUARDO BERTO GALDIANO

\section{TÉCNICA DE JULGAMENTO DE RECURSOS REPETITIVOS PELO SUPREMO TRIBUNAL FEDERAL E PELO SUPERIOR TRIBUNAL DE JUSTIÇA}

Dissertação apresentada à Banca Examinadora da Faculdade de Direito da Universidade de São Paulo, como exigência parcial para obtenção do título de Mestre em Direito Processual, sob a orientação do Professor Doutor Antonio Carlos Marcato. 
BANCA EXAMINADORA 
À Thaís, companheira de todas as horas, com todo o теи amor.

Ao João, minha alegria e orgulho, presente enviado por Deus para me ensinar o significado do profundo e indescritível sentimento de amor de pai.

Aos meus amados e admirados pais, Miro e Ana, com toda a gratidão por tudo. 


\section{AGRADECIMENTOS}

A Deus, minha maior fortaleza e fonte de paz, segurança e sabedoria, que nunca deixou de me estender generosamente a mão.

À Thaís, minha amada esposa e companheira que tanto me ajudou a chegar até aqui. Obrigado por sua paciência, compreensão, amizade, incentivo e força. Por ter se privado de tanta coisa nesses anos. Só nós sabemos como foi difícil... E obrigado por sempre ter acreditado em mim, isso fez toda diferença!

Aos meus pais, que fizeram e fazem tanto por mim. Saibam que serei eternamente grato e que tudo o que sou e conquistei foi por causa de vocês.

Um agradecimento especial também aos meus avós, que sempre estiveram no meu coração: José (in memoriam), Emma, Amélia (in memoriam) e Eduardo (in memoriam).

Ao meu orientador, Professor Marcato, que tanto admiro, como acadêmico, profissional e pessoa. Obrigado pela grande oportunidade e por todos os inestimáveis ensinamentos.

A alguns amigos que me ajudaram de forma especial nessa conquista: William Callado, Bruno Vainer, William Ferreira, João Piza e Fábio Azevedo.

Por fim, agradeço em geral a todos os amigos e colegas que estiveram ao meu lado durante esses anos, com quem dividi e continuo dividindo momentos inesquecíveis e de grande valor. 


\section{RESUMO}

GALDIANO, José Eduardo Berto. Técnica de julgamento de recursos repetitivos pelo Supremo Tribunal Federal e pelo Superior Tribunal de Justiça. 2014. 396 p. Dissertação (Mestrado em Direito) - Faculdade de Direito da Universidade de São Paulo, São Paulo, 2014.

Esta dissertação analisa a técnica de julgamento de recursos repetitivos pelo Supremo Tribunal Federal (STF) e Superior Tribunal de Justiça (STJ) - técnica de julgamento "por amostragem" -, instituída no direito brasileiro pelas Leis federais ns. 11.418/2006 e 11.672/2008, que respectivamente incluíram no Código de Processo Civil os artigos 543-B e 543-C. Na primeira parte do trabalho, são abordados temas correlatos, relativos à tendência de valorização da jurisprudência no direito brasileiro, bem como às funções, importância e admissibilidade dos recursos extraordinários e especiais. $\mathrm{Na}$ segunda parte, são analisadas as justificativas de criação da técnica, relacionadas ao equacionamento do problema do excesso de recursos repetitivos no STF e no STJ. Além disso, são traçados os aspectos gerais do instituto, analisando-se a sua inspiração em procedimentos de julgamento por amostragem do direito estrangeiro, a sua caracterização como técnica de ampliação da eficácia persuasiva dos precedentes do STF e do STJ e suas diferenças e semelhanças com a repercussão geral. São também enfrentadas as questões relativas à constitucionalidade do julgamento por amostragem, apresentando-se um olhar crítico sobre a jurisprudência do STF e do STJ, que vêm interpretando suas regras de forma excessivamente restritiva ao direito das partes. A terceira e última parte é dedicada ao exame do funcionamento da técnica de julgamento de recursos repetitivos, enfrentando-se as diversas questões relativas às várias fases de seu procedimento, tais como os requisitos para instauração, competência, sobrestamento de recursos repetitivos, participação de terceiros e efeitos do julgamento. São também analisados os resultados práticos, principalmente à luz das estatísticas do STF e STJ, após a sua positivação, bem como as modificações previstas na versão atual do projeto de novo CPC. Trata-se de um legítimo e eficiente instrumento de potencialização dos precedentes do STF e do STJ que, sem prejuízo de necessários aperfeiçoamentos, bem como da sua adequada interpretação e aplicação à luz dos princípios constitucionais, mostra-se teoricamente adequado para conciliar a atual realidade dos problemas gerados pelos recursos repetitivos com a verdadeira função dos recursos excepcionais, de proteção e unificação do direito federal constitucional e infraconstitucional.

Palavras-chave: Recursos excepcionais - Recursos repetitivos - Valorização dos precedentes dos Tribunais Superiores - Julgamento por amostragem. 


\begin{abstract}
GALDIANO, José Eduardo Berto. Technique of judgment of repetitive appeals by Supreme Court (STF) and by Superior Court of Justice (STJ). 2014. 396 p. Master's Dissertation (Master in Law) - Faculdade de Direito da Universidade de São Paulo, São Paulo, 2014.
\end{abstract}

This Master's Dissertation analyzes the technical of judgment of "recursos repetitivos" [repetitive appeals, as a free translation] by Superior Court of Justice (STJ) and Federal Supreme Court (STF) - technical of "julgamento por amostragem" [judgment by sampling, as a free translation] established in Brazilian legal system by the Brazilian Federal Laws Ns. 11.418/2006 and 11.672/2008, which respectively included in the Code of Civil Procedure the Articles 543-B and 543-C. In the first part of this work, correlated themes are addressed, related to the trend of appreciation of the jurisprudence in Brazilian law, as well as the functions, importance and acceptability of extraordinary and special appeals. In the second part, this work analyzes the reasons for the creation of the technique related to solution of the problem of excessive repetitive appeals on Federal Supreme Court (STF) and Superior Court of Justice (STJ). Furthermore, the general aspects on this matter are plotted by the analyze of its inspiration in trial procedures "by sampling" of foreign law, its characterization as a technique of enlargement of the persuasive effectiveness of precedents of Supreme Court (STF) and of Superior Court of Justice (STJ) and its differences and similarities with the "repercussão geral" [general impact, as a free translation]. This work also challenges the questions related to the constitutionality of the judgment by sampling presenting a critical vision at the jurisprudence of the Supreme Court (STF) and of Superior Court of Justice (STJ) that have been interpreting the rules of the judgment by sampling excessively restrictive to the right of the parties. The third and last part of this work deals with the examination of the operation of the technique of repetitive appeals trial, facing up of several questions relating to the various stages of its procedure, such as conditions of filing, jurisdiction, halting of repetitive appeals, third parties participation and effects of the judgment. This work also analyzes the practical results, particularly in light of the statistics of Supreme Court (STF) and of Superior Court of Justice (STJ), after the legalization of the repetitive appeals as well as the changes planned in the current draft version of the new CPC. It is a legitimate and efficient instrument of potentiation of the precedents of the STF and STJ, which, notwithstanding necessary improvements, as well as their adequate interpretation and application in the light of the constitutional principles proves to be adequate to conciliate the current reality of the problems caused by repetitive appeals with the true function of the of exceptional appeals, to protect and to unify the constitutional and infra-constitutional federal law.

Keywords: Exceptional appeals - Repetitive appeals - Valorization of precedents of the Superior Courts - Judgment by sampling. 


\section{SIGLAS E ABREVIATURAS}

AC - Apelação cível

ADI - Ação direta de inconstitucionalidade

AgR - Agravo regimental

AG - Agravo de instrumento

$\mathrm{AI}$ - Agravo de instrumento

AREsp - Agravo em recurso especial

BDJur - Biblioteca Digital Jurídica

CDA - Certidão de Dívida Ativa

CDC - Código de Defesa do Consumidor

CF - Constituição Federal

CLT - Consolidação das Leis do Trabalho

CNJ - Conselho Nacional de Justiça

CPC - Código de Processo Civil

CPTA - Código de Processo nos Tribunais Administrativos

DJe - Diário da Justiça Eletrônico

DJ - Diário da Justiça

DJU - Diário de Justiça da União

EC - Emenda Constitucional

ED - Embargos de declaração

GLO - Group Litigation Order

GRU - Guia de Recolhimento da União

$\mathrm{HC}$ - Habeas corpus

ISS - Imposto sobre Serviços de Qualquer Natureza

MC - Medida Cautelar

Min. - Ministro

MP - Medida Provisória

MS - Mandado de segurança

NURER - Núcleo de Repercussão Geral e Recursos Repetitivos

PEC - Projeto de Emenda Constitucional

Pet - Petição

QO - Questão de ordem

Rcl - Reclamação 
RE - Recurso extraordinário

Rel. - Relator

REsp - Recurso especial

RISTF - Regimento Interno do Supremo Tribunal Federal

RISTJ - Regimento Interno do Superior Tribunal de Justiça

STF - Supremo Tribunal Federal

STJ - Superior Tribunal de Justiça

TJAP - Tribunal de Justiça do Amapá

TJBA - Tribunal de Justiça da Bahia

TJES - Tribunal de Justiça do Espirito Santo

TJGO - Tribunal de Justiça de Goiás

TJMG - Tribunal de Justiça de Minas Gerais

TJMT - Tribunal de Justiça de Mato Grosso

TJRJ - Tribunal de Justiça do Rio de Janeiro

TJSP - Tribunal de Justiça de São Paulo

TJRS - Tribunal de Justiça do Rio Grande do Sul

TRE/GO - Tribunal Regional Eleitoral de Goiás

TSE - Tribunal Superior Eleitoral

TSM - Tribunal Superior Militar

TST - Tribunal Superior do Trabalho 


\section{SUMÁRIO}

1 INTRODUÇÃ

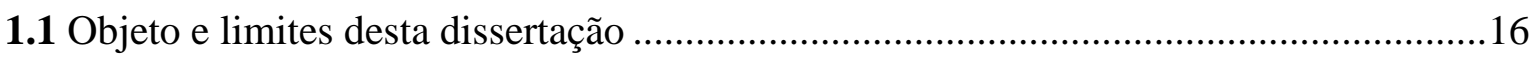

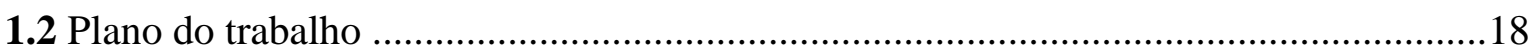

\section{PRIMEIRA PARTE}

Temas correlatos: valorização da jurisprudência - recursos extraordinários e especiais (funções, importância e admissibilidade)

\section{A VALORIZAÇÃO DA JURISPRUDÊNCIA}

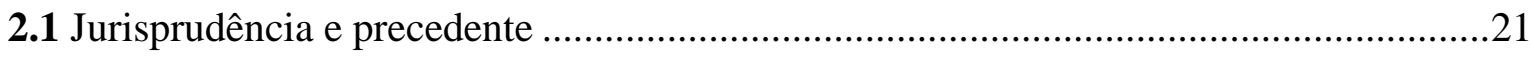

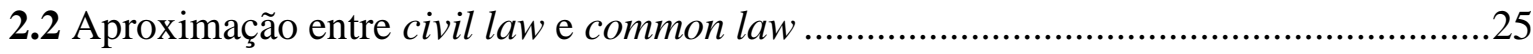

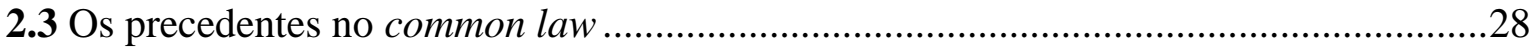

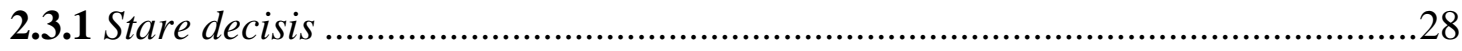

2.3.2 Precedentes vinculantes e precedentes persuasivos ........................................29

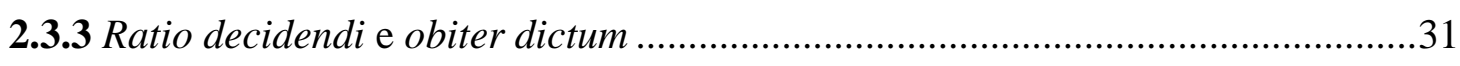

2.3.4 Eficácias vertical e horizontal dos precedentes..................................................33

2.3.5 Flexibilidade na aplicação dos precedentes: overruling e distinguishing .............34

2.4 A valorização da jurisprudência no Brasil ......................................................................36

2.4.1 A necessidade de interpretação e o problema da divergência jurisprudencial .....36

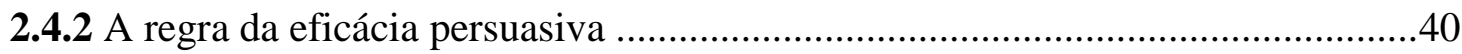

2.4.3 Fundamentos para a valorização da jurisprudência ...........................................42

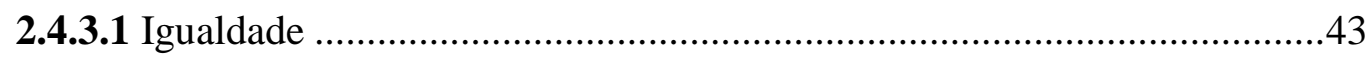

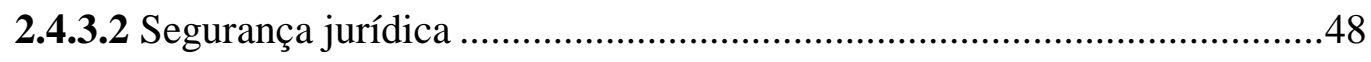

2.4.3.3 Razoável duração do processo..............................................................52

2.4.4 Tendência de ampliação da força da jurisprudência e as diferentes acepções de "eficácia vinculante" no direito processual civil brasileiro .............................57

\section{RECURSOS EXTRAORDINÁRIOS E ESPECIAIS: FUNÇÕES, IMPORTÂNCIA} E ADMISSIBILIDADE

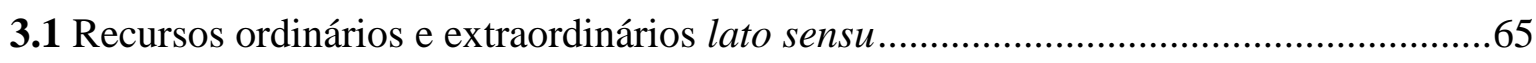

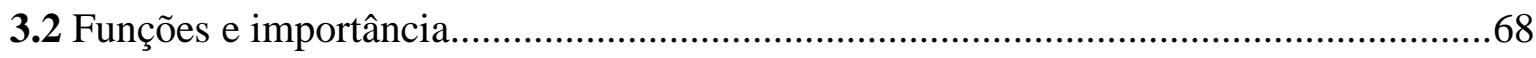


3.2.1 A função pública especial dos recursos excepcionais .68

3.2.2 Funções nomofilácica e de uniformização da jurisprudência ..............................70

3.2.3 A importância da jurisprudência dos Tribunais Superiores .................................73

3.2.4 Relação entre o interesse privado das partes recorrentes e o interesse público

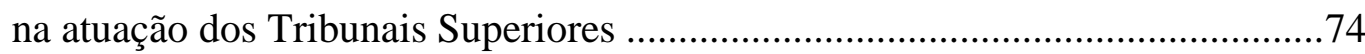

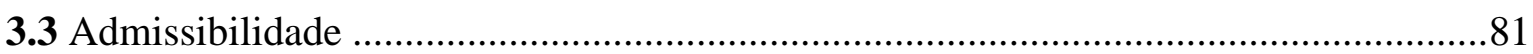

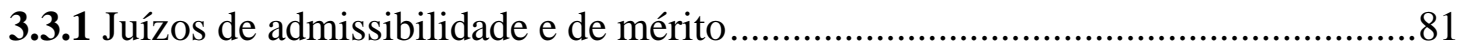

3.3.2 Juízo prévio de admissibilidade pelo tribunal de origem: limites.........................85

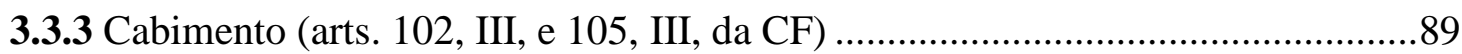

3.3.4 Outros requisitos específicos de admissibilidade................................................94

\section{SEGUNDA PARTE:}

Justificativa, aspectos gerais e constitucionalidade da técnica de julgamento de recursos repetitivos

\section{AS CRISES DO SUPREMO TRIBUNAL FEDERAL E DO SUPERIOR TRIBUNAL DE JUSTIÇA E OS RECURSOS REPETITIVOS ..................................97}

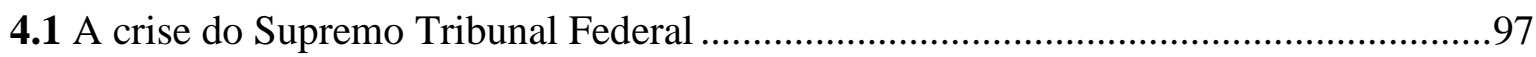

4.2 Óbices de acesso como tentativa de conter a crise..................................................102

4.3 A criação do Superior Tribunal de Justiça: tentativa de solução da crise do

Supremo e ampliação do acesso das partes aos órgãos de cúpula ..............................103

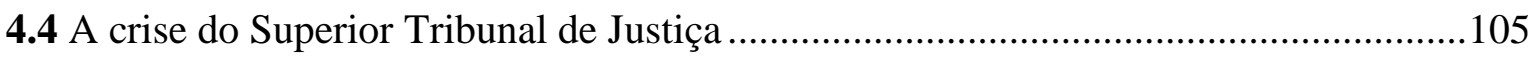

4.5 Excesso na interpretação dos requisitos de admissibilidade dos recursos

excepcionais e a jurisprudência defensiva

4.6 Os recursos repetitivos e a justificativa para a criação da técnica dos artigos 543-B e 543-C do CPC

\section{ASPECTOS GERAIS DA TÉCNICA DE JULGAMENTO DE} RECURSOS REPETITIVOS

5.1 Normas legais e regimentais que regulamentam a técnica de julgamento de recursos repetitivos

5.2 A inspiração no procedimento-modelo do direito alemão (Musterverfahren) .............126

5.3 Outras técnicas de julgamento por amostragem do direito estrangeiro 
5.4 Os artigos 543-B e 543-C do CPC como técnica de ampliação da eficácia persuasiva dos precedentes do STF e STJ

5.5 Repercussão geral e recursos repetitivos

5.5.1 A antiga relevância da questão federal e a atual repercussão geral ...................142

5.5.2 Proximidade entre repercussão geral e recursos repetitivos

5.5.3 Distinção entre repercussão geral (requisito de admissibilidade) e técnica de julgamento de recursos repetitivos (procedimento)

5.5.4 O artigo 543-C do CPC: retorno da relevância da questão federal?

\section{ANÁLISE DA CONSTITUCIONALIDADE DA TÉCNICA DE JULGAMENTO}

\section{DE RECURSOS REPETITIVOS PELO SUPREMO TRIBUNAL FEDERAL}

\section{E PELO SUPERIOR TRIBUNAL DE JUSTIÇA}

6.1 Colocação do problema

6.2 Princípio constitucional do acesso à justiça

6.3 Ausência de violação à competência constitucional do STF e do STJ e de criação por lei ordinária de novo requisito de admissibilidade para os recursos excepcionais 162

6.4 Ausência de efeito vinculante

6.5 Necessidade de se permitir a impugnação ao STF e ao STJ das decisões dos órgãos de origem que negam seguimento aos recursos repetitivos por contrariedade ao acórdão paradigma. Crítica à jurisprudência

\section{TERCEIRA PARTE}

A técnica de julgamento de recursos repetitivos aplicada: aspectos procedimentais e resultados práticos

\section{INSTAURAÇÃO DO PROCEDIMENTO PREVISTO NOS ARTIGOS 543-B E 543-C DO CPC: REQUISITOS, COMPETÊNCIA E EFEITOS SOBRE O DIREITO DE DESISTÊNCIA DO RECURSO}

7.1 Requisitos para a instauração do procedimento

7.1.1 Requisito quantitativo: efetiva existência de "multiplicidade de recursos"

7.1.2 Desnecessidade de prévia jurisprudência dominante ou sumulada sobre a questão controvertida

7.1.3 Requisito qualitativo: "idêntica controvérsia" ou "idêntica questão de direito"203 
7.1.4 Instauração de ofício ou a requerimento das partes

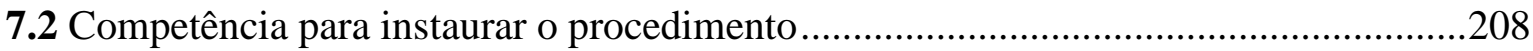

7.3 Seleção do caso representativo da controvérsia .......................................................210

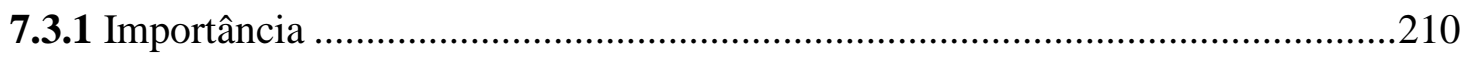

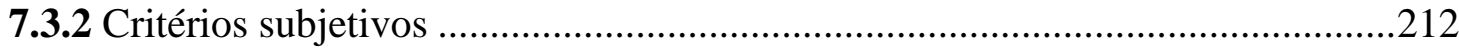

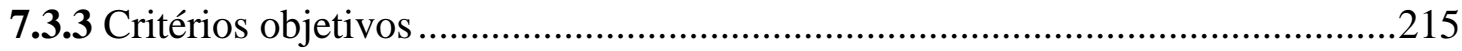

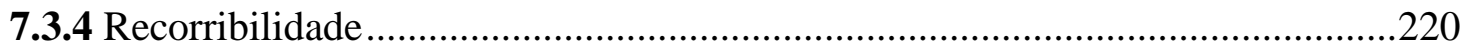

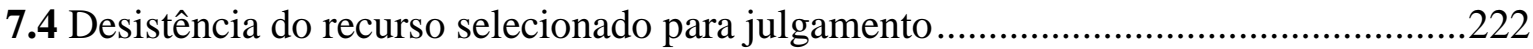

8 SOBRESTAMENTO DOS RECURSOS REPETITIVOS ........................................230

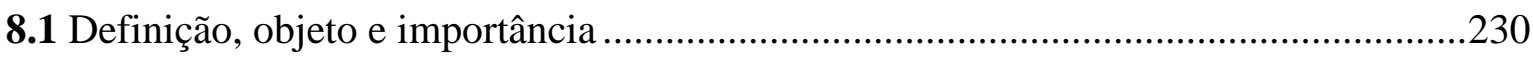

8.2 A questão da necessidade de limitação do prazo de duração do sobrestamento..........234

8.3 Sobrestamento dos recursos extraordinários e especiais em trâmite nos tribunais de origem

8.4 Sobrestamento dos recursos extraordinários e especiais já enviados ao STF e ao STJ

8.5 Sobrestamento dos agravos interpostos na forma do artigo 544 do CPC

8.6 A questão sobre a possibilidade de sobrestamento de outros recursos e processos nas instâncias inferiores

8.6.1 Panorama normativo e a jurisprudência do STF e do STJ

8.6.2 Análise da conveniência e legitimidade das diversas hipóteses de extensão dos efeitos do sobrestamento

8.6.2.1 Sobrestamento dos processos e outros recursos até a definição da controvérsia.

8.6.2.2 Sobrestamento dos processos individuais em razão da pendência de processo coletivo

8.7 Controle da decisão que determina o sobrestamento

8.7.1 Conteúdo decisório e possibilidade de impugnação da decisão de sobrestamento - crítica à jurisprudência do STJ e do STF

8.7.2 Agravo de admissão (art. 544 do CPC), pedido de reconsideração, embargos de declaração ou outros meios (mandado de segurança, reclamação ou medida cautelar)?

8.7.3 Agravo interno 


\section{JULGAMENTO DOS RECURSOS REPRESENTATIVOS DA CONTROVÉRSIA: PREPARAÇÃO, PARTICIPAÇÃO DE TERCEIROS E ÓRGÃO COMPETENTE}

9.1 Solicitação de informações aos Tribunais de Justiça e Tribunais Regionais Federais

e concessão de vista ao Ministério Público ...............................................................2275

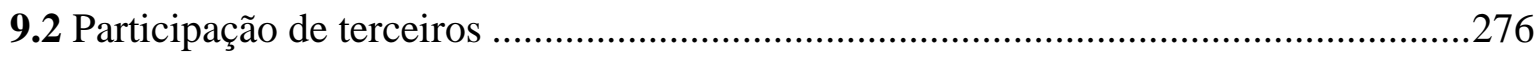

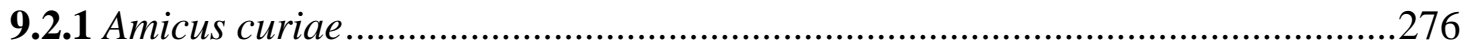

9.2.2 Aspectos procedimentais da participação do amicus curiae ..............................280

9.2.3 Intervenção dos que figuram como partes nos recursos sobrestados? ...............286

9.2.4 Como ampliar adequadamente a participação das partes que sofrerão a influência do julgamento? ...........................................................................293

9.3 Competência do órgão mais complexo e quorum qualificado .....................................294

\section{EFEITOS DO JULGAMENTO DOS RECURSOS REPRESENTATIVOS}

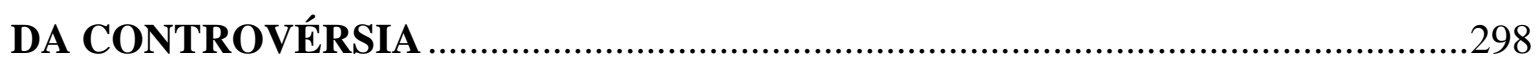

10.1 Momento de eficácia do acórdão que julga os recursos representativos da controvérsia

10.2 Efeitos do julgamento dos recursos extraordinários representativos da controvérsia, quando o STF nega a existência de repercussão geral.

10.3 Efeitos do julgamento de mérito dos recursos representativos da controvérsia, em relação aos recursos repetitivos sobrestados

10.3.1 Recursos repetitivos interpostos contra decisões que convergem com a tese fixada pela instância superior

10.3.2 Recursos repetitivos interpostos contra decisões que divergem da tese fixada pela instância superior 306

10.3.2.1 Juízo positivo de retratação ...............................................................306

10.3.2.2 Juízo negativo de retratação (manutenção da divergência) ....

10.4 Efeitos do julgamento de mérito dos recursos representativos da controvérsia, em relação aos novos recursos extraordinários e especiais (e respectivos agravos de admissão ou interno)

10.5 A questão da impugnação da decisão que nega seguimento aos recursos repetitivos contrários ao acórdão paradigma.

10.6 Efeitos do julgamento de mérito dos recursos representativos da controvérsia, em relação às causas e recursos nas demais instâncias 
10.7 Possibilidade de modulação dos efeitos do julgamento de mérito dos recursos representativos da controvérsia

10.8 Cabimento de ação rescisória (art. 485, inc. V, do CPC) em face de decisões contrárias ao acórdão que define a controvérsia

11 RESULTADOS PRÁTICOS.

11.1 Os números no Supremo Tribunal Federal e no Superior Tribunal de Justiça, após a aplicação da técnica de julgamento de recursos repetitivos

11.2 O problema do tempo de duração do procedimento de julgamento de recursos repetitivos

11.3 Quadro geral em relação aos procedimentos instaurados. 340

11.4 Consequências práticas em relação ao funcionamento dos Tribunais de origem e a criação dos Núcleos de Repercussão Geral e Recursos Repetitivos (NURER) ...344

12 O PROJETO DE NOVO CÓDIGO DE PROCESSO CIVIL

12.1 O estágio atual do projeto 348

12.2 Valorização da jurisprudência 349

12.3 Manutenção e aperfeiçoamento do sistema de julgamento de recursos repetitivos ...352

12.4 A proposta de instituição de um novo "incidente de resolução de demandas repetitivas"

13 CONCLUSÃO 


\section{INTRODUÇÃO}

\subsection{Objeto e limites desta dissertação}

O objeto desta dissertação é o estudo da técnica de julgamento de recursos extraordinários e especiais fundados em idêntica questão de direito (recursos repetitivos), prevista nos artigos 543-B e 543-C do Código de Processo Civil (CPC), e regulamentada por normas regimentais do Supremo Tribunal Federal (STF) e do Superior Tribunal de Justiça (STJ).

A mencionada técnica surgiu no contexto de agravamento da crise de excesso de recursos no STF e no STJ, que vinha praticamente inviabilizando o adequado exercício da sua função constitucional de fixação do sentido único do direito objetivo federal, por meio do controle e da uniformização da jurisprudência. Apresentou-se, assim, como uma tentativa de lidar com o problema, racionalizando a atuação dos órgãos de cúpula, diante de milhares de casos versando sobre a mesma questão de direito.

Em linhas gerais, os artigos 543-B e 543-C do CPC permitem ao STF e ao STJ que, diante de uma multiplicidade de recursos repetitivos, julguem apenas um ou alguns recursos representativos da controvérsia, a fim de que a tese jurídica fixada no julgamento possa, ao final, ser simplesmente aplicada aos demais recursos, que devem permanecer sobrestados, à espera da definição da controvérsia.

Essa técnica, como outras que atuam como filtro de acesso das partes aos órgãos jurisdicionais, ataca as consequências, e não as causas do problema. O desenvolvimento dos métodos alternativos de soluções de conflitos, a ampliação da estrutura e o investimento de maiores recursos financeiros no Poder Judiciário, o aperfeiçoamento dos instrumentos de tutela coletiva dos direitos e a mudança de cultura do próprio Estado (responsável pelo maior número de processos em tramitação) são medidas, aqui citadas a título meramente exemplificativo, que talvez pudessem evitar a chegada de centenas de milhares de recursos repetitivos aos Tribunais Superiores. 
Além disso, não se pode desconsiderar o elevado custo dessa racionalização da atuação do STF e do STJ: ela acaba por resvalar em nada menos que o direito de acesso das partes aos órgãos de cúpula, constitucionalmente responsáveis pela revisão de decisões contrárias, em tese, ao direito federal constitucional e infraconstitucional.

Este trabalho, porém, não tem por objeto analisar, no plano macro, a conveniência da técnica de julgamento de recursos repetitivos à luz de outros meios mais ou menos viáveis e adequados para a solução dos problemas do Poder Judiciário e, mais especificamente, do STF e do STJ.

Na verdade, esta dissertação parte do pressuposto de que a técnica de julgamento de recursos repetitivos está posta e consolidada, representando uma importante realidade do sistema de julgamento de recursos extraordinários e especiais.

De fato, além de positivada pelos artigos 543-B e 543-C do CPC e regulamentada por normas regimentais, a técnica vem sendo fortemente aplicada (e até excessivamente interpretada, conforme criticaremos oportunamente neste trabalho) pela jurisprudência do próprio STF e STJ. Ademais, ao que tudo indica, no novo CPC (cujo projeto atualmente tramita na Câmara dos Deputados) ela deverá ser mantida, aperfeiçoada e, de certa forma, estendida aos processos repetitivos que tramitam no primeiro grau de jurisdição (por meio do novo "incidente de resolução de demandas repetitivas").

Partindo desse pressuposto, a proposta desta dissertação é examinar essa nova forma de processamento dos recursos extraordinários e especiais, respeitando-se as seguintes limitações: análise das justificativas que levaram à sua criação, de suas características gerais e da sua controvertida constitucionalidade; descrição de seus aspectos procedimentais, à luz do direito positivo, da doutrina e da jurisprudência; e breve exame dos resultados práticos até aqui produzidos.

Não se trata, assim, de um trabalho sobre as diversas técnicas de tratamento adequado de litígios de massa ou das causas repetitivas, nem sobre a teoria dos precedentes judiciais (o que inclui a discussão sobre a conveniência e a legitimidade de ampliação da sua força), ou sobre os problemas gerais enfrentados pelos Tribunais Superiores e as respectivas soluções. Sob um ângulo mais técnico e restrito, o objeto de estudo consiste 
especificamente na análise do funcionamento da técnica de julgamento de recursos extraordinários e especiais repetitivos regulamentada pelos artigos 543-B e 543-C do CPC.

De qualquer forma, é claro que, no decorrer do trabalho, alguns temas que se relacionam com seu objeto, inclusive os mencionados acima, serão tangenciados, até para a fixação de premissas e conceitos necessários ao cumprimento do escopo principal.

Do mesmo modo, ao longo do desenvolvimento dos capítulos virá inevitavelmente à tona a nossa visão crítica a respeito do instituto, a qual pode ser, desde já, em linhas gerais, antecipada: trata-se de um legítimo e eficiente instrumento de potencialização dos precedentes do STF e do STJ, que, sem prejuízo de necessários aperfeiçoamentos, mostrase teoricamente adequado para conciliar a atual realidade dos problemas gerados pelos recursos repetitivos com a verdadeira função dos recursos excepcionais (controle e uniformização da jurisprudência, com o fim de concretização dos princípios da igualdade e da segurança jurídica).

Para tanto, porém, não pode prevalecer, em certos aspectos, a jurisprudência do STF e do STJ, que, para ampliar os efeitos da técnica de julgamento de recursos repetitivos, vêm interpretando os artigos 543-B e 543-C do CPC de forma excessivamente restritiva às garantias das partes, sobretudo no que diz respeito à impossibilidade de impugnação da decisão que aplica o acórdão paradigma ao recurso repetitivo.

\subsection{Plano do trabalho}

Por razões didáticas, os capítulos que compõem o desenvolvimento deste trabalho estão reunidos em três partes.

Na primeira, que abrange os Capítulos 2 e 3, são abordados temas correlatos, relativos à tendência de valorização da jurisprudência no direito brasileiro, bem como às funções, importância e admissibilidade dos recursos extraordinários e especiais.

A finalidade dessa primeira parte é simplesmente traçar premissas e apresentar conceitos que serão recuperados ao longo do trabalho, facilitando a abordagem das questões mais centrais. 
Na segunda parte, composta pelos Capítulos 4, 5 e 6, são analisados os motivos de criação, os aspectos gerais e a constitucionalidade da técnica de julgamento de recursos repetitivos, oportunidade em que terão de ser adiantados alguns posicionamentos a respeito do seu funcionamento, aos quais se fará mera referência nos capítulos seguintes, relativos à terceira parte.

Pretende-se, nessa segunda parte, lançar um olhar geral sobre o instituto, descrevendo seus aspectos normativos, a influência do direito estrangeiro, a sua caracterização como técnica de potencialização dos precedentes do STF e STJ, bem como a sua relação com o instituto da repercussão geral. Além disso, serão analisados os principais problemas relacionados à sua constitucionalidade, apresentando críticas, não à técnica em si (que, para nós, pode ser considerada legítima), mas sim à interpretação restritiva ao direito das partes que lhe vem atribuindo a jurisprudência do STF e do STJ.

A terceira e última parte, composta dos Capítulos 7 a 12, é dedicada ao exame do funcionamento da técnica de julgamento de recursos repetitivos, organizado conforme as várias fases de seu procedimento (instauração, sobrestamento, preparação para julgamento e efeitos do julgamento), bem como, por fim, de seus resultados práticos e das modificações previstas na versão atual do projeto do novo CPC.

Por fim, concluiremos com uma síntese das principais questões abordadas durante o trabalho e com a exposição de uma posição crítica a respeito do funcionamento do instituto. 


\section{PRIMEIRA PARTE}

Temas correlatos: valorização da jurisprudência - recursos extraordinários e especiais (funções, importância e admissibilidade) 


\section{A VALORIZAÇÃO DA JURISPRUDÊNCIA}

\subsection{Jurisprudência e precedente}

Diante da evolução do termo jurisprudência ao longo do tempo ${ }^{1}$ e do espaço ${ }^{2}$, o seu sentido não é unívoco, podendo ter três significações diferentes: a) a "ciência do direito" (também denominada "dogmática jurídica" ou "jurisprudência"); b) o conjunto de decisões dos tribunais, em sentido amplo, abrangendo tanto a jurisprudência uniforme como a contraditória; e, c) em sentido estrito e técnico-jurídico, o conjunto de decisões uniformes.

$\mathrm{Na}$ atualidade, é mais relevante e usual a concepção de jurisprudência naquele sentido estrito, qual seja, o de conjunto de decisões uniformes dos tribunais ${ }^{3}$, pois nesse

\footnotetext{
${ }^{1}$ Pode-se dizer que a origem do que hoje conhecemos como a jurisprudência dos tribunais está em Roma, onde a atividade jurisdicional era exercida tanto pelos editos dos pretores, como pelas respostas dos prudentes. Ou seja, o termo jurisprudência guardava identidade tanto com a atividade de aplicação concreta do direito (éditos dos magistrados), como também com a própria ciência do direito (coleções de responsa dos jurisconsultos). (PARENTE, Eduardo de Albuquerque. Jurisprudência: da divergência à uniformização. São Paulo: Atlas, 2006. p. 4).

${ }^{2}$ Após as migrações dos povos no continente europeu, em razão das guerras de conquista, o direito romano sofreu influências diversas, e a partir daí a jurisprudência passou a apresentar características e finalidades também diversas, marcando maior ou menor presença em cada sistema. Os sistemas do continente europeu continuaram a se inspirar nas fontes romanas, formando os "direitos codicísticos", com prevalência da norma escrita. Por sua vez, os sistemas da vertente anglo-saxã basearam-se no precedente judiciário. Assim, o termo jurisprudência passou a apresentar significados diversos nos sistemas anglo-saxão, de common law (onde a principal fonte do direito são os precedentes judiciários), e continental-europeu, ou romanogermânico, de civil law (onde, diferentemente, o direito decorre da lei escrita). (MANCUSO, Rodolfo de Camargo. Divergência jurisprudencial e súmula vinculante. 4. ed. rev., atual. e ampl. São Paulo: Revista dos Tribunais, 2010. p. 25). O sistema brasileiro, que teve sua origem nas "Ordenações" lusitanas, filia-se a esse último sistema. Sobre a filiação de Portugal, e consequentemente do Brasil, ao sistema de civil law, ver: MARCATO, Antonio Carlos. Crise da justiça e influência dos precedentes judiciais no direito processual civil brasileiro. Tese (Professor Titular - Direito Processual Civil) - Faculdade de Direito da Universidade de São Paulo, 2008. p. 159.
}

${ }^{3}$ Nesse sentido, a jurisprudência envolve apenas decisões emanadas de órgãos do Estado dotados de poder jurisdicional, embora também se fale em "jurisprudência" de órgãos administrativos, dos Tribunais de Contas, etc. Além disso, ela abarca apenas acórdãos, e não as decisões monocráticas e as sentenças de primeiro grau, pois o conjunto harmônico de decisões sobre determinada matéria pressupõe certa estabilidade, incompatível com as decisões sujeitas ordinariamente a revisão. Conforme Carlos Aurélio Mota de Souza: "As sentenças de $1^{a}$ instância podem tornar-se caso julgado quando as partes não recorrem, mas tais decisões não fazem jurisprudência e apresentam menor grau de certeza jurídica. Somente decisões múltiplas, sobre temas jurídicos semelhantes, levam à formação de Jurisprudência; e por serem colegiadas as decisões de $2^{\text {a }}$ instância oferecem maior grau de certeza jurídica." (SOUZA, Carlos Aurélio Mota de. Direito judicial, jurisprudencial e sumular. Revista de Processo, São Paulo, v. 20, n. 80, p. 208, out./dez. 1995). Observe-se, porém, que o art. 285-A do CPC, incluído pela Lei n. 11.277/2006, atribui eficácia panprocessual também às sentenças de primeiro grau sobre matéria repetitiva, permitindo a improcedência prima fácie da demanda fundada em tese já reiteradamente rejeitada pelo Juízo. Ocorre que, nesse caso, não se poderá falar em jurisprudência no seu sentido técnico-jurídico, bastando lembrar que referidas sentenças poderão ser objeto de apelação ou, nos casos do art. 475 do $\mathrm{CPC}$, de reexame necessário. Aliás, o dispositivo tem sido criticado justamente por não exigir que as sentenças repetitivas estejam em consonância, pelo menos, com a jurisprudência do tribunal de segundo grau a que o respectivo Juízo está sujeito. 
caso ela indica a toda a sociedade qual o sentido das normas jurídicas, à luz de determinadas situações fáticas, além de exercer influência sobre outras decisões judiciais nos casos sucessivos. Como bem destacado por Rodolfo de Camargo Mancuso, "a tese fixada se destaca, projetando efeitos em face de outras demandas, virtuais ou pendentes, assim projetando eficácia panprocessual". ${ }^{4}$

Além disso, a jurisprudência, naquele sentido mais estrito, pode ser qualificada pela circunstância de ser dominante (o que ocorre quando o conjunto de decisões em determinado sentido predomina quantitativamente sobre outro conjunto) ou sumulada (quando o Tribunal edita um enunciado sintético sobre a sua jurisprudência dominante a respeito de determinado tema).

Nesses casos, em razão de técnicas previstas na legislação, permite-se que a jurisprudência exerça influência direta sobre o julgamento de outros casos que tratam das mesmas questões jurídicas, por exemplo vinculando a interpretação da norma à luz de determinada situação concreta, como ocorre com as súmulas vinculantes; ou, ainda a título de exemplo, permitindo o julgamento monocrático de recursos nos tribunais, como ocorre com a técnica prevista nos artigos 544, $§ 4^{\circ}$, e 557 do CPC.

O tema da jurisprudência relaciona-se intimamente ao dos precedentes, a ponto de serem muitas vezes tratados como sinônimos, pois ambos estão ligados à análise dos efeitos externos das decisões judiciais, no sentido da sua capacidade de influenciar, em maior ou menor grau, a solução de casos semelhantes sucessivos. ${ }^{5}$

Nesse sentido, precedentes são espécies de decisões judiciais que, em virtude de determinadas qualidades, ao julgar o caso concreto, fixam ou consolidam uma tese jurídica, projetando, a respeito da matéria de direito por ela solucionada, efeitos externos,

\footnotetext{
${ }^{4}$ MANCUSO, Rodolfo de Camargo, Divergência jurisprudencial e súmula vinculante, cit., p. 148.

5 Analisando a dimensão estrutural dos precedentes, Michele Taruffo afirma que o precedente pode ser único, como ocorre comumente nos sistemas de common law, em face do número limitado de decisões pronunciadas por suas cortes e pelo sistema de reporting, que permitem aos tribunais elegerem os casos que pretendem estabelecer como precedentes. E pode também ocorrer de se fazer referência a várias decisões uniformes sobre a mesma questão, o que ocorre com maior frequência nos sistemas de civil law, em que os precedentes decorrem da jurisprudência dominante (TARUFFO, Michele. Dimensiones del precedente judicial. In: __. Páginas sobre justicia civil. Traducción de Maximiliano Aramburo Calle. Madrid: Marcial Pons, 2009. p. 552). Note-se que, para o autor, precedente e jurisprudência fariam parte da mesma realidade, diferenciando-se apenas em relação à sua estrutura.
} 
relativos a outros casos que tratam das mesmas questões. Essas qualidades estão ligadas, dentre outras circunstâncias, ao ineditismo da interpretação da lei em determinado caso concreto, à quantidade dos argumentos analisados, à consolidação dos argumentos já enfrentados em casos anteriores e à autoridade do órgão judicial que prolata a decisão. ${ }^{6}$

Note-se a diferença entre precedente e decisão. Nem toda decisão é precedente, embora todo precedente seja decisão. Uma decisão só será precedente se, ao fixar ou consolidar uma tese jurídica a respeito de determinada questão, for apta a exercer legitimamente efeitos externos, relativos a casos sucessivos.

Da mesma forma, apesar da sua íntima relação, podem-se identificar diferenças entre precedente e jurisprudência ${ }^{7}$. A primeira distinção é óbvia, e pauta-se pelo critério quantitativo: a jurisprudência envolve um conjunto de acórdãos consonantes, enquanto precedente refere-se a apenas um julgado sobre determinado tema. ${ }^{8}$

Outra distinção refere-se ao grau de influência exercida pela jurisprudência e pelo precedente, que varia conforme o sistema em que os mesmos são analisados.

Nos sistemas de common law, embora a aplicação reiterada de um precedente possa levar à ampliação do seu grau de influência ${ }^{9}$, isso não é necessário para que ele projete

${ }^{6}$ MARINONI, Luiz Guilherme. Precedentes obrigatórios. 2. ed. rev. e atual. São Paulo: Revista dos Tribunais, 2011. p. 215.

${ }^{7}$ José Rogério Cruz e Tucci, ao abordar o tema dos precedentes como fonte do direito, embora reconhecendo que o termo jurisprudência é de uso muito mais comum em nossa linguagem jurídica, opta por precedente, em face da falta de univocidade do termo jurisprudência, que serve tanto para designar o conjunto de decisões dos tribunais, como também a ciência do direito e a própria atividade profissional (jurisprudência forense ou prática contraposta à teórica) (TUCCI, José Rogério Cruz e. Precedente judicial como fonte do direito. São Paulo: Revista dos Tribunais, 2004. p. 9).

8 Conforme Sidnei Agostinho Beneti: "O linguajar jurídico nacional vem solapando o conceito de jurisprudência, que é a interpretação consistente dos tribunais a respeito das lides, igualando-a pela de precedente, que é cada julgamento individual". Para o autor: "Um julgado não é jurisprudência, mas um precedente, que interagirá com outros casos idênticos ou análogos, no sentido da formação, ou não, de jurisprudência." (BENETI, Sidnei Agostinho, Doutrina de precedentes e organização judiciária. BDJur, Brasília, DF, 8 maio 2008, p. $1 . \quad$ Disponível <http://bdjur.stj.gov.br/xmlui/bitstream/handle/2011/17006/Doutrina_Precedentes_Organiza\%c3\%a7\%c3\% a3o.pdf?sequence $=1>$. Acesso em: 10 nov. 2013). Nesse caso, porém, o autor menciona o termo precedente como sinônimo de decisão judicial. E, como vimos, nem toda decisão é precedente, embora todo precedente seja decisão.

9 “O princípio aplicável verificou-se num único caso ou terá tido seu valor e adequação social reafirmados? A toda evidência a autoridade dos precedentes varia consideravelmente. Num extremo estão os precedentes tidos como vinculativos; noutro, aqueles que se consideram de todo inaplicáveis ao caso em exame." (RE, Edward D. "Stare decisis”. Revista dos Tribunais, São Paulo, v. 83, n. 702, p. 10, abr. 1994, p. 10). 
efeitos externos, inclusive vinculando a interpretação das questões jurídicas nos casos sucessivos. Assim, muito mais do que a quantidade, importa a qualidade do precedente, em termos de aprofundamento da fundamentação e novidade ou singularidade do caso, bem como de hierarquia da corte que o proferiu. ${ }^{10}$

Já nos sistemas de civil law, os precedentes geralmente produzem efeitos externos, em maior ou menor grau, apenas quando formam jurisprudência (ou seja, apenas quando reiterados), sobretudo dominante ou sumulada, trabalhando-se mais com jurisprudência do que com precedentes ${ }^{11}$. Nesse caso, portanto, tem grande importância o aspecto repetitivo, pois em regra é ele que determina o maior grau de influência a ser exercida nos casos sucessivos.

No Brasil, excepcionalmente, o precedente (independentemente da sua conversão em jurisprudência) também pode exercer maior influência, como ocorre com as decisões emanadas do STF em sede de controle direito de constitucionalidade (que inclusive são dotadas de eficácia vinculante) e, após a técnica de julgamento de recursos repetitivos, também com os acórdãos do STF e do STJ que julgam os recursos extraordinários e especiais representativos da controvérsia. ${ }^{12}$

\footnotetext{
10 "No regime da common law a palavra 'jurisprudência' não está, necessariamente, jungida ao sentido de 'reiteração de julgados', podendo ocorrer que um só precedente, por sua convincente fundamentação e/ou singularidade de objeto, seja difundido e faça escola, assim projetando extraautos a força vinculativa de sua ratio decidendi (os chamados biding ou leading precedents). Diferentemente, pode suceder que sobre um mesmo tema haja vários precedentes que, todavia, não se notabilizam por alguma singularidade da matéria de fato ou pela fundamentação jurídica, de sorte que projetarão apenas uma 'força persuasiva' (persuasive prcedentes) em face dos juízes encarregados de decidir casos análogos." (MANCUSO, Rodolfo de Camargo, Divergência jurisprudencial e súmula vinculante, cit., p. 207).

11 "Nos sistemas de civil law, de regra, precedentes começam a gozar de respeito quando formam jurisprudência predominante." (WAMBIER, Teresa Arruda Alvim. Estabilidade e adaptabilidade como objetivos do direito: civil law e common law. Revista de Processo, São Paulo, v. 34, n. 172, p. 144, jun. 2009).

12 "Muito excepcionalmente, um precedente vincula, no sistema brasileiro. Ocorrem, espontaneamente, os tais leading cases. Por outro lado, há o método de julgamento criado pelos arts. 543-B e 543-C, em que o caso 'piloto' deve (sob pena de se frustrarem as finalidades dos dispositivos) determinar o teor dos julgamentos dos recursos, cujo procedimento terá ficado sobrestado.” (WAMBIER, Teresa Arruda Alvim. Interpretação da lei e de precedentes: civil law e common law. Revista dos Tribunais, São Paulo, v. 99, n. 893, p. 33, mar. 2010). Sobre o conceito de leading case no sistema de common law, Guido Fernando Silva Soares leciona: "Uma decisão que se tenha constituído em regra importante, em torno do qual outras decisões gravitam, se denomina um leading case, que passa a ser determinante para o estudante e o advogado, como primeiro approach na solução de uma questão prática." (SOARES, Guido Fernando Silva. O que é a "Common Law", em particular, a dos EUA. Disponível em: <http: // www.migalhas.com.br/ arquivo_artigo/ O_\%20que_\%20e_\%20a_\%20Common.htm>. Acesso em: 08 jun. 2012).
} 


\subsection{Aproximação entre civil law e common law}

A diferença mais marcante entre os sistemas de civil law e de common law é que, no primeiro, a principal fonte formal do direito é a norma escrita, enquanto que o segundo baseia-se no direito costumeiro, aplicado pela jurisprudência. ${ }^{13}$

Porém, uma crise geral de legitimidade do poder jurisdicional, decorrente da perda de credibilidade da sociedade na Justiça e nos juízes, tem sido invocada como uma das causas do movimento de constante aproximação entre os sistemas. Essa crise, decorrente da "elevação da consciência jurídica da população e do grau de exigência em relação ao desempenho do judiciário", faz com que os países de civil law voltem "os olhos para os da common law, procurando lá encontrar soluções para problemas comuns através de institutos que não existem na civil law" e, por sua vez, com que os países da common law também busquem soluções para seus problemas no nosso sistema. ${ }^{14}$

No campo do direito processual, pode-se citar, a título de exemplo desse movimento de convergência entre os sistemas, a crescente ampliação, nos Estados Unidos e na Inglaterra, dos poderes instrutórios do juiz, o que faz parte do sistema inquisitorial típico dos países de civil law. ${ }^{15}$

De outro lado, observa-se a influência, no Brasil (país filiado ao civil law), de institutos do direito norte-americano, como os juizados especiais (inspirados nas small claims courts), a previsão das ações civis públicas (originadas das class actions) e a repercussão geral (semelhante ao sistema de certiorari).

\footnotetext{
${ }^{13}$ Segundo Mauro Cappelletti, representa "diferença fundamental" entre os dois sistemas o fato de que: "Nos países de 'Civil Law', tende-se a identificar o direito com a lei, com a consequência de que, também em face da lacuna legislativa, entende-se, ou se pretende entender, que de qualquer modo o juiz não faz senão aplicar a lei [...]. Nos países de 'Common Law', pelo contrário, o direito legislativo é visto em certo sentido como fonte excepcional do direito. Em face da lacuna, o juiz daqueles países sabe que 'sempre há, para além da lei, o 'common law', ou seja, o direito desenvolvido pelos próprios juízes, que disciplinará as relações jurídicas das partes (não disciplinadas pela lei)'.” (CAPPELLETTI, Mauro. Juízes legisladores? Tradução de Carlos Alberto Alvaro de Oliveira. Porto Alegre: Sergio Antonio Fabris, 1993. p. 122).

${ }^{14}$ GRECO, Leonardo. Instituições de processo civil. 2. ed. Rio de Janeiro: Forense, 2010. v. 1, p. 3.

${ }^{15}$ MOREIRA, José Carlos Barbosa. Correntes e contracorrentes no processo civil contemporâneo. In: Temas de direito Processual: nona série, São Paulo: Saraiva: 2007. p. 55-67; TARUFFO, Michele. Observações sobre os modelos processuais de civil law e de common law. Revista de Processo, São Paulo, v. 28, n. 110, p. 145, abr./jun. 2003.
} 
Desse modo, tem razão José Carlos Barbosa Moreira ao afirmar a possibilidade de um dia existirem entre os sistemas de civil law e common law mais semelhanças que divergências. ${ }^{16}$

Mas a demonstração mais marcante dessa convergência, que também é a que interessa a este trabalho, diz respeito ao fato de que, no civil law, a importância e o grau de influência da jurisprudência e dos precedentes judiciais têm sido cada vez mais ampliados, enquanto que, no common law, observa-se um movimento de crescente valorização da norma escrita. ${ }^{17}$

Nesse sentido, o civil law aproxima-se constantemente do common law, na medida em que a cada dia aumentam as técnicas de valorização da jurisprudência e dos precedentes, sobretudo dos Tribunais Superiores, com o fim de acelerar a tornar mais eficiente a prestação jurisdicional, bem como de viabilizar julgamentos efetivamente uniformes de questões iguais, prestigiando-se os princípios da igualdade e da segurança jurídica.

A técnica de julgamento de recursos repetitivos pelo STF e STJ, objeto de estudo da presente dissertação, é uma clara demonstração disso, posto que, como veremos ao

\footnotetext{
16 “Talvez não seja arbitrário, em todo caso, divisar no que está acontecendo mais um sintoma de certa propensão à convergência das duas famílias tradicionais no universo processual do ocidente: bem pode suceder que um dia o processo de civil law e o processo de common law venham a caracterizar-se mais por aquilo em que se assemelham do que por aquilo em que contrastam." (MOREIRA, José Carlos Barbosa, Correntes e contracorrentes no processo civil contemporâneo, in Temas de direito Processual: nona série, cit., p. 67).

${ }^{17}$ Segundo Neil Andrews: “O direito inglês, hoje em dia, está fortemente influenciado por leis escritas. Estas incluem o direito derivado (sobretudo normas codificadas - veja 2.9). Os 'regulamentos' europeus têm força igual à legislação primária". Apesar disso, o autor ressalta que "o sistema de precedentes continua sendo a base do direito inglês" (ANDREWS, Neil. O moderno processo civil: formas judiciais e alternativas de resolução dos conflitos na Inglaterra. Orientação e revisão da tradução de Teresa Arruda Alvim Wambier. São Paulo: Revista dos Tribunais, 2009. p. 39). Michele Taruffo chega a afirmar que "a referência ao precedente não é há tempos uma característica peculiar dos ordenamentos do common law, estando agora presente em quase todos os sistemas, mesmo os de civil law. Por isso, a distinção tradicional segundo a qual os primeiros seriam fundados sobre os precedentes, enquanto os segundos seriam fundados sobre a lei escrita, não tem mais - admitindo-se que realmente tenha tido no passado - qualquer valor descritivo. De um lado, na verdade, nos sistemas de civil law se faz amplo uso da referência à jurisprudência, enquanto nos sistemas de common law se faz amplo uso da lei escrita e inteiras áreas desses ordenamentos - do direito comercial ao direito processual - são, na realidade, 'codificadas"” (TARUFFO, Michele. Precedente e jurisprudência. Revista de Processo, São Paulo, v. 36, n. 199, p. 139, set. 2011).
} 
longo do trabalho, atua justamente no sentido da ampliação da autoridade dos precedentes do STF e do STJ. ${ }^{18}$

$\mathrm{Na}$ verdade, essa tendência de fortalecimento dos precedentes e da jurisprudência não é fenômeno exclusivo do sistema brasileiro, pois em diversos outros países que adotam o sistema de civil law, como França, Itália, Espanha e Alemanha, tem ocorrido movimento semelhante. ${ }^{19}$

Conforme demonstrado por Katja Funken, a Espanha e a Alemanha vêm positivando técnicas no sentido da vinculação expressa dos precedentes de seus tribunais constitucionais, além da grande importância da eficácia persuasiva dos precedentes dos demais Tribunais Superiores para a uniformização da jurisprudência. $\mathrm{O}$ mesmo se observa na França e em outros países, nos quais, embora não se possa falar em efeito vinculante, há uma grande tendência de observância dos precedentes dos Tribunais Superiores. ${ }^{20}$

Daí o interesse em analisar um pouco mais de perto o funcionamento do sistema de precedentes no common law.

\footnotetext{
18 “O instituto do recurso especial repetitivo - que, embora recém-introduzido no Código de Processo Civil (art. 543-C do CPC), já faz parte da prática do STJ - é prova bastante de que se começa a trilhar caminho rumo ao precedente com força obrigatória." (MARINONI, Luiz Guilherme. Aproximação crítica entre as jurisdições de civil law e de common law e a necessidade de respeito aos precedentes no Brasil. Revista de Processo, São Paulo, v. 34, n. 172, p. 229, jun. 2009). No mesmo sentido, vejamos trechos de acórdão do STJ em que, ao serem apreciadas questões submetidas ao julgamento pelo procedimento do art. 543-C do CPC, menciona-se a relação entre o nosso sistema de potencialização dos precedentes dos Tribunais Superiores e o sistema de julgamento com base nos precedentes vigentes na common law: "A força da jurisprudência dos Tribunais Superiores informa o hodierno sistema, unindo as famílias do civil Law e da common Law, de sorte que, não perpassa pelo princípio da razoabilidade poder a Corte local decidir diversamente do que assentou a Corte Superior." (STJ - QO AI n. 1.154.599/SP, Corte Especial, rel. para voto Min. Cesar Asfor Rocha, DJe, de 12.05.2011). "Deveras, a estratégia político-jurisdicional do precedente, mercê de timbrar a interpenetração dos sistemas do civil law e do common law, consubstancia técnica de aprimoramento da aplicação isonômica do Direito, por isso que para "casos iguais", 'soluções iguais"” (STJ - REsp n. 1.111.743/DF, Corte Especial, rel. para acórdão Min. Luiz Fux, j. 25.02.2010, DJe, de 21.06.2010).

${ }^{19}$ Segundo Teresa Arruda Alvim Wambier, “A influência da jurisprudência tem sido cada vez mais sentida nos países de civil law, embora, isto não seja sempre confessado expressamente, como ocorre na França. Na Itália, os precedentes também têm sido observados, desde que se trate de uma linha jurisprudencial firme e iterativa". (WAMBIER, Teresa Arruda Alvim, Estabilidade e adaptabilidade como objetivos do direito: civil law e common law, cit., p. 138).
}

${ }^{20}$ FUNKEN, Katja. "The best of both worlds": the trend towards convergence of the civil law and the common law system. Disponível em: <www.jurawelt.com/sunrise/media/mediafiles/13598/convergence.pdf>. Acesso em: 08 jun. 2012. 


\subsection{Os precedentes no common law}

O tema da valorização da jurisprudência convida à análise, ainda que breve, de alguns conceitos relacionados à teoria dos precedentes vigente nos sistemas de common law. Esclareça-se que tomamos por base os modelos norte-americano e inglês, eis que, em embora não sejam os únicos ${ }^{21}$, são os mais importantes e os que mais influenciaram os demais países filiados ao common law. ${ }^{22}$

\subsubsection{Stare decisis}

No sistema de common law há também normas escritas (statue law), que se referem às normas criadas pelo legislador, mas é inegável que a principal fonte do direito é o case law, isto é, o precedente judiciário (judge-made law). ${ }^{23}$

Isso porque os modelos inglês e norte-americano de common law adotam a doutrina do stare decisis, originada da formulação stare decisis et non quieta movere (ou seja, mantenha-se a decisão e não se disturbe o que foi decidido), segundo a qual os casos sucessivos, baseados nas mesmas circunstâncias fáticas, devem receber a mesma decisão proferida no caso anterior. Assim, com a solução do caso, destaca-se uma regra, ou um princípio, o qual necessariamente deverá ser aplicado aos casos semelhantes posteriores. ${ }^{24}$

21 “Principais países que pertencem à família da 'Common Law': Austrália, Nova Zelândia, Canadá (Província de Quebec), Índia, Paquistão, Bangladesh, Quênia, Nigéria, Hong Kong, Guiana, Trinidad Tobago e Barbados, dentre outros. Os EUA, salvo o Estado da Luisiana, são considerados um sistema misto, conquanto pertencente à "Common Law' [...]." (SOARES, Guido Fernando Silva, O que é a "Common Law", em particular, a dos EUA, cit.).

${ }^{22}$ Conforme Sidnei Agostinho Beneti, o Reino Unido e os Estados Unidos são "a terra do common law, do stare decisis e dos precedentes" (BENETI, Sidnei Agostinho, Doutrina de precedentes e organização judiciária, cit., p. 4). Pode-se afirmar, porém, que no direito norte-americano o sistema de vinculação é menos rígido e é significativa a presença de normas escritas (statue law).

${ }^{23}$ Guido Fernando Silva Soares descreve da seguinte forma a mentalidade dominante nos sistemas de common law: "O 'case law' constitui a regra e o 'statute' é o direito de exceção, portanto integrativo." (SOARES, Guido Fernando Silva, O que é a "Common Law", em particular, a dos EUA, cit.). No mesmo sentido, conforme Antonio Carlos Marcato, "enquanto em nosso sistema os operadores do Direito apoiamse na lei e, subsidiariamente, na jurisprudência, no sistema da common law o caminho é inverso: primeira fonte é o case e, havendo lacuna, a lei escrita; o case law é a regra e o statue a exceção de direito, atuando, portanto, de forma integrativa" (MARCATO, Antonio Carlos, Crise da justiça e influência dos precedentes judiciais no direito processual civil brasileiro, cit., p. 46).

${ }^{24}$ Procurando apresentar um conceito para a doutrina do stare decisis, Edward Re explica que ela "tem raízes na orientação do common law segundo a qual um princípio de direito deduzido através de uma decisão judicial será considerado e aplicado na solução de um caso semelhante no futuro. Na essência, esta orientação indica a probabilidade de que uma causa idêntica ou assemelhada que venha a surgir no futuro seja decidida da mesma maneira" (RE, Edward D., "Stare decisis", cit., p. 8). 
Dessa forma, as decisões no sistema de common law têm dupla função: resolver a controvérsia entre as partes e adquirir valor de precedente para nortear o julgamento futuro de caso semelhante. Essa segunda função é desempenhada porque, na doutrina do stare decisis, vige o princípio da presunção a favor do precedente, consubstanciada na circunstância de que a decisão contrária ao precedente poderá levar à sua impugnação e revisão pelo órgão superior.

Segundo Antonio Carlos Marcato, a doutrina do stare decisis pode ser sintetizada a partir de algumas regras, tais como: o efeito vinculante dos precedentes dos tribunais superiores; a força de toda decisão relevante pronunciada por qualquer tribunal; a restrição da obrigatoriedade do precedente à sua ratio decidendi, isto é, ao princípio geral de direito estabelecido como seu fundamento; e a manutenção da vigência do precedente ao longo do tempo, sem prejuízo da possibilidade de sua não aplicação, diante de circunstâncias modernas. $^{25}$

Ademais, o precedente é um princípio, ou seja, um ponto de partida para a solução do novo caso, de forma que nesse processo de aplicação do precedente, poderá ocorrer uma expansão ou restrição do princípio, contribuindo-se para o desenvolvimento e evolução do direito. $^{26}$

Com isso, o stare decisis estabelece como regra a força vinculante dos precedentes em relação aos casos sucessivos semelhantes, de forma que o caso julgado representa a principal fonte normativa do sistema.

\subsubsection{Precedentes vinculantes e precedentes persuasivos}

Conforme o grau de influência em relação à solução dos casos sucessivos, os precedentes podem ser vinculantes ou persuasivos. No primeiro caso, são obrigatórios e devem necessariamente ser observados, sob pena de se considerar que a decisão violou o próprio direito. No segundo, ainda que altamente relevantes e até determinantes para a

\footnotetext{
${ }^{25}$ MARCATO, Antonio Carlos, Crise da justiça e influência dos precedentes judiciais no direito processual civil brasileiro, cit., p. 152.

${ }^{26}$ RE, Edward D., "Stare decisis", cit., p. 8.
} 
decisão, os precedentes exercem força meramente argumentativa, de modo que o sistema não considera obrigatória a sua observância.

Apesar do stare decisis, a autoridade do precedente não é sempre a mesma no common law, podendo ser vinculativa (binding authority), hipótese em que definirá o julgamento do caso sucessivo semelhante, ou persuasiva (persuasive authority), caso em que o precedente, aqui também chamado precedente de fato ou revestido de valor moral, pode até não ser aplicado ou, em o sendo, pode haver variação no grau e extensão da aplicação.

Em linhas gerais, para que o precedente seja vinculativo, as questões a ele referentes devem ter sido suscitadas, consideradas e decididas. Por sua vez, os fatos do caso são extremamente importantes, porque é deles que surgem as questões a serem decididas. $^{27}$

Assim, diz-se que "a autoridade do precedente depende e é limitada aos 'fatos e condições particulares do caso' que o processo anterior 'pretendeu adjudicar'”, daí decorrendo que os precedentes não devem ser aplicados de forma automática. Pelo contrário, conforme Re, "o precedente deve ser analisado cuidadosamente para determinar se existem similaridades de fato e de direito e para determinar a posição atual da Corte com relação ao caso anterior". 28

Além disso, a força obrigatória ou persuasiva do precedente varia conforme a estrutura da decisão que o originou, bem como da relação hierárquica entre o órgão que o criou e o órgão que o irá aplicar.

\footnotetext{
${ }^{27}$ Conforme Guido Fernando Silva Soares, o precedente na common law está intimamente ligado aos fatos, não se referindo a uma regra abstrata: "O precedente não é uma regra abstrata, mas uma regra intimamente ligada aos fatos que lhe deram origem. Por tal motivo, o conhecimento das razões da decisão e seu íntimo relacionamento com os fatos discutidos, torna-se imprescindível. A exemplo, as regras contidas num case que envolveu uma anulação de casamento, não tem qualquer serventia para resolver questões relativas a divórcio, ou a questões sobre contratos entre esposos ou obrigações alimentícias, embora possam ser bastante semelhantes." (SOARES, Guido Fernando Silva, O que é a "Common Law", em particular, a dos EUA, cit.).

${ }^{28}$ RE, Edward D., "Stare decisis", cit., p. 9.
} 
De qualquer modo, conforme Michele Taruffo, o mais adequado à maioria dos sistemas, inclusive os de common law, seria considerar que os precedentes não se reduzem aos vinculantes ou não vinculantes. A hipótese da eficácia puramente vinculante existe apenas em fenômenos como, por exemplo, os efeitos da coisa julgada, que não têm a ver com precedente em sentido estrito. No outro extremo, tem-se a hipótese de eficácia puramente persuasiva, em que o juiz tem total discricionariedade quanto a seguir ou não o precedente, conforme se sinta ou não convencido quanto aos seus fundamentos, sem existir sequer a necessidade de sua menção na fundamentação. ${ }^{29}$

Assim, o mais importante é analisar os precedentes conforme o seu maior ou menor grau de eficácia ou de influência. O grau mais alto seria aquele vigente no sistema inglês, em que o precedente é binding, isto é, ele precisa ser seguido, exceto nas hipóteses (expressamente admitidas pelo sistema) em que ele não precisa ser observado. Em seguida, tem-se o precedente que é defeasibly binding, ou seja, ele deve ser seguido, desde que não haja boas razões para seu abandono. Embora deva, o juiz tem liberdade para não seguir o precedente, desde que exponha fundamentadamente as respectivas razões. ${ }^{30}$

O último grau, existente em muitos sistemas de civil law, é o do precedente weakly binding, que ocorre quando se considera conveniente que se observe o precedente, existindo até mesmo uma expectativa de que isso ocorra, mas não há qualquer consequência para o caso do juiz abandonar o precedente sem apresentar qualquer razão para tanto. Seria o caso dos precedentes persuasivos geralmente previstos nos sistemas de civil law. ${ }^{31}$

\subsubsection{Ratio decidendi e obiter dictum}

Não são todas as questões discutidas no precedente que vinculam. Analisando a dimensão objetiva dos precedentes, Michele Taruffo destaca os elementos da decisão que

\footnotetext{
${ }^{29}$ TARUFFO, Michele, Dimensiones del precedente judicial, in Páginas sobre justicia civil, cit., p. 552.

${ }^{30}$ Ibidem, p. 552.

31 No Brasil, embora se considere que os precedentes, em geral, não têm força vinculante, mas apenas persuasiva, pode-se dizer que, a partir da previsão de julgamento de recursos repetitivos pelo STF e STJ (arts. 543-B e 543-C do CPC), inseriu-se no sistema a necessidade de que os juízes e tribunais fundamentem expressamente as decisões em caso de não aplicação do precedente do STF e STJ, pelo que, ainda que não sejam obrigatórios, não se pode afirmar que possam ser simplesmente abandonados.
} 
têm maior ou menor poder de influência, determinando o precedente. Fala-se, assim, na ratio decidendi e no obiter dictum, para se referir, respectivamente, à parte do precedente que pode vincular e à que assume função meramente persuasiva. ${ }^{32}$

A noção de ratio decidendi é ambígua na doutrina do próprio common law. Ela pode significar a regra de direito emanada do caso (ênfase na questão jurídica) ou a qualificação dos fatos relevantes da controvérsia (ênfase na referência aos fatos). Isso sem contar que a determinação da ratio decidendi depende em alguma medida da interpretação do precedente, a ser realizada pelo juiz do caso posterior.

De qualquer modo, pode-se afirmar com certa segurança que a ratio decidendi representa a razão jurídica que determina a decisão, ou seja, "constitui a essência da tese jurídica suficiente para decidir o caso concreto (rule of law)". 33

Por exclusão, tem-se como obiter dictum tudo o que não constitui a ratio decidendi, incluindo-se princípios jurídicos mencionados na decisão, mas que não a determinam, observações relativas aos fatos da causa e à valoração das provas, invocação de fatos alheios à hipótese de fato objeto da controvérsia e até argumentos ad abundantiam. Os dicta apresentam força meramente persuasiva, conforme diversos fatores, como, por exemplo, seu grau de influência no contexto da decisão que os contém, a autoridade intelectual da corte ou juiz que o proferiu, a sua razoabilidade. ${ }^{34}$

Desse modo, verifica-se que apenas o núcleo da fundamentação necessária e suficiente para a decisão - a ratio decidendi (na Inglaterra) ou holdin (nos Estados Unidos)

\footnotetext{
${ }^{32}$ TARUFFO, Michele, Dimensiones del precedente judicial, in Páginas sobre justicia civil, cit., p. 547.

${ }^{33}$ TUCCI, José Rogério Cruz e, Precedente judicial como fonte do direito, cit., p. 175.

34 “Estuda-se o precedente para determinar se o princípio nele deduzido constitui a fundamentação da decisão ou tão somente um dictum. Apenas os fundamentos da decisão merecem reconhecimento e acatamento com força vinculativa. Um dictum é apenas uma observação ou opinião e, como tal, goza tão somente de força persuasiva. Os fatores que afetam ou determinam o grau de persuasão que podem alcançar os dicta são muitos e de diversa natureza. Que grau de pertinência ou relevância tem o dictum no contexto da decisão de que é integrante? A Corte ou o Juiz que o proferiu goza de especial respeito por sua sabedoria ou cultura jurídica? O dictum é razoável?" (RE, Edward D., "Stare decisis”, cit., p. 9). Conforme Teresa Arruda Alvim Wambier, obiter dicta ou gratis dicta "significam literalmente: o que é dito para morrer, o que é dito por nada, inutilmente. Tudo o que é dito numa decisão e que não integra a ratio decidendi é obiter dicta, e o que é dito obiter dicta tem um peso meramente persuasivo" (WAMBIER, Teresa Arruda Alvim, Estabilidade e adaptabilidade como objetivos do direito: civil law e common law, cit., p. 131).
} 
- é que pode apresentar força vinculante. As demais ponderações, ainda que relevantes, são dotadas de força meramente persuasiva.

Por sua vez, vale ressaltar que, nos sistemas de civil law, mesmo a ratio decidendi tem, em regra, eficácia meramente persuasiva, salvo se o próprio sistema jurídico, em virtude de alguma previsão expressa, excepcionalmente determinar a força obrigatória do precedente. $^{35}$

\subsubsection{Eficácias vertical e horizontal dos precedentes}

A força vinculativa do precedente no common law também depende da sua direção. Isso significa que ela se altera conforme a relação (vertical ou horizontal) existente entre o órgão prolator do precedente e o órgão que julga o caso sucessivo. É o que Michele Taruffo chama de dimensão institucional do precedente. ${ }^{36}$

Quanto ao critério vertical, que se baseia na autoridade e no respeito do órgão que proferiu a decisão, se o juiz do caso sucessivo encontra-se sob um grau hierarquicamente inferior, o precedente será vinculante. ${ }^{37}$

Por sua vez, quanto ao critério horizontal, o precedente originado de órgão da mesma hierarquia do juiz do caso sucessivo exerce força meramente persuasiva, a qual dependerá muito mais da qualidade intrínseca da decisão ${ }^{38}$. No entanto, é recomendável que, tratando-se de precedente originado das Cortes Superiores, ele seja, ao menos em regra, observado também pelo próprio órgão, sob pena de perda da sua autoridade. Nesse

\footnotetext{
${ }^{35}$ De fato, no Brasil, país filiado ao civil law, a ratio decidendi dos precedentes exerce, em regra, força persuasiva e não vinculante (exceção feita à súmula vinculante e às decisões do STF em sede de controle abstrato de constitucionalidade, tal como expressamente ressalvado pela Constituição Federal).

${ }^{36}$ TARUFFO, Michele, Dimensiones del precedente judicial, in Páginas sobre justicia civil, cit., p. 544.

${ }^{37}$ Sobre o sistema inglês, Neil Andrews leciona: "Existe uma hierarquia de precedentes nessa pirâmide de tribunais. Assim, as decisões da House of Lords são vinculantes para todos os tribunais inferiores, incluindo a Court of Appeal. As decisões da Court of Appeal não são vinculantes para a House of Lords, que é superior na hierarquia. As decisões da Court of Appeal são vinculantes não só para tribunais inferiores (como a High Court ou as county courts), mas também para a própria Court of Appeal." (ANDREWS, Neil, $O$ moderno processo civil: formas judiciais e alternativas de resolução dos conflitos na Inglaterra, cit., p. 40).

38 No sistema inglês, excepcionalmente "precedentes de longa data, em qualquer nível, dentro desta hierarquia, podem adquirir força considerável na medida em que se consagram como um princípio fundamental" (ANDREWS, Neil, op. cit., p. 41).
} 
caso, fala-se no autoprecedente, que ocorre quando um mesmo órgão aplica seus próprios precedentes.

Isso não exclui, e não deve excluir, uma certa dose de elasticidade, para que a Corte Superior altere seus próprios precedentes, sempre que eles se mostrarem obsoletos em face de mudanças das condições econômicas, sociais e culturais, ou até mesmo em face da peculiaridade dos casos, apenas aparentemente idênticos.

Nesse sentido, Michele Taruffo menciona o Practise Statement de 1966, por meio do qual a House of Lords inglesa passou a não se considerar mais vinculada aos próprios precedentes (embora nas décadas seguintes a referida Corte tenha continuado, na prática, a seguir os próprios precedentes na maior parte dos casos). Menciona-se também a prática da Suprema Corte dos Estados Unidos de geralmente selecionar para julgamento apenas casos que possam dar origem a precedentes novos ou que possam superar precedentes antigos que se tornaram obsoletos. ${ }^{39}$

\subsubsection{Flexibilidade na aplicação dos precedentes: overruling e distinguishing}

Basta observar a possibilidade de a própria House of Lords revogar seus precedentes e a prática da Suprema Corte dos Estados Unidos de superar precedentes antigos que se tornaram obsoletos para se constatar o quão equivocada é a ideia de que a doutrina do stare decisis funda-se na força vinculante irrestrita e absoluta dos precedentes.

Como já exposto, o princípio deduzido do precedente pode ser aplicável ou não e, em o sendo, essa aplicação poderá se dar em diferentes graus. Com isso, embora o sistema privilegie a igualdade e a previsibilidade (por viabilizar soluções estáveis e uniformes), ele também se mostra flexível, diante da necessidade de mudança e progresso.

\footnotetext{
${ }^{39}$ TARUFFO, Michele, Precedente e jurisprudência, cit., p. 150. Cappelletti também afirma ser necessário reconhecer que "a doutrina do 'stare decisis' pode ser aplicada de maneira muito flexível, o que realmente ocorre especialmente nos Estados Unidos, enquanto que na Grã-Bretanha a rigidez de sua aplicação também tem sido atenuada ultimamente, entre outros motivos, pela famosa declaração do Lord Chanceler que, em 1966, falando pela unanimidade da House of Lords, afirmou o poder daquela Corte de alterar a própria jurisprudência” (CAPPELLETTI, Mauro, Juízes legisladores?, cit., p. 122).
} 
Daí dizer-se que, segundo o stare decisis, "não se altera o já decidido, sem motivos extremamente relevantes, como a mudança da lei, ou a forte alteração das condições jurídico-sociais subjacentes, que imponha revisão de alteração". " Ou seja, havendo motivos relevantes, ou sendo alteradas as condições jurídico-sociais inerentes ao caso, é perfeitamente possível a revisão do precedente.

A respeito dessa flexibilização, destacam-se no common law dois institutos voltados a justificar a não incidência do precedente ao caso sucessivo: o distinguishing e o overruling. ${ }^{41}$

O distinguishing é uma forma de se demonstrar que o caso, embora semelhante ao precedente, apresenta peculiaridades que impedem a sua aplicação, exigindo-se a apreciação do caso à luz das novas questões fáticas ou jurídicas não discutidas no precedente. Note-se que, na verdade, não se trata de excepcionar a eficácia vinculante do precedente, mas sim de demonstrar que o caso é diverso, merecendo nova e diversa solução.

Já o overruling refere-se à superação do precedente em face da alteração das circunstâncias fáticas e jurídicas que lhe deram origem ${ }^{42}$. Aqui, o caso é de superação e de revogação do precedente por não ser mais conveniente a sua aplicação aos casos sucessivos, dando-se origem a uma nova orientação. ${ }^{43}$

\footnotetext{
${ }^{40}$ BENETI, Sidnei Agostinho, Doutrina de precedentes e organização judiciária, cit., p. 4.

${ }^{41}$ Conforme Michele Taruffo, "mesmo no sistema inglês, que parece ser aquele no qual o precedente é dotado de maior eficácia, os juízes usam numerosas e sofisticadas técnicas argumentativas, dentre as quais o distinguishing e o overruling, a fim de não se considerarem vinculados ao precedente que não pretendem seguir. [...] No sistema americano, a força do precedente existe, mas em um grau menor: os juízes americanos aplicam os precedentes com grande discricionariedade, ou seja - por assim dizer - quando não encontram razões suficientes para não o fazer. O stare decisis continua a existir, portanto, e por isso os juízes normalmente explicam porque não pretendem seguir o precedente: parece, todavia, claro que o precedente tem eficácia só quando o segundo juiz dele compartilha. No caso contrário, o precedente vem overruled (TARUFFO, Michele, op. cit., p. 147).
}

42 THEODORO JÚNIOR, Humberto; NUNES, Dierle José Coelho; BAHIA, Alexandre Gustavo Melo Franco. Breves considerações sobre a politização do Judiciário e sobre o panorama de aplicação no direito brasileiro: análise de convergência entre o civil law e o common law e dos problemas da padronização decisória. Revista de Processo, São Paulo, v. 35, n. 189, p. 42, nov. 2010.

43 “Quando se detecta a necessidade de mudança, ou porque (a) se considera agora, a norma errada; ou porque (b) se considera agora a norma errada, embora ela não estivesse errada, quando foi criada, ocorre o overruling. Esta é uma das principais técnicas, usadas no sistema de common law, para adaptar/corrigir/flexibilizar o direito. [...] Overruling é o afastamento do precedente e a declaração de que este precedente foi superado. O overruling, porém, também pode ser implícito. Quando ocorre o overruling, uma nova regra é criada para os casos subsequentes." (WAMBIER, Teresa Arruda Alvim, Estabilidade e adaptabilidade como objetivos do direito: civil law e common law, cit., p. 135-136). 
Conforme Antonio Carlos Marcato, existe também a possibilidade do retrospective overruling (caso em que a revogação do precedente terá eficácia retroativa, impedindo-se que a decisão anterior seja invocada como paradigma para casos pendentes de julgamento), do prospective overruling (caso em que a Suprema Corte dos Estados Unidos da América revoga o precedente com eficácia ex nunc, de forma que sua revogação produza efeitos apenas para casos futuros) e do antecipatory overruling (quando os tribunais inferiores norte-americanos revogam preventivamente um precedente, sob o fundamento de que ele foi repudiado, ainda que implicitamente, por precedente da Corte Superior). ${ }^{44}$

Ao seu turno, o distinguishing diferencia-se do overruling pelo fato de que, naquela, a regra do precedente permanece, e até incide no caso sucessivo, embora com adaptações. Nesse sentido, "a regra do precedente não é abandonada, mas reformulada, levando em consideração características específicas do caso". ${ }^{45}$

\subsection{A valorização da jurisprudência no Brasil}

Apresentados os principais conceitos relacionados à teoria dos precedentes vigente nos sistemas de common law, passamos a analisar a questão da tendência de valorização da jurisprudência no Brasil.

\subsubsection{A necessidade de interpretação e o problema da divergência jurisprudencial}

No exercício da função jurisdicional, o Estado, por meio do Poder Judiciário, julga as controvérsias que lhes são submetidas, o que envolve a realização de um silogismo: valendo-se da premissa maior (direito objetivo) e da premissa menor (fatos da causa), chega-se à conclusão a respeito da incidência da norma ao caso concreto, com a aplicação dos efeitos jurídicos que ela prevê para aquela situação.

\footnotetext{
${ }^{44}$ MARCATO, Antonio Carlos, Crise da justiça e influência dos precedentes judiciais no direito processual civil brasileiro, cit., p. 154.

${ }^{45}$ WAMBIER, Teresa Arruda Alvim, Estabilidade e adaptabilidade como objetivos do direito: civil law e common law, cit., p. 136.
} 
Ocorre que a aplicação da lei aos fatos do caso concreto exige não só o trabalho investigativo em relação à apuração dos fatos da causa, mas também a atividade de investigação do sentido das normas abstratas (premissa maior), nem sempre claros e $\operatorname{precisos}^{46}$. Assim, na sua atividade de julgador, o juiz tem que se valer da interpretação para descortinar o sentido da lei (aqui considerada em seu sentido amplo) a ser aplicada ao caso concreto.

Porém, ao realizar essa atividade interpretativa, embora o juiz exponha o raciocínio que fez para aferir o sentido da norma abstrata aplicável ao caso, é certo que o faz tanto quanto qualquer doutrinador ou cidadão quando raciocina sobre o sentido do direito objetivo, pelo simples fato de que esse entendimento só serve para justificar a decisão. O seu valor está apenas na força persuasiva que decorre da sua qualidade técnica. ${ }^{47}$

Diferentemente dos motivos (onde se encontra exposto aquele raciocínio relativo à atividade interpretativa), a decisão do juiz, ou mais precisamente a sua parte dispositiva ou decisum, tem peso oficial porque representa a norma jurídica concreta aplicada na solução do litígio. Tanto é assim que só a parte dispositiva fica imunizada pela coisa julgada e, de qualquer modo, essa imunização é restrita às partes do caso concreto, não alcançando aqueles que não participaram do processo. ${ }^{48}$

No entanto, algo diferente ocorre na prática, em que o peso da fundamentação das decisões é muito significativo. Pela especial circunstância de emanar dos órgãos públicos incumbidos de declarar o direito subjetivo das partes, essa interpretação jurisdicional realizada em determinado caso transmite a todos, no plano fático, a convicção de corresponder ao sentido oficial da lei, inclusive para os casos sucessivos semelhantes (eficácia persuasiva).

\footnotetext{
${ }^{46}$ As normas podem conter pontos omissos (lacunas) ou obscuros, exigindo interpretação. Podem, ainda, ser propositalmente dotadas de conceitos vagos ou indeterminados, a fim de que o juiz apure e adapte o seu sentido conforme as peculiaridades do caso concreto e a evolução da sociedade, que nem sempre pode ser acompanhada tempestivamente pelo legislador.

${ }^{47}$ CALAMANDREI, Piero. La casación civil: bosquejo general del instituto. Traducción de Santiago Sentís Melendo. Buenos Aires, Argentina: Editorial Bibliográfica Argentina, 1945. v. 2, p. 72.

${ }^{48}$ Como demonstraremos adiante, mesmo nos sistemas de common law, a interpretação das normas jurídicas, realizadas pelos juízes ao julgar casos concretos, não fica imunizada pela coisa julgada; o que permite que os motivos determinantes (fundamentos) da decisão judicial vinculem com eficácia erga omnes casos futuros no stare decisis (sistema de precedentes obrigatórios) não é a coisa julgada, mas sim o próprio direito positivo que lhes atribui oficialmente esse plus.
} 
Isso se dá principalmente porque, na prática, as decisões tendem a se repetir, ou seja, o entendimento jurisdicional relativo ao sentido das normas abstratas, exposto em decisão proferida em um caso inédito, tende a ser seguido ou observado pelas decisões judiciais seguintes em casos semelhantes, formando jurisprudência. Daí a conclusão de Piero Calamandrei, no sentido de que a auctoritas rerum similiter iudicatarum (autoridade decorrente das decisões semelhantes), ainda que não se a considere como fonte do direito objetivo, exerce grande influência sobre o desenvolvimento prático do direito. ${ }^{49}$

Diante da pluralidade de órgãos judiciais decidindo simultaneamente inúmeras controvérsias semelhantes, as mesmas normas jurídicas, que deveriam ser únicas dentro de um mesmo Estado e na mesma época, passam a receber uma constante interpretação divergente, pela diversidade de influências regionais, concepções pessoais de cada julgador diante de questões novas etc. Essa divergência, inerente à realidade da organização judiciária de praticamente a todos os Estados, produz duas espécies de dano: um atual e um potencial.

O dano atual, que ocorre de imediato com o julgamento divergente das controvérsias envolvendo partes diversas, mas baseadas em circunstâncias fáticas idênticas ou semelhantes, traduz-se na violação ao princípio da igualdade. ${ }^{50}$

Por sua vez, o dano potencial diz respeito à possibilidade de a divergência afetar a todos os jurisdicionados, e não apenas aqueles que são partes nas causas semelhantes, por meio do comprometimento da unidade do direito, e, assim, a própria noção de Estado, gerando extrema incerteza nos jurisdicionados, quanto a qual interpretação devem tomar como base para as suas condutas. Afirma-se, assim, que a divergência jurisprudencial destrói a certeza do direito. ${ }^{51}$

\footnotetext{
${ }^{49}$ CALAMANDREI, Piero, La casación civil: bosquejo general del instituto, cit., v. 2, p. 77.

${ }^{50}$ Conforme Calamandrei, a divergência jurisprudencial destrói a igualdade do direito, pois "se os dois fatos particulares que, segundo a hipótese estabelecida, são juridicamente idênticos, recebem simultaneamente, no Estado onde está em vigor uma só norma, um tratamento jurídico profundamente diverso, resulta violado o princípio constitucional [...] segundo o qual os cidadãos são iguais perante a lei” (No original: "si los dos hechos particulares que, según la hipótesis estabelecida, son juridicamente identicos, reciben simultaneamente, en el Estado donde se halla en vigor una sola norma, un trato jurídico profundamente diverso, resulta violado el principio constitucional [..]) según el cual todos los ciudadanos 'son iguales ante la ley"'. (CALAMANDREI, Piero, La casación civil: bosquejo general del instituto, cit., v. 2, p. 79 nossa tradução).

${ }^{51}$ Ibidem, v. 2, p. 181.
} 
De fato, a divergência jurisprudencial transmite a ideia de que pelo menos parte dos juízes está desrespeitando o ordenamento jurídico, posto que, se a norma é única, e vale igualmente para todos na mesma situação fática, a divergência de soluções representa logicamente o desrespeito, pelo menos parcial, ao direito pelos juízes. Se a mesma norma encontra sentidos diversos para casos iguais, não sendo única no mesmo território e na mesma época, restam ameaçados os princípios da igualdade e da segurança jurídica (no sentido da certeza e unidade do direito) e, consequentemente, a própria noção de Estado de Direito.

Daí o peso e a importância da jurisprudência, bem como a necessidade de que ela seja uniforme, sob pena de se ameaçar a autoridade e unidade do direito e, portanto, do próprio Estado. Fica também revelado o interesse público do Estado em atuar sobre a atividade dos demais órgãos jurisdicionais para, fixando o sentido único do direito objetivo, controlar e evitar que, ao julgarem as controvérsias, desrespeitem as normas abstratas e produzam divergência jurisprudencial.

Essa finalidade poderia ser alcançada, por exemplo, pela instituição de um sistema de precedentes obrigatórios, típico dos ordenamentos anglo-americanos, em que a sentença tem valor de norma obrigatória para os casos sucessivos similares, de forma que o juiz apresenta-se como um verdadeiro criador do direito positivo (judge made law) e a decisão relativa a determinado caso produz o efeito de tornar impossível uma interpretação diversa da já alcançada em outro precedente (stare decisis).

No entanto, em razão das opções políticas relacionadas à tradição e base do ordenamento constitucional de cada país, nos sistemas de civil law o controle da jurisprudência é tradicionalmente feito pela instituição de um órgão jurisdicional superior, situado no topo da pirâmide da hierarquia judiciária, com a função de exercer, por meio de sua competência recursal extraordinária, a unificação da inteligência do direito positivo, dizendo a última palavra sobre a sua interpretação.

Por ora, pretende-se apenas colocar o problema da divergência jurisprudencial e a importância da jurisprudência nos sistemas de civil law; as características daquele sistema de controle pela via da instância extraordinária serão estudadas no Capítulo 3. 


\subsubsection{A regra da eficácia persuasiva}

A jurisprudência no Brasil, como nos sistemas de civil law em geral, não constitui, em regra, fonte do direito ${ }^{52}$, pela simples razão de que ela não é obrigatória, não apresentando qualquer coercitividade típica das normas legais, nem qualquer eficácia vinculante, mas apenas persuasiva.

Nesse sentido, Cândido Rangel Dinamarco leciona que "a influência dos precedentes jurisprudenciais reduz-se, nos sistemas jurídicos da família romano-germânica, à advertência dos riscos a que estão sujeitos os comportamentos divergentes", o que faz da jurisprudência, entre nós, "mais do que um conselho e menos do que uma ordem" "53. Tanto isso é verdade que, via de regra, as decisões contrárias à jurisprudência não são consideradas ilegítimas em nosso sistema.

Por sua vez, segundo Vicente Ráo, a jurisprudência não pode ser admitida como fonte do direito "porque, por maior que seja a influência dos precedentes judiciais, jamais eles adquirem o valor de uma norma obrigatória e universal". ${ }^{54}$

De fato, além de carecer do trinômio generalidade-impessoalidade-abstração, característico da norma legal, a jurisprudência não apresenta coercitividade, atuando como simples "meio suplementar de integração do Direito, sinalizando um paradigma para a

52 Fontes do direito, ou as "formas de expressão do direito", são, conforme André Franco Montoro, os "modos de expressar as regras da vida em comum", de forma que se distinguem "as fontes formais, isto é, os fatos que dão a uma regra o caráter de direito positivo e obrigatório, das fontes materiais, representadas pelos elementos que concorrem para a formação do conteúdo ou matéria da norma jurídica" (MONTORO, André Franco. Introdução à ciência do direito. 23. ed. São Paulo: Revista dos Tribunais, 1995. p. 323).

53 DINAMARCO, Cândido Rangel. A instrumentalidade do processo. 14. ed. rev. e atual. São Paulo: Malheiros, 2009. p. 129-131. Para Leonardo Greco, também a ausência de impositividade é razão suficiente para considerar que, nos sistemas de civil law, "a jurisprudência não é fonte formal" (GRECO, Leonardo, Instituições de processo civil, cit., v. 1, p. 42).

${ }^{54} \mathrm{O}$ autor explica que, mesmo nos casos em que, deparando-se com norma omissa ou lacunosa, o juiz decide o caso a partir de analogia ou dos princípios gerais, ele está, em última análise, aplicando norma que "já se achava subentendida ou admitida nas normas expressas, legislativas, não se podendo qualificar, por isso, como nova norma jurídica". E mesmo quando a lei excepcionalmente confere poder ao juiz para criar a norma aplicável ao caso concreto (o que se verifica naqueles casos em que a norma traz propositalmente conceitos vagos ou indeterminados), "forçoso é considerar-se que semelhante atribuição resulta da lei e, mais, que o preceito criado para cada caso não reveste força de norma geral e obrigatória, pois o mesmo juiz poderá aplicar preceito diverso a casos idênticos e futuros, se assim entender" (RÁO, Vicente. $O$ direito e a vida dos direitos. 5. ed. anotada e atual. por Ovídio Rocha Barros Sandoval. São Paulo: Revista dos Tribunais, 1999. p. 270). 
resolução de outros casos análogos, pendentes e futuros" ${ }^{\text {"55 }}$. Predomina, portanto, a regra da eficácia persuasiva da jurisprudência e dos precedentes judiciais. ${ }^{56}$

No direito brasileiro, esse entendimento é confirmado pela norma constitucional segundo a qual "ninguém será obrigado a fazer ou deixar de fazer alguma coisa senão em virtude de lei" (art. 5, II, da CF). Ao mesmo tempo, porém, a própria Constituição Federal aponta, a título de exceção, a força obrigatória da súmula vinculante. ${ }^{57}$

Quanto aos precedentes do STF formados em sede de controle concentrado e abstrato da constitucionalidade das normas, cujo efeito vinculante também está previsto na Constituição, destaca-se a peculiaridade de não decorrerem do julgamento de casos concretos (não se tratando, pois, de jurisprudência vinculante), mas sim de "processos objetivos", desprovidos de partes interessadas na defesa de seus direitos subjetivos, e que têm por finalidade o exercício do controle direto da constitucionalidade dos atos normativos.

Essa realidade do nosso direito constitucional positivo dispensa, sobretudo em razão dos limites deste trabalho, a necessidade de enfrentamento dos argumentos contrários aos precedentes obrigatórios (violação aos princípios da separação dos Poderes, da legalidade, do livre convencimento judicial, do contraditório e da ampla defesa; risco de petrificação da jurisprudência).

Se a hipótese de eficácia vinculante da jurisprudência (súmula vinculante) foi bem definida e demarcada, após longo e profundo debate político e jurídico, pela própria Constituição Federal (que aliás exige requisitos e procedimento próprio para a sua

\footnotetext{
${ }^{55}$ MANCUSO, Rodolfo de Camargo, Divergência jurisprudencial e súmula vinculante, cit., p. 76.

56 "A doutrina civilista pátria contemporânea, claramente dominada pelos influxos do condicionamento histórico, apresenta marcante tendência de admitir apenas eficácia persuasiva aos precedentes judiciais. [...] Realmente, entendemos também que os precedentes judiciais constituem valioso subsídio que auxilia hermenêutica de casos concretos, embora careçam de força vinculante. É importante relevar, a tal propósito, a constante possibilidade de revisão da jurisprudência sedimentada não apenas por iniciativa dos órgãos jurisdicionais, mas, igualmente, por provocação das partes interessadas.” (TUCCI, José Rogério Cruz e, Precedente judicial como fonte do direito, cit., p. 275).

${ }^{57}$ As súmulas vinculantes, assim, "são verdadeiras normas jurídicas que o Supremo Tribunal Federal edita, com um grau de generalidade e abstração inferior ao que as leis têm, mas com uma eficácia que transcende os casos postos em julgamento, como é próprio à jurisdição. Editar súmulas vinculantes, ou sumular, constitui portanto uma atividade normativa, não jurisdicional" (DINAMARCO, Cândido Rangel, $A$ instrumentalidade do processo, cit., p. 132).
} 
formação), pode-se concluir que, quanto aos demais casos, a jurisprudência e os precedentes, não obstante a sua grande importância, não constituem fonte formal do direito e não possuem eficácia vinculante.

Noutras palavras, a circunstância de a Constituição prever o princípio da legalidade como direito fundamental e ressalvar expressamente os casos em que a jurisprudência vincula representa argumento suficiente para excluir a legitimidade de quaisquer técnicas que, previstas em legislação infraconstitucional, pretendam atribuir eficácia vinculante à jurisprudência ou aos precedentes.

Assim, entendemos que o efeito vinculante, típico do common law, só existe entre nós quando autorizado expressamente pela Constituição Federal, não podendo ser simplesmente extraído por interpretação das demais regras e princípios nela encartados.

\subsubsection{Fundamentos para a valorização da jurisprudência}

Apesar do caráter predominantemente persuasivo, não se pode negar que no Brasil e em outros países de civil law, têm constantemente aumentado a importância e a força da jurisprudência.

De um modo geral, esse fenômeno iniciou-se a partir da passagem história ocorrida no final do século XIX (industrialização e favorecimento do Executivo) e início do século $\mathrm{XX}$, quando passaram a surgir problemas inéditos ao Judiciário, e também como decorrência das economias globalizadas das sociedades de comunicação, que geram fatos muito além da previsibilidade legislativa. ${ }^{58}$

A sociedade tornou-se muito mais complexa, de modo que a alteração das fontes substanciais do direito (dados culturais, econômicos, políticos e sociológicos) ocorre em velocidade muito superior à natural lentidão da produção legislativa. Consequentemente, passaram a ter grande importância no sistema as normas dotadas de conceitos vagos, que exigem interpretação judicial para serem concretizadas.

\footnotetext{
${ }^{58}$ PARENTE, Eduardo de Albuquerque, Jurisprudência: da divergência à uniformização, cit., p. 7-8.
} 
A complexidade da sociedade massificada não é apenas qualitativa, mas também quantitativa. Os litígios que versam sobre questões repetitivas multiplicam-se exponencialmente, de modo que, embora sejam individuais, escondem uma inegável dimensão coletiva.

Consequentemente, o problema da divergência jurisprudencial, embora seja um fenômeno natural, ganha proporções inaceitáveis e passa a afetar de forma mais drástica a estabilidade do sistema jurídico. Decisões divergentes poderão, em determinados casos, representar na prática a coexistência de inúmeras normas jurídicas divergentes, afetando gravemente os princípios da igualdade e da segurança jurídica, além do princípio da razoável duração do processo.

Analisemos, assim, o conteúdo desses dispositivos, a fim de demonstrar em que medida eles justificam a positivação de técnicas de ampliação da eficácia da jurisprudência como forma de uniformizar o sentido das normas jurídicas, bem como de acelerar e tornar mais eficiente a prestação jurisdicional.

\subsubsection{Igualdade}

A primeira parte do caput do artigo $5^{\circ}$ da Constituição Federal, constante no Título relativo aos "Direitos e Garantias Fundamentais", contém a seguinte redação: "Todos são

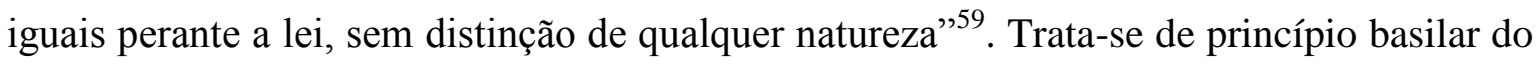
sistema, constituindo "o signo fundamental da democracia"60 e "o centro medular do Estado social e de todos os direitos de sua ordem jurídica". ${ }^{61}$

O princípio está endereçado, em primeiro lugar, ao legislador, proibindo a criação de normas legais que dispensem tratamento diferenciado a alguém, e impondo a criação de

\footnotetext{
${ }^{59} \mathrm{O}$ que significa tratar igualmente os iguais e, ao mesmo tempo, desigualmente os desiguais, na medida dessa desigualdade.

${ }^{60}$ SILVA, José Afonso da. Curso de direito constitucional positivo. 24. ed. rev. e atual. São Paulo: Malheiros, 2005. p. 211.

${ }^{61}$ BONAVIDES, Paulo. Curso de direito constitucional. 8. ed. São Paulo: Malheiros, 1999. p. 340.
} 
normas preservem ou recomponham positivamente a igualdade entre os sujeitos das relações jurídicas. ${ }^{62}$

No entanto, não basta que a norma legal - geral e abstrata - respeite o princípio da igualdade. Para que o princípio da igualdade tenha algum sentido, é essencial que, na prática (isto é, no momento de concretização da norma legal, por meio da sua aplicação, pela Administração Pública ou pelo Poder Judiciário, na solução dos litígios), os iguais sejam efetivamente tratados da mesma forma.

Caso contrário, o princípio da igualdade seria totalmente inócuo, vazio. A norma legal seria criada com respeito ao tratamento isonômico entre todos, mas, no momento em que ela ganhasse vida, isto é, no momento em que realmente incidisse nas situações fáticas e concretas, a igualdade não seria observada, em face da sua interpretação e aplicação desigual pela Administração e pelo Poder Judiciário. Daí porque, segundo Celso Antônio Bandeira de Mello, "dúvida não padece que, ao se cumprir uma lei, todos os abrangidos por ela hão de receber tratamento parificado". 63

Nesse sentido, se, por exemplo, uma lei institui um tributo, não é possível que uma pessoa seja obrigada a pagá-lo, mas outra, em situação fática exatamente igual, não o seja. Situações como essa, que podem muito bem ocorrer, e ocorrem, em razão da possibilidade de divergência na interpretação das normas jurídicas pelos órgãos da Administração e do Judiciário, ferem o princípio constitucional da igualdade.

Fala-se, assim, em igualdade judiciária, que, em uma de suas vertentes ${ }^{64}$, impõe também ao Poder Judiciário a interpretação e a aplicação de uma norma jurídica sempre da mesma forma para casos idênticos. Nesse sentido, o princípio da igualdade constitui "uma regra de interpretação para o juiz, que deverá sempre dar à lei o entendimento que não crie

\footnotetext{
${ }^{62}$ BONAVIDES, Paulo, Curso de direito constitucional, cit., p. 343.

${ }^{63}$ MELLO, Celso Antonio Bandeira de. O conteúdo jurídico do princípio da igualdade. 3. ed., 8. tiragem. Malheiros: São Paulo, 2000. p. 10.

${ }^{64} \mathrm{O}$ princípio da igualdade em relação à atividade jurisdicional também tem o sentido de igualdade processual, no sentido de "paridade de armas". Aqui, a norma impõe que as partes litiguem em igualdade de condições, o que muitas vezes exige, em razão das diferenças materiais entre elas, um tratamento diferenciado, a fim de equiparar suas chances de vencer o litígio. O sentido de que estamos falando é diverso, pois refere-se à interpretação das normas a serem aplicadas aos casos concretos pelo Poder Judiciário.
} 
distinções", caracterizando, assim, uma "interdição ao juiz de fazer distinção entre situações iguais, ao aplicar a lei". ${ }^{65}$

Ou seja, extrai-se do princípio constitucional da igualdade o preceito de que não só as normas devem tratar todos de forma isonômica, sem qualquer distinção, mas também que o Poder Judiciário deve interpretar as normas, no momento de sua aplicação aos casos concretos, de forma isonômica, pois é isso que garantirá efetivamente um tratamento igualitário de todos perante a lei.

Ocorre que, como já exposto, a divergência na interpretação e aplicação da lei aos casos concretos (a divergência jurisprudencial) é uma realidade insuperável, sendo impossível garantir que os diversos órgãos judiciais, ao julgar os casos envolvendo questões idênticas, realizem a mesma interpretação. ${ }^{66}$

Conforme tragam conceitos minuciosos ou vagos, as normas admitirão maior ou menor divergência na sua interpretação. Quando os conceitos são minuciosos, a tolerância quanto à divergência é menor, posto que se o comando legal é claro e preciso, não há qualquer razão para que o juiz o desobedeça, sob pena de se ter uma clara violação à sua função jurisdicional de julgar conforme o direito. ${ }^{67}$

Já quando a norma traz conceitos vagos, a serem concretizados pelo juiz à luz das peculiaridades de cada caso, é mais tolerável e esperado que, num primeiro momento, haja

\footnotetext{
${ }^{65}$ SILVA, José Afonso da, Curso de direito constitucional positivo, cit., p. 218.

${ }^{66} \mathrm{Na}$ verdade, conforme Rodolfo de Camargo Mancuso, "a divergência jurisprudencial, tomada de per si, não configura 'um mal nem um bem', apenas se apresentando como uma contingência previsível, num sistema jurisdicional como o nosso", de forma que o problema não é, na verdade, "com a essência desse fenômeno, mas com a forma, a intensidade ou as consequências dele em face dos destinatários ou, se se quiser, dos consumidores da prestação jurisdicional", ou seja, com "o crescimento desmesurado, despropositado e incontrolado dessa divergência" (MANCUSO, Rodolfo de Camargo, Divergência jurisprudencial e súmula vinculante, cit., p. 130).

${ }^{67}$ Quando se trata de norma minuciosa - na qual o legislador não transfere ao julgador qualquer poder criativo, preferindo, antes, regular precisamente determinada situação fática de forma a lhe conferir maior estabilidade - é menos aceitável a divergência jurisprudencial. Nesse caso, por não se admitir margem alguma de liberdade ao julgador, a divergência causa perplexidade, eis que nada justifica o reconhecimento de um direito a um jurisdicionado, e a sua negação a outro. "Em casos como estes, é nefasto para o sistema e para os jurisdicionados que haja decisões conflitantes", de forma que nem no mesmo momento histórico nem ao longo do tempo deve-se permitir a divergência, pois "a forma como a norma foi redigida não permite ao intérprete que leve em conta 'variações' da sociedade e dos costumes para incidir” (WAMBIER, Teresa Arruda Alvim. Recurso especial, recurso extraordinário e ação rescisória. 2. ed. São Paulo: Revista dos Tribunais, 2008, p. 143).
} 
alguma divergência. No entanto, mesmo aqui se fala em regra projetadamente "destinada a comportar somente um entendimento, desde que presentes, rigorosamente, as mesmas e idênticas condições" ${ }^{\prime 68}$, de forma que, com a repetição da situação e a reiteração da sua análise pelo Judiciário, impõe-se a estabilização paulatina da sua interpretação. ${ }^{69}$

Além da questão das normas dotadas de conceitos vagos ${ }^{70}$, destaca-se o impacto do neoconstitucionalismo sobre a atividade de interpretação do direito, pois esse movimento impõe a interpretação da norma sempre à luz da Constituição e, sobretudo, dos direitos fundamentais. Isso obviamente amplia o risco de subjetividade das decisões judiciais e, consequentemente, de divergência jurisprudencial. ${ }^{71}$

Ambos os fenômenos (normas dotadas de conceitos vagos e neoconstitucionalismo) conferem maior margem de liberdade ao Judiciário na interpretação da norma. Se o legislador não traz conceitos minuciosos, e se o juiz deve exercer o controle constitucional das normas a cada julgamento (controle difuso e concreto de constitucionalidade), o método dedutivo revela-se insuficiente (pois o sentido do direito não está claro na lei, não sendo suficiente a sua mera aplicação), exigindo a adoção do método indutivo (que se legitima pelo discurso, pela argumentação).

Isso significa que a jurisprudência passa inevitavelmente a exercer uma função normativa: com a repetição de julgamentos sobre casos semelhantes, ou o surgimento de verdadeiros precedentes a respeito da aplicação da norma, as decisões atribuem sentido e integram a norma geral. Ainda que não possa ser equiparada à lei, por lhe faltar o caráter coercitivo, a jurisprudência passa a nortear, de modo geral, as condutas dos cidadãos.

68 ARRUDA ALVIM, José Manoel de. Arguição de relevância no recurso extraordinário. São Paulo: Revista dos Tribunais, 1988. p. 21.

69 "Se estas válvulas ou poros, a que nos referimos anteriormente dão certa margem de liberdade ao juiz, para que decida de forma mais rente e adaptada aos casos concretos, é imperioso que, uma vez delineada a regra, haja um movimento da jurisprudência no sentido de segui-la. Só assim se preserva a igualdade, criando-se estabilidade e previsibilidade." (WAMBIER, Teresa Arruda Alvim, Estabilidade e adaptabilidade como objetivos do direito: civil law e common law, cit., p. 145).

70 “'...] diante da percepção do inevitável envelhecimento e esgotamento das disposições legislativas, tornouse clara a necessidade de a lei conter espaços capazes de dar ao juiz o poder de adaptação da norma às novas realidades e valores. Surge, a partir daí, a noção de cláusulas gerais, vista como técnica legislativa que se contrapõe à técnica casuística [...] as cláusulas gerais são caracterizadas por vagueza ou imprecisão de conceitos, tendo o objetivo de permitir o tratamento de particularidades concretas e de novas situações, inexistentes e imprevisíveis à época da elaboração da norma." (MARINONI, Luiz Guilherme, Precedentes obrigatórios, cit., p. 152).

${ }^{71}$ MARINONI, Luiz Guilherme, Precedentes obrigatórios, cit., p. 162-166. 
Diante desse caráter normativo assumido pela jurisprudência, as mesmas razões que impõem a observância do princípio da igualdade pelo legislador aplicam-se à função do juiz.

Nesse sentido, Piero Calamandrei já há muito tempo afirmava, quanto às normas dotadas de conceitos vagos e elásticos - as quais são as válvulas de segurança ou os órgãos respiratórios do direito objetivo, que lhe permitem alimentar-se de oxigênio sempre novo, adaptando-se com elasticidade e rapidez às variações da atmosfera que o circundam -, que a necessidade prática de se atingir a igualdade e a certeza do direito por meio de uma jurisprudência uniforme manifesta-se em grau superlativo nos casos em que, para a melhor formulação de alguns conceitos jurídicos, o legislador deliberadamente conta com a cooperação do juiz. ${ }^{72}$

Daí a importância dos instrumentos disponibilizados pelo sistema para a uniformização da jurisprudência e, entre eles, dos recursos excepcionais, de competência dos órgãos de cúpula, cuja função precípua é justamente fixar o sentido único do direito federal, para que ele possa ser aplicado uniformemente em todo o território nacional. ${ }^{73}$

Mas não basta a fixação do sentido único das normas, nem a possibilidade da correção de decisões que o desrespeite. Para que o princípio da igualdade seja realmente observado, é necessário estimular ou até impor que a interpretação fixada pelos Tribunais Superiores seja efetivamente observada pelos órgãos inferiores, evitando-se, na medida do possível, decisões divergentes.

Conforme Luiz Guilherme Marinoni, "é preciso impedir que haja uma multiplicidade de normas jurídicas para casos iguais, gerando insegurança e desigualdade. Aplica-se aí, literalmente, a máxima do common law, no sentido de que casos iguais devem ser tratados da mesma forma (treat like cases alike)". 74

\footnotetext{
${ }^{72}$ CALAMANDREI, Piero, La casación civil: bosquejo general del instituto, cit., v. 2, p. 97.

${ }^{73}$ Andrea Proto Pisani fala do valor da uniformidade da jurisprudência como imposição do princípio da igualdade, porque esse princípio é gravemente lesado se, no mesmo período histórico, os juízes de um mesmo país situados em comarcas diferentes interpretam determinada disposição legal de modos diversos (PISANI, Andrea Proto. Principio d'eguaglianza e ricorso per cassazione. Revista de Processo, São Paulo, v. 36, n. 191, p. 206, jan. 2011).

${ }^{74}$ MARINONI, Luiz Guilherme, Precedentes obrigatórios, cit., p. 154.
} 
Diante disso, é fácil constatar a importância das técnicas que visam ampliar a eficácia da jurisprudência ou dos precedentes, para permitir a aplicação da mesma solução aos casos iguais. $^{75}$

Obviamente, essa finalidade pode ser atingida com maior rendimento nos sistemas em que vige o stare decisis, ou seja, em que apenas excepcionalmente os precedentes, tidos por obrigatórios, podem ser abandonados. ${ }^{76}$

De qualquer modo, mesmo nos sistemas de civil law, em que a jurisprudência não tem, em regra, essa força vinculante, as técnicas que ampliam a sua eficácia persuasiva contribuem fortemente para a concretização da igualdade, eis que, na prática, elas aumentam a chance de decisões iguais para casos iguais. Daí a legitimidade e grande importância de, também nos sistemas de civil law, serem previstas técnicas de atribuição de maior força à jurisprudência ou aos precedentes: é isso que garantirá o tratamento judiciário isonômico das situações idênticas ou semelhantes.

\subsubsection{Segurança jurídica}

A Constituição Federal refere-se à segurança em seu artigo $5^{\circ}$, caput, erigindo-a a condição de direito fundamental. Embora não se fale ali em segurança jurídica, é inegável que se trata de princípio básico e elementar do Estado Democrático de Direito, o qual só existe se o ordenamento jurídico e o sistema jurisdicional destinado a protegê-lo proporcionarem previsibilidade e estabilidade, elementos que integram a segurança jurídica.

Por previsibilidade deve-se entender a aptidão do direito de preestabelecer pautas de conduta bem definidas aos cidadãos que, nelas depositando a sua confiança, poderão nortear suas ações e fundamentar suas expectativas em relação às ações de terceiros

\footnotetext{
75 “Ora, o elemento crucial que efetivamente justifica a recepção analógica da decisão anterior para a solução da hipótese posterior é o 'princípio da universalidade', entendido como uma exigência natural de que casos substancialmente iguais sejam tratados de modo semelhante. É ele, com efeito, o componente axiológico que sempre revestiu a ideia de Justiça 'como qualidade formal'." (TUCCI, José Rogério Cruz e, Precedente judicial como fonte do direito, cit., p. 25).

${ }^{76}$ Por exemplo, na Inglaterra, o sistema de precedentes vinculantes é aplicado de forma muito rígida, justamente em nome do princípio da igualdade (WAMBIER, Teresa Arruda Alvim, Estabilidade e adaptabilidade como objetivos do direito: civil law e common law, cit., p. 131).
} 
(incluindo o próprio Estado) ${ }^{77}$. Trata-se, como se vê, de uma dimensão mais subjetiva da segurança jurídica.

Como a aplicação da lei exige interpretação, não é suficiente para a previsibilidade que aquela pauta de conduta esteja definida nos textos legais; é necessário que ela decorra também da jurisprudência ${ }^{78}$. De nada adianta um ordenamento sólido, unívoco e coerente se, ao concretizá-lo à luz das situações fáticas relativas aos conflitos de interesse, o Poder Judiciário apresenta respostas divergentes e incoerentes. Segundo Luiz Guilherme Marinoni, "porque a inteligência de uma norma pode ser controvertida, é claro que a norma em abstrato não é suficiente para que o cidadão possa prever o comportamento dos terceiros que com ele podem se deparar". 79

Com isso, fica fácil observar que da previsibilidade decorrem a certeza do direito e a proteção da confiança.

No contexto em que estamos tratando, a certeza do direito exige a uniformidade da jurisprudência, pois é impossível prever a interpretação que será dada a determinada situação concreta se não há consenso pelo Poder Judiciário a seu respeito e os tribunais mudam a todo momento de entendimento quanto à mesma situação. ${ }^{80}$

77 “O princípio da segurança jurídica é um dos pilares de sustentação do Estado Democrático de Direito e seu objetivo é proteger e preservar as justas expectativas das pessoas.” (DANTAS, Bruno. A jurisprudência dos tribunais e o dever de velar por sua uniformização e estabilidade. Revista de Informação Legislativa, Brasília, v. 48, n. 190 t. 1, p. 64, abr./jun. 2011).

${ }^{78}$ Segundo Eduardo Cambi, "quando uma mesma regra ou princípio é interpretado de maneira diversa por Juízes ou Tribunais em casos iguais, isso gera insegurança jurídica, pois, para o mesmo problema, uns obtêm e outros deixam de obter a tutela jurisdicional. [...] Dessa maneira, a efetivação do valor segurança jurídica - pela clara previsão dos direitos, deveres e obrigações, bem como dos modos pelos quais devem ser exercidos ou cumpridos - é um valor imprescindível ao convívio social" (CAMBI, Eduardo. Jurisprudência lotérica. Revista dos Tribunais, São Paulo, v. 90, n. 786, p. 111-112, abr. 2001).

${ }^{79} \mathrm{O}$ autor chega a afirmar ser “evidente que a segurança jurídica está ligada à decisão judicial e não à norma jurídica em abstrato. Não é por outra razão que Massimo Corsale concluiu que, para que se possa realizar a certeza da ação através do direito, o que conta, em última análise, não é tanto a fórmula escrita no código, a norma abstrata, mas a dita norma individual, a concretização da regra no caso específico" (MARINONI, Luiz Guilherme, Precedentes obrigatórios, cit., p. 126).

80 “Uma das funções primordiais do Direito, na dinâmica judiciária, é de fornecer a 'certeza do Direito', entendida como aquela consistente na possibilidade, proporcionada aos jurisdicionados de que, através de um instrumento, haja o caminho capaz de estabelecer a maior previsibilidade possível. A atividade jurisdicional, no seu conjunto, deve proporcionar e traduzir essa certeza, havendo de resultar da tarefa de se dizer o Direito, no seu todo, um panorama de decisões apreciavelmente coincidentes sobre os mesmos temas. [...] Se o comando da lei é um só, deve ser uno, inclusive, e, principalmente, na ordem prática, mas se é entendido diferentemente, em face da mesma norma, ainda que essa seja destinada a encerrar uma conduta, num mesmo instante histórico, acaba essa diversidade por representar uma multiplicidade de 
Por sua vez, o princípio da proteção da confiança está ligado ao da segurança jurídica e da previsibilidade, na medida em que não há como prever sem confiar, da mesma forma como não é possível confiar sem previsibilidade. Desse modo, é dever do Estado "proteger a confiança do cidadão em relação às consequências das suas ações e às reações dos terceiros diante dos seus atos, assim como no que diz respeito aos efeitos dos atos do poder público". E se há previsibilidade quanto à resposta judiciária a ser dada a determinada situação, estará tutelada a confiança que o cidadão deposita no Estado. ${ }^{81}$

Quanto à estabilidade, mais ligada à dimensão objetiva da segurança jurídica, é necessário que a lei e a jurisprudência sejam estáveis, isto é, tenham um mínimo de continuidade, proporcionando-se um Estado de Direito consolidado, e não provisório. ${ }^{82}$

Abra-se um parêntese para se anotar que a segurança jurídica, assim como a certeza do direito, a proteção da confiança e a estabilidade são valores que também estão relacionados ao instituto da coisa julgada. Nesse caso, porém, a segurança atua em outra dimensão, relativa à definição da norma incidente ao caso concreto e sua estabilização, imunizando-a contra futuras pretensões de rediscussão. Trata-se da segurança vista sob o prisma do titular do direito discutido em juízo, e não de todos os cidadãos.

Já a segurança jurídica relacionada à previsibilidade do direito - e, portanto, das respostas judiciárias - relaciona-se ao cidadão enquanto jurisdicionado, ou seja, enquanto sujeito às decisões do Poder Judiciário.

Advirta-se, porém, que essa segurança jurídica que exige a uniformidade da jurisprudência não significa que esta nunca possa ser alterada. Nem a certeza do direito nem a estabilidade são absolutas. Na verdade, o julgado pode e deve distanciar-se da

\footnotetext{
comandos, o que, se de uma parte é inevitável, de outra, é indesejável, por comprometer a 'certeza do Direito'." (ARRUDA ALVIM, José Manoel de, Arguição de relevância no recurso extraordinário, cit., p. 33). No mesmo sentido: "A uniformização da jurisprudência impõe-se, portanto, como uma necessidade social, a fim de assegurar a estabilidade da ordem jurídica. [...] Se os magistrados mantiverem entendimentos diversos na aplicação da mesma norma jurídica, deixarão de ser a voz da lei, porque esta não pode ter dois comandos antagônicos. Para alcançar a unidade na aplicação da lei, é indispensável armar o Poder Judiciário de um instrumento apto a manifestar um entendimento uniforme simultâneo, que não exclui uma interpretação variada sucessiva." (BUZAID, Alfredo. Uniformização da jurisprudência. Ajuris, Revista da Associação dos juízes do Rio Grande do Sul, Porto Alegre, v. 12, n. 34, p. 211, jul. 1985).

${ }^{81}$ MARINONI, Luiz Guilherme, Precedentes obrigatórios, cit., p. 137.

${ }^{82}$ Ibidem, p. 131.
} 
jurisprudência predominante contemporânea nos casos de alteração das fontes substanciais da norma legal, ou quando sobrevenha direito novo. Nesses casos, não há violação à segurança jurídica, pois, justamente por serem pontos de distinção, essas circunstâncias viabilizam a previsão de que o caso não seguirá necessariamente a jurisprudência até ali formada, legitimando, portanto, uma decisão em sentido diverso.

Conforme Alfredo Buzaid, o que preocupa é a "divergência simultânea", isto é, que "sobre a mesma regra jurídica deem os tribunais interpretação diversa e até contraditória, quando as condições em que ela foi editada continuam as mesmas", pois a divergência, nesse caso, “debilita a autoridade do Poder Judiciário, ao mesmo passo que causa profunda decepção às partes que postulam perante os tribunais”. Dessa forma, o autor afirma que "enquanto forem as mesmas condições em que surgiu o direito, a tendência é a sua certeza, assegurada pela estabilidade de sua interpretação constante pelos tribunais". ${ }^{83}$

Analisando a questão da segurança jurídica sob o ponto de vista econômico-social, Arnold Wald menciona a exigência de interpretação uniforme pelos tribunais, "para que as empresas possam planejar o seu futuro e fazer os investimentos necessários e imprescindíveis para a sua sobrevivência numa economia globalizada, dinâmica e cada vez mais competitiva". ${ }^{84}$

Assim, o princípio da segurança jurídica justifica e exige a adoção de mecanismos aptos a uniformizar a jurisprudência, sobretudo por meio da fixação, pelos Tribunais Superiores, do sentido único das normas jurídicas a serem aplicadas em todo o território nacional, proporcionando previsibilidade às respostas judiciárias. Também nesse caso, porém, não basta corrigir a divergência já instaurada, sendo necessário, na medida do possível, estimular preventivamente a uniformidade na interpretação do direito, o que se obtém por meio das técnicas de potencialização da jurisprudência.

É o que ocorre no sistema de common law, em que a exigência de previsibilidade apresenta-se como uma das principais razões para a atribuição de força vinculante aos

\footnotetext{
${ }^{83}$ BUZAID, Alfredo, Uniformização da jurisprudência, cit., p. 192.

${ }^{84}$ WALD, Arnoldo. Eficiência judiciária e segurança jurídica: a racionalização da legislação brasileira e reforma do Poder Judiciário. In: MACHADO, Fábio Cardoso; MACHADO, Rafael Bicca (Coords.). A reforma do Poder Judiciário. São Paulo: Quartier Latin, 2006. p. 56.
} 
precedentes. ${ }^{85}$ Nesse sentido, Antonio Carlos Marcato, ao comentar a doutrina do stare decisis, afirma que "com a garantia da estabilidade, o uso do precedente também atua no sentido de conferir segurança jurídica e proteção de confiança na aplicação do Direito". ${ }^{86}$

Mas as técnicas de ampliação da eficácia persuasiva da jurisprudência nos sistemas de civil law também contribuem para a concretização do princípio da segurança jurídica, na medida em que, na prática, fazem com que as decisões sejam efetivamente respeitadas no julgamento de casos sucessivos versando sobre questões idênticas.

\subsubsection{Razoável duração do processo}

Com a promulgação da Carta de 5 de outubro de 1988, a garantia à concessão da tutela jurisdicional em tempo razoável, que já podia ser deduzida das regras insertas na legislação processual, ganhou status constitucional, pois passou a ser implicitamente prevista nas cláusulas do devido processo legal (art. $5^{\circ}$, LIV) e da inafastabilidade do controle jurisdicional ou acesso à justiça $\left(\operatorname{art} .5^{\circ}, \mathrm{XXXV}\right) .{ }^{87}$

Sem prejuízo, o princípio da razoável duração do processo acabou sendo incorporado explicitamente ao nosso ordenamento jurídico pelo Decreto n. 678, de 6 de novembro de 1992, que promulgou a Convenção Americana sobre Direitos Humanos (Pacto de São José da Costa Rica), adotada no âmbito da Organização dos Estados Americanos. $^{88}$

\footnotetext{
85 “Constitui lugar comum, na literatura inglesa e estadunidense, a afirmação de que a previsibilidade constitui razão para seguir precedentes. O stare decisis é visto como um instituto disciplinado para garantir a segurança jurídica.” (MARINONI, Luiz Guilherme, Precedentes obrigatórios, cit., p. 128).

${ }^{86}$ MARCATO, Antonio Carlos, Crise da justiça e influência dos precedentes judiciais no direito processual civil brasileiro, cit., p. 157.

${ }^{87}$ Conforme Cândido Rangel Dinamarco: “Ao definir e explicitar muito claramente garantias e princípios voltados à tutela constitucional do processo, a nova Constituição tornou crítica a necessidade não só de realizar um processo capaz de produzir resultados efetivos na vida das pessoas (efetividade da tutela jurisdicional), como também de fazê-lo logo (tempestivamente) e mediante soluções aceitáveis segundo o direito posto e a consciência comum da nação (justiça). Efetividade, tempestividade e justiça são os predicados essenciais sem os quais não é politicamente legítimo o sistema processual de um país (Kazuo Watanabe)." (DINAMARCO, Candido Rangel. A reforma da reforma. São Paulo: Malheiros, 2002. p. 29).

${ }^{88}$ Conforme o artigo $8^{\circ}, 1$, do referido Pacto, agregado ao rol de direitos fundamentais entre nós vigentes (art. $5^{\circ}, \S 2^{\circ}$, da $\mathrm{CF} / 88$ ), trouxe, a título de “Garantias judiciais”, o seguinte direito: “1. Toda pessoa terá o direito de ser ouvida, com as devidas garantias e dentro de um prazo razoável, por um juiz ou Tribunal competente, independente e imparcial, estabelecido anteriormente por lei, na apuração de qualquer acusação penal formulada contra ela, ou na determinação de seus direitos e obrigações de caráter civil, trabalhista, fiscal ou de qualquer outra natureza."
} 
Em 2004, a Emenda Constitucional n. 45 acrescentou o inciso LXXVIII ao rol de garantias fundamentais previsto pelo artigo $5^{\circ}$ da Constituição, segundo o qual "a todos, no âmbito judicial e administrativo, são assegurados a razoável duração do processo e os meios que garantam a celeridade de sua tramitação".

Com isso, a norma da razoável duração do processo, que já podia ser deduzida claramente dos demais princípios constitucionais vigentes, deixou de ser princípio implícito para integrar explicitamente o rol de garantias constitucionais, passando a ser inquestionável a necessidade de sua observância, independentemente de qualquer interpretação sistemática.

Ao contrário do que se poderia à primeira vista imaginar, a norma constitucional garante não apenas a celeridade processual, mas também, e sobretudo, a eficiência da atividade jurisdicional. Isso porque as ideias de celeridade e de rapidez não são suficientes para a compreensão do princípio da razoável duração em toda a sua extensão.

Tanto é assim que a própria leitura do texto constitucional (art. $5^{\circ}$, LXXVIII, da $\mathrm{CF}$ ) revela que a norma traz duas garantias: a de que todos terão um processo administrativo ou judicial que dure um tempo razoável e a de que serão assegurados os instrumentos ou meios necessários para acelerar a sua tramitação. Ora, se os termos fossem sinônimos, o constituinte não teria utilizado duas expressões, já que entia praeter necessitatem non esse multiplicanda.

Nesse sentido, entendemos que, diferentemente da celeridade, a razoável duração do processo não busca obrigatoriamente a rapidez na prática do ato, mas sim a sua prática no tempo necessário para o cumprimento ideal da sua finalidade, nem mais, nem menos tempo. Surge aí a ideia de atos praticados com eficiência, e não necessariamente com celeridade. Atos praticados no melhor tempo, isso não significando atos praticados necessariamente no menor tempo. ${ }^{89}$

\footnotetext{
89 “Não se busca a celeridade da prestação jurisdicional a qualquer custo, o que se pretende é um processo em que sejam respeitadas todas as garantias, porém sem dilações indevidas ou inoportunas." (NOTARIANO JUNIOR, Antônio de Pádua. Garantia da razoável duração do processo. In: WAMBIER, Teresa Arruda Alvim et al. (Coords.). Reforma do judiciário: primeiros ensaios críticos sobre a EC n. 45/2004. São Paulo: Revista dos Tribunais, 2005. p. 61).
} 
Ou seja, a prática de cada ato com eficiência, antes da sua prática com vistas à mera celeridade, é o que efetivamente contribuirá para a consecução de um processo que dure tempo razoável. ${ }^{90}$

Em conferência proferida em abril de 2000, José Carlos Barbosa Moreira já ressaltava que consiste equívoco a estipulação, como remédio à crise de duração do processo, a busca cega e irrestrita por uma justiça rápida. Para o ilustre processualista, "uma justiça muito rápida" não será "necessariamente uma justiça boa". E o "que todos devemos querer é que a prestação jurisdicional venha a ser melhor do que é". ${ }^{91}$

No nosso entendimento, essa qualidade da tutela jurisdicional é o que efetivamente garante uma justiça em prazo razoável, pelo que o princípio insculpido no artigo $5^{\circ}$, LXXVIII, da Constituição Federal exige dos criadores e aplicadores do direito não só medidas céleres mas, muito mais do que isso, uma atuação jurisdicional eficiente, de qualidade $^{92}$, é dizer, comprometida, a cada ato do processo, com o alcance da sua finalidade com o melhor desempenho e ao menor custo possível (daí, também, a sua relação com a economia processual), pois só assim é que se poderá garantir, inteligentemente, a duração razoável do processo.

Nesse sentido, Arnold Wald leciona que "com a Emenda Constitucional n. 19, de 4 de julho de 1998, acrescentou-se que, além das suas outras características, a administração pública também deveria ser eficiente, cabendo, pois, à Justiça ser eficiente”. E, segundo o

90 É o que nos ensina William Santos Ferreira: “A razoável duração dos processos estabelecida no inciso LXXVIII do art. $5^{\circ}$ da Constituição Federal é muito mais que um comando de aceleração dos processos, porque intrinsecamente transmite que cada ato processual deve se dar da forma mais eficiente possível, para alcançar o fim a que se destina, do contrário, ter-se-ia uma dilação temporal ineficiente ou inútil." (FERREIRA, William Santos. Princípios fundamentais da prova cível. São Paulo: Revista dos Tribunais, 2014. p. 189).

${ }^{91}$ MOREIRA, José Carlos Barbosa. O futuro da justiça: alguns mitos. Revista de Processo, São Paulo, v. 25, n. 99, p. 141-144, jul./set. 2000.

92 Conforme Belmiro Jorge Patto, “a qualidade da decisão será capaz de exercer grande influência na dimensão temporal do processo", pois "o sistema possibilita, ele mesmo, quando a decisão não contém aqueles conteúdos necessários, o retardamento no tempo da efetivação da decisão, pois aumenta a possibilidade de recorribilidade, uma vez que o comando decisório não esclarece os termos indeterminados do conceito, gerando aquilo que é chamado na pragmática da comunicação de redundância, podendo acarretar sobrecarga no sistema que, in casu, traduz-se na morosidade" (PATTO, Belmiro Jorge. Aspetos da dimensão temporal do processo civil nas alterações advindas da EC n. 45, de 8 de dezembro de 2004. In: WAMBIER, Teresa Arruda Alvim et al. (Coords.). Reforma do judiciário: primeiros ensaios críticos sobre a EC n. 45/2004. São Paulo: Revista dos Tribunais, 2005. p. 103). 
autor, "a necessidade de o Poder Judiciário ser eficiente foi recentemente reiterada pela Emenda Constitucional n. 45, de 30 de dezembro de 2004, que deu nova redação ao art. $5^{\circ}$ da nossa Carta Magna, acrescentando-lhe o inciso LXXVIII". 93

Essas considerações sobre a caracterização do princípio da razoável duração do processo como exigência de um processo eficiente e de qualidade, antes que um processo meramente célere, ganha destacada importância quando se pensa na sua invocação como justificativa para a positivação de técnicas de ampliação da eficácia da jurisprudência.

Como veremos no item 2.4.3.4 infra, após a Emenda Constitucional n. 45, e a consequente conversão da razoável duração do processo em garantia expressa na Constituição Federal, uma série de instrumentos de potencialização da jurisprudência foram positivados no direito brasileiro, sob a justificativa de acelerar o procedimento.

No entanto, a verdade é que, além de estarem relacionados também, e de forma até mais intensa, aos princípios da igualdade e segurança jurídica, esses instrumentos justificam-se não tanto por razões de celeridade, mas sim por tornarem a prestação jurisdicional mais eficiente e racional.

De um lado, a solução do caso à luz da jurisprudência ou dos precedentes qualificados dispensa o órgão julgador do exame aprofundado - e consequentemente demorado - das questões jurídicas envolvendo a espécie. A tese já foi suficientemente desenvolvida em casos anteriores, tendo o Poder Judiciário firmado o entendimento definitivo sobre a questão, inclusive superando eventuais divergências, o que facilita e acelera o trabalho dos julgadores ao apreciar os casos sucessivos.

De outro lado, ao proporcionar a efetiva previsibilidade do direito, a existência de jurisprudência potencializada sobre a questão, que indique o modo como ela realmente será enfrentada pelo Poder Judiciário, desestimula a litigância e a interposição de recursos, pois as partes já sabem qual será o pronunciamento dos tribunais. Com menos demandas e

93 WALD, Arnoldo, Eficiência judiciária e segurança jurídica: a racionalização da legislação brasileira e reforma do Poder Judiciário, in A reforma do Poder Judiciário, cit., p. 51. 
recursos sobre questões já pacificadas, a atividade jurisdicional será racionalizada, contribuindo para a eficiência e a diminuição do tempo de duração dos processos. ${ }^{94}$

No mesmo sentido, a previsibilidade favorece a solução dos litígios por meio de acordos, na medida em que permite às partes envolvidas considerar seguramente as vantagens e desvantagens do litígio. A parte que tem conhecimento de que o Poder Judiciário solucionará sua demanda de acordo com a jurisprudência que lhe é desfavorável ficará logicamente mais propensa a ceder para viabilizar a realização de um acordo. E o acordo diminui o tempo do litígio, reduz o número de demandas e racionaliza a atividade do Judiciário.

A questão ganha ainda maior importância diante do crescente número de demandas idênticas sobre a mesma questão, com reflexos diretos sobre o número e a qualidade dos litígios. São milhares de demandas individuais e coletivas baseadas em situações fáticas idênticas, sendo evidente que o Poder Judiciário - e sobretudo os Tribunais Superiores, em razão de suas funções específicas (ver o Capítulo 3) - não analisará cada uma delas da mesma forma como analisou as primeiras, quando a questão jurídica pertinente ainda era inédita.

Naturalmente, uma vez enfrentada a questão por diversas vezes, e firmada a jurisprudência em determinado sentido, o Poder Judiciário deve passar a solucionar os próximos processos de forma mais rápida, econômica e eficiente, simplesmente aplicando a jurisprudência aos casos idênticos. ${ }^{95}$

\footnotetext{
${ }^{94}$ Conforme Luiz Guilherme Marinoni: “A previsibilidade das decisões judiciais certamente dissuade a propositura de demandas. Quando a parte que se julga prejudicada tem conhecimento de que o Judiciário não ampara a sua pretensão, esta certamente não gastará tempo e dinheiro em busca de uma tutela jurisdicional que, de antemão, sabe que lhe será desfavorável. Contudo, quando ao advogado não resta outra alternativa a não ser informar o seu cliente de que, no que diz respeito ao seu problema, o Judiciário já decidiu e tem decidido de várias formas, fica a parte com a viva impressão de que deve propor a demanda, arriscando obter uma decisão favorável. [...] Há nítida possibilidade de o Judiciário ser visto como casa lotérica, em que a aposta seja conveniente, mesmo pagando-se alto. Na verdade, o custo dessa loteria é mais alto para o Estado. Ao não corresponder à expectativa de confiança do cidadão, em virtude da indefinição de solução jurisdicional ao caso, o Judiciário fica obrigado a arcar com os custos das várias demandas que se aventuram à 'sorte judicial'. Diante desse acúmulo despropositado de serviço, a administração da justiça gera mais despesas, torna-se burocrática, lenta e, sobretudo, destituída de capacidade de conferir adequada atenção aos conflitos." (MARINONI, Luiz Guilherme, Precedentes obrigatórios, cit., p. 182).

95 “É fácil compreender - sobretudo por quem haja exercido, como o autor destas linhas, função judicante em segundo grau de jurisdição - o enfado com que os tribunais encaram a necessidade de ocupar-se, pela enésima vez, de questões jurídicas cuja solução já se pacificou na crônica jurisprudencial. A própria
} 
Isso não significa prestigiar apenas a rapidez, pois o que está por trás desse ganho de tempo é o aproveitamento da experiência e do trabalho já desenvolvido e aprofundado. Trata-se, como se vê, de racionalizar a atividade jurisdicional, para que ela seja mais rápida, econômica e, principalmente, mais eficiente. ${ }^{96}$

Nesse sentido, Edward Re afirma que o stare decisis foi recebido nos Estados Unidos por permitir, dentre outras funções benéficas, que se poupassem "os juízes da tarefa de reexaminar as regras de direito a cada caso subsequente" ${ }^{97}$. Ou seja, nos sistemas de common law, embora a rapidez e a eficiência não sejam os principais objetivo do sistema de julgamento a partir dos precedentes judiciais, esses valores também são destacados como uma das vantagens de se julgar os casos futuros idênticos com aproveitamento da experiência relativa aos casos anteriores.

Seguindo essa mesma linha de raciocínio, pode-se afirmar que as técnicas de potencialização da jurisprudência contribuem para tonar mais rápida, econômica e, principalmente, eficiente a prestação jurisdicional, com o que se dá concretude ao princípio previsto no artigo $5^{\circ}$, LXXVIII, da Constituição Federal.

\subsubsection{Tendência de ampliação da força da jurisprudência e as diferentes acepções de "eficácia vinculante" no direito processual civil brasileiro}

Os fatores mencionados no item 2.4.3 supra justificam a adoção de técnicas que ampliam a eficácia da interpretação judicial realizada no julgamento dos casos concretos

exigência de racionalização do serviço recomenda que se coíba a reiteração ad infinitum de tentativas de ressuscitar, sem qualquer motivo sério, discussões mortas e enterradas. Não há vantagem prática em obrigar, por exemplo, o Supremo Tribunal Federal a gastar tempo e energias, que poderiam ser mais bem aproveitados, na incessante repetição de coisas ditas e reditas a propósito de um mesmo assunto." (MOREIRA, José Carlos Barbosa. Algumas inovações da Lei 9.756 em matéria de recursos cíveis. In: WAMBIER, Teresa Arruda Alvim; NERY JUNIOR, Nelson. (Coords.). Aspectos polêmicos e atuais dos recursos cíveis de acordo com a Lei 9.756/98. São Paulo: Revista dos Tribunais, 1999. p. 325).

96 "Se, ao respeitar precedentes, o sistema torna o processo mais célere e barato, não há dúvida que o Poder Judiciário afigura-se mais eficiente. [...] O respeito aos precedentes é imprescindível para a atribuição de racionalidade ao sistema, fazendo com que o desenvolvimento do processo imediatamente cesse quando a definição do caso depender da análise de questão de direito definida por tribunal superior. Nessa perspectiva, o respeito aos precedentes constitui elemento garantidor da eficiência e da legitimidade democrática do Poder Judiciário.” (MARINONI, Luiz Guilherme, Precedentes obrigatórios, cit., p. 190).

${ }^{97}$ RE, Edward D., "Stare decisis", cit., p. 8. 
também nos sistemas de civil law, gerando uma crescente "expansão da carga eficacial da jurisprudência para além dos lindes propriamente forenses". 98

As decisões judiciais passam a desempenhar cada vez mais a dupla função de solucionar o caso concreto e, na medida em que formem jurisprudência ou precedentes, fixar a tese jurídica a respeito de determinada questão, a fim de que o entendimento seja uniformemente aplicado aos inúmeros casos sucessivos em que a mesma questão se repete.

Assim, no Brasil e nos sistemas de civil law em geral, têm sido positivadas técnicas que, observados certos requisitos ou circunstâncias, ampliam a eficácia dos motivos determinantes da decisão (ratio decidendi), a fim de que eles se projetem para fora do processo, influenciando fortemente e até determinando (como no caso das súmulas vinculantes) o julgamento de casos semelhantes.

Com isso, a concepção tradicional individualista do processo, em que as decisões judiciais solucionam única e exclusivamente os casos nos quais elas são proferidas, vai cedendo a uma nova realidade, em que a interpretação judicial a respeito do direito objetivo, realizada pelos precedentes no julgamento de cada litígio, extrapola os limites do caso para influenciar, em maior ou menor grau, as decisões a serem proferidas em outros casos, ganhando, assim, uma dimensão coletiva.

Frise-se que isso nada tem a ver com a ampliação dos limites subjetivos e objetivos da coisa julgada material. Autoridade do precedente e coisa julgada são assuntos distintos, tanto que no próprio common law os institutos são tratados separadamente, e com escopos diferentes. Uma coisa é a autoridade da interpretação jurisdicional realizada pelos precedentes, a qual se relaciona com influência que ele exerce sobre a interpretação da mesma questão jurídica a ser realizada em casos sucessivos semelhantes. Outra coisa, bem diversa, é estabilizar, para as partes envolvidas no litígio, a decisão (ou até mesmo os

\footnotetext{
${ }^{98}$ MANCUSO, Rodolfo de Camargo, Divergência jurisprudencial e súmula vinculante, cit., p. 84.
} 
motivos determinantes, conforme as opções políticas de cada sistema) que solucionou a controvérsia. $^{99}$

O que se tem, portanto, é um movimento de crescente ampliação da eficácia da jurisprudência, cujo caráter meramente persuasivo, embora ainda seja predominante, tem sido potencializado e, em alguns casos, até substituído por uma força vinculante. ${ }^{100}$

Nesse sentido, adotando-se a classificação proposta pro Eduardo Talamini, fala-se na existência de três diferentes acepções de "vinculação" no direito positivo brasileiro. Nos dois extremos, estão as hipóteses de eficácia meramente persuasiva e de eficácia vinculante propriamente dita, e no plano intermediário tem-se a eficácia persuasiva ampliada por técnicas processuais diferenciadas.

No primeiro caso, tem-se a força meramente persuasiva de um determinado precedente ou da jurisprudência (qualificada ou não como dominante ou sumulada). Falase, aqui, em "vinculação persuasiva"101 ou "vinculação fraca"102, mas não existe propriamente uma espécie de vinculação, e sim aquela eficácia tradicional da jurisprudência observada nos sistemas de civil law, segundo a qual as decisões judiciais, sobretudo quando reiteradas, atuam como argumento de autoridade invocado pelas partes

\footnotetext{
99 "A qualidade que reflete a imutabilidade da decisão judicial em relação às partes - denominada coisa julgada - não se confunde com o stare decisis. A coisa julgada garante às partes a imutabilidade da decisão. $\mathrm{O}$ respeito aos precedentes confere aos jurisdicionados a estabilidade de dada interpretação. [...] No sistema americano, a coisa julgada divide-se em dois tipos - res judicata e collateral estoppel -, não se confundindo, em nenhuma de suas versões, com o stare decisis." (MARINONI, Luiz Guilherme, Precedentes obrigatórios, cit., p. 111). No mesmo sentido, Eduardo Talamini lembra que "a força vinculante apresenta-se inclusive em decisões não transitadas em julgado e, portanto, ainda não revestidas da coisa julgada (p. ex., liminares em ações diretas). Então, a força vinculante não é pura e simplesmente a coisa julgada erga omnes" (TALAMINI, Eduardo. Novos aspectos da jurisdição constitucional brasileira: repercussão geral, força vinculante, modulação dos efeitos do controle de constitucionalidade e alargamento do objeto do controle direto. Tese (Livre Docência) - Departamento de Direito Processual, Área de Direito Processual Civil, Faculdade de Direito da Universidade de São Paulo, São Paulo, 2008. p. 91).

100 "Em síntese, continuamos fiéis à posição romano-germânica de que a jurisprudência não é fonte formal de direito; é uma fonte complementar. Contudo, existe uma revolução forte no direito brasileiro no sentido de dar mais importância à jurisprudência, e até de obrigar os juízes e tribunais inferiores e a Administração Pública a respeitá-la, através das súmulas vinculantes e das súmulas impeditivas de recurso." (GRECO, Leonardo, Instituições de processo civil, cit., v. 1, p. 51).

${ }^{101}$ MARINONI, Luiz Guilherme; MITIDIERO, Daniel. Repercussão geral no recurso extraordinário. São Paulo: Revista dos Tribunais, 2007. p. 61.

102 TALAMINI, Eduardo, Novos aspectos da jurisdição constitucional brasileira: repercussão geral, força vinculante, modulação dos efeitos do controle de constitucionalidade e alargamento do objeto do controle direto, cit., p. 92.
} 
para influenciar a convicção do órgão julgador ou invocado pelo julgador a título de fundamentação da decisão a ser tomada nos casos sucessivos.

É importante ressaltar que, embora não obrigue o órgão julgador a seguir o precedente, essa eficácia persuasiva, justamente por consistir em argumento da parte, deve necessariamente integrar a fundamentação da decisão, sob pena de sua nulidade. Caso contrário, a eficácia será tão diminuta que nem mesmo em persuasão se poderá falar. ${ }^{103}$

No outro extremo, a acepção de vinculação refere-se à força vinculante propriamente dita, que desde muito cedo, com as Ordenações Manuelinas, fez parte da experiência do direito brasileiro, na figura dos assentos obrigatórios ${ }^{104}$. Os assentos foram extintos apenas com a Constituição Republicana de 1891, que pela primeira vez atribuiu ao Supremo Tribunal Federal a função de resolver, em sede definitiva, as questões relacionadas à autoridade e aplicação uniforme da Constituição e da legislação federal.

Em 1963, a partir das ideias do ministro Victor Nunes Leal, por meio de modificação do Regimento Interno da Corte, foi instituída a Súmula do Supremo Tribunal Federal, que autorizava o arquivamento monocrático, pelo relator, do recurso extraordinário e do agravo de instrumento que contrariassem o respectivo entendimento ${ }^{105}$. Mas ainda não se cogitava a força vinculante desses enunciados.

\footnotetext{
103 “O precedente, quando persuasivo, constitui um argumento da parte, e, por isso mesmo, não pode ser adotado ou rejeitado sem a devida fundamentação. Aliás, a desconsideração do precedente está, no mínimo, no mesmo plano do descaso em relação à prova, devendo gerar a nulidade da decisão. Enfim, apenas há eficácia persuasiva quando o precedente deve ser considerado pelo órgão judiciário, o que significa poder rejeitá-lo, mas sempre com a adequada justificativa." (MARINONI, Luiz Guilherme, Precedentes obrigatórios, cit., p. 118).

${ }^{104}$ Os assentos têm origem nas Ordenações Manuelinas, datadas de 1521, que determinavam o registro da interpretação oficial da lei, inclusive prevendo a suspensão dos julgadores que a descumprissem (Livro V, título 58, § $1^{\circ}$ ). Nas Ordenações Filipinas, de 1603, foram finalmente previstos os Assentos da Casa de Suplicação (Livro I, título V, $\S 5^{\circ}$ ), que eram anotados no "Livro da Relação", e que objetivavam fixar o verdadeiro sentido da lei, ganhando força de lei quando tomados na Mesa Grande (MANCUSO, Rodolfo de Camargo, Divergência jurisprudencial e súmula vinculante, cit., p. 219). Com a vinda da Família Real para o Brasil em 1808, iniciou-se o período do Reino-Unido, e a Relação do Rio de Janeiro foi elevada à condição de Casa de Suplicação, transformando-se no mais importante Tribunal de Justiça do país, com predicados idênticos aos da Casa de Suplicação de Lisboa, ou seja, "dar interpretação autêntica às leis e tomar assentos com força de lei". Conforme Antonio Carlos Marcato, "esses assentos, dotados de força vinculante - e dispensados, agora, da prévia aprovação pela Casa de Suplicação lisboeta - representaram o embrião das atuais súmulas vinculantes do Supremo Tribunal Federal" (MARCATO, Antonio Carlos, Crise da justiça e influência dos precedentes judiciais no direito processual civil brasileiro, cit., p. 125).

105 DINAMARCO, Cândido Rangel. O relator, a jurisprudência e os recursos. In: WAMBIER, Teresa Arruda Alvim; NERY JUNIOR, Nelson (Coords.). Aspectos polêmicos e atuais dos recursos cíveis de acordo com a Lei 9.756/98. São Paulo: Revista dos Tribunais, 1999. p. 129.
} 
No anteprojeto do CPC de 1973, elaborado por Alfredo Buzaid, chegou-se a prever que a decisão do STF (questão federal) e dos Tribunais de Justiça (direito local), tomadas por maioria absoluta, teria força obrigatória, enquanto não alterada por igual critério, e, editado o Assento, ele teria força de lei após 45 dias da sua publicação no órgão oficial. Tratava-se da volta dos assentos obrigatórios portugueses. Mas a proposta sofreu forte crítica, por se entender que, se implementada, seria considerada inconstitucional. ${ }^{106}$

Assim, a força vinculante propriamente dita veio a ser novamente admitida em nosso ordenamento a partir da Emenda Constitucional n. 7, de 13 de abril de 1977, que atribuiu competência ao STF para julgar representação para interpretação de lei ou de ato normativo federal ou estadual, prevendo-se por norma regimental a força vinculante e a eficácia erga omnes dessa interpretação.

Já sob a égide da Constituição de 1988, a Emenda Constitucional n. 3, de 17 de março de 1993, introduziu no sistema a ação declaratória de constitucionalidade, prevendo de forma expressa o efeito vinculante e eficácia erga omnes de suas decisões finais. ${ }^{107}$

Finalmente, com Emenda Constitucional n. 45/2004, foi instituída a súmula vinculante, oficializando-se o caráter vinculante da jurisprudência do STF, mas apenas quando convertida em súmula editada a partir de determinados requisitos.

Além disso, a mesma Emenda modificou o regime jurídico do efeito vinculante das decisões proferidas em ações de controle de constitucionalidade, com previsão expressa dessa eficácia em relação às ações direta de inconstitucionalidade e declaratória de constitucionalidade, e com a ampliação do campo de sua incidência aos demais órgãos do Poder Judiciário e à Administração Pública.

\footnotetext{
${ }^{106}$ Nesse contexto é que foi criado, em substituição aos assentos obrigatórios, o incidente de uniformização de jurisprudência (art. 476), considerado "uma solução a meio do caminho, mal ajambrada entre a força persuasiva (que a jurisprudência, de algum modo, sempre projeta) e a força vinculativa, que a súmula derivada daquele incidente não chega, propriamente, a alcançar" (MANCUSO, Rodolfo de Camargo, Divergência jurisprudencial e súmula vinculante, cit., p. 231).

${ }^{107}$ Essa eficácia vinculante foi, depois, estendida expressamente à ação direta de inconstitucionalidade pela Lei n. 9.868/99 e à arguição do descumprimento de preceito fundamental pela Lei n. 9.882/99. Note-se que, diante da peculiaridade desses processos objetivos, o STF reconheceu a constitucionalidade da Lei n. 9.868/1999 (QO Rcl n. 1.880), sob o fundamento principal da "similitude substancial de objetos nas ações declaratórias de constitucionalidade e direta de inconstitucionalidade".
} 
Assim, pode-se afirmar que atualmente a jurisprudência só tem eficácia vinculante propriamente dita nos casos de súmula vinculante (art. 103-A), além das decisões proferidas nos processos objetivos de controle abstrato de constitucionalidade (art. 102, § $\left.2^{\circ}\right)$.

Nesses casos, o próprio sistema normativo impõe coercitivamente a adoção desses provimentos pelos demais órgãos aplicadores do direito, inclusive sob pena de reclamação constitucional, aí residindo, portanto, o seu caráter excepcionalmente normativo e sua eficácia vinculante em sentido estrito.

No plano intermediário, tem-se a terceira acepção de vinculação, que está relacionada às hipóteses em que a existência de jurisprudência (qualificada como dominante ou sumulada) e de determinados precedentes (qualificados em razão do procedimento diferenciado de sua formação) autoriza, segundo a própria lei, a adoção pelo Poder Judiciário e pela Administração Pública de providências de simplificação do procedimento, e por consequência, a abreviação da duração do processo. ${ }^{108}$

Deve-se acrescentar que, além da abreviação da duração do processo, essas hipóteses, a cada dia mais numerosas em nosso sistema jurídico, também se justificam, e talvez até com maior razão, pela viabilização de maior uniformização jurisprudencial, em benefício dos princípios da igualdade e da segurança jurídica.

Conforme Eduardo Talamini, nessa acepção também não se pode falar propriamente em "vinculação", pois não há obrigatoriedade de adoção dessas medidas, mas apenas uma autorização legal. Assim, “o órgão que deixa de dar aplicação a tais regras não afronta a autoridade do tribunal do qual provém o precedente, a súmula ou a jurisprudência dominante". 109

\footnotetext{
108 TALAMINI, Eduardo, Novos aspectos da jurisdição constitucional brasileira: repercussão geral, força vinculante, modulação dos efeitos do controle de constitucionalidade e alargamento do objeto do controle direto, cit., p. 92.

109 Tanto isso é verdade que, como bem observado pelo autor, não cabe reclamação contra as decisões que não adotam as providências autorizadas pela lei, além de, em alguns casos, a própria lei prever, de forma expressa, que o órgão judicial é livre para adotá-la ou não (como ocorre com as hipóteses dos artigos 543B, $\S 3 .^{\circ}$ e 543-C, $\S 7^{\circ}$, do CPC). (TALAMINI, Eduardo, op. cit., p. 92).
} 
É o que ocorre, por exemplo, com as regras processuais positivadas nos últimos anos, que permitem o julgamento monocrático de recursos ou conflitos de competência, com base em súmula ou jurisprudência dominante do respectivo tribunal ou dos Tribunais Superiores, conforme os artigos 38 da Lei n. 8.037/90 e 121, parágrafo único, 557 (conforme redação dada pela Lei n. 9.756/98) e 544, $\S 4^{\circ}$ (conforme redação da Lei n. 12.322/2010), todos do CPC. ${ }^{110}$

O mesmo se verifica quanto à (i) possibilidade de dispensa da remessa da questão de constitucionalidade para o plenário ou órgão especial do tribunal, quando já houver pronunciamento deste ou do plenário do STF, nos termos do artigo 481, parágrafo único, do CPC, conforme redação da Lei n. 9.756/98; bem como quanto à (ii) dispensa de reexame necessário quando "a sentença estiver fundada em jurisprudência do plenário do Supremo Tribunal Federal ou em súmula deste Tribunal ou do tribunal superior competente" (art. 475, $\S 3^{\circ}$, do CPC) e à (iii) possibilidade de modificação da competência para julgar recurso, remetendo-se os autos ao órgão colegiado competente para a uniformização de jurisprudência, dispensando-se a instauração do incidente previsto pelo artigo 476/479 do CPC (art. 555 do CPC), conforme alterações promovidas pela Lei n. $10.352 / 2001$.

Mas esses mecanismos de valorização da jurisprudência parecem não ter se mostrado suficientes, e entramos no século XXI com os tribunais abarrotados de processos e a crise da Justiça extremamente agravada ${ }^{111}$, dando ensejo à chamada Reforma do Judiciário, implementada pela Emenda Constitucional n. 45/2004, a qual, entre outras medidas, converteu o princípio da razoável duração do processo em garantia constitucional

\footnotetext{
${ }^{110}$ Conforme Cândido Rangel Dinamarco, “o notório e angustiante congestionamento do Poder Judiciário vem conduzindo o processo civil brasileiro por tentativas e caminhos novos que incluem o reforço dos poderes do relator, em associação com meios e modos de valorizar os precedentes judiciários colegiados". Além disso, como bem observado pelo autor, foi nesse contexto que o sistema passou a mencionar, além da súmula, o termo "jurisprudência dominante", igualando essas duas formas de potencialização dos precedentes: "Nessa escalada, a nova lei generaliza em diversos dispositivos o manejo do binômio súmula e jurisprudência dominante." (DINAMARCO, Cândido Rangel, O relator, a jurisprudência e os recursos, in Aspectos polêmicos e atuais dos recursos cíveis de acordo com a Lei 9.756/98, cit., p. 128).

111 Segundo Antonio Carlos Marcato, “é praticamente consensual o reconhecimento dessa crise, havendo discrepância, exclusivamente, em relação a qual daqueles dois fatores deve ser conferido maior peso: se à duração do processo, preocupação central nos países filiados à família romano-germânica, ou, preferencialmente, ao seu custo, como se posicionam os ligados ao sistema anglo-saxônico". Além disso, segundo o autor, essa crise não é problema exclusivamente brasileiro, o que justifica as sucessivas reformas por que vêm passando os modelos processuais das famílias de civil law e common law (MARCATO, Antonio Carlos, Crise da justiça e influência dos precedentes judiciais no direito processual civil brasileiro, cit., p. 220).
} 
expressa. A partir daí, foi editada uma série de leis voltadas à ampliação da eficácia da jurisprudência e dos precedentes.

Nesse contexto, pode-se citar a instituição de autorização para o reconhecimento da inadmissibilidade da apelação contrária a súmula do STJ ou do STF (art. 518, § $1^{\circ}$, do CPC, acrescido pela Lei n. 11.276/2006) e de julgamento de improcedência prima facie das ações repetitivas (art. 285-A do CPC, acrescido pela Lei n. 11.277/2006).

Também foram editadas as Leis ns. 11.417/2006 e 11.418/2006, que passaram a permitir o reconhecimento, pelo órgão a quo, da inadmissibilidade do recurso extraordinário repetitivo por falta de repercussão geral, com base em precedente do STF que nega a repercussão geral da questão constitucional, ao apreciar os recursos representativos da controvérsia (arts. 543-A, § 5 , e 543-B, § $2^{\circ}$, do CPC), bem como o exercício do juízo de retratação quanto ao acórdão recorrido ou a negativa de seguimento do recurso excepcional repetitivo, com base em precedente do STF ou do STJ que julga os recursos representativos da controvérsia (arts. 543-B, § $3^{\circ}$, e 543-C, $\S 7^{\circ}$, do CPC).

Note-se que, em todos esses casos, embora não haja vinculação propriamente dita, a existência de regras que atribuem de forma expressa efeitos especiais aos precedentes ou à jurisprudência permite que se fale em "vinculação média" ou, como entendemos ser ainda mais adequado, em eficácia persuasiva ampliada ou especial.

De todo modo, o fato é que a ampliação dessas hipóteses ao longo dos anos "retrata a intensificação da importância atribuída à jurisprudência em nosso sistema, em prol da economia processual e da segurança jurídica", sendo certo que "os valores subjacentes e os fins visados são em larga medida os mesmos da eficácia vinculante propriamente dita". 112

\footnotetext{
112 TALAMINI, Eduardo, Novos aspectos da jurisdição constitucional brasileira: repercussão geral, força vinculante, modulação dos efeitos do controle de constitucionalidade e alargamento do objeto do controle direto, cit., p. 94. No mesmo sentido, fazendo referência aos artigos 476 e seguintes, $555, \S 1^{\circ}, 544, \S 3^{\circ} \mathrm{e}$ 557, $\S 1^{\circ}$ do CPC, Fátima Nancy Andrighi observou que de fato trata-se de um movimento de crescente valorização da jurisprudência: "Todas essas previsões legais significam que o ordenamento jurídico brasileiro acentuava a atribuição aos precedentes de um peso cada vez maior, caminhando para a vinculação." (ANDRIGHI, Fátima Nancy. Recursos repetitivos. Revista de Processo, São Paulo, v. 35, n. 185, p. 267, jul. 2010).
} 


\section{RECURSOS EXTRAORDINÁRIOS E ESPECIAIS: FUNÇÕES, IMPORTÂNCIA E ADMISSIBILIDADE}

\subsection{Recursos ordinários e extraordinários lato sensu}

No sistema processual brasileiro, recursos são meios de impugnação às decisões judiciais aptos a ensejar a sua reforma, invalidação, esclarecimento ou integração dentro da mesma relação processual. Têm lugar enquanto não transitada em julgado - isto é, enquanto não imunizada pela coisa julgada - a decisão a ser impugnada. ${ }^{113}$

No sistema europeu, a tendência é denominar recurso tanto os meios de impugnação exercitáveis na mesma relação processual, como aqueles que têm lugar após a formação da coisa julgada, considerando-se como ordinários os primeiros e extraordinários os segundos. ${ }^{114}$

Também no Brasil existem recursos ordinários e extraordinários, conforme a classificação mencionada pelo próprio CPC na parte final do artigo 467. Mas tanto os recursos ordinários como os extraordinários representam meios de impugnação às decisões judiciais na mesma relação processual e antes da formação da coisa julgada, de modo que o critério que orienta essa classificação diz respeito à finalidade e à função dos recursos no sistema, ou seja, "ao objeto a que visa o sistema imediatamente tutelar através do recurso". 115

Recursos ordinários são aqueles que visam proteger de forma imediata e primordial o direito subjetivo das partes litigantes contra o suposto vício ou injustiça da decisão recorrida. Daí porque viabilizam o amplo reexame da decisão impugnada, seja quanto aos seus aspectos jurídicos, seja quanto aos seus aspectos fático-probatórios. Trata-se de

\footnotetext{
${ }^{113}$ Os recursos diferem dos meios de impugnação exercitáveis por intermédio de ações autônomas, as quais ensejam a instauração de novos processos e têm por pressuposto a formação da coisa julgada material, tais como, por exemplo, a ação rescisória, a ação anulatória prevista pelo artigo 486 do CPC, o mandado de segurança contra ato judicial e a ação declaratória de nulidade ou inexistência de relação processual.

${ }^{114}$ LIMA, Alcides de Mendonça. Introdução aos recursos cíveis. 2. ed. rev. e atual. São Paulo: Revista dos Tribunais, 1976. p. 165.

115 PINTO, Nelson Luiz. Recurso especial para o STJ: teoria geral e admissibilidade. 2. ed. rev., atual. e ampl. São Paulo: Malheiros, 1996. p. 34.
} 
viabilizar a revisão da própria justiça da decisão proferida no caso concreto, ensejando um novo julgamento da causa por órgão diverso, razão pela qual se diz que os recursos ordinários relacionam-se ao princípio do duplo grau de jurisdição.

Já o objeto imediato dos recursos extraordinários é tutelar o direito objetivo, não proteger o direito subjetivo das partes, que só reflexamente acaba sendo agasalhado por seu julgamento. Essa é a razão de não se admitir aquele reexame tão amplo da decisão, que fica restrita a determinadas questões de direito. Daí serem também chamados de recursos excepcionais, ou recursos de estrito direito.

A finalidade precípua desses recursos está prevista na própria Constituição Federal e diz respeito à garantia da integridade do sistema jurídico, não à viabilização de novo julgamento da causa, nem à realização de justiça no caso concreto - o que justifica a afirmação de que eles não têm a finalidade de servir de terceira ou quarta instância. ${ }^{116}$

Apesar disso, no Brasil os recursos excepcionais não atuam como instrumento voltado à mera cassação da decisão contrária ao direito objetivo, e sim como recursos de revisão, eis que o seu acolhimento gera, via de regra, o rejulgamento da causa. ${ }^{117}$

Assim, conforme Nelson Nery Junior, os recursos excepcionais submetem-se a três juízos: admissibilidade, cassação e revisão, de modo que, em razão desse último, cassada a

\footnotetext{
${ }^{116}$ Segundo Rodolfo de Camargo Mancuso, recursos especiais, excepcionais ou extraordinários são aqueles que, diferentemente dos comuns, normais ou ordinários, "apresentam uma rigidez formal de procedibilidade; são restritos às quaestiones juris; dirigem-se aos Tribunais de cúpula judiciária; não são vocacionados à correção da mera 'injustiça' da decisão; e apresentam, como diz Frederico Marques, a particularidade de exigirem 'a sucumbência e um plus que a lei processual determina e especifica" (MANCUSO, Rodolfo de Camargo. Recurso extraordinário e recurso especial. 11. ed. rev., atual. e ampl. São Paulo: Revista dos Tribunais, 2010. p. 112).

117 É o que dispõe a Súmula 456 do STF: "O Supremo Tribunal Federal, conhecendo do recurso extraordinário, julgará a causa, aplicando o direito à espécie". Redação muito semelhante consta do artigo 257 do Regimento Interno do STJ: "No julgamento do recurso especial, verificar-se-á, preliminarmente, se o recurso é cabível. Decidida a preliminar pela negativa, a Turma não conhecerá do recurso; se pela afirmativa, julgará a causa, aplicando o direito à espécie". Conforme Alfredo Buzaid, a revisão se diferencia da cassação porque nesta "só se examinam as questões jurídicas contidas na sentença, ao passo que na revisão (pelo menos quando se trata de infração de direito material) examina-se toda a sentença; o Tribunal de Cassação somente pode anular a sentença; o de Revisão desce ao mérito e resolve a controvérsia". (BUZAID, Alfredo. A crise do Supremo Tribunal Federal. In: São Paulo: Saraiva, 1972. p. 131). . Estudos de direito I.
} 
decisão recorrida pelo provimento do recurso, será o caso de se rejulgar por completo a causa. $^{118}$

O recurso extraordinário surgiu no direito brasileiro no momento histórico em que o Estado brasileiro estava sendo formado, por inspiração norte-americana, sob a forma federativa, o que ocorreu logo após a proclamação da República ${ }^{119}$. Inspirado no writ of error criado nos Estados Unidos pelo Judiciary Act, de setembro de 1798, sua função era a de garantir a supremacia da lei federal e da Constituição em toda a Federação. ${ }^{120}$

Foi instituído inicialmente pelo Decreto n. 848, de 11.10.1890, cujo artigo $9^{\circ}$, parágrafo único, criou "recurso para o Supremo Tribunal Federal, das sentenças definitivas, proferidas pelos tribunais e juízes do Estado”, especificando, em seguida, hipóteses de cabimento muito semelhantes às que regulavam o writ of error, e que são bem parecidas com as que até hoje estabelecem as hipóteses de cabimento dos recursos extraordinário e especial.

Já em nossa primeira Constituição, de 1891, o recurso ganhou status constitucional $^{121}$ e sua concepção como instrumento de proteção e uniformização do direito federal infraconstitucional e constitucional foi mantida pelas Constituições de 1934, 1937, 1946 e 1967 (inclusive com a EC n. 1/1969), sendo, porém, modificada pela Constituição de 1988.

Com a promulgação da atual Constituição, e em resposta à chamada crise do Supremo, surgiu ineditamente o recurso especial dirigido a uma nova corte, o Superior Tribunal de Justiça. Na verdade, desde os anos 60, um grupo de juristas integrado por

\footnotetext{
${ }^{118}$ NERY JUNIOR, Nelson. Teoria geral dos recursos. São Paulo: Revista dos Tribunais, 2004. p. 442.

${ }^{119}$ Nas palavras de Pontes de Miranda, o recurso extraordinário "penetrou no direito brasileiro com a República federativa. Prende-se ele, como galhos e tronco à raiz, à necessidade de se assegurar, em todo o território e em todas as dimensões do ambiente jurídico nacional, a aplicação uniforme da lei federal" (PONTES DE MIRANDA, Francisco Cavalcanti. Comentários à Constituição de 1967: com a Emenda n. 1, de 1969: arts. 118 a 153, § 1º. 2. ed. rev. São Paulo: Revista dos Tribunais, 1970. v. 4, p. 82).

${ }^{120}$ PINTO, Nelson Luiz, Recurso especial para o STJ: teoria geral e admissibilidade, cit., p. 40.

${ }^{121}$ Só com o Regimento Interno do Supremo Tribunal Federal, também de 1891, o recurso passou a receber a denominação de "recurso extraordinário". A Lei n. 221/1894 denominou o recurso de apelação e, depois, a Lei n. 1.939/1907 modificou novamente o nome para o anterior, situação que foi definitivamente consolidada com a previsão expressa do recurso extraordinário pelo artigo 76, "2", III, da Constituição de 1934.
} 
nomes como José Frederico Marques, Seabra Fagundes, Miguel Reale, Alfredo Buzaid e José Afonso da Silva, entre outros, já idealizara a criação do Superior Tribunal de Justiça e do atual recurso especial, como forma de desafogar o STF. ${ }^{122}$

A nova corte e o novo recurso especial apresentaram-se como meros desdobramentos do STF e do recurso extraordinário (que passou a veicular unicamente questões sobre direito constitucional), fazendo suas vezes quanto às hipóteses de cabimento relacionadas à matéria de direito infraconstitucional federal.

Assim, o sistema atual prevê duas espécies de recursos excepcionais: o recurso extraordinário propriamente dito (voltado à tutela do direito federal constitucional), de competência do STF; e o recurso especial (voltado à tutela do direito federal infraconstitucional), de competência do STJ. Ao lado deles (na verdade, representando sua mera extensão), há os embargos de divergência (art. 546 do CPC), cabíveis em casos de divergência no julgamento dos recursos excepcionais pelos órgãos internos do STF ou do STJ.

\subsection{Funções e importância}

\subsubsection{A função pública especial dos recursos excepcionais}

Por serem julgados por um órgão jurisdicional único e hierarquicamente superior, e por estarem sujeitos a requisitos específicos, os recursos excepcionais têm a especial função, não de apreciar a justiça da decisão no caso concreto (função exercida pelos órgãos da jurisdição ordinária), mas sim de controlar a atuação dos demais órgãos judiciais na aplicação das normas abstratas ao caso concreto.

\footnotetext{
122 "Preconizaram esses eminentes Juristas, então, um tribunal que fizesse as vezes do STF, vale dizer, de um tribunal para julgamento de recursos extraordinários relativos ao Direito federal Comum. [...] No ano de 1963 - um pouco antes, portanto, dessa mesa-redonda - em tese de concurso que apresentou para obtenção da cátedra de Direito Constitucional, o Prof. José Afonso da Silva propugnou pela criação de um Superior Tribunal de Justiça, para o fim de fazer as vezes do STF, no que tange ao Direito federal Comum, nos moldes do que foi instituído pelo Constituinte de 1988." (VELLOSO, Carlos Mário da Silva. O Superior Tribunal de Justiça na Constituição de 1988. Revista dos Tribunais, São Paulo, v. 77, n. 638, p. 17-18, dez. 1988).
} 
$\mathrm{Na}$ verdade, a razão de ser do referido órgão superior e dos recursos excepcionais consiste na necessidade de se realizar, em um Estado de Direito onde coexistem inúmeros órgãos jurisdicionais que apreciam simultaneamente as diversas controvérsias que lhes são submetidas pelas partes, um "controle do controle", ou seja, um controle sobre as decisões dos demais órgãos jurisdicionais, para garantir que, ao desempenharem suas funções jurisdicionais, respeitem o sentido único do direito objetivo, proferindo decisões corretas e uniformes.

Daí dizer-se que os Tribunais Superiores, enquanto julgam recursos excepcionais, constituem a chamada instância de superposição, que nada tem a ver com terceira ou quarta instância.

Nas palavras de Pontes de Miranda, em referência ao antigo "recurso extraordinário", a sua função é assegurar a inteireza positiva, a validade, a autoridade e a uniformidade de interpretação da Constituição e das leis federais; ou, de forma mais sintética: "É função, pois, do recurso extraordinário manter a autoridade e a unidade de inteligência das leis federais."123

Atente-se, porém, ao fato de que o objeto dos recursos excepcionais é precisamente o erro quanto à premissa maior (direito objetivo), ou seja, o erro de direito. É que, embora o erro de fato também seja uma transgressão à norma, o erro de direito é situação muito mais inconveniente e grave para o Estado, em razão da origem do vício, que representa uma violação da própria norma constitucional, a qual impõe ao juiz julgar de acordo com a lei, para fins de legitimação do poder que lhe foi atribuído pelo sistema. ${ }^{124}$

Além disso, o erro de direito também é muito mais grave do que o erro de fato (sujeito unicamente ao controle da instância ordinária) porque não se limita, como este

\footnotetext{
${ }^{123}$ PONTES DE MIRANDA, Francisco Cavalcanti, Comentários à Constituição de 1967: com a Emenda n. 1: arts. 118 a $153, \S 1^{\circ}$, cit., v. 4, p. 107.

${ }^{124}$ Nesse último caso, tem-se uma "transgressão por parte do juiz da norma que lhe fixa, para aquele e para todos os casos futuros, a condição e o limite de seu poder". No original: "transgresión por parte del juez de la norma que le fija, para aquél y para todos lós casos futuros, la condición y el límite de su poder" (CALAMANDREI, Piero, La casación civil: bosquejo general del instituto, cit., v. 2, p. 56 - nossa tradução).
} 
último, aos contornos do caso concreto, mas sim transborda os seus limites, para contagiar outras decisões, produzindo desigualdade e desestabilizando a ordem jurídica. ${ }^{125}$

Dessa forma, o interesse público que justifica a atuação da instância extraordinária consiste na exata e uniforme interpretação do direito objetivo em sua vontade geral, adquirindo, assim, uma projeção coletiva, no sentido de interessar, de forma especial, ao Estado e a toda a sociedade, e não apenas às partes recorrentes.

\subsubsection{Funções nomofilácica e de uniformização da jurisprudência}

Uma das funções exercidas pelos recursos excepcionais é a de nomofilaquia ${ }^{126}$, por meio da qual se garante a observância por parte dos órgãos jurisdicionais da norma que lhes prescreve decidir segundo a lei as controvérsias que lhes são confiadas, mantendo-os na esfera de seu poder e invalidando as decisões pronunciadas fora dos seus limites. ${ }^{127}$

Trata-se de um aspecto negativo da finalidade dos recursos excepcionais, por meio do qual as decisões contrárias às normas jurídicas são cassadas e substituídas por outras que observem a correta interpretação da lei.

Apesar do caráter político que está na base da origem histórica do instituto, e de sua inegável relação com os princípios constitucionais da legalidade e da separação e harmonia entre os poderes, não se trata de equiparar os atuais Tribunais Superiores à antiga Corte de Cassação francesa, órgão estranho à estrutura do Judiciário, que servia para controlar

\footnotetext{
${ }^{125}$ Vale também mencionar, a esse respeito, as observações de Buzaid, no sentido de que "[...] para o legislador brasileiro, em consonância com o melhor entendimento da doutrina, os erros na apreciação de fato, embora fossem deploráveis e deles pudessem resultar injustiças, não têm a mesma gravidade dos erros de direito". E, com base em lição de José Alberto dos Reis, afirma ser "incontestável que erros de direito têm significado mais alarmante e constituem perigo muito mais grave do que os erros de fato. Significado mais alarmante, porque são o sintoma de uma anomalia estranha na ordem jurídica. O Juiz, em vez de respeitar escrupulosamente a lei, ditando o comando concreto perfeitamente conforme ao comando abstrato expresso na norma jurídica, permite-se violar a regra legal; em vez de se limitar a declarar o direito, vai até ao ponto de criar direito em oposição com o que o legislador formulou. Quer dizer, comete uma usurpação no domínio mais delicado da ordem jurídica: o domínio constitucional. Perigo mais grave na esfera social, porque, como muito bem nota Carnelutti, o erro de direito tem esta nocividade específica: é um erro contagioso, no sentido de que tende a propagar-se a outras decisões" (BUZAID, Alfredo, A crise do Supremo Tribunal Federal, in Estudos de direito I, cit., p. 137).

${ }^{126}$ Palavra derivada dos vocábulos gregos nomos e phylasso, que significam lei e guarda.

${ }^{127}$ CALAMANDREI, Piero, La casación civil: bosquejo general del instituto, cit., v. 2, p. 50.
} 
politicamente a atuação dos juízes, inclusive censurando-os pessoalmente, quando ocorria uma violação à lei. Trata-se apenas de se reconhecer que a legitimidade, integridade e unidade do sistema jurídico exigem a atuação de mecanismos de controle que garantam a observância das normas jurídicas em todo Estado de Direito.

Por outro lado, da mesma forma que podem interpretar as normas de forma equivocada, os órgãos jurisdicionais podem fazer coexistir múltiplas interpretações divergentes, trazendo desestabilidade e insegurança ao sistema. Nesse sentido, o recurso excepcional incide para afastar essa divergência, fixando, por sua função de uniformização da jurisprudência, o sentido único da norma, em todo o território e na mesma época.

Trata-se de função dotada, segundo Calamandrei, de aspecto positivo que "tende a assegurar no Estado a uniformidade da jurisprudência e, por consequência, a unidade e a igualdade do direito objetivo, através da revisão e da seleção das diversas interpretações de uma mesma norma jurídica, coexistentes na jurisprudência". ${ }^{128}$

Não se trata de buscar, dentre os entendimentos divergentes, a interpretação verdadeira no sentido de se apurar a verdade absoluta a respeito do significado da norma, mas sim de alcançar uma convenção a respeito de qual é a interpretação única no Estado em determinada época, em prol da igualdade e da segurança jurídica.

Note-se que as funções nomofilácica e uniformizadora são duas faces da mesma moeda. Com a cassação de decisões que dão ao direito objetivo uma interpretação equivocada, fixa-se o verdadeiro sentido da norma, evitando-se que o vício contagie novas decisões e gere divergência jurisprudencial; por outro lado, quando a cassação fundamentase na divergência jurisprudencial, fica demonstrada qual a interpretação correta (única) da

\footnotetext{
${ }^{128}$ No original: "Tiende a asegurar en el Estado la uniformidad de la jurisprudencia y, por conseguiente, la unidad y la igualdad del derecho objetivo, a través de la revisión y de la selección de las diversas interpretaciones de una misma norma jurídica, coexistentes en la jurisprudencia a causa de la pluralidad simultánea de los órganos judiciales de un mismo grado." (CALAMANDREI, Piero, La casación civil: bosquejo general del instituto, cit., v. 2, p. 102 - nossa tradução).
} 
lei, estimulando os juízes a respeitarem o verdadeiro sentido da norma; desse modo, uma função serve à outra, representando os aspectos negativo e positivo da mesma realidade. ${ }^{129}$

Dessa forma, pode-se em suma afirmar que a função pública especial desenvolvida pelos recursos excepcionais é basicamente única e consiste na fixação da interpretação correta e única das normas abstratas (direito objetivo), por meio de precedentes que deverão ser observados não só no caso concreto em que produzidos (nomofilaquia), mas também em todos os casos futuros semelhantes (uniformização da jurisprudência).

Daí afirmar-se atualmente que a função dos Tribunais Superiores por meio dos recursos excepcionais é fixar, pelos seus precedentes, os parâmetros decisórios a serem observados por todos os demais órgãos judiciais, no julgamento de questões semelhantes. Ou seja, eles atuam como "cortes de precedentes", exercendo uma espécie de "nomofilaquia através do precedente". ${ }^{130}$

Com isso, os efeitos dos precedentes dos Tribunais Superiores projetam-se, de forma especial, para fora do caso por eles julgado, para atingir os casos futuros e a sociedade em geral. Como esses julgamentos visam - além de corrigir eventual erro na aplicação do direito objetivo - definir o verdadeiro sentido de tais normas para todo o Estado, eles acabam dando lugar a decisões paradigmas, que regularão e unificarão a jurisprudência de todos os outros órgãos jurisdicionais do Estado, trazendo segurança para

\footnotetext{
${ }^{129}$ O Estado tem interesse na interpretação verdadeira e uniforme; daí as funções de garantir a observância da lei e a uniformização da jurisprudência. Esses dois interesses, que excepcionalmente podem se apresentar separados, geralmente coincidem. Isso porque não pode haver no Estado mais que uma interpretação correta da mesma norma. Assim, ao cassar uma decisão que viola a lei, ainda que de forma isolada, a Corte de Cassação revela o verdadeiro e único sentido da norma, impedindo futuras interpretações divergentes. A nomofilaquia age aqui também em favor da uniformização. Por outro lado, havendo divergência, e sendo ela eliminada pela escolha, pela Corte de Cassação, da interpretação correta, ocorre aqui uma prevenção da futura violação à norma. Ou seja, uma finalidade age em benefício da outra, de forma que elas acabam invariavelmente coincidindo. Daí dizer-se que constituem, na verdade, a mesma finalidade (CALAMANDREI, Piero, La casación civil: bosquejo general del instituto, cit., v. 2, p. 109).

${ }^{130}$ Vale mencionar aqui as atuais observações de Michele Taruffo sobre as conclusões a que chegou Piero Calamandrei em sua obra a que vimos fazendo referência: "Calamandrei apresentava a ideia que a Corte de Cassação, uma vez unificada, torna-se aquilo que em termos modernos se chama 'corte do precedente' e assim desenvolveria as suas funções, e em particular aquela de nomofilaquia, através de decisões capazes de orientar a jurisprudência sucessiva. Ele antecipava, em verdade, aquela que é hoje a função principal das cortes superiores em muitos ordenamentos, de common law e de civil law, que é a de assegurar o controle de legitimidade através da fixação de precedentes destinados a projetar-se como pontos de referência sobre decisões dos outros juízes. Com fórmula sintética se pode falar de 'nomofilaquia através do precedente', justamente para indicar que a função típica de uma corte superior é de assegurar o uniforme respeito à lei através de decisões 'universalizáveis' e projetáveis para o futuro." (TARUFFO, Michele, Precedente e jurisprudência, cit., p. 153).
} 
a realização de atos na vida em sociedade e servindo de padrão para os julgamentos futuros em todas as instâncias do Poder Judiciário.

Também se fala, assim, na função paradigmática dos recursos excepcionais, isto é, função não só de proteção do direito objetivo, com a correção das decisões equivocadas quanto à aplicação do direito objetivo (função nomofilácica), mas também de fixação de precedentes unificadores da interpretação dessas normas em todo o território. ${ }^{131}$

\subsubsection{A importância da jurisprudência dos Tribunais Superiores}

A compreensão das funções exercidas pela jurisprudência dos Tribunais Superiores no julgamento dos recursos excepcionais explica, por si só, a sua grande importância no sistema jurídico. Na verdade, a função dessas cortes identifica-se com a própria função interpretativa da jurisprudência, ainda que todos os demais órgãos colaborem com a sua construção.

É assim porque, embora em regra todos os demais órgãos sejam livres para interpretar a norma abstrata, é da instância superior o monopólio de enunciar a única interpretação oficialmente conforme a lei, "frente à qual todas as interpretações jurídicas diferentes dela são declaradas falsas ou ilegais", o que, aliás, "naturalmente, aumenta consideravelmente a eficácia de fato das interpretações proferidas por este órgão supremo". ${ }^{132}$

Essa eficácia de fato dos precedentes dos órgãos superiores (eficácia persuasiva) decorre do risco de declaração da contrariedade da sentença com o direito positivo, pelo

\footnotetext{
${ }^{131}$ A doutrina chega a mencionar que a existência da Corte Superior é inerente à forma federativa do Estado (WAMBIER, Teresa Arruda Alvim, Recurso especial, recurso extraordinário e ação rescisória, cit., p. 243; LIMA, Alcides Mendonça de. Recurso extraordinário e recurso especial. In: TEIXEIRA, Sálvio Figueiredo (Coord.). Recursos no Superior Tribunal de Justiça. São Paulo: Saraiva, 1991. p. 135). Sem prejuízo, a doutrina lembra, com razão, que mesmo nos Estados unitários existe a necessidade do órgão superior, em face da existência de múltiplos órgãos do mesmo grau julgando controvérsias semelhantes (SANTOS, Francisco Cláudio de Almeida. Recurso especial: visão geral. In: TEIXEIRA, Sálvio Figueiredo (Coord.). Recursos no Superior Tribunal de Justiça. São Paulo: Saraiva, 1991. p. 95-97).

${ }^{132}$ No original: "en la práctica [...] la interpretación de la Casación aparece en el Estado como la única interpretación de la ley, frente a la cual todas las interpretaciones jurídicas diversas de ella son declaradas falsas o ilegales. Esto, naturalmente, aumenta considerablemente la eficacia de hecho de las interpretaciones preferidas por este órgano supremo." (CALAMANDREI, Piero, La casación civil: bosquejo general del instituto, cit., v. 2, p. 115 - nossa tradução).
} 
simples fato de a sentença estar em desacordo com a decisão da corte, podendo-se dizer que ela exerce uma autoridade predominante e diretiva, de forma que seus efeitos extrapolam o caso concreto, para exercer influência sobre todos os casos sucessivos semelhantes. ${ }^{133}$

\subsubsection{Relação entre o interesse privado das partes recorrentes e o interesse público na atuação dos Tribunais Superiores}

Diante das especiais funções públicas de preservação da autoridade e da unidade do direito objetivo desempenhadas pelos recursos excepcionais, a doutrina comumente afirma a sua prevalência em relação ao interesse particular das partes em defender o seu direito subjetivo.

Referindo-se ao recurso especial, Sálvio de Figueiredo Teixeira afirma ser sua finalidade, "por previsão constitucional, preservar a unidade e a autoridade do direito federal, sob a inspiração de que nele o interesse público, refletido na correta interpretação da lei, deve prevalecer sobre os interesses das partes". ${ }^{134}$

Na mesma linha, Athos Gusmão Carneiro ensina que os recursos extraordinários lato sensu têm caráter político, e visam à proteção imediata de interesse de ordem pública em ver prevalecer a autoridade e a exata aplicação da Constituição e da lei federal, e só mediatamente à tutela do interesse das partes. Segundo o autor, o interesse particular das partes é mais um móvel e estímulo para a interposição do "recurso extremo". ${ }^{135}$

É interessante mencionar a referência de Francisco Claudio de Almeida Santos à contraposição entre a função nomofilácica e a "função que Juan Carlos Hitters denomina

\footnotetext{
133 Da mesma forma, conforme Arruda Alvim, as decisões as proferidas pelos Tribunais de cúpula "transcendem o ambiente das partes", de modo que "a expectativa, senão mesmo a imprescindível necessidade social - em relação às decisões de um Tribunal de cúpula [...] -, é a de que sejam paradigmáticas, pois que o rumo dessas vale como roteiro para os demais Tribunais e jurisdicionados, mercê dos precedentes assentados" (ARRUDA ALVIM, José Manoel de. A alta função jurisdicional do Superior Tribunal de Justiça no âmbito do recurso especial e a relevância das questões. Revista de Processo, São Paulo, v. 24, n. 96, p. 38, out./dez. 1999).

134 TEIXEIRA, Sálvio Figueiredo. O recurso especial e o Superior Tribunal de Justiça. In: (Coord.). Recursos no Superior Tribunal de Justiça. São Paulo: Saraiva, 1991. p. 69.

${ }^{135}$ CARNEIRO, Athos Gusmão. Recurso especial, agravos e agravo interno. 7. ed. atual. e ampl., inclusive com anotações relativas ao projeto de novo Código de Processo Civil. Rio de Janeiro: Forense, 2011. p. 8.
} 
de dikelógica, isto é, de fazer justiça do caso concreto, aparecendo, destarte, o recurso como meio impugnativo da parte para reparar um agravo a direito seu”. Segundo o autor, "a finalidade principal do recurso especial é, porém, a primeira, de preservação da ordem pública". 136

Surgem, porém, algumas questões: se o interesse público perseguido pelos recursos excepcionais prevalece sobre o interesse subjetivo das partes, como explicar que a atuação daquele dependa do ato destas de interpor o recurso? E como justificar a sua inadmissibilidade por questões relacionadas apenas ao interesse das partes e que, em tese, não impedem o exercício das funções nomofilácica e paradigmática? ${ }^{137}$

De fato, questões como essas, aliadas ao fato de que a própria Constituição disponibiliza expressamente os recursos extraordinário e especial como mais um instrumento à disposição das partes para a defesa de seus interesses particulares em juízo, levam alguns autores a mitigar aquela prevalência das funções públicas dos recursos excepcionais.

Assim, José Carlos Barbosa Moreira entende, quanto ao recurso extraordinário, ser "excessivo negar que também sirva de instrumento à tutela de direitos subjetivos das partes ou de terceiros prejudicados". ${ }^{138}$ Na mesma linha, Francisco Claudio de Almeida Santos, embora reconheça que a função nomofilácica é mais importante, afirma que a função dikelógica é indisfarçável nos recursos excepcionais, pois sem alegação de ofensa ao direito subjetivo da parte, o recurso sequer poderia ser interposto, até porque não há no Brasil o recurso de cassação no interesse da lei (tal como ocorre, por exemplo, na França e na Itália), por iniciativa do Ministério Público.

\footnotetext{
${ }^{136}$ SANTOS, Francisco Claudio de Almeida, Recurso especial: visão geral, in Recursos no Superior Tribunal de Justiça, cit., p. 94.

${ }^{137}$ Por exemplo, a inadmissibilidade fundada na doutrina do fundamento incidente, prevista pelas Súmulas 283 do STF ("É inadmissível o recurso extraordinário, quando a decisão recorrida assenta em mais de um fundamento suficiente e o recurso não abrange todos eles”) e 126 do STJ (“É inadmissível recurso especial, quando o acórdão recorrido assenta em fundamentos constitucional e infraconstitucional, qualquer deles suficiente, por si só, para mantê-lo, e a parte vencida não manifesta recurso extraordinário”).

138 MOREIRA, José Carlos Barbosa. Comentários ao Código de Processo Civil: Lei n. 5.869, de 11 de janeiro de 1973, arts. 476 a 565. 16. ed. rev., atual. e ampl. Rio de Janeiro: Forense, 2012. v. 5. p. 582.
} 
Indo mais além, Cândido Rangel Dinamarco lembra que a oferta constitucional de diferentes graus de jurisdição, inclusive da instância de superposição representada pelos recursos excepcionais, integra as garantias do devido processo legal e do acesso à justiça, razão pela qual se conclui pela "negação daquele confinamento técnico-jurídico do recurso extraordinário" e pela sua ligação não só ao objetivo de "preservar a ordem jurídica em sua autoridade e unidade de interpretação", como também de "servir de canal para as insatisfações e inconformismos, e portanto, meio instrumental da justiça". 139

Igualmente, Alcides Mendonça Lima destaca a importância do interesse das partes na interposição dos recursos extraordinários: “A preservação da 'unidade ou incolumidade do direito objetivo' não se resolve em simples discussão teórica dentro dos pretórios, mas sempre tem como mira primacial defender a parte atingida pela errônea ou defeituosa interpretação e aplicação do texto legal respectivo." $" 140$

Realmente, chama a atenção o fato de que o sistema não subsiste sem esse móvel, que é o interesse das partes na correção do eventual equívoco da decisão objeto dos recursos extraordinários. Ou seja, o próprio sistema elegeu esse interesse, fazendo com que as maiores questões a respeito da interpretação das normas federais constitucionais e infraconstitucionais sejam levadas às Cortes Superiores pelas próprias partes, interessadas na melhora da sua situação no processo.

Na verdade, como demonstrado por Piero Calamandrei, não há de se falar exatamente na prevalência de um ou outro interesse, mas sim de se observar que são diferentes, e que servem mutuamente um ao outro, pois o Estado percebeu que é a partir dessas supostas lesões praticadas nos casos concretos e da interpretação realizada pelos demais órgãos jurisdicionais que surgem as verdadeiras questões a respeito da interpretação do direito objetivo. ${ }^{141}$

\footnotetext{
139 DINAMARCO, Cândido Rangel. Superior Tribunal de Justiça e acesso à ordem jurídica justa. In: TEIXEIRA, Sálvio Figueiredo (Coord.). Recursos no Superior Tribunal de Justiça. São Paulo: Saraiva, 1991, p. 252.

${ }^{140}$ LIMA, Alcides de Mendonça, Introdução aos recursos cíveis, cit., p. 314.

${ }^{141}$ Nesse sentido, citando Mortara, Calamandrei observa que as sentenças dos órgãos inferiores são, para a cassação, contínuas fontes de ensinamento "abriendo las vías correctas de la interpretación de la ley; son desarrollo vivo y fecundo del derecho nacional en todas sus múltiples manifestaciones, en todas sus beneficiosas adaptaciones a las necesidades de la civilidad y de la convivencia social" (CALAMANDREI, Piero, La casación civil: bosquejo general del instituto, cit., v. 2, p. 98).
} 
Para as partes litigantes, pouco importa a motivação da sentença, se o dispositivo lhe favorece. Mas, se o dispositivo lhe é desfavorável, a parte procura a qualquer custo uma forma de melhorar sua situação e passa a buscar na motivação algum erro de direito que lhe permita acessar a via extraordinária.

Por sua vez, o Estado tem interesse em que as motivações das decisões sejam submetidas à via extraordinária, a fim de exercer as funções nomofilácica e de uniformização da jurisprudência. Assim, o Estado se vale do interesse dos particulares em alterar o dispositivo da sentença como instrumento de controle da autoridade e unidade do direito positivo.

$\mathrm{O}$ risco desse sistema - que deixa à iniciativa da parte, em virtude de interesses egoísticos, o impulso necessário ao atingimento de uma finalidade pública - poderia ser a omissão das partes quanto à interposição do recurso excepcional, deixando sem apreciação possíveis lesões ao direito objetivo. No entanto, a ideia de confiar aos particulares a vigilância sobre a exata interpretação da lei sempre se mostrou muito profícua e nunca apresentou qualquer risco de ausência de interposição de recursos para controlar as sentenças. Pelo contrário, o risco que ele sempre apresentou foi o de excesso de recursos, ao ponto de até ameaçar o exercício das funções públicas da cassação.

Isso porque nenhum órgão público, por mais escrupuloso que fosse, poderia vigiar a jurisprudência de forma tão eficiente como a que os particulares empregam para encontrar, na motivação de uma sentença que os condena, um erro de direito, quando sabem que esse erro de direito poderá melhorar a sua situação no processo. Isso sem contar que "o fato de se ter confiado aos particulares o ofício de vigiar na defesa da exata interpretação jurisdicional tem assegurado a vitalidade do instituto da cassação, que recebe do interesse individual um impulso sempre vivo". ${ }^{142}$

Essas são as engrenagens do sistema: o Estado exerce as funções públicas de nomofilaquia e uniformização a partir da previsão, pelo direito objetivo, de normas que reconheçam o direito subjetivo das partes à interposição do recurso de cassação e ao seu

\footnotetext{
${ }^{142}$ No Original: "el haber confiado a los particulares el oficio de vigilar en la defensa de la exacta interpretación jurisprudencial, ha asegurado la vitalidad al instituto de la casación, que recibe del interés individual un impulso siempre vivo" (CALAMANDREI, Piero, La casación civil: bosquejo general del instituto, cit., v. 2, p. 152-153 - nossa tradução).
} 
acolhimento, sempre que determinados requisitos estejam presentes. E, para fazer a ponte entre o interesse das partes e o interesse público almejado pelo Estado, o sistema elege como requisitos vícios relacionados às finalidades públicas de preservação da autoridade e uniformidade do direito.

Daí poder-se afirmar que, em sede de recursos extraordinários, o interesse privado é reconhecido e tutelado apenas enquanto coincida com aquele especial interesse público que constitui a base do instituto. O particular que interpõe o recurso estimulado pelo próprio interesse individual atua, ainda que não o saiba, como instrumento de utilidade pública do Estado, o qual, em troca, lhe concede a oportunidade de melhorar sua situação individual no processo, obtendo a cassação da decisão contrária à lei.

Ou seja, o objetivo dos recursos excepcionais realmente não é atuar como um recurso ordinário, que visa à correção da justiça da decisão, mas sim para satisfazer o interesse subjetivo da parte na cassação da decisão viciada, interesse esse que está relacionado a requisitos que permitem o exercício das funções públicas de nomofilaquia e unificação da jurisprudência.

Isso explica, por exemplo, porque não se concebe a cassação de sentenças que, apesar de violarem a lei ou divergirem da jurisprudência, sustentam-se por outros fundamentos. Essas sentenças fazem surgir o interesse público na cassação da decisão recorrida, mas não o interesse do particular, já que, por outros fundamentos, a parte dispositiva se sustenta.

Da mesma forma, quando há uma violação à lei que não se relaciona aos pressupostos públicos dos recursos excepcionais (como ocorre quando há erro de fato ou quanto à interpretação de normas locais), não se admite a atuação da via extraordinária, porque aqui só o interesse particular em modificar o dispositivo está presente, mas não o interesse público em atingir as finalidades de nomofilaquia e uniformização. 
Tem-se, portanto, "uma inseparável cooperação do interesse público com o interesse privado; se um destes dois coeficientes chega a faltar, cessa também a razão de ser do instituto". 143

Assim, a necessidade desse móvel (interesse privado das partes), e até mesmo o fato de ele representar um direito das partes decorrente das garantias do devido processo legal e do acesso à justiça ${ }^{144}$, não desnaturam, pelo contrário, fazem parte do sistema, que permite o desenvolvimento da principal função desempenhada pelos recursos excepcionais, que realmente é a de preservar a ordem jurídica e uniformizar a interpretação do direito federal constitucional e infraconstitucional.

O nosso sistema parece ajustar-se perfeitamente a essas regras: a Constituição prevê o cabimento dos recursos extraordinário e especial em hipóteses que permitem ao STF e ao STJ controlar eventuais inobservâncias ou divergências quanto à interpretação do direito federal. De um lado, a parte passa a ter o direito subjetivo ao recurso. De outro, o exercício desse direito subjetivo permite o atingimento das funções públicas especiais que justificam a previsão dos recursos excepcionais no sistema.

Isso significa que não pode ser olvidada nem exacerbada nenhuma das engrenagens do sistema, devendo-se, pelo contrário, buscar um equilíbrio. Ou seja, não se pode fazer dos recursos excepcionais um simples meio de impugnação à disposição das partes para que façam justiça no caso concreto, tanto quanto a apelação. Na verdade, para a justiça do caso, o sistema se contenta com o duplo grau e todas as garantias processuais. A partir daí, certa ou errada a motivação, e a despeito do interesse público sempre tentar ajustar os

\footnotetext{
${ }^{143}$ No original: "una inseparable cooperación del interés público com el interés privado; si uno de estos dos coeficientes llega a faltar, cesa también la razón de ser del instituto" (CALAMANDREI, Piero, La casación civil: bosquejo general del instituto, cit., v. 2, p. 172 - nossa tradução).

${ }^{144}$ De fato, conforme afirma Dinamarco: "Tanto quanto o recurso extraordinário, porém, também o especial tem uma destinação institucional e um significado sistemático que transcendem a mera função de dar efetividade à ordem jurídica. Ele é um recurso, no sentido integral do vocábulo. Tanto quanto os demais recursos, ele constitui uma oportunidade a mais para o vencido. Serve de canal através do qual a parte contrariada veicula ao órgão mais elevado o seu inconformismo e pedido de nova decisão, na esperança de obter melhor resultado. Por isso desaconselham-se interpretações muito restritivas quanto à sua admissibilidade, que frustrem ao recorrente as expectativas de acesso ao grau superior e à ordem jurídica justa, com infração à cláusula due process of law". Mais adiante, porém, o próprio autor reconhece que a realidade do país impede o atingimento do ideal de um acesso tão amplo que permita a submissão de todas as causas à instância superior, afirmando que "isso não pode significar que se alvitrem soluções de exagerada abertura, a ponto de descaracterizar a conotação de extraordinariedade desse recurso" (DINAMARCO, Cândido Rangel, Superior Tribunal de Justiça e acesso à ordem jurídica justa, in Recursos no Superior Tribunal de Justiça, cit., p. 254).
} 
fundamentos da decisão à ordem jurídica, prevalece o interesse na estabilização do conflito, com a imunização do dispositivo.

Porém, olhos postos na necessidade de controlar a atuação dos demais órgãos judiciais, o sistema passa a permitir que a parte vencida interponha mais um recurso, direcionado à instância extraordinária (no caso do Brasil, dois recursos, o extraordinário e o especial). Mas, se a disponibilização do recurso não está, por algum problema (como, por exemplo, o excesso de litigiosidade na instância extraordinária), permitindo o exercício daquele controle, algo precisa ser feito para se restaurar o necessário equilíbrio.

Por outro lado, não se pode, em nome do atingimento das finalidades públicas dos recursos excepcionais, cercear drasticamente o acesso das partes aos órgãos superiores. O direito subjetivo à impugnação faz parte do sistema, e, mais do que isso, depende dele para funcionar. Inclusive, como visto, é a forma mais conveniente de levar à corte as verdadeiras questões a respeito da interpretação do direito objetivo, mantendo sempre vivo, atual e dinâmico o instituto. Daí porque restrições muito rígidas devem ser evitadas, para manter o equilíbrio entre o impulso particular na provocação da instância extraordinária e o adequado exercício das funções públicas que o sistema lhe incumbe.

Na verdade, não há novidade alguma nessa discussão. A história da cassação revela que sempre se lidou com o equilíbrio entre a necessidade de permitir o acesso das partes (como móvel para a atuação das funções públicas da instância extraordinária) e a de viabilizar que um órgão único superior exerça adequadamente as suas funções.

No mais, é pertinente a indagação de Teresa Arruda Alvim Wambier a respeito de qual seria a utilidade do direito objetivo (cuja proteção representa o interesse primário do Estado por meio da instituição dos recursos excepcionais), se não a de garantir direitos subjetivos, e mais ainda a sua resposta: "A ofensa ao direito objetivo é mais perniciosa porque potencialmente implica ou pode implicar uma pluralização das ofensas a direitos subjetivos que seriam decorrentes da regra violada, cuja eficácia fica já em tese comprometida." 145

\footnotetext{
${ }^{145}$ WAMBIER, Teresa Arruda Alvim, Recurso especial, recurso extraordinário e ação rescisória, cit., p.
} 247. 
De fato, no final, as funções públicas de nomofilaquia e uniformização da jurisprudência perseguidas pela instituição dos recursos excepcionais, as quais se desenvolvem a partir da atuação das partes (ainda que em prol de interesses particulares), não visam no plano mediato a outra finalidade que não à proteção dos próprios direitos subjetivos dos indivíduos, que são constantemente lesados diante de decisões divergentes que ameaçam os princípio da igualdade e da segurança jurídica.

\subsection{Admissibilidade}

\subsubsection{Juízos de admissibilidade e de mérito}

Assim como se exigem alguns requisitos formais para a admissão do exame do mérito da causa (pressupostos processuais e condições da ação), também em sede recursal o pedido do recorrente (reforma, anulação, esclarecimento ou integração da decisão recorrida) só poderá ser apreciado se estiverem presentes os requisitos de admissibilidade do recurso.

Para todos os recursos (ordinários ou extraordinários), exige-se a observância do cabimento (previsão legal do recurso interposto, em respeito ao princípio da taxatividade), da tempestividade (interposição dentro do prazo legal), do preparo (prévio recolhimento das custas judiciais), da legitimidade e do interesse recursal (semelhantes à legitimidade $\mathrm{e}$ o interesse processual, mas relativos à fase recursal), da regularidade formal (exigências legais a respeito da forma de interposição, como instrução com peças obrigatórias, forma escrita etc.) e dos pressupostos negativos (ausência de fato impeditivo ou extintivo do direito de recorrer, como, por exemplo, a desistência, a renúncia etc.). São os requisitos gerais de admissibilidade dos recursos.

Quanto aos recursos excepcionais, além dos requisitos gerais, exige-se a observância de requisitos especiais ou específicos de admissibilidade, o que se dá justamente em razão das funções públicas especiais desempenhadas por esses recursos e pelo fato de que suas hipóteses de cabimento estão previstas na Constituição Federal (de onde se extraem outros requisitos além dos previstos no sistema processual infraconstitucional). 
Assim, além das hipóteses de cabimento previstas expressamente na própria Constituição Federal, a admissibilidade de tais recursos está condicionada a outras exigências específicas, como o prequestionamento, o esgotamento da instância ordinária, a ausência de necessidade de reapreciação de matéria de fato ou reexame de provas etc. No caso do recurso extraordinário, exige-se também a repercussão geral, requisito específico relacionado ao cabimento.

Ressalte-se que, por decorrem da própria Constituição Federal, a lei não pode alargar ou restringir as hipóteses de cabimento e os demais pressupostos específicos de admissibilidade dos recursos excepcionais, sob pena de inconstitucionalidade.

A inobservância dos requisitos - gerais ou específicos - de admissibilidade leva ao não conhecimento do recurso e, consequentemente, à ausência de apreciação do pedido ou do mérito recursal.

Na medida em que todo recurso representa uma extensão ao direito de ação e de defesa, pode-se dizer que esses requisitos de admissibilidade constituem uma restrição ao direito de recorrer e, portanto, aos princípios do acesso à justiça, da ampla defesa e do contraditório. Apesar disso, a sua exigência é legítima, porquanto visa satisfazer outros princípios processuais igualmente importantes, como a segurança jurídica, a efetividade, a celeridade e a eficiência processual. No caso dos requisitos específicos, a legitimidade decorre da própria Constituição Federal, e justifica-se pela função de tais recursos definida pelo texto constitucional. ${ }^{146}$

Quanto ao mérito do recurso, não se pode confundi-lo com mérito da própria causa: uma coisa é o pedido recursal de reforma, invalidação, esclarecimento ou integração da decisão; outra é o pedido formulado pelo autor da ação, que constituirá o mérito ou o objeto do processo. E esses pedidos não necessariamente coincidem. ${ }^{147}$

\footnotetext{
${ }^{146}$ GRECO, Leonardo, Instituições de processo civil, cit., v. 1, p. 223.

${ }^{147}$ Assim, o mérito do recurso pode ou não confundir-se com o mérito da causa, o que ocorrerá quando se aponta error in judicando na decisão recorrida e pede-se a sua reforma, caso em que o julgamento do recurso levará à substituição do julgado objeto da impugnação. Pode ocorrer, porém, de o recorrente apontar error in procedendo e pedir a invalidação da decisão recorrida (não incide, aqui, o efeito substitutivo, e acolhido o pedido, em regra, o processo deve retornar para que o órgão prolator da decisão invalidada profira outra em seu lugar), ou então pedir, em sede de embargos de declaração, o seu esclarecimento ou integração. Nesses casos, o mérito recursal será totalmente distinto do mérito da causa. Quanto aos recursos excepcionais, diz-se que eles se submetem a três juízos: de admissibilidade, de cassação e de revisão. Este último se justifica em face do teor da Súmula 456 do STF, no sentido de que admitido o recurso, a Corte deverá julgar a causa, aplicando o direito à espécie.
} 
Tecnicamente, os requisitos de admissibilidade devem ser analisados de forma preliminar, pois se não estiverem presentes, impedirão o exame do mérito do recurso. Com isso, verifica-se que há uma distinção bem clara entre os planos da admissibilidade e do mérito. No entanto, tem-se quanto a esse ponto um problema, quando se trata de recursos de fundamentação vinculada, cujas hipóteses de cabimento confundem-se com o próprio mérito recursal. ${ }^{148}$

É o caso, por exemplo, dos embargos de declaração, que, à luz do artigo 535 do CPC, só podem ser opostos para discussão dos vícios de contradição, obscuridade e omissão da decisão embargada. O mesmo ocorre com os recursos excepcionais, que só podem ser interpostos com fundamento na arguição de violação ao direito federal constitucional ou infraconstitucional, nos termos especificados pelos artigos 102, III, e 105, III, da Constituição Federal.

Se o acórdão viola norma federal constitucional ou infraconstitucional, o recurso extraordinário ou especial não só deverá ser admitido, como também deverá ser provido, para cassação e, se o caso, reforma do acórdão recorrido.

Daí a afirmação de Teresa Arruda Alvim Wambier, no sentido de que existe possibilidade - típica dos recursos com fundamentação vinculada - de sobreposição entre juízo de admissibilidade e juízo de mérito, porque a norma elege, como requisito desses recursos, algo que, na verdade, confunde-se com seu próprio mérito. ${ }^{149}$

Isso levava a jurisprudência do STF a afirmar, em muitos casos de inexistência de violação à norma federal, que o recurso extraordinário não era conhecido ou admitido. Ou

\footnotetext{
${ }^{148}$ Recursos de fundamentação vinculada são aqueles em que a lei estipula previamente quais fundamentos poderão ser invocados pela parte recorrente. Diferentemente do que ocorre com os recursos de fundamentação livre, em que se admite a ampla e irrestrita arguição de questões aptas a ensejar o acolhimento do pedido, naquela espécie recursal não se admite qualquer outro fundamento, que não o apontado pela lei.

${ }^{149}$ WAMBIER, Teresa Arruda Alvim, Recurso especial, recurso extraordinário e ação rescisória, cit., p. 248.
} 
seja, apesar de o julgamento ser de mérito, no sentido do não acolhimento da pretensão recursal, o recurso se considerava não admitido. ${ }^{150}$

No âmbito dos recursos extraordinários, essa situação é problemática, porque a natureza da decisão é importante, por exemplo, para definir a competência para a ação rescisória (que é do órgão que exerceu o juízo de mérito) ${ }^{151}$ e os limites da competência dos órgãos de origem (restrita ao juízo de admissibilidade).

A saída para o problema, inteligentemente sugerida pela doutrina, seria considerar que basta a alegação de contrariedade ou negativa de vigência à norma federal (constitucional ou infraconstitucional) para a admissibilidade do recurso extraordinário ou especial $^{152}$. Com isso, ficariam bem definidos os dois planos: alegando-se ofensa à norma, seria reconhecido o cabimento do recurso; ocorrendo efetivamente a ofensa alegada, ele seria provido; não ocorrendo a ofensa alegada, seria o caso de improvimento.

Atualmente, há precedentes do STF que estabelecem a distinção ${ }^{153}$. No mesmo sentido, há muitos julgados em que o STJ distingue nitidamente a admissibilidade do

${ }^{150}$ Segundo esse entendimento, não existiria, quanto a tais recursos, casos de admissão e desprovimento do recurso. Ou ele seria admitido e provido, ou então seria sempre inadmitido - mesmo nos casos em que todos os requisitos de admissibilidade, gerais e específicos, estivessem presentes (MOREIRA, José Carlos Barbosa. Juízo de admissibilidade e juízo de mérito no julgamento do recurso especial. In: TEIXEIRA, Sálvio Figueiredo (Coord.). Recursos no Superior Tribunal de Justiça. São Paulo: Saraiva, 1991. p. 166). Ressalte-se que no STJ o entendimento também encontrou adeptos, como se verifica pelo ED REsp n. 328.445/ES, 4a Turma, rel. Min. Fernando Gonçalves, DJ 03.05.2004, p. 169, onde se afirma: "O não conhecimento do especial fundado na letra 'a' significa desprovimento, podendo, também, se dar por razões processuais. Mera questão de técnica."

${ }^{151}$ Em face da insegurança jurídica gerada por tal situação, o STF editou a Súmula 249, com o seguinte teor: "É competente o Supremo Tribunal Federal para a ação rescisória quando, embora não tendo conhecido do recurso extraordinário, ou havendo negado provimento ao agravo, tiver apreciado a questão federal"; ela é bastante criticada, em face da contradição de seu teor, que confunde juízo de admissibilidade com juízo de mérito (MOREIRA, José Carlos Barbosa, op. cit., p. 168).

152 "Para que o recorrente tenha razão, e por conseguinte o recurso mereça provimento (juízo de mérito), já se assinalou, é preciso que exista realmente a contrariedade; para que o órgão ad quem possa legitimamente averiguar essa existência, e portanto o recurso mereça conhecimento (juízo de admissibilidade), é suficiente que a contrariedade seja alegada (MOREIRA, José Carlos Barbosa, op. cit., p. 166).

153 “Alteração da tradicional orientação jurisprudencial do STF, segundo a qual só se conhece do RE, a, se for para dar-lhe provimento: distinção necessária entre o juízo de admissibilidade do RE, a - para o qual é suficiente que o recorrente alegue adequadamente a contrariedade pelo acórdão recorrido de dispositivos da Constituição nele prequestionados - e o juízo de mérito, que envolve a verificação da compatibilidade ou não entre a decisão recorrida e a Constituição, ainda que sob prisma diverso daquele em que se hajam baseado o Tribunal a quo e o recurso extraordinário." (STF - RE n. 298.695/SP, Pleno, rel. Min. Sepúlveda Pertence, $D J$, de 24.10.2003, p. 12). No mesmo sentido: STF - RE n. 219.852/SP, rel. Min. Ellen Gracie, $D J$, de 28.10.2004, p. 46; STF - AI n. 579.710/SP, rel. Min. Eros Grau, j. 22.05.2006, DJ, de 19.06.2006, p. 21). Observe-se, porém, que a exigência atual de repercussão geral traz mais um elemento para a 
mérito do recurso especial, tanto que o recurso é conhecido e provido, ou conhecido e provido em parte, ou até conhecido e improvido. ${ }^{154}$

Entendemos que o mais adequado é considerar que, havendo pelo órgão judicial o exercício das funções nomofilácica ou de uniformização (juízo positivo ou negativo de cassação e eventualmente de revisão, vinculado ao controle da observância da correta interpretação e aplicação do direito objetivo), estar-se-á, independentemente do nome atribuído à decisão, adentrando no juízo de mérito do recurso, devendo, portanto, ser dispensada à decisão tratamento compatível com a sua natureza. ${ }^{155}$

\subsubsection{Juízo prévio de admissibilidade pelo tribunal de origem: limites}

O primeiro juízo de admissibilidade dos recursos excepcionais é realizado pelo próprio órgão a quo (art. 542, $\S 1^{\circ}$, do CPC). Trata-se de juízo prévio, sujeito a confirmação do STF ou STJ. Quando o juízo é positivo, a reapreciação da presença dos requisitos deve ser realizada independentemente de qualquer recurso. Quando negativo, a parte interessada poderá submeter a questão ao STF e ao STJ por meio do agravo previsto pelo artigo 544 do CPC.

Esse controle bifásico da admissibilidade é, na verdade, trifásico, eis que no STF ou STJ o relator tem poderes para negar seguimento ao recurso nos casos do artigo 544, § $4^{\circ}$, do CPC e da Lei n. 8.038/90, por decisão monocrática sujeita a agravo interno ao órgão colegiado competente.

Trata-se de uma filtragem dos recursos excepcionais, sujeitos a rígidos requisitos de admissibilidade, tudo com o fim de evitar que cheguem ao STF e ao STJ, já assoberbados de trabalho, recursos fadados ao insucesso.

\footnotetext{
admissibilidade do recurso extraordinário, de forma que, mesmo havendo suposta violação à norma constitucional, o recurso poderá ser inadmitido em virtude da ausência de transcendência da questão.

${ }^{154}$ STJ - REsp n. 698.855/RJ, $3^{\text {a }}$ Turma, rel. Min. Nancy Andrighi, DJ, de 29.10.2007, p. 818; STJ - REsp n. 682.279/RS, $2^{\text {a }}$ Turma, rel. Min. Castro Meira, DJ, de 26.04.2007, p. 235.

155 "Relevantíssimo, todavia, é fixar-se a necessária consequência do quanto se disse: não se pode deixar de dar tratamento de decisão de mérito, para todos os efeitos, àquelas decisões em que se diz: não conheço do recurso, porque não há a ofensa à lei ou à Constituição Federal, pois isto equivaleria, como diz Barbosa Moreira, a se dizer: não julgo o mérito, porque julgo o mérito negativamente." (WAMBIER, Teresa Arruda Alvim, Recurso especial, recurso extraordinário e ação rescisória, cit., p. 256).
} 
O juízo definitivo de admissibilidade, porém, compete exclusivamente ao STF e STJ, razão pela qual a recorribilidade da decisão de admissão por agravo é o que garante a constitucionalidade desse sistema, até porque, conforme José Carlos Barbosa Moreira, trata-se de princípio fundamental que "seja qual for o recurso, pelo menos a questão da admissibilidade não deve jamais ser subtraída à apreciação do órgão ad quem". Dessa forma, ainda segundo o processualista, "salvo expressa exceção legal, nenhum recurso pode ser rejeitado como inadmissível pelo órgão perante o qual se interpõe, se dessa decisão a lei não faculta ao recorrente outro recurso, ou remédio análogo, para o juízo a que trocaria julgar o primeiro". ${ }^{156}$

Além disso, não há dúvida de que o juízo de mérito também compete exclusivamente à instância superior, o que desperta a seguinte indagação: seria legítimo permitir ao tribunal a quo inadmitir o recurso excepcional sob o fundamento da ausência de violação à norma federal constitucional ou infraconstitucional?

Entendemos que, em princípio, a resposta é negativa, pois do contrário os tribunais de origem - competentes, nos termos da lei, unicamente para a realização do juízo prévio de admissibilidade dos recursos extraordinários (art. 542, § $1^{\circ}$, do CPC) - estariam avaliando o próprio mérito desses recursos, invadindo a competência exclusiva do STF e do STJ. ${ }^{157}$

Esse, porém, não é o entendimento de parte da doutrina e da jurisprudência do STJ, para quem os tribunais de origem podem sim negar seguimento ao recurso nesses casos, sob o fundamento de que a própria Constituição criou uma hipótese de cabimento que tangencia o mérito. Segundo Athos Gusmão Carneiro, ao órgão a quo cabe "exarar juízo fundamentado (CPC, art. 542, § $1^{\circ}$ ) de delibação sobre a razoabilidade, a plausibilidade da arguição de contrariedade à lei federal". ${ }^{158}$

\footnotetext{
${ }^{156}$ MOREIRA, José Carlos Barbosa, Comentários ao Código de Processo Civil: Lei n. 5.869, de 11 de janeiro de 1973, arts. 476 a 565, cit., v. 5, p. 264.

157 "Não compete ao presidente ou ao vice-presidente examinar o mérito do recurso extraordinário ou especial, nem lhe é lícito indeferi-lo por entender que o recorrente não tem razão: estaria, ao fazê-lo, usurpando a competência do Supremo Tribunal Federal ou do Superior Tribunal de Justiça.” (MOREIRA, José Carlos Barbosa, op. cit., v. 5, p. 605).

${ }^{158}$ CARNEIRO, Athos Gusmão, Recurso especial, agravos e agravo interno, cit., p. 94.
} 
A jurisprudência atual do STJ também se orienta nesse sentido, afirmando não caracterizarem invasão da competência constitucional do STJ as decisões de inadmissão proferidas pelos tribunais de origem, sob o fundamento da ausência de violação à lei federal. ${ }^{159}$

Para nós, esse entendimento mitiga a distinção entre juízo de admissibilidade e de mérito, colocando em cheque a competência constitucional do STF e do STJ para apreciar o mérito dos recursos excepcionais e, com isso, decidir em caráter definitivo quando ocorre e quando não ocorre violação às normas federais, constitucionais e infraconstitucionais.

Não se pode perder de vista que, ainda que a Constituição Federal tenha criado hipótese de cabimento (admissibilidade) que tangencie o mérito, a competência para aferir a ocorrência da alegada violação às normas federais continua a ser, segundo a mesma Constituição, exclusiva do STF e do STJ.

Daí porque, para justificar a legitimidade dessa interpretação, pacificamente aceita pela jurisprudência, deve-se buscar uma distinção entre a apreciação da inocorrência de violação ao direito federal em sede de juízo prévio de admissibilidade (o que se permite aos órgãos de origem e, mesmo assim, sob a condição do cabimento de agravo de admissão contra a respectiva decisão) e a apreciação do próprio mérito dos recursos excepcionais (de competência exclusiva do STF e STJ).

Nesse sentido, o que parece razoável é admitir que o tribunal a quo, podendo aferir objetivamente a ausência de probabilidade da alegação de violação ao direito federal, fica autorizado a negar seguimento (inadmitir) o recurso excepcional. Não haverá, aí, juízo de valor pelo órgão a quo a respeito da definitiva interpretação do direito federal (e, portanto,

\footnotetext{
159 "Deve ser afastada a alegação de que o egrégio Sodalício a quo invadiu a competência desta colenda Corte, em razão da jurisprudência do Superior Tribunal de Justiça ter pacificado o entendimento de ser possível a Tribunal local adentrar no mérito do recurso especial quando do processamento do juízo de admissibilidade, na medida em que tal exame envolve o próprio mérito da controvérsia, em face dos pressupostos constitucionais previstos na alínea 'a' do inciso III do art. 105 da Constituição Federal, observada sua natureza especial, a qual determina que o Julgador, para admiti-lo, deverá examinar a plausibilidade das alegações do recorrente. Assim sendo, não há como escapar do exame do mérito do recurso." (STJ - ED AG n. 415.937/SP, 4ª Turma, rel. Min. Massami Uyeda, DJ, de 19.11.2007, p. 229). E ainda: "[...] A jurisprudência desta Corte pacificou o entendimento segundo o qual a emissão de juízo sobre o mérito do recurso especial, pelo Tribunal de origem, por ocasião do exame provisório de admissibilidade, não implica usurpação da competência do Superior Tribunal de Justiça. Precedentes." (STJ - AgR AREsp

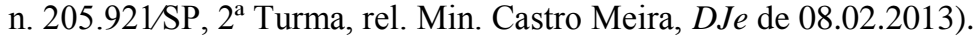


não haverá exercício das funções nomofilácica e de uniformização), mas sim a constatação, a partir de critérios objetivos, da ausência de alegação apta a gerar o efetivo reconhecimento de violação à correta interpretação do direito federal.

É como se, diante da previsão constitucional no sentido de que cabe recurso excepcional nos casos de violação à lei federal, fosse permitida a negativa de seguimento desses recursos (ou seja, a sua inadmissibilidade) sempre que possível a aferição objetiva da inocorrência dessa violação, ou seja, sem necessidade de interpretação, pelo próprio órgão encarregado do juízo prévio de admissibilidade, da questão controvertida de direito federal.

Pense-se, assim, na hipótese em que o recurso excepcional contraria a jurisprudência pacífica do STF e do STJ. Pode-se presumir, nesse caso, que se o recorrente defende tese simplesmente superada pela jurisprudência do órgão superior, sem apontar argumentos novos, seu recurso excepcional não terá sucesso, porque a razão de ser de tais recursos, conquanto representem um meio de impugnação à disposição das partes, é ajustar a interpretação do direito federal realizada pela decisão recorrida à interpretação correta fixada pelos órgãos superiores.

Nesse caso, um dado objetivo indica a ausência de chance de êxito do recurso (contrariedade à jurisprudência do órgão ad quem), de modo que o permissivo constitucional não justificaria a subida do recurso, autorizando, assim, a sua inadmissão pelo órgão competente para a realização do controle prévio de admissibilidade. É o que, de certa forma, já foi consolidado há bastante tempo pelas Súmulas 286 do STF e 83 do STJ.

Trata-se de questão importante e diretamente relacionada a um dos principais problemas da técnica de julgamento de recursos repetitivos, pois, segundo os artigos 543-B e 543-C do CPC, uma vez julgado o caso representativo da controvérsia, os próprios tribunais de origem, onde os recursos repetitivos aguardavam sobrestados, deverão considerar prejudicados ou negar seguimento (leia-se: deverão inadmitir) os recursos contrários ao entendimento fixado pelo STF e STJ. Seria legítimo esse sistema? Não equivaleria a um desprovimento do recurso excepcional, em ofensa à Constituição Federal, que atribui ao próprio STF e STJ competência exclusiva para o julgamento do mérito de tais recursos? Trataremos dessas questões no Capítulo 6 (item 6.3). 


\subsubsection{Cabimento (arts. 102, III, e 105, III, da CF)}

As hipóteses de cabimento dos recursos excepcionais estão expressamente previstas na Constituição Federal e relacionam-se intimamente com suas funções públicas especiais de nomofilaquia e uniformização.

O artigo 102, III, estabelece a competência recursal extraordinária do Supremo Tribunal Federal, prevendo o cabimento de "recurso extraordinário" quando a decisão recorrida: "a) contrariar dispositivo desta Constituição; b) declarar a inconstitucionalidade de tratado ou lei federal; c) julgar válida lei ou ato de governo local contestado em face desta Constituição; d) julgar válida lei local contestada em face de lei federal.”

Por sua vez, o $\S 3^{\circ}$ do artigo 102 prevê que, em relação a qualquer das hipóteses de cabimento, a questão constitucional seja qualificada pela repercussão geral (ver Capítulo 5, item 5.5).

Quanto ao recurso especial, dispõe o artigo 105, III, da Constituição Federal, ao prever a competência recursal extraordinária do Superior Tribunal de Justiça, ser ele cabível quando a decisão recorrida: “a) contrariar tratado ou lei federal, ou negar-lhe vigência; b) julgar válido ato de governo local contestado em face de lei federal; c) der a lei federal interpretação divergente da que lhe haja atribuído outro tribunal.”

A primeira hipótese, comum aos recursos extraordinário e especial (alínea "a" dos arts. 102, III, e 105, III), diz respeito à contrariedade, pela decisão recorrida, a norma federal constitucional ou infraconstitucional.

Na verdade, trata-se do único fundamento dos recursos excepcionais, de forma que as demais alíneas seriam meras especificações ou subespécies da hipótese prevista na alínea "a", que sempre deverá de alguma forma estar presente para fins de cabimento do recurso. ${ }^{160}$

\footnotetext{
160 "A nosso ver, na verdade, os únicos fundamentos possíveis destes recursos estão nos arts. 102, III, a, e 105, III, a". (WAMBIER, Teresa Arruda Alvim, Recurso especial, recurso extraordinário e ação rescisória, cit., p. 260).
} 
De fato, o recurso extraordinário ou especial sempre veiculará, independentemente da alínea em que se fundamente, uma alegação de violação à Constituição ou à lei federal. As demais alíneas tratam, na verdade, de meras hipóteses objetivas que permitem presumir a suposta ocorrência daquela violação, a ensejar a abertura da instância extraordinária para o exame do mérito da questão. ${ }^{161}$

Frise-se que não há distinção entre contrariar (alínea "a" dos arts. 102, III, e 105, III) ou negar vigência (alínea "a" do art. 105, III) à norma ${ }^{162}$. E em todos esses casos, o que se tem indistintamente é o fundamento único, a verdadeira hipótese de cabimento dos recursos excepcionais. Nem poderia ser diferente, posto que a função de tais recursos, como já demonstrado acima, consiste na garantia de que o direito constitucional e infraconstitucional federal seja corretamente aplicado por todos os demais órgãos judiciais da Federação, segundo a interpretação definida pelo STF e pelo STJ.

A alínea "c" do artigo 105, III, prevê o cabimento do recurso especial quando a decisão recorrida interpretar alguma norma federal inconstitucional de forma divergente da interpretação já realizada por outro tribunal ${ }^{163}$. Sobre essa hipótese, devemos desenvolver com um pouco mais de vagar algumas considerações.

161 A diferença entre as hipóteses da alínea "a" e das demais é que, em relação a estas, a norma é axiologicamente neutra quanto à definição do cabimento, por não se exigir a prévia verificação da ocorrência do vício (MOREIRA, José Carlos Barbosa, Comentários ao Código de Processo Civil: Lei n. 5.869, de 11 de janeiro de 1973, arts. 476 a 565, cit., v. 5, p. 589).

162 "Para efeito de cabimento dos recursos especial e extraordinário, ofender a lei, contrariar-se a lei, negar vigência à lei são hoje expressões equivalentes. Interpretar mal o texto de lei é contrariá-lo, é negar-lhe vigência, é ofendê-lo." (WAMBIER, Teresa Arruda Alvim, Recurso especial, recurso extraordinário e ação rescisória, cit., p. 262).

${ }^{163}$ Essa hipótese foi incorporada ao rol de hipóteses de cabimento do recurso extraordinário pela Emenda Constitucional de 5 de setembro de 1926 , cujo artigo $60, \S 1^{\circ}$, não só previa a possibilidade de interposição do recurso "quando dois uma mais tribunais locais interpretarem de modo diferente a mesma lei federal", como a possibilidade de "o recurso ser também interposto por qualquer dos tribunais referidos ou pelo Procurador-Geral da República". Com redações um pouco distintas, mas mantendo-se inclusive a legitimidade dos tribunais e do Ministério Público, a hipótese foi mantida pelas Constituições de 1934 (art. 76, III, “d”) e de 1937 (art. 101, III, “d”). Tal legitimidade foi suprimida pela Constituição de 1946, que manteve apenas a hipótese de cabimento do extraordinário em caso de divergência na interpretação da lei federal entre os tribunais, mencionando, desta vez, o próprio STF. O texto foi praticamente mantido pela Constituição de 1967, com alteração dada pela Emenda de 1969. Por fim, chegou-se ao texto da atual Constituição promulgada em 1988, que transferiu ao STJ, então criado, a competência para julgar, mediante recurso especial, as decisões contrárias à lei federal e que instaurem divergência a respeito da sua interpretação. 
Tratar-se-ia de hipótese autônoma de cabimento, distinta e independente da prevista na alínea "a"? E mais: sendo que ela é prevista apenas no artigo 105, III, e não no artigo 102, III, da Constituição, tratar-se-ia de hipótese exclusiva do recurso especial?

Quanto à primeira questão, todo recurso que aponta divergência entre a interpretação adotada pela decisão recorrida e a adotada por outro tribunal traz necessariamente a alegação de que a interpretação correta da lei federal é a que foi dada pelo acórdão paradigma, e não pela decisão recorrida, ou, em outros termos, a alegação de que a decisão recorrida viola a lei federal.

Na verdade, a própria função uniformizadora de jurisprudência está ligada à ideia de proteção do direito objetivo e inteireza do sistema jurídico. Como bem salientado por Pontes de Miranda, a ratio legis da norma que prevê o cabimento do recurso excepcional em caso de divergência de interpretação está "na uniformidade de inteligência da lei federal, na integridade lógica do direito objetivo, na inteireza do sistema jurídico"164. Já Alfredo Buzaid afirma que "o recurso extraordinário com fundamento na letra 'd' [hoje equivalente ao recurso especial com fundamento no art. 102, III, “c”] ou dá lugar a um recurso artificial ou se reconduz à hipótese da letra 'a'". 165

De fato, não basta para o sucesso do recurso especial a demonstração da divergência; é preciso, além disso, que o STJ se convença do acerto da interpretação divergente do acórdão paradigma, ou seja, do erro de interpretação da decisão recorrida (o que equivale, para todos os fins, à contrariedade ou negativa de vigência à lei federal, como previsto na alínea “a”).

A ideia e utilidade da alínea "c" é a de que, demonstrada a divergência, presume-se que a decisão recorrida interpretou de alguma forma a lei federal, abrindo-se com maior

\footnotetext{
${ }^{164}$ PONTES DE MIRANDA, Francisco Cavalcanti, Comentários à Constituição de 1967: com a Emenda n. 1: arts. 118 a 153, $\S 1^{\circ}$, cit., v. 4, p. 166. No mesmo sentido, Rodolfo de Camargo Mancuso afirma que "não há negar a estreita relação entre as alíneas 'a' e 'c' do art. 105, III da CF [...] o objetivo ali perseguido é o de possibilitar unidade de interpretação da lei federal em todo o território nacional" (MANCUSO, Rodolfo de Camargo, Recurso extraordinário e recurso especial, cit., p. 296). E também Teresa Arruda Alvim Wambier: "A função 'uniformizadora' é também exercida pelo STF e a situação não é substancialmente diferente da que ocorre com o recurso especial, salvo em virtude de aspectos procedimentais." (WAMBIER, Teresa Arruda Alvim, Recurso especial, recurso extraordinário e ação rescisória, cit., p. 262).

${ }^{165}$ BUZAID, Alfredo, A crise do Supremo Tribunal Federal, in Estudos de direito I, cit., p. 155.
} 
facilidade a instância extraordinária para se verificar se a interpretação foi correta, ou seja, se a norma foi corretamente aplicada. Com isso, protege-se o direito positivo (corrigindo eventual erro na aplicação da lei federal ao caso concreto) e, ao mesmo tempo, unifica-se a jurisprudência, afirmando-se qual das interpretações está correta. ${ }^{166}$

Além disso, a alínea "c" explicita a ideia de que, para o sistema, existe apenas uma interpretação correta, não se podendo falar em duas ou mais interpretações razoáveis. Se pudessem existir duas interpretações divergentes e corretas, não se poderia admitir recurso especial com base em dissídio jurisprudencial. Pretende-se justamente afirmar o sentido unívoco da lei federal no território nacional, garantindo-se segurança jurídica e igualdade na aplicação do direito.

Daí porque não pode prevalecer a Súmula 400 do STF, segundo a qual: "Decisão que deu razoável interpretação à lei, ainda que não seja a melhor, não autoriza recurso extraordinário pela letra 'a' do art. 101, III, da Constituição Federal”'. ${ }^{167}$

Note-se, de qualquer forma, que a função uniformizadora da jurisprudência também é desempenhada quando a interposição do recurso fundamenta-se unicamente na alínea “a”. Definindo-se a interpretação da norma no julgamento de determinado recurso especial,

\footnotetext{
166 "A letra $c$ do art. 105, III, da Constituição Federal não aumenta o espectro de cabimento do recurso especial, mas sim facilita o seu julgamento, por ser a divergência circunstância aferível objetivamente. Não é mais uma hipótese de cabimento, senão uma oportunidade conferida pelo legislador para se atingir de forma absoluta um dos objetivos primordiais do recurso especial: que o entendimento e a interpretação de uma determinada norma federal sejam os mesmos, uniformes, em todo o território nacional." (JORGE, Flávio Cheim. Recurso especial com fundamento na divergência jurisprudencial. In: NERY JUNIOR, Nelson; WAMBIER, Teresa arruda Alvim (Coords.). Aspectos polêmicos e atuais dos recursos cíveis e de outras formas de impugnação às decisões judiciais. São Paulo: Revista dos Tribunais, 2001. p. 386).

${ }^{167}$ Conforme Pontes de Miranda: "Para tribunal que julga quaestiones iuris, não é possível admitir-se que ache duas interpretações razoáveis. Por mais razoáveis que sejam as interpretações que se possam dar à mesma regra jurídica, só uma é verdadeira, só uma tem razão. A razoabilidade para duas ou mais interpretações seria de lege ferenda; nunca, de lege lata. Para tribunal uniformizador da jurisprudência seja o da revista, seja o do recurso extraordinário - só uma interpretação é a certa, a verdadeira, a que tem razão." (PONTES DE MIRANDA, Francisco Cavalcanti, Comentários à Constituição de 1967: com a Emenda n. 1: arts. 118 a 153, § $1^{\circ}$, cit., v. 4, p. 168). Da mesma forma, Rodolfo de Camargo Mancuso leciona: "A estabilidade das relações sociais, e mesmo das instituições, exige que uma Corte Superior específica diga - com exclusividade e eficácia incontrastável - que o texto constitucional x merece a interpretação y, ficando afastada(s) outra(s) possível(is) inteligência(s) [...] também o STJ não poderá deixar de conhecer de recurso especial invocando a Súmula 400, na medida em que só ele é o exegeta maior e definitivo do direito federal infraconstitucional, e não pode abdicar dessa competência, ou 'dividila' com os Tribunais locais ou regionais." (MANCUSO, Rodolfo de Camargo, Recurso extraordinário e recurso especial, cit., p. 251-253). Observe-se, porém, que essa súmula, apesar de críticas, ainda é atual: STJ - AI n. 922.774, rel. Min. Nilson Naves, DJ 20.09.2007; STF - AI n. 163.521, rel. Min. Rel. Joaquim Barbosa DJ 25.11.2004.
} 
todos os demais tribunais poderão orientar-se no sentido da decisão do STJ, atenuando-se ou prevenindo-se a divergência jurisprudencial.

Assim, vê-se que, na verdade, a alínea "c" sequer precisaria existir para que fosse autorizado o cabimento do recurso especial em caso de divergência jurisprudencial, pela simples razão de que a alínea "a" já desempenha essa função, a qual, como visto, está relacionada à própria função essencial de todo recurso excepcional.

Isso também responde à segunda questão formulada acima: a função uniformizadora é igualmente exercida pelo STF sempre que julga pelo mérito recursos extraordinários interpostos com fundamento em qualquer das alíneas previstas no artigo 102, III. Em todos os casos, o STF define, por meio do recurso extraordinário, a interpretação de determinada norma constitucional, eliminando divergências existentes ou potenciais.

Assim, demonstrado no recurso extraordinário que outro tribunal, ou o próprio STF, deu à questão constitucional interpretação divergente da que lhe atribuiu a decisão recorrida, o fundamento do recurso (independentemente da alínea) será reforçado.

Ao comentar sobre os pressupostos do recurso extraordinário por divergência de interpretação (à época, a função hoje desempenhada pelo recurso especial pela hipótese da alínea "c" era de competência do STF, via recurso extraordinário), Pontes de Miranda já observava que "o texto permite o recurso extraordinário no caso de divergência entre tribunais na interpretação da lei federal”. E acrescenta: “(com maioria de razão, se se trata de interpretação da Constituição)". 168

\footnotetext{
${ }^{168}$ PONTES DE MIRANDA, Francisco Cavalcanti, Comentários à Constituição de 1967: com a Emenda n. 1: arts. 118 a $153, \S 1^{\circ}$, cit., v. 4, p. 164, grifos no original. Da mesma forma, vejamos a lição de Flávio Cheim Jorge: "Apesar de a divergência jurisprudencial não constar expressamente como hipótese de cabimento de recurso extraordinário, o Supremo Tribunal Federal de maneira mediata proporciona um resultado aproximado ao alcançado pelo Superior Tribunal de Justiça quando julga o recurso especial pela letra $c$, do art. 105, III, da Constituição Federal. Isto porque, quando conhece do recurso extraordinário, o Supremo Tribunal Federal fixa um determinado posicionamento sobre a interpretação do texto constitucional, ou seja, o Supremo unifica o entendimento sobre a interpretação e o alcance de uma determinada norma jurídica constitucional." (CHEIM JORGE, Flávio Cheim, Recurso especial com fundamento na divergência jurisprudencial, in Aspectos polêmicos e atuais dos recursos cíveis e de outras formas de impugnação às decisões judiciais, cit., p. 385).
} 
Vê-se, então, que as diferenças entre a alínea "c" e as alíneas "a" e "b" do artigo 105, III, são meramente procedimentais. De fato, para a admissão pela alínea “c", que de qualquer forma gera a presunção de que a decisão recorrida deu interpretação controvertida à lei federal (permitindo, assim, a abertura da instância extraordinária), o sistema exige alguns requisitos adicionais, como o apontamento de precedente de "outro tribunal" (como consta no próprio texto da alínea “c") ${ }^{169}$, a comprovação da existência do acórdão paradigma ${ }^{170}$, a demonstração formal e analítica da divergência ${ }^{171}$ e a atualidade da decisão divergente. $^{172}$

\subsubsection{Outros requisitos específicos de admissibilidade}

Além das hipóteses específicas de cabimento, há outros requisitos de admissibilidade que decorrem direta ou indiretamente do texto constitucional e que também estão relacionados às funções exercidas pelos recursos excepcionais no sistema.

\footnotetext{
${ }^{169}$ A norma constitucional exige que a divergência refira-se a "outro tribunal" porque a ideia é uniformizar a interpretação da lei federal em âmbito nacional. Para eliminar divergências internas (ou seja, entre órgãos do próprio tribunal em que proferida a decisão recorrida) já existem outros instrumentos, como o incidente de uniformização da jurisprudência, os embargos de divergência, os embargos infringentes (arts. 476 e 546 do CPC; art. 330 do RISTF; art. 266 do RISTJ; Súmula 369 do STF; Súmula 13 do STJ).

${ }^{170}$ Nos termos do artigo 541, parágrafo único, do CPC, com a redação dada pela Lei n. 11.341/2006 e artigo 255 do RISTJ.

${ }^{171}$ O que deverá ser feito por meio da comparação de trechos da decisão recorrida e das decisões divergentes que demonstrem terem sido dadas soluções díspares para situações fáticas idênticas. Exige-se a comparação minuciosa, sendo recomendável a referência aos trechos do próprio corpo do acórdão, e não apenas das ementas. Essas exigências, de comprovação da existência do acórdão paradigma e demonstração analítica da divergência, tendem a ser atenuadas nos casos de notória divergência jurisprudencial, o que, no nosso entendimento, pode-se presumir nos casos em que já tiver havido julgamento de recurso pela sistemática do artigo 543-C do CPC.

${ }^{172}$ Se a ideia é uniformizar o direito federal, não há cabimento em se admitir o recurso especial por dissídio quando o entendimento adotado pela decisão paradigma ficou superado pela jurisprudência atual do próprio STJ. Estar-se-ia admitindo a pretensão do recorrente no sentido de alegar que a interpretação da decisão recorrida, conquanto conforme da jurisprudência atual do STJ, não prevalece perante aquela do acórdão paradigma, mesmo já tendo sido superada. Daí o teor da Súmula 83 do STJ, que substituiu a antiga Súmula 286 do STF, no sentido de que "Não se conhece do recurso especial pela divergência, quando a orientação do Tribunal se firmou no mesmo sentido da decisão recorrida". Há que se fazer apenas uma observação: se, por qualquer razão, o recorrente traz argumentos de fato e de direito novos, atuais, no sentido de que deve voltar a prevalecer a tese atualmente superada do acórdão paradigma (overruling), então o recurso deve ser admitido, ainda que para se rejeitar quanto ao mérito esses argumentos do recorrente e confirmar-se a jurisprudência atual do STJ.
} 
Assim, por exemplo, exige-se o esgotamento da instância ordinária ${ }^{173}$, porque a própria Constituição prevê o cabimento dos recursos contra decisões sobre "causas decididas em única ou última instância" (art. 102, III) e sobre "causas decididas em única ou última instância", mas acrescenta "pelos Tribunais Regionais Federais ou pelos tribunais dos Estados, do Distrito Federal e Territórios" (art. 105, III). ${ }^{174}$

Tem-se, ainda, o requisito do prequestionamento, relacionado ao conceito de "causas decididas", que em sua concepção atual significa fundamentalmente a necessidade de que conste na decisão impugnada o enfrentamento, a decisão, o exercício de um juízo de valor sobre a questão de direito federal, constitucional ou infraconstitucional. ${ }^{175}$

Por fim, como já exposto quando se tratou das funções dos recursos excepcionais, também se exige que as questões discutidas nos recursos excepcionais sejam exclusivamente de direito federal constitucional ou infraconstitucional, vedando-se a discussão de matéria fática e o reexame de $\operatorname{provas}^{176}$, o que também justifica a afirmação de que são recursos com efeito devolutivo limitado.

173 Conforme a Súmula 281 do STF, que também é aplicada pelo STJ: “É inadmissível o recurso extraordinário, quando couber, na justiça de origem, recurso ordinário da decisão impugnada”. Por sua vez, segundo a Súmula 207 do STJ: "É inadmissível recurso especial quando cabíveis embargos infringentes contra o acórdão proferido no tribunal de origem."

${ }^{174}$ Ou seja, enquanto o recurso extraordinário é cabível contra decisões proferidas por órgãos de qualquer instância (inclusive, portanto, o primeiro grau da instância ordinária, nos casos em que se caracterize como instância única), o recurso especial não prescinde de que a decisão recorrida tenha sido proferida por tribunal (Estadual de Justiça ou Regional Federal, excluídos os Juizados Especiais, conforme Súmula 203 do STJ) e, consequentemente, seja colegiada.

175 Nesse sentido, as Súmulas 282 (“É inadmissível o recurso extraordinário, quando não ventilada, na decisão recorrida, a questão federal suscitada") e 356 (“O ponto omisso da decisão, sobre o qual não foram opostos embargos declaratórios, não pode ser objeto de recurso extraordinário, por faltar o requisito do prequestionamento") do STF, que têm aplicação no STJ.

176 Daí as Súmulas 279 do STF e 7 do STJ, que dispõem respectivamente que "Para simples reexame de prova não cabe recurso extraordinário" e "A pretensão de simples reexame de prova não enseja recurso especial". 


\section{SEGUNDA PARTE}

Justificativa, aspectos gerais e constitucionalidade da técnica de julgamento de recursos repetitivos 


\section{AS CRISES DO SUPREMO TRIBUNAL FEDERAL E DO SUPERIOR TRIBUNAL DE JUSTIÇA E OS RECURSOS REPETITIVOS}

\subsection{A crise do Supremo Tribunal Federal}

De início, esclareça-se que a "crise" do STF e do STJ estudada neste capítulo refere-se especificamente ao problema de excesso de feitos nesses órgãos de cúpula e ao consequente comprometimento da celeridade e qualidade de seus julgamentos.

Conforme adverte Barbosa Moreira, o problema de acúmulo de trabalho nas Cortes Supremas não é exclusivo do Brasil, gerando em toda parte problemas relativos à celeridade e à qualidade dos julgamentos. ${ }^{177}$

Da mesma forma, Jordi Nieva-Fenoll relata que o problema é antigo e comum a todos os sistemas em que existe um órgão jurisdicional de cúpula (exceto nos Estados Unidos e na Inglaterra, em que o certiorari permite às Cortes Supremas selecionar discricionariamente as causas que julgarão ${ }^{178}$ ), conforme se vê na Espanha, na Itália, na França, no Tribunal de Justiça da União Europeia, no Tribunal Europeu de Direitos Humanos e até na Alemanha. ${ }^{179}$

\footnotetext{
177 "Em mais de um país tem-se feito sentir o problema do acúmulo de trabalho nas Cortes Supremas. O grande número de litígios que lhes chegam, sobretudo por via recursal, é fator importante de retardamento do desfecho dos pleitos. Ademais, a considerável variedade dos temas suscitados pode desviar a atenção dos juízes para assuntos menores, com prejuízo da respectiva concentração nas questões de mais relevância." (MOREIRA, José Carlos Barbosa, Comentários ao Código de Processo Civil: Lei n. 5.869, de 11 de janeiro de 1973, arts. 476 a 565, cit., v. 5, p. 613).

178 Mas mesmo nesses sistemas há preocupação com o problema do congestionamento de processos, conforme lembrado por Ilmar Nascimento Galvão, ao relatar que "apesar do writ of certiorari, o problema do congestionamento da Suprema Corte americana também não foi solucionado, encontrando-se em discussão diversas propostas para seu desafogo, tais como mudanças processuais internas, exacerbação do valor das custas, eliminação dos recursos obrigatórios e a criação de novo tribunal acima das cortes federais, a exemplo do que aconteceu conosco" (GALVÃO, Ilmar Nascimento. Poder Judiciário; reforma de 1988: o recurso especial no Superior Tribunal de Justiça. In: TEIXEIRA, Sálvio Figueiredo (Coord.). Recursos no Superior Tribunal de Justiça. São Paulo: Saraiva, 1991. p. 88).

${ }^{179}$ NIEVA-FENOLL, Jordi. El modelo anglosajón en las Cortes Supremas: ¿solución o elusión del problema de la casación? Revista de Processo, São Paulo, v. 38, n. 219, p. 185, maio 2013.
} 
No Brasil, desde cedo o Supremo Tribunal Federal começou a sentir a crise relativa ao desequilíbrio entre o número excessivo de feitos a ele submetidos e a sua efetiva capacidade de apreciação, logo chamada pelos doutrinadores de crise do Supremo. ${ }^{180}$

Nesse sentido, Alfredo Buzaid lembra o emblemático exemplo da disposição constante no Decreto n. 20.669, de 23 de novembro de 1931, que determinava a realização de quatro sessões semanais pela Corte "enquanto não esgotar a pauta das causas com dia". O autor lembra também como cresceu o número de recursos extraordinários submetidos à corte a partir de 1934 (de 150 em 1935 chegou a 6.597 em 1957), e que a crise foi agravada após 1946, com a criação do recurso ordinário constitucional em mandado de segurança. $^{181}$

A partir de 1960, o número de processos enviados ao STF começou a crescer ainda mais. As médias anuais de processos protocolizados respectivamente nas décadas de 1960 e de 1970 foram de 7.822 e 7.213. E, nas décadas seguintes, as médias aumentaram constantemente: 16.395 (1980), 32.649 (1990) e 107.460 (2000). De 2010 a 2012, já sob o novo regime de restrição do cabimento do recurso extraordinário pela exigência da repercussão geral e de julgamento de recursos repetitivos, a média anual caiu para $69.278 .^{182}$

\footnotetext{
${ }^{180}$ Na verdade, como observado por Theotonio Negrão em artigo publicado (RT Informa, São Paulo, n. 109, p. 3-7, jul. 1974) e republicado "pela coincidência entre grande parte das ideias ali expendidas e o que, quase 15 anos depois, foi aprovado pela Constituição de 1988", a crise é há muito tempo geral, e não atinge apenas os órgãos de cúpula do Judiciário: "Quando se examina o problema do bom funcionamento da Justiça em nosso País, o que logo chama a atenção é que praticamente todo o aparelhamento judiciário se acha em crise." (NEGRÃO, Theotonio. Uma nova estrutura para o Judiciário. Revista dos Tribunais, São Paulo, v. 79, n. 639, p. 242, jan. 1989).

${ }^{181}$ Segundo Alfredo Buzaid, apesar do aumento do índice demográfico; do crescimento do volume de causas oriundas do "surto industrial e comercial"; da intervenção da União no domínio econômico, criando vários órgãos; do intenso movimento de elaboração legislativa e de sua centralização, inclusive da legislação processual civil e penal, sempre presente inclusive nas causas que versam sobre direito estadual; enfim, apesar de todos esses fatores exemplificativamente mencionados demonstrarem a clara tendência de constante aumento dos feitos a serem submetidos ao STF, o legislador constituinte ampliou sua competência (BUZAID, Alfredo, A crise do Supremo Tribunal Federal, in Estudos de direito I, cit., p. 145150).

${ }^{182}$ Números extraídos do site do STF, disponíveis no campo "Estatística", "Movimentação Processual". Disponível em: <http:// www.stf.jus.br /portal/ cms/verTexto.asp? servico=estatistica\&pagina $=$ movimentoProcessual $>$. Acesso em: 10 set. 2013. As médias foram calculadas somando-se os números de processos protocolizados em cada década e dividindo-se o resultado por dez. Especificamente sobre as estatísticas relacionadas aos recursos extraordinários, ver Capítulo 11.
} 
As causas dessa explosão numérica são inúmeras. Conforme visto no Capítulo 3, nosso recurso extraordinário surgiu no momento histórico em que o Estado brasileiro estava sendo formado, por inspiração norte-americana, sob a forma federativa. Ocorre que a importação do modelo norte-americano não se deu conta de uma enorme distinção entre os processos de criação dos dois sistemas federativos. A Federação nos Estados Unidos surgiu a partir do movimento de colônias e da consequente existência de unidades fortes e independentes, que abriram mão parcialmente de sua competência em favor da União. Já no Brasil, o processo foi inverso: não existiam unidades fortes e independentes antes da criação da Federação, mas sim um Estado unitário e centralizador. A criação da Federação pela Constituição de 1891, justificada sobretudo em razão da extensão territorial do país, é que deu origem às unidades, estabelecendo suas competências. ${ }^{183}$

Segundo Teresa Arruda Alvim Wambier, ao contrário do que ocorreu nos Estados Unidos (em que as partes autônomas formaram o todo, preservando-se a autonomia e a grande competência das partes, e a diminuta competência do todo), no Brasil partiu-se do todo para a criação de uma Federação (partes), concentrando na União a maior parte da competência. ${ }^{184}$

Se a função do recurso extraordinário era, tal qual o writ of error, garantir a supremacia da lei federal e da Constituição em toda a Federação, não é difícil imaginar qual foi a consequência da sua simples importação a uma Federação em que a União, e não os Estados membros, detém a maior parte da competência legislativa: a hipertrofia das matérias sujeitas ao recurso extraordinário.

Além disso, o fato de os Estados Unidos serem filiados ao common law também justifica uma quantidade muito menor de causas a serem submetidas à Suprema Corte, porque os conflitos decorrentes das divergências entre a legislação estadual e a legislação federal $^{185}$, assim como os decorrentes da própria violação à norma escrita ${ }^{186}$, ocorrem em número muito menor do que o observado nos países de civil law.

\footnotetext{
${ }^{183}$ PINTO, Nelson Luiz, Recurso especial para o STJ: teoria geral e admissibilidade, cit., p. 45.

${ }^{184}$ WAMBIER, Teresa Arruda Alvim, Recurso especial, recurso extraordinário e ação rescisória, cit., p. 244.

${ }^{185}$ Ibidem, p. 244.

${ }^{186}$ PINTO, Nelson Luiz, op. cit., p. 46.
} 
Com o tempo, essa situação foi gerando uma constante e incrível multiplicação de recursos extraordinários, submetidos, como todo órgão de cúpula, a uma corte que não fora criada para revisar individualmente cada litígio do país, mas sim para preservar, em benefício de toda a coletividade, a autoridade e uniformidade do direito objetivo.

Outras circunstâncias também ajudam a explicar a enorme quantidade de feitos e, consequentemente, a crise dos Tribunais Superiores. São circunstâncias que se relacionam com a própria crise da Justiça em geral, mas que geram consequências ainda mais graves quando se fala nos órgãos de cúpula, propositalmente integrados por um reduzido número de julgadores (o que é conveniente, basicamente por evitar divergências e aumentar a autoridade dos julgamentos), dadas as suas funções de proteção e unificação da interpretação do direito federal.

Pode-se mencionar, assim, o crescimento demográfico ${ }^{187}$, a industrialização e o desenvolvimento econômico em todos os setores, a partir da década de sessenta ${ }^{188}$, a ampliação do acesso à justiça a partir da Constituição de 1988, com a consequente explosão do número de processos ${ }^{189}$ e o sistema recursal, que de uma forma geral prevê o direito de as partes recorrerem a praticamente todas as instâncias, inclusive ao STF e ao STJ. $^{190}$

187 Theotonio Negrão falava na necessidade de se levar em conta "que o simples aumento vegetativo da população tem de acarretar, consequentemente, maior número de demandas". E mencionando especificamente a crise do recurso extraordinário, que então cumulava a função de unificação da interpretação da lei federal, observava o risco de agravamento da situação diante da iminência da entrada em vigor de vários instrumentos legislativos, como o Código de Processo Civil, o Código Penal e a Lei de Registros Públicos (NEGRÃO, Theotonio, Uma nova estrutura para o Judiciário, cit., p. 243-244).

${ }^{188}$ SANTOS, Francisco Claudio de Almeida, Recurso especial: visão geral, in Recursos no Superior Tribunal de Justiça, cit., p. 92.

189 “A causa principal da lentidão da justiça é o aumento do número de processos, uma verdadeira explosão de ações, que decorre do fato de que, à medida que se acentua a cidadania, as pessoas procuram mais os tribunais, certo que a Constituição de 1988 deseja que a cidadania seja exercida por todos, convocados os cidadãos a fiscalizar a coisa pública, a res publica, efetivando-se essa fiscalização mediante o ajuizamento de medidas judiciais." (VELLOSO, Carlos Mário da Silva. Do Poder Judiciário: como torná-lo mais ágil e dinâmico: efeito vinculante e outros temas. Revista de Informação Legislativa, Brasília, v. 35, n. 138, p. 76, abr./jun. 1998. Disponível em: <http://www2.senado.leg.br/bdsf/bitstream/handle/id/368/r13808.pdf? sequence=4>. Acesso em: 10 nov. 2013).

190 “Outra causa da lentidão da justiça, que me parece, aliás, a mais importante, é o formalismo das leis processuais e o sistema irracional de recursos [...] O sistema recursal, com um número muito grande de recursos, é irracional. O despejo de um botequim pode chegar ao Superior Tribunal de Justiça e ao Supremo Tribunal Federal." (VELLOSO, Carlos Mário da Silva, Do Poder Judiciário: como torná-lo mais ágil e dinâmico: efeito vinculante e outros temas, cit., p. 77). Note-se que, diferentemente do que ocorre entre nós, no sistema inglês, por exemplo, o controle da carga de trabalho é realizado por meio de um sistema que não prevê a direito das partes a recorrerem perante a Suprema Corte. Confira-se a lição de Neil 
De qualquer modo, independentemente da causa, os números falam por si só, e não deixam dúvida sobre a existência de uma verdadeira crise de excesso de recursos. Afinal, não é razoável que a principal corte do país, incumbida de desempenhar funções públicas essenciais ao Estado Democrático de Direito (conforme Capítulo 3), e composta por apenas onze julgadores, possa satisfatoriamente lidar com dezenas e até centenas de milhares de processos por ano. Ressalte-se que, só em 2002, foram 160.453 processos protocolizados no STF, e a média anual para a década de 2000 foi de 107.460 processos!

Como salientado por Sidnei Agostinho Beneti, “os números judiciários nacionais são imensos. A produção dos juízes nacionais é, de longe, a maior do mundo". ${ }^{191}$

Embora se fale muito em quantidade de casos, esse não é o único problema. $\mathrm{O}$ excesso de recursos gera naturalmente o comprometimento da qualidade dos julgamentos, que têm especial importância quando se trata de recursos excepcionais. ${ }^{192}$

Quanto às características da crise, é consenso que ela se confunde, na verdade, com a crise do próprio recurso extraordinário, o maior responsável pelo gigantesco número de

Andrews: "Não existe o direito de se interpor um recurso perante a Suprema Corte. Desde 1934, de fato, a House of Lords passou a empregar um método de autoproteção: a necessidade de que o recorrente obtenha uma licença para recorrer, hoje chamada de permissão. A prática sobrevive. E então, muito provavelmente, a Suprema Corte, como a sua antecessora, a House of Lords, não julgarão mais que 80 recursos por ano.". (ANDREWS, Neil. A Suprema Corte do Reino Unido: reflexões sobre o papel da mais alta Corte Britânica. Revista de Processo, São Paulo, v. 35, n. 186, p. 308, ago. 2010).

${ }^{191}$ Além disso, o autor anota que "comparados aos do foro internacional, os números são inacreditáveis. Bem conhecida a história de que em um congresso internacional, o Min. Sálvio de Figueiredo Teixeira relatava o número de casos por ele relatados durante o ano no STJ e, ao referir-se, em inglês, a one thousand, o presidente da sessão, admirado, pretendeu corrigir o termo para one hundred, já julgando muito!". (BENETI, Sidnei Agostinho, Doutrina de precedentes e organização judiciária, cit., p. 18).

192 Comentando sobre a importância das decisões dos órgãos de cúpula, em virtude da função paradigmática que exercem no sistema, Arruda Alvim afirma: "Tais decisões, em devendo ser exemplares, hão, igualmente, de carregar consigo alto poder de convicção, justamente porque são, em escala máxima, os precedentes a serem observados e considerados pelos demais Tribunais". E anota que, em virtude da avalanche de processos a que o STJ e o STF estão submetidos, tem sido extremamente difícil alcançar essa qualidade: "Os votos proferidos, justamente com vistas ao atingimento das qualidades de excelência que são exigidas do Superior Tribunal de Justiça, têm demandado um trabalho exaustivo e autenticamente brutal dos seus ministros. O trabalho no STJ difere, numa distância estelar, dos demais Tribunais congêneres, de outros países, e, entre nós, há de ser feita exceção particular ao Supremo Tribunal Federal, igualmente, sacrificado de uma forma dramática, hoje e na sua história recente." (ARRUDA ALVIM, José Manoel de, A alta função jurisdicional do Superior Tribunal de Justiça no âmbito do recurso especial e a relevância das questões, cit., p. 38-39). No mesmo sentido, Rodolfo de Camargo Mancuso observa: "Essas cifras expressivas não reduzem o problema e uma crise meramente numérica ou quantitativa, devendo-se, ao contrário, ter presente que a 'quantidade afeta a qualidade'. Por isso, quando um órgão judicial postado na cumeeira da organização judiciária recebe mais processos do que pode julgar, começam as mazelas que desprestigiam a Justiça e afligem os jurisdicionados [...]." (MANCUSO, Rodolfo de Camargo, Recurso extraordinário e recurso especial, cit., p. 73). 
processo que desaguou na Corte desde o início de sua existência. De fato, basta observar que, de 1990 a 2013, 90\% dos feitos distribuídos referem-se a recursos extraordinários e agravos contra a decisão de inadmissão, e só $10 \%$ dizem respeito a outras classes. ${ }^{193}$

\section{2 Óbices de acesso como tentativa de conter a crise}

O fenômeno da crise do Supremo gerou uma série de medidas legais e regimentais, por meio das quais se tentou equacionar o problema, e todas elas têm a ver com a restrição, de alguma forma, do acesso das partes à corte por meio do recurso extraordinário.

Por meio da Lei n. 3.396/58, passou-se a exigir a fundamentação das decisões dos órgãos a quo de admissibilidade do recurso extraordinário - até então só as decisões de inadmissão precisavam ser fundamentadas. Com isso, esperava-se que a admissão do recurso fosse mais rigorosa desde a origem, por ocasião do juízo prévio de admissibilidade.

Por emenda regimental de 28.08.1963, foi criada a súmula da jurisprudência do Supremo, como instrumento de trabalho para facilitar a fundamentação dos julgados. No mesmo ano, a corte aprovou 370 enunciados.

Em 1964, também por emenda regimental, estabeleceu-se a possibilidade de se julgar prejudicados os recursos que se encontravam no STF há mais de dez anos sem julgamento, desde que, convocadas previamente, as partes não se manifestassem. ${ }^{194}$

Já em 1965, pela Emenda Regimental 16/65, instituiu-se o controle concentrado de constitucionalidade e o STF passou a ter competência para julgar representações de inconstitucionalidade de leis e atos normativos, estaduais e federais, permitindo-lhe em um único julgamento resolver a questão da constitucionalidade dessas normas, com o que se esperava estancar a fonte de recursos extraordinários que surgiriam se a questão tivesse que ser analisada caso a caso.

\footnotetext{
${ }^{193}$ Números extraídos do site do STF, disponíveis no campo "Estatística", "RE, AI e ARE - \% Distribuição". Disponível em: < http:// www.stf.jus.br/ portal/ cms/ verTexto.asp?servico =estatistica\&pagina= REAIProcessoDistribuido >. Acesso em: 10 set. 2013.

${ }^{194}$ NAVES, Nilson Vital. Panorama dos problemas no Poder Judiciário e suas causas; o Supremo, o Superior Tribunal e a reforma. Revista CEJ, Brasília, n. 13, p. 11, jan./abr. 2001. Disponível em: <http://www2.cjf.jus.br/ojs2/index.php/revcej/article/viewFile/372/553>. Acesso em: 30 out. 2013.
} 
Por sua vez, a Emenda Constitucional n. 1/69 acrescentou ao artigo 119 da CF de 1967, então vigente, preceito que permitia ao STF indicar em seu regimento as causas que desafiariam recurso extraordinário, atendendo-se à sua natureza, espécie e valor pecuniário.

As restrições foram previstas pelo regimento interno que entrou em vigor em 1970, o qual previa em seu artigo 308 as causas excluídas do cabimento do recurso extraordinário (critério negativo). Depois, a restrições foram intensificadas pela Emenda Regimental n. $2 / 85$, que passou a prever taxativamente as causas que desafiavam o recurso (critério positivo), ficando excluídas do cabimento todas as demais.

Ressalte-se que desde 1975 essas restrições eram, de certa forma, aliviadas pelo instituto da relevância da questão federal (ver Capítulo 5, item 5.5.1), cuja arguição atuava como válvula de escape para permitir o excepcional conhecimento do recurso extraordinário nas hipóteses expressamente vedadas pelo regimento.

Deve-se mencionar também que, desde longa data, o próprio Regimento Interno do STF prevê um procedimento diferenciado para o julgamento conjunto, ou em bloco, de “processos que versem sobre a mesma questão jurídica". O artigo 132 do regimento de 1970 previa, desde sua versão original, que "processos que versem sobre a mesma questão jurídica, embora apresentem aspectos peculiares, poderão ser julgados conjuntamente", caso em que, nos termos do parágrafo único, “os relatórios sucessivos poderão reportar-se ao anterior, indicando as peculiaridades do caso". A norma foi mantida, com praticamente a mesma redação, pelo artigo 127 do regimento atual, em vigor desde 1980.

Por fim, faz-se referência aos óbices jurisprudenciais, consubstanciados em verbetes sumulares sobre o rígido sistema de admissibilidade do recurso extraordinário, e à jurisprudência defensiva, dos quais falaremos no item 4.5 infra.

\subsection{A criação do Superior Tribunal de Justiça: tentativa de solução da crise do Supremo e ampliação do acesso das partes aos órgãos de cúpula}

A insatisfação com todos esses óbices era geral na comunidade jurídica. O acesso das partes ao STF, sobretudo quanto às questões de direito federal infraconstitucional, estava cada vez mais difícil. Conforme assinalado por Carlos Mário da Silva Velloso, em 
artigo publicado em 1988, "todas essas exigências, tornavam o recurso extraordinário recurso difícil, que se colocava distante dos advogados brasileiros". ${ }^{195}$

Segundo Athos Gusmão Carneiro, os óbices regimentais e jurisprudenciais representaram soluções limitadas e transitórias para o problema da crise e, ao mesmo tempo, suscitaram "restrições por parte dos litigantes e corporações advocatícias, desejosas de maior amplitude no acolhimento de irresignação dirigida a um Tribunal nacional". ${ }^{196}$

Da mesma forma, Ilmar Nascimento Galvão anota que os mencionados obstáculos, se por um lado aliviaram um pouco o STF e viabilizaram o exercício de suas funções, “de outra parte reduziram o recurso extraordinário a um recurso de natureza excepcional, de difícil e incerta admissibilidade, gerando, por consequência, sério inconformismo nos meios jurídicos do País". 197

Foi nesse contexto de insatisfação com a restrição do acesso das partes ao órgão de cúpula do Judiciário brasileiro que, na linha daquelas ideias defendidas por inúmeros juristas desde a década de 1960, as funções do STF foram partilhadas com outro tribunal, incumbido de apreciar pela via do recurso especial as questões relativas ao direito federal infraconstitucional, deixando ao STF unicamente as questões relativas ao direito constitucional. A criação do STJ pela Constituição de 1988 teve como objetivos aproximar o jurisdicionado dos órgãos de cúpula e, ao mesmo tempo, conter a crise do próprio STF. ${ }^{198}$

Em 1974, Theotonio Negrão escreveu que restava "uma solução, e nada mais que uma solução, para o STF: entregar-lhe o conhecimento apenas das questões e dos recursos em que se alegue ofensa à Constituição", para o que haveria a "necessidade de criar um Superior Tribunal de Justiça, com a mesma posição hierárquica do TST, do TSE e do

\footnotetext{
${ }^{195}$ VELLOSO, Carlos Mário da Silva, O Superior Tribunal de Justiça na Constituição de 1988, cit., p. 17.

${ }^{196}$ CARNEIRO, Athos Gusmão. Anotações sobre o recurso especial. In: TEIXEIRA, Sálvio Figueiredo (Coord.). Recursos no Superior Tribunal de Justiça. São Paulo: Saraiva, 1991. p. 111.

${ }^{197}$ GALVÃO, Ilmar Nascimento, Poder Judiciário: reforma de 1988: o recurso especial no Superior Tribunal de Justiça, in Recursos no Superior Tribunal de Justiça, cit., p. 86.

198 “A reação não demorou e, tanto a Comissão dos Notáveis como a maioria esmagadora dos constituintes de 1988, atendendo aos anseios dos advogados, inconformados com as rigorosas limitações do recurso extraordinário, optaram pelo desdobramento do apelo extremo e a criação de um novo Tribunal Superior". (SANTOS, Francisco Claudio de Almeida, Recurso especial: visão geral, in Recursos no Superior Tribunal de Justiça, cit., p. 93).
} 
STM", o qual deveria "conhecer de todos os recursos extraordinários, provenham da Justiça Federal ou da estadual". 199

Em artigo publicado em 1990, Cândido Rangel Dinamarco afirmou que, em razão dos restritivos óbices regimentais e dos pesados óbices jurisprudenciais à admissibilidade do recurso extraordinário, o sistema ia perdendo legitimidade, de forma que: "Para prevalência dos valores do Estado-de-direito, era indispensável alargar o canal de acesso à instância de superposição", o que se fez pela criação do "novo tribunal", representativo da "viva tomada de posição do constituinte de 1988 pelo acesso à justiça como valor democrático a ser cultuado". 200

A ideia, assim, era minimizar o problema de excesso de recursos no STF e, ao mesmo tempo, abrir o acesso das partes à nova Corte, oferecendo uma resposta aos até então rígidos requisitos de admissibilidade do recurso extraordinário, principalmente em matéria de lei federal. ${ }^{201}$

\subsection{A crise do Superior Tribunal de Justiça}

Não tardou, porém, para se verificar que a crise do STF não estava sendo contida, e que, pior, o próprio STJ estava entrando em crise, frustrando aqueles que, esperançosos, enxergavam na sua criação a grande solução para os principais problemas. ${ }^{202}$

${ }^{199}$ Conforme artigo publicado na $R T$ Informa de 15.07.1974, e depois republicado "pela coincidência entre grande parte das ideias ali expendidas e o que, quase 15 anos depois, foi aprovado pela Constituição de 1988" (NEGRÃO, Theotonio, Uma nova estrutura para o Judiciário, cit., p. 244).

${ }^{200}$ DINAMARCO, Cândido Rangel, Superior Tribunal de Justiça e acesso à ordem jurídica justa, in Recursos no Superior Tribunal de Justiça, cit., p. 252-253.

${ }^{201}$ Como registrado por Athos Gusmão Carneiro, “a criação do STJ atendeu aos reclamos”. Isso porque, além da liberação do STF para o exercício da sua missão primordial de custodiar a Constituição e tutelar os direitos e garantias individuais, a nova Corte iria "exercer, sem óbices regimentais, a guarda da legislação federal infraconstitucional, nos casos previstos na Lei Maior" (CARNEIRO, Athos Gusmão, Anotações sobre o recurso especial, in Recursos no Superior Tribunal de Justiça, cit., p. 111).

${ }^{202}$ Confira-se a observação de Alcides de Mendonça Lima sobre a criação do STJ: "É evidente que, com os novos rumos, o Supremo ficará aliviado, sem os percalços de pletoras de processos, muito fora das lindes do recurso extraordinário com o objetivo de procrastinar o desfecho da causa antes de defender direito ou reparar injustiça." (LIMA, Alcides de Mendonça, Recurso extraordinário e recurso especial, in Recursos no Superior Tribunal de Justiça, cit., p. 139). Por outro lado, sobre os animadores resultados iniciais das primeiras atividades do recém-criado STJ, Cândido Rangel Dinamarco observava que "um resultado muito positivo já se fez sentir: a surpreendente celeridade nos julgamentos pelo Superior Tribunal de Justiça, um órgão ágil que se vai impondo ao respeito do mundo jurídico também pela presteza no serviço jurisdicional que lhe cabe" (DINAMARCO, Cândido Rangel, op. cit., p. 253). 
Sálvio de Figueiredo Teixeira, quase que profetizando esse quadro, em artigo publicado logo nos primeiros anos de instalação da nova Corte, ao mesmo tempo que elogiava a rapidez e qualidade dos julgamentos proferidos até então, afirmou:

[...] só o tempo poderá dizer do acerto ou não do modelo adotado e dos reparos e correções de rota a fazer, especialmente quando se conhece o volume extraordinário de causas que tramitam no foro de um país de aproximadamente cento e cinquenta milhões de habitantes e se atenta para a circunstância de que o constituinte de 1988, certamente sob o impulso do inconformismo com as restrições do sistema precedente, houve por bem não ensejar a seletividade contemplada nos ordenamentos estrangeiros. ${ }^{203}$

Da mesma forma, Francisco Claudio de Almeida Santos anteviu que, a despeito da criação da nova corte, a ausência de algum critério de seletividade das causas submetidas ao STF e ao STJ, "ao contrário do que acontece em quase todos os países do mundo", poderia provocar "no futuro, uma carga de trabalho impossível de ser suportada, em especial, no STJ". 204

Os números, mais uma vez, falam por si: em 1989, ano da instalação do STJ, foram distribuídos 6.103 processos e, no ano seguinte, foram 14.087 distribuições. Dez anos depois, o número aumentou para incríveis 150.738 feitos distribuídos, chegando a 198.613 em 2001, 226.440 em 2003 e 313.364 em $2007 !^{205}$

Observe-se que os números referem-se ao total de processos distribuídos e não apenas ao número de recursos especiais e agravos contra as decisões de inadmissão. Entretanto, tal como ocorre no STF, referidos recursos são os grandes responsáveis pela

\footnotetext{
${ }^{203}$ TEIXEIRA, Sálvio Figueiredo, O recurso especial e o Superior Tribunal de Justiça, in Recursos no Superior Tribunal de Justiça, cit., p. 81. Do mesmo modo, Ilmar Nascimento Galvão observava que a criação do recurso especial e do STJ como forma de aproximar as partes dos órgãos de cúpula e solucionar o problema da crise se trata de solução "cujo acerto somente o futuro poderá atestar", e que os defeitos e problemas que surgissem constituiriam "motivo de novos desafios à argúcia e à inteligência dos legisladores" (GALVÃO, Ilmar Nascimento, Poder Judiciário: reforma de 1988: o recurso especial no Superior Tribunal de Justiça, in Recursos no Superior Tribunal de Justiça, cit., p. 87).

${ }^{204}$ SANTOS, Francisco Claudio de Almeida, Recurso especial: visão geral, in Recursos no Superior Tribunal de Justiça, cit., p. 97.

${ }^{205}$ Números extraídos dos Boletins Estatísticos divulgados pelo próprio STJ em seu site (Disponível em: <http://www.stj.gov.br/webstj/Processo/Boletim/verpagina.asp?vPag=0\&vSeq=237>. Acesso em: 15 jul. 2013.
} 
crise, por representarem a maior parte dos processos distribuídos, podendo-se também aqui falar em crise do recurso especial. ${ }^{206}$

Como consequência dessa situação, e contrariando as expectativas relativas à ampliação do acesso das partes à instância extraordinária, o que se observou foi, de certa forma, a mudança de discurso em relação ao papel a ser desempenhado pelo STJ. Aquela ampla abertura e aproximação dos jurisdicionados em relação à corte acabou por ameaçar a viabilidade do exercício das atividades do STJ, quase que impondo uma postura restritiva em relação ao acesso das partes.

Em artigo publicado em 2001, Nilson Vital Naves comentava que a primeira das aflições do STJ "tem a ver com o número de processos, com aqueles que lá chegam ou pelo recurso especial, ou pelo agravo de instrumento de decisão denegatória”. E destaca o papel da corte, que não é "rolar eternamente enorme rochedo na subida de uma vertente, tal o mitológico castigo imposto por Zeus a Sísifo”, mas sim o de, zelando pela guarda dos tratados ou leis federais, "cuidar das questões significativas ou relevantes". Daí, segundo o autor e ex-ministro do STJ, ser necessário e urgente "que haja, também para o Superior, instrumentos de contenção do recurso especial". ${ }^{207}$

Por sua vez, Athos Gusmão Carneiro destaca as dificuldades para dar vazão ao "regime de intensíssimo volume de processos, muito superior à normal capacidade de uma Corte composta por apenas 33 magistrados". ${ }^{208}$

Assim, surgiu no STJ aquela tendência, já observada em relação ao recurso extraordinário, de interpretar de forma fortemente restritiva os requisitos de admissibilidade do recurso especial, e até de criar, na medida do possível à luz do atual texto constitucional, mecanismos regimentais de filtragem de recursos. ${ }^{209}$

\footnotetext{
206 Por exemplo, em 2002, os recursos especiais e agravos contra as decisões de inadmissão foram responsáveis por mais de $88 \%$ do número total de processos distribuídos no STJ. Em 2007, o percentual foi de $68 \%$, e em 2012, de mais de $60 \%$.

${ }^{207}$ NAVES, Nilson Vital, Panorama dos problemas no Poder Judiciário e suas causas: o Supremo, o Superior Tribunal e a reforma, cit., p. 16.

${ }^{208}$ CARNEIRO, Athos Gusmão, Recurso especial, agravos e agravo interno, cit., p. 19.

${ }^{209}$ Como, por exemplo, o Núcleo de Agravos da Presidência (NAPRE), criado pela Resolução n. 4/2007, órgão destinado a filtrar os recursos manifestamente descabidos, evitando-se a sua distribuição aos relatores para apreciação e julgamento.
} 
Observe-se que esse "efeito sanfona", de constante restrição e abertura do acesso das partes aos órgãos superiores, ocorrido no Brasil nas últimas décadas, não representa qualquer novidade na história do funcionamento dos recursos excepcionais. Como demonstrado por Calamandrei ${ }^{210}$, a necessidade e conveniência de se contar com a atuação dos particulares para o exercício das funções públicas dos recursos excepcionais (abertura) sempre teve o efeito colateral de gerar uma litigiosidade excessiva, a ser contida por restrições de acesso das partes aos órgãos de cúpula (restrição), que volta e meia, na história, acaba justificando novas aberturas (como ocorreu com a criação do STJ).

Atualmente, a instituição da repercussão geral (que, conforme veremos no Capítulo 5 , item 5.5, se pretende estender ao recurso especial) e da técnica de julgamento de recursos repetitivos pelo STF e STJ confirma esse ciclo de constante abertura e restrição na história do funcionamento dos nossos órgãos de cúpula.

\subsection{Excesso na interpretação dos requisitos de admissibilidade dos recursos excepcionais e a jurisprudência defensiva}

Como visto, as relevantes funções públicas desempenhadas pelos recursos extraordinário e especial no sistema decorrem da própria Constituição Federal, de onde também se extraem diretamente seus requisitos específicos de admissibilidade. Isso significa que a lei não pode alargar ou restringir as hipóteses de cabimento e os demais pressupostos para a admissão dos recursos excepcionais, sob pena de inconstitucionalidade.

Por outro lado, em razão da crise histórica do STF, e da subsequente crise também do STJ (criado justamente para tentar equacionar aquele problema e ampliar o acesso das

\footnotetext{
210 “A história da cassação e dos institutos dela derivados nos mostra, em efeito [...], um contínuo conflito entre a tendência que quer limitar a utilização do recurso àqueles únicos casos em que o mesmo pode favorecer à satisfação do interesse público e a tendência que, superando a razão política em que o mesmo tinha tido origem, quer admitir aos particulares aproveitarem-se dele mesmo quando a sentença esteja viciada por erros de direito que não ameacem de modo algum a uniformidade da jurisprudência". No original: "La historia de la Casación y de los institutos derivados de ella nos muestra, en efecto [...], un continuo conflicto entre la tendencia que quiere limitar la utilización del recurso a aquellos únicos casos en que el mismo puede favorecer a la satisfacción del interés público y la tendencia que, superando la razón política en que el mismo ha tenido origen, quiere admitir a los particulares a aprovecharse de él aun cuando la sentencia esté viciada por errores de hecho que no amenacen en modo alguno la uniformidad de la jurisprudência." (CALAMANDREI, Piero, La casación civil: bosquejo general del instituto, cit., v. 2, p. 153 - nossa tradução.
} 
partes à instância extraordinária), ambas as cortes passaram a lidar com um contingente de trabalho incompatível com suas dimensões e com a importância das funções por elas desempenhadas no sistema.

Diante disso, como já exposto acima, o ciclo repetiu-se, e tanto o STF quanto o STJ passaram a restringir ao máximo a admissibilidade dos recursos extraordinário e especial, principalmente por meio de óbices jurisprudenciais, vedando ilegitimamente o acesso das partes à instância extraordinária.

Com isso, passou-se a falar na "jurisprudência defensiva", isto é, no conjunto de decisões do STJ e do STF que interpretam excessivamente os requisitos de admissibilidade dos recursos excepcionais, com o fim de viabilizar o trabalho de tais cortes, diante do enorme número de feitos que lhes são submetidos.

Conforme Flávio Cheim Jorge, a jurisprudência defensiva "consiste, em última análise, na interpretação inadequada dos requisitos de admissibilidade, por intermédio da imposição de restrições ilegítimas, indevidas e ilegais ao conhecimento dos recursos". ${ }^{211}$

Por sua vez, para José Miguel Garcia Medina, isso significa que a jurisprudência “passa a adotar postura não apenas mais rigorosa em relação aos requisitos recursais, mas vai além, impondo às partes a observância de exigências não previstas em qualquer norma jurídica" ${ }^{212}$, com o fim de viabilizar o funcionamento da corte, levando-se em conta o número de processos que poderia julgar.

Pela definição de Humberto Gomes de Barros, então presidente do STJ, a jurisprudência defensiva "consiste na criação de entraves e pretextos para impedir a chegada e o conhecimento dos recursos que lhe são dirigidos”, medida adotada pela Corte "para fugir do 'alvitante destino' de transformar-se em terceira instância". 213

\footnotetext{
211 JORGE, Flávio Cheim. Requisitos de admissibilidade dos recursos: entre a relativização e as restrições indevidas (jurisprudência defensiva). Revista de Processo, São Paulo, v. 38, n. 217, p. 30, mar. 2013.

${ }^{212}$ MEDINA, José Miguel Garcia. Pelo fim da jurisprudência defensiva: uma utopia? Consultor Jurídico, jul. 2013. Disponível em: <http://www.conjur.com.br/2013-jul-29/processo-fim-jurisprudencia-defensivautopia>. Acesso em: 29 jul. 2013.

213 Notícia publicada no site do STJ em 07/04/2008 (Disponível em: <http://www.stj.gov.br/portal_stj/publicacao/engine.wsp?tmp.area=398\&tmp.texto=87058>. Acesso em: 23 out. 2013).
} 
Há vários exemplos de entendimento jurisprudencial do STF e do STJ a respeito da admissibilidade dos recursos excepcionais que são, no mínimo, questionáveis.

A jurisprudência do STF entende ser inadmissível o recurso extraordinário quando a contrariedade à norma constitucional, ainda que presente, não seja direta e frontal, mas sim indireta e reflexa. Isso significa que, sendo necessário analisar normas infraconstitucionais para se chegar à violação da $\mathrm{CF}$, o recurso extraordinário será inadmissível. $^{214}$

Note-se que os princípios processuais, por exemplo, estão fartamente previstos no texto constitucional e, ao mesmo tempo, regulamentados no CPC. A aplicação restrita do entendimento de que só cabe recurso extraordinário quando a ofensa é direta e frontal exclui do STF a apreciação de decisões que desrespeitam princípios caros ao Estado Democrático de Direito, como o do devido processo legal e todos os princípios dele decorrentes, v.g., contraditório, ampla defesa etc.

Assim, segundo Teresa Arruda Alvim Wambier, isso leva a um paradoxo: a CF consagra um princípio e, apenas pelo fato de a lei ordinária o repetir, o STF, incumbido de guardar a própria $\mathrm{CF}$, abdica dessa função. Segundo a autora, trata-se de um exemplo de situação em que "deixa-se para trás a razão de ser dos tribunais superiores, a natureza jurídica do recurso extraordinário e do recurso especial, e se ficam restrições (e aí são de fato restrições!) sem o indispensável apoio dogmático". ${ }^{215}$

\footnotetext{
${ }^{214}$ O mesmo ocorre na Espanha, com o Tribunal Constitucional. Segundo Jordi Nieva-Fenoll, chega-se a falar na prática de uma política de admissibilidade que pode ser qualificada de "certiorari de fato" (só a partir de 2007 o critério da relevância ou transcendência foi adotado de forma oficial na Espanha). Isso porque, sem qualquer amparo na legislação, há vários anos a corte passou a inadmitir os recursos sob o argumento de falta de conteúdo constitucional, levando a taxa de inadmissibilidade a percentuais em torno de 95\%. (NIEVA-FENOLL, Jordi, El modelo anglosajón en las Cortes Supremas: ¿solución o elusión del problema de la casación?, cit., p. 191).

${ }^{215}$ WAMBIER, Teresa Arruda Alvim, Recurso especial, recurso extraordinário e ação rescisória, cit., p. 268. Vale mencionar, porém, que há precedentes, ainda que raros, nos quais o próprio STF reconhece a admissibilidade do recurso extraordinário voltado à discussão de questões relativas ao devido processo legal e ao princípio da legalidade: "A intangibilidade do preceito constitucional que assegura o devido processo legal direciona ao exame da legislação comum. Daí a insubsistência da tese no sentido de que a ofensa à Carta Política da República suficiente a ensejar o conhecimento de extraordinário há de ser direta e frontal. Caso a caso, compete ao Supremo Tribunal Federal exercer crivo sobre a matéria, distinguindo os recursos protelatórios daqueles em que versada, com procedência, a transgressão a texto constitucional, muito embora torne-se necessário, até mesmo, partir- se do que previsto na legislação comum. Entendimento diverso implica relegar à inocuidade dois princípios básicos em um Estado Democrático de Direito: o da legalidade e do devido processo legal, com a garantia da ampla defesa, sempre a pressuporem a consideração de normas estritamente legais.". (STF - RE n. 247.262, Segunda Turma, rel. Min. Marco Aurélio, DJ, de 18.05.2001, p. 449).
} 
Por sua vez, a jurisprudência do STJ entende que, nos casos em que o texto constitucional é praticamente repetido pelo texto da lei federal, o recurso cabível é o extraordinário, não o especial ${ }^{216}$. Ou seja, o STF entende que, nesses casos, cabe recurso especial (já que a ofensa direta é à lei federal, não à CF) e o STJ entende que cabe recurso extraordinário, o que deixa as partes em situação de extrema insegurança.

Outro caso de criação jurisprudencial de requisitos não previstos no sistema é o da legibilidade do carimbo de protocolo do recurso interposto, com o fim de permitir a verificação da tempestividade do recurso. Se o carimbo de protocolo do recurso não está legível - pouco importando que sua má qualidade decorra de fato atribuível ao próprio Poder Judiciário, nem a circunstância de o próprio tribunal de origem ter considerado tempestivo o recurso -, o recurso não é conhecido pela instância superior. ${ }^{217}$

Da mesma forma, injustificadamente restritiva é a Súmula 735 do STF, segundo a qual "não cabe recurso extraordinário contra acórdão que defere medida liminar". A decisão liminar, a despeito da sua provisoriedade, pode tornar-se irreversível com o passar do tempo, representando o próprio julgamento definitivo da causa ${ }^{218}$, além do que a CF não distingue entre as decisões provisórias e definitivas, tanto que os recursos excepcionais podem ser interpostos contra decisões de conteúdo eminentemente processual (art. 267 do CPC), que também não são definitivas. ${ }^{219}$

\footnotetext{
${ }^{216}$ STJ -REsp n. 71.964/SP, 2 ${ }^{\text {a }}$ Turma, rel. Min. Ari Pargendler, DJU, de 30.06.1997, p. 30.973.

${ }^{217}$ STJ - AgR AI n. 741.714/MS, $1^{\text {a }}$ Turma, rel. Min. Luiz Fux, DJ, de 19.06.2006, p. 110.

218 "A decisão liminar pode tornar-se praticamente irreversível, na medida em que for impossível restaurar, passados meses ou anos, a situação anterior, e reverter a situação de dano ao direito material já criada ou mantida. Temos por certo, assim, que a recepção da Súmula n. 735-STF pelo STJ deve ser condicionada aos princípios maiores da efetividade da justiça e da tutela ao direito material questionado." (CARNEIRO, Athos Gusmão, Recurso especial, agravos e agravo interno, cit., p. 25).

${ }^{219}$ Vale citar importante acórdão do STJ a respeito da incidência da Súmula 735 do STF em relação ao recurso especial: "Relativamente ao recurso especial, não se pode afastar, de modo absoluto, a sua aptidão como meio de controle da legitimidade das decisões que deferem ou indeferem medidas liminares. Todavia, a exemplo do recurso extraordinário, o âmbito da revisibilidade dessas decisões, por recurso especial, não se estende aos pressupostos específicos da relevância do direito (fumus boni iuris) e do risco de dano (periculum in mora). Relativamente ao primeiro, porque não há juízo definitivo e conclusivo das instâncias ordinárias sobre a questão federal que dá suporte ao direito afirmado; e relativamente ao segundo, porque há, ademais, a circunstância impeditiva decorrente da súmula 07/STJ, uma vez que a existência ou não de risco de dano é matéria em geral relacionada com os fatos e as provas da causa." (STJ - REsp 664.224/RJ, rel. Min. Teori Albino Zavascki, DJ, de 01.03.2007, p. 230).
} 
Também caracteriza restrição excessiva e ilegítima ao cabimento dos recursos excepcionais a exigência de que a parte reitere as razões de seu recurso extraordinário ou especial interposto contra decisão que veio a ser impugnada pela parte contrária por meio de embargos de declaração. A exigência decorreria da necessidade de interposição do recurso contra decisões de última instância. No entanto, se os embargos foram rejeitados ou, mesmo tendo sido acolhidos, não geraram a modificação da decisão na parte que foi objeto do recurso excepcional, não há qualquer razão para se entender que este não se voltou contra decisão de última instância. Daí a ilegitimidade da exigência de reiteração formal do recurso, não prevista em qualquer parte do texto constitucional ou legal.

Vale mencionar, ainda, o entendimento de que "na instância especial é inexistente recurso interposto por advogado sem procuração nos autos" ${ }^{220}$. Por que não aplicar o artigo 13 do CPC, que permite a regularização da representação processual?

Por fim, faz-se referência ao entendimento jurisprudencial de que "os valores relativos ao porte de remessa e retorno devem ser recolhidos em rede bancária, mediante o correto preenchimento de Guia de Recolhimento da União (GRU), com a anotação do respectivo código de receita e com a indicação do número do processo, sob pena de deserção",221. Note-se que não há norma legal ou constitucional alguma prevendo esse requisito de admissibilidade, sendo, portanto, ilegítima a não apreciação do mérito do recurso com base nessa mera formalidade.

Como já dito, essas e outras interpretações excessivas, que caracterizam a chamada "jurisprudência defensiva", visam apenas barrar a entrada de recursos do STF e STJ, com o fim de reduzir o número de feitos submetidos aos órgãos de cúpula, na tentativa de viabilizar o adequado desempenho de suas funções. Apesar de serem ilegítimos, esses óbices bem retratam a situação crítica do funcionamento de nossos Tribunais Superiores e os mecanismos a que os próprios órgãos de cúpula acabam recorrendo para lidar com a situação.

\footnotetext{
${ }^{220}$ Conforme a Súmula 115 do STJ.

${ }^{221}$ STJ - AgR AREsp n. 89.312/PR, 4 ${ }^{\text {a }}$ Turma, rel. Min. Antonio Carlos Ferreira, DJe, de 19.06.2013.
} 


\subsection{Os recursos repetitivos e a justificativa para a criação da técnica dos artigos 543-B e 543-C do CPC}

Com a evolução da sociedade, que se tornou mais complexa qualitativa e quantitativamente, e também com a transformação do Estado puramente liberal em Estado social $^{222}$, os conflitos de interesse também evoluíram, deixando de ser meramente individuais, para adquirirem uma dimensão coletiva.

Assim, a massificação da sociedade deu lugar ao surgimento de novas modalidades de conflitos, relativos a direitos caracterizados ora pela indeterminação da titularidade e indivisibilidade material (difusos e coletivos), ora pela multiplicidade de pretensões individuais isomórficas (individuais homogêneos) ${ }^{223}$, exigindo-se que lhes fosse dispensado um tratamento jurisdicional também novo, isto é, coletivizado, “com isso molecularizando a tutela jurisdicional ainda que de início destinada exclusivamente ao exame de meros átomos (ou seja, de litígios individuais)". ${ }^{224}$

O tratamento fragmentado desses litígios de massa gera inevitavelmente uma divergência jurisprudencial ainda mais grave, comprometendo com maior seriedade os princípios da igualdade, da segurança jurídica e da razoável duração do processo. Nesse sentido, Rodolfo de Camargo Mancuso assevera que a divergência jurisprudencial, conquanto possa, até certo ponto, ser administrada no plano da jurisdição singular, “já o

\footnotetext{
222 "A virada de tendência no chamado Estado-Providência (ou Estado Social) pode ser explicada por inúmeros fatores: a predominância assumida pelo Poder Executivo; a explosão da produção legislativa; a consagração constitucional de direitos sociais e econômicos; e a proliferação de direitos, consequência, em parte, da atuação de atores coletivos." (PINTO, Luis Filipe Marques Porto Sá. Técnicas de tratamento macromolecular dos litígios: tendência de coletivização da tutela processual civil. Revista de Processo, São Paulo, v. 35, n. 185, p. 120, jul. 2010).

223 "Direitos coletivos são direitos subjetivamente transindividuais (= sem titular determinado, razão pela qual são tutelados em juízo invariavelmente pelo regime de substituição processual) e materialmente indivisíveis (= são lesados ou satisfeitos necessariamente em sua globalidade, o que determina tutela judicial também de forma conjunta e universalizada). Já os direitos individuais homogêneos são, simplesmente, direitos subjetivos individuais (= com titular determinado) e, portanto, materialmente divisíveis (= podem ser lesados ou satisfeitos por unidades isoladas), o que propicia a sua tutela jurisdicional tanto de modo coletivo (por regime de substituição processual) como individual (por regime de representação)." (ZAVASKI, Teori Albino. Reforma do processo coletivo: indispensabilidade de disciplina diferenciada para direitos individuais homogêneos e para direitos transindividuais. In: GRINOVER, Ada Pellegrini; MENDES, Aluisio Gonçalves de Castro; WATANABE, Kazuo (Coords.). Direito processual coletivo e o anteprojeto de Código Brasileiro de Processos Coletivos. São Paulo: Revista dos Tribunais, 2007. p. 33-35).

${ }^{224}$ DINAMARCO, Cândido Rangel. Decisões vinculantes. Revista de Processo, São Paulo, v. 25, n. 100, p. 171, out./dez. 2000.
} 
mesmo não se passa na jurisdição coletiva, porque aqui os interesses em lide são de massa, têm natureza plurissubjetiva, concernindo a segmentos mais ou menos vastos da sociedade, e, portanto, a resposta judiciária deve ser uma". 225

Da mesma forma, Sidnei Agostinho Beneti afirma que "em época de sociedade de massas, não há mais como imaginar a satisfação jurisdicional apenas em cada caso concreto", até porque a divulgação de decisões contraditórias "destrói a crença no Poder Judiciário, e incrementa o surgimento de lides, realimentando-se a si próprio".226

Daí porque as “questões 'sazonais' repetitivas" - isto é, aquelas que surgem com a instabilidade da própria legislação, como as decorrentes do bloqueio de ativos financeiros pelo "Plano Collor", as questões previdenciárias, as alterações das normas que regem os planos de saúde, a discussão sobre percentuais de correção monetária etc. - formam uma "macrolide", a exigir uma solução consistente e "com urgência, pois, enquanto tal não se obtém, geram imenso número de processos individuais que desagregam a orientação a todo o meio negocial, administrativo e, mesmo, judiciário". 227

Por sua vez, Kazuo Watanabe menciona os conflitos baseados em relações “pseudoindividuais" que, também decorrentes da massificação da sociedade, só aparentemente são individuais, pois, por sua própria natureza ou por força de lei, não são divisíveis e exigem uma única solução (coletivizada), sob pena de contradição prática (e não apenas lógica) entre os comandos. É o caso, por exemplo, da nulidade de cláusula contratual que estabelece obrigação do usuário pelo pagamento de assinatura por utilização de linha telefônica. ${ }^{228}$

Ocorre que os institutos até então disponíveis têm se mostrado insuficientes quanto ao objetivo de impor o tratamento molecularizado dos litígios repetitivos ou de massa, tanto que não é incomum a coexistência de inúmeras ações individuais e ações coletivas

\footnotetext{
${ }^{225}$ MANCUSO, Rodolfo de Camargo, Divergência jurisprudencial e súmula vinculante, cit., p. 188.

${ }^{226}$ BENETI, Sidnei Agostinho, Doutrina de precedentes e organização judiciária, cit., p. 31.

${ }^{227}$ Ibidem, p. 28.

${ }^{228}$ WATANABE, Kazuo. Relação entre demandas coletivas e demandas individuais. In: GRINOVER, Ada Pellegrini; MENDES, Aluisio Gonçalves de Castro; WATANABE, Kazuo (Coords.). Direito processual coletivo e o anteprojeto de Código Brasileiro de Processos Coletivos. São Paulo: Revista dos Tribunais, 2007. p. 158.
} 
versando sobre a mesma questão de direito, mantendo-se, com isso, a proliferação da divergência jurisprudencial exacerbada e todos os malefícios dela decorrentes, sobretudo em relação aos princípios da igualdade, da segurança jurídica e da razoável duração do processo. $^{229}$

De fato, mesmo havendo instrumentos aptos a viabilizar o tratamento coletivizado das pretensões isomórficas a partir da iniciativa das próprias partes (como, por exemplo, a ação civil pública), os litígios individuais permanecem e as próprias ações coletivas se repetem.

Tudo isso ocorre, entre outros fatores, em razão da extensão territorial do país, de deficiências no sistema de processo coletivo, da falta de representatividade (ou, muitas vezes, de organização) das associações e demais pessoas legitimadas a fazer uso das demandas coletivas, das dificuldades em se relacionar as demandas individuais e coletivas sobre a mesma questão (litispendência, conexão e continência), da proibição do uso da ação civil pública para algumas espécies de questões, como a tributária etc.

Além disso, persistem questões repetitivas que não estão relacionadas a direitos individuais homogêneos (e que, portanto, não podem ser tratadas uniformemente pela via das ações coletivas), como, por exemplo, as discussões a respeito de determinado prazo prescricional ou decadencial, as questões processuais, como o cabimento de determinado recurso, o termo inicial de incidência de uma multa processual, a admissibilidade de uma forma de intervenção de terceiros etc. Todas essas questões também se repetem em larga escala, gerando grave divergência jurisprudencial.

\footnotetext{
229 "Mesmo com a implantação de um regime próprio para os processos coletivos, persistem as demandas repetitivas, que se multiplicam a cada dia." (CUNHA, Leonardo José Carneiro da. O regime processual das causas repetitivas. Revista de Processo, São Paulo, v. 35, n. 179, p. 142, jan. 2010). "Todavia, como mecanismo de pacificação e de efetiva inibição ou redução de litígios de massa, pouco fez a ação civil pública pelo processo civil brasileiro. A existência de tal mecanismo não impediu a massificação dos processos [...].” (AMARAL, Guilherme Rizzo. Efetividade, segurança, massificação e a proposta de um “incidente de resolução de demandas repetitivas". Revista de Processo, São Paulo, v. 36, n. 196, p. 253, jun. 2011).
} 
Dessa forma, fala-se em uma terceira modalidade de litigiosidade, paralela aos litígios individuais e coletivos, chamada de repetitiva, serial ou de massa ${ }^{230}$, que se caracteriza pelo imenso volume de demandas individuais e coletivas ${ }^{231}$, nas quais se discutem questões materiais ou processuais idênticas ${ }^{232}$, litigiosidade essa que também exige um tratamento diferenciado.

Se a existência desses litígios gera problemas graves para o Poder Judiciário como um todo ${ }^{233}$, os efeitos são ainda mais graves em relação aos órgãos de cúpula, seja em razão de suas dimensões reduzidas, seja em razão da importância particular de seus julgamentos para todo o país.

Nesse sentido, verifica-se que o caráter repetitivo dos recursos é característica antiga do grande volume de processos que chegam aos órgãos de cúpula. Conforme comentários do ministro Victor Nunes Leal, extraídos de texto publicado em 1965, "o que

\footnotetext{
230 "Especialmente em face da ampliação da agenda do sistema jurisdicional brasileiro, sabe-se que não é possível, na atualidade, esquecer que a ciência jurídica (e processual) precisa lidar, de modo a viabilizar uma aplicação legítima e eficiente, com três tipos de litigiosidade: (a) individual ou 'de varejo': sobre a qual o estudo e dogmática foram tradicionalmente desenvolvidos, envolvendo lesões e ameaças a direito isoladas; (b) a litigiosidade coletiva: envolvendo direitos coletivos e difusos, nos quais se utilizam procedimentos coletivos representativos, normalmente patrocinados por legitimados extraordinários (órgão de execução do Ministério Público, Associações representativas etc.); e (c) em massa ou de alta intensidade: que dá margem à propositura de ações repetitivas ou seriais, que possuem como base pretensões isomórficas, com especificidades, mas que apresentam questões (jurídicas e/ou fáticas) comuns para a resolução da causa." (THEODORO JÚNIOR, Humberto; NUNES, Dierle José Coelho; BAHIA, Alexandre Gustavo Melo Franco. Breves considerações sobre a politização do Judiciário e sobre o panorama de aplicação no direito brasileiro: análise de convergência entre o civil law e o common law e dos problemas da padronização decisória, cit., p. 24).

231 "Várias demandas individuais podem caracterizar-se como causas repetitivas. De igual modo, várias demandas coletivas podem caracterizar-se como causas repetitivas. O que importa não é o objeto litigioso, mas a homogeneidade, ou seja, a existência de situações jurídicas homogêneas. A litigiosidade de massa é o que identifica as demandas repetitivas, independentemente de o direito ser individual ou coletivo." (CUNHA, Leonardo José Carneiro da. Anotações sobre o incidente de resolução de demandas repetitivas previsto no Projeto do novo Código de Processo Civil. Revista de Processo, São Paulo, v. 36, n. 193, p. 258, mar. 2011).

232 “As demandas repetitivas fundam-se em situações jurídicas homogêneas, que possuem um perfil que lhes é próprio e não se resumem aos direitos individuais homogêneos, como vêm sendo tratados pela doutrina. [...] As demandas homogêneas se identificam no plano abstrato, no que diz respeito à questão fática ou jurídica em tese, mas não no âmbito de cada situação concreta. [...] A categorização das demandas de massa dá-se pelos critérios acima expostos: identidade em tese, e não em concreto, da causa de pedir e do pedido, associada à repetição em larga escala." (BASTOS, Antonio Adonias Aguiar. Situações jurídicas homogêneas: um conceito necessário para o processamento das demandas de massa. Revista de Processo, São Paulo, v. 35, n. 186, p. 96-100, jul. 2010).

233 “Todos são unânimes em proclamar que a Justiça está abarrotada e é lenta, que os casos repetitivos recebem tratamentos desiguais e trazem o seriíssimo mal da quebra da equidade, que essa situação desgasta o Poder Judiciário e prejudica o universo de consumidores dos serviços jurisdicionais, etc." (DINAMARCO, Cândido Rangel, Decisões vinculantes, cit., p. 185).
} 
na verdade assoberba os tribunais, prejudicando o acurado exame dos temas difíceis, são os casos que se multiplicam, seriadamente, como se houvesse uma fábrica montada para fazer dos juízes estivadores". Para o autor, seria injustificável obrigar o STF a lidar com esses casos, após a definição da orientação da corte. ${ }^{234}$

Ao seu turno, Carlos Mario da Silva Velloso relata que, em visita à Suprema Corte norte-americana, e em conversa com um de seus juízes, informou-lhe que o STF julgava, à época, cerca de trinta mil recursos por ano; e que, logo em seguida, acrescentou: "antes que o senhor pense que os juízes brasileiros são super-homens ou que seja eu um grande mentiroso, esclareço que mais de $80 \%$ desses recursos são repetidos." 235

Após informar que, em 1995 a Suprema Corte norte-americana recebeu cerca de 4.000 propostas de recursos, tendo admitido 300 e julgado apenas 180, o citado autor complementa, informando que: "Em 1996, o Supremo Tribunal recebeu 30.706 processos e julgou 29.000. Mais de $80 \%$ desses recursos são repetidos.",236

Paradoxalmente, o maior responsável pela proliferação das demandas repetitivas é o próprio Estado, que "no Brasil vem sendo o grande alimentador da litigiosidade e congestionador dos serviços forenses", eis que "persevera em continuar a exigir, a demandar, a resistir, a recorrer até à última instância", obrigando os tribunais a "repetir-se em julgados e mais julgados, mesmo muito tempo depois de estar pacificada ou mesmo uniformizada sua jurisprudência". ${ }^{237}$

É natural que o Estado, que mantém relação jurídica com todos os indivíduos, e que passou a ser responsável por uma série de providências positivas (direitos sociais), tenha passado a protagonizar inúmeros litígios individuais, idênticos e repetitivos, envolvendo grande número de pessoas. Apenas para exemplificar, pense-se nas discussões tributárias, previdenciárias, sobre planos de governo, sobre a regulamentação dos serviços públicos

\footnotetext{
${ }^{234}$ LEAL, Victor Nunes. Aspectos da reforma judiciária. Revista de Informação Legislativa, Brasília, DF, v. 2, n. 7, p. 44, set. 1965. Disponível em: <http:// www2.senado.leg.br/ bdsf/ bitstream/ handle/id/180663/000347537.pdf?sequence=1>. Acesso em: 08 out. 2013.

235 VELLOSO, Carlos Mário da Silva, Do Poder Judiciário: como torná-lo mais ágil e dinâmico: efeito vinculante e outros temas, cit., p. 78.

${ }^{236}$ Ibidem, p. 79.

${ }^{237}$ DINAMARCO, Cândido Rangel, Decisões vinculantes, cit., p. 168-169.
} 
por agências reguladoras etc. Some-se a isso a postura de um Estado que não hesita em descumprir suas obrigações, utilizando a máquina judiciária - e a demora por ela proporcionada - para postergar até o último instante o cumprimento de seus compromissos perante os cidadãos. O resultado é um único litigante (o próprio Estado) responsável por mais de $80 \%$ dos recursos pendentes nos tribunais superiores. ${ }^{238}$

Mas os casos repetitivos não envolvem exclusivamente o Estado. Pense-se nas causas envolvendo consumidores, as questões sobre direito bancário, os litígios relativos às questões ambientais, ao mercado de capitais. Essas e outras questões geram uma grande multiplicidade de casos, sempre versando sobre questões repetitivas.

A ministra do STJ Fátima Nancy Andrighi faz uma interessante ligação entre o excesso de trabalho e a consequente demora na prestação jurisdicional, decorrente da multiplicidade de casos repetitivos, e o tratamento desigual que isso gera aos jurisdicionados:

A situação criada pelo excesso de ações em torno do mesmo tema era, e ainda é, perniciosa, pois consegue inverter a ordem natural do trabalho dos juízes. A repetição de julgamentos idênticos amplia a produtividade individual de cada juiz, transmitindo a falsa ideia de que são decididas variadas questões de direito. No entanto, os recursos com elevado grau de complexidade acabam sendo relegados a segundo plano, e, em detrimento da produção intelectual dos julgadores, o trabalho jurisdicional passa a ser direcionado para atender a demanda em massa de poucos e determinados escritórios de advocacia ou de partes que sobrecarregam o sistema judicial com uma avalanche de recursos. ${ }^{239}$

Conforme Athos Gusmão Carneiro, o sistema que obriga sejam remetidos "ao STJ centenas, milhares de recursos especiais que versem a mesma questão de direito, obrigando a Corte a julgamentos 'por atacado', apresenta 'inconveniências óbvia'”, 240

\footnotetext{
238 “A verdadeira vilã da proliferação dos processos repetitivos é a Administração Pública, direta e indireta, responsável por mais de $80 \%$ dos recursos pendentes nos tribunais superiores, perante os quais a situação é gravíssima." (GRINOVER, Ada Pellegrini. O tratamento dos processos repetitivos. In: JAYME, Fernando Gonzaga; FARIA, Juliana Cordeiro de; LAUAR, Maira Terra (Orgs.). Processo civil: novas tendências: homenagem a Humberto Theodoro Júnior. Belo Horizonte: Del Rey, 2008. p. 1).

${ }^{239}$ ANDRIGHI, Fátima Nancy, Recursos repetitivos, cit., p. 268.

${ }^{240}$ CARNEIRO, Athos Gusmão, Recurso especial, agravos e agravo interno, cit., p. 107.
} 
No mesmo sentido, sobre os recursos extraordinários e especiais repetitivos, Rodolfo de Camargo Mancuso faz referência ao fato de que "as estatísticas do STF e STJ identificavam [tais recursos] como os grandes vilões da sobrecarga de trabalho nessas Cortes". 241

Diante dessa situação crítica, além da jurisprudência defensiva, o STF e o STJ já vinham de certa forma adotando procedimentos que, na prática, representavam a apreciação em bloco dos casos repetitivos, reduzindo sobremaneira a chance de efetiva apreciação de eventuais peculiaridades e fundamentos diferentes e relevantes de cada caso, com o indesejável comprometimento não só da celeridade, como também, e principalmente, da própria qualidade das decisões da instância superior.

E foi essencialmente nesse contexto de crise que surgiu a ideia da técnica de julgamento de recursos repetitivos.

Quanto aos recursos extraordinários, consta no Parecer da Comissão de Constituição e Justiça do Senado Federal que analisou o Projeto de Lei n. 6.648/2006, que deu origem à Lei n. 11.418/2006, as seguintes considerações que, embora diretamente relacionadas à repercussão geral, bem revelam o espírito daquela lei, que afinal acabou por instituir também a técnica de julgamento de recursos repetitivos:

É inegável que o STF vive atualmente a maior crise de sua história, abarrotado de processos de relevância duvidosa, capazes tão somente de postergar, obliterar ou impedir a prestação da jurisdição constitucional que a sociedade e as instituições brasileiras entendem devida e rotineiramente por essa clamam e esperam. Nesse particular, a proposição permitirá que as causas submetidas ao STF sejam efetivamente selecionadas, de modo a se impedir o julgamento de recursos cuja irrelevância constitucional, sob os aspectos econômico, político, social ou jurídico, seja manifesta. Afastaremos, pois, os recursos extraordinários que apenas refletirem o espírito de emulação e de inconformismo das partes. $^{242}$

\footnotetext{
${ }^{241}$ MANCUSO, Rodolfo de Camargo, Recurso extraordinário e recurso especial, cit., p. 356.

242 Disponível em: <http:// www.camara.gov.br /proposicoesWeb/ prop_mostrarintegra;jsessionid= 01693481CC691A16CCEF4F530883C429.node2? codteor $=399380$ \&filename $=$ PRL $+1+$ CCJC +\%3D\%3E+ PL+6648/2006>. Acesso em: 24 out. 2013.
} 
Por sua vez, quanto aos recursos especiais, na exposição de motivos do anteprojeto de lei que deu origem ao atual artigo 543-C do CPC, consta o seguinte:

[...] faz-se necessária a alteração do sistema processual brasileiro com o escopo de conferir racionalidade e celeridade ao serviço de prestação jurisdicional [...] O presente projeto de lei é baseado em sugestão do exmembro do Superior Tribunal de Justiça, Ministro Athos Gusmão Carneiro, com o objetivo de criar mecanismo que amenize o problema representado pelo excesso de demanda daquele Tribunal. ${ }^{243}$

O mesmo documento informa que, em 2005, foram remetidos mais de 210.000 processos ao STJ, sendo grande parte deles fundados em matérias idênticas, com entendimento já pacificado. Em 2006, o número subiu para 251.020, o que demonstraria uma preocupante tendência de crescimento - justificando, assim, a elaboração do anteprojeto "com o intuito de amenizar o problema". ${ }^{244}$

Como se vê, a justificativa oficial para a positivação da técnica sob estudo foi a de equacionar o problema da crise e racionalizar a atuação do STF e do STJ, atacando especificamente o problema dos recursos extraordinários e especiais repetitivos, a fim de viabilizar, com isso, o adequado exercício desses órgãos superiores.

\footnotetext{
${ }^{243}$ Disponível em: <http://www.planalto.gov.br/ccivil_03/Projetos/EXPMOTIV/MJ/2007/40.htm >. Acesso em: 24 out. 2013.

${ }^{244}$ Disponível em: <http://www.planalto.gov.br/ccivil_03/Projetos/EXPMOTIV/MJ/2007/40.htm〉. Acesso em: 24 out. 2013.
} 


\section{ASPECTOS GERAIS DA TÉCNICA DE JULGAMENTO DE RECURSOS REPETITIVOS}

\subsection{Normas legais e regimentais que regulamentam a técnica de julgamento de recursos repetitivos}

Naquele contexto de crise descrito no Capítulo 4, foi inserido em nosso sistema o procedimento de julgamento por amostragem de recursos extraordinários e especiais repetitivos, que se vale da concentração do julgamento das questões repetitivas por meio da técnica do "recurso-piloto", "recurso-modelo" ou "recurso-líder". ${ }^{245}$

Na verdade, desde 2001 o sistema brasileiro já previa, por meio da Lei n. 10.259/2001, técnica que, de certa forma, vale-se de uma forma de julgamento por amostragem para realizar, no âmbito dos Juizados Especiais Federais, a uniformização da interpretação da lei federal pelo STJ ${ }^{246}$ ou da Constituição Federal pelo STF.

Quanto aos recursos extraordinários interpostos no âmbito dos Juizados Especiais Federais, por força da delegação contida no artigo 15 daquela Lei, o Supremo editou a Emenda Regimental n. 12, de 12 de dezembro de 2003, regulamentando procedimento bastante semelhante ao atualmente regulamentado pelo artigo 543-B do CPC.

Com a referida Emenda, o artigo 321, $\S 5^{\circ}$, do RISTF passou a prever a possibilidade de concessão de medida cautelar para determinar o sobrestamento na origem dos processos versando sobre idêntica controvérsia constitucional; a possibilidade de manifestação dos que não sejam parte no processo, após trinta dias da publicação da cautelar; a abertura de vista ao Ministério Público; e, após o julgamento do recurso extraordinário, a posterior aplicação do acórdão paradigma aos casos que estavam sobrestados, para fins de retratação de entendimento eventualmente divergente ou

\footnotetext{
${ }^{245}$ TAVARES JUNIOR, Homero Francisco. Recursos especiais repetitivos: aspectos da Lei 11.672/2008 e da Res. 8/2008 do STJ. Revista de Processo, São Paulo, v. 33, n. 166, p. 195, dez. 2008.

${ }^{246}$ Segundo o artigo $14, \S 2^{\circ}$ dessa Lei, o pedido de instauração do incidente pode ser fundado não só em caso de divergência entre decisões de turmas de diferentes regiões, mas também quando essas decisões forem proferidas "em contrariedade a súmula ou jurisprudência dominante do STJ". A parte interessada pode provocar o incidente e o STJ pode suspender liminarmente todos os processos nos quais a controvérsia esteja estabelecida, até a definição da questão.
} 
prejudicialidade de recursos contrários à orientação firmada pela corte ${ }^{247}$. Com a Emenda Regimental n. 21/2007, o artigo 321, § 5º do RISTF foi revogado.

De qualquer forma, além de ser restrita aos procedimentos do Juizado Especial Federal (e, no caso do STJ, ao incidente de uniformização de jurisprudência contrária ao entendimento sumulado ou dominante desta Corte), a técnica só admite a suspensão dos demais casos idênticos quando "presente a plausibilidade do direito invocado e havendo fundado receio de dano de difícil reparação" (art. 14, § 5º da Lei n. 10.259/2001).

Diante disso, é possível afirmar que com a técnica de julgamento de recursos repetitivos pelo STF e STJ, o sistema, pela primeira vez, de forma mais ampla e abrangente, passou a permitir o sobrestamento dos recursos que versam sobre questão idêntica e a seleção de um ou mais recursos representativos da controvérsia, a fim de que eles sejam submetidos a um julgamento qualificado por procedimento diferenciado, tudo com a finalidade de que o acórdão ou precedente paradigma nele proferido venha a ser aplicado na solução dos casos repetitivos.

Inicialmente, a técnica foi positivada apenas para a hipótese de recursos extraordinários repetitivos, pois a ideia era regulamentar o instituto constitucional da repercussão geral, conforme a delegação contida no artigo 102, $\S 3^{\circ}$, inserido pela Emenda Constitucional n. 45/2004 (“nos termos da lei”).

O contexto, como já dito, era o de agravamento da crise do STF, comprometedora do cumprimento do princípio da razoável duração do processo (art. $5^{\circ}$, LXXVIII, também inserido pela EC n. 45/2004), situação esta que se pretendia amenizar pelo filtro da repercussão geral.

Ocorre que, ao regulamentar a repercussão geral, o legislador ordinário inseriu no Código de Processo Civil, de uma só vez, os artigos 543-A e 543-B (Lei n. 11.418/2006), estabelecendo, nesse último, que a aferição do novo requisito de admissibilidade, na

\footnotetext{
${ }^{247}$ Esse sistema de julgamento por amostragem foi aplicado, por exemplo, no julgamento em que o Pleno concedeu medida cautelar para suspender os processos versando sobre o mesmo tema constitucional ali discutido, prevenindo a interposição de centenas de milhares de recursos extraordinários. (STF - MC AC n. 272/RJ, Pleno, rel. Min. Ellen Gracie, j. 06.10.2004, DJ, de 25.02.2005).
} 
hipótese de multiplicidade de recursos fundados em idêntica controvérsia, ocorreria na forma ali regulamentada.

Além do procedimento para aferição da repercussão geral por amostragem, ou por "recurso-piloto", o artigo 543-B estabeleceu que a apreciação do próprio mérito do recurso extraordinário representativo da controvérsia, quando for o caso de sua apreciação, também gerará efeitos sobre os recursos sobrestados.

Quanto ao direito intertemporal, segundo o artigo $4^{\circ}$ da Lei n. 11.418/2006, publicada no Diário Oficial da União em 20.12.2006, “aplica-se esta Lei aos recursos interpostos a partir do primeiro dia de sua vigência". Na verdade, tratando-se de norma que regulamenta novo requisito de admissibilidade do recurso extraordinário (a repercussão geral), a interpretação que se deve fazer é a de que ela se aplica apenas aos recursos interpostos contra decisões publicadas a partir da sua entrada em vigor, porque esse é o momento em que surge para as partes o interesse recursal. ${ }^{248}$

Considerando-se a vacatio legis de sessenta dias prevista em seu artigo $5^{\circ}$, a Lei entrou em vigor em 18.02.2007. Mas, como ela ainda dependia da regulamentação pelo RISTF, o que só veio a ocorrer pela Emenda Regimental n. 21, de 2 de maio de 2007, a nova sistemática só passou a ser aplicada aos recursos interpostos contra decisões publicadas a partir de 03.05.2007..$^{249}$

Com base na delegação contida no caput do artigo 543-B, a Corte Suprema promoveu alterações regimentais importantes na técnica em questão, conforme os artigos 328 (Emenda Regimental n. 21/2007) e 328-A (Emenda Regimental n. 23/2008) do RISTF, que serão oportunamente estudadas neste trabalho.

\footnotetext{
248 ABBUD, André de Albuquerque Cavalcanti. A repercussão geral dos recursos extraordinários e o julgamento por amostragem no âmbito do Supremo Tribunal Federal (CPC, arts. 543-A e 543-B). In: GIANNICO, Maurício; MONTEIRO, Vítor José de Mello (Coords.). As novas reformas do CPC e de outras normas processuais. São Paulo: Saraiva, 2009. p. 316; ARRUDA ALVIM, José Manoel de. A EC n. 45 e o instituto da repercussão geral. In: WAMBIER, Teresa Arruda Alvim et al. (Coords.). Reforma do Judiciário: primeiros ensaios críticos sobre a EC n. 45/2004. São Paulo: Revista dos Tribunais, 2005. p. 99; GOMES JUNIOR, Luiz Manoel. A repercussão geral da questão constitucional no recurso extraordinário. Revista de Processo, São Paulo, v. 30, n. 119, p. 91-116, jan. 2005.

249 Assim decidiu o Supremo, ao julgar (QO AI n. 664.567, Pleno, rel. Min. Sepúlveda Pertence, j. 10.06.2007.
} 
Dessa forma, em linhas gerais, os recursos extraordinários repetitivos devem permanecer sobrestados nos órgãos de origem ${ }^{250}$, a fim de que o STF aprecie, num primeiro momento, a repercussão geral do recurso-piloto. Rejeitada a repercussão geral, “a decisão valerá para todos os recursos sobre matéria idêntica, que serão indeferidos liminarmente, salvo revisão da tese" (art. 543-A, § 5\%), e "os recursos sobrestados considerar-se-ão automaticamente não admitidos" (art. 543-B, § $2^{\circ}$ ).

Presente a repercussão geral da matéria constitucional e apreciado mérito do recurso extraordinário para a definição da interpretação da questão de direito constitucional, os recursos sobrestados sofrerão os efeitos do precedente paradigmático, na forma $\operatorname{dos} \S \S 3^{\circ}$ e $4^{\circ}$ do artigo 543-B e demais normas regimentais.

Embora a repercussão geral tenha ficado restrita ao recurso extraordinário, o legislador ordinário vislumbrou a possibilidade de, com o mesmo intuito de tentar amenizar a crise do STJ, instituir técnica de julgamento de recursos repetitivos semelhante.

Porém, a apreciação pelo STJ de recursos especiais repetitivos por amostragem, ou por "recurso-modelo", não poderia avançar no sentido da apreciação de uma eventual "repercussão geral" dessa espécie de recurso, pois, como visto, o filtro recursal ficou restrito ao recurso extraordinário. Assim, a Lei n. 11.672/2008, publicada no Diário Oficial da União de 09.05.2008, incluiu o artigo 543-C no CPC, para regulamentar o procedimento de processamento e julgamento do mérito do recurso especial na hipótese de "multiplicidade de recursos com fundamento em idêntica questão de direito".

Segundo o artigo $2^{\circ}$ da Lei n. 11.672/2008, “aplica-se o disposto nesta Lei aos recursos já interpostos por ocasião da sua entrada em vigor", o que, considerando-se a vacatio legis de noventa dias prevista em seu artigo $3^{\circ}$ e o fato de que se trata de regra de procedimento (e não de admissibilidade do recurso), significa a possibilidade de aplicação da nova técnica aos recursos já protocolados, a partir de $07.08 .2008 .^{251}$

\footnotetext{
${ }^{250} \mathrm{O}$ artigo 543-B, $\S 1^{\circ}$, fala inapropriadamente em "Tribunal de origem". No entanto, nem sempre o recurso extraordinário é interposto contra decisão de tribunal, já que, como visto no Capítulo 3 (item 3.3.3), é cabível contra decisões de "última ou única instância" (art. 102, III, da CF) de qualquer órgão jurisdicional.

251 "Impende observar que a lei não institui nem extingue recursos, e sim regulamenta o procedimento a ser adotado, em determinados casos, pelo recurso especial. Trata-se, pois, do princípio da imediata incidência das leis processuais, não havendo direito adquirido a formas processuais." (CARNEIRO, Athos Gusmão. Primeiras observações sobre a lei dos recursos repetitivos no STJ. Revista de Processo, São Paulo, v. 33, n.
} 
A norma foi regulamentada, na forma do $\S 9^{\circ}$ do artigo 543-C, pela Resolução n. $8 / 2008$ do STJ, a cujos artigos faremos constante menção no decorrer deste trabalho. ${ }^{252}$

O procedimento estabelecido pelos dois artigos (543-B e 543-C) do CPC e pelas normas regimentais que os regulamentam é bastante semelhante, apesar das distinções de redação. Essencialmente, além de algumas diferenças procedimentais que serão comentadas no momento oportuno, os procedimentos distinguem-se apenas em relação à questão da repercussão geral, que se refere exclusivamente à hipótese de recursos extraordinários: sendo ela rejeitada, os recursos repetitivos sobrestados considerar-se-ão, nos termos do texto expresso da lei, automaticamente inadmitidos.

Porém, quando reconhecida a repercussão geral, o sistema praticamente se iguala em relação a recursos extraordinários e especiais, de modo que prevalece, em ambos os casos, a ideia de se definir a controvérsia sobre a interpretação do direito federal constitucional ou infraconstitucional por meio do julgamento do recurso-piloto, a fim de que o entendimento fixado no acórdão ou precedente, que pode ser adjetivado de paradigma ou qualificado, possa ser aplicado na solução dos demais casos repetitivos.

Revelando a tendência de se manter a técnica de julgamento de recursos repetitivos pelo STF e pelo STJ, o projeto de novo Código de Processo Civil, em sua versão atual, prevê uma subseção exclusiva para tratar conjuntamente do "julgamento dos recursos extraordinários e especiais repetitivos", estabelecendo, nos artigos 1.049 a 1.054 e seus diversos parágrafos, o procedimento comum para a apreciação das duas espécies de recursos excepcionais "sempre que houver multiplicidade de recursos com fundamento em idêntica questão de direito". 253

160, p. 86, jun. 2008.). Em sentido contrário, Nelson Nery Junior e Rosa Maria Borrielo de Andrade Nery entendem, a partir da interpretação dos artigos $2^{\circ}$ e $3^{\circ}$ da Lei, que a sistemática só pode ser aplicada em relação aos recursos interpostos após o início da vigência da norma (NERY JUNIOR, Nelson; NERY, Rosa Maria de Andrade. Código de Processo Civil comentado e legislação extravagante. 11. ed. rev., ampl., e atual. até 17.02.2010. São Paulo: Revista dos Tribunais, 2010. p. 985).

${ }^{252}$ Inicialmente, o STJ editou a Resolução n. 7/2008, que extrapolava os limites do artigo 543-C do CPC, ao prever, por exemplo, a extensão do sobrestamento a todos os processos em primeiro e segundo graus, bem como o não cabimento de novo recurso especial contra a decisão do tribunal local que exercesse a retratação para ajustar o acórdão à decisão do STJ.

${ }^{253}$ Sobre o projeto de novo CPC, ver Capítulo 12. 


\subsection{A inspiração no procedimento-modelo do direito alemão (Musterverfahren)}

A doutrina tem relacionado a técnica de julgamento de recursos repetitivos prevista nos artigos 543-B e 543-C do CPC ao procedimento-modelo do direito alemão (Musterverfahren), no qual ela teria encontrado inspiração. ${ }^{254}$

Quanto ao "incidente de resolução de demandas repetitivas" previsto no projeto de novo CPC e que caracteriza uma ampliação da técnica dos atuais artigos 543-B e 543-C aos processos repetitivos desde o primeiro grau de jurisdição (ver Capítulo 12, item 12.4), os próprios idealizadores do projeto expressamente reconhecem a influência do instituto do direito alemão. ${ }^{255}$

O Musterverfahren foi instituído na Alemanha no ano de 2005, por meio de "lei experimental”, com vigência até 01.11.2010, mas depois prorrogada até 31.10.2012 e, por fim, tornada definitiva pela Lei federal n. 50, de 19.10.2012, que entrou em vigor em 01.11.2012.

Considerando-se que a Alemanha é um país de pouca tradição na regulamentação da tutela coletiva, o instituto foi criado como reação ao ajuizamento de inúmeras ações individuais repetitivas em razão de um megalitígio surgido entre a empresa Deutsche Telekom AG e seus milhares de acionistas, em decorrência do prejuízo causado pela alegada incorreção de informações por ela prestadas ao mercado sobre seu patrimônio.

\footnotetext{
${ }^{254}$ Nesse sentido: THEODORO JÚNIOR, Humberto; NUNES, Dierle José Coelho; BAHIA, Alexandre Gustavo Melo Franco. Litigiosidade em massa e repercussão geral no recurso extraordinário. Revista de Processo, São Paulo, v. 34, n. 177, p. 9-46, nov. 2009; CUNHA, Leonardo José Carneiro da, Anotações sobre o incidente de resolução de demandas repetitivas previsto no Projeto do novo Código de Processo Civil, cit., p. 255-279; CUNHA, Leonardo José Carneiro da. O regime processual das causas repetitivas, cit., p. 151-153; CABRAL, Antonio do Passo. O novo procedimento-modelo (Musterverfahren) alemão: uma alternativa às ações coletivas. Revista de Processo, São Paulo, v. 32, n. 147, p. 123-146, maio 2007; CASTRO, Daniel Penteado de. Questões polêmicas sobre o julgamento por amostragem do recurso especial repetitivo. Revista de Processo, São Paulo, v. 37, n. 206, p. 79-118, abr. 2012; PINTO, Luis Filipe Marques Porto Sá, Técnicas de tratamento macromolecular dos litígios: tendência de coletivização da tutela processual civil, cit., p. 117-144.

${ }^{255}$ AMARAL, Guilherme Rizzo, Efetividade, segurança, massificação e a proposta de um "incidente de resolução de demandas repetitivas", cit., p. 255.
} 
Trata-se, assim, de instrumento de julgamento de ações repetitivas relativas a litígios do mercado de capitais por meio de processos-modelo, no qual uma "causa-piloto" ou processo-teste é selecionado para processamento e decisão sobre os pontos fáticos e jurídicos comuns a todas as demais ações idênticas, as quais permanecem sobrestadas. ${ }^{256}$

A cognição a ser realizada pela instauração do instituto da Musterverfahren envolve tanto as questões fáticas como as jurídicas das relações jurídicas referentes aos casos repetitivos, e a ideia é resolver coletivamente essas questões comuns em um primeiro momento, para que, depois, os processos individuais sejam apreciados a partir do entendimento alcançado no incidente, sem prejuízo da consideração das singularidades de cada caso. ${ }^{257}$

A instauração do incidente depende de pedido do autor ou réu, sendo vedada a instauração de ofício. Exige-se o apontamento dos pontos litigiosos que se pretende sejam tratados coletivamente, indicando-se os meios de prova a serem produzidos e demonstrando-se a repercussão processual do caso, isto é, o risco de interferência na resolução dos casos repetitivos.

Reconhecida a admissibilidade do incidente, o juízo de origem determina a inclusão de um extrato com o pedido, partes, objetivo do procedimento etc., em um cadastro eletrônico público e gratuito (gerido pelo Ministério da Justiça), com isso possibilitando posteriores registros de pedidos semelhantes. O procedimento só será instaurado se, no prazo de quatro meses após a publicação do primeiro registro, houver pelo menos nove outros pedidos versando sobre a mesma questão (totalizando um mínimo de dez requerimentos de instauração da Musterverfahren).

Confirmando-se a instauração por decisão irrecorrível do juízo onde formulado o primeiro incidente, a competência para seu processamento e julgamento será do tribunal que lhe for hierarquicamente superior, ou então de Tribunal Superior, caso a questão envolva cortes estaduais diversas.

\footnotetext{
256 AMARAL, Guilherme Rizzo, Efetividade, segurança, massificação e a proposta de um "incidente de resolução de demandas repetitivas", cit., p. 255-258.

${ }^{257}$ CABRAL, Antonio do Passo, O novo procedimento-modelo (Musterverfahren) alemão: uma alternativa às ações coletivas, cit., p. 132.
} 
O tribunal competente, então, deve escolher um líder para os vários autores e outro para os réus, líder esse que passará a atuar como "parte principal", fazendo a intermediação entre as demais partes e interessados e a corte. As demais partes, embora não possam contrariar as posições do líder, podem integrá-las com novos elementos de convicção. Embora a escolha desse líder seja discricionária, ela deve atender a critérios estabelecidos na lei, que levam em consideração, por exemplo, a magnitude do litígio e a possibilidade de entendimento e comunicação entre os interessados. ${ }^{258}$

Com a publicação da instauração do incidente no registro, incluindo-se as partes líderes, são suspensos por decisão irrecorrível todos os processos que versam sobre as questões a serem decididas ou esclarecidas no processo-modelo. ${ }^{259}$

Ponto importantíssimo do Musterverfahren é a permissão da participação direta dos interessados no julgamento do processo-modelo, como visto acima. Isso se dá por uma forma de intervenção de terceiros também prevista para o processo administrativo, a chamada Beiladung, que é, segundo Antonio do Passo Cabral, "às vezes assemelhada às intervenções de terceiro, outras similar ao litisconsórcio". 260

Na verdade, no caso da Musterverfahren, tanto o sobrestamento como a eficácia da decisão final só atingem os processos já ajuizados quando da publicação da decisão do tribunal que instaura o incidente (que são considerados automaticamente como intervenientes, independentemente da sua participação efetiva), e não os processos futuros, não se podendo falar, portanto, propriamente em efeito vinculante do precedente, nas sim em extensão da coisa julgada aos intervenientes. ${ }^{261}$

Proferida a decisão, cabe recurso tanto pela parte principal e pelos intervenientes, mas o recorrente deve demonstrar a sua "significação fundamental", requisito semelhante à

\footnotetext{
${ }^{258}$ CABRAL, Antonio do Passo, O novo procedimento-modelo (Musterverfahren) alemão: uma alternativa às ações coletivas, cit., p. 135.

${ }^{259}$ CUNHA, Leonardo José Carneiro da, O regime processual das causas repetitivas, cit., p. 153.

${ }^{260}$ CABRAL, Antonio do Passo, op. cit., p. 136.

${ }^{261}$ Ibidem, p. 137.
} 
nossa repercussão geral do recurso extraordinário. Além disso, a lei prevê a nomeação de outros líderes, caso as partes principais não recorram ou desistam. ${ }^{262}$

Como se vê, apesar de se tratar de uma técnica de julgamento por processo-modelo em que ocorre o sobrestamento dos casos repetitivos até a solução das questões comuns (pelo que o instituto guarda semelhanças com a técnica de julgamento de recursos repetitivos), ele se distingue da técnica dos artigos 543-B e 543-C do CPC em inúmeros pontos.

No Musterverfahren podem ser apreciadas tanto questões de direito como questões de fato repetitivas. Ademais, embora nada impeça que questões processuais comuns também sejam decididas, a instauração do procedimento justifica-se para a solução de questões repetitivas de direito material. Ao que parece, portanto, o procedimento se assemelha a um incidente de solução coletiva de litígios individuais envolvendo interesses individuais homogêneos, e não quaisquer espécies de questões jurídicas repetitivas (processuais ou materiais).

Além disso, a decisão final atinge apenas os processos já instaurados quando da publicação da instauração do procedimento, e não os processos futuros. As partes dos processos sobrestados são consideradas partes intervenientes do processo-modelo, podendo inclusive recorrer ${ }^{263}$. Com isso, ocorre uma extensão da eficácia da decisão e da coisa julgada às partes dos processos repetitivos envolvidos diretamente no incidente, e não um efeito vinculante da ratio decidendi em relação a casos futuros.

Como veremos adiante, nada disso ocorre na técnica de julgamento de recursos repetitivos pelo STF e STJ. Só questões de direito podem ser apreciadas, pois a ideia é gerenciar a divergência jurisprudencial sobre a interpretação do direito federal constitucional e infraconstitucional. Nesse sentido, qualquer questão repetitiva, seja de direito material, seja de direito processual, pode justificar a instauração do procedimento, que não depende da iniciativa das partes. E não se exige que as questões de direito

\footnotetext{
${ }^{262}$ CABRAL, Antonio do Passo, O novo procedimento-modelo (Musterverfahren) alemão: uma alternativa às ações coletivas, cit., p. 135.

${ }^{263}$ CONSOLO, Claudio; RIZZARDO, Dora. Due modi di mettere le azione colletive alla prova: Inghilterra e Germania. Rivista Trimestrale di Diritto e Procedura Civile, Milano, Giuffrè, v. 60, n. 3, p. 905, set. 2006.
} 
repetitivo tenham uma origem comum, de modo a caracterizar direitos individuais homogêneos.

Por sua vez, o entendimento consolidado no precedente não atinge somente as partes que tiveram seus recursos sobrestados até a instauração do procedimento, mas também os processos futuros, na qualidade de acórdão paradigma sobre a questão. Ademais, as partes dos recursos sobrestados não se consideram partes do recurso-piloto, admitindo-se apenas a intervenção de amicus curiae, conforme estejam presentes os requisitos para tanto. Também por isso, esses terceiros não podem recorrer contra a decisão final, que exerce mera influência, ainda que potencializada pelas técnicas dos artigos 543B e 543-C, em relação aos casos sobrestados.

\subsection{Outras técnicas de julgamento por amostragem do direito estrangeiro}

Além do Musterverfahren, há no direito estrangeiro outras técnicas que se valem de alguma forma de julgamento por amostragem, ou de processo-modelo, as quais, apesar de se basearem na mesma ideia de sobrestar os casos repetitivos e realizar um julgamento concentrado de casos representativos selecionados, também se distanciam da técnica prevista nos artigos 543-B e 543-C do nosso CPC, razão pela qual, em relação a elas, passamos a dar breve notícia.

No direito espanhol, existe técnica restrita ao contencioso administrativo, cujo objetivo é agilizar a tramitação de causas mediante a extensão dos efeitos da sentença proferida no julgamento de recursos semelhantes, desde que voltados à impugnação do mesmo ato. $^{264}$

O instituto é regulamentado pelos artigos 37.1 e 37.2 da Ley 29/1998, que permite ao tribunal eleger o julgamento de apenas um recurso ou parte deles, suspendendo o processamento dos demais. Ao final, as partes cujos recursos foram suspensos são notificadas, podendo então optar pela desistência, pela extensão ao seu caso da decisão proferida ou até pelo prosseguimento do seu processo.

${ }^{264}$ CASTRO, Daniel Penteado de, Questões polêmicas sobre o julgamento por amostragem do recurso especial repetitivo, cit., p. 86. 
No direito português, também no âmbito do contencioso administrativo, existe técnica bastante semelhante à do direito espanhol, que é prevista no artigo $48^{\circ}$, n. 1 , do Código de Processo nos Tribunais Administrativos (CPTA).

A norma dispõe que, havendo mais de vinte processos relativos a decisões da mesma entidade administrativa, e que digam respeito à mesma relação jurídica material ou tratem de idêntica situação fática a receber a incidência das mesmas normas jurídicas, o presidente do tribunal pode, ouvidas as partes, selecionar para julgamento um ou alguns casos, que serão apensados e serão processados de acordo com o disposto no CPTA para processos urgentes ${ }^{265}$, e determinar a suspensão dos demais casos (inclusive dos ajuizados posteriormente, conforme o n. 2 do art. $48^{\circ}$ ).

Segundo o n. 3 do artigo 48, essa suspensão não tem o alcance de limitar o âmbito da instrução a ser realizada nos casos repetitivos sobrestados, não podendo afastar a apreciação de fatos ou a realização de qualquer prova necessária à apuração da verdade.

Com o trânsito em julgado da decisão proferida nos casos selecionados, e entendendo-se que ela pode ser aplicada aos casos suspensos por não apresentarem eles singularidades, as partes nos processos suspensos são notificadas para, em trinta dias, desistir da sua ação, requerer a extensão dos efeitos da decisão ao seu próprio processo, requerer a continuação do seu próprio processo, ou recorrer da sentença, se ela tiver sido proferida em primeira instância, tudo nos termos do n. 5 do artigo $48^{\circ}$.

Também em Portugal, porém no contencioso judicial, vige outro sistema, chamado de agregação de causas repetitivas ${ }^{266}$, instituído pelo Decreto-Lei n. 108/2006, que versa sobre o "regime processual experimental". Esse regime, inicialmente destinado a vigorar até 16.10.2008, foi depois prorrogado por prazo indeterminado pelo Decreto-Lei n. 187/2008.

\footnotetext{
${ }^{265}$ Cf. o artigo $48^{\circ}$, n. 4: "Ao processo ou processos seleccionados segundo o disposto no n. 1 é aplicável o disposto neste Código para os processos urgentes e no seu julgamento intervêm todos os juízes do tribunal ou da secção".

${ }^{266}$ A agregação de causas aplica-se apenas aos processos entre particulares, e não aos processos envolvendo o Poder Público, que em Portugal, onde há dualidade de jurisdição, ficam a cargo do Contencioso Administrativo.
} 
A técnica é aplicável a algumas regiões do país, e onde se verificar obstrução dos tribunais em razão da grande quantidade de causas, com a finalidade de estabelecer "um tratamento especial aos chamados litigantes de massa, com a previsão de decisões judiciais que abranjam, a um só tempo, vários processos". ${ }^{267}$

As duas ideias principais do instituto são o aprofundamento do princípio da adequação formal (atribuindo-se ao juiz maiores poderes para flexibilizar o procedimento e com isso ajustá-lo às peculiaridades do caso concreto) e a possibilidade de concentração da prática de atos processuais a serem aplicados em vários processos semelhantes, ou seja, a chamada agregação de ações prevista no artigo $6^{\circ}$.

Nos termos da exposição de motivos do Decreto-Lei n. 108/2006, o instituto visa concretizar o imperativo "de assegurar um tratamento específico, no âmbito dos meios jurisdicionais, aos litigantes de massa, permitindo, designadamente, a prática de decisões judiciais que abranjam vários processos". ${ }^{268}$

Segundo Luís Correia de Mendonça, o instituto foi inspirado nas técnicas do contencioso administrativo do direito espanhol e do próprio direito português, e a ideia é permitir "que o juiz, em qualquer momento, pratique ou realize uma diligência extensível a vários processos ('actos em massa') sem que estes percam a sua individualidade e

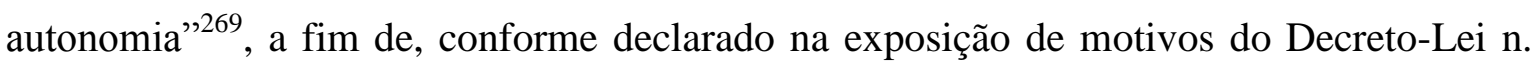
108/2006, "assegurar um tratamento específico, no âmbito dos meios jurisdicionais, aos litigantes de massa, permitindo, designadamente, a prática de decisões judiciais que abranjam vários processos".

Não se trata a agregação de apensamento ou reunião de causas em razão de uma conexão (caso em que os processos correm em conjunto), mas sim de reunião transitória dos processos que poderiam ser ajuizados em litisconsórcio facultativo apenas para a prática de um ou mais atos processuais (intimação, audiência, prova, tutela de urgência ou

\footnotetext{
${ }^{267}$ CUNHA, Leonardo José Carneiro da, O regime processual das causas repetitivas, cit., p. 154.

268 Disponível em: <http://www.pgdlisboa.pt/pgdl/leis/lei_mostra_articulado.php?nid=855\&tabela=leis > Acesso em: 16 jul. 2012.

269 MENDONÇA, Luís Correia de. Processo civil líquido e garantias: o regime processual experimental português. Revista de Processo, São Paulo, v. 34, n. 170, p. 236, abr. 2009.
} 
até a própria sentença), ganhando-se tempo e evitando-se decisões conflitantes sobre questões fáticas e jurídicas comuns aos casos repetitivos ${ }^{270}$. Os processos, portanto, continuam a correr em separado, apenas os atos comuns são praticados de forma concentrada.

Conforme Junior Alexandre Moreira Pinto, esse sistema propicia vantagens para a economia processual e para a prevenção de decisões conflitantes sobre assuntos semelhantes, apresentando-se como técnica de julgamento de conflitos de massa. ${ }^{271}$

Por sua vez, Paula Costa e Silva ressalta tratar-se de um "meio de agilização processual" e compara a técnica com o instituto da Musterverfahren do direito alemão, no sentido de se seguir o caminho dos processos-modelo. Mas, para a autora, o legislador poderia ter ido mais longe, não condicionando a possibilidade de agregação à "verificação dos pressupostos de admissibilidade do litisconsórcio, da coligação, da oposição ou da reconvenção", com o que "restringiu-se o impacto da medida". ${ }^{272}$

É importante ressaltar que, segundo o artigo 6º ${ }^{\circ}$ n. 5, do Decreto-Lei n. 108/2006, a decisão de agregação deve ser notificada às partes, com a convocação para a diligência conjunta ou com o despacho ou a sentença praticados conjuntamente. Ou seja, há permissão para a participação direta das partes nos "processos-modelo".

Por fim, no âmbito do common law, existe a técnica do group litigation do direito inglês, inserida no sistema pela Civil Procedure Rules de 1998 e pelas emendas nela realizadas no ano 2000 (Part 19, seção III, rules 19.10 a 19.15), que passou a ser o instrumento de tutela da maior parte dos litígios coletivos (multi-party litigation), até mesmo em razão do subdesenvolvimento do processo coletivo de modo representativo no direito inglês.

\footnotetext{
${ }^{270}$ Nos termos da exposição de motivos: “O juiz passa, portanto, a poder praticar 'actos em massa', bastando que exista um elemento de conexão entre as acções e que da realização conjunta de um acto processual ou diligência resulte a simplificação do serviço do tribunal." (Disponível em: <http://www.pgdlisboa.pt/pgdl/leis/lei_mostra_articulado.php?nid=855\&tabela=leis>. Acesso em: 16 jul. 2012).

271 PINTO, Junior Alexandre Moreira. O regime processual experimental português. Revista de Processo, São Paulo, v. 32, n. 148, p. 169-180, jun. 2007.

${ }^{272}$ COSTA E SILVA, Paula. A ordem do juízo de D. João III e o regime processual experimental. Revista de Processo, São Paulo, v. 33, n. 156, p. 245, fev. 2008.
} 
Conforme Neil Andrews, a essência das ações de grupo consiste em permitir que um conjunto de partes reunidas em um só bloco atue durante todo o processo para fins de análise conjunta da multiplicidade de questões idênticas ou semelhantes (de forma que cada membro do grupo seja tratado como uma parte, ao invés de uma "não parte" substituída, como ocorre nos processos representativos), permitindo-se, com isso, que as questões comuns sejam decididas de forma eficiente, consistente, em caráter definitivo, com divisão dos custos e com a rapidez adequada. ${ }^{273}$

A rule 19.10 define a group litigation order (GLO) como a ordem de gerenciamento dos casos que dão origem a questões comuns de fato ou de direito. A ordem pode ser dada em caso de existência ou risco de existência de ações baseadas na mesma questão fática ou jurídica (rule 19.11); aqueles que desejam se juntar e se beneficiar da decisão a ser proferida na GLO devem se registrar como partes, ou pelo menos adicionar sua demanda individual ao grupo, podendo pedir posteriormente a exclusão do registro (rule 19.14). ${ }^{274}$

Quanto aos efeitos das determinações e julgamentos, a rule 19.12 estabelece o efeito vinculante (binding effect) imediato em relação a todas as partes constantes no registro do grupo, inclusive os retardatários, efeito esse que pode depois ser modificado por decisão do tribunal, e as partes afetadas pela decisão podem pedir permissão para apelar. Ademais, segundo a rule 19.13, podem ser nomeados advogados de uma ou mais partes para atuar como líderes, ou ainda selecionadas uma ou mais demandas do grupo para atuar como caso-teste (test claims). ${ }^{275}$

Conforme a rule 19.15, com a instauração dos test claims, as decisões ali tomadas serão vinculantes em relação a todas as causas semelhantes e podem também vincular ações subsequentes adicionadas ao registro. ${ }^{276}$

\footnotetext{
273 ANDREWS, Neil. Multi-party proceedings in England: representative and group actions. Duke Journal of Comparative and International Law, Durham, NC, v. 11, n. 2, p. 258, Spring 2001.

${ }^{274}$ Ibidem, p. 260.

275 19.13: "Directions given by the management court may include directions [...] (b) providing for one or more claims on the group register to proceed as test claims."

276 "Decisions in that case are binding on all similar claims on the group registrer. [...] The result of the test claim can also bind subsequent claims added to the register, If the court so directs." (ANDREWS, Neil, op. cit., p. 261).
} 
Como se vê, o procedimento inglês permite a veiculação tanto de questões fáticas como de questões jurídicas comuns entre as causas a serem inseridas no grupo; além disso, exige a manifestação individual, no sentido da adesão ao processo de grupo (opt-in) como condição para a eficácia vinculante da decisão final; por fim, ainda que possa ser selecionado apenas um caso para julgamento (test claim), há a formação de um grupo, inclusive com a escolha de um advogado líder, com o que se pretende dar maior legitimidade à decisão a ser aplicada aos casos semelhantes.

Essa breve análise das técnicas do direito estrangeiro que adotam, de alguma forma, o julgamento por amostragem ou o procedimento-modelo para a tutela de casos envolvendo questões repetitivas revela que, na verdade, apesar de alguma proximidade com a técnica de julgamento de recursos repetitivos pelo STF e STJ, elas se diferenciam tanto quanto o Musterverfahren - desse procedimento, por uma série de circunstâncias.

De um modo geral, as técnicas comentadas acima admitem a instauração do procedimento para o tratamento uniforme de questões de fato e de direito, e não se cogita da instauração do procedimento apenas para o tratamento unificado de questões repetitivas de direito processual.

Ademais, as partes dos processos repetitivos suspensos passam a ser consideradas como verdadeiras partes dos casos selecionados para julgamento, podendo inclusive recorrer.

Por sua vez, ocorre a extensão da eficácia da decisão final e da respectiva coisa julgada, de forma semelhante à que ocorre nos processos coletivos de modo representativo, e não propriamente um efeito vinculante da ratio decidendi da decisão proferida no processo-modelo. Aliás, a efetiva possibilidade de participação no processo-líder pelos que figuram como partes nos processos repetitivos, ou então a adequada representatividade das partes que neles atuam, estão diretamente relacionadas ao grau de eficácia da decisão final em relação a essas mesmas partes. Às vezes, as partes podem optar pela não incidência dos efeitos da decisão, de modo semelhante aos sistemas de opt out.

Conforme demonstraremos ao longo deste trabalho, essas características não estão presentes na técnica dos artigos 543-B e 543-C do CPC. 


\subsection{Os artigos 543-B e 543-C do CPC como técnica de ampliação da eficácia persuasiva dos precedentes do STF e STJ}

De modo geral, os temas relacionados à tutela coletiva e à valorização dos precedentes guardam alguma relação entre $\mathrm{si}^{277}$. Em ambos os casos busca-se, entre outras finalidades, a obtenção de decisões com dimensões coletivas, que preservem o quadrinômio "igualdade-segurança-economia-respeitabilidade", diante dos problemas gerados pelo aspecto repetitivo dos litígios de massa. ${ }^{278}$

Porém, as técnicas relacionadas à tutela coletiva lidam com o problema da legitimidade ativa e da possibilidade de extensão dos limites subjetivos da coisa julgada, enquanto que as técnicas de valorização da jurisprudência lidam com o problema do grau de eficácia (vinculante ou persuasiva) da ratio decidendi que se admite em cada sistema, em relação aos precedentes judiciais.

O procedimento de julgamento de recursos repetitivos previsto pelos artigos 543-B e 543-C do CPC identifica-se como técnica de valorização dos precedentes do STF e STJ.

Claro que, até mesmo antes da técnica dos artigos 543-B e 543-C do CPC, os precedentes do STF e STJ já eram importantes para toda a sociedade, tendo dimensão coletiva. Esses órgãos de cúpula, como demonstrado no Capítulo 3, têm como função primordial unificar o entendimento sobre o direito federal no país, regulando a jurisprudência e, com isso, prestigiando os princípios da igualdade e da segurança jurídica.

\footnotetext{
${ }^{277}$ Conforme demonstrado por: MARQUEZINI, Paulo Roberto da Silva. Técnicas de julgamento de causas repetitivas no direito brasileiro. 2012. 172 f. Dissertação (Mestrado em Direito Processual Civil). Faculdade de Direito, Universidade de São Paulo, São Paulo, 2012.

${ }^{278}$ Nesse sentido, Dinamarco relata que, já há algum tempo, sob a iniciativa de Ada Pellegrini Grinover, formou-se um grupo com o fim de buscar uma forma de preservar o quadrinômio igualdade-segurançaeconomia-respeitabilidade das ameaças do tratamento indevidamente atomizado de demandas repetitivas. A ideia era elaborar um anteprojeto de lei que instituísse "um incidente de coletivização da tutela jurisdicional, a ser suscitado em processos individuais sempre que se tratasse de causa dependente da solução de questão significativamente reiterada nos tribunais ou, de todo modo, causa envolvendo direitos ou interesses de membros de algum grupo ou categoria ou um número grande de pessoas". O autor esclarece que se tratava de uma proposta "mais ligada às premissas das class actions", mas que se identificava com a da súmula vinculante no sentido de se buscar uma solução "capaz de impedir que o trato de questões potencialmente portadoras de um impacto de massa prosseguisse no plano puramente individual e sem consideração do interesse coletivo que lhes está à base". Isso porque o grupo tinha "consciência da inadequação de uma insistência pela tutela individual, fragmentária e contraditória, em tempos de coletivização da tutela jurisdicional e em clima de um direito de massa, inerente à sociedade de massa deste fim de século" (DINAMARCO, Cândido Rangel, Decisões vinculantes, cit., p. 171).
} 
Por isso, quando julgavam determinado caso versando sobre questão repetitiva, o precedente já era utilizando como parâmetro para a solução dos demais casos, tendo importância não só para o caso julgado, mas também para toda a sociedade.

E, com os artigos 543-B e 543-C do CPC, essa dimensão coletiva foi realmente ampliada, pois a técnica prestigia, regulamenta e potencializa os efeitos dos precedentes do STF e STJ, de forma compatível com suas funções constitucionais.

No entanto, não se trata, nesse caso, de uma tutela coletiva dos pedidos deduzidos nos casos repetitivos, e sim da apreciação concentrada de uma controvérsia jurídica repetitiva, ou seja, de uma simples questão repetitiva a respeito da interpretação do direito federal à luz de determinada hipótese fática, a fim de que ela seja solucionada de forma uniforme, racional, eficiente e efetiva.

Aliás, a questão repetitiva sequer precisa ser relacionada ao direito material, razão pela qual nem sempre os recursos repetitivos versarão sobre direitos individuais homogêneos. Muito frequentemente, a multiplicidade de recursos funda-se em controvérsias sobre a interpretação e aplicação do direito processual, considerando-se o excessivo número de casos (independentemente da identidade das questões de direito material neles versadas) e a natural repetição das discussões processuais presentes em grande parte deles.

Além disso, não se pode afirmar que a técnica em questão identifique-se com uma espécie de procedimento coletivo por amostragem que permita o julgamento direto, pelo STF e pelo STJ, dos recursos repetitivos sobrestados. O julgamento do recurso-piloto não gera o julgamento dos próprios pedidos recursais veiculados nos recursos extraordinários ou especiais repetitivos.

Nesse sentido, note-se que, no caso dos recursos repetitivos, embora ocorra a seleção de um recurso-piloto e o sobrestamento dos demais recursos repetitivos, a decisão proferida pelo STF ou pelo STJ no julgamento do recurso representativo da controvérsia não solucionará, ela própria, de forma automática ou a partir de mera declaração dos órgãos de origem, os recursos selecionados, e muito menos as relações jurídicas objeto 
dos casos repetitivos sobrestados, como ocorre nos processos submetidos à jurisdição coletiva.

Ao apreciar o recurso representativo da controvérsia e definir a interpretação única a respeito da questão constitucional (qualificada pela repercussão geral) ou infraconstitucional, o STF ou o STJ não estará julgando os recursos repetitivos sobrestados, mas sim proferindo uma decisão paradigma a respeito da interpretação do direito federal, a fim de que ela possa ser em seguida aplicada como precedente dotado de eficácia especial (ainda que não vinculante), aos recursos sobrestados e aos casos sucessivos. $^{279}$

Isso significa que, como demonstrado por Luiz Guilherme Marinoni ${ }^{280}$, a coisa julgada inerente ao julgamento do recurso-piloto não se estende aos casos repetitivos sobrestados, até porque, se assim, fosse, o sistema violaria os princípios do contraditório e da ampla defesa, pela simples razão de que não se exige a representação adequada das partes do recurso-piloto e veda-se a participação direta e ampla dos que figuram como parte nos casos repetitivos sobrestados.

Nesse sentido, vale mencionar o seguinte precedente do STJ, em que se afasta qualquer relação entre os efeitos da coisa julgada relativa ao julgamento do caso representativo da controvérsia e os casos sobrestados:

[...] Por outro lado, o trânsito em julgado do acórdão proferido no julgamento do REsp 1.114.398PR, representativo de controvérsia repetitiva, não tem o condão de transformar em definitiva a execução provisória em curso na presente ação.

Isso porque, o julgamento de recurso especial representativo de controvérsia repetitiva, sob o rito do art. 543-C do CPC, não transmuta, por óbvio, a ação a que dito recurso se refere em ação coletiva ou ação

279 Em sentido contrário: MARQUEZINI, Paulo Roberto da Silva, Técnicas de julgamento de causas repetitivas no direito brasileiro, cit., p. 72.

280 “Ora, a decisão tomada em recurso repetitivo obviamente não atinge a todos, como se produzisse coisa julgada erga omnes. A coisa julgada, formada diante do recurso selecionado que versa 'questão idêntica', evidentemente não pode atingir os titulares de 'direitos individuais idênticos'. Não há, nesta situação, 'objeto litigioso coletivo' - como se poderia pensar. Tratando-se de recurso repetitivo, apenas pode importar a eficácia do precedente, ou melhor, a eficácia dos fundamentos determinantes do precedente. Assim, o sobrestamento dos recursos nada mais é do que a suspensão dos processos repetitivos à espera da eficácia do precedente fixado no recurso selecionado." (MARINONI, Luiz Guilherme, Precedentes obrigatórios, cit., p. 498). 
civil pública, a permitir a conversão de ações individuais em execução de sentença coletiva, como entende o agravante. [...].

Com efeito, a regra geral é que os efeitos da coisa julgada atinjam apenas as partes do processo, não podendo favorecer nem lesar terceiros estranhos à lide.

Da simples leitura do art. 543-C do Código de Processo Civil se extrai que o legislador não atribuiu características de ação coletiva, mais especificamente, quanto aos efeitos da coisa julgada, ao recurso julgado sob a sua égide. ${ }^{281}$

De fato, a análise dos efeitos do julgamento do recurso-piloto, tal como previsto pela sistemática dos artigos 543-B e 543-C do CPC, revela que em nenhuma hipótese o acórdão paradigma tem o efeito de fazer com que se considerem automaticamente julgados os recursos repetidos sobrestados.

Deve-se esclarecer que, embora a lei mencione que "os recursos sobrestados serão apreciados" pelos órgãos de origem (art. 543-B, § $3^{\circ}$ ) ou que "serão novamente examinados pelo tribunal de origem" (art. 543-C, $\S 7^{\circ}$, I), isso não significa que órgão $a$ quo julgará diretamente os recursos excepcionais, mas sim que reapreciará o mérito dos recursos de sua competência (quando suas decisões divergirem da decisão do STF ou STJ) ou apreciará a admissibilidade dos recursos excepcionais sobrestados (quando suas decisões convergirem com a decisão do STF ou STJ). ${ }^{282}$

Assim, vê-se que, definida a controvérsia pelo STF ou pelo STJ, podem ocorrer duas situações: a orientação fixada pelo órgão superior diverge da tese adotada pelas decisões recorridas objeto dos recursos repetitivos sobrestados ou, pelo contrário, ela coincide com tal tese.

No primeiro caso (divergência entre as teses adotadas pelos órgãos inferiores e superiores), o acórdão paradigma não produzirá o efeito de gerar o automático provimento do recurso excepcional, para reformar ou anular o acórdão recorrido, mas sim produzirá o efeito de devolver a apreciação do recurso anterior ao órgão julgador competente, a fim de

\footnotetext{
${ }^{281}$ STJ - AgR AREsp n. 189.515/PR, 4 ${ }^{\mathrm{a}}$ Turma, rel. ministro Luis Felipe Salomão, , j. 21.08.2012, DJe, de 29.08.2012.

282 “O que será rejulgado, em face da divergência, serão os acórdãos recorridos nas apelações (em embargos infringentes, em embargos de declaração ou em recurso ordinário); mesmo porque os recursos sobrestados (que são os especiais) não são julgados, no mérito, pelos tribunais de origem, por não serem da sua competência." (ALVIM, José Eduardo Carreira. Recursos especiais repetitivos: mais uma tentativa de desobstruir os tribunais. Revista de Processo, São Paulo, v. 33, n. 162, p. 183, ago. 2008).
} 
que este exerça um juízo positivo ou negativo de retratação, à luz do entendimento fixado pela instância extraordinária.

Se o juízo de retratação for negativo, prossegue-se normalmente com o processamento do recurso excepcional, apreciando-se a sua admissibilidade e, se o caso, enviando-o à instância superior. Fica claro, aqui, que o julgamento do recurso-piloto não acarreta o julgamento automático do recurso repetitivo sobrestado.

Em caso de juízo positivo de retratação, o órgão julgador competente modifica o acórdão recorrido, para ajustá-lo ao entendimento fixado pela instância superior. Consequentemente, o recurso excepcional interposto contra aquele acórdão fíca prejudicado. Note-se que isso não equivale ao julgamento automático do recurso sobrestado pelo próprio órgão superior - situação que autorizaria o entendimento de que a competência para julgar a ação rescisória contra tal acórdão seria diretamente o STF ou o STJ. $^{283}$

O julgamento do recurso anterior à luz da jurisprudência dos Tribunais Superiores caracteriza mera aplicação do precedente, ou melhor, da ratio decidenci fixada no precedente sobre a questão idêntica. A competência para eventual ação rescisória contra esse julgado é do próprio órgão julgador, e não da instância superior. ${ }^{284}$

A segunda situação (convergência entre as teses adotadas pelos órgãos inferiores e superiores) acarreta, segundo a lei, a prejudicialidade ou a negativa de seguimento do recurso excepcional.

\footnotetext{
${ }^{283}$ Discordamos, portanto, do entendimento de José Henrique Mouta Araújo: “Outrossim, sendo atendido o precedente ou readaptada a decisão local, a parte que pretender mover rescisória o fará contra esta ou contra a própria interpretação do STJ? Como já observado, esse é o ideal visando a diminuição do tempo do processo. A rigor, estando sobrestado o andamento do processo repetitivo no tribunal local, a decisão que será proferida pelo Tribunal Superior no julgamento do caso piloto terá caráter vinculante. Portanto, o art. 543-C do CPC, objetiva impedir a sucessividade de recursos iguais perante o STJ, funcionando o órgão local apenas como repetidor da decisão superior. Percebe-se, nesse sentido, que tanto nos recursos representativos da controvérsia quanto nos que ficaram sobrestados, há análise final (direta ou indireta) pelo STJ. Logo, se a parte prejudicada no âmbito local pretender desconstituir seu julgado, parece razoável entender que a rescisória deve ser apresentada no STJ - no recurso representativo da controvérsia." (ARAÚJO, José Henrique Mouta. Processos repetitivos e o desafio do Judiciário: rescisória contra interpretação de Lei Federal. Revista de Processo, São Paulo, v. 35, n. 183, p. 162-163, maio 2010).

284 "No tocante aos julgamentos proferidos pelos tribunais de segundo grau, com fundamento no acórdãoparadigma, o que transitará em julgado, para efeitos de eventual rescisão será o acórdão do tribunal, que aplicar o paradigma do STJ." (ALVIM, José Eduardo Carreira, Recursos especiais repetitivos: mais uma tentativa de desobstruir os tribunais, cit., p. 180).
} 
Nesse caso, também não ocorre um julgamento automático dos recursos sobrestados pelo acórdão paradigma. Tanto é assim que a lei diz apenas que os órgãos de origem "poderão declará-los prejudicados" (art. 543-B, § 3, do CPC) ou que "terão seguimento denegado" na origem (art. 543-C, $\S 7^{\circ}$, I, do CPC), o que significa que prevalecerá o acórdão proferido pelo órgão a quo, objeto dos recursos repetitivos.

Nem a lei nem a doutrina esclarecem com precisão a natureza dessa decisão do tribunal de origem que declara prejudicado ou denega seguimento ao recurso excepcional contrário à decisão que adota tese firmada pelo STF e pelo STJ no julgamento do recursopiloto. Se se tratar de decisão de mérito, que nega provimento ao recurso excepcional, então surge o problema da constitucionalidade dos dispositivos, pela violação da competência exclusiva dos órgãos superiores para apreciar o mérito dos recursos extraordinários e especiais; se, por outro lado, tratar-se de inadmissibilidade, então surge outro problema de constitucionalidade, porque a lei poderia estar criando novos requisitos de admissibilidade, não contemplados pela Constituição Federal. Trataremos dessa questão no Capítulo 6 (item 6.3).

De qualquer modo, como se verifica desde já, em ambos os casos a técnica de julgamento de recursos repetitivos não implica a solução, pelo STF e pelo STJ, dos recursos repetitivos sobrestados, mas sim a construção de um precedente qualificado a respeito da interpretação do direito federal, com alto poder de eficácia sobre a solução de controvérsias repetitivas.

Por isso mesmo, não se pode dizer que seria dispensável uma norma constitucional autorizando a aplicação vinculante do acórdão-paradigma, sob o argumento de que não se trataria de um típico efeito vinculante, mas sim da declaração dos efeitos que emanam diretamente da decisão coletiva do STF ou do STJ.

O mesmo se diga, por fim, quanto à situação em que o STF, ao apreciar o recursopiloto, nega a existência de repercussão geral da questão constitucional. Nesse caso, embora o artigo 543-B, $\S 2^{\circ}$, mencione que "os recursos sobrestados considerar-se-ão automaticamente não admitidos", o fato é que a inadmissibilidade depende de decisão do órgão de origem, perante o qual o recurso é processado. Isso significa que, também nesse 
caso, o que se tem é a aplicação do precedente do STF sobre a ausência de repercussão geral.

$\mathrm{Na}$ verdade, estabelecido que se trata da aplicação do precedente, afasta-se a questão da extensão dos limites da coisa julgada e fica claro que todo o problema diz respeito à existência ou inexistência do efeito vinculante ${ }^{285}$, ou melhor, à possibilidade ou não de se prever esse efeito independentemente de previsão constitucional, problema que também será enfrentado no Capítulo 6 (item 6.4), a partir das premissas já apresentadas no Capítulo 2.

\subsection{Repercussão geral e recursos repetitivos}

Prosseguindo com o propósito de descrever os aspectos gerais da técnica sob estudo, passamos a compará-la com o instituto da repercussão geral, o que se justifica pela relação entre ambas as técnicas e pelo fato de que o julgamento por amostragem, no caso de recursos extraordinários, atua não só para a fixação da interpretação definitiva do direito federal constitucional, mas também para a filtragem de recursos que não apresentam o requisito específico da repercussão geral.

\subsubsection{A antiga relevância da questão federal e a atual repercussão geral}

A ideia de se permitir aos órgãos de cúpula do Poder Judiciário a escolha das causas que devem ser por eles apreciadas foi disseminada entre nós a partir de duas palestras proferidas em 1965 (em São Paulo e em Belo Horizonte) pelo ministro Victor Nunes Leal, depois convertidas no artigo publicado pela Revista de Informação Legislativa do Senado Federal. Para ele, tratava-se de válvula que "reduziria o serviço do Supremo Tribunal a proporções exequíveis, como daria melhor teor doutrinário às suas decisões, em correspondência com sua posição de Tribunal de cúpula". ${ }^{286}$

\footnotetext{
${ }^{285}$ Como demonstrado no Capítulo 2, uma coisa é a questão da eficácia da coisa julgada, outra, bem diversa, é a questão da eficácia vinculante da ratio decidendi, relacionada à extensão da eficácia dos fundamentos da decisão (ou melhor, da parte da fundamentação em que ocorre a interpretação das normas jurídicas à luz de determinada hipótese fática) a outros casos semelhantes.

${ }^{286}$ LEAL, Victor Nunes, Aspectos da reforma judiciária, cit., p. 38.
} 
O instituto era visto como uma forma de desafogar o STF e, ao mesmo tempo, valorizar os seus precedentes, não pela repetição de julgamento de casos iguais, mas sim pela importância da questão, pela singularidade da decisão e pela maior profundidade da sua fundamentação.

Assim, com base no poder legiferante atribuído pela Constituição Federal de 1967 ao $\mathrm{STF}^{287}$, o Regimento Interno de 1970 passou a prever taxativamente em seu artigo 308 as causas excluídas do cabimento do recurso extraordinário. Entre elas, por exemplo, os litígios decorrentes de acidente do trabalho, os mandados de segurança extintos por sentença terminativa e as causas com valor inferior a 60 salários mínimos.

Mas o próprio artigo 308 excepcionava, entre as cláusulas excluídas do cabimento, os "casos de ofensa à Constituição ou discrepância manifesta da jurisprudência predominante no Supremo Tribunal Federal".

Depois, com a Emenda Regimental n. 3, de 12 de junho de 1975, o artigo 308 do Regimento Interno passou a prever que "salvo nos casos de ofensa à Constituição ou relevância da questão federal, não caberá o recurso extraordinário [...]”. Ou seja, inseriu-se no Regimento Interno o critério da relevância da questão federal, como válvula de escape a permitir o cabimento excepcional do recurso extraordinário naquelas hipóteses em que o sistema o vedava.

Com a Emenda Constitucional n. 7, de 1977, o instituto da relevância da questão federal foi encampado pelo próprio texto constitucional: o $\S 1^{\circ}$ do artigo 119 da CF passou a prever que "as causas a que se refere o item III, alíneas 'a' e 'd', deste artigo, serão indicadas pelo Supremo Tribunal Federal no regimento interno, que atenderá à sua natureza, espécie, valor pecuniário e relevância da questão federal".

Em 1985, verificada a insuficiência do mecanismo de restrição até então utilizado no Regimento Interno, a lógica do sistema foi invertida: com a Emenda Regimental n. 2, de 4 de dezembro de 1985, passou-se a prever que somente seria cabível recurso

\footnotetext{
${ }^{287}$ Segundo a redação do artigo 119, III, da Constituição Federal de 1967, dada pela Emenda Constitucional n. 1 , de 17 de outubro de 1969, cabia recurso extraordinário ao STF contra as decisões proferidas em única ou última instância por outros tribunais, nas hipóteses descritas nas alíneas "a" a "d". E seu parágrafo único dispunha que essas causas seriam "indicadas pelo Supremo Tribunal Federal no regimento interno, que atenderá à sua natureza, espécie ou valor pecuniário".
} 
extraordinário pelas alíneas 'a' e 'd' do artigo 119, III, da CF nas poucas hipóteses taxativamente previstas no artigo 325 do Regimento, entre elas quando houvesse "ofensa à Constituição Federal" (inc. I) e "em todos os demais feitos, quando reconhecida a relevância da questão federal" (inc. XI).

Ou seja, o óbice regimental que antes utilizava critério negativo (previam-se os casos em que não era cabível o recurso) passou a ser positivo (com a previsão taxativa dos casos de cabimento) e, portanto, mais restritivo. Mas, dentre as hipóteses de cabimento, foi prevista uma que englobava todas as demais: a relevância da questão federal.

Por sua vez, o artigo $327, \S 1^{\circ}$, do RISTF passou a definir como relevante a questão federal que "pelos reflexos na ordem jurídica, e considerados os aspectos morais, econômicos, políticos ou sociais da causa, exigir a apreciação do recurso extraordinário pelo Tribunal".

Assim, a relevância da questão federal atuava como válvula de escape às rígidas restrições de cabimento do recurso extraordinário quanto às hipóteses das alíneas "a" e "d" do artigo 119, III, da CF: o recurso, em geral, não era cabível, exceto se o caso se encaixasse em uma das hipóteses do artigo 325 ou, quanto a todos os demais, se a questão federal fosse relevante.

Vale ressaltar que essa válvula de escape referia-se apenas às questões de direito federal infraconstitucional, pois os casos de ofensa à Constituição Federal eram previstos tanto no artigo 119, III, “a”, da CF, como também no artigo 325, I, do RISTF. Ou seja, a hipótese de ofensa à Constituição Federal era presumidamente relevante, eis que cabível o recurso extraordinário, sem qualquer necessidade de qualificação da questão. O mesmo, porém, não se podia dizer dos casos de contrariedade à lei federal e aos tratados, ou de divergência na interpretação da lei federal (demais hipóteses do art. 119, III, "a" e "d", da $\mathrm{CF})$, nos quais o recurso extraordinário só seria cabível se a hipótese se encaixasse em um dos incisos do artigo 325 do Regimento, ou então se ela fosse qualificada pela relevância da questão federal. ${ }^{288}$

\footnotetext{
288 Conforme Antonio Carlos Marcato: "Criou-se, assim, notável restrição à admissão do recurso extraordinário, apto a veicular, a partir daí, toda e qualquer questão constitucional (art. 119, II, alíneas 'a', $1^{\mathrm{a}}$ parte, 'b' e 'c'), mas apenas as questões federais consideradas relevantes pelo Tribunal." (MARCATO, Antonio Carlos, Crise da justiça e influência dos precedentes judiciais no direito processual civil brasileiro, cit., p. 190).
} 
Além disso, vale registrar que a segunda hipótese de cabimento do recurso extraordinário, prevista no artigo 325, II, do RISTF, era a "de divergência [da decisão recorrida] com a Súmula do Supremo Tribunal Federal". Ou seja, o confronto da decisão com a jurisprudência predominante (e, no caso, sumulada da Suprema Corte) justificava por si só o cabimento do recurso extraordinário, pelo que se conclui que o sistema presumia, nesses casos, a existência de relevância da questão federal.

Dessa forma, se a questão versada no caso não se enquadrasse em uma das hipóteses do artigo 325, incisos I a X, do RISTF, restava à parte defender que se tratava de questão federal relevante, para o que deveria se valer do expediente de arguição de relevância da questão federal, regulamentado também pelo Regimento Interno.

Tratava-se, pois, de incidente regimental ao recurso extraordinário, nitidamente inspirado no writ of certiorari do direito norte-americano, instrumento pelo qual a Suprema Corte dos Estados Unidos escolhe discricionariamente as causas que irá revisar, conforme as considere importantes ou significativas.

A arguição de relevância foi duramente criticada, sobretudo porque a decisão a seu respeito era tomada em sessão secreta e irrecorrível, que vinha apenas indicada na respectiva ata, sem qualquer necessidade de motivação.

Após pouco mais de treze anos de existência do instituto, entrou em vigor a atual Constituição Federal, que criou o Superior Tribunal de Justiça com competência para julgar, mediante recurso especial, todas as causas que versem sobre direito federal (art. 105, III). Assim, toda questão federal infraconstitucional, independentemente da sua qualificação como relevante, passou a justificar a revisão da causa pela instância extraordinária, desaparecendo o incidente de arguição de relevância.

Quanto ao recurso extraordinário, como visto no Capítulo 3, suas hipóteses de cabimento passaram, a partir da Constituição de 1988, a ser previstas exclusivamente pelo texto constitucional, que em seu artigo 102, III, traz apenas hipóteses relativas a normas constitucionais, não se exigindo qualquer critério de relevância para fins de admissibilidade. Pelo menos até 2004. 
No contexto de crise do STF (conforme Capítulo 4), a Emenda Constitucional n. 45/2004 fez ressurgir instituto análogo à arguição de relevância, conforme o novo $\S 3^{\circ}$ então adicionado ao artigo 102, segundo o qual o recorrente, no recurso extraordinário, deverá demonstrar "a repercussão geral das questões constitucionais discutidas no caso, nos termos da lei, a fim de que o Tribunal examine a admissão do recurso, somente podendo recusá-lo pela manifestação de dois terços de seus membros”.

Com a regulamentação legal da matéria pela Lei n. 11.418/2006, definiu-se que “para efeito da repercussão geral, será considerada a existência, ou não, de questões relevantes do ponto de vista econômico, político, social ou jurídico, que ultrapassem os interesses subjetivos da causa" (art. 543-A, $\S 1^{\circ}$, do CPC) e que "haverá repercussão geral sempre que o recurso impugnar decisão contrária a súmula ou jurisprudência dominante do Tribunal" (art. 543-A, § $3^{\circ}$, do CPC). ${ }^{289}$

A ideia central da repercussão geral é a mesma da antiga arguição de relevância: instituir, na linha do wirt of certiorari do direito norte-amerciano, critério de importância para fins de admissibilidade do recurso extraordinário, no sentido de o interesse envolvido no julgamento ter de transbordar ou transcender o interesse subjetivo das partes, a fim de que o STF só aprecie questões relevantes para a sociedade, firmando-se como corte constitucional, e não como mera instância recursal. ${ }^{290}$

\footnotetext{
${ }^{289}$ Interessante observar que, desde 2001, o artigo 896-A da Consolidação das Leis do Trabalho, incluído pela Medida Provisória n. 2.226, de 04.09.2001, já condicionava a admissibilidade do recurso de revista ao requisito da "transcendência com relação aos reflexos gerais de natureza econômica, política, social ou jurídica". A norma chegou a ser impugnada por ação direta de inconstitucionalidade (ADI n. 2.527) ajuizada pelo Conselho Federal da Ordem dos Advogados do Brasil, que aguarda julgamento pelo STF. No entanto, a liminar foi indeferida, dentre outros fundamentos, pelo fato da Constituição Federal submeter expressamente à lei a regulamentação da competência do TST (art. 111-A, $\S 1^{\circ}$ ), diferentemente do que ocorre com o STF e STJ, que têm sua competência estritamente delimitada pelo próprio texto constitucional. Apesar disso, o TST não tem aplicado a técnica, sob o fundamento de que ela prescinde de regulamentação. Sobre o tema, ver: MARTINS FILHO, Ives Gandra da Silva. O critério de transcendência no recurso de revista: Projeto de Lei no 3.267/00. Revista Jurídica Virtual, v. 2, n. 20, jan. 2001. Disponível em: <http://www.planalto.gov.br/ccivil_03/revista/rev_20/artigos/IvesGandra_rev20.htm>. Acesso em: 10 nov. 2013.

${ }^{290}$ Conforme Teresa Arruda Alvim Wambier, a semelhança entre os institutos da repercussão geral e da antiga arguição de relevância justifica-se por se tratar "de um sistema de filtro, idêntico, sob o ponto de vista substancial, ao sistema da relevância, que faz com que ao STF cheguem questões cuja importância transcenda à daquela causa em que o recurso foi interposto. Entende-se, com razão, que, dessa forma, o STF será reconduzido à sua verdadeira função, que é a de zelar pelo direito objetivo - sua eficácia, sua inteireza e a uniformidade de sua interpretação -, na medida em que os temas trazidos à discussão tenham relevância para a Nação." (WAMBIER, Teresa Arruda Alvim, Recurso especial, recurso extraordinário e ação rescisória, cit., p. 292).
} 
Trata-se, assim, tanto quanto ocorria em relação à relevância da questão federal, de novo requisito de admissibilidade de todo recurso extraordinário: com a exigência de que a questão constitucional apresente repercussão geral, o sistema agregou uma qualificadora às hipóteses de cabimento previstas nas alíneas "a" a "d" do artigo 102, III, excluindo a admissibilidade de recursos sobre temas considerados irrelevantes.

Não obstante a semelhança quanto à ideia central, os institutos são diferentes, sobretudo porque, enquanto a relevância era hipótese de cabimento do recurso extraordinário relativo apenas a questões de direito federal não especificadas nos incisos do artigo 325 do RISTF, a repercussão geral refere-se exclusivamente às questões de direito constitucional e atua como requisito de admissibilidade de todo e qualquer recurso extraordinário.

Quanto ao procedimento, as diferenças são fundamentais, valendo ressaltar a necessidade de motivação e ampla publicidade dos julgamentos do STF sobre a repercussão geral, o que não ocorria com a arguição de relevância, que era julgada em sessão secreta e dispensava motivação.

Quanto ao momento de aferição da repercussão geral, que ocorre em sede do "Plenário Virtual"291, e sobre o qual silenciou a lei, a doutrina diverge. Arruda Alvim, por exemplo, entende que antes de tudo o STF deve apreciar se existe ou não repercussão geral, para só então analisar a eventual presença dos demais requisitos de admissibilidade. $^{292}$

Por outro lado, José Rogério Cruz e Tucci entende que todos os demais requisitos devem ser analisados previamente pelo próprio relator do recurso extraordinário, e apenas no caso de ser positivo esse juízo de admissibilidade é que a questão da repercussão geral deve ser submetida à Turma ${ }^{293}$. Com isso, evita-se o desgaste de se submeter à Turma (e

\footnotetext{
${ }^{291}$ Ou seja, do procedimento de coleta de votos por meio eletrônico, tal como disciplinado pelos artigos 323 a 325 do RISTF.

${ }^{292}$ ARRUDA ALVIM, José Manoel de, A EC n. 45 e o instituto da repercussão geral, in Reforma do Judiciário: primeiros ensaios críticos sobre a EC n. 45/2004, cit., p. 64.

${ }^{293}$ TUCCI, José Rogério Cruz e. Anotações sobre a repercussão geral como pressuposto de admissibilidade do recurso extraordinário (Lei 11.418/2006). Revista de Processo, São Paulo, v. 32, n. 145, p. 158, mar. 2007.
} 
até mesmo ao próprio Plenário, se o caso) a apreciação da repercussão geral, com o risco de, posteriormente, o recurso ser inadmitido pela ausência de algum outro requisito geral ou específico de admissibilidade. Essa última posição, que nos parece mais razoável, lógica e eficiente, é a que foi adotada pelo STF, conforme a redação do artigo 323 de seu Regimento Interno. ${ }^{294}$

Fala-se, assim, na formação de "um provimento subjetivamente complexo" nos casos em que a corte primeiro examina os requisitos gerais e específicos de admissibilidade e a depois a repercussão geral, nessa ordem. Positivo o juízo de admissibilidade, lavra-se o acórdão relativo à repercussão geral para, em seguida, apreciarse o mérito da pretensão recursal, dando-se ou negando-se provimento ao recurso. ${ }^{295}$

Apesar da evolução do instituto - agora mais democrático e transparente -, ele não deixa de continuar representando um óbice ao acesso direto das partes à mais alta corte do país, implantado sob a justificativa de resolver os problemas de excesso de recursos, o que desperta a insurgência de parte da doutrina, para quem a repercussão geral aproximaria o recurso extraordinário de instrumento de uma justiça menos democrática e mais aristocrática. $^{296}$

Outra parte da doutrina, porém, defende a sua adoção. Destacando que a utilização dos recursos extraordinários em diversos países, ao longo do tempo, tem sofrido restrições conforme a importância da matéria, Arruda Alvim já afirmava há muito tempo que "os mais altos Tribunais da maioria dos países devem ter uma função eminentemente

\footnotetext{
294 “Art. 323. Quando não for caso de inadmissibilidade do recurso por outra razão, o(a) Relator(a) ou o Presidente submeterá, por meio eletrônico, aos demais Ministros, cópia de sua manifestação sobre a existência, ou não, de repercussão geral". Da mesma forma, confira-se o seguinte precedente: "A repercussão geral pressupõe recurso admissível sob o crivo dos demais requisitos constitucionais e processuais de admissibilidade (art. 323 do RISTF). Consectariamente, se o recurso é inadmissível por outro motivo, não há como se pretender seja reconhecida 'a repercussão geral das questões constitucionais discutidas no caso' (art. 102, III, § $3^{\circ}$, da CF).” (STF - AQgR AI n. 637.327/GO, $1^{\text {a }}$ Turma, rel. Min. Luiz Fux, DJe, de 12.06.2013).

${ }^{295}$ TUCCI, José Rogério Cruz e, Anotações sobre a repercussão geral como pressuposto de admissibilidade do recurso extraordinário (Lei 11.418/2006), cit., p. 158.

296 Conforme Leonardo Greco, "Essa restrição, aparentemente heróica, pois visa a reduzir o número excessivo de recursos para o Supremo Tribunal Federal, é péssima para os cidadãos. (...) A justiça não existe para servir ao Estado, mas para servir aos cidadãos". (GRECO, Leonardo, Instituições de processo civil, cit., v. 1, p. 50).
} 
'exemplar', e os casos que julguem devem ser paradigmáticos, refugindo da grande rotina da judicatura". 297

Realmente, além do writ of certiorari do direito norte-americano, instituto semelhante é previsto pelo direito argentino, em que a admissão do recurso extraordinário fica afastada quanto às questões "insubstanciales o carentes de transcendencia" (Codigo Procesal Civil y Comercial de La Nación, art. 280 e ss. - alterados pela Lei 23.744/90), requisito que, mesmo antes de ser positivado, já vinha sendo exigido pela Corte Suprema, a partir do desenvolvimento do conceito de "gravidad institucional" da questão para ser apreciada pela instância extraordinária. ${ }^{298}$

Também no Japão, na Alemanha e na Áustria a admissibilidade de recursos endereçados à Corte Suprema está condicionada à exigência de alguma espécie de relevância da questão, o que revela que esse filtro recursal, como forma de tentar resolver o problema do congestionamento dos órgãos de cúpula, é adotado em diversos países de tradição democrática, sem que sejam considerados ilegítimos. ${ }^{299}$

Conforme Teresa Arruda Alvim Wambier, não se trata de óbice ao acesso à justiça, pois as partes contam com dois graus de jurisdição e um sistema recursal marcadamente abundante. Além disso, embora uma das razões da implantação da repercussão geral no Brasil tenha sido a sobrecarga excessiva de trabalho do STF, o instituto realmente se

\footnotetext{
297 ARRUDA ALVIM, José Manoel de, Arguição de relevância no recurso extraordinário, cit., p. 41. Na mesma linha, Rodolfo de Camargo Mancuso afirma ser "indisputável que algum tipo de controle, filtro ou triagem há de existir para o acesso às Cortes Superiores, quanto mais não seja ante a evidente desproporção entre o número de ministros e o volume exacerbado de processos que, de outro modo, ali aportariam, sem um critério distintivo ou regulador" (MANCUSO, Rodolfo de Camargo, Recurso extraordinário e recurso especial, cit., p. 77).

298 TALAMINI, Eduardo, Novos aspectos da jurisdição constitucional brasileira: repercussão geral, força vinculante, modulação dos efeitos do controle de constitucionalidade e alargamento do objeto do controle direto, cit., p. 29.

299 No Japão, apenas as questões constitucionais e outras atinentes a graves erros procedimentais (taxativamente previstas no Código de Processo Civil) têm acesso assegurado à Corte Suprema, sendo que as demais ficam condicionadas à demonstração de divergência jurisprudencial ou da relevância da questão de direito (CPC japonês, art. 318) (GOMES JUNIOR, Luiz Manoel, A repercussão geral da questão constitucional no recurso extraordinário, cit., p. 98). Por sua vez, na Alemanha e na Áustria, o recurso de revisão está condicionado à demonstração de que a questão tem "significação fundamental" ( grundsätzliche Bedeutung) (TALAMINI, Eduardo, op. cit., p. 30).
} 
justifica, por ser capaz de gerar jurisdição de melhor qualidade, pois as decisões do STF tenderão a ser paradigmáticas. ${ }^{300}$

De qualquer modo, o fato é que a repercussão geral foi inserida por emenda constitucional. Assim, conveniente ou não, trata-se da opção política realizada como forma de lidar com o problema da crise do STF e da importância de seus pronunciamentos para a unidade do direito constitucional.

Tem-se, assim, um requisito de admissibilidade cuja presença é aferível exclusivamente pelo $\mathrm{STF}^{301}$ e que impede a apreciação de recursos extraordinários envolvendo temas irrelevantes para a sociedade, ou seja, temas que digam respeito exclusivamente ao interesse individual das partes litigantes. Trata-se de uma potencialização da verdadeira função pública dos recursos excepcionais, a ponto de se considerar inadmissíveis (e, portanto, inaptos à abertura da instância extraordinária) os que não apresentem a qualificadora prevista na Constituição.

\subsubsection{Proximidade entre repercussão geral e recursos repetitivos}

A repercussão geral guarda proximidade com a técnica de julgamento de recursos repetitivos pelo STF e pelo STJ, pois ambos os institutos estão relacionados à redução da sobrecarga de recursos nos órgãos de cúpula. Aliás, como visto, a técnica de julgamento de recursos extraordinários repetitivos foi inserida no sistema justamente pela mesma lei que veio a regulamentar a repercussão geral. ${ }^{302}$

\footnotetext{
${ }^{300}$ WAMBIER, Teresa Arruda Alvim, Recurso especial, recurso extraordinário e ação rescisória, cit., p. 290-303.

${ }^{301}$ A competência exclusiva do STF para apreciar a existência de repercussão geral é prevista pelo próprio artigo 102, § $3^{\circ}$, da $\mathrm{CF}$, segundo o qual o STF só poderá considerar inexistente a repercussão geral "pela manifestação de dois terços de seus membros" (isto é, pelo voto de pelo menos oito ministros), o que foi ratificado pelo artigo 543-A do CPC, cujo caput reafirma a competência exclusiva do STF e cujo $\S 4^{\circ}$ dispõe que "se a Turma decidir pela existência da repercussão geral por, no mínimo, 4 (quatro) votos, ficará dispensada a remessa do recurso ao Plenário". Ressalte-se, porém, que a aferição da presença de alegação formal da existência de repercussão geral pelo recorrente, inconfundível com a aferição da sua própria existência, pode ser desde logo reconhecida pelo tribunal de origem, gerando a negativa de seguimento ao recurso.

302 OLIVEIRA, Guilherme José Braz de. Repercussão geral das questões constitucionais e suas consequências para o julgamento do recurso extraordinário. Dissertação (Mestrado em Direito Processual) - Faculdade de Direito da Universidade de São Paulo, São Paulo, 2009. p. 336.
} 
Outro ponto que aproxima os institutos é o fato de que a existência de uma multiplicidade de casos versando sobre questão idêntica, ao mesmo tempo que constitui um dos requisitos para a instauração do procedimento de julgamento por amostragem (conforme Capítulo 7, item 7.1.1), é elemento apto a justificar a identificação de relevância ou repercussão geral de tal questão.

Daí a explicação de que uma das hipóteses de relevância, a ensejar a abertura da via extraordinária, sempre foi, inclusive em outros sistemas (como nos Estados Unidos e na Alemanha), ao lado das causas que envolvem diretamente grande número de litigantes, a "questão ou causa, cujo julgamento, provoque natural repercussão, ainda que virtual, sobre um grande número de pessoas, em virtude do procedente criado" ${ }^{\text {„303 }}$. Não que só existirá repercussão geral quando houver multiplicidade de feitos fundados em questão idêntica, mas a existência dessa multiplicidade parece sinalizar, por si só, a repercussão geral, pelo menos do ponto de vista social. ${ }^{304}$

Além disso, o modo diferenciado de tratamento dos recursos repetitivos (arts. 543B e 543-C do CPC) gera, tal como ocorria com a arguição de relevância e ocorre na repercussão geral, um precedente paradigmático ou qualificado, com alto poder de influência sobre o julgamento dos demais casos, apto a sinalizar à sociedade como um todo o entendimento definitivo dos órgãos de cúpula sobre a interpretação do direito federal.

Daí porque, tal como se passa com a repercussão geral, a técnica de julgamento de recursos repetitivos também confere à atuação do STF e do STJ um maior caráter de objetivação, eis que a ideia é, mais do que simplesmente definir a controvérsia daquele caso concreto, definir a interpretação em tese do direito federal constitucional e infraconstitucional, ampliando a dimensão coletiva dos precedentes emanados da instância

\footnotetext{
303 ARRUDA ALVIM, José Manoel de, Arguição de relevância no recurso extraordinário, cit., p. 178.

304 “Grande parcela do volume de recursos extraordinários que chegavam ao STF (um número assim grande, de todo modo, em termos absolutos) concernia a causas repetitivas (p.ex., envolvendo questões de direito público: previdenciário, tributário matéria atinente a servidores públicos etc.). Ora, precisamente são essas as causas em relação às quais não há maiores dúvidas acerca da configuração do requisito da repercussão geral das questões constitucionais nelas discutidas. A relevância da questão para um grande número de casos faz com que esteja configurada a repercussão. Vale dizer: no que depender do requisito da repercussão geral, em si mesmo, essas causas não serão barradas no acesso ao Supremo Tribunal Federal." (TALAMINI, Eduardo, Novos aspectos da jurisdição constitucional brasileira: repercussão geral, força vinculante, modulação dos efeitos do controle de constitucionalidade e alargamento do objeto do controle direto, cit., p. 229).
} 
superior - o que é perfeitamente condizente com as funções constitucionais dos recursos extraordinário e especial estudadas no Capítulo $3 .^{305}$

\subsubsection{Distinção entre repercussão geral (requisito de admissibilidade) e técnica de julgamento de recursos repetitivos (procedimento)}

Apesar da proximidade entre os institutos, é clara a distinção entre a repercussão geral e a técnica de julgamento de recursos repetitivos.

A técnica dos artigos 543-B e 543-C do CPC é um procedimento diferenciado de julgamento dos recursos extraordinários e especiais repetitivos. A repercussão geral, diferentemente, é um requisito de admissibilidade do recurso extraordinário.

Não se pode sequer afirmar que a técnica de julgamento de recursos repetitivos seja inerente à repercussão geral, como se a aplicação prática desta dependesse necessariamente daquela. Basta lembrar que, mesmo antes da repercussão geral, o julgamento por amostragem já existia para os recursos extraordinários provenientes dos Juizados Especiais Federais. Além disso, a antiga relevância da questão federal não contava com procedimento semelhante ao do julgamento por amostragem.

Tudo isso demonstra, conforme bem assinalado por Eduardo Talamini, que "o procedimento da amostragem, conquanto constitucionalmente legítimo, nem é da essência do instituto da repercussão geral", de modo que, a bem da verdade, “o filtro da repercussão e a amostragem são mecanismos autônomos". 306

Tratando-se de recursos extraordinários, a técnica de apreciação dos recursos repetitivos será utilizada tanto para, num primeiro momento, aferir-se a presença da

\footnotetext{
${ }^{305}$ Conforme Serau Junior e Reis, em referência ao artigo 543-C do CPC, embora o julgamento dos recursos repetitivos continue a ensejar um controle difuso de constitucionalidade e legalidade, ele "possui o condão de produzir efeitos semelhantes aos do controle abstrato de constitucionalidade: definirá, in abstracto, a interpretação da norma jurídica infraconstitucional" (SERAU JUNIOR, Marco Aurélio; REIS, Silas Mendes dos. Recursos especiais repetitivos no STJ. São Paulo: Método, 2009. p. 83).

306 TALAMINI, Eduardo, Novos aspectos da jurisdição constitucional brasileira: repercussão geral, força vinculante, modulação dos efeitos do controle de constitucionalidade e alargamento do objeto do controle direto, cit., p. 229.
} 
repercussão geral; ausente a repercussão, o procedimento se encerra e cumpre sua missão; presente a repercussão, prossegue-se para o exame do mérito do recurso extraordinário, isto é, para a análise da questão controvertida sobre a interpretação do direito constitucional.

Por sua vez, tratando-se de recursos especiais, a técnica de apreciação dos recursos repetitivos será utilizada apenas para a aferição do mérito dos recursos especiais. Aliás, como veremos no Capítulo 7 (item 7.1), é requisito da instauração do procedimento que os recursos especiais selecionados sejam admissíveis sob todos os aspectos.

A circunstância de que a técnica de julgamento de recursos extraordinários repetitivos é utilizada tanto para aferição da repercussão geral como para o julgamento do mérito dos recursos extraordinários selecionados, enquanto a técnica de julgamento de recursos especiais repetitivos está restrita a essa última hipótese, faz apenas com que existam algumas diferenças procedimentais entre os artigos 543-B e 543-C do CPC, que serão oportunamente abordadas ao longo da terceira parte deste trabalho.

\subsubsection{O artigo 543-C do CPC: retorno da relevância da questão federal?}

Do exposto no item 5.5.3 supra decorre a seguinte conclusão: a técnica de julgamento dos recursos repetitivos, também aplicável aos recursos especiais (art. 543-C do (PC), não representa o retorno da relevância da questão federal, não se confundindo com o instituto da repercussão geral, já prevista para o recurso extraordinário desde a Emenda Constitucional n. 45/2004. ${ }^{307}$

Aliás, nem poderia ser diferente, posto que a restrição da admissibilidade do recurso especial, por meio da criação de tal requisito, só poderia ser estabelecida por

\footnotetext{
307 “Todavia, o primeiro ponto que deve ser destacado da atual lei sobre o procedimento de recursos especiais repetitivos é que, ao contrário do que ocorre com o recurso extraordinário, para o recurso especial não foi criado um novo requisito de admissibilidade." (RODRIGUES NETTO, Nelson. Análise crítica do julgamento "por atacado" no STJ: (Lei 11.672/2008 sobre recursos especiais repetitivos). Revista de Processo, São Paulo, v. 33, n. 163, p. 235-236, set. 2008.
} 
emenda constitucional ${ }^{308}$ e nunca por normas infraconstitucionais, sob pena de violação ao artigo 105, III, da Constituição. ${ }^{309}$

Tanto é assim que atualmente está em tramitação na Câmara dos Deputados a Proposta de Emenda à Constituição n. 209/2012, por meio da qual se pretende acrescentar o $\S 1^{\circ}$ ao artigo 105 da Constituição Federal, prevendo-se o instituto da relevância das questões federais para admissibilidade do recurso especial, de modo equivalente ao que hoje ocorre com a repercussão geral. ${ }^{310}$

Assim, não há que se falar na inconstitucionalidade do artigo 543-C do CPC, pelo fato dele ter sido incluído por norma infraconstitucional: não se trata de novo requisito de admissibilidade (o que realmente exigiria emenda à Constituição), mas sim de técnica de processamento do recurso especial. ${ }^{311}$

${ }^{308}$ Segundo Teresa Arruda Alvim Wambier, “a repercussão geral da questão federal somente poderia ser exigida, como requisito para o cabimento do recurso especial, somente após reforma constitucional, tal como ocorreu com a Emenda Constitucional n. 45/2004, que inseriu o $\S 3^{\circ}$ no art. 102 da Constituição, estabelecendo a repercussão geral da questão constitucional como requisito para o recurso extraordinário" (WAMBIER, Teresa Arruda Alvim, Recurso especial, recurso extraordinário e ação rescisória, cit., p. 306-307).

309 Antonio Carlos Marcato observa que inexiste "previsão constitucional estabelecendo a existência de repercussão geral de questão federal como pressuposto de admissibilidade via recursal especial" e entende ser possível afirmar-se "a constitucionalidade dessa nova sistemática do recurso especial, embora criada sem emenda à Constituição, pois a lei regente (Lei 11.672/2008) não fixou condição de admissibilidade diferente daquelas previstas no art. 105, III, da Constituição Federal, mas apenas estabeleceu procedimento próprio para a tramitação de recurso especial considerado repetitivo" (MARCATO, Antonio Carlos, Crise da justiça e influência dos precedentes judiciais no direito processual civil brasileiro, cit., p. 197).

${ }^{310}$ A redação do dispositivo é a seguinte: "No recurso especial, o recorrente deverá demonstrar a relevância das questões de direito federal infraconstitucional discutidas no caso, nos termos da lei, a fim de que o Tribunal examine a admissão do recurso, somente podendo recusá-lo pela manifestação de dois terços dos membros do órgão competente para o julgamento."

311 Segundo Cassio Scarpinella Bueno, assumido que não se trata de hipótese de cabimento do recurso especial, mas sim de questão relacionada ao seu processamento, fica descartada qualquer pecha de inconstitucionalidade do sistema, "na exata medida em que a nova disciplina legal não diria respeito ao cabimento do recurso mas, apenas e tão somente, ao seu processamento, legitimando, consequentemente, a aplicação da nova disciplina legislativa nos processos em curso" (BUENO, Cassio Scarpinella. Curso sistematizado de direito processual civil. São Paulo: Saraiva, 2011. v. 5, p. 313). No mesmo sentido, Humberto Theodoro Júnior leciona que "não há motivo para entrever inconstitucionalidade na nova sistemática do recurso especial criada sem emenda à Constituição. É que a Lei n. 11.672/2008 não cuidou de impor condição de admissibilidade diferente daquelas previstas na Constituição (art. 105, inc. III). Apenas instituiu procedimento especial a ser observado na tramitação do recurso, quando inserido no episódio das causas repetitivas ou seriadas" (THEODORO JÚNIOR, Humberto. O novo art. 543-C do Código de Processo Civil (Lei n ${ }^{\circ}$ 11.672, de 8.5.2008). Revista Forense, Rio de Janeiro, v. 104, n. 397, p. 198, maio/jun. 2008). E também: "Pode-se dizer que, para que seja cabível o recurso extraordinário, a questão constitucional é qualificada. O mesmo não ocorre com as questões federais infraconstitucionais, nada dispondo o art. 543-C do CPC a respeito. [...] Vê-se, assim, que o art. 543-C do CPC contém apenas regra de processamento dos recursos especiais, que não diz respeito ao cabimento de tais recursos." (WAMBIER, Teresa Arruda Alvim; MEDINA, José Miguel Garcia. Sobre o novo art. 543-C do CPC: sobrestamento de recursos especiais "com fundamento em idêntica questão de direito". Revista de Processo, São Paulo, v. 33, n. 159, p. 216, maio 2008). 
Aliás, considerando-se que a repercussão geral e a técnica de julgamento por amostragem são institutos distintos, pode-se afirmar que se o artigo 543-C fosse inconstitucional, o artigo 543-B do CPC também o seria. Afinal, ao criar a repercussão geral, a Emenda Constitucional n. 45 em momento algum autorizou o julgamento por amostragem, seja para aferição do requisito da repercussão, seja para a definição da interpretação da questão de direito constitucional.

Dessa forma, pode-se afirmar que, diferentemente do que ocorre com a repercussão geral, a ausência dos requisitos exigidos pelos artigos 543-B e 543-C do CPC para a instauração do procedimento de julgamento de recursos repetitivos não impede - nem pode impedir - o acesso ao STF e ao STJ pelo procedimento "normal" de processamento dos recursos extraordinário e especial.

Noutras palavras, no Brasil, mesmo após a inclusão do artigo 543-C do CPC, a admissibilidade do recurso especial não está adstrita aos casos de repercussão geral ou relevância da matéria, o que leva ao seguinte questionamento: por que, com a Emenda Constitucional n. 45/2004, admitiu-se que exista matéria constitucional relevante e não relevante, mas não se fez o mesmo quanto à matéria federal? É razoável o sistema admitir a existência de matéria constitucional irrelevante, mas não de matéria federal irrelevante ${ }^{312}$

Nesse sentido, parte da doutrina vem defendendo a adoção, em nosso sistema, da exigência de repercussão geral não só para o recurso extraordinário ao STF, mas também para o recurso especial ao STJ. ${ }^{313}$

\footnotetext{
${ }^{312}$ MANCUSO, Rodolfo de Camargo, Recurso extraordinário e recurso especial, cit., p. 179.

313 Conforme Arnold Wald, “também para os recursos especiais deve ser adotada a demonstração de repercussão geral das questões discutidas no caso", posto que "o Superior Tribunal de Justiça também está abarrotado de processos" (WALD, Arnoldo, Eficiência judiciária e segurança jurídica: a racionalização da legislação brasileira e reforma do Poder Judiciário, in A reforma do Poder Judiciário, cit., p. 64). No mesmo sentido: ARRUDA ALVIM, José Manoel de, A EC n. 45 e o instituto da repercussão geral, in Reforma do Judiciário: primeiros ensaios críticos sobre a EC n. 45/2004, cit., p. 68. Em sentido contrário, e criticando a PEC 209/2012, José Miguel Garcia Medina argumenta que "se o Superior Tribunal de Justiça, através do recurso especial, atua para promover a uniformidade de interpretação da lei federal, tal proposta de emenda constitucional tende a desvirtuar seu papel” (MEDINA, José Miguel Garcia. Justiça não pode ser medida apenas em números. Consultor Jurídico, set. 2013. Disponível em: <http://www.conjur.com.br/2013-set-16/processo-justica-nao-medida-apenas-numeros>. Acesso em: 16 set. 2013).
} 
No entanto, o tempo relativamente curto de existência do STJ e a previsível insatisfação que seria gerada na população e na comunidade jurídica, caso ocorresse, de uma só vez, a restrição do acesso dos jurisdicionados aos dois mais importantes tribunais do país, bem como a necessidade de um controle superior mais amplo quanto aos demais tribunais $^{314}$, talvez justifiquem o fato de a repercussão geral permanecer, por enquanto, como requisito exclusivo do recurso extraordinário.

${ }^{314}$ Teresa Arruda Alvim Wambier fala da "inexorabilidade do exercício de uma certa função 'controladora', pelo STJ, em relação aos Tribunais de segundo grau de jurisdição" (WAMBIER, Teresa Arruda Alvim, Recurso especial, recurso extraordinário e ação rescisória, cit., p. 290). 


\section{ANÁlise DA CONSTITUCIONALIDADE DA TÉCNICA DE JULGAMENTO DE RECURSOS REPETITIVOS PELO SUPREMO TRIBUNAL FEDERAL E PELO SUPERIOR TRIBUNAL DE JUSTIÇA}

\subsection{Colocação do problema}

A sujeição dos recursos repetitivos ao procedimento dos artigos 543-B e 543-C desperta algumas questões a respeito da sua constitucionalidade.

Primeiro, como já exposto, os recursos excepcionais representam, a despeito de suas finalidades públicas relacionadas às funções nomofilácica e paradigmática, um direito subjetivo de impugnação das partes, previstos expressamente na Constituição Federal. Mais do que isso, é por meio desses recursos que as partes podem obter a correção de interpretação e aplicação eventualmente equivocadas do direito federal pelas instâncias inferiores do Poder Judiciário no julgamento de cada caso concreto. Diante disso, indagase se a técnica de julgamento dos recursos repetitivos, na medida em que limita o acesso direto das partes ao STF e STJ, não caracterizaria uma violação ao princípio constitucional do acesso à justiça (art. $5^{\circ}, \mathrm{XXXV}$, da $\left.\mathrm{CF}\right)$.

Segundo, há que se questionar se a previsão legal no sentido de que o órgão de origem deverá aplicar o entendimento fixado no julgamento do recurso-piloto aos recursos sobrestados não representaria uma violação à competência constitucional do STF e do STJ para julgar recursos extraordinários e especiais, ou então a criação de novo requisito de admissibilidade para tais recursos (relacionado à ausência de confronto à jurisprudência dominante do respectivo órgão superior, fixada no julgamento do recurso representativo da controvérsia), contrariando-se, em ambos os casos, os artigos 102, III, e 105, III, da CF.

Terceiro, se a ideia do sistema é que o STF e o STJ julguem apenas os casos representativos da controvérsia, por decisão paradigmática que definirá a sorte dos recursos extraordinários e especiais repetitivos, não se estaria criando, também por lei ordinária, uma nova hipótese de efeito vinculante das decisões do STF e do STJ não contemplada pela Constituição? 
Quarto e último: a interpretação da jurisprudência do STF e do STJ, no sentido de que, contra a decisão do tribunal de origem que aplica o precedente, não cabe, em qualquer hipótese, agravo de admissão, mas apenas agravo interno, implica a inconstitucionalidade do sistema?

As respostas a essas questões são importantes para se definir a constitucionalidade do sistema de julgamento de recursos extraordinários e especiais repetitivos estabelecido pelos artigos 543-B e 543-C do CPC. É o que passamos a analisar.

\subsection{Princípio constitucional do acesso à justiça}

O moderno conceito do direito constitucional da ação previsto no artigo $5^{\circ}, \mathrm{XXXV}$, da $\mathrm{CF}$, encampado pela garantia do acesso à justiça, envolve não só o direito de pedir ao Poder Judiciário a reparação ou a proteção de direito que se afirma existente e lesado ou ameaçado, mas também o direito a todos os meios (garantias processuais) necessários à obtenção da reparação ou proteção do direito material ${ }^{315}$ e à própria obtenção efetiva dessa reparação ou proteção, traduzindo-se, na conhecida expressão de Kazuo Watanabe, como o direito de "acesso à ordem jurídica justa". 316

Em outros termos, o acesso à justiça envolve muito mais que o mero direito de acesso formal ao Poder Judiciário; engloba o direito a um processo com a observância de todas as garantias processuais abrangidas pela cláusula do devido processo legal e o direito à efetiva, adequada e tempestiva obtenção, por meio desse processo, da tutela do direito material. ${ }^{317}$

\footnotetext{
${ }^{315}$ Segundo José Roberto dos Santos Bedaque: “Acesso à justiça, ou, mais propriamente, acesso à ordem jurídica justa, significa proporcionar a todos, sem qualquer restrição, o direito de pleitear a tutela jurisdicional do Estado e de ter à disposição o meio constitucionalmente previsto para alcançar esse resultado." (BEDAQUE, José Roberto dos Santos. Tutela cautelar e tutela antecipada: tutelas sumárias e de urgência (tentativa de sistematização). 5. ed. rev. e ampl. São Paulo: Malheiros, 2009, p. 74).

316 “Ora, o inc. XXXV do art. $5^{\circ}$ da CF/1988 deve ser interpretado, como ficou acima sublinhado, não apenas como garantia de mero acesso aos órgãos do Poder Judiciário, mas como garantia de acesso à ordem jurídica justa, de forma efetiva, tempestiva e adequada." (WATANABE, Kazuo. Política pública do Poder Judiciário nacional para tratamento adequado dos conflitos de interesses. Revista de Processo, São Paulo, v. 36, n. 195, p. 384, maio 2011.

317 “ $O$ tema do acesso à justiça, dos mais caros aos olhos processualistas contemporâneos, não indica apenas o direito de aceder aos tribunais, mas também o de alcançar, por meio de um processo cercado das garantias do devido processo legal, a tutela efetiva dos direitos violados ou ameaçados. Na feliz expressão de Kazuo Watanabe, o acesso à justiça resulta no 'acesso à ordem jurídica justa'.”. (GRINOVER, Ada Pellegrini. Direito processual coletivo. In: GRINOVER, Ada Pellegrini; CASTRO MENDES, Aluisio Gonçalves de; WATANABE, Kazuo (Coords.). Direito processual coletivo e o anteprojeto de Código Brasileiro de Processos Coletivos. São Paulo: Revista dos Tribunais, 2007. p. 12).
} 
Nesse sentido, considerando-se que a própria Constituição disponibiliza às partes os recursos excepcionais como um meio de impugnação das decisões judiciais, e que é justamente por esse meio que elas podem insurgir-se contra eventuais erros na interpretação e aplicação do direito federal relativos aos seus casos concretos, não há como deixar de associar o direito aos recursos excepcionais ao princípio do acesso à justiça. ${ }^{318}$

Dessa forma, deve-se indagar se as normas que regulamentam o julgamento de recursos repetitivos pelo STF e STJ, ao limitarem o acesso direto das partes a essas cortes por meio dos recursos excepcionais, não estariam violando o princípio do acesso à justiça.

A resposta, porém, não pode deixar de lado o fato de que, mesmo antes do sistema de julgamento de recursos repetitivos, o acesso efetivo a essas cortes já não vinha sendo garantido pela mera possibilidade de interposição de recursos extraordinários e especiais nos tribunais de origem.

Como exposto no Capítulo 4, em razão da grave crise do STF e do STJ, o acesso efetivo das partes a essas cortes por meio de recursos excepcionais vinha sendo, na prática, limitado e restringido pela imposição de rígidos (e muitas vezes ilegítimos) requisitos de admissibilidade, exigidos pela própria jurisprudência dos órgãos superiores (jurisprudência defensiva) como reação àquela crise e como forma de viabilizar o seu adequado funcionamento.

Como bem observado por William Santos Ferreira, "essa aparente 'democratização de acesso' na verdade é um perigosíssimo canto da sereia”. O autor lembra que o volume é

\footnotetext{
${ }^{318}$ Nesse sentido, comentando o papel do STJ, Cândido Rangel Dinamarco destaca a postura dessa corte "no contexto da efetivação de uma ordem jurídica realmente justa", de forma que "ampliar o acesso à alta esfera federal do Poder Judiciário constitui um valor muito precioso que, somado ao obstinado compromisso de julgar bem, abre novas perspectivas e esperanças de maior acesso da população brasileira à alcandorada fruição dos bens da justiça substancial" (DINAMARCO, Cândido Rangel, Superior Tribunal de Justiça e acesso à ordem jurídica justa, in Recursos no Superior Tribunal de Justiça, cit., p. 258). Na Itália, conforme Comoglio, o direito das partes à cassação representa uma garantia constitucional (COMOGLIO, Luigi Paolo. Accesso alle corti e garanzie costituzionali. In: YARSHELL, Flávio Luiz; MORAES, Maurício Zanóide de (Coords.). Estudos em homenagem à Professora Ada Pellegrini Grinover. São Paulo: DPJ, 2005. p. 269). Por sua vez, Leonardo Greco fala da "necessidade de criação de uma Corte Suprema e de instituição de um recurso a ela dirigido, para que ela possa exercer essa importantíssima função de dizer a última palavra a respeito de quais são os direitos tutelados pelo ordenamento jurídico". Isso, segundo o autor, para "assegurar a todos os cidadãos em igualdade de condições o mais rápido e econômico acesso à justiça" (GRECO, Leonardo. Princípios de uma teoria geral dos recursos. Revista Eletrônica de Direito Processual, REDP, Rio de Janeiro, ano 4, v. 5, p. 50, jan./jun. 2010. Disponível em: <http://www.redp.com.br/arquivos/redp_5a_edicao.pdf>. Acesso em: 10 nov. 2013).
} 
tão grande que não basta um grande esforço e uma grande estrutura à disposição, e que "a imprescindível e desesperadora economia de escala em órgãos de cúpula é uma contradição, uma invalidação das razões de sua existência". 319

Além disso, consideradas as condições socioeconômicas e as dimensões territoriais do país, não se pode dizer que seja tão fácil e efetivamente disponível a todos os jurisdicionados o acesso, inclusive físico, aos órgãos superiores sediados em Brasília. Muitas vezes, faz-se necessária a realização de audiências com os ministros relatores, a apresentação de memoriais, a realização de sustentação oral e a prática de outras medidas para que, entre a avalanche de processos submetidos à apreciação do reduzido número de ministros, as peculiaridades de determinado caso sejam efetivamente consideradas no julgamento.

Tudo isso já vinha comprometendo a efetiva atuação do STF do STJ e atingindo, ao mesmo tempo, o adequado exercício de suas relevantes funções nomofilácica e paradigmática e o devido funcionamento dos recursos excepcionais como instrumento de impugnação à disposição das partes.

Com o procedimento dos artigos 543-B e 543-C do CPC, que amplia a eficácia persuasiva dos precedentes do STF e STJ, torna-se mais provável que, no plano prático, tenham eficácia os recursos excepcionais interpostos no órgão de origem contra decisões contrárias à correta interpretação e aplicação do direito objetivo. As partes permanecem com o direito de interpor o recurso e, independentemente de sua adequação aos rígidos requisitos de admissibilidade, eles passam a ser mais aptos à correção de decisões viciadas. Isso porque, interposto o recurso, independentemente da sua admissibilidade, o órgão de origem poderá ajustar a decisão impugnada ao entendimento firmado pelo STF e pelo STJ.

Ademais, com esse procedimento, as decisões paradigmáticas do STF e do STJ ganham maior força e visibilidade, tornando-se mais provável que, no futuro, os órgãos de origem respeitem o entendimento uniforme sobre a interpretação do direito objetivo,

\footnotetext{
${ }^{319}$ FERREIRA, William Santos. Sistema recursal brasileiro: de onde viemos, onde estamos e para onde (talvez) iremos. In: COSTA, Hélio Rubens Batista Ribeiro; RIBEIRO, José Horácio Halfed Rezende; DINAMARCO, Pedro da Silva (Orgs.). Linhas mestras do processo civil: Comemoração dos 30 anos de vigência do CPC. São Paulo: Atlas, 2004. p. 747.
} 
independentemente da efetiva interposição, admissibilidade e julgamento dos recursos excepcionais. $^{320}$

Tudo isso beneficia uma grande quantidade de jurisdicionados que, não fosse esse procedimento, talvez não tivessem acesso efetivo à interpretação do direito federal fixada pelos órgãos superiores.

Por outro lado, quanto às decisões proferidas em conformidade com a jurisprudência dos órgãos superiores, os recursos excepcionais interpostos serão inadmitidos, o que de qualquer forma ocorreria, mesmo sem o rito dos repetitivos. Havendo razões que justifiquem a insistência na admissibilidade, como a distinção do caso ou a existência de fundamentos fáticos e jurídicos diferentes dos já apreciados, a parte pode - ou deveria poder ${ }^{321}$ - interpor agravo de admissão ao órgão superior.

Claro que o ideal seria a possibilidade de acesso amplo e direto de cada parte individualmente considerada até a última instância da organização judiciária. O STF e o STJ poderiam, nesse plano ideal ${ }^{322}$, analisar detidamente cada caso individual, afastando eventuais equívocos na aplicação do direito constitucional e federal em todo o país e modificando ou fortalecendo a sua jurisprudência. Na prática, porém, isso é impossível.

Ao mesmo tempo, não se pode perder de vista que, segundo a própria Constituição, os recursos extraordinário e especial só serão providos e gerarão a cassação (e eventual substituição) da decisão recorrida quando houver violação à correta interpretação do direito federal.

\footnotetext{
${ }^{320}$ Em observações relacionadas à repercussão geral, mas que se aplicam perfeitamente à técnica de julgamento de recursos repetitivos, Eduardo Cambi e Aline Neves afirmam: "Deve ser acrescido que a repercussão geral não priva o cidadão do acesso à Justiça; ao contrário, é um meio de promoção de acesso à ordem jurídica justa, pois racionaliza a prestação jurisdicional e propicia celeridade na tramitação processual, além de assegurar os princípios constitucionais da isonomia, da segurança jurídica e da proteção da confiança. Racionaliza-se a prestação jurisdicional e propicia a celeridade processual, pois os Tribunais de origem devem seguir a orientação jurisprudencial consolidada no STF e no STJ, evitando a longa tramitação processual para que os Tribunais Superiores confirmem as decisões." (CAMBI, Eduardo; NEVES, Aline Regina das. Repercussão geral e PEC 209/2012. Revista de Processo, São Paulo, v. 38, n. 220, p. 199-200, jun. 2013).

${ }^{321}$ A jurisprudência do STF e do STJ não admitem a interposição do agravo de admissão nessa hipótese, conforme demonstraremos e criticaremos neste Capítulo (item 6.5).

${ }^{322}$ Em que todas as garantias são perfeitamente observadas, sem necessidade de preocupação com a possibilidade real da sua implementação prática (COMOGLIO, Luigi Paolo. Etica e tecnica del "giusto processo". Torino: Giappichelli, 2004).
} 
Se o sistema dos recursos repetitivos preserva e até potencializa essa sua função (racionalizando e regulamentando o procedimento relativo ao seu julgamento), o acesso efetivo das partes à ordem jurídica justa fica preservado e até ampliado, a despeito da maior dificuldade de se fazer com que o recurso chegue individualmente a ser apreciado pelo STF e pelo STJ.

Entre um acesso direto (mas meramente formal e mitigado pela jurisprudência defensiva e por outras dificuldades práticas) e um acesso indireto (mas que viabilize a efetiva fruição pelas partes do entendimento consolidado dos órgãos superiores a respeito da correta e uniforme interpretação do direito objetivo), este último parece mais apto a atingir a concretização do princípio do acesso à ordem jurídica justa.

Assim, entendemos que a técnica de julgamento de recursos repetitivos, de uma forma geral, amplia o acesso das partes ao entendimento firmado pelo STF e pelo STJ, ou seja, viabiliza, com maior aptidão, que o seu caso concreto seja julgado de acordo com a interpretação correta do direito objetivo. Por isso, ela não viola o princípio constitucional do acesso à justiça.

\subsection{Ausência de violação à competência constitucional do STF e do STJ e de criação por lei ordinária de novo requisito de admissibilidade para os recursos excepcionais}

Conforme visto no Capítulo 3, é do STF e do STJ a competência constitucional para apreciar a admissibilidade e julgar o mérito dos recursos extraordinários e especiais (arts. 102, III, e 105, III, da CF), permitindo-se, quanto à admissibilidade, que os órgãos de origem realizem um juízo prévio, sempre sujeito ao controle da instância superior pela via do agravo de admissão (art. 544, CPC).

Quanto à repercussão geral, embora se trate de requisito de admissibilidade, o próprio artigo 102, $\S 3^{\circ}$, da $\mathrm{CF}$, é categórico em afirmar a competência exclusiva do STF para aferi-la, tanto que a corte só pode recusar o recurso "pela manifestação de dois terços de seus membros" no sentido da ausência de repercussão geral (Capítulo 5, item 5.5). 
Por outro lado, as hipóteses de cabimento e os demais requisitos específicos de admissibilidade dos recursos excepcionais estão previstos diretamente na Constituição Federal, não podendo a lei ordinária ampliá-la sem prévia delegação de norma constitucional.

Diante disso, se a técnica prevista nos artigos 543-B e 543-C do CPC, inserida no sistema por lei ordinária, importar em modificação da competência dos órgãos superiores ou na criação de novos requisitos de admissibilidade para o julgamento dos recursos excepcionais, ter-se-á de concluir pela sua inconstitucionalidade.

Analisemos primeiro a hipótese de acórdão recorrido que se mostra divergente do entendimento fixado pela instância superior no julgamento dos recursos representativos da controvérsia. O problema, nesse caso, não se refere à suposta criação de novos requisitos de admissibilidade, mas sim à eventual modificação da competência para julgamento do mérito dos recursos extraordinários, porque a lei prevê a submissão do recurso anterior à apreciação do órgão julgador competente, para exercício de juízo positivo ou negativo de retratação.

No entanto, como demonstrado no Capítulo 5 (item 5.4), nessa hipótese os órgãos de origem serão livres para, em sede de juízo de retratação, modificar ou manter o acórdão divergente, e em nenhum dos casos o recurso excepcional tem seu mérito apreciado pelo órgão a quo: havendo modificação do acórdão (juízo positivo de retratação), o recurso excepcional repetitivo fica logicamente prejudicado; não havendo modificação (juízo negativo de retratação), o mesmo recurso terá sua admissibilidade normalmente apreciada, com a eventual remessa dos autos à instância superior.

Como se vê, não há aqui qualquer inconstitucionalidade, eis que, na hipótese de persistir o interesse recursal, o recurso excepcional será normalmente processado, ficando preservada a competência da instância superior.

A dificuldade maior está na hipótese de acórdão recorrido convergente com o entendimento fixado pela instância superior, caso em que caberá ao órgão de origem julgar 
prejudicado ou negar seguimento ao recurso excepcional repetitivo sobrestado ${ }^{323}$. Isso equivaleria a um julgamento de mérito do recurso excepcional pelo órgão a quo, com violação à competência do STF e STJ?

Interpretando os dispositivos do CPC que veiculam o termo "negar seguimento" (arts. 544, $\S 4^{\circ}$, e 557), a doutrina ensina que ele abrange tanto o juízo de mérito como o juízo de admissibilidade, a depender do conteúdo da decisão, embora em princípio esteja mais relacionado à inadmissibilidade, sendo, inclusive, semanticamente inadequada a sua utilização para o caso de improvimento. ${ }^{324}$

De qualquer modo, quando a hipótese é de negativa de seguimento para reconhecimento da improcedência manifesta do recurso ou da sua contrariedade à jurisprudência dos órgãos superiores, então a decisão tem natureza de mérito. ${ }^{325}$

Diante disso, surge a questão: permitir ao órgão de origem negar seguimento ao recurso, com base no fundamento de que o entendimento nele defendido contraria a jurisprudência dominante do STF ou STJ, não equivale a permitir o julgamento do seu mérito por esse mesmo órgão? Se a resposta for positiva, deve-se concluir pela violação à competência constitucional do STF e do STJ.

Se, por outro lado, tratar-se de inadmissibilidade, então surge outro problema de constitucionalidade, porque a lei poderia estar criando novo requisito de admissibilidade

\footnotetext{
${ }^{323}$ Uma vez julgado o caso representativo da controvérsia, os próprios tribunais de origem, onde os recursos extraordinário e especial aguardavam sobrestados, deverão considerar prejudicados (art. 543-B) ou negar seguimento (art. 543-C) aos recursos contrários ao entendimento fixado pelo STF e pelo STJ. Em ambos os casos, a ideia é negar seguimento ou indeferir o processamento do recurso.

324 “A rigor, o relator negará seguimento apenas na hipótese de inadmissibilidade do recurso. Se o recurso for manifestamente improcedente, tem o relator de negar provimento ao mesmo." (MARINONI, Luiz Guilherme; MITIDIERO, Daniel. Código de Processo Civil: comentado artigo por artigo. São Paulo: Revista dos Tribunais, 2008. p. 582).

325 Conforme José Carlos Barbosa Moreira, decisões monocráticas proferidas nos termos dos artigos 554, § $4^{\circ}$, e 557, que reconhecem a contrariedade do recurso em relação à jurisprudência, têm conteúdo de mérito e, por isso mesmo, substituem as decisões recorridas, sendo aquelas, e não estas, objeto de eventual ação rescisória, sejam ou não confirmadas pela via do agravo interno (MOREIRA, José Carlos Barbosa, Comentários ao Código de Processo Civil: Lei n. 5.869, de 11 de janeiro de 1973, arts. 476 a 565, cit., v. 5, p. 115 e 684). No mesmo sentido, Cassio Scarpinella Bueno afirma que as decisões monocráticas que negam seguimento a recurso com base em contrariedade à jurisprudência são de mérito (BUENO, Cassio Scarpinella, Curso sistematizado de direito processual civil, cit., v. 5, p. 126).
} 
(ausência de contrariedade à jurisprudência dominante do órgão superior fixada em sede de julgamento de recursos repetitivos), não contemplado pela Constituição Federal.

A resposta a essas questões impõe que se desvende a natureza dessa negativa de seguimento.

Para Eduardo Talamini, trata-se de juízo de mérito, e não haveria aí qualquer inconstitucionalidade, desde que se admita a impugnação dessa decisão por meio de agravo de admissão, na mesma linha do que ocorre com o artigo 518, § $1^{\circ}$, do CPC. O autor apresenta um interessante argumento: se a apreciação do mérito pelo tribunal de origem afronta a competência constitucional da instância superior para o julgamento desses recursos, então também seria inconstitucional a realização do juízo prévio de admissibilidade por aquele órgão, eis que nesse caso a competência é igualmente constitucional. Diante disso, poder-se-ia afirmar que a decisão é de mérito, e que sua constitucionalidade estaria garantida pela possibilidade de interposição de agravo à instância superior. ${ }^{326}$

No entanto, julgar o mérito de um recurso excepcional, atividade exclusiva do STF e do STJ, é realizar juízo de valor sobre a ocorrência ou inocorrência de violação ao direito federal constitucional e infraconstitucional, com a finalidade de firmar a interpretação correta e única do direito objetivo no território nacional. E nada disso ocorre quando o órgão a quo nega seguimento ao recurso extraordinário ou especial repetitivo, com base no precedente relativo ao julgamento dos recursos representativos da controvérsia.

Note-se que uma coisa é o tribunal competente para o julgamento de determinado recurso negar-lhe seguimento monocraticamente, ou então dar-lhe provimento monocraticamente, com base na jurisprudência dominante, sumulada ou formada a partir de julgamento de recursos representativos da controvérsia. Essa hipótese, prevista pelos artigos 544, $\S 4^{\circ}$, e 557 do CPC, caracteriza uma legítima decisão de mérito porque, embora também se trate de juízo prévio, ele é realizado pelo próprio tribunal competente para o julgamento do recurso, a título de antecipação do resultado da apreciação de

\footnotetext{
${ }^{326}$ TALAMINI, Eduardo, Novos aspectos da jurisdição constitucional brasileira: repercussão geral, força vinculante, modulação dos efeitos do controle de constitucionalidade e alargamento do objeto do controle direto, cit., p. 77.
} 
mérito que seria realizada pelo órgão colegiado. Além disso, nesse caso o órgão competente para o julgamento do mérito do recurso está se posicionando quanto à aplicação ou não da jurisprudência dominante ou sumulada ao caso e, por isso, está julgando o seu mérito.

Outra coisa, bem diferente, é o órgão a quo realizar o juízo prévio de admissibilidade do recurso excepcional. O órgão a quo não é o tribunal competente para julgar o mérito do recurso excepcional, mas sim a instância superior. Por isso, não cabe àquele órgão apreciar a possibilidade de seguimento do recurso, a título de uma eventual antecipação do resultado de um julgamento de mérito que não se enquadra na sua própria competência.

$\mathrm{Na}$ verdade, ao realizar o juízo prévio de admissibilidade dos recursos excepcionais, os órgãos a quo não realizam qualquer juízo de valor sobre a violação ao direito federal (mérito), mas apenas realizam um controle dos requisitos formais de admissibilidade desses recursos. Tanto isso é verdade que, quando o juízo é positivo, isso não significa que, na avaliação do órgão a quo, tenha ocorrido alguma violação ao direito federal, mas sim que, do ponto de vista formal, o recurso deve ter seu mérito apreciado pela instância superior.

Por sua vez, quando o juízo prévio de admissibilidade é negativo, isso também não significa que o órgão a quo tenha interpretado o direito federal e, à luz dessa interpretação, tenha concluído pela ausência de violação às normas constitucionais ou infraconstitucionais.

Fazemos aqui referência à crítica, por nós apresentada no Capítulo 3 (item 3.3.2), ao entendimento doutrinário e jurisprudencial no sentido de que seria autorizado aos órgãos de origem examinar a ocorrência de violação à lei federal para fins de admissão do recurso especial. Deve-se fazer, nesse caso, uma distinção entre a apreciação da inocorrência de violação ao direito federal em sede de juízo prévio de admissibilidade a partir de critério objetivos (o que se permite aos órgãos de origem, e mesmo assim sob a condição do cabimento de agravo de admissão contra a respectiva decisão) e a apreciação do próprio mérito dos recursos excepcionais (de competência exclusiva do STF e do STJ). 
Conforme defendemos no referido item, o que parece razoável é admitir que o tribunal a quo, podendo aferir objetivamente a ausência de probabilidade da alegação de violação ao direito federal, fica autorizado a negar seguimento (inadmitir) o recurso excepcional. Não haverá, aí, juízo de valor pelo órgão a quo a respeito da definitiva interpretação do direito federal, mas sim a constatação, a partir de critérios objetivos, da ausência de alegação apta a gerar o efetivo reconhecimento de violação à correta interpretação do direito federal.

O mesmo se diga, e com maior razão, quanto à negativa de seguimento do recurso excepcional pelo órgão a quo com base na decisão do STF ou do STJ que julga os recursos representativos da controvérsia (arts. 543-B e 543-C do CPC). Nesse caso, a negativa de seguimento baseia-se na interpretação previamente fixada pelo próprio órgão competente para o julgamento do mérito (STF ou STJ). Ao negar seguimento aos recursos repetitivos sobrestados, o órgão de origem não está realizando absolutamente qualquer juízo de valor sobre a interpretação do direito federal (e por isso não está julgando seu mérito), mas apenas reconhecendo a ausência de plausibilidade do recurso, a partir de um dado eminentemente objetivo: acórdão da superior instância em sentido contrário à pretensão recursal.

Trata-se de algo semelhante ao que ocorre com a técnica de inadmissibilidade de apelação contrária a súmula do STF ou do STJ prevista no artigo 518, § $1^{\circ}$, do $\mathrm{CPC}$, em que o órgão a quo, encarregado do juízo prévio de admissibilidade do recurso, indefere o seu processamento com base em súmula do STF ou do STJ, mas sem realizar qualquer juízo de valor a respeito da questão ${ }^{327}$, até porque não é dele a competência para apreciar o mérito do recurso.

Para parte da doutrina, essa norma é inconstitucional, pois equivale à instituição de súmula vinculante por meio de lei ordinária, observando-se, inclusive, que pende de

\footnotetext{
${ }^{327}$ Sobre o artigo 518, § $1^{\circ}$, Barbosa Moreira afirma: "Em caso algum fica o órgão a quo autorizado a denegar a apelação - ab initio ou mais tarde - só por entendê-la infundada. A hipótese do § $1^{\circ}$, introduzido no art. 518 pela Lei no 11.276 , não constitui propriamente exceção a essa regra: a denegação do recurso não se baseia no entendimento pessoal do juiz, mas no fato de conformar-se a sentença a enunciado da Súmula do STJ ou do STF." (MOREIRA, José Carlos Barbosa, Comentários ao Código de Processo Civil: Lei n. 5.869, de 11 de janeiro de 1973, arts. 476 a 565, cit., v. 5, p. 461).
} 
apreciação pelo Congresso Nacional a PEC 358/2005, por meio da qual se pretende instituir o sistema de súmula impeditiva de recurso. ${ }^{328}$

No entanto, como defende Cassio Scarpinella Bueno, é possível interpretar essa norma em conformidade com a Constituição Federal, nela enxergando uma regra inerente ao juízo de admissibilidade do recurso, desde que, segundo o autor, restrinja-se a sua aplicação ao âmbito dos recursos ordinários. Nesse sentido, a norma deveria ser interpretada como a previsão de uma hipótese em que objetivamente o recorrente não tem chance de êxito, permitindo-se ao órgão competente para o juízo prévio que, identificando tal situação, impeça o prosseguimento do recurso. Segundo o autor, é preferível "até como forma de manter o mais íntegro possível o sistema processual civil, entender que a baixíssima (ou nula) probabilidade de êxito no recurso é caso de sua inadmissão, e não de seu improvimento". 329

Dentre as justificativas apresentadas para a adoção desse entendimento a respeito do artigo 518, $\S 1^{\circ}$, do CPC, destacam-se as seguintes: contra a decisão de inadmissão, cabe recurso para contrastar o não recebimento do recurso; interpretar que esse trancamento equivale ao mérito contrastaria com o "modelo constitucional de direito processual civil"; e a própria lei refere-se a não recebimento do recurso (juízo de admissibilidade), e não a julgamento do recurso (juízo de mérito). ${ }^{330}$

\footnotetext{
${ }^{328}$ Conforme Rodolfo de Camargo Mancuso, "o direito sumular - salvo quando expressamente vinculante não tem como projetar o severo efeito de inibir o acesso ao segundo grau de jurisdição, parecendo-nos, assim, que o legislador ordinário precipitou-se ao se antecipar aos sucessos futuros, quando inseriu no art. 518 do CPC este $\S 1^{\circ}$ " (MANCUSO, Rodolfo de Camargo, Recurso extraordinário e recurso especial, cit., p. 168). Barbosa Moreira, observando que a súmula impeditiva de recursos só não foi inserida na Constituição Federal pela Emenda Constitucional n. 45/2004 por não ter sido aprovado pelo Senado Federal o texto enviado pela Câmara dos Deputados, também considera ser "paradoxal, no mínimo, que a Lei $\mathrm{n}^{\mathrm{o}} 11.276$, por via indireta, atribua a quaisquer proposições sumuladas pelo Superior Tribunal de Justiça e pelo Supremo Tribunal Federal efeito praticamente equiparável, ou quase, ao da denominada 'súmula vinculante' - e mais: sem sequer subordiná-lo ao concurso dos pressupostos ali enumerados!' (MOREIRA, José Carlos Barbosa, Comentários ao Código de Processo Civil: Lei n. 5.869, de 11 de janeiro de 1973, arts. 476 a 565 , cit., v. 5 , p. 460 ). Claro que, se a súmula mencionada no artigo $518, \S 1^{\circ}$, tivesse a mesma força da súmula prevista na PEC 358/2005, a regra seria inconstitucional. Na referida PEC, simplesmente não se admite recurso contrário à súmula, prevendo-se que "são insuscetíveis de recurso e de quaisquer meios de impugnação e incidentes as decisões judiciais, em qualquer instância, que deem a tratado ou lei federal a interpretação determinada pela súmula impeditiva de recurso". Ela é, portanto, mais do que uma súmula vinculante, porque impede expressamente que as partes se insurjam formalmente contra a sua aplicação no caso concreto. De fato, só por emenda constitucional é possível instituir um instituto com essa força no sistema.

${ }^{329}$ BUENO, Cassio Scarpinella, Curso sistematizado de direito processual civil, cit., v. 5, p. 83. Ver, porém, o entendimento desse autor sobre a inaplicabilidade dessa interpretação aos recursos excepcionais, em nota abaixo.

${ }^{330}$ Ibidem, v. 5, p. 83.
} 
No caso dos artigos 543-B e 543-C do CPC, tem-se exatamente uma hipótese em que o órgão inferior afere objetivamente a chance de êxito do recurso, em face da sua contrariedade à tese firmada no julgamento do recurso-piloto. Note-se que o tribunal de origem não realiza a função do STF ou do STJ, no sentido de escolher a interpretação definitiva do direito federal, mas apenas coteja o recurso interposto na origem com essa escolha, a fim de concluir que objetivamente o recorrente não tem chance de êxito. ${ }^{331}$

Ademais, ao menos em regra, também cabe recurso contra essa decisão de inadmissão (agravo do art. 544 do CPC), e a própria lei não menciona a hipótese de julgamento do recurso excepcional, mas sim de negativa de seguimento, expressão que, como já dito, é mais adequada para significar apenas o juízo negativo de admissibilidade.

Assim, poder-se-ia da mesma forma dizer que a técnica de julgamento de recursos repetitivos prevê, quanto aos efeitos do acórdão paradigma em relação aos recursos repetitivos sobrestados que defendem tese divergente, uma hipótese de juízo de admissibilidade, de modo que ela não importaria em violação à competência dos Tribunais Superiores para o julgamento do mérito dos recursos excepcionais.

E, de fato, parte da doutrina tem afirmado expressamente que se trata, aqui, de juízo negativo de admissibilidade ${ }^{332}$, ainda que influenciado pelo juízo de mérito realizado no julgamento do recurso-piloto. ${ }^{333}$

\footnotetext{
331 "Malgrado a diferença terminológica entre as disposições legais, sua essência parece ser a mesma. Elas impõem o trancamento dos recursos sobrestados, sem um formal juízo acerca do seu mérito, ao menos aos olhos do legislador, que procura encaminhar as coisas nessa direção com os termos 'prejudicados' e 'seguimento denegado." (BONDIOLI, Luiz Guilherme Aidar. A nova técnica de julgamento dos recursos extraordinário e especial repetitivos. p. 25. Disponível em: <http://www.dinamarco.com.br/wpcontent/uploads/NovaTecnica.pdf>. Acesso em: 14 nov. 2013.

332 "Julgada a controvérsia, os recursos especiais sobrestados na origem poderão ser inadmitidos, na hipótese de o acórdão recorrido coincidir com a orientação firmada pelo Superior Tribunal de Justiça." (MARINONI, Luiz Guilherme; MITIDIERO, Daniel, Código de Processo Civil: comentado artigo por artigo, cit., p. 572). "A hipótese prevista no inciso I do $\S 7^{\circ}$ do art. 543-C do CPC, é de fácil compreensão, pois quando o acórdão recorrido, objeto do recurso especial sobrestado, coincidir com a orientação do STJ, o recurso especial contra ele interposto será denegado, na fase de admissibilidade; mesmo porque, se fosse admitido, a decisão recorrida provavelmente seria reformada." (ALVIM, José Eduardo Carreira, Recursos especiais repetitivos: mais uma tentativa de desobstruir os tribunais, cit., p. 180).

${ }^{333}$ RODRIGUES NETTO, Nelson, Análise crítica do julgamento "por atacado" no STJ: (Lei 11.672/2008 sobre recursos especiais repetitivos), cit., p. 242.
} 
Diante disso, surge aquele outro problema: se o recurso pode ser inadmitido por contrariedade à jurisprudência do STF ou do STJ, não se estaria criando novos requisitos de admissibilidade para os recursos excepcionais por lei ordinária, quando, para tanto, se exigiria emenda à Constituição?

Para Cassio Scarpinella Bueno, a resposta é positiva, razão pela qual o autor, coerentemente, exclui a possibilidade de aplicar regra análoga à do artigo 518, § $1^{\circ}$, do CPC aos recursos excepcionais, por violar a regra de que só a Constituição Federal pode criar requisitos de admissibilidade para esses recursos. ${ }^{334}$

Porém, conforme defendido por parte da doutrina, pode-se afirmar que a negativa de seguimento, nesse caso, representa um juízo de admissibilidade relacionado à aferição do interesse recursal, na medida em que, pacificada a jurisprudência em sentido contrário ao pretendido pelo recorrente, seu recurso não teria utilidade. ${ }^{335}$

De fato, se o recurso está endereçado ao órgão superior, e este acaba de pronunciar entendimento contrário à tese defendida pelo recorrente, é possível afirmar que, objetivamente, e à luz da orientação firmada pelo próprio órgão ad quem, a insurgência é inútil, faltando o pressuposto do interesse recursal ${ }^{336}$. E o interesse recursal não caracteriza novo requisito de admissibilidade, podendo, assim, ser perfeitamente reconhecido pelo órgão a quo.

\footnotetext{
${ }^{334}$ BUENO, Cassio Scarpinella, Curso sistematizado de direito processual civil, cit., v. 5, p. 85.

335 “De outro lado, poderá declarar 'prejudicados' os recursos, se as decisões recorridas estiverem em conformidade com o pronunciamento de mérito feito no Supremo. Nessa última hipótese, o órgão a quo estará deixando de conhecê-lo por carência de interesse recursal (utilidade), partindo da premissa de que a tese neles sustentada já foi rechaçada pela superior instância em caráter definitivo. Só mesmo na ausência de um pressuposto recursal poder-se-ia fundar essa decisão; a atribuição ao órgão a quo de competência para o julgamento do mérito dos recursos extraordinários importaria evidente inconstitucionalidade $(\mathrm{CF}$, art. 102, III)." (ABBUD, André de Albuquerque Cavalcanti, A repercussão geral dos recursos extraordinários e o julgamento por amostragem no âmbito do Supremo Tribunal Federal (CPC, arts. 543-A e 543-B), in As novas reformas do CPC e de outras normas processuais, cit., p. 314). No mesmo sentido: OLIVEIRA, Guilherme José Braz de, Repercussão geral das questões constitucionais e suas consequências para o julgamento do recurso extraordinário, cit., p. 298.

${ }^{336}$ Em sentido contrário, Eduardo Talamini afirma: "Não procede o argumento de que se trataria, na hipótese, de mera falta de interesse recursal. O interesse está plenamente justificado com a sucumbência e a aptidão, em tese, do recurso para removê-la. A constatação de que o recurso está (provavelmente) fadado ao desprovimento não constitui uma avaliação do interesse processual, mas do próprio mérito." (TALAMINI, Eduardo, Novos aspectos da jurisdição constitucional brasileira: repercussão geral, força vinculante, modulação dos efeitos do controle de constitucionalidade e alargamento do objeto do controle direto, cit., p. 77).
} 
Ademais, considerando-se as funções dos recursos excepcionais (Capítulo 3), com as quais se identificam diretamente as hipóteses de cabimento desses recursos, não deixa de ser razoável a interpretação de que a instância extraordinária não se considera aberta quando o recurso excepcional limita-se a contrariar a jurisprudência dominante do STF ou do STJ, sem demonstrar a ocorrência de argumentos de fato e de direito diversos dos já apreciados por essas cortes no julgamento dos casos paradigma.

Nesse sentido, há muito tempo consolidou-se o entendimento jurisprudencial no sentido de que não se conhece do recurso excepcional por divergência jurisprudencial, se a jurisprudência do órgão superior firmou-se no sentido da interpretação adotada pelo acórdão recorrido (Súmulas 286 do STF e 83 do STJ). E, conforme recentes julgados do STJ, esse entendimento aplica-se tanto à alínea "c" como à alínea "a" do permissivo constitucional $^{337}$, podendo-se concluir que não se conhece do recurso para simplesmente se rediscutir interpretação já definida pela jurisprudência da corte.

Vê-se, assim, que outro fundamento a justificar essa interpretação diz respeito às finalidades previstas pela própria Constituição Federal para os recursos excepcionais, que parecem autorizar a conclusão de que eles só abrem a instância extraordinária quando veiculam questões não pacificadas ou, tratando-se de questões pacificadas, veiculam argumentos fáticos e jurídicos novos, aptos, em tese, a levar à criação de novo precedente ou superar o precedente já existente sobre a questão.

Nesse sentido, o órgão de origem, ao realizar o juízo de admissibilidade dos recursos excepcionais repetitivos sobrestados, pode inadmiti-los por contrariedade à jurisprudência dominante dos órgãos superiores fixada no julgamento do recurso-piloto, em face da manifesta improbabilidade de êxito desses recursos. Trata-se de uma hipótese legalmente prevista que, em consonância com as funções dos recursos excepcionais, identifica um critério objetivo representativo da ausência de probabilidade de seu êxito.

\footnotetext{
337 “A Súmula 83 do STJ, a despeito de referir-se somente à divergência pretoriana, é perfeitamente aplicável à alínea 'a' do art. 105, III, da Constituição Federal.” (STJ - AgR Ag n. 1.401.587/RS, 2a Turma, rel. Min. Herman Benjamin, j. 04.10.2011, DJe, de 17.10.2011). “Aplica-se o Enunciado n ${ }^{\circ} 83$ da Súmula do Superior Tribunal de Justiça quando o recurso especial tiver fundamento nas alíneas 'a' e 'c' do permissivo constitucional." (STJ - AgR AREsp 'n. 10.808SE, 33 Turma, rel. Ministro Sidnei Beneti, j. 28.06.2011, DJe, de 01.07.2011).
} 
É como se o sistema criasse a seguinte presunção: se o tema foi pacificado por precedente formado em julgamento de recursos repetitivos, a alegação de violação à norma federal não é suficiente para que se considere satisfeito o requisito de admissibilidade relativo ao cabimento.

Observe-se, porém, que o órgão de origem pode, por exemplo, verificar que o recurso excepcional repetitivo sobrestado apresenta alguma distinção fática ou jurídica em relação ao que foi julgado pelo órgão superior, ou que contém argumentos aptos a demonstrar a necessidade, em tese, de superação do precedente, e nesses casos não só poderá como deverá necessariamente deferir o seu processamento, para fins de eventual distinguishing ou overruling a ser realizado pelo órgão superior. Ou seja, não há obrigação de negativa de seguimento aos recursos contrários ao entendimento firmado pelo STF ou STJ.

Da mesma forma, como toda decisão de inadmissibilidade proferida pelo órgão encarregado do juízo prévio, também esta precisa estar sujeita a agravo de admissão ou outro meio de impugnação diretamente ao órgão superior.

Desse modo, pode-se concluir que, quando há precedente qualificado do STF e do STJ, decorrente do julgamento de recursos repetitivos, presume-se a ausência de plausibilidade na arguição de contrariedade à norma constitucional ou infraconstitucional apresentada pelo recorrente, permitindo-se, nesses casos, o juízo negativo de admissibilidade pelo órgão a quo, desde que a decisão possa ser impugnada por agravo de admissão (art. 544 do CPC). ${ }^{338}$

\footnotetext{
${ }^{338}$ Sobre a questão da constitucionalidade do juízo prévio de admissibilidade do recurso extraordinário pelo tribunal de origem ou pelos ministros relatores, Pontes de Miranda conclui não haver qualquer invasão de competência, desde que se admita o contraste da decisão por meio de agravo: "Se lei ordinária deixasse de dar o meio jurídico para que o Supremo Tribunal Federal apreciasse o ato do presidente do Tribunal de Justiça, ou de outro tribunal, seria inconstitucional; porque, então, teria tirado à cognição do Supremo Tribunal Federal as preliminares do recurso". É interessante notar como, na sequência, Pontes de Miranda equipara o problema do exercício do juízo prévio de admissibilidade pelo tribunal de origem ao problema desse mesmo exercício por qualquer outro órgão que não o colegiado do Supremo Tribunal Federal, inclusive pelos ministros relatores: "Pode-se entregar o conhecimento in limine, recorrível o despacho, ao presidente do Tribunal de Justiça, ou de outro tribunal, ou ao juiz relator do feito, ou a qualquer ministro do Supremo Tribunal Federal, desde que, proferido o despacho negativo do recurso extraordinário, caiba recurso para o Supremo Tribunal Federal, a que se não pode tirar a cognição das preliminares." (PONTES DE MIRANDA, Francisco Cavalcanti, Comentários à Constituição de 1967: com a Emenda n. 1: arts. 118 a $153, \S 1^{\circ}$, cit., v. 4, p. 125$)$.
} 
Enfim, não se trata de autorizar a criação de novos requisitos de admissibilidade para os recursos excepcionais não previstos na Constituição, nem de alterar a competência constitucional do STF e do STJ para apreciá-los, mas de se estender a tais recursos, à míngua de argumentos que justifiquem um tratamento diferenciado, o sistema que, à luz da tendência de valorização da jurisprudência com fundamento nos princípios constitucionais da isonomia, segurança jurídica e razoável duração do processo, permite, em sede de juízo prévio de admissibilidade, a negativa de seguimento aos recursos contrários à jurisprudência pacificada, desde que se garanta a possibilidade de interposição de agravo contra a decisão de inadmissão.

Por fim, resta analisar a hipótese de reconhecimento de ausência de repercussão geral da questão constitucional (que não se confunde com a apreciação da controvérsia sobre a interpretação do direito constitucional). Nesse caso, o artigo 543-B, $\S 2^{\circ}$, do CPC prevê que os recursos repetitivos considerar-se-ão automaticamente inadmitidos. Mas o que efetivamente ocorre é a declaração dessa inadmissibilidade pelo órgão a quo, a partir da aplicação do acórdão paradigma do STF, o qual, à luz da redação do referido dispositivo legal, parece ser dotado de uma espécie de efeito vinculante.

Se, como demonstrado neste item, o órgão de origem pode negar seguimento ao recurso contrário à tese pacificada por meio do julgamento do mérito do recurso-piloto, com maior razão poderá fazê-lo em relação ao recurso que versa sobre questão constitucional reconhecidamente desprovida de repercussão geral, nos termos do acórdão paradigma do STF.

Obviamente não existe aqui o problema da criação de novos requisitos de admissibilidade por lei ordinária, pois a repercussão geral foi criada pela própria Constituição Federal.

Por sua vez, também não existe nesse caso qualquer problema relacionado à competência exclusiva do STF, porque, embora o artigo 102 , $\S 3^{\circ}$, preveja a competência exclusiva do STF para aferir a repercussão geral, o órgão a quo não chega a apreciar a existência ou inexistência de repercussão geral, mas apenas declara a incidência do precedente do próprio STF, atuando de forma similar àquela descrita acima, em relação à negativa de seguimento com base na contrariedade do recurso repetitivo em relação ao precedente qualificado dos órgãos superiores. 
Ou seja, ao inadmitir o recurso por ausência de repercussão geral com base no artigo 543-B, $\S 2^{\circ}$, o órgão de origem não afere, nos termos do artigo 102 , $\S 3^{\circ}$, da $\mathrm{CF}$, a repercussão geral da questão constitucional. O sentido dessa norma é atribuir exclusivamente ao STF a competência para afirmar que determinada questão é desprovida de repercussão. E essa competência já terá sido exercida pelo próprio STF, de modo que o órgão a quo simplesmente reconhece de forma objetiva a incidência do respectivo precedente ao caso. Por isso, não há ofensa à competência constitucional.

Ademais, se o STF tivesse de repetir em cada um dos milhares de casos repetitivos que determinada questão não oferece repercussão geral, restaria esvaziado o sentido da norma constitucional que exclui da sua apreciação determinadas questões reconhecidamente desprovidas de transcendência, de modo que a interpretação teleológica do artigo 102, $\S 3^{\circ}$, da CF autorizaria afirmar a constitucionalidade técnica da apreciação por amostragem da repercussão geral dos recursos repetitivos. ${ }^{339}$

$\mathrm{Na}$ verdade, o verdadeiro problema quanto a esse ponto não é a questão da competência, mas sim (i) a previsão do artigo 543-B, § $2^{\circ}$, do CPC, no sentido de que os recursos considerar-se-ão automaticamente inadmitidos, criando-se uma espécie de efeito vinculante por meio de norma infraconstitucional, bem como (ii) a interpretação dada pela jurisprudência do STF, no sentido que não cabe qualquer recurso ou outro meio de impugnação ao STF contra a decisão do órgão de origem, questões essas que serão analisadas nos itens 6.4 e 6.5 infra.

\subsection{Ausência de efeito vinculante}

Já demonstramos no Capítulo 2 (item 2.4.2) que, entre nós, a jurisprudência não constitui, em regra, fonte do direito, justamente diante da falta do caráter coercitivo típico das normas legais, estas sim a principal fonte normativa do nosso sistema, segundo a

\footnotetext{
${ }^{339}$ No entanto, não deixa de chamar a atenção o fato de que, se determinada questão constitucional repete-se aos milhares em processos individuais e coletivos por todo o país, talvez isso seja um indicativo de que ela apresenta sim repercussão geral, por assumir no mínimo uma relevância social, pelo que a própria lei deveria presumir, nesses casos, a existência da repercussão geral. Com isso, a técnica de julgamento de recursos repetitivos só seria aplicada para o julgamento do próprio mérito da pretensão recursal, posto que, sempre que presente a multiplicidade de recursos fundados em idêntica questão de direito, estaria presumida a existência da repercussão geral, tornando-se totalmente desnecessário estabelecer esse sistema de inadmissão automática dos recursos sobrestados.
} 
cláusula constitucional no sentido de que ninguém poderá ser obrigado a fazer ou deixar de fazer alguma coisa senão em virtude de lei.

Porém, também como já demonstramos, a própria Constituição Federal excepciona essa regra, prevendo expressamente o efeito vinculante das decisões definitivas de mérito proferidas pelo Supremo Tribunal Federal nas ações diretas de inconstitucionalidade e nas ações declaratórias de constitucionalidade (art. 102, § 2º ), bem como das súmulas aprovadas pela mesma corte de acordo com os parâmetros estabelecidos pelo artigo 103-A da Constituição (súmulas vinculantes).

Com relação às súmulas vinculantes, sabe-se que a sua inserção no sistema, ocorrida pela Emenda Constitucional n. 45/2004, só veio após muitos anos de discussões e polêmicas doutrinárias a respeito da sua conveniência e da viabilidade de sua adoção em nosso sistema, e que mesmo assim o referido artigo 103-A estabelece requisitos ${ }^{340}$ e um sistema próprio de aprovação, revisão e cancelamento da súmula.

Se a própria Constituição Federal excepciona os casos de decisões vinculantes, fica fácil concluir pela ilegitimidade de qualquer norma infraconstitucional que pretenda ampliar esse rol, estabelecendo novos casos dissociados das hipóteses previstas expressamente na Constituição Federal. Se qualquer norma infraconstitucional pudesse estabelecer o efeito vinculante, qual seria o sentido das normas constitucionais que preveem excepcionalmente o efeito vinculante apenas de determinadas decisões judiciais do STF?

Estabelecida essa premissa, passamos a analisar se a técnica de julgamento de recursos repetitivos estabelecida pelos artigos 543-B e 543-C do CPC prevê efeito vinculante das decisões do STF e do STJ proferidas no julgamento do recurso representativo da controvérsia.

\footnotetext{
${ }^{340}$ A norma exige, como requisito para a aprovação de súmula vinculante, não só a existência de "reiteradas decisões sobre a matéria", mas também a existência de "controvérsia atual entre órgãos judiciários ou entre esses e a administração pública que acarrete grave insegurança jurídica e relevante multiplicação de processos sobre questão idêntica".
} 
Parte da doutrina e da jurisprudência vem entendendo que há efeito vinculante. Essa é a posição de Cassio Scarpinella Bueno, que coerentemente considera, justamente por esta razão, inconstitucional a técnica dos artigos 543-B e 543-C do CPC. ${ }^{341}$

Por sua vez, Luiz Guilherme Marinoni defende que pode e deve haver efeito vinculante. Aliás, para o autor, qualquer decisão do STF ou do STJ tem efeito vinculante em relação aos demais órgãos do Poder Judiciário, em respeito à função constitucional dessas cortes e, dentre outros, aos princípios da igualdade e da segurança jurídica. A possibilidade de efeito vinculante decorreria logicamente dessas regras e princípios constitucionais, sem necessidade de previsão expressa. ${ }^{342}$

Assim, para o referido autor, com maior razão os órgãos inferiores teriam o dever de respeitar o entendimento firmado no julgamento do recurso-piloto, de modo que o artigo 543-B, § $4^{\circ}$, do CPC - no qual se menciona a possibilidade de manutenção, pelos órgãos de origem, do entendimento contrário àquele firmado pelo STF - só poderia ser interpretado como "norma que prescreve reação contra algo que o tribunal de origem está proibido de fazer". 343

Sobre o artigo 543-C, $\S 8^{\circ}$, do CPC - no qual também se menciona a possibilidade de manutenção, pelos órgãos de origem, do entendimento contrário àquele firmado pelo STJ - o mesmo autor entende que a norma deve ser vista não como indicativo da possibilidade de divergência, mas sim como "preceito que considera um ato de rebeldia do tribunal de origem, ao manter a divergência com o precedente do Superior Tribunal de Justiça". 344

\footnotetext{
${ }^{341}$ BUENO, Cassio Scarpinella, Curso sistematizado de direito processual civil, cit., v. 5, p. 312.

${ }^{342}$ Essa tese é brilhantemente defendida (MARINONI, Luiz Guilherme, Precedentes obrigatórios, cit.), mas persistem algumas questões: como justificar as previsões constitucionais específicas no sentido de se autorizar apenas excepcionalmente o efeito vinculante das decisões judiciais, como no caso das súmulas vinculantes? Não se argumente que, neste caso, a necessidade de emenda constitucional estaria relacionada à extensão da vinculação à Administração Pública, pois neste caso não teria sentido a previsão, constante na norma constitucional, de que a súmula vincula também os demais órgãos do Poder Judiciário. De qualquer forma, em outra obra o autor parece admitir que "essa, todavia, não é a solução proposta ao problema pelo direito brasileiro - mantida a solução divergente, far-se-á o exame de admissibilidade do recurso especial (art. 543-C, $\S \S 7^{\circ}$, II, e $8^{\circ}$, CPC" (MARINONI, Luiz Guilherme; MITIDIERO, Daniel, Código de Processo Civil: comentado artigo por artigo, cit., p. 573).

${ }^{343}$ MARINONI, Luiz Guilherme, Precedentes obrigatórios, cit., p. 480.

${ }^{344}$ Ibidem, p. 500.
} 
A jurisprudência do STF também tem interpretado que a técnica de julgamento de recursos repetitivos autoriza o efeito vinculante, como se observa em passagens de alguns precedentes. $^{345}$

No âmbito do STJ, embora já se tenha afirmado a existência do efeito vinculante ${ }^{346}$, prevalece claramente nas três Seções o entendimento de que a possibilidade de manutenção do entendimento divergente pelo órgão de origem, expressamente prevista pelo artigo 543$\mathrm{C}, \S 8^{\circ}$, do CPC, indica de forma clara que o acórdão paradigma não vincula os demais órgãos judiciais. ${ }^{347}$

De qualquer modo, a tendência parece ser a de se inserir no sistema expressamente o efeito vinculante, prevendo-se inclusive reclamação contra a decisão que não observa o acórdão paradigma. ${ }^{348}$

Trata-se, a nosso ver, de interpretação que contrasta com a Constituição Federal. Pelas razões já expostas acima e no Capítulo 2 (itens 2.4 .2 e 2.4.3.4), o efeito vinculante só pode ser autorizado pela própria Constituição Federal.

Mais correto, no nosso entendimento, é a opinião de Athos Gusmão Carneiro, comentando o artigo 543-C do CPC, no sentido de que o efeito vinculante não está

\footnotetext{
${ }^{345}$ Por exemplo, o seguinte precedente do Pleno: “As decisões proferidas pelo Plenário do Supremo Tribunal Federal quando do julgamento de recursos extraordinários com repercussão geral vinculam os demais órgãos do Poder Judiciário na solução, por estes, de outros feitos sobre idêntica controvérsia." (STF - Rcl n. 10.793, Pleno, rel. Min. Ellen Gracie, j. 13.04.2011).
}

${ }^{346}$ No STJ, o relator menciona em seu voto que seria obrigatória a adoção da tese repetitiva adotada pelo tribunal competente para conferir a última exegese à legislação (REsp n. 1.111.743/DF, Corte Especial, rel. Min. Nancy Andrighi, rel. para acórdão Min. Luiz Fux, DJe, de 21.06.2010),

347 "É inadmissível a utilização da reclamação prevista no art. 105 , I, 'f', da $\mathrm{CF} / 88$, quando se revele manifesta a ilegitimidade ativa dos reclamantes, por não terem figurado na relação processual em que foi proferida a decisão judicial oriunda deste Tribunal Superior tida como descumprida, mesmo que resulte esta do julgamento de recurso nos moldes do art. 543-C do CPC, vez que não existe previsão legal para que a decisão proferida pelo STJ no recurso repetitivo tenha efeito vinculante". (STJ - AgR Rcl n. 5.121/SP, $2^{\text {a }}$ Seção, rel. Min. Nancy Andrighi, j. 23.02.2011, DJe, de 02.03.2011). "Processual Civil. Agravo Regimental na Reclamação. Alegação de que a corte de origem contrariou entendimento consolidado em Recurso Especial Repetitivo. Efeito vinculante inexistente. Pedido incabível”. (STJ - AgR Rcl n. 4.353/SP, $1^{a}$ Seção, rel. Min. Benedito Gonçalves, j. 24.10.2010, Dje, de 30.11.2010). "Reclamação. Julgamento pelo STF de matéria afetada como Recurso Especial Repetitivo. Ausência de efeito vinculante do julgamento do STJ” (STJ - AgR Rcl n. 3.644/DF, 3ª Seção, rel. Min. Jorge Mussi, j. 28.10.2009, DJe, de 26.11.2009).

${ }^{348}$ É o que se observa na redação atual do projeto do CPC, que contém disposições no sentido de prever reclamação para garantir a observância da "tese firmada em julgamento de casos repetitivos" (art. 1.000, IV). 
presente na técnica de julgamento de recursos repetitivos, tratando-se apenas de uma "tendência”, cuja implementação, porém, “exigirá expressa previsão legal”. E mesmo assim, ao comentar o efeito vinculante previsto no incidente de resolução de demandas repetitivas de que trata o projeto de novo CPC (que de certa forma estende a técnica dos arts. 543-B e 543-C do CPC em vigor ao julgamento das próprias demandas repetitivas no primeiro grau), o autor afirma tratar-se de previsão “cuja constitucionalidade merecerá, por certo, profunda reflexão". 349

No mesmo sentido, Teresa Arruda Alvim Wambier, ao comentar o artigo 543-B, § $4^{\circ}$, do CPC, que permite a manutenção do entendimento divergente pelo órgão de origem, afirma que tal hipótese "não pode ser afastada, a não ser que o STF edite súmula vinculante sobre o tema" 350 . Esse também é o entendimento de José Miguel Garcia Medina. ${ }^{351}$

Por sua vez, Eduardo Talamini demonstra claramente que "a retratação não é obrigatória" e que, portanto, "não há na hipótese força vinculante propriamente dita". O que há, na visão do autor, com a qual concordamos, é um efeito persuasivo ampliado do precedente formado com o julgamento do recurso representativo da controvérsia:

\begin{abstract}
A posição assumida pelo Supremo Tribunal em julgamento destinado precisamente a pautar uma pluralidade de recursos (portanto, uma decisão que se pode supor adotada com adicional prudência), se não vincula estritamente, é fortíssimo argumento de autoridade. Some-se a isso a imposição de razoabilidade: se a decisão não for objeto de retratação, será depois revista pelo próprio STF. Daí que, ainda que o órgão prolator da decisão recorrida tenha a possibilidade de não se retratar, apenas deverá seguir por essa senda se reputar que o caso posto para o seu exame reveste-se de peculiaridades que não autorizam submetê-lo à decisãoquadro ou, ainda, se entender que dispõe de argumentos que não foram considerados no julgamento do recurso-amostra. ${ }^{352}$
\end{abstract}

\footnotetext{
${ }^{349}$ CARNEIRO, Athos Gusmão, Recurso especial, agravos e agravo interno, cit., p. 115.

${ }^{350}$ WAMBIER, Teresa Arruda Alvim, Recurso especial, recurso extraordinário e ação rescisória, cit., p. 306.

351 MEDINA, José Miguel Garcia. Código de Processo Civil comentado: com remissões e notas comparativas ao Projeto do novo CPC. São Paulo: Revista dos Tribunais, 2011. p. 663.

352 TALAMINI, Eduardo, Novos aspectos da jurisdição constitucional brasileira: repercussão geral, força vinculante, modulação dos efeitos do controle de constitucionalidade e alargamento do objeto do controle direto, cit., p. 77.
} 
De fato, o sistema atualmente vigente é muito claro em estabelecer a plena possibilidade de manutenção do entendimento adotado pelo órgão de origem, mesmo quando contrário à orientação firmada pelo STF ou pelo STJ. O que muda nesse caso é apenas que o órgão de origem passa a ter que fundamentar sua decisão, expondo persuasivamente os motivos pelos quais mantém o entendimento contrário à posição do órgão superior.

Esse dever de fundamentação, que inclusive já levou à anulação de decisões dos órgãos de origem que simplesmente se recusaram a seguir a orientação dos precedentes sem exposição dos motivos dessa decisão ${ }^{353}$, nada tem a ver com efeito vinculante. Tratase de um dever que decorre diretamente do próprio princípio constitucional da motivação das decisões judiciais, o qual, no nosso entendimento, impõe que se levem em consideração as decisões oficialmente dotadas de alto poder de influência no sistema, eis que emanadas dos órgãos criados pela Constituição Federal justamente para estabelecer a exata e uniforme interpretação do direito positivo no território nacional (ver Capítulos 2 e $3){ }^{354}$

Ademais, ainda segundo as disposições do sistema atualmente em vigor, quando o órgão de origem adota entendimento que coincide com a decisão do órgão superior, ele passa a ter de negar seguimento ao recurso excepcional sobrestado. Mas isso também não implica qualquer efeito vinculante, pois não se está falando do dever de observar a interpretação fixada pelo órgão superior (aliás, ela já foi observada, tanto que as decisões são coincidentes), mas sim do dever de indeferir liminarmente ou negar seguimento ao recurso contrário à jurisprudência. E, mesmo assim, trata-se, aqui, de eficácia persuasiva, de modo que o órgão de origem pode e deve admitir o recurso excepcional, sobretudo quando verificar que a parte recorrente aponta distinções e fundamentos de fato e de direito novos em seu caso, com relação aos precedentes do STF e do STJ. ${ }^{355}$

\footnotetext{
${ }^{353}$ STJ - QO REsp n. 1.148.726/RS; REsp n. 1.146.696/RS; REsp n. 1.153.937/RS; REsp n. 1.154.288/RS; REsp n. 1.155.480/RS e REsp n. 1.158.872/RS, rel. Min. Aldir Passarinho Junior, j. 10.12.2009.

${ }^{354}$ A esse respeito, aliás, merece aplauso a disposição prevista na versão atual do projeto de CPC, prevendo que não se considera fundamentada a decisão que não leva em consideração o teor do precedente, seja para aplicá-lo seja para abandoná-lo por distinguishing ou overruling. Nesse sentido, ver artigos $499, \S 1^{\circ}$, VI, e $521, \S 6^{\circ}$.

355 “Também nessa hipótese, não há vinculação propriamente dita. O órgão a quo pode remeter o recurso extraordinário ao STF, em vez de considerá-lo prejudicado (art. 543-B, § 4º." (TALAMINI, Eduardo, Novos aspectos da jurisdição constitucional brasileira: repercussão geral, força vinculante, modulação dos efeitos do controle de constitucionalidade e alargamento do objeto do controle direto, cit., p. 78).
} 
Note-se, ainda, que no sistema atual não cabe reclamação contra a decisão que deixa de observar o precedente fixado pelo STF e pelo STJ no julgamento do caso representativo da controvérsia, o que também confirma que o sistema de julgamento de recursos repetitivos não estabelece qualquer efeito vinculante.

Por fim, deve-se analisar especificamente a hipótese de reconhecimento de ausência de repercussão geral da questão constitucional, pois a própria lei declara, de forma expressa, que "os recursos sobrestados considerar-se-ão automaticamente não admitidos" (art. 543-B, $\S 2^{\circ}$, do CPC), em uma espécie de efeito vinculante criado por lei ordinária.

Quanto a esse ponto, a única forma de se entender pela constitucionalidade da norma é interpretar que não há efeito vinculante propriamente dito ${ }^{356}$, inerente às súmulas editadas sob o procedimento do artigo 103-A da Constituição, mas sim efeito persuasivo especial, tal como aquele tratado no Capítulo 2 (item 2.4.3.4), relacionado a providências de simplificação do procedimento. ${ }^{357}$

Isso significa que, havendo precedente do STF reconhecendo a ausência de repercussão geral, o órgão de origem deve sim declarar a inadmissibilidade do recurso extraordinário repetitivo por ausência de repercussão geral, para fins de celeridade, economia e eficiência processual. A necessidade de envio dos autos ao STF, para que este repetisse a afirmação de que a questão é desprovida de repercussão, seria contraproducente, servindo apenas para atrasar o procedimento e tornar mais custosa e difícil a prestação jurisdicional.

Permite-se, assim, que o próprio órgão de origem reconheça a incidência do precedente ao caso, negando seguimento ao recurso. Com isso, esses órgãos não estarão emitindo juízo de valor sobre a inexistência da repercussão (matéria que compete

\footnotetext{
${ }^{356}$ Conforme Cassio Scarpinella Bueno, "não há efeitos vinculantes nas decisões proferidas pelo Supremo Tribunal Federal em sede de recurso extraordinário, inclusive quando se fixa a existência (ou a inexistência) da repercussão geral ainda que a partir do exame de casos repetitivos" (BUENO, Cassio Scarpinella, Curso sistematizado de direito processual civil, cit., v. 5, p. 299).

357 TALAMINI, Eduardo, Novos aspectos da jurisdição constitucional brasileira: repercussão geral, força vinculante, modulação dos efeitos do controle de constitucionalidade e alargamento do objeto do controle direto, cit., p. 92.
} 
exclusivamente ao STF), mas simplesmente antecipando a inadmissibilidade por razões de eficiência, celeridade e economia (princípio da razoável duração do processo).

No entanto, para que a norma seja considerada constitucional, é imperioso interpretar que não há propriamente obrigação de inadmitir o recurso extraordinário, de modo que o órgão a quo pode admiti-lo por decisão fundamentada e enviá-lo ao STF, até para a realização de eventual distinguishing ou overruling em relação ao precedente que afastou a repercussão geral. Caso contrário, dificilmente o STF teria oportunidade de revisar a tese sobre a ausência de repercussão geral.

Assim, admitido o recurso e enviado à instância superior, o STF não poderá cassar a decisão de admissão, pois não houve descumprimento de qualquer precedente obrigatório, cabendo-lhe apenas realizar o juízo definitivo de admissibilidade do recurso, que muito provavelmente será no sentido do não conhecimento por ausência de repercussão geral, de acordo com o próprio precedente sobre a questão, sem prejuízo da eventual revisão da tese.

Porém, deve-se consignar que essa interpretação, aqui apresentada como a mais correta e consentânea com o modelo constitucional do nosso processo civil, fica prejudicada pelo entendimento da jurisprudência do próprio STF que, como se demonstrará no item 6.5 infra, não admite agravo de admissão nem reclamação contra a decisão do órgão a quo que aplica o precedente sobre a ausência de repercussão geral e, mais do que isso, entende que a Corte Suprema não tem sequer competência para negar seguimento aos recursos repetitivos com base em repercussão geral já reconhecida (essa competência seria, segundo a sistemática de julgamento de recursos repetitivos, dos órgãos de origem).

Ou seja, segundo a jurisprudência do STF, na prática, o precedente que reconhece a ausência de repercussão geral de fato tem eficácia vinculante propriamente dita, ou atua como precedente impeditivo de recurso, o que, a nosso ver, compromete a constitucionalidade do sistema quanto a esse ponto. 


\subsection{Necessidade de se permitir a impugnação ao STF e ao STJ das decisões dos órgãos de origem que negam seguimento aos recursos repetitivos por contrariedade ao acórdão paradigma. Crítica à jurisprudência}

Como demonstrado no Capítulo 3, a constitucionalidade da competência dos órgãos de origem para o juízo prévio de admissibilidade dos recursos excepcionais está condicionada à recorribilidade da eventual decisão de inadmissão por meio do agravo previsto pelo artigo 544 do CPC, o qual, uma vez interposto, deve, segundo a jurisprudência do STF e do STJ, ser simplesmente remetido ao tribunal ad quem, sem qualquer manifestação sobre sua admissibilidade, sob pena de violação à competência constitucional da instância superior e possibilidade do destrancamento do recurso pela via da reclamação constitucional. ${ }^{358}$

Pelas mesmas razões, interpretando as regras previstas nos artigos 543-B e 543-C do CPC, a doutrina vem defendendo o cabimento do agravo de admissão (art. 544 do CPC) contra a decisão do tribunal de origem que nega seguimento ao recurso repetitivo contrário à tese fixada no julgamento do acórdão paradigma pela instância superior (no sentido do reconhecimento da ausência da repercussão geral ou da definição da controvérsia sobre a questão federal constitucional ou infraconstitucional), sobretudo porque o recurso pode tratar de caso distinto daquele apreciado pela instância superior, ou ainda veicular argumentos novos e diferentes dos efetivamente levados em consideração no julgamento do recurso representativo da controvérsia.

\footnotetext{
${ }^{358}$ No âmbito do STF, a matéria foi fixada pela Súmula 727: "Não pode o magistrado deixar de encaminhar ao Supremo Tribunal Federal o agravo de instrumento interposto da decisão que não admite recurso extraordinário, ainda que referente a causa instaurada no âmbito dos juizados especiais". Confira-se, ainda, o seguinte precedente: "Cabe reclamação, para o Supremo Tribunal Federal, nos casos em que o Presidente da Turma Recursal, usurpando competência outorgada à Suprema Corte, nega trânsito a agravo de instrumento interposto contra decisão que não admitiu recurso extraordinário. Precedentes". (STF - Rcl n. 1.025/SC, Pleno, rel. Min. Celso de Mello, DJ, de 28.02.2003, p. 10). Os precedentes do STJ são no mesmo sentido: “1. Nos termos do art. 544, $\S \S 3^{\circ}$ e $4^{\circ}$, do Código de Processo Civil, compete ao Relator, no Superior Tribunal de Justiça, decidir o agravo de instrumento interposto contra decisão que não admite o recurso especial. 2. É defeso ao Tribunal de origem obstar o seguimento do agravo de instrumento dirigido a esta Corte, ainda que esteja totalmente convencido de sua fragilidade. Precedentes. 3. Procedência da reclamação para determinar ao Tribunal local a remessa dos autos do agravo de instrumento a este Superior Tribunal de Justiça." (STJ - Rcl n. 1.453/PE, 2 ${ }^{a}$ Seção, rel. Min. Fernando Gonçalves, DJ, de 11.10.2007).
} 
Nesse sentido, Athos Gusmão Carneiro leciona que, "caso seu recurso especial venha por fim a ser considerado como prejudicado, e portanto com seguimento denegado, poderá interpor agravo de instrumento ao STJ (art. 544 do CPC)". ${ }^{359}$

Da mesma forma, Luiz Rodrigues Wambier e Rita de Cássia Corrêa de Vasconcelos defendem que, sendo negado seguimento ao recurso que estava sobrestado, "não poderá ser negada a via recursal, permitindo-se a interposição de agravo de instrumento ao STJ (CPC, art. 544). Até porque, é possível que se esteja diante de hipótese em que não haja identidade entre a questão veiculada no recurso sobrestado e a que se julgou no recurso escolhido". 360

Também é esse o entendimento de Nelson Rodrigues Netto que, em comentário ao artigo 543-C do CPC, conclui que "o juízo negativo de admissibilidade proferido pelos Tribunais de origem é provisório, de modo que contra esta decisão é cabível o recurso de agravo, na modalidade instrumento, e com as peculiaridades de processamento previstas no art. 544 do CPC". 361

Para André Almeida Garcia, "a hipótese de aplicação indevida do decidido no caso líder ao recurso sobrestado não comportaria maior polêmica: afinal, uma vez denegado o seguimento de recurso extraordinário ou especial, pelo motivo que for, a lógica seria a interposição do agravo do art. 544 do CPC ao Tribunal competente". ${ }^{362}$

Todas essas considerações, embora relacionadas diretamente o artigo 543-C, valem para o artigo 543-B do CPC, inclusive para os casos em que a negativa de seguimento se funda na ausência de repercussão geral da questão constitucional.

\footnotetext{
${ }^{359}$ CARNEIRO, Athos Gusmão, Primeiras observações sobre a lei dos recursos repetitivos, cit., p. 86.

${ }^{360}$ WAMBIER, Luiz Rodrigues; VASCONCELOS, Rita de Cássia Corrêa de. Recursos especiais repetitivos: reflexos das novas regras (Lei 11.672/2008 e Resolução 8 do STJ) nos processos coletivos. Revista de Processo, São Paulo, v. 33, n. 163, p. 31-32, set. 2008.

361 RODRIGUES NETTO, Nelson, Análise crítica do julgamento “por atacado" no STJ: (Lei 11.672/2008 sobre recursos especiais repetitivos), cit., p. 242.

362 GARCIA, André Almeida. O drama dos "sobrestados" e a utilização de um incidente autônomo de julgamento por amostragem. Disponível em: <http:// www.lex.com.br/ doutrina_ 23260023_O_ DRAMA_DOS_SOBRESTADOS_E_A_UTILIZACAO_DE_UM_INCIDENTE_AUTONOMO_DE_JUL GAMENTO_POR_AMOSTRAGEM.aspx>. Acesso em: 09 set. 2013. O cabimento do agravo de admissão também é defendido em: THEODORO JÚNIOR, Humberto, O novo art. 543-C do Código de Processo Civil (Lei $\mathrm{n}^{\circ}$ 11.672, de 8.5.2008), cit., p. 197; BONDIOLI, Luiz Guilherme Aidar, A nova técnica de julgamento dos recursos extraordinário e especial repetitivos, cit., p. 14.
} 
Aliás, conforme Humberto Theodoro Júnior, Dierle José Coelho Nunes e Alexandre Gustavo Melo Franco Bahia, a constitucionalidade do sistema de inadmissibilidade de recursos extraordinários repetitivos por ausência de repercussão geral está condicionada à possibilidade de interposição de agravo de admissão pelas partes, instrumento esse que inclusive passa a ter "sua importância redimensionada e potencializada eis que se apresentaria como um peculiar mecanismo mediante o qual a parte, que teve seu recurso extraordinário (espécie) inadmitido, demonstrasse que seu caso se encontra fora do espectro da tese já manifestada". ${ }^{363}$

Em comentário ao artigo 543-B, § 2º do CPC, André de Albuquerque Cavalcanti Abbud também entende que "naturalmente, contra essa decisão caberá o agravo de instrumento previsto no art. 544 do Código de Processo Civil (RISTF, art. 313). Ele será, com efeito, o instrumento hábil a pleitear a correção de eventuais equívocos ou abusos cometidos na origem na inadmissão de recursos reputados idênticos". 364

De fato, tratando-se, como visto no item 6.3 supra, de decisão de inadmissão do recurso excepcional (seja pela ausência de repercussão geral da matéria constitucional objeto do recurso extraordinário, seja pela contrariedade à tese defendida no recurso extraordinário ou especial em relação à tese fixada no julgamento do recurso paradigma pelo STF ou STJ), a possibilidade de interposição do agravo está prevista no próprio texto legal (art. 544 do CPC), sem qualquer ressalva pelos artigos 543-B e 543-C do CPC.

Não fosse isso o bastante, negar a possibilidade de interposição de agravo de admissão nessas hipóteses equivaleria a negar o acesso das partes à instância superior, mesmo quando seu caso individual não se identificasse perfeitamente com o recurso julgado pelo STF ou STJ. Equivaleria, também, a violar a garantia do contraditório e da ampla defesa, pois pode ocorrer de os fundamentos arguidos pela parte que tem seu recurso

\footnotetext{
363 THEODORO JÚNIOR, Humberto; NUNES, Dierle José Coelho; BAHIA, Alexandre Gustavo Melo Franco. Litigiosidade em massa e repercussão geral no recurso extraordinário. Revista de Processo, São Paulo, v. 34, n. 177, p. 43, nov. 2009.

364 ABBUD, André de Albuquerque Cavalcanti, A repercussão geral dos recursos extraordinários e o julgamento por amostragem no âmbito do Supremo Tribunal Federal (CPC, arts. 543-A e 543-B), in As novas reformas do CPC e de outras normas processuais, cit., p. 313.
} 
sobrestado não serem apreciados no julgamento dos recursos representativos da controvérsia. ${ }^{365}$

Com isso, os artigos 102, III, e 105, III, da CF seriam duplamente afrontados, seja pela violação ao direito subjetivo das partes à interposição dos recursos extraordinário e especial, seja pelo impedimento da atuação das próprias funções públicas (nomofilácica e paradigmática) exercidas por esses recursos no sistema.

Ou seja, a vedação do agravo representaria um cerceamento muito rígido do acesso das partes ao STF e ao STJ, afetando o necessário equilíbrio entre o direito das partes à utilização dos recursos excepcionais como meio disponibilizado pelo sistema para a tentativa de melhorar a sua situação particular no processo e a peculiar função pública exercida por esses recursos no sistema jurídico.

Ademais, como já demonstrado em no item 6.4 supra, a decisão do STF ou do STJ que julga o recurso representativo da controvérsia não tem eficácia vinculante, razão pela qual a parte pode impugnar a decisão do órgão de origem que, com base nela, negar seguimento a recurso repetitivo. Caso contrário, estaria instituído, por lei ordinária, algo semelhante à súmula impeditiva de recurso que se pretende positivar por meio da PEC $358 / 2005$, e, portanto, o sistema seria inconstitucional.

As mesmas razões aqui expostas justificam o cabimento do agravo de admissão também contra a decisão que nega seguimento ao recurso excepcional interposto pela parte contrária (antes vencedora e agora vencida) contra o novo acórdão do tribunal de origem

\footnotetext{
365 “[...] uma vez que o julgamento se dá apenas sobre alguns recursos (ainda que idênticos), apenas as razões/teses debatidas pelo(s) recorrente(s)/ recorrido(s) pinçado(s) serão consideradas pelo Tribunal $a d$ quem. Nada garante, inclusive, que sejam as melhores/mais completas. O que acontece com as razões daqueles que não tiveram a 'sorte' de ter seus recursos escolhidos? Percebe-se uma clara violação aos princípios do devido processo legal, ampla defesa e contraditório, na medida em que a parte que não teve suas razões consideradas pelo STF terá tido, por isso, um sério prejuízo à sua defesa, além do que o contraditório, mais do que garantir o direito a se manifestar, garante o direito subjetivo de que as razões jurídicas apresentadas pela parte sejam devidamente consideradas (e, portanto, enfrentadas) pelo órgão julgador." (BAHIA, Alexandre Gustavo Melo Franco; VECCHIATTI, Paulo Roberto Iotti. Inconstitucionalidade do requisito da repercussão geral do recurso extraordinário e da técnica do julgamento por pinçamento. Revista dos Tribunais, São Paulo, v. 100, n. 911, p. 248-249, set. 2011).
} 
que, em virtude da retratação autorizada pelos artigos 543-B e 543-C do CPC, ajusta seu entendimento àquele fixado pelo STF e pelo STJ. ${ }^{366}$

E o mesmo se diga quanto às decisões denegatórias de seguimento aos futuros recursos extraordinários e especiais, eventualmente interpostos contra acórdãos que apliquem o entendimento firmado pelo STF ou pelo STJ no julgamento dos recursos representativos da controvérsia.

Na verdade, toda decisão proferida em sede de juízo prévio de admissibilidade que conclua pela inadmissão do recurso tem de ser contrastável por recurso apto a levar a questão ao órgão competente para a realização do juízo definitivo, pois é isso que garante a sua legitimidade.

Por exemplo, segundo o artigo 518, $\S 1^{\circ}$, do CPC, o juízo a quo inadmitirá o recurso de apelação contrário à súmula do STF ou do STJ, mas a parte poderá interpor agravo de instrumento ao tribunal competente para exercer o juízo definitivo de admissibilidade e apreciar o mérito do recurso. No tribunal, o relator pode negar seguimento monocraticamente ao recurso, mas a parte sempre pode interpor agravo interno ao órgão colegiado. ${ }^{367}$

\footnotetext{
366 "De todo modo - e eis a condição inafastável para que a nova sistemática possa ser aceita como constitucional -, a decisão que negar seguimento ao recurso ou que promover a retratação será passível, ela mesma, de recurso para o Superior Tribunal. A decisão de retratação poderá dar ensejo a outro recurso especial, do adversário do recorrente original - que terá de observar todos os requisitos de cabimento recursal. A decisão que negar seguimento ao recurso especial poderá ser objeto de agravo de instrumento. Em qualquer das duas hipóteses, o recorrente poderá demonstrar, por exemplo, que seu caso não é idêntico ao recurso 'amostra' julgado pelo Superior Tribunal e que teria ensejado a retratação ou a negativa de subida." (TALAMINI, Eduardo. Julgamento de recursos no STJ "por amostragem". Informativo Justen, Pereira, Oliveira e Talamini, Curitiba, PR, n. 14, abr. 2008. Disponível em: <http:// www.justen.com.br/ /informativo.php?\&informativo=14\&artigo=796\&l=pt\#>. Acesso em: 11 nov. 2013.

${ }^{367}$ Segundo Barbosa Moreira, em comentário ao artigo 557 do CPC, com a ressalva das súmulas vinculantes, nem sempre será condenável a impugnação de decisão que aplica a jurisprudência dominante ou sumulada e o relator deve analisar com cuidado especial as razões do recurso. Isso porque "sempre é possível que haja aí argumentos novos, até então não considerados. Preferível suportar algum peso a mais na carga de trabalho dos tribunais a contribuir para a fossilização da jurisprudência. A lei do menor esforço não é necessariamente, sob quaisquer condições, boa conselheira" (MOREIRA, José Carlos Barbosa, Comentários ao Código de Processo Civil: Lei n. 5.869, de 11 de janeiro de 1973, arts. 476 a 565, cit., v. 5, p. 683). Para Cassio Scarpinella Bueno, a importância do agravo interno é maior quando se trata de decisão monocrática que nega seguimento a recurso com base em contrariedade à jurisprudência, pois aqui, mais do que permitir o exame do acerto ou desacerto da decisão monocrática, trata-se de "viabilizar uma mais ampla discussão dos próprios precedentes e sua aplicação em cada caso concreto" (BUENO, Cassio Scarpinella, Curso sistematizado de direito processual civil, cit., v. 5, p. 127).
} 
O mesmo se passa no STF e no STJ: embora o relator possa julgar monocraticamente o recurso excepcional, a lei prevê expressamente o cabimento de agravo interno ao órgão colegiado, o que, segundo a doutrina e a jurisprudência dos próprios Tribunais Superiores, é necessário para garantir a constitucionalidade desse sistema.

Poder-se-ia questionar a conveniência desse sistema: de que adiantaria toda essa sistemática se, no fim, as partes poderiam insistir na submissão do seu caso ao STF e ao STJ por meio de agravo de admissão? Não restariam frustrados os objetivos do sistema, ao menos quanto à concretização do princípio da razoável duração do processo?

$\mathrm{O}$ mesmo se diga quanto à técnica do artigo 518, § $1^{\circ}$, do $\mathrm{CPC}$ e do julgamento monocrático dos recursos nos tribunais. No primeiro caso, a inadmissibilidade do recurso com base em contrariedade à súmula pode ser inútil e só fazer aumentar a quantidade de recursos: ao invés de um recurso (apelação), podem surgir três (apelação, agravo de instrumento e agravo interno contra a decisão monocrática de inadmissão do agravo de instrumento no tribunal). No segundo caso, de que serve o julgamento monocrático se se garante à parte interpor agravo interno ao órgão colegiado? Não seria melhor já submeter o recurso diretamente ao órgão colegiado?

Ao que parece, a inadmissibilidade prévia dos recursos por contrariedade à jurisprudência dominante ou sumulada atua como um filtro eficiente. É o que se nota, por exemplo, pela verificação da taxa de recorribilidade interna das decisões proferidas pelo STJ, que tem sido de aproximadamente $20 \%{ }^{368}$

O que se espera é que, quando a inadmissão baseia-se em jurisprudência dominante ou sumulada, e desde que seja corretamente aplicada, a parte fique desestimulada de agravar, haja vista a identificação de que o seu caso de fato ajusta-se à jurisprudência dominante. Agravar, nesses casos, representa inclusive um risco a ser contabilizado pela parte, haja vista a possibilidade de aplicação de multa por litigância de má-fé (arts. 14, 17 e $557, \S 2^{\circ}$, do $\mathrm{CPC}$ ), caso o recurso não aponte distinções fáticas ou fundamentos novos, não apreciados pelo STF ou pelo STJ nos precedentes invocados para justificar a negativa de seguimento ao recurso.

\footnotetext{
${ }^{368}$ Por exemplo, segundo as estatísticas do STJ, a taxa de recorribilidade interna da Corte ficou em 20,88\% no ano de 2012 (Disponível em: 〈www.stj.jus.br〉. Acesso em: 15 jun. 2013).
} 
Assim, principalmente se a aplicação fundamentada da multa por recurso protelatório tornar-se uma realidade prática, a tendência deve ser a de que o agravo só seja interposto nos casos em que realmente a parte tem um fundamento fático ou jurídico novo, com aptidão de superar o precedente (overruling), ou então quando o caso apresentar alguma particularidade que o diferenciar do precedente invocado pela decisão de inadmissão (distinguishing), hipóteses em que o recurso será saudável para o sistema, por evitar o engessamento da jurisprudência e contribuir para a evolução do direito.

De qualquer modo, conveniente ou não, esse é o sistema posto e que está em conformidade com a Constituição Federal.

Entretanto, o STF e o STJ pacificaram o entendimento de que não cabe agravo de admissão (art. 544, CPC) nem reclamação contra a decisão do tribunal de origem que nega seguimento a recurso extraordinário ou especial contrário à tese fixada no julgamento do recurso representativo da controvérsia. E, tratando-se de negativa de seguimento de agravo de admissão repetitivo, também não cabe reclamação, a despeito do teor da Súmula 727 do STF.

No STF, esse entendimento foi firmado com o julgamento da Questão de Ordem no Agravo de Instrumento n. 760.358, concluído em 19.11.2009 ${ }^{369}$. Por votação unânime, restou definido que contra a decisão do tribunal de origem que aplica o precedente do STF firmado no julgamento do mérito do recurso paradigma, para declarar prejudicado (ou negar seguimento) o recurso repetitivo divergente que estava sobrestado, não cabe agravo de instrumento, mas sim agravo regimental (ou melhor, agravo interno), a ser decidido pelo próprio tribunal de origem.

Em resumo, os fundamentos adotados pelos integrantes do STF para chegar a tal conclusão referem-se à necessidade de se interpretar a técnica de julgamento de recursos extraordinários repetitivos de acordo com a lógica do sistema, no sentido de redução do número de feitos na Corte Suprema. Admitir agravo de admissão ou reclamação equivaleria a manter o sistema anterior, em que a corte era obrigada a apreciar individualmente os recursos das partes. As partes sempre insistiriam na submissão do caso

${ }^{369}$ STF - QO AI n. 760.358/SE, rel. Min. Gilmar Mendes, DJe, de 11.02.2010. 
ao STF, alegando algum equívoco na aplicação do precedente. A solução, assim, seria admitir o agravo regimental no âmbito do próprio tribunal de origem, como forma de conferir à parte algum meio de controle de eventuais erros cometidos pela decisão que aplica o precedente.

Na mesma data, o STF julgou a Reclamação n. 7.569, sob a relatoria da ministra Ellen Gracie, no qual restou assentado, de forma unânime, que "se não houve juízo de admissibilidade do recurso extraordinário, não é cabível a interposição do agravo de instrumento previsto no art. 544 do Código de Processo Civil". ${ }^{370}$ A parte ajuizara a reclamação porque o órgão a quo julgou prejudicado seu recurso extraordinário com base em decisão do STF que, apreciando recurso extraordinário representativo da controvérsia, considerou inexistir repercussão geral na matéria constitucional repetitiva. Entretanto, segundo a parte recorrente, seu caso não se identificaria totalmente com a matéria apreciada no caso representativo da controvérsia.

O acórdão do STF, relatado pela então ministra Ellen Gracie, menciona que até então integrantes da corte vinham, em casos análogos, acolhendo reclamações para admitir o processamento do recurso extraordinário. Mas isso causava preocupação, pois a reclamação se transformaria em via de acesso ao STF, e ocorreria uma violação da finalidade do instituto da repercussão geral e do sistema de julgamento de recursos repetitivos, previsto nos artigos 543-B do CPC e 328-A do RISTF, de diminuir a quantidade de recursos a serem apreciados pela Corte Suprema.

Nos termos do acórdão, os mencionados dispositivos preveem que o tribunal de origem não deverá realizar o juízo de admissibilidade de recursos extraordinários sobrestados, nem processar os agravos de instrumento (art. 544) já interpostos, até a definição da matéria pelo STF, a fim de que, negada a repercussão geral, os recursos sobrestados se considerem automaticamente inadmitidos ou prejudicados. Assim, não ocorrendo juízo de admissibilidade pelo tribunal de origem, não há que se falar no cabimento do agravo do artigo 544 do CPC.

${ }^{370} \mathrm{STF}-\mathrm{Rcl}$ n. 7.569, Pleno, rel. Min. Ellen Gracie, DJe, de 10.12.2009. 
No entanto, como já demonstrado nos itens anteriores, é claro que, julgado o recurso paradigma, o órgão a quo realiza sim um juízo de admissibilidade do recurso repetitivo, justamente para declarar que, à luz do acórdão do STF, ele não pode ser conhecido por falta de repercussão geral.

Ademais, ainda segundo o mencionado precedente, a jurisdição do STF só estaria instaurada na hipótese de o tribunal de origem manter o entendimento contrário ao fixado pela instância superior no julgamento do mérito do recurso extraordinário (conforme anteriormente decidido no julgamento da QO MC n. 2.177/PE, DJe, de 20.02.2009), caso em que caberia ao tribunal simplesmente remeter o agravo (art. 544 do CPC) ao STF. ${ }^{371}$

Todavia, também aqui o argumento merece ser criticado, pois a interpretação de que a lei ordinária (art. 543-B do CPC) limitou a jurisdição do STF quanto aos recursos extraordinários repetitivos fere o artigo 102, III, da CF, sendo, pois, inconstitucional.

De qualquer modo, aqueles dois precedentes de 19.11.2009 definiram ser incabível qualquer agravo de admissão ou reclamação contra as decisões dos tribunais de origem que aplicam o acórdão paradigma (seja o que define a ausência de repercussão geral da matéria constitucional, seja o que, reconhecendo-a, julga o mérito do recurso extraordinário), de modo que a parte que se sentir prejudicada pela aplicação eventualmente errônea do acórdão deve interpor agravo interno, a ser julgado pelo próprio tribunal de origem. ${ }^{372}$

Em face da modulação dos efeitos desses precedentes, os agravos e reclamações protocolados até então passaram a ser devolvidos à instância de origem para, com base no

\footnotetext{
${ }^{371}$ Isso porque, como veremos no Capítulo 10 (item 10.3), os $\S \S 3^{\circ}$ e $4^{\circ}$ do artigo 543-B dispõem que cabe ao tribunal de origem, após o julgamento do mérito do recurso extraordinário selecionado, reexaminar a questão e, no caso de divergência, retratar-se ou manter o entendimento divergente; nessa última hipótese, sendo admitido o recurso extraordinário, ou tratando-se de agravo de admissão anteriormente interposto, os autos deverão ser enviados ao STF. Deste modo, segundo o STF, o sistema indicaria que a jurisdição do tribunal de origem não se esgota enquanto não ocorrer eventual manutenção do entendimento contrário ao fixado pelo STF.

${ }^{372}$ Vale registrar que a discussão sobre o cabimento da reclamação foi restaurada no julgamento de agravos regimentais interpostos nas Reclamações ns. 11.427 e 11.408, iniciado em junho de 2011, e que ainda se encontra pendente no STF. Em 30.10.2013, após os votos dos ministros Ricardo Lewandowski, Ellen Gracie (aposentada) e Gilmar Mendes, todos contrários à reclamação, e do Ministro Marco Aurélio, favorável à admissão desse meio de impugnação, o ministro Luís Roberto Barroso Pediu vista dos autos. Conforme notícia divulgada pelo site do STF em 30.10.2013, os ministros Gilmar Mendes e Teori Albino Zavascki sinalizaram a possibilidade de admissão excepcional da reclamação em casos teratológicos (Disponível em: <http://www.stf.jus.br/portal/cms/verNoticiaDetalhe.asp?idConteudo=252370>. Acesso em: 31 out. 2013).
} 
princípio da fungibilidade, serem processados como agravo interno. E, a partir de então, os novos agravos e reclamações passaram a não ser mais conhecidos.

Além disso, a jurisprudência do STF também pacificou o entendimento de que os eventuais recursos extraordinários ou agravos de admissão (art. 544 do CPC) repetitivos que estejam no STF, ou forem enviados à Corte Suprema após a instauração do procedimento de julgamento de recursos repetitivos, devem ser imediatamente remetidos ao tribunal de origem para oportuna aplicação dos efeitos do acórdão paradigma, por decisão irrecorrível e que não precisa ser nem mesmo publicada!

Os agravos regimentais (ou internos) interpostos pelas partes contra essas decisões monocráticas não são sequer conhecidos, porque, para o STF, selecionado o recurso representativo da controvérsia, nenhum outro recurso repetitivo precisará voltar a ser apreciado, exceto na hipótese de, reconhecida a repercussão geral e julgado o mérito da controvérsia, houver manutenção de eventual decisão divergente pelo tribunal de origem. $^{373}$

No STJ, após alguma divergência ${ }^{374}$, a questão foi pacificada no mesmo sentido. No julgamento da Questão de Ordem no Agravo de Instrumento n. 1.154.599/SP (DJe, de 12.05.2011), em que a Corte Especial realizou a "exegese dos arts. 543 e 544 do CPC",

\footnotetext{
373 "Ato do relator que, admitindo o recurso extraordinário, determina a devolução dos autos respectivos ao Tribunal de origem, para que, neste, seja observado o que dispõe o art. 543-B do CPC - ato judicial que não possui conteúdo decisório nem se reveste de lesividade - irrecorribilidade - consequente não conhecimento do primeiro recurso de agravo - inconformismo da parte interessada que deduziu novo recurso de agravo ('agravo interno'), desta vez contra a decisão que não conheceu do primeiro recurso de agravo improvimento desse novo recurso, com determinação de devolução imediata dos autos ao Tribunal de origem, independentemente da publicação do acórdão referente ao presente julgamento." (STF - AgR AI n. 503.064 /MG, $2^{\mathrm{a}}$ Turma, rel. Min. Celso de Mello, j. 02.03.2010, DJe, de 25.03.2010).

${ }^{374}$ Por exemplo, a $1^{\text {a }}$ Seção chegou a admitir, por unanimidade, reclamação contra a decisão que, com base na sistemática do artigo 543-C do CPC, denegou seguimento a agravo de admissão: “[...] 4. A Súmula 727/STF, em releitura para o âmbito do Superior Tribunal de Justiça, teria a seguinte redação: Não pode o magistrado deixar de encaminhar ao Superior Tribunal de Justiça o agravo de instrumento interposto da decisão que não admite recurso especial, ainda que referente a 'recurso repetitivo' (art. 543-C do CPC). 5. Apesar de muitas vezes indesejado, em razão da celeridade processual, o direito posto é claro ao dar ao agravo de instrumento de despacho denegatório cunho forçado para alcançar o Tribunal Superior, inexistindo autorização legal para que seja obstado pelo Tribunal de origem (ressalvada a exceção do art. $542, \S 3^{\circ}$, do CPC, situação que não se trata nestes autos). Reclamação procedente, para determinar a subida do agravo de instrumento de despacho denegatório do recurso especial." (STJ - Rcl n. 3825/RJ, $1^{\text {a }}$ Seção, rel. Min. Humberto Martins, j. 10.11.2010, DJe, de 17.11.2010).
} 
ficou assentado o entendimento de que "não cabe agravo de instrumento contra decisão que nega seguimento a recurso especial com base no art. $543, \S 7^{\circ}$, inciso I, do CPC". ${ }^{375}$

No referido julgamento, prevaleceu o voto do relator, ministro César Asfor Rocha, no sentido do descabimento do agravo por razões que decorrem, basicamente, da interpretação teleológica da técnica de julgamento de recursos repetitivos instituída pelo artigo 543-C do CPC, criada para resolver o problema do excesso de recursos na instância superior e a consequente afetação do exercício adequado das funções do STJ.

Ou seja, o cabimento do agravo de admissão e a obrigatoriedade de seu envio ao STJ sob pena de usurpação da competência da corte (conforme jurisprudência pacífica do próprio STJ em relação ao agravo do art. 544) contrariariam as finalidades do sistema, razão pela qual eventuais equívocos da decisão que nega seguimento ao recurso repetitivo deveriam ser corrigidos por agravo interno.

Vale ressaltar o voto vencido do ministro Teori Albino Zavascki, que enxergou na vedação à interposição do agravo do artigo 544 o comprometimento da constitucionalidade do sistema de julgamento de recursos especiais repetitivos (art. 543-C do CPC), por razões semelhantes às que apresentamos ao longo deste capítulo. Segundo o referido voto, a inadmissão do agravo representaria a inadmissão do próprio recurso especial, caracterizando a instituição por via pretoriana de novo requisito de admissibilidade do recurso.

Além desse problema, o voto vencido identifica que a negativa de acesso das partes ao STJ pela possibilidade de interposição de agravo (art. 544 do CPC) não só equivaleria à instituição de efeito vinculante como também conferiria um caráter de absoluta imutabilidade às decisões do STJ, o que não existe nem mesmo em relação à súmula vinculante e às decisões do STF em controle abstrato de constitucionalidade, que são hipóteses constitucionalmente previstas de efeito vinculante das decisões judiciais em nosso país.

375 STJ - QO AI n. 1.154.599/SP, Corte Especial, rel. para acórdão Min. César Asfor Rocha, DJe, de 12.05.2011. 
Por fim, o voto vencido ressalta os resultados contrários que, conforme demonstrado pela experiência brasileira, são produzidos pelas tentativas de eliminação drástica do cabimento de recursos, em face da substituição da via recursal por meios alternativos, como o do mandado de segurança, das medidas cautelares ou da reclamação. No caso, a interposição do agravo interno contra a decisão de negativa de seguimento levaria a questão da admissibilidade do recurso excepcional ao colegiado do tribunal de origem, cujo acórdão poderia ser atacado por novo recurso especial.

Assim, o caminho para evitar a interposição injustificada dos recursos contrários à tese fixada pelo STJ seria a aplicação das sanções pecuniárias, na forma das regras já previstas no sistema, e não a supressão de recursos.

Realmente, como demonstramos nos itens anteriores, a regra do artigo 543-C do CPC que permite ao tribunal de origem negar seguimento ao recurso especial contrário à orientação do STJ só pode ser considerada constitucional diante da interpretação de que se trata de decisão de inadmissibilidade sujeita à revisão do próprio STJ pela via do agravo do art. 544 do $C P C$.

Ressalte-se que, conforme outros precedentes, a jurisprudência do STF e do STJ também não admite reclamação contra a decisão do tribunal de origem que julga o agravo interno, deixando as partes sem meios adequados para a correção de eventuais equívocos na aplicação dos precedentes da instância superior e para a eventual superação desses precedentes em face de argumentos novos ainda não apreciados pela instância superior. ${ }^{376}$

Seria o caso de se admitir, então, a interposição de recursos especial contra a decisão colegiada do tribunal de origem que nega provimento ao agravo interno, por violação aos artigos 543-B e 543-C do CPC. Essa possibilidade é inegável, à luz do permissivo constitucional (art. 105, III) e desde que satisfeitos todos os demais requisitos de admissibilidade ${ }^{377}$. Mas, nesse caso, a ideia de evitar a subida do recurso que pretende

\footnotetext{
${ }^{376}$ STF - Rcl n. 14.340, decisão monocrática, rel. Min. Celso de Mello, DJe, de 20.09.2012; STF - AgR Rcl n. 7.578DF, Pleno, rel. Min. Joaquim Barbosa, DJe, de 01.02.2012; STJ - AgR Rcl n. 10.306RS, $2^{\mathrm{a}}$ Seção, rel. Min. Luis Felipe Salomão, j. 28.11.2012, DJe, de 03.12.2012.

${ }^{377}$ Defendendo o cabimento de recurso especial nessa hipótese, ver: GARCIA, André Almeida, O drama dos "sobrestados" e a utilização de um incidente autônomo de julgamento por amostragem, cit.
} 
discutir a aplicação ou a correção do precedente fica frustrada, e de forma ainda mais irracional, pois apenas se alonga o caminho para a parte acessar a instância superior.

Alguns tribunais, em âmbito local, chegaram a estabelecer regras regimentais prevendo o agravo interno e até mesmo vedando a interposição de recursos contra o acórdão do órgão colegiado que o aprecia. É o caso do Tribunal de Justiça do Estado de São Paulo, que por meio do Assento Regimental n. 397/2011, criou a Câmara Especial dos Presidentes, com competência para julgar os "agravos regimentais" interpostos contra as decisões monocráticas que aplicam os artigos 543-B, §§ $2^{\circ}$ e $3^{\circ}$, e 543-C, $\S 7^{\circ}$, do CPC, prevendo que "de suas decisões não caberá recurso". 378

Vê-se, assim, que o problema não é o sistema em si (arts. 543-B e 543-C do CPC), mas a jurisprudência do STF e do $\mathrm{STJ}^{379}$, que de forma drástica e ilegítima veda o contraste da decisão do tribunal a quo por meio de agravo de admissão, negando inconstitucionalmente o seu acesso aos órgãos de cúpula (competentes, em todo caso, para realizar o juízo definitivo de admissibilidade e o juízo de mérito do recurso excepcional) e deixando as partes sem instrumento para a prática efetiva do distinguishing e do overruling, com risco de engessamento de sua jurisprudência. ${ }^{380}$

\footnotetext{
${ }^{378}$ É evidente a ilegalidade e inconstitucionalidade de tal dispositivo, haja vista que regimento interno não pode restringir regras do CPC, nem criar normas sobre processo civil, vedando a interposição de recursos, haja vista a competência constitucional privativa da União Federal para legislar sobre direito processual (art. 22, I da CF).

379 Já houve quem chamasse esse entendimento de "jurisprudência defensiva de segunda geração", que consistiria na interpretação das regras dos artigos 543-B e 543-C do CPC de forma a extrair limitações de acesso das partes à instância superior ainda maiores do que as já previstas nesses filtros (TEDESCO, Paulo Camargo. Jurisprudência defensiva de segunda geração. Revista de Processo, São Paulo, v. 35, n. 182, p. 268-269, abr. 2010).

380 "O julgamento por amostragem, desde que aplicado em seus devidos limites e com a observância das cautelas e garantias aqui brevemente destacadas, não parece ofender os princípios constitucionais do processo nem as regras sobre competência recursal do Superior Tribunal de Justiça. Trata-se de racionalizar a atividade do STJ, na esteira do que também se procurou fazer com o STF, precisamente em casos que já vinham recebendo decisões homogêneas, meramente reiterativas. E a institucionalização desse procedimento inclusive possibilita seu controle de modo mais eficiente. Com o procedimento institucionalizado da amostragem, confere-se inclusive destaque ao recurso amostra - que assim poderá receber atenção especial do Superior Tribunal, da sociedade e de outros interessados (envolvidos em outros processos que versam sobre a mesma questão), que dentro de certas condições poderão até intervir como amicus curiae. Cerca-se assim de maiores garantias - viabilizando-se um contraditório mais adequado um procedimento que informalmente já ocorria. Enfim, institucionaliza-se, sob o pálio das garantias do processo, algo que já vinha ocorrendo de modo sub-reptício." (TALAMINI, Eduardo, Julgamento de recursos no STJ "por amostragem", cit.).
} 
Essa interpretação - que se distancia do entendimento majoritário da doutrina e que, a nosso ver, visa reduzir recursos sem amparo legal e constitucional - compromete a legitimidade do sistema, merecendo, por isso, as críticas ora apresentadas.

Como resultado, tem-se um sistema que, a nosso ver, embora conserve os atributos de tornar mais eficiente as funções constitucionais do STF e do STJ e potencializar seus precedentes (favorecendo, com isso, a concretização dos princípios da igualdade, da segurança jurídica e da razoável duração do processo), acaba contrariando a Constituição Federal, além de apresentar o inconveniente de tornar a jurisprudência mais rígida do que a própria súmula vinculante, que conta com sistema de revisão para modificação ou extinção da tese sumulada.

A questão poderá ser alterada, caso seja aprovado o projeto de novo CPC em sua versão atual (ver Capítulo 12), eis que, segundo seu artigo 1.055, § $1^{\circ}$, II, cabe agravo de admissão contra a decisão de inadmissão do recurso extraordinário ou especial, mesmo nos casos em que essa inadmissão se fundamentar em decisão anterior do STF de inexistência de repercussão geral ou em entendimento firmado em julgamento de casos repetitivos, com a única exigência de que, nessas hipóteses, a parte demonstre, de forma expressa, a existência de "distinção entre o caso em análise e o precedente invocado ou a superação da tese". 
TERCEIRA PARTE

A técnica de julgamento de recursos repetitivos aplicada: aspectos procedimentais e resultados práticos 


\section{INSTAURAÇÃO DO PROCEDIMENTO PREVISTO NOS ARTIGOS 543-B E 543-C DO CPC: REQUISITOS, COMPETÊNCIA E EFEITOS SOBRE O DIREITO DE DESISTÊNCIA DO RECURSO}

\subsection{Requisitos para a instauração do procedimento}

Os requisitos estabelecidos pela lei para a instauração do procedimento relativo ao julgamento de recursos repetitivos são de duas ordens: quantitativa e qualitativa. Quanto ao primeiro caso, a norma menciona a expressão "multiplicidade de recursos" e, quanto ao segundo, exige-se que todos os recursos integrantes dessa multiplicidade tenham "fundamento em idêntica controvérsia" (art. 543-B do CPC) ou "fundamento em idêntica questão de direito" (art. 543-C do CPC).

\subsubsection{Requisito quantitativo: efetiva existência de "multiplicidade de recursos"}

O legislador não precisou a quantidade exata de recursos ${ }^{381}$, e isso realmente não seria recomendável, pois a caracterização da multiplicidade (que ontologicamente significa mais do que três) depende das peculiaridades do caso concreto. Isso porque, mais do que a quantidade, interessa o grau de maturidade da questão, que varia de caso a caso. ${ }^{382}$

Realmente, o sobrestamento da multiplicidade de casos idênticos e a seleção de apenas alguns para julgamento pressupõe que já tenha ocorrido um significativo desenvolvimento da controvérsia, com apresentação e julgamento, em vários casos e

\footnotetext{
381 "No tocante ao primeiro requisito - a existência de multiplicidade de recursos -, é de se notar que a lei não determinou um número mínimo de casos, o que deverá ser, salvo melhor juízo, enfrentado pela doutrina e, principalmente, pela jurisprudência. É bastante provável que atingirá, sobremaneira, àquelas pretensões denominadas de massa, que atingem considerável parcela da população, cada vez mais frequentes, tendo em conta, entre outras circunstâncias, a maior facilidade e conscientização do acesso ao Judiciário por parte da população." (TIMM, Luciano Benetti; TRINDADE, Manoel Gustavo Neubarth. As recentes alterações legislativas sobre recursos aos Tribunais Superiores: a repercussão geral e os processos repetitivos sob a ótica da law and economics. Revista de Processo, São Paulo, v. 34, n. 178, p. 172, dez. 2009).

382 "Mais importante do que o número de recursos repetitivos existentes é o grau de maturidade e solidez das reflexões em torno da controvérsia a ser examinada. Registre-se que as controvérsias são de complexidade variável, o que faz oscilar o volume e a intensidade das atividades que devem preceder a sua solução." (BONDIOLI, Luiz Guilherme Aidar, A nova técnica de julgamento dos recursos extraordinário e especial repetitivos, cit., p. 9).
} 
sentidos, de inúmeros argumentos sobre a tese jurídica sob discussão. É a existência dessa maturidade que permite a instauração do procedimento de julgamento por amostragem, possibilitando a seleção de casos que realmente representem a controvérsia, bem como, ao final, a aplicação da mesma decisão para todos os demais casos repetitivos. ${ }^{383}$

Discute-se, assim, se o sistema de julgamento de recursos repetitivos teria ou não caráter preventivo da divergência jurisprudencial e da multiplicação de recursos repetitivos. Noutras palavras, esse sistema só poderia ser aplicado diante da efetiva existência de recursos repetitivos ou, diferentemente, admitir-se-ia a sua instauração diante do mero potencial de divergência e repetição?

De um lado, poder-se-ia afirmar que, sendo a técnica fundamentada essencialmente nos princípios da isonomia, segurança jurídica e razoável duração do processo, nada impediria a instauração do procedimento diante da mera possibilidade de surgimento de recursos repetitivos. Além de viabilizar decisões uniformes de primeiro e segundo grau sobre a mesma questão (isonomia) e previsibilidade quanto aos casos futuros (segurança jurídica), isso desestimularia a interposição de novos recursos e, quanto aos interpostos, facilitaria o seu gerenciamento pelo Poder Judiciário (razoável duração do processo).

Nesse sentido, o artigo 328, caput, do RISTF menciona a possibilidade de instauração do procedimento diretamente pelo próprio STF quando "protocolado ou distribuído recurso cuja questão for suscetível de reproduzir-se em múltiplos feitos”, o que sugere a viabilidade de utilização dessa técnica para prevenir a multiplicação de recursos repetitivos.

No entanto, consta no caput dos artigos 543-B e 543-C do CPC que o procedimento só será instaurado "quando houver multiplicidade de recursos", dando-se a ideia de que ele foi criado para gerenciar uma multiplicidade de recursos já existentes, e não para impedir o seu surgimento futuro. Essa redação condiz com a conveniência de se atingir certa

\footnotetext{
383 “O parâmetro numérico revelado pela interpretação estrita do vocábulo multiplicidade (mais do que três = quatro) serve apenas para estabelecer condições mínimas sem as quais não se pode iniciar o julgamento por amostragem, dentro da ideia já lançada de que um mínimo de repetição é saudável. Esse mínimo de repetição, aliás, é essencial para que se possa contar com material adequado à seleção dos recursos representativos da controvérsia" (BONDIOLI, Luiz Guilherme Aidar, A nova técnica de julgamento dos recursos extraordinário e especial repetitivos, cit., p. 9).
} 
maturidade da controvérsia antes de instaurar o procedimento, o que pressupõe a efetiva existência da multiplicidade de recursos.

Em razão do alto grau de eficácia persuasiva do precedente, é muito provável que ocorrerá a sua simples menção a título de fundamentação do julgamento da idêntica questão de direito nos casos repetitivos sobrestados. Embora não fique cristalizada, a revisão ou modificação da tese firmada pelo STF e pelo STJ será mais difícil, sendo altamente arriscada e prejudicial à segurança jurídica a sua definição sem que se tenha atingido aquela necessária maturidade no enfrentamento da matéria.

Lembremos ainda que, como visto no Capítulo 3, as funções públicas dos recursos excepcionais são, segundo a Constituição Federal, exercidas com a colaboração indireta das partes que, interessadas em proteger seu direito subjetivo, questionam perante o STF e o STJ a interpretação e aplicação do direito federal. A instauração do procedimento a partir da existência de um número reduzido de recursos poderia prejudicar esse sistema, fazendo com que o STF e o STJ pacifiquem a questão sem que ela esteja suficientemente desenvolvida, o que também diminuirá a própria legitimidade do precedente (no sentido de sua aceitação pelas partes e demais órgãos judiciais).

Assim, o procedimento só poderá ser instaurado quando já existir uma multiplicidade de recursos repetitivos, e não mero potencial do seu surgimento. Ao mesmo tempo, já tendo se desenvolvido suficientemente a questão, é razoável que o procedimento seja instaurado o quanto antes, não se postergando por muito tempo o estado de divergência jurisprudencial, a fim de preservar os princípios da igualdade, segurança e a própria eficiência jurisdicional.

\subsubsection{Desnecessidade de prévia jurisprudência dominante ou sumulada sobre a questão controvertida}

A necessidade de efetiva existência, e não do mero potencial de existência, de recursos repetitivos não significa que para a instauração do procedimento precisa haver prévia jurisprudência dominante ou sumulada sobre a questão no STF ou no STJ. Isso 
significa que o procedimento pode ser utilizado não só para confirmar, mas também para formar ou rever a jurisprudência dominante sobre determinada questão.

De fato, a norma não exige, em momento algum, a existência de precedentes múltiplos do STF ou do STJ em determinado sentido. Ademais, no caso do artigo 543-C do CPC, o procedimento poderá ser instaurado pelo próprio STJ "ao identificar que sobre a controvérsia já existe jurisprudência dominante ou que a matéria já está afeta ao colegiado", o que sinaliza a possibilidade de instauração também quando a matéria ainda não foi definida pela corte, estando meramente afeta ao colegiado.

Nesse sentido, Fátima Nancy Andrighi relata a existência de dois grupos no STJ a respeito da interpretação das possibilidades envolvidas no julgamento de recursos repetitivos: os integrantes do primeiro restringem-no à ratificação da jurisprudência já existente e os do segundo, ao qual ela se filia, "veem o mecanismo como uma possibilidade de ir além na jurisprudência - observando nova legislação sobre a qual não há precedente, por exemplo: consórcio - ou então corrigir eventuais equívocos na formulação pregressa desse entendimento consolidado". ${ }^{384}$

Recentemente, o STJ decidiu conter o julgamento de recursos submetidos à sistemática do artigo 543-C do CPC, a fim de evitar a formação de precedente qualificado em sentido contrário à jurisprudência atual, sob o argumento de que a votação seria apertada e não estavam presentes todos os integrantes da Primeira Seção. Surgiu, então, uma discussão entre os ministros no sentido da possibilidade de utilização do procedimento de recursos repetitivos apenas para ratificar jurisprudência dominante, ou se ele também autorizaria a revisão de entendimentos consolidados. Após alguma discussão, a Primeira Seção decidiu, por unanimidade, que o caso não seria julgado nos termos do artigo 543-C do CPC, de modo que o precedente deveria ser simples. ${ }^{385}$

O entendimento de que o procedimento só poderia ser instaurado para confirmar jurisprudência dominante parte do pressuposto de que a reiteração dos julgados é essencial

\footnotetext{
${ }^{384}$ ANDRIGHI, Fátima Nancy, Recursos repetitivos, cit., p. 277.

385 Conforme notícia publicada em 11.09.2013 no Valor Econômico (Disponível em: <http://professormedina.com/2013/09/15/stj-comecaa-a-conter-julgamento-de-recursos-repetitivos>. Acesso em: 15 set. 2013).
} 
para a ampliação da eficácia da jurisprudência, em razão do grau de maturidade que se atinge com a constante repetição de decisões no mesmo sentido. ${ }^{386}$

Nesse sentido, José Miguel Garcia Medina argumenta que "sem uma jurisprudência constante que ostente entendimento amplamente compartilhado, o resultado de tal julgamento será frágil, e tenderá a não ser observado pelo próprio tribunal [...] e por outros órgãos julgadores". E conclui: "Sendo assim, o Superior Tribunal de Justiça acabará falhando no seu papel de indicar qual o correto modo de interpretar a lei federal.",387

Porém, tratando-se de Tribunais Superiores, cuja função constitucional é justamente regular a jurisprudência (Capítulo 3), parece mais adequada a interpretação de que, fixado o precedente, sobretudo aquele preordenado a servir de parâmetro para a solução de uma multiplicidade de casos repetitivos, e que só é formado a partir de um procedimento diferenciado (seleção de recursos representativos da controvérsia, participação de amicus curiae, informações dos tribunais de origem, manifestação do Ministério Público etc.), ele passa a representar a interpretação única e definitiva sobre a questão de direito, sem necessidade de se aguardar a sua reiteração.

Admitir a necessidade de uma prévia reiteração de julgados parece supor a fragilidade dos precedentes desses órgãos de cúpula e sua inaptidão para representar a verdadeira e única interpretação do direito federal no país, o que não condiz com as funções que eles exercem no sistema, segundo a própria Constituição Federal (Capítulo 3).

Essa é a orientação que parece prevalecer no STJ, como restou definido no voto do ministro Sidnei Beneti no julgamento do Recurso Especial n. 1.147.595/RS pela Segunda

\footnotetext{
386 “A rigor, a posição do Tribunal a respeito de determinado tema só seria de se considerar firmada após a apreciação, por ambas as turmas ou pelo plenário, de número de recursos aptos a demonstrar que a Casa discutiu, amadureceu e consolidou determinado entendimento. Essa evolução, protraída no tempo, retrataria a sedimentação da jurisprudência constitucional a respeito da matéria, fator de legitimidade da extensão monocrática do paradigma a casos idênticos." (ABBUD, André de Albuquerque Cavalcanti, A repercussão geral dos recursos extraordinários e o julgamento por amostragem no âmbito do Supremo Tribunal Federal (CPC, arts. 543-A e 543-B), in As novas reformas do CPC e de outras normas processuais, cit., p. 314).

${ }^{387}$ MEDINA, José Miguel Garcia, Justiça não pode ser medida apenas em números, cit.
} 
Seção em 08.09.2010 ${ }^{388}$. Segundo esse precedente, o julgamento do recurso-piloto poderá definir (quando ela ainda não existir), reafirmar (quando já existir e o julgamento a confirmar) ou modificar (quando já existir mas for alterada) a jurisprudência dominante do STF ou do STJ sobre a questão repetitiva.

No mesmo sentido, o STF assentou o entendimento de que o sistema de repercussão geral (subentendendo-se, aí, o de julgamento de recursos extraordinários repetitivos) também se aplica aos casos em que já existe jurisprudência dominante ou sumulada, podendo a corte, em se reconhecendo a presença da repercussão, "quanto ao mérito, (a) manifestar-se pela subsistência do entendimento já consolidado ou (b) deliberar pela renovação da discussão do tema". Ou seja, o STF pode confirmar, formar ou até rever a orientação até então dominante. ${ }^{389}$

O problema que poderia advir desse entendimento é a eventual formação de precedentes por votações apertadas e que, sem a observância de um quorum qualificado, não exprimam a orientação da efetiva maioria dos integrantes da corte. Considerando-se a ampla eficácia persuasiva e o alto grau de influência do precedente, isso realmente não é recomendado. Nesse caso, o melhor seria não processar o recurso segundo a técnica dos artigos 543-B e 543-C do CPC, caso em que a decisão formaria um precedente simples.

No entanto, entendemos que esse problema deve ser solucionado pela submissão do julgamento do recurso-piloto aos órgãos mais complexos do STF e do STJ (respectivamente o Plenário e a Seção especializada ou a Corte Especial), bem como pela exigência de quorum qualificado (conforme exporemos no Capítulo 9, item 9.3), e não com

\footnotetext{
388 "Três modalidades de julgamento de multiplicidade de recursos ao ver do Relator do presente podem ocorrer, segundo o critério distintivo de os temas já haverem sido enfrentados e julgados por este Tribunal Superior de Justiça: $1^{\mathrm{a}}$ ) julgamentos de consolidação de jurisprudência estável, quando vários recursos já tenham sido julgados pelo Tribunal, havendo formado orientação consistente; $2^{\mathrm{a}}$ ) julgamentos de formação de jurisprudência nova, quando vários recursos sobre os mesmos temas estejam sendo enfrentados, mas ainda não tenha sido consolidada orientação consistente por intermédio de somatória considerável de julgamentos anteriores; $3^{\mathrm{a}}$ ) julgamentos de revisão de jurisprudência - modalidade naturalmente rara, que, sistematicamente, contudo, deve ser ressalvada, dada a garantia da independência e da liberdade da manifestação jurisdicional à luz de novos argumentos ou da própria evolução do direito interpretado salientando-se a excepcionalidade da hipótese, ante a necessidade de estabilidade jurídica, que exige a constância da interpretação jurisprudencial, tendente à solidez jurídica, similar nacional do princípio do 'stare decisis et non quieta movere'." (STJ - REsp n. 1.147.595/RS, 2a Seção, rel. Min. Sidnei Beneti, DJe, de 06.05.2011).
}

${ }^{389}$ STF - QO RE n. 579.431/RS, Pleno, rel. Min. Gilmar Mendes, j. 13.03.2008, DJe, de 23.10.2008. 
a interpretação restritiva do sistema instituído justamente para potencializar a eficácia das decisões dos Tribunais Superiores.

\subsubsection{Requisito qualitativo: "idêntica controvérsia" ou "idêntica questão de direito"}

Para a instauração do procedimento, a multiplicidade de recursos deve ter por objeto controvérsias ou questões de direito que sejam idênticas.

Questão é todo ponto controvertido no processo. Ou seja, todo fundamento de fato ou de direito que venha a ser posto em dúvida pela parte contrária ou pelo juiz, exigindo solução para viabilizar a decisão sobre o pedido. ${ }^{390}$

As questões podem ser de fato ou de direito e, nesse último caso, podem referir-se à relação jurídica de direito material ou a situações do processo (condições da ação, pressupostos processuais, nulidades etc.); serão, assim, questões substanciais (ou de direito material) ou questões processuais. ${ }^{391}$

A "controvérsia" e a "questão de direito" mencionadas respectivamente nos artigos 543-B e 543-C do CPC são, portanto, as razões ou os fundamentos de direito material ou processual arguidos pelas partes e postos em dúvida no processo, os quais precisam ser solucionados pelo juiz como passo necessário para a decisão sobre o pedido, este relacionado ao mérito do processo. Vale lembrar que a solução dada pelo juiz às questões

\footnotetext{
390 "Ponto é, em prestigiosa doutrina, aquele fundamento da demanda ou da defesa, que haja permanecido incontroverso durante o processo, sem que as partes tenham levantado discussão a respeito (e sem que o juiz tenha, de ofício, posto em dúvida o fundamento); discordes as partes, porém, isto é, havendo contestação de algum ponto por uma delas (ou, ainda, havendo o juiz suscitado a dúvida), o ponto se erige em questão. Questão é, portanto, o ponto duvidoso. Há questões de fato, correspondentes à dúvida quanto a uma assertiva de fato contida nas razões de alguma das partes; e de direito, que correspondem à dúvida quanto à pertinência de alguma norma ao caso concreto, à interpretação de textos, legitimidade perante norma hierarquicamente superior." (DINAMARCO, Cândido Rangel. O conceito de mérito em processo civil. Revista de Processo, São Paulo, v. 9, n. 34, p. 25, abr./jun. 1984.

391 "Dito isso, percebe-se que dúvidas podem ocorrer (e, portanto, questões) em torno dos fatos e direito relativos à própria situação jurídico-material controvertida; como surgir também podem, com referência a situações do processo mesmo e à ação e suas condições. Daí a distinção entre questões substanciais e questões processuais (ou, como foi dito e já referi, questões 'formais' ou 'de rito')." (DINAMARCO, Cândido Rangel, op. cit., p. 25).
} 
de fato e de direito, diferentemente da decisão sobre o pedido, fazem parte do fundamento da sentença e não ficam imunizadas pela coisa julgada material (art. 469 do CPC).

Por se tratar de técnica de julgamento de recursos de estrito direito (Capítulo 3), o procedimento dos artigos 543-B e 543-C do CPC envolve a apreciação de questões de direito idênticas (ou repetitivas) ou, mais especificamente, questões relacionadas à interpretação das normas federais constitucionais e infraconstitucionais.

Note-se que não importa diretamente, para essa técnica, as decisões sobre os pedidos formulados pelas partes, mas sim a solução dada pelos diversos órgãos jurisdicionais às questões de direito federal envolvidas na multiplicidade de processos, na fundamentação daquelas decisões. Isso porque a ideia do procedimento é, entre outros pontos, gerenciar a divergência jurisprudencial a respeito da interpretação dessas normas, trazendo previsibilidade e igualdade na aplicação do direito.

Sobre a natureza da questão jurídica controvertida, ela pode, como já adiantado acima, ser material ou processual. Aliás, muitos recursos repetitivos baseiam-se em discussões sobre questões eminentemente processuais, sem qualquer outra semelhança entre os casos do ponto de vista do direito material.

Outro ponto a se observar é que, para serem consideradas como repetitivas nos termos dos artigos 543-B e 543-C do CPC, as questões devem ser realmente idênticas, não bastando que sejam semelhantes ou análogas. Isso significa que as questões devem envolver a discussão da interpretação de normas jurídicas constitucionais ou infraconstitucionais idênticas, à luz de situações fáticas substancialmente semelhantes. Distinções fáticas, ainda que tênues, podem eventualmente justificar interpretações diversas, o que só pode ser solucionado a partir da análise de cada caso concreto, aferindose a eventual relevância de cada ponto de distinção.

Por exemplo, o STJ já determinou a desafetação de recurso selecionado como representativo da controvérsia, cancelando-se a instauração do procedimento, por verificar que a questão supostamente repetitiva dependeria do exame das peculiaridades de cada caso concreto, sendo impossível identificar uma única questão a ser resolvida de modo a nortear a solução de outros processos. No caso, a corte "decidiu não julgar a validade das 
Certidões de Dívida Ativa (CDAs), que autorizam a Fazenda Pública a cobrar débitos tributários judicialmente. Os ministros também tiraram o tema da relação de recursos repetitivos". Isso porque, para a maioria dos integrantes da Primeira Seção, "o assunto sempre pedirá uma análise particular, caso a caso. Nesse sentido, seria impossível fixar uma tese jurídica que sirva de orientação para os tribunais estaduais e federais". 392

Por sua vez, o que se exige não é a identidade de recursos, mas sim a identidade das questões jurídicas a que eles se referem. A mesma questão de direito pode constituir a base de fundamentação de qualquer dos integrantes da relação de direito material ou processual, além de ser veiculada em demandas ajuizadas com base em procedimentos diversos, e com pedidos também diversos, e mesmo assim se estará diante de recursos fundados em idêntica questão de direito.

Por exemplo, inúmeros clientes de um banco ajuízam ação declaratória de invalidade de cláusula contratual que estipular determinado índice de reajuste, por se entender que ele é ilegal, enquanto que o banco ajuíza inúmeras ações de cobrança contra clientes, com base na mesma cláusula. Em todos esses processos, se discutirá a constitucionalidade ou legalidade do índice, mas em alguns casos os recursos serão dos clientes e originados em ação declaratória ou de cobrança, enquanto que, noutros casos, os recursos serão do banco, em ação de cobrança ou declaratória. Tudo dependerá de como for julgada cada demanda, o que em nada interfere na identidade jurídica da questão central.

Por isso, a expressão "recursos repetitivos", tão utilizada pela doutrina e principalmente pela jurisprudência do STF e do STJ (o que justifica, por sua utilidade prática, a sua constante menção no tratamento da matéria e até mesmo o título deste trabalho), não é a mais precisa, eis que não se tem propriamente identidade de recursos, mas sim das questões jurídicas nas quais eles se baseiam. Recursos repetitivos, portanto, é expressão que significa recursos que versam sobre questões de direito material ou processual idênticas.

\footnotetext{
392 Disponível em: <http://www.aasp.org.br/aasp/imprensa/clipping/cli_noticia.asp?idnot=13938>. Acesso em: 05 dez. 2013.
} 
Nem todas as questões envolvidas nos recursos precisam ser repetitivas. Neste caso, porém, é preciso analisar se a questão repetitiva guarda relação de prejudicialidade em relação às demais. Havendo essa relação, o recurso será considerado repetitivo para fins de incidência das regras dos artigos 543-B e 543-C do CPC. Não existindo essa relação, não há como justificar a sujeição do recurso ao referido procedimento, até porque isso implicaria o seu sobrestamento até o julgamento do recurso-piloto pelo STF ou pelo STJ, atrasando indevidamente a apreciação de questões não repetitivas. $\mathrm{O}$ melhor, nesse caso, é processar o recurso para apreciação das questões não repetitivas e, conforme o resultado, persistindo o interesse no julgamento da questão repetitiva, sobrestá-lo até o julgamento do recurso piloto. ${ }^{393}$

Nesse sentido, dispõe o artigo $1^{\circ}, \S 2^{\circ}$, da Resolução n. 8 do STJ que "o agrupamento de recursos repetitivos levará em consideração apenas a questão central discutida, sempre que o exame desta possa tornar prejudicada a análise de outras questões arguidas no mesmo recurso".

De fato, como leciona Luiz Guilherme Aidar Bondioli, o princípio da razoável duração do processo impõe que "se um recurso especial ou extraordinário for fundado não só na idêntica questão de direito repetida em outros recursos, mas também em outras autônomas e peculiares questões de direito, ele deve seguir adiante, sem sobrestamento". 394

Por fim, observe-se que não se exige que as partes dos processos envolvendo questões repetitivas estejam de qualquer forma ligadas entre si, seja por alguma circunstância de fato, relação jurídica base ou mesmo origem comum (expressões usadas pelo art. 81 do CDC para caracterizar os interesses difusos, coletivos e individuais

\footnotetext{
${ }^{393}$ Conforme André Almeida Garcia, "para que um caso possa ser sobrestado é preciso que verse sobre a mesma questão jurídica e apenas sobre ela. Caso outras questões sejam levantadas, o recurso não pode ser suspenso, a não ser que guardem relação de prejudicialidade com aquela" (GARCIA, André Almeida, $O$ drama dos "sobrestados" e a utilização de um incidente autônomo de julgamento por amostragem, cit.). Segundo Eduardo Talamini, ó sobrestamento é indevido quando "embora o recurso da parte veicule a questão constitucional objeto da amostragem, ele trata também de outras questões constitucionais, inconfundíveis com aquela e relativamente às quais não se justifica o sobrestamento" (TALAMINI, Eduardo, Novos aspectos da jurisdição constitucional brasileira: repercussão geral, força vinculante, modulação dos efeitos do controle de constitucionalidade e alargamento do objeto do controle direto, cit., p. 68).
}

${ }^{394}$ BONDIOLI, Luiz Guilherme Aidar, A nova técnica de julgamento dos recursos extraordinário e especial repetitivos, cit., p. 13. 
homogêneos). Não se exige, assim, que esteja necessariamente envolvido na multiplicidade de processos algum grupo da coletividade. Basta pensar na hipótese de recursos repetitivos envolvendo matéria penal ou processual, em que geralmente não há absolutamente qualquer relação entre as partes de cada processo.

Por isso, conforme já exposto no Capítulo 5 (item 5.4), não se pode afirmar que a técnica de julgamento de recursos repetitivos identifique-se eminentemente com uma técnica de julgamento coletivo de casos envolvendo direitos individuais homogêneos ${ }^{395}$, embora essa espécie de direitos coletivos seja responsável por boa parte dos recursos repetitivos sujeitos ao procedimento dos artigos 543-B e 543-C.

\subsubsection{Instauração de ofício ou a requerimento das partes}

Finalmente, se a lei estabelece requisitos objetivos para a instauração do procedimento, pode-se afirmar que, estando eles presentes, o recurso extraordinário ou especial deverá necessariamente ser processado na forma dos artigos 543-B e 543-C do CPC.

A própria norma é imperativa, ao afirmar que, havendo "multiplicidade de recursos com fundamento em idêntica questão de direito, o recurso especial será processado nos termos deste artigo", podendo-se aplicar o mesmo entendimento ao artigo 543-B, que também é imperativo ao determinar a instauração do procedimento "quando houver multiplicidade de recursos com fundamento em idêntica controvérsia”.

Nada impede, portanto, que as partes requeiram a instauração do procedimento, cabendo, em último caso, ao Poder Judiciário fazê-lo de ofício.

\footnotetext{
395 “As demandas repetitivas fundam-se em situações jurídicas homogêneas, que possuem um perfil que lhes é próprio e não se resumem aos direitos individuais homogêneos, como vêm sendo tratados pela doutrina. [...] As demandas homogêneas se identificam no plano abstrato, no que diz respeito à questão fática ou jurídica em tese, mas não no âmbito de cada situação concreta. [...] A categorização das demandas de massa dá-se pelos critérios acima expostos: identidade em tese, e não em concreto, da causa de pedir e do pedido, associada à repetição em larga escala." (BASTOS, Antonio Adonias Aguiar, Situações jurídicas homogêneas: um conceito necessário para o processamento das demandas de massa, cit., p. 96-100).
} 


\subsection{Competência para instaurar o procedimento}

A competência para instauração do procedimento envolve, por consequência lógica, a competência para selecionar os casos representativos da controvérsia e determinar o sobrestamento dos demais casos repetitivos, eis que todos esses atos ocorrem praticamente no mesmo momento. Mas a quem compete instaurar o procedimento: ao tribunal de origem, ao STF, ao STJ? Ou se trata de competência concorrente?

Nos termos dos artigos 543-B, $\S 1^{\circ}$, do CPC, caberá ao tribunal de origem selecionar um ou mais recursos extraordinários representativos da controvérsia e encaminhá-los ao STF, sobrestando os demais até pronunciamento definitivo da corte; quanto ao recurso especial, o artigo 543-C, $\S 1^{\circ}$, do CPC dispõe que caberá ao presidente do tribunal de origem admitir um ou mais recursos representativos da controvérsia e encaminhá-los ao STJ, ficando suspensos os demais recursos especiais, até o pronunciamento definitivo do STJ. ${ }^{396}$

Está claro que, internamente ao órgão ou tribunal de origem, a competência é da presidência ou vice-presidência responsável pela realização do juízo de admissibilidade dos recursos extraordinários e especiais (que pode contar com o auxílio de outros órgãos, como o NURER - ver Capítulo 11, item 11.4), e não do colegiado que proferiu a decisão recorrida. Isso porque, ato seguinte à instauração do procedimento, todos os recursos repetitivos são sobrestados, sendo mais adequado que esse sobrestamento seja determinado pela Presidência ou Vice-Presidência, perante a qual são processados os recursos excepcionais. Além disso, o mesmo órgão deverá selecionar os recursos representativos da controvérsia, o que pressupõe a sua admissibilidade, a ser aferida justamente pela Presidência ou Vice-Presidência.

\footnotetext{
${ }^{396} \mathrm{O}$ artigo $1^{\text {o }}$ da Resolução n. 8 do STJ afirma que a instauração do procedimento "caberá ao presidente ou ao vice-presidente do tribunal recorrido (CPC, art. 541)" (destacamos). Nesse ponto, o artigo 543-B do CPC e o RISTF valeram-se de melhor técnica ao não mencionar o órgão competente, no tribunal de origem, para as providências em questão. Trata-se de matéria de organização judiciária, que pode e deve ficar a cargo das normas locais. No mais, a Resolução n. 8 do STJ diverge do artigo 543-C, $\S 1^{\circ}$, do CPC, pois enquanto este menciona a competência do presidente, aquela menciona presidente ou vice-presidente, ensejando dúvidas desnecessárias e discussões inconvenientes sobre a constitucionalidade da regra. Nesse sentido: MELLO, Rogério Licastro Torres de. Recursos especiais repetitivos: problemas de constitucionalidade da Resolução 8/2008, do STJ. Revista de Processo, São Paulo, v. 33, n. 163, p. 193, set. 2008.
} 
Por sua vez, o $\S 2^{\circ}$ do artigo 543-C afirma que não adotada a providência pelo tribunal de origem, o próprio relator no STJ, identificando que sobre a controvérsia já existe jurisprudência dominante, ou que a matéria já está afeta ao colegiado, “poderá determinar a suspensão, nos tribunais de segunda instância, dos recursos nos quais a controvérsia esteja estabelecida".

No mesmo sentido, os artigos 328, parágrafo único, do $\operatorname{RISTF}^{397}$ e $2^{\circ}, \S \S 1^{\circ}$ e $2^{\circ}$ da Resolução n. 8, de 7 de agosto de 2008, do $\operatorname{STJ}^{398}$ estendem a competência para instauração do procedimento ao STF e ao STJ. No âmbito do STF, tanto a Presidência quanto o ministro relator poderão instaurar o procedimento do artigo 543-B. Ao seu turno, no STJ, cabe aos ministros relatores afetarem os recursos já distribuídos, na forma do artigo 543-C do CPC, de modo que "a decisão do Relator será comunicada aos demais Ministros e ao Presidente dos Tribunais de Justiça e dos Tribunais Regionais Federais, conforme o caso, para suspender os recursos que versem sobre a mesma controvérsia”.

Como se vê, tanto os órgãos de origem como a instância superior (STF e STJ), de forma concorrente, e de qualquer modo sempre sob o controle desses últimos, deverão, ao identificar a multiplicidade de recursos extraordinários e especiais fundados em idêntica controvérsia jurídica, instaurar o rito dos artigos 543-B e 543-C do CPC, a fim de, em seguida, selecionar o recurso ou os recursos representativos da controvérsia e determinar o sobrestamento dos demais recursos até a definição da questão.

No entanto, quando a instauração é determinada pelo órgão de origem, atingindose, conforme veremos adiante, apenas os recursos que tramitam na respectiva localidade, $o$ STF e o STJ, ao apreciarem inicialmente os recursos enviados, exercerão um controle sobre a decisão de sobrestamento, caso em que poderão inclusive estender seus efeitos a todos os demais tribunais do país.

\footnotetext{
${ }^{397}$ Conforme o artigo 543-B, caput, do CPC: "Quando houver multiplicidade de recursos com fundamento em idêntica controvérsia, a análise da repercussão geral será processada nos termos do Regimento Interno do Supremo Tribunal Federal, observado o disposto neste artigo".

398 Conforme o artigo 543-C, $\S 9^{\circ}$, do CPC: “O Superior Tribunal de Justiça e os tribunais de segunda instância regulamentarão, no âmbito de suas competências, os procedimentos relativos ao processamento e julgamento do recurso especial nos casos previstos neste artigo".
} 
Conforme assentado pela ministra Fátima Nancy Andrighi no julgamento da Reclamação n. 3.652/DF ${ }^{399}$, o STJ exercerá um papel de controle, assim como exerce o segundo - e definitivo - juízo de admissibilidade dos recursos especiais. Poderá então inadmitir o recurso enviado ${ }^{400}$ ou entender que ele não é representativo da controvérsia. Revogará, nesses casos, a suspensão decretada pelo tribunal de origem.

No caso do recurso extraordinário, em que a análise preliminar diz respeito à repercussão geral, não é diferente, posto que o recurso selecionado deverá reunir os demais requisitos gerais e específicos de admissibilidade (tempestividade, preparo, prequestionamento etc.), para só então admitir-se o sobrestamento dos recursos idênticos. Caso contrário, haveria o risco de se sobrestar inutilmente inúmeros recursos.

A diferença em relação ao recurso especial é que, superada a fase de admissibilidade geral e específica, avança-se na apreciação da repercussão geral, de modo que, sendo ela rejeitada, todos os demais recursos sobrestados considerar-se-ão automaticamente inadmitidos (art. 543-B, $\S 2^{\circ}$ ) e, estando ela presente, a corte passará ao julgamento do mérito do recurso. ${ }^{401}$

\subsection{Seleção do caso representativo da controvérsia}

\subsubsection{Importância}

A seleção do recurso representativo da controvérsia, que também é chamado de "recurso piloto" ou "recurso líder" 402 , é o primeiro ato que deverá ser praticado após a instauração do procedimento de julgamento de recursos repetitivos.

\footnotetext{
${ }^{399}$ STJ - Rcl n. 3.652, $2^{\text {a }}$ Seção, rel. Min. Nancy Andrighi, v.u., j. 14.10.2009, DJe, de 04.12.2009.

400 “Apesar de serem representativos da controvérsia, esses recursos continuam se sujeitando aos requisitos de admissibilidade comuns a todo o recurso especial. O sistema do duplo juízo de admissibilidade segue hígido, de forma que a admissão do especial pelo Tribunal de origem não vincula o STJ, que pode entender em sentido diferente e negar seguimento ao recurso." (ANDRIGHI, Fátima Nancy, Recursos repetitivos, cit., p. 271-272).

401 Como demonstrado no Capítulo 5, item 5.5, após divergência da doutrina, o STF pacificou o entendimento de que primeiro devem ser apreciados os requisitos gerais e específicos de admissibilidade do recurso extraordinário e só em um segundo momento apreciada a questão da repercussão geral.

402 TAVARES JUNIOR, Homero Francisco, Recursos especiais repetitivos: aspectos da Lei 11.672/2008 e da Res. 8/2008 do STJ, cit., p. 195.
} 
A seleção ocorrerá a partir da análise por amostragem dos fundamentos das partes recorrentes. Em tese, não há como garantir que todos os fundamentos serão efetivamente apreciados, embora isso seja o ideal. O fato é que, de toda a "multiplicidade de recursos" que versam sobre "idêntica questão de direito", apenas um ou alguns serão selecionados, e é a partir da sua apreciação que o entendimento do STF e do STJ será firmado, construindo-se um precedente com forte carga persuasiva e alto poder de influência sobre os demais casos repetitivos.

Surge, então, a pergunta: qual ou quais recursos deverão ser selecionados? A resposta está nos artigos 543-B, $\S 1^{\circ}$, e $543-\mathrm{C}, \S 1^{\circ}$ : aqueles que forem "representativos da controvérsia".

Essas poucas palavras têm um significado não tão simples e muito importante. Primeiro, observa-se que se trata de um conceito vago, justamente para que possa ser ajustado às peculiaridades fáticas de cada caso. Segundo, o conceito tem significado muito claro, relacionado à exigência de que os recursos selecionados não sejam quaisquer recursos da multiplicidade de casos, mas sim aqueles que efetivamente representem a controvérsia.

Para ser ainda mais claro, seria melhor que o legislador tivesse incluído o termo "adequadamente", pois o que se exige é a seleção de recursos que sejam adequadamente representativos da controvérsia. E, como veremos nos itens seguintes, essa adequação pode ser atingida a partir da observância de critérios objetivos e subjetivos na seleção dos recursos, a fim de garantir que eles efetivamente representem, de uma forma geral, a controvérsia objeto da multiplicidade de casos idênticos.

Isso é essencial para a qualidade e legitimidade do julgamento por amostragem, assim como a adequada seleção da amostra é importantíssima para a qualidade do resultado do exame que se pretende realizar em qualquer matéria. Não basta qualquer amostra, sendo imperiosa a coleta de material que represente o todo, sob pena de resultado desvirtuado.

No caso do julgamento dos recursos repetitivos, a seleção inadequada poderá acarretar a falta de legitimidade e representatividade do julgamento que servirá de 
parâmetro para a solução de todos os demais recursos repetitivos. Poderá não levar em consideração todos os pontos de vista e argumentos relevantes a respeito da questão, violando os princípios constitucionais do contraditório e da ampla defesa. Poderá, ainda, gerar um julgamento desigual, na medida em que um dos litigantes pode ser mais frágil, não tendo as mesmas condições que a outra parte para defender o seu ponto de vista.

Quando todos esses problemas ocorrem em processo individual, não sujeito à técnica dos artigos 543-B e 543-C do CPC, a situação já é preocupante. Imagine-se, então, quando isso ocorre em processo-piloto, cujo julgamento influenciará toda a multiplicidade de casos idênticos. Nesse caso, a técnica concebida para trazer agilidade, eficiência e, principalmente, segurança jurídica e isonomia na aplicação e interpretação do direito federal poderá atuar como instrumento de instabilidade, insegurança e produção em massa de injustiça.

Nota-se, assim, uma evidente relação entre a adequada representatividade subjetiva e objetiva dos recursos selecionados para a formação do precedente e a legitimidade desse mesmo precedente - em que se inclui a sua aptidão para influenciar, com eficácia diferenciada, e sem violação ao contraditório, o julgamento dos casos repetitivos. Quanto maior a participação das partes e a qualidade do recurso apreciado, maior a legitimidade da decisão que influenciará os demais casos repetitivos. Daí a importância da seleção adequada dos recursos paradigma, cujos critérios passamos a analisar.

\subsubsection{Critérios subjetivos}

As ações repetitivas, por suas próprias características, normalmente envolvem o que Mauro Cappelletti e Bryant Garth chamaram de "litigantes eventuais" e "litigantes habituais", classificação baseada na frequência de encontros com o sistema judicial ou, em outras palavras, com a habitualidade e experiência das partes na atividade de litigar. ${ }^{403}$

Os "litigantes habituais" teriam as seguintes vantagens: (a) maior experiência com o Direito, possibilitando-lhes melhor planejamento do litígio; (b) economia de escala,

403 CAPPELLETTI, Mauro; BRYANT, Garth. Acesso à justiça. Tradução de Ellen Gracie Northfleet. Porto Alegre: Fabris, 1988. p. 25. 
porque têm mais casos; (c) oportunidades de desenvolver relações informais com os membros dos órgãos julgadores; (d) possibilidade de diluir os riscos da demanda por maior número de casos; (e) possibilidade de testar estratégias com determinados casos, de modo a garantir expectativa mais favorável em relação a casos futuros. ${ }^{404}$

Por sua vez, o "litigante eventual” é aquele que vai a juízo poucas vezes durante sua vida, não sendo acostumado com os assuntos da Justiça. ${ }^{405}$

Assim, os "litigantes habituais" ou "organizacionais" são mais eficientes do que os indivíduos, havendo uma desigualdade entre os acessos de um e de outro à justiça.

Segundo Leonardo José Carneiro da Cunha, "numa demanda de massa ou numa causa repetitiva, é frequente a presença de um litigante habitual num dos polos da relação processual, tendo, no outro polo, um outro litigante habitual ou, até mesmo, um litigante eventual". Com isso, segundo o autor, há um "desequilíbrio de forças, sendo certo que o litigante habitual terá mais condições de suportar a demora do processo, reunindo, com mais facilidade, os meios de prova necessários à comprovação dos fatos alegados". 406

E, segundo Cappelletti e Garth, essa desigualdade pode ser atacada com maior eficiência "se os indivíduos encontrarem maneiras de agregar suas causas e desenvolver estratégias de longo prazo, para fazer frente às vantagens das organizações que eles devem amiúde enfrentar". 407

Nesse sentido, as técnicas do processo coletivo de modo representativo permitem uma minimização dessa desigualdade, seja por estimular a organização dos litigantes individuais (na formação de associações, por exemplo), seja por permitir que terceiros mais fortes e melhor preparados defendam, em nome próprio, o seu interesse em juízo (lembremos que podem ajuizar ação civil pública o Ministério Público ${ }^{408}$, a Defensoria Pública e as pessoas integrantes da Administração Pública Direta e Indireta).

\footnotetext{
${ }^{404}$ CAPPELLETTI, Mauro; BRYANT, Garth, Acesso à justiça, cit., p. 25.

${ }^{405}$ CUNHA, Leonardo José Carneiro da, O regime processual das causas repetitivas, cit., p. 144.

${ }^{406}$ Ibidem, p. 144 e 147.

${ }^{407}$ CAPPELLETTI, Mauro; BRYANT, Garth, op. cit., p. 26.

${ }^{408}$ Sobre os limites da atuação do Ministério Público em sede de ação civil pública na defesa dos interesses individuais homogêneos, ver: BEDAQUE, José Roberto dos Santos. Legitimidade processual e legitimidade política. In: SALLES, Carlos Alberto de (Org.). Processo civil e interesse público: o processo como instrumento de defesa social. São Paulo: Revista dos Tribunais, 2003, p. 101-111.
} 
Observe-se que, no Brasil, não se admite o ajuizamento de ação civil pública por um indivíduo, em nome da exigência de que o autor tenha representatividade adequada. A legitimidade é necessariamente de entes mais preparados e organizados, o que representa uma clara opção política, no sentido de se evitar que processos versando sobre interesses de inúmeras pessoas sejam instaurados e conduzidos por indivíduos, cuja atuação pode ser insuficiente para enfrentar os litigantes habituais.

No caso do julgamento de recursos repetitivos por amostragem, embora não se trate propriamente de um processo coletivo e não se possa falar em coisa julgada erga omnes (Capítulo 5, item 5.4), essa mesma desigualdade entre os litigantes pode estar, e normalmente está, presente no processo relativo aos recursos repetitivos selecionados para julgamento pelo STF e pelo STJ.

Isso pode levar a que a definição da questão controvertida, que influenciará o julgamento da multiplicidade de casos repetitivos, seja defendida de modo desigual perante o STF e o STJ. Os litigantes habituais terão maiores condições de contratar os melhores advogados para a apresentação de pareceres e realização de audiências prévias com os ministros e sustentação oral por ocasião do julgamento. Por outro lado, os litigantes eventuais não só terão condições reduzidas de realizar os mesmos atos como a questão poderá não ser, do ponto de vista individual, tão importante para eles.

Essa desigualdade poderá refletir-se na violação do princípio do contraditório e da ampla defesa e, consequentemente, na legitimidade do precedente que influenciará o julgamento dos casos repetitivos sobrestados e sucessivos. Embora a participação de terceiros, na forma autorizada pelos artigos 543-B e 543-C do CPC, tenda a minimizar esse problema, ela talvez não seja suficiente, sobretudo em razão das limitações dessa participação (ver Capítulo 9, item 9.2.3).

Diante disso, no caso do julgamento de recursos repetitivos, sendo eles originados de ações individuais e ações coletivas, é imperioso selecionar, entre os casos idênticos, também aqueles que se refiram a essas últimas.

Essas ações coletivas terão sido ajuizadas pelo Ministério Público, pela Defensoria, pela Administração Pública ou, ainda, por associações constituídas para a defesa dos 
interesses em discussão. Em tese, esses litigantes terão melhores condições de defender o ponto de vista de todos aqueles que aguardam com seus processos individuais sobrestados, representando mais adequadamente a controvérsia e trazendo maior qualidade e legitimidade para o julgamento.

Assim, conforme Ada Pellegrini Grinover, havendo processos repetitivos coletivos e individuais, "deverá ser selecionado no mínimo um recurso atinente às ações individuais e um representativo das ações coletivas". 409

Para Luiz Rodrigues Wambier e Rita de Cássia Corrêa de Vasconcelos, os legitimados a ajuizar ações coletivas devem ter representatividade adequada, o que pressupõe melhores condições de defesa dos direitos sob discussão perante os Tribunais Superiores. Daí porque, havendo ao lado dos recursos originados de ações individuais recursos originados de ações coletivas, estes devem ser escolhidos, justamente para viabilizar a maior representatividade do precedente paradigmático e preservar a igualdade de condições entre os litigantes. ${ }^{410}$

Assim, considerando-se que os artigos 543-B e 543-C do CPC determinam a seleção de recursos "representativos da controvérsia" - o que deve ser lido como exigência de representatividade adequada do recurso paradigma -, não há dúvida sobre a necessidade de seleção também de ações coletivas, sempre que, ao lado das ações individuais, houver recursos excepcionais originados daquelas ações.

\subsubsection{Critérios objetivos}

O primeiro critério objetivo para a seleção do recurso representativo da controvérsia é a sua admissibilidade, seja quanto aos pressupostos gerais (tempestividade,

\footnotetext{
${ }^{409}$ GRINOVER, Ada Pellegrini, O tratamento dos processos repetitivos, in Processo civil: novas tendências: homenagem a Humberto Theodoro Júnior, cit., p. 8.

410 "Lembre-se aqui do requisito da pertinência temática. Ainda que, objetivamente, haja a mesma 'quantidade de fundamentos' em todos os recursos, não faria sentido selecionar o que tenha sido interposto por uma associação - por exemplo - cujos fins institucionais não têm qualquer relação com o objeto tutelado. Certamente se espera do ente legitimado, cujos fins institucionais incluam a própria defesa dos interesses e direitos tutelados na ação coletiva, que tenham melhores condições de desenvolver os fundamentos a serem analisados pelo Tribunal Superior." (WAMBIER, Luiz Rodrigues; VASCONCELOS, Rita de Cássia Corrêa de. Recursos especiais repetitivos: reflexos das novas regras (Lei 11.672/2008 e Resolução 8 do STJ) nos processos coletivos, cit., p. 46).
} 
preparo, regularidade formal, interesse, legitimidade etc.), seja quanto aos requisitos específicos (prequestionamento, fundamentação vinculada às hipóteses constitucionais).

Excepciona-se, apenas, o requisito da repercussão geral do recurso extraordinário, cuja análise pelo tribunal de origem restringe-se à existência de sua alegação em sede de preliminar no corpo do recurso. Os motivos dessa exceção são óbvios: a competência para o exame da repercussão geral é exclusiva do STF, além do que a sua própria aferição no caso de multiplicidade de recursos extraordinários é motivo ensejador da instauração do rito do artigo 543-B do CPC. Assim, quanto ao recurso extraordinário, deverão ser selecionados recursos que atendam a todos os demais requisitos de admissibilidade, excetuando-se a existência de repercussão geral.

Sobre a previsão legal desse critério qualitativo, a norma do artigo 543-C do CPC foi mais precisa, pois seu $\S 1^{\circ}$ afirma que o tribunal de origem deverá "admitir um ou mais recursos representativos da controvérsia". Talvez o termo não tenha sido explicitado pelo artigo 543-B do CPC justamente em razão da repercussão geral, que, enquanto elemento integrante do cabimento do recurso extraordinário, também se apresenta como requisito de admissibilidade. Mas, como dito acima, os demais requisitos também deverão estar presentes quanto ao recurso extraordinário paradigma.

Nesse sentido, segundo Rodrigo Valente Giublin Teixeira, "o procedimento previsto no art. 543-C do CPC, não se aplica aos recursos que não preencherem os seguintes pressupostos genéricos de admissibilidade, tais como a tempestividade, preparo, regularidade formal, cabimento, legitimidade e interesse recursal". 411

Por sua vez, conforme Fátima Nancy Andrighi, “apesar de serem representativos da controvérsia, esses recursos continuam se sujeitando aos requisitos de admissibilidade comuns a todo o recurso especial" 412 . Daí porque, segundo a autora, é importante que os tribunais de origem exerçam um rigoroso controle de admissibilidade na escolha dos processos representativos da controvérsia, posto que, do contrário, haverá "uma

\footnotetext{
${ }^{411}$ TEIXEIRA, Rodrigo Valente Giublin. Recursos especiais repetitivos fundados em idêntica questão de direito no âmbito do Superior Tribunal de Justiça. Revista de Processo, São Paulo, v. 36, n. 191, p. 166, jan. 2011.

${ }^{412}$ ANDRIGHI, Fátima Nancy, Recursos repetitivos, cit., p. 271.
} 
interrupção desnecessária no curso de diversos outros recursos", sem contar a prática desnecessária de atos para a formação do incidente. ${ }^{413}$

Como se vê, a admissibilidade não precisa ser de todas as questões do recurso, mas apenas daquela que será afetada para julgamento por amostragem, razão pela qual se pode falar em admissibilidade parcial.

Além disso, considerando-se que a escolha do recurso representativo da controvérsia cabe tanto ao STF e ao STJ como aos tribunais de origem, estes também devem escolher recursos admissíveis, senão o incidente poderá ser indeferido pelo ministro relator, ao realizar o segundo juízo de admissibilidade, inclusive monocraticamente (art. 557 do CPC). É o que foi decidido pelo STJ na Questão de Ordem no REsp n. 1.087.108/MS, rel. Min. Nancy Andrighi, j. 16.02.2009.

De fato, não poderia ser de outra forma. A circunstância de se ter criado um novo procedimento para o julgamento dos recursos repetitivos não significa que os requisitos de admissibilidade possam ser ignorados. Pelo contrário, considerando-se que a decisão poderá ser aplicada para o julgamento de inúmeros recursos repetitivos, a seleção de um recurso-piloto que preencha os requisitos de admissibilidade é imperiosa, inclusive para conferir maior qualidade e segurança ao julgamento.

Ademais, não se pode esquecer que a técnica de julgamento de recursos repetitivos não afasta, nem poderia afastar, a função constitucional do STF e do STJ de proteger e unificar o direito federal, aplicando a norma ao caso concreto, e não simplesmente apreciando a lei em tese - sem prejuízo do maior caráter de objetivação conferido à função dessas cortes pela técnica de julgamento de recursos repetitivos.

$\mathrm{Na}$ verdade, o grande problema de ordem prática é a própria jurisprudência defensiva do STF e do STJ (Capítulo 4, item 4.5), que pode acabar dificultando a escolha de recursos representativos da controvérsia. As razões que justificam a criação da jurisprudência defensiva (viabilização dos trabalhos do STF e do STJ) não fazem sentido

\footnotetext{
413 “Assim, a questão idêntica que caracteriza a multiplicidade de recursos, além de ser selecionada na decisão que instaura o incidente, deve ter sido: 1) expressamente debatida no acórdão impugnado; 2) debatida nas razões do recurso especial; 3) preencher todos os requisitos de admissibilidade. Só assim, a referida questão poderá ser objeto de julgamento e produzir os efeitos do $\S 7^{\circ}$ do art. 543-C do CPC." (ANDRIGHI, Fátima Nancy, Recursos repetitivos, cit., p. 271).
} 
quando se está diante do procedimento dos artigos 543-B e 543-C do CPC, por meio do qual a instância superior supostamente se debruçará uma única vez sobre a questão. Pouco importa, por exemplo, se o carimbo de protocolo está ou não legível, desde que se possa aferir a tempestividade do recurso por qualquer outro modo.

Outro critério objetivo de seleção dos recursos representativos da controvérsia é aquele trazido pelo artigo $1^{\mathrm{o}}, \S 2^{\mathrm{o}}$, da Resolução n. 8 do STJ, ao dispor que "serão selecionados pelo menos um processo de cada Relator e, dentre esses, os que contiverem maior diversidade de fundamentos no acórdão e de argumentos no recurso especial". Não se verifica norma de igual teor quanto aos recursos extraordinários, mas sua aplicação pode e deve ser analogamente estendida ao rito do artigo 543-B do CPC.

A ideia é a seleção dos recursos mais abrangentes e que melhor representem a controvérsia, trazendo maior qualidade e legitimidade para o julgamento por amostragem. Nesse sentido, todos os critérios são elogiáveis, por pautarem-se na maior abrangência de argumentos e pontos de vista sobre a questão jurídica.

O primeiro critério, ao mencionar a seleção de pelo menos um processo de cada relator, refere-se à necessidade de seleção de pelo menos um recurso excepcional interposto contra cada acórdão relatado por julgador integrante dos tribunais de origem. A medida é interessante, por presumir que cada relator, com sua experiência e conhecimento, pode ter enxergado a questão de uma forma, obtendo-se uma diversidade que, também presumivelmente, haverá de se refletir nos respectivos recursos especiais, enriquecendo o debate.

Entretanto, é preciso considerar que, no plano prático, a medida é de difícil implementação, dada a dificuldade de se selecionar um processo de cada relator, sobretudo em tribunais altamente complexos, como por exemplo o Tribunal de Justiça do Estado de São Paulo, que conta com cerca de 360 desembargadores. ${ }^{414}$

\footnotetext{
${ }^{414}$ Segundo Rogério Licastro Torres de Mello, diversas normas contidas na Resolução n. 8 extrapolam os limites do artigo 543-C do CPC, apresentando problemas de constitucionalidade, na medida que compete exclusivamente à União legislar sobre processo civil (art. 22). Por isso, o Tribunal de origem não estaria obrigado a selecionar um recurso de cada relator, porque isso vai além do artigo 543-C. Esse requisito número de recursos - não está na lei e seria impraticável (MELLO, Rogério Licastro Torres de, Recursos especiais repetitivos: problemas de constitucionalidade da Resolução 8/2008, do STJ, cit., p. 192).
} 
Os outros dois critérios - "os que contiverem maior diversidade de fundamentos no acórdão e de argumentos no recurso especial" - são igualmente importantes. Deverão ser selecionados os acórdãos que contêm maior diversidade e, poderíamos acrescentar, profundidade de fundamentação, bem como os recursos especiais que contiverem mais e melhores fundamentos. Tudo para retratar a controvérsia de forma mais qualificada e abrangente possível. ${ }^{415}$

Também aqui há uma dificuldade prática, pois a análise comparativa exata dos melhores acórdãos e recursos exigiria um exame de todos os múltiplos casos idênticos. Assim, deve-se realizar ao menos uma análise por amostragem dos casos, selecionando-se aqueles que contiverem mais e melhores fundamentos e argumentos.

Por fim, tem-se um critério que, apesar de não previsto na legislação, é bastante lembrado pela doutrina: a seleção de acórdãos e recursos em sentidos opostos. Nessa linha, Ada Pellegrini Grinover afirma que "se houver acórdãos em sentido oposto, devem ser selecionados recursos representativos em cada um dos sentidos". 416

Esse também é o entendimento de Luiz Rodrigues Wambier e Rita de Cássia Corrêa de Vasconcelos, para quem "devem ser selecionados os recursos que melhor retratarem a questão discutida, independentemente de as decisões recorridas serem num mesmo sentido". Assim, os autores entendem que, havendo acórdãos em sentidos opostos, "devem ser selecionados recursos representativos em cada um dos sentidos, pois a simples existência de decisões antagônicas no âmbito dos tribunais locais já traduz a diversidade de fundamentos a justificar a análise e julgamento pelo Tribunal Superior". Tudo para se permitir, "tanto quanto possível, o conhecimento completo da controvérsia estabelecida nas instâncias ordinárias". 417

\footnotetext{
415 "Para ser eleito como o mais representativo, o recurso especial deveria ser aquele que incluísse todo e qualquer fundamento que, se acolhido, pudesse importar a reforma do acórdão recorrido. $\mathrm{O}$ que mais interessa, na verdade, não é a diversidade dos fundamentos, mas a sua qualidade, entendida como aptidão para justificar a reforma do acórdão recorrido.” (MESQUITA, José Ignácio Botelho de et al. A repercussão geral e os recursos repetitivos: economia, direito e política. Revista de Processo, São Paulo, v. 38, n. 220, p. 27, jun. 2013).

${ }^{416}$ GRINOVER, Ada Pellegrini, O tratamento dos processos repetitivos, in Processo civil: novas tendências: homenagem a Humberto Theodoro Júnior, cit., p. 7.

${ }^{417}$ WAMBIER, Luiz Rodrigues; VASCONCELOS, Rita de Cássia Corrêa de, Recursos especiais repetitivos: reflexos das novas regras (Lei 11.672/2008 e Resolução 8 do STJ) nos processos coletivos, cit., p. 33. No mesmo sentido: TAVARES JUNIOR, Homero Francisco, Recursos especiais repetitivos: aspectos da Lei 11.672/2008 e da Res. 8/2008 do STJ, cit., p. 195.
} 
Realmente, a seleção de acórdãos e recursos em sentidos opostos, além de pressupor a maior diversidade de fundamentos, é essencial para a adequação e legitimidade da representação da controvérsia. Havendo pedidos recursais em sentidos opostos, a seleção de apenas um deles ofenderia o princípio constitucional do contraditório, na medida em que a questão seria apreciada considerando-se unicamente argumentos de violação ao direito federal em um dos sentidos. Embora o posicionamento contrário possa estar representado nas contrarrazões, trata-se de peça não obrigatória para a admissibilidade, e que pode não ter a mesma contundência do próprio recurso, no qual o litigante desenvolve todo o esforço argumentativo no sentido da cassação do acórdão recorrido.

\subsubsection{Recorribilidade}

Verificados os critérios e a importância da seleção do recurso representativo da controvérsia, indaga-se se a decisão dos órgãos competentes (tribunais de origem e STF ou STJ) a esse respeito está ou não sujeita a algum recurso.

É inegável que há certa margem de liberdade na escolha dos recursos representativos da controvérsia. Afinal, trata-se de uma multiplicidade de recursos idênticos, muitas vezes aos milhares, dos quais apenas um ou alguns devem ser selecionados para julgamento. Se não houvesse essa liberdade, os órgãos jurisdicionais teriam que justificar pontualmente a razão pela qual escolheram alguns, mas deixaram de escolher cada um dos outros milhares de recursos, tornando impraticável o procedimento dos artigos 543-B e 543-C do CPC.

Na verdade, havendo dezenas, centenas, milhares de casos fundados em idêntica questão de direito, não há sentido exigir o exame minucioso das características de cada caso. O julgamento será realmente realizado "por amostragem”, o que pressupõe a seleção de uma "amostra" dos casos, que será profundamente analisada para fins de definição da interpretação da norma federal controvertida, aplicando-se, à massa dos casos idênticos, o entendimento firmado pelo STF e pelo STJ.

Porém, ao mesmo tempo que, pelos motivos expostos acima, é indispensável essa margem de liberdade, não se pode ignorar que a "amostra" a ser selecionada deve ser adequada, ou seja, deve representar efetivamente toda a controvérsia travada nos demais 
casos idênticos, sob pena de violação ao contraditório e ilegitimidade do julgamento por amostragem.

Daí o estabelecimento, pelas próprias normas que regulam julgamento de recursos repetitivos, de critérios para a seleção do recurso paradigma, os quais, como visto, também são extraídos do sistema pela doutrina. Ainda que possam atuar como mero norte aos órgãos encarregados da seleção - o que autoriza que sua aplicação seja flexível, à luz das peculiaridades e possibilidades fáticas de cada caso - esses critérios não poderão ser desprezados, nem estão sujeitos a um juízo meramente discricionário. ${ }^{418}$

Isso implica na obrigatoriedade da observância dos critérios de seleção, sempre que essa medida se mostre possível na prática, e na necessidade de motivação da decisão que seleciona os recursos representativos da controvérsia. Além de ser exigência constitucional expressa e indispensável à validade de toda e qualquer decisão judicial (art. 93, IX da CF), o dever de motivação estimula o órgão a efetuar uma seleção adequada, prestando contas à sociedade dos critérios que pautaram a escolha dos casos paradigmas. ${ }^{419}$

Como consequência disso, tem-se que, embora não se possa falar em direito subjetivo das partes à escolha do seu recurso como representativo da controvérsia, deve-se permitir que de alguma forma ela possa contribuir para a ampliar e pluralizar o debate no julgamento do recurso selecionado. ${ }^{420}$

\footnotetext{
${ }^{418}$ Parte da doutrina afirma que a seleção adequada de recursos, ou seja, a seleção de recursos que efetivamente sejam representativos da controvérsia é um pressuposto processual do julgamento sob a sistemática dos recursos repetitivos, de modo "deve considerar-se admissível a impugnação da escolha do recurso tido como representativo, por faltar-lhe a representatividade necessária, cabendo a legitimidade para essa impugnação a quem figurar como recorrente no recurso eleito ou em qualquer dos demais que tenham sido agrupados" (MESQUITA, José Ignácio Botelho de et al., A repercussão geral e os recursos repetitivos: economia, direito e política, cit., p. 27).

419 "Devem os presidentes dos tribunais fundamentar quais os motivos pelos quais, dentre outros vários recursos existentes, optaram por remeter aquele específico ao STJ.” (TEIXEIRA, Rodrigo Valente Giublin, Recursos especiais repetitivos fundados em idêntica questão de direito no âmbito do Superior Tribunal de Justiça, cit., p. 166).

420 "A parte não tem o direito de exigir que o seu recurso sirva como amostra, sob o argumento de que ele está melhor formulado ou fundamentado. A ausência de escolha do seu recurso como amostra não é passível de impugnação. Isso obviamente não significa que a parte tenha de ficar com sua sorte atrelada ao resultado do julgamento de um recurso-amostra ruim. Como contrapartida pela negativa de um direito subjetivo da parte à escolha do seu recurso como amostra, cumpre reconhecer-lhe: (i) o direito a alguma forma de participação no julgamento do recurso escolhido; (ii) o direito de posteriormente recorrer para demonstrar que em seu recurso a questão envolve argumentos ou fundamentos novos e distintos daqueles apreciados no julgamento por amostragem." (TALAMINI, Eduardo, Novos aspectos da jurisdição constitucional brasileira: repercussão geral, força vinculante, modulação dos efeitos do controle de constitucionalidade e alargamento do objeto do controle direto, cit., p. 69).
} 
Vale registrar que, com o intuito de sistematizar e tornar mais eficiente a seleção dos recursos representativos da controvérsia, o STJ editou a Portaria n. 507, de 17 de setembro de 2013, por meio da qual foi criado o Fórum Permanente de Recursos Repetitivos, integrado por membros do STJ e dos tribunais de origem, entre servidores, juízes e outros colaboradores.

Conforme noticiado pela própria corte, "o fórum virtual será uma importante ferramenta de interlocução entre o STJ e os tribunais de segunda instância, com o objetivo de facilitar a sistematização do rito dos recursos repetitivos". E, entre outras atribuições, seus membros, sob a coordenação do STJ, "poderão definir, por exemplo, o melhor recurso representativo de uma controvérsia, levando em conta, além dos requisitos de admissibilidade, a maior diversidade de fundamentos no acórdão recorrido e de argumentos no recurso especial". 421

Por fim, faz-se referência à proposta, apresentada no Capítulo 9 (item 9.2.4), para aumentar de forma racional a participação das partes que não tiveram seus recursos selecionados, ampliando a legitimidade e representatividade do acórdão que julga os recursos representativos da controvérsia.

\subsection{Desistência do recurso selecionado para julgamento}

A instauração do procedimento de julgamento dos recursos repetitivos gera, segundo a jurisprudência do STJ, um efeito peculiar, qual seja, a extinção do direito, expressamente previsto no artigo 511 do CPC, de desistência dos recursos selecionados para julgamento.

Como exposto no Capítulo 3, o que justifica a existência dos recursos excepcionais é o interesse público no controle da jurisprudência dos demais órgãos jurisdicionais do país. Ao mesmo tempo, porém, o sistema conta, para o atingimento de tal finalidade, com o interesse particular das partes em melhorar sua situação no processo, razão pela qual lhes

421 TUDO pronto para o início do Fórum Permanente de Recursos Repetitivos. Disponível em: <http://www.stj.jus.br/portal_stj/publicacao/engine.wsp?tmp.area=398\&tmp.texto=111547\&tmp.area_anter ior=44\&tmp.argumento_pesquisa=repetitivos $>$. Acesso em: 09 out. 2013. 
disponibiliza a possibilidade de interposição de recursos excepcionais, desde que satisfeitos certos requisitos, os quais se identificam com aquelas funções públicas.

Por meio desse sistema, o interesse particular das partes recorrentes é reconhecido e tutelado apenas em quanto coincida com aquele especial interesse público que constitui a base do instituto. O particular que interpõe o recurso estimulado pelo próprio interesse individual atua, ainda que não o saiba, como instrumento da utilidade pública do Estado, o qual, em troca, lhe concede a oportunidade de melhorar sua situação individual no processo, obtendo a cassação da decisão contrária à lei.

Por essa razão, pode-se dizer que, ao julgar um recurso extraordinário ou especial, o STF ou o STJ não profere uma decisão que interesse apenas às partes recorrentes, mas também uma decisão que, definindo a correta interpretação e aplicação do direito objetivo federal, atuará em benefício de toda a coletividade. Aliás, é exclusivamente em razão da oportunidade de atingir essa última finalidade que o sistema disponibiliza os recursos excepcionais às partes. Caso contrário, seria suficiente o duplo grau de jurisdição.

Diante disso, pode-se afirmar que, ao julgar um recurso especial ou extraordinário, mesmo antes do procedimento de julgamento de recursos repetitivos, o STF ou o STJ já atuava em duas fases ${ }^{422}$, ainda que nem sempre explícitas nos respectivos acórdãos: em relação ao caso particular, ocorre a correção ou confirmação da interpretação do direito objetivo realizada pela decisão recorrida, aplicando-se o direito à espécie para confirmar, reformar ou anular tal decisão (função dikelógica); e, em relação ao interesse público, ocorre a definição da correta interpretação e aplicação do direito objetivo, para que ela sirva de parâmetro para o julgamento de todos os casos semelhantes (funções nomofilácica e paradigmática).

Com a instituição da técnica de julgamento de recursos repetitivos (arts. 543-B e 543-C do CPC), foi potencializada a atuação do STF e do STJ em prol da definição da tese a ser observada nos demais casos, ou seja, da emissão de julgado paradigma ${ }^{423}$, de modo que, no julgamento do recurso-piloto, é inclusive comum o destaque expresso às duas fases

\footnotetext{
${ }^{422}$ ASSIS, Araken de. Manual dos recursos. 2. ed. rev., atual. e ampl. São Paulo: Revista dos Tribunais, 2008. p. 826.

${ }^{423}$ Ibidem, p. 826.
} 
mencionadas acima: decisão sobre o caso particular e decisão sobre a definição da tese que influenciará os casos repetitivos. ${ }^{424}$

Fala-se, inclusive, que a técnica de julgamento de recursos repetitivos gera, à semelhança da declaração incidental de inconstitucionalidade (art. 97 da CF) e da uniformização da jurisprudência (arts. 476 a 479 do CPC), a instauração de um incidente processual, cuja finalidade é interpretar o direito objetivo, cindindo os momentos de interpretação e aplicação do direito. ${ }^{425}$

É que, como já demonstrado com esse procedimento, a função paradigmática exercida pelo STF e pelo STJ com o julgamento dos recursos extraordinários e especiais fica potencializada, pois o julgamento dos recursos selecionados, que ocorre de forma concentrada e com a participação de terceiros, exercerá força persuasiva diferenciada em relação aos casos repetitivos atuais e futuros, posto que resultará na fixação de precedente apto, por si só, a produzir os mesmos efeitos da jurisprudência dominante da corte sobre o tema.

A doutrina tem inclusive afirmado que a técnica de julgamento de recursos repetitivos passou a conferir um caráter de maior objetivação aos recursos extraordinário e especial, eis que passaram a atuar não tanto para a definição do direito subjetivo das partes recorrentes, mas principalmente para a definição da lei em tese, ou seja, da correta interpretação do direito objetivo. ${ }^{426}$

\footnotetext{
424 “Do julgamento do recurso extraordinário com repercussão geral, do mesmo modo que do julgamento do recurso especial com recursos repetitivos, decorrerá a aprovação de uma tese, que terá duplo alcance: (a) será aplicada na decisão do mérito do recurso interposto no caso concreto e (b) passará a influir na decisão das demais causas em que se controverta a respeito da mesma questão de direito." (MESQUITA, José Ignácio Botelho de et al. A repercussão geral e os recursos repetitivos: economia, direito e política, cit., p. 28).

${ }^{425}$ YOSHICAWA, Eduardo Henrique de Oliveira. Julgamento por amostragem e desistência do recurso especial. Revista Dialética de Direito Processual, São Paulo, v. 76, p. 35, jul. 2009.

${ }^{426}$ CÔRTES, Osmar Mendes Paixão. A "objetivação" no processo civil: as características do processo objetivo no procedimento recursal. Revista de Processo, São Paulo, v. 34, n. 178, p. 221, dez. 2009. Sobre os efeitos da decisão que nega a existência de repercussão geral, José Ignácio Botelho de Mesquita e outros afirmam: "A atribuição de eficácia erga omnes a uma tal decisão só se explica na medida em que a possamos considerar como produto de um processo incidente no processo dos recursos extraordinários, análogo ao processo da ação direta e inconstitucionalidade, caracterizado pela ausência de partes e pela sua natureza de processo objetivo, que não obstam a produção de eficácia erga omnes. [...] Também por analogia [...] parece aplicável ao caso do incidente de declaração da repercussão geral a regra de que, 'Proposta a ação direta, não se admitirá desistência' (art. $5^{\circ}$ da Lei 9.868/1999)." (MESQUITA, José Ignácio Botelho de et al., A repercussão geral e os recursos repetitivos: economia, direito e política, cit., p. 20).
} 
Diante disso, surge uma questão: pode a parte recorrente desistir do recurso representativo da controvérsia, selecionado para julgamento sob o rito dos recursos repetitivos, tal como lhe autoriza o artigo 501 do CPC?

No nosso entendimento, a resposta é positiva. Primeiro, trata-se de direito de todo recorrente, previsto expressamente no artigo 501 do $\mathrm{CPC}$, e que poderia ter sido, mas não foi, excepcionado pelos artigos 543-C e 543-B do CPC.

Segundo, as funções públicas nomofilácia e paradigmática dos recursos excepcionais não excluem a sua caracterização como verdadeiros recursos, sujeitos a todas as regras e princípios inerentes à teoria geral dos recursos, inclusive a voluntariedade. Na verdade, como visto no Capítulo 3 (item 3.2.4), o sistema de controle da jurisprudência funciona exatamente a partir da previsão desses recursos como mais um meio de impugnação à disposição das partes, justamente para que elas, visando defender seus interesses particulares, sirvam de veículo para a atuação da instância extraordinária.

Tanto isso é verdade que a jurisprudência não admite os recursos excepcionais quando, por exemplo, o recorrente perde o interesse recursal, por não impugnar todos os fundamentos aptos a sustentar a decisão recorrida (Súmulas 283 do STF e 126 do STJ). Trata-se de hipótese em que o STF e o STJ abrem mão do exercício das funções constitucionais inerentes a esses recursos por razões exclusivamente relacionadas à perda do interesse individual e particular dos recorrentes.

Da mesma forma, não há qualquer razão para excluir-se o direito de as partes recorrentes desistirem de seu recurso, ainda que se levem em consideração as funções públicas ou coletivas desses recursos, ou a própria potencialização dessas funções, em razão da sua afetação para julgamento em sede do procedimento dos recursos repetitivos, que não o desnatura como mais um recurso à disposição das partes recorrentes. ${ }^{427}$

\footnotetext{
427 "Dada a natureza jurídica do instituto da desistência do recurso, vale dizer, do negócio jurídico unilateral não receptício, sua eficácia é plena, independe da concordância ou anuência do recorrido e dispensa homologação judicial. Daí porque o recorrente que interpôs RE e/ou RESP pode dele desistir, ainda que tenha sido empregado ao seu recurso excepcional o rito do recurso repetitivo (CPC 543-B e 543-C). Isto porque o caso que será julgado pelo STF e/ou STJ como recurso repetitivo tem, como matéria de fundo, lide individual que encerra discussão sobre direito subjetivo.” (NERY JUNIOR, Nelson; NERY, Rosa Maria Andrade, Código de Processo Civil comentado e legislação extravagante, cit., p. 985).
} 
Ou seja, às partes sempre interessou e continua interessando apenas e tão somente a melhora da sua situação no processo, como ocorre com todos os recursos ordinários. $\mathrm{O}$ fato de tal recurso servir ao interesse público não influi no direito de a parte interpor o - e, na forma do art. 501 do CPC, dispor do - recurso extraordinário ou especial.

Uma interpretação intermediária seria admitir a desistência e, ao mesmo tempo, prosseguir no julgamento apenas para definição da tese, ou seja, prosseguir na parte que interesse à coletividade.

Esse é o entendimento de Fredie Didier Jr. e Leonardo José Carneiro da Cunha, que destacam a existência de dois procedimentos, um recursal, principal, destinado a resolver questão individual do recorrente; e outro incidental, de definição do precedente ou da tese a ser adotada nos casos repetitivos. Esse último tem feição coletiva, não devendo ser objeto de desistência, da mesma forma que não se admite a desistência em ações coletivas (ação civil pública, ADI etc.). Quando ocorre desistência pelo recorrente, ela deve atingir apenas o procedimento recursal, e não deve ser negada, pois produz efeitos imediatos, não dependendo da concordância da outra parte, nem de autorização ou homologação judicial. Ademais, a parte pode realmente precisar da desistência para um acordo ou negócio jurídico. Sem contar que o processo civil é pautado pelo princípio dispositivo. Mas a desistência não atinge o segundo procedimento, o incidente instaurado para a definição da tese. $^{428}$

A justificativa para esse entendimento é que, instaurado o rito do artigo 543-B e 543-C do CPC, inúmeros casos repetitivos serão sobrestados e ficarão aguardando a definição da controvérsia. Não seria razoável que, em razão da mera desistência do recorrente, aquele sobrestamento restasse inútil ou fosse prolongado pela necessidade de seleção de novos casos - e a consequente repetição de inúmeros atos necessários à preparação do julgamento.

\footnotetext{
${ }^{428}$ DIDIER JR., Fredie; CUNHA, Leonardo José Carneiro da. Curso de direito processual civil. 7. ed. Salvador, BA: Juspodivm, 2009. v. 3, p. 324. Outra opção seria a seleção de novos recursos, como sugerido por Eduardo Henrique de Oliveira Yoshicawa (Julgamento por amostragem e desistência do recurso especial, cit., p. 33-39). Porém, a preparação do julgamento envolve tempo e a prática de inúmeros atos, de modo que selecionar novos recursos e repetir os atos preparatórios poderia atentar contra a eficiência, a celeridade e a economia. Isso sem contar a possibilidade de desistência nos recursos sucessivamente selecionados, impedindo, na prática, a instauração do procedimento.
} 
No entanto, não se pode esquecer de que, apesar do caráter de maior objetivação atribuído aos recursos excepcionais pelo procedimento dos artigos 543-B e 543-C do CPC, o STF e o STJ continuam a julgar casos concretos, e não a lei em tese. Aliás, repita-se que as funções públicas especiais objeto dos recursos excepcionais são exercidas pela atuação das partes em busca de seu interesse subjetivo, sem o que não há como autorizar o julgamento (Capítulo 3, item 3.2.4).

Além disso, observe-se que a desistência do recurso revela o desinteresse da parte recorrente. Admitir o prosseguimento do julgamento equivaleria a permitir que a questão fosse apreciada sem qualquer combate pela parte interessada. Note-se que, embora se admita a participação de terceiros, sua atuação é limitada, sendo inclusive vedada a interposição de recursos contra o acórdão que definir a controvérsia (conforme Capítulo 9, item 9.2.2). Isso geraria a formação de um precedente sem partes, em hipótese não autorizada e regulamentada pelo sistema, fragilizando sua qualidade e representatividade.

Assim, a possibilidade da desistência e o prosseguimento do julgamento para a definição da tese não é suficiente. A desistência deve produzir seus efeitos normais, prejudicando o julgamento do recurso e da própria tese. Claro que isso não poderá significar o abandono da aplicação da técnica de julgamento de recursos repetitivos, na qual há inegável interesse coletivo. Mas esse julgamento pode muito bem prosseguir por meio da escolha de outros recursos como representativos da controvérsia.

O STJ, porém, não adota esse posicionamento, e vem entendendo que a parte perde o direito de desistir do recurso especial não só quando afetado para julgamento nos termos do artigo 543-C do CPC, mas também do recurso não sujeitos ao procedimento dos recursos repetitivos, sempre que o interesse público na definição da controvérsia justificar a mitigação do direito individual da parte recorrente. ${ }^{429}$

Na verdade, a discussão originou-se no STJ bem antes do artigo 543-C do CPC, como se observa no acórdão que julgou Questão de Ordem no ERESP n. 218.426/SP, Corte Especial, rel. Min. Vicente Leal, DJ, de 19.04.2004, em que, por maioria, o pedido

\footnotetext{
${ }^{429}$ Criticando fortemente esse entendimento, ver: STREK, Lenio Luiz. O STJ e a desistência de recurso. Jus Navigandi, Teresina, ano 14, n. 2016, 7 jan. 2009. Disponível em: 〈http://jus.com.br/artigos/12173>. Acesso em: 10 nov. 2013.
} 
de desistência formulado pela parte recorrente após o início do julgamento foi simplesmente indeferido, sob o fundamento de que, apesar do entendimento jurisprudencial e doutrinário a respeito do alcance do artigo 501 do CPC (que permite a desistência a qualquer tempo, mesmo tratando-se de recurso excepcional e tendo sido iniciado o julgamento), deveria prevalecer o interesse público na apreciação da controvérsia (para definição da correta interpretação das normas de direito federal questionadas) sobre o interesse individual da parte recorrente.

Com a instituição da técnica de julgamento de recursos repetitivos, a questão voltou a ser apreciada no julgamento de Questões de Ordem no REsp n. 1.063.343/RS, em que ficaram vencidas as propostas de possibilidade de desistência e de possibilidade de desistência com prosseguimento da apreciação das questões controvertidas, para se definir que, afetado o recurso para julgamento, a parte não pode dele desistir, em razão da prevalência do interesse público sobre o interesse particular das partes. ${ }^{430}$

Conforme o entendimento da ministra Fátima Nancy Andrighi, admitir a desistência mesmo após a afetação do recurso significaria entregar às partes a possibilidade de fazer com que o Poder Judiciário julgasse, um a um, milhares de recursos idênticos, favorecendo quem sabe que não tem sua pretensão amparada pelo direito material e pelos precedentes. Assim, a regra do artigo 501, por estar relacionada exclusivamente ao interesse subjetivo do recorrente e ser anterior ao sistema de julgamento de recursos repetitivos, precisaria ser adaptada ao novo sistema, que visa garantir a plena realização do direito à luz da razoável duração do processo e da isonomia. Diante desse conflito entre o interesse individual do recorrente e o interesse coletivo na apreciação do mérito do recurso selecionado, deve prevalecer o segundo, indeferindo-se o pedido de desistência. ${ }^{431}$

Indo mais além, a Segunda Seção do STJ, ao julgar o REsp n. 1.067.237/SP, chegou a vedar a desistência da própria ação, para permitir o prosseguimento do julgamento do recurso especial afetado para julgamento segundo o rito do artigo 543-C do CPC. Na oportunidade, afirmou-se que, afetado o recurso, nem mesmo a realização de acordo entre as partes poderia prejudicar a apreciação da controvérsia. Porém, ressalvou-se

\footnotetext{
${ }^{430}$ STJ - QO REsp n. 1.063.343/RS, Corte Especial, rel. Min. Nancy Andrighi, j. 17.12.2008, DJe, de 04.06.2009.

${ }^{431}$ ANDRIGHI, Fátima Nancy, Recursos repetitivos, cit., p. 274.
} 
ao final que a decisão não produziria efeitos para o caso concreto, considerando-se prejudicado o recurso em face da desistência da ação. ${ }^{432}$

Já no julgamento do REsp n. 1.129.971/BA, a Primeira Seção do STJ indeferiu o pedido de desistência do recurso afetado para julgamento, mesmo tendo ele sido formulado com o fim de atender às exigências impostas pela lei para a concessão de benefício fiscal à parte. No acórdão, o STJ recomendou à Fazenda Nacional que os motivos do indeferimento da desistência fossem considerados, para fins de concessão do benefício fiscal almejado pela parte. ${ }^{433}$

Mais recentemente, o STJ indeferiu o processamento do recurso especial, mesmo não estando sujeito ao procedimento do artigo 543-C do CPC, embora com fundamento nos mesmo argumentos relacionados à prevalência do interesse público no exercício das funções constitucionais da corte sobre o interesse particular da parte recorrente. ${ }^{434}$

Registre-se, por fim, que, pelo projeto de novo CPC, pretende-se positivar a proposta intermediária, no sentido de permitir a desistência, mas ao mesmo tempo autorizar o prosseguimento do julgamento, para fins exclusivo de definição da controvérsia. $^{435}$

\footnotetext{
${ }^{432}$ STJ - REsp n. 1.067.237/SP, 2 ${ }^{\text {a }}$ Seção, rel. Min. Luis Felipe Salomão, DJe, de 23.09.2009.

433 “[...] pelo contexto apresentado, seria de todo louvável que de tal indeferimento não fosse extraída a consequência de impedir a contribuinte de usufruir os benefícios fiscais visados, visto que a ausência da desistência e da renúncia acontece contra a sua vontade expressamente manifestada nos autos. A observação aqui é feita apenas a título de recomendação para a Fazenda Nacional." (STJ - REsp n. 1.129.971/BA, $1^{\text {a }}$ Seção, rel. Min. Mauro Campbell Marques, DJe, de 10.03.2010).

${ }^{434}$ STJ - REsp n. 1.308.830/RS, $3^{\text {a }}$ Turma, rel. Min. Nancy Andrighi, DJe, de 19.06.2012.

435 “Art. 1.011 - O recorrente poderá, até o início da votação, sem a anuência do recorrido ou dos litisconsortes, desistir do recurso. Parágrafo único - A desistência do recurso não impede a análise de questão cuja repercussão geral já tenha sido reconhecida e daquela objeto de julgamento de recursos extraordinários ou especiais repetitivos."
} 


\section{SOBRESTAMENTO DOS RECURSOS REPETITIVOS}

\subsection{Definição, objeto e importância}

Por meio da técnica do sobrestamento dos recursos repetitivos prevista nos artigos 543-B e 543-C do CPC, o sistema faz com que os recursos não selecionados aguardem a análise da repercussão geral (no caso do recurso extraordinário) ou a definição da controvérsia (no caso de recurso extraordinário com repercussão geral e de recurso especial) por meio da apreciação do caso paradigma pelo STF ou pelo STJ para, em seguida, viabilizar (o que não significa impor) a aplicação do entendimento consolidado aos casos que aguardavam sobrestados.

O sobrestamento, em regra ${ }^{436}$, é do recurso, e não do próprio processo em que o recurso foi interposto ${ }^{437}$, sob pena de se emprestar indiretamente aos recursos extraordinários e especiais um efeito suspensivo ope legis, contrariando-se assim o artigo $542, \S 2^{\circ}$, do CPC. Isso significa, por exemplo, que a decisão objeto do recurso sobrestado pode ser normalmente executada, embora pelo regime da execução provisória.

Assim, não se pode confundir a suspensão ou o sobrestamento de que se está tratando com a suspensão dos efeitos da decisão recorrida, esta regulada pelas regras que disciplinam os efeitos suspensivos ope legis e ope judicis de cada recurso (entre outros, ver os arts. 520, caput e incisos, 527, III, 558 do CPC). Daí porque o sobrestamento de recursos extraordinários ou especiais repetitivos, que são recursos desprovidos de efeito suspensivo ope legis, não impede a execução da decisão recorrida, salvo a eventual concessão de medidas voltadas à atribuição de efeito suspensivo excepcional (ope judicis). ${ }^{438}$

\footnotetext{
${ }^{436}$ Veremos ao longo deste capítulo que a eficácia do sobrestamento tem sido ampliada pela doutrina e jurisprudência, para excepcionalmente permitir, em alguns casos, a paralisação também de processos em primeiro e segundo graus de jurisdição.

${ }^{437}$ Como defendem: MESQUITA, José Ignácio Botelho de et al., A repercussão geral e os recursos repetitivos: economia, direito e política, cit., p. 24.

438 "A determinação do sobrestamento dos recursos que versam sobre questão idêntica não implica a sustação dos efeitos da decisão recorrida. Apenas a concessão de uma medida cautelar propiciará esse resultado." (TALAMINI, Eduardo, Novos aspectos da jurisdição constitucional brasileira: repercussão geral, força vinculante, modulação dos efeitos do controle de constitucionalidade e alargamento do objeto do controle direto, cit., p. 71).
} 
Abra-se parêntese para um esclarecimento de ordem terminológica: o artigo 543-C do CPC trata como sinônimos os termos suspensão e sobrestamento. Nos $\S \S 1^{\circ}$ e $2^{\circ}$, fala-se em suspensão, enquanto que no $\S 7^{\circ}$ fala-se indistintamente em sobrestamento. Diferentemente, o artigo 543-B fala apenas em sobrestamento. Assim, pode-se referir aos dois termos, que são sinônimos. ${ }^{439}$

Diz-se que com o sobrestamento o sistema busca evitar trabalho inútil e privilegiar a economia processual ${ }^{440}$, e de fato esse foi um dos motivos oficiais da instituição do sistema de julgamento de recursos repetitivos (conforme Capítulo 4, item 4.6).

Não fosse o sobrestamento, o STF e o STJ, cortes reduzidas cuja missão constitucional é definir a exata interpretação do direito federal no país, continuariam a ter de processar e apreciar individualmente inúmeros casos repetitivos, despendendo tempo e recursos materiais que não estão relacionados com a sua missão de proferir julgamentos qualificados e aprofundados sobre questões que interessam a toda a coletividade. Como se vê, não se trata de simplesmente aliviar a sobrecarga de trabalho dos órgãos superiores, e sim viabilizar, como decorrência disso, a prestação de uma jurisdição de maior qualidade.

Ademais, o sobrestamento visa viabilizar a fixação, em precedente único, alcançado a partir de julgamento diferenciado e concentrado da questão, a correta e única interpretação sobre o direito federal no país, permitindo, com isso, a solução uniforme de um maior número de casos repetitivos, a fim de prevenir e controlar de forma mais eficiente e efetiva a divergência jurisprudencial.

Quanto aos casos decididos de forma divergente à que vier a ser consolidada pelo STF ou pelo STJ, é inegável que o sobrestamento, somado à possibilidade de reexame da decisão pelo órgão de origem, agora à luz do entendimento consolidado sobre a correta interpretação do direito federal, permitirá que a parte seja beneficiada com a aplicação do

\footnotetext{
${ }^{439}$ Realmente, os termos têm o mesmo significado, tanto que, no dicionário, sobrestar aparece como: "1 Não ir avante, não prosseguir até segunda ordem ou nova determinação; cessar, parar, pôr ponto [...] 3 Suspender, sustar: Sobrestar o inquérito. vti.” (MICHAELIS: moderno dicionário da língua portuguesa. Disponível em: <http://michaelis.uol.com.br/>. Acesso em: 22 jun. 2013).

${ }^{440}$ MESQUITA, José Ignácio Botelho de et al., A repercussão geral e os recursos repetitivos: economia, direito e política, cit., p. 24.
} 
entendimento uniforme do direito federal ao seu caso concreto, mesmo naqueles casos em que o recurso extraordinário ou especial não seria, por qualquer razão, admitido.

É o que se terá no caso de o tribunal de origem efetivamente exercer o juízo de retratação e modificar a decisão de origem, ajustando-a ao entendimento consolidado do STF ou do STJ.

Pode ocorrer, porém, de o tribunal de origem não ajustar seu acórdão ao entendimento consolidado da instância superior, mantendo a divergência. Nesse caso, poder-se-ia argumentar que o sobrestamento foi totalmente inútil, autorizando a conclusão de que não há sentido suspender o andamento do feito para, ao final, autorizar a manutenção da mesma decisão.

Claro que a ausência de efeito vinculante diminui a eficácia do sistema, ao menos nos casos em que a divergência for mantida. Mas nem por isso o sistema é imprestável e desprovido de sentido porque, mesmo na hipótese de manutenção da divergência, os tribunais de origem terão de motivar sua decisão, o que, na prática, deve estimular a aplicação do precedente.

Assim, o sobrestamento, seguido da formação de um precedente mais qualificado pelo STF ou pelo STJ, e do dever de o tribunal de origem reexaminar a questão e fundamentar analiticamente a eventual decisão de manutenção da divergência, resulta em procedimento que amplia a eficácia persuasiva da jurisprudência da instância superior, e que tende a favorecer a aplicação do entendimento uniforme a um maior número de casos.

Ademais, não se pode desconsiderar que, quando mantida fundamentadamente a divergência, a jurisdição ganhará em qualidade, pois serão levantados novos fundamentos fáticos e jurídicos, ainda não apreciados pela instância superior, contribuindo para a revisão qualificada dos precedentes e, consequentemente, para a evolução do direito.

Por outro lado, quanto aos casos decididos de forma convergente à que vier a ser consolidada pelo STF ou pelo STJ, o sobrestamento realmente atua mais no sentido da racionalização dos trabalhos da instância superior, represando os recursos repetitivos no tribunal de origem e desestimulando as partes, com a subsequente negativa de seguimento 
ao seu recurso, a insistir na submissão de seus casos diretamente aos tribunais de superposição.

Assim, de modo geral, com o sobrestamento dos casos idênticos até o julgamento definitivo da matéria pelo STF e pelo STJ, viabiliza-se a obtenção de resultados de duas ordens: de um lado, permite-se uma maior eficiência (quantidade e qualidade) quanto à atuação dos tribunais de origem, do STF e do STJ, que ficam dispensados de praticar inúmeros atos inúteis, racionalizando-se a apreciação dos recursos (razoável duração do processo); de outro lado, viabiliza-se a obtenção de um precedente que indica claramente o posicionamento definitivo da corte sobre a matéria (segurança jurídica) e propicia-se que um número maior de casos iguais seja julgado uniformemente, ou seja, a partir de uma única interpretação sobre a mesma norma jurídica sob discussão (igualdade).

Por todas essas razões, pode-se dizer que, por meio do sobrestamento, os precedentes firmados pelo STF e pelo STJ no julgamento do recurso representativo da controvérsia passam a ser dotados de uma eficácia persuasiva especial e diferenciada, em relação aos demais precedentes, favorecendo a concretização dos princípios da razoável duração do processo, da igualdade e da segurança jurídica. ${ }^{441}$

Na verdade, a possibilidade de sobrestamento dos casos repetitivos à espera do precedente não é inédita no sistema brasileiro, mas foi com o sobrestamento previsto nos artigos 543-B e 543-C do CPC que a técnica ganhou relevo, em face da sua expressiva utilização no dia a dia de nossos tribunais. ${ }^{442}$

\footnotetext{
${ }^{441}$ Como bem observado pela doutrina, a finalidade do sistema de julgamento de recursos repetitivos não se restringe à desobstrução dos Tribunais Superiores, sendo até mais importante "homogeneizar as decisões, proporcionando, para situações iguais, igual solução. Em outras palavras, visa-se a assegurar prestação jurisdicional homogênea para processos em que se discute idêntica questão de direito", tratando-se, portanto, "de técnica voltada, ao mesmo tempo, à homogeneização da jurisprudência e à aceleração e simplificação do julgamento dos recursos repetitivos pelo STJ” (WAMBIER, Teresa Arruda Alvim; MEDEIROS, Maria Lúcia Lins Conceição. Recursos repetitivos: realização integral da finalidade do novo sistema impõe mais do que a paralisação dos recursos especiais que estão no $2^{\circ}$ grau. Revista de Processo, São Paulo, v. 36, n. 191, p. 191 e 189, jan. 2011).

${ }^{442}$ Por exemplo, o artigo $5^{\circ}, \S 3^{\circ}$, da Lei n. 9.882/99, já dispunha que a liminar concedida em sede de ADPF pode consistir na determinação de que juízes e tribunais suspendam o andamento de processo ou os efeitos de decisões judiciais que apresentem relação com a matéria objeto da arguição, salvo se decorrentes da coisa julgada. O mesmo se diga quanto ao artigo 14 da Lei n. 10.259/2001, que instituiu procedimento de uniformização da jurisprudência dos Juizados Especiais Federais a ser dirimido pelo STJ e o processamento do recurso extraordinário ao STF no âmbito desses Juizados.
} 


\subsection{A questão da necessidade de limitação do prazo de duração do sobrestamento}

A paralisação dos recursos extraordinários e especiais para posterior aplicação do entendimento firmado pelo STF e pelo STJ no julgamento dos recursos selecionados, se por um lado tem, entre seus escopos, a racionalização do julgamento dos recursos por esses tribunais, prestigiando o princípio da razoável duração do processo, por outro lado, paradoxalmente, pode acabar acarretando a violação desse mesmo princípio, em razão do atraso inútil da tramitação dos processos, sobretudo nos casos em que a orientação da instância superior firmar-se no mesmo sentido do acórdão atacado pelos recursos repetitivos sobrestados.

Note-se que o sobrestamento sempre representará um ganho de tempo para a parte que não tem razão, atrasando a entrega definitiva da tutela jurisdicional à parte vencedora, na medida em que prolonga o trânsito em julgado da decisão objeto do recurso extraordinário e especial.

Como veremos adiante, o sobrestamento adia não só o julgamento do mérito, mas também a apreciação da própria admissibilidade do recurso excepcional. Imagine-se que, por qualquer razão (ausência de preparo, falta de prequestionamento etc.), o recurso não reúna condições de admissibilidade - o que, aliás, não é nada incomum, haja vista as baixas taxas de admissibilidade desses recursos, sobretudo em face da jurisprudência defensiva do STF e do STJ (conforme Capítulo 4, item 4.5). Nesse caso, o reconhecimento imediato da inadmissibilidade poderia representar, para a parte vencedora, uma oportunidade de executar provisoriamente a decisão, sem necessidade de caução ${ }^{443}$. Com o sobrestamento, entretanto, isso fica adiado para o momento posterior à definição da controvérsia.

Ou seja, embora o sobrestamento racionalize o julgamento dos recursos repetitivos pelo STF e pelo STJ, ele pode paradoxalmente representar, para as partes, um atraso injustificado na entrega definitiva da prestação jurisdicional. A própria ideia de sobrestamento, relacionada à paralisação do processamento do recurso, é em si mesma

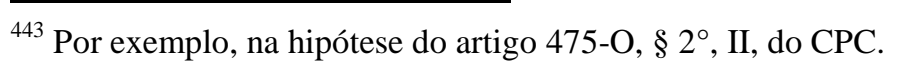


contraditória com a ideia de celeridade, que integra o princípio da razoável duração do processo.

Daí porque o sobrestamento, para atingir os benefícios dele esperados, não pode durar por um período excessivo de tempo. $\mathrm{O}$ fato de as partes aguardarem por algum tempo até que sejam apreciados pelo STF e pelo STJ os recursos repetitivos selecionados é benéfico, não só ao Poder Judiciário (que terá sua atividade de julgamento racionalizada), como aos próprios jurisdicionados, em face da atuação dos princípios da razoável duração do processo, da igualdade e da segurança jurídica. No entanto, se o tempo pelo qual o sobrestamento perdurar for excessivo, esses benefícios passam a ser confrontados pela demora no julgamento definitivo da causa individualmente considerada.

Assim, a estipulação legal de prazo máximo de sobrestamento - prazo esse que, paralelamente, seria utilizado como parâmetro para julgamento do recurso representativo da controvérsia pelo STF e pelo STJ - apresenta-se como uma medida apta a equilibrar os valores em jogo.

Com isso, permite-se a paralisação, a fim de viabilizar o atingimento dos princípios da razoável duração do processo, igualdade e segurança jurídica, mas, ao mesmo tempo, estipula-se um prazo máximo de sobrestamento (no qual se espera que a matéria já tenha sido apreciada pelo STF e pelo STJ), impedindo-se que, sob a justificativa de se racionalizar a atividade dos Tribunais Superiores, acabe-se atrasando ainda mais a entrega da tutela jurisdicional à parte.

Apesar disso, os artigos 543-B, $\S 1^{\circ}$, e 543-C, $\S 1^{\circ}$, do CPC não estipulam qualquer prazo de duração do sobrestamento, pelo contrário, impõem expressamente a suspensão "até o pronunciamento definitivo" do STF e do STJ.

Em contrapartida, o $\S 6^{\circ}$ do artigo 543-C, em regra que foi repetida pelo artigo $4^{\circ}$ da Resolução n. 8 do STJ, determina a inclusão do recurso especial selecionado em pauta, “devendo ser julgado com preferência sobre os demais feitos, ressalvados os que envolvam réu preso e os pedidos de habeas corpus". 
Ou seja, no caso dos recursos especiais repetitivos, optou-se por uma norma mais flexível, que prevê a mera preferência no julgamento, deixando-se de estipular um prazo máximo para o sobrestamento dos demais recursos especiais, o que, em princípio, seria suficiente para rebater eventuais argumentos no sentido de que o sobrestamento contraria o princípio da razoável duração do processo. ${ }^{444}$

Não há regra prevendo julgamento prioritário dos recursos extraordinários, embora o STF tenha optado, em alguns casos, por estipular tempo máximo de paralisação, conforme ocorreu no Agravo de Instrumento n 754.745, rel. Min. Gilmar Mendes, tratando do Plano Collor II, em que se limitou a suspensão ao prazo máximo de 180 dias.

Embora a Resolução n. 8 do STJ apenas repita o artigo 543-C do CPC, é curioso notar que a Resolução n. 7, que teve menos de um mês de vigência, sendo logo substituída pela atual Resolução n. 8, falava em prazo máximo de suspensão de 180 dias (art. $1^{\circ}$ ) e seu artigo $6^{\circ}$, fazendo menção ao inciso LXXVIII do artigo $5^{\circ}$ da $\mathrm{CF}$ (princípio da razoável duração do processo), estipulava prazo máximo de 60 dias para encerramento do julgamento do recurso especial repetitivo. Vencido o prazo, os presidentes dos tribunais de origem poderiam autorizar o prosseguimento dos recursos suspensos, remetendo ao STJ os que fossem admissíveis.

O projeto de novo Código de Processo Civil, em seu artigo $1.050, \S \S 4^{\circ}$ e $5^{\circ}$, fixa, além da preferência, o prazo de um ano para julgamento dos recursos afetados, sob pena de cessar a suspensão dos processos em todo o território nacional.

No nosso entendimento, não é razoável prever apenas julgamento prioritário do recurso paradigma, deixando-se de estipular prazo de sobrestamento. Embora haja uma movimentação do próprio STF e do STJ para julgamento mais célere dos recursos repetitivos, o jurisdicionado afetado pela suspensão tem direito constitucional a uma

\footnotetext{
${ }^{444}$ Nesse sentido, para Teresa Arruda Alvim Wambier e Maria Lúcia Lins Conceição: “A regra de que o julgamento do recurso especial sob regime repetitivo deve ter preferência, estabelecida no art. $4 .^{\circ}$ da Res. STJ 8/2008, rebate a eventual crítica de que, com a suspensão da eficácia da decisão impugnada, estar-se-ia contrariando o princípio da razoável duração do processo. Se, de um lado, o processamento do recurso especial será sobrestado e obstada estará a eficácia da decisão a que se refere, de outro tem-se a garantia de que o julgamento do recurso afetado terá prioridade, o que acaba por gerar o equilíbrio do sistema." (WAMBIER, Teresa Arruda Alvim; MEDEIROS, Maria Lúcia Lins Conceição, Recursos repetitivos: realização integral da finalidade do novo sistema impõe mais do que a paralisação dos recursos especiais que estão no $2^{\circ}$ grau, cit., p. 191).
} 
delimitação razoável do tempo de paralisação do processamento do seu recurso (art. $5^{\circ}$, LXXVIII, da CF). E esse direito fica lesado quando ocorre uma demora excessiva na apreciação do recurso representativo da controvérsia, o que acaba desvirtuando as finalidades e os benefícios almejados pelo sobrestamento. ${ }^{445}$

\subsection{Sobrestamento dos recursos extraordinários e especiais em trâmite nos tribunais de origem}

Instaurado o procedimento, todos os recursos excepcionais em tramitação na origem deverão ser sobrestados, não importando se a decisão de instauração foi proferida pela instância superior ou pelo órgão $a$ quo.

Quando a decisão de instauração é do STF ou do STJ, os órgãos de origem deverão identificar os recursos extraordinários e especiais repetitivos, determinando a incidência, a cada caso, do sobrestamento. Nessa hipótese, a decisão sobre o sobrestamento do caso só aparentemente terá sido proferida pela instância extraordinária. Na verdade, o STF ou o STJ terão apenas instaurado o procedimento (determinando, em decisão de cunho geral, o sobrestamento dos casos repetitivos na forma da lei). O órgão de origem é que identificará a controvérsia e aplicará a decisão ao caso concreto, razão pela qual se pode afirmar que ele é que estará determinando o sobrestamento do caso individual.

O sobrestamento atinge integralmente a tramitação do recurso já interposto e dos que vierem a ser interposto até a definição da controvérsia pela instância superior, de modo que nem mesmo a sua admissibilidade pode ser apreciada.

Quanto aos recursos extraordinários, isso fica claro pela letra do artigo 318-A do RISTF, segundo o qual "nos casos previstos no art. 543-B, caput, do Código de Processo Civil, o Tribunal de origem não emitirá juízo de admissibilidade sobre os recursos extraordinários já sobrestados, nem sobre os que venham a ser interpostos, até que o Supremo Tribunal Federal decida os que tenham sido selecionados".

\footnotetext{
${ }^{445}$ A prática tem demonstrado que o prazo de suspensão tem sido excessivamente elevado, conforme os números analisados no Capítulo 11, item 11.2.
} 
Quanto aos recursos especiais, o próprio artigo 543-C do CPC parece impor a não apreciação da admissibilidade dos recursos especiais repetitivos até a definição da controvérsia, pois dispõe, em seu $\S 8^{\circ}$, que o juízo de admissibilidade só ocorrerá na hipótese de manutenção de eventual decisão divergente da orientação fixada pelo STJ. Apesar disso, como veremos adiante, a jurisprudência do STJ orienta-se no sentido de que os recursos especiais já enviados à instância superior não devem ser suspensos, sobretudo quando se identifica a sua inadmissibilidade.

Sobrestar os recursos sem aferir sua admissibilidade significa permitir que as partes que interpuseram recursos eventualmente inadmissíveis poderão eventualmente se beneficiar tanto do período de suspensão (que atuará no sentido de prolongar o trânsito em julgado da decisão que lhe é desfavorável) como, eventualmente, dos efeitos do precedente a ser formado com o julgamento do recurso representativo da controvérsia.

Note-se que esse precedente poderá gerar, inclusive, o juízo positivo de retratação pelo órgão julgador, caso o acórdão recorrido seja divergente do posicionamento fixado pela instância superior.

Entretanto, deve mesmo ser assim, posto que, como bem observado por Teresa Arruda Alvim Wambier e José Miguel Garcia Medina, a finalidade do sistema é justamente permitir que uma mesma solução fixada pela instância superior "seja aplicada à maior quantidade possível de esferas jurídicas, o que é mais consentâneo com o princípio da isonomia", pouco importando que, como resultado, eventualmente, a solução da instância superior "venha a beneficiar a parte que interpôs recurso inadmissível, mas cuja inadmissibilidade ainda não tenha sido constatada, no juízo a quo". 446

No entanto, é preciso ressalvar os casos de intempestividade do recurso, que caracteriza vício de inadmissibilidade muito grave e que, em regra, gera o imediato trânsito em julgado da decisão recorrida. Permitir o sobrestamento do recurso e a eventual modificação do acórdão impugnado com base na pendência de recurso interposto fora do prazo seria desproporcional e contrariaria a própria coisa julgada.

\footnotetext{
${ }^{446}$ WAMBIER, Teresa Arruda Alvim; MEDINA, José Miguel Garcia, Sobre o novo art. 543-C do CPC: sobrestamento de recursos especiais "com fundamento em idêntica questão de direito", cit., p. 220 e 221.
} 
Outro ponto a se considerar é que, tratando-se de instauração do procedimento para apreciação de questão constitucional em sede de recurso extraordinário, só os recursos extraordinários repetitivos (e, como veremos no item 8.5 infra, os respectivos agravos de admissão) é que serão sobrestados. Por sua vez, quando o procedimento tiver por objeto questão infraconstitucional em sede de recurso especial, só os recursos especiais repetitivos (e respectivos agravos) poderão ser sobrestados. Isso significa que o sobrestamento de recursos extraordinários não se estende aos recursos especiais, e vice-versa, conforme já teve oportunidade de esclarecer a jurisprudência do STJ. ${ }^{447}$

Como visto no Capítulo 7 (item 7.2), a competência para a instauração do procedimento é concorrente do tribunal de origem e da instância superior.

Quando é o próprio tribunal de origem que toma a iniciativa de instaurar o procedimento, a suspensão inicialmente atinge apenas os recursos repetitivos em trâmite nesse mesmo tribunal, bem como os que vierem a ser ali interpostos após a afetação do caso paradigma. Afinal, em razão do princípio federativo, os tribunais locais e regionais não guardam relação de hierarquia entre si, e não possuem competência para tomar decisões a respeito dos processos em tramitação em outros tribunais.

Na verdade, isso se dá não apenas em razão da redação dos artigos 543-B, $\S 1^{\text {º }}$, e 543-C, $\S 1^{\circ}$, do CPC, que parece claramente restringir essa suspensão aos recursos ali interpostos, ou do pacto federativo, que claramente impede qualquer relação hierárquica entre os tribunais de cada Estado ou região da Federação, mas também porque não seria razoável que a decisão de um Tribunal de Justiça ou Tribunal Regional Federal sobre o sobrestamento dos recursos repetitivos simplesmente se estendesse de forma automática a todas as cortes do território nacional, ao menos não antes de sua confirmação pelo STF e pelo STJ.

Pode ocorrer, por exemplo, que os recursos selecionados sejam inadmissíveis, ou não atendam aos demais requisitos para a instauração do procedimento, casos em que a

\footnotetext{
447 “É descabido o sobrestamento do recurso especial em decorrência do reconhecimento da repercussão geral de matéria constitucional pelo STF, pois o art. 328-A do Regimento Interno daquela Corte determina o sobrestamento, tão somente, do juízo de admissibilidade dos Recursos Extraordinários e dos Agravos de Instrumento contra o despacho denegatório a eles relacionados." (STJ - AgR Ag n. 1.319.462/RS, $1^{\text {a }}$ Turma, rel. Min. Benedito Gonçalves, DJe, de 02.02.2011).
} 
decisão do tribunal de origem poderá ser revogada pelo STF ou pelo STJ ${ }^{448}$. Admitir que antes da confirmação da decisão pela instância superior o sobrestamento se estendesse a todas as cortes do país poderia ser temerário, gerando enorme tumulto e desvirtuando a finalidade da técnica de julgamento de recursos repetitivos.

Também pode ocorrer, por exemplo, que a multiplicidade de recursos seja meramente local, não tendo sentido a extensão do sobrestamento a todos os tribunais do país, com desperdício, no mínimo, da atividade administrativa necessária para a comunicação de todas as cortes deste nosso país de dimensões continentais. ${ }^{449}$

Apesar dessas considerações, o ponto desfavorável de se permitir que a suspensão ocorra só em caráter local é a perplexidade gerada pelo fato de que, em alguns Estados ou regiões da Federação, o processamento dos recursos fica sobrestado, enquanto que os recursos de outras localidades continuam a ser enviado ao STF ou ao STJ para julgamento. Nesse caso, tratando-se de questão sobre a qual já existe jurisprudência dominante, a parte cujo pedido estiver em consonância com a orientação da jurisprudência dominante da instância superior sofrerá o grave inconveniente do prolongamento do processo ou da sujeição à decisão desfavorável, mesmo tendo a certeza (decorrente da constante reafirmação do precedente pelo STF ou pelo STJ, diante do julgamento dos recursos repetitivos vindos de outra localidade) de que sairá vencedora. ${ }^{450}$

De qualquer forma, realizado pelo STF ou pelo STJ o juízo definitivo a respeito da afetação do recurso representativo da controvérsia à sistemática dos artigos 543-B e 543-C

\footnotetext{
448 “Atualmente, é salutar que os Tribunais de origem exerçam também um rigoroso controle de admissibilidade na escolha dos processos representativos da controvérsia, para que não haja uma interrupção desnecessária no curso de diversos outros recursos e também para que não sejam praticados desnecessariamente diversos atos processuais preparatórios para a formação do incidente, como a remessa de ofícios aos diversos Tribunais do país e a notificação de vários amicus curiae, que acabam por se manifestar em processo que não terá a sobrevida esperada." (ANDRIGHI, Fátima Nancy, Recursos repetitivos, cit., p. 272)

449 Nesse sentido, segundo Nancy Andrighi, deve-se acrescentar "ao juízo duplo de admissibilidade nos recursos representativos de controvérsia a necessidade de exame do cabimento ou não da extensão dos efeitos da suspensão anteriormente determinada a todo o país, o que deve ocorrer se a tese tiver impacto em mais de um Estado da federação. Com efeito, tratando-se de reiteração de processos que versem sobre um acontecimento fático bem delineado - citando-se, a título de exemplo, o julgamento de indenizações por danos materiais e morais sofridos por comunidade de pescadores em face de acidente ambiental - seria de todo inútil a extensão dos efeitos da suspensão a entes da federação nos quais o problema sequer ocorreu." (ANDRIGHI, Fátima Nancy, Recursos repetitivos, cit., p. 276).
}

${ }^{450}$ STJ - Rcl n. 3.652, 2 ${ }^{\mathrm{a}}$ Seção, rel. Min. Nancy Andrighi, v.u., j. 14.10.2009, DJe, de 04.12.2009. 
do CPC, o sobrestamento estender-se-á aos recursos repetitivos em trâmite em todos os tribunais de segundo grau do país ${ }^{451}$. Realmente, uma vez definitivamente acolhido pelo STF ou pelo STJ o julgamento do caso sob o procedimento dos recursos repetitivos, nada justificaria permitir que os demais tribunais, onde a mesma controvérsia estivesse instaurada, continuassem a enviar recursos aos Tribunais Superiores.

\subsection{Sobrestamento dos recursos extraordinários e especiais já enviados ao STF e ao STJ}

Quanto aos recursos já enviados ao STF e ao STJ, o entendimento a respeito dos efeitos do sobrestamento varia conforme se trate de recurso extraordinário ou especial.

Tratando-se de recurso extraordinário, o artigo 328, parágrafo único, do RISTF afirma que, instaurado o procedimento, a Presidência do STF ou o relator "determinará a devolução dos demais aos tribunais ou turmas de juizado especial de origem, para aplicação dos parágrafos do art. 543-B do Código de Processo Civil”. Não há dúvida, portanto, de que todos os recursos extraordinários ainda não julgados, e que estejam no STF, não apenas serão sobrestados, como serão devolvidos aos tribunais de origem, para que aguardem a definição da controvérsia.

No que diz respeito aos recursos especiais, a questão é tratada de forma diferente, pois, segundo a jurisprudência do STJ, os recursos eventualmente já enviados à instância superior não são atingidos pelo sobrestamento, nem devolvidos à origem. ${ }^{452}$ Isso porque a suspensão prevista no artigo 543-C do CPC não se referiria, em momento algum, aos recursos em trâmite no STJ, mas apenas aos recursos que estejam no tribunal de origem e ainda não foram enviados à instância superior.

Nesse sentido, o sobrestamento dos casos que já estão no STJ seria facultativo, e não obrigatório, não tendo a parte o direito de pedir a suspensão do caso, impedindo sua

\footnotetext{
${ }^{451}$ Com a ressalva, já feita acima, em relação aos casos em que a questão disser respeito a multiplicidade meramente local, hipótese em que o STF/STJ poderá delimitar o âmbito de abrangência do sobrestamento.

${ }^{452}$ Essa situação foi recentemente alterada por nova resolução do STJ, conforme exporemos em seguida.
} 
apreciação (quanto à admissibilidade e quanto ao mérito) até que a corte se pronuncie definitivamente sobre a questão. ${ }^{453}$

Esse entendimento decorre da interpretação literal do artigo 543-C do CPC (que menciona apenas o sobrestamento dos recursos no tribunal de origem) e do princípio da eficiência: já estando o recurso especial no STJ, nada impediria a sua apreciação, sobretudo diante da constatação de que, na imensa maioria dos casos, a decisão a respeito da sua admissibilidade é negativa, encerrando definitivamente a questão.

Ou seja, para o STJ, se o recurso especial não é admissível, e já se encontra no STJ, isso também justifica que ele não deve ser sobrestado: "O sobrestamento do julgamento de recurso especial que trate de matéria submetida ao regime dos recursos repetitivos, nos termos do art. 543-C, do CPC, revela-se dispensável quando ausentes os requisitos de admissibilidade do apelo extremo". 454

Essa interpretação parece não ser a mais adequada, pois subverte o procedimento do artigo 543-C do CPC, que impõe a não apreciação da admissibilidade do recurso enquanto não definida a controvérsia, até para que, em nome da igualdade, o caso receba o mesmo tratamento, independentemente de onde esteja o recurso excepcional e de ser ou não admissível (exceto no caso de intempestividade).

Note-se que, nos termos da jurisprudência do STJ, pelo simples fato de o recurso já se encontrar na instância superior, ele não será sobrestado, com o que se descartará a chance de aplicação, a ele, do entendimento fixado no acórdão paradigma. Aplica-se um tratamento diferenciado aos recursos especiais (tratando-se desigualmente as respectivas partes) pela mera circunstância de já ter ocorrido o envio dos autos ao STJ.

\footnotetext{
${ }^{453}$ A título de exemplo, confira-se o entendimento do STJ: "Descabida a suspensão do feito com base em recursos representativos da controvérsia encaminhados ao STJ pelo Vice-Presidente do Tribunal de Justiça do Estado de Minas Gerais, uma vez que a suspensão a que diz respeito o artigo $1^{\circ}$ da Resolução $n^{\circ}$ 8/2008/STJ e o artigo 543-c do CPC são aquelas determinadas aos recursos especiais a serem processados pelo Tribunal de origem, e não aqueles já encaminhados a esta Corte Superior para julgamento." (STJ AgR REsp n. 1.020.152/MG, 4 a Turma, rel. Min. Luis Felipe Salomão, DJe, de 29.03.2010). Ver, ainda, os seguintes precedentes: STJ - AgR REsp n. 1.026.407/CE, 6 ${ }^{\mathrm{a}}$ Turma, rel. Min. Maria Thereza de Assis Moura, DJe, de 19.04/.011; STJ - AgR REsp n. 1.051.389/RS, 5 a Turma, rel. Min. Laurita Vaz, DJe, de 21.03.2011.

${ }^{454}$ STJ - ED AgR REsp n. 1.100.700/BA, 1ª Turma, rel. Min. Luiz Fux, j. 11.05.2010.
} 
Pode ocorrer, então, que dois recursos idênticos (inclusive preparados pelo mesmo advogado) recebam tratamento totalmente diverso. Imagine-se que ambos os recursos sejam, à luz da jurisprudência do STJ, inadmissíveis por falta de prequestionamento. Quanto ao recurso especial que aguarda sobrestado no tribunal de origem, essa circunstância será irrelevante e haverá possibilidade de aplicação do entendimento firmado pelo STJ, por meio de eventual retratação do órgão julgador na instância de origem. O mesmo, porém, não ocorrerá quanto ao recurso já enviado ao STJ. Nesse caso, a ausência de sobrestamento e a inadmissibilidade serão suficientes para a consolidação do acórdão proferido pelo tribunal de origem, em sentido diverso do firmado pelo STJ.

$\mathrm{Na}$ verdade, não importa se já subiu ou não o recurso especial: em nome da igualdade e da segurança jurídica, ele deve ser devolvido à origem e ficar sobrestado, a fim de que lhe sejam aplicados os efeitos decorrentes do julgamento do recurso-piloto.

Afinal, se todos os recursos especiais repetitivos ficarão sobrestados nos tribunais de origem de todo o país, justamente para que situações semelhantes recebam entendimento semelhante, qual a lógica de se admitir que, diferentemente, os recursos especiais já enviados ao STJ possam ser individualmente julgados antes da definição da questão pela apreciação do recurso-piloto?

Dessa forma, à luz dos princípios da isonomia e segurança jurídica, os recursos especiais repetitivos em trâmite no STJ devem ser devolvidos à instância de origem, permanecendo sobrestados até a definição da controvérsia, tal como ocorre com os recursos extraordinários.

Esse também é o entendimento de Teresa Arruda Alvim Wambier e Maria Lúcia L. Conceição Medeiros, para quem “a compreensão adequada do dispositivo legal autoriza que se afirme abranger, esta regra, o sobrestamento do andamento de todos os recursos especiais, quer daqueles que estejam ainda no tribunal de origem, quer daqueles que já tenham sido encaminhados para o STJ". 455

\footnotetext{
455 "De fato, essa regra deve ser interpretada à luz da tendência que se vem, nos últimos anos, fazendo presente, de forma inequívoca, no direito brasileiro, no sentido de criar maior uniformização na aplicação da lei e dando-se força mais visível aos precedentes. Por essa razão, a leitura que se deve fazer da norma é aquela que mais próxima esteja de assegurar a simetria não só verticalizada, mas também horizontal das decisões, proporcionando maior rendimento ao regime instaurado pelo art. 543-C." (WAMBIER, Teresa Arruda Alvim; MEDEIROS, Maria Lúcia Lins Conceição, Recursos repetitivos: realização integral da finalidade do novo sistema impõe mais do que a paralisação dos recursos especiais que estão no $2^{\circ}$ grau, cit., p. 192).
} 
É interessante notar que a jurisprudência do STJ, ao afirmar o não sobrestamento e a possibilidade de apreciação da admissibilidade do recurso repetitivo, parece estar em confronto com a própria Resolução n. 8 , cujo artigo $2^{\circ}, \S 2^{\circ}$, dispõe que "a decisão do Relator [...] será comunicada aos demais Ministros e ao Presidente dos Tribunais de Justiça e dos Tribunais Regionais Federais, conforme o caso, para suspender os recursos que versem sobre a mesma controvérsia". Ou seja, a norma não faculta a suspensão dos recursos especiais, mas sim a impõe, ao estabelecer que a decisão do relator será comunicada inclusive aos demais ministros, "para suspender os recursos que versem sobre a mesma controvérsia". 456

No Agravo Regimental n. 1.294.841 (DJe, de 04.08.2010), o relator, ministro Massami Uyeda, em juízo de retratação, anulou sua decisão anterior sobre a inadmissibilidade de recurso especial que versava sobre a mesma controvérsia objeto de recurso especial afetado pelo STJ para julgamento sob o procedimento do artigo 543-C do $\mathrm{CPC}^{457}$. Trata-se, porém, de decisão isolada, pois, como visto, o entendimento que vem sendo reiteradamente manifestado é no sentido da inexistência de previsão legal para sobrestamento dos recursos repetitivos já distribuídos no STJ, e também da inaplicabilidade da sistemática do artigo 543-C no caso de recurso inadmissível.

Porém, em 01.02.2013, foi publicada a Resolução n. 5 do STJ, posteriormente substituída pelas Resoluções ns. 16, de 20.08.2013, e 17, de 04.09.2013, norma que prevê a devolução ao tribunal de origem dos recursos repetitivos enviados ao STJ, quando pendentes de julgamento os recursos representativos da controvérsia.

\footnotetext{
456 "É certo que a Resolução não pode dispor além do que preconiza a norma por ela regulamentada, portanto, não há como entender que o preceptivo em evidência determina aos Membros desta Corte a suspensão dos apelos que versem sobre matéria submetida ao rito dos recursos repetitivos. Na verdade, conjugando os arts. 543-C do CPC e o $2^{\circ}, \S 2^{\circ}$, da Resolução $n^{\circ} 08 / 08$ desta Corte, conclui-se que o relator responsável pela submissão do apelo extremo aos moldes do dispositivo processual comunicará aos demais Ministros tal fato para que dele tomem ciência. Já os Presidentes do Tribunal de Justiça ou do Tribunal Regional Federal, conforme o caso, serão oficiados para, nos termos do mencionado preceito, providenciar a suspensão dos recursos que cuidem da mesma controvérsia" (STJ - AgR REsp n. 671.032, $4^{\mathrm{a}}$ Turma, rel. Min. Luis Felipe Salomão, j. 07.12.2010).

457 Conforme constou da decisão: "Em 03/11/2009, foi afetada, para julgamento nos moldes da Lei 11.672/2008, pelo rito dos recursos repetitivos, a questão atinente à cobrança de correção monetária dos saldos da caderneta de poupança nos períodos relativos aos Planos Bresser, Verão, Collor I e II (ut REsp 1.107.201/DF e REsp 1.147.595/RS, julgamento conjunto, Rel. Min. Sidnei Beneti, DJ de 03/11/2009). Nesse contexto, nulas as decisões proferidas após a data de afetação da matéria para julgamento do recurso repetitivo, uma vez que deveria ter sido sobrestado o andamento do feito em comento, mormente porque houve prejuízo para a parte."
} 
Embora isso não signifique que os recursos já distribuídos quando da instauração do procedimento serão devolvidos ou sobrestados pelos respectivos ministros relatores, a norma garante que os casos repetitivos eventualmente enviados ao STJ pelos tribunais de origem também sejam sobrestados, evitando-se a sua apreciação antes da definição da controvérsia. $^{458}$

Por fim, ressalta-se que a versão atual do projeto de novo CPC prevê expressamente, em seu artigo 1.050, II, a suspensão de todos os processos pendentes, individuais ou coletivos, que versem sobre a questão e tramitem no território nacional - o que inclui, logicamente, o sobrestamento dos recursos extraordinários e especiais em tramitação também no STF e STJ.

\subsection{Sobrestamento dos agravos interpostos na forma do artigo 544 do CPC}

Com a instauração do procedimento, são sobrestados no tribunal de origem os recursos excepcionais já interpostos e também os que continuam a ser interpostos até a definição da controvérsia pelo STF ou pelo STJ. Com isso, o tribunal de origem não realiza o juízo prévio de admissibilidade desses recursos, até que o recurso-piloto seja apreciado, quando, então, serão aplicados os efeitos do acórdão paradigma, na forma dos parágrafos dos artigos 543-B e 543-C do CPC.

Porém, antes da instauração do procedimento, provavelmente a admissibilidade de muitos recursos repetitivos já terá sido aferida pelo tribunal de origem. Nesse caso, quanto aos juízos negativos de admissibilidade, as partes poderão ter interposto agravo de admissão (art. 544, CPC).

\footnotetext{
${ }^{458}$ Eis o que dispõe o artigo $2^{\circ}$, I, da mencionada Resolução: “Art. $2^{\circ}$ - Verificada a subida de recursos fundados em controvérsia idêntica a controvérsia já submetida ao rito previsto no art. 543-C do Código de Processo Civil, o presidente poderá: I - determinar a devolução ao tribunal de origem, para nele permanecerem sobrestados os casos em que não tiver havido julgamento do mérito do recurso recebido como representativo da controvérsia."
} 
Indaga-se, assim, se o sobrestamento também atinge tais recursos ou se o tribunal de origem deverá, a despeito da instauração do procedimento, encaminhá-los imediatamente à instância superior.

Quanto aos recursos extraordinários, o artigo 543-B do CPC nada diz a respeito e sujeita o processamento dos recursos extraordinários repetitivos aos "termos do Regimento Interno do Supremo Tribunal Federal”. Por sua vez, o RISTF dispõe em seu artigo 328-A, $\S 1^{\circ}$, que "o Tribunal de origem sobrestará os agravos de instrumento contra decisões que não tenham admitido os recursos extraordinários". Não há dúvida, portanto, de que o sobrestamento atinge os agravos. ${ }^{459}$

Quanto aos recursos especiais, a Resolução n. 8 do STJ afirma, em seu artigo $7^{\circ}$, que o regime do artigo 543-C do CPC aplica-se "no que couber, aos agravos de instrumento interpostos contra a decisão que não admitir recurso especial”. Embora o artigo 543-C, $\S 1^{\circ}$, do CPC mencione a suspensão dos “demais recursos especiais", não há porque excluir a sua extensão aos agravos de admissão.

De fato, não haveria sentido sobrestar os recursos excepcionais (recurso principal), mas não os respectivos agravos de admissão (recurso acessório). Lembremos que mesmo os recursos principais não terão sua admissibilidade apreciada (sendo possível, portanto, que também não reúnam os requisitos de admissibilidade, tanto quanto os recursos inadmitidos pela decisão objeto dos agravos) e ainda assim poderão se beneficiar dos efeitos do precedente.

Essa solução conta ainda com uma vantagem: evita que sejam enviados inúmeros agravos ao STF e ao STJ para julgamento individual, corroborando com a finalidade da técnica de julgamento de recursos repetitivos de racionalização da atuação dos órgãos superiores.

\footnotetext{
${ }^{459}$ Embora a norma regimental faça menção a "agravos de instrumento", no sistema atual não mais se interpõe esse agravo na forma de instrumento, mas sim nos próprios autos do recurso extraordinário ou especial, conforme a redação do artigo 544 dada pela Lei n. 12.322/2010.
} 
O único problema do sobrestamento dos agravos de admissão é que a posterior aplicação do precedente qualificado para negar seguimento ao agravo sobrestado deixaria a parte sem instrumento apto a insurgir-se contra a decisão perante a instância superior.

Ou seja, quando se trata do recurso principal, a parte pode, como defendido no Capítulo 6 (item 6.5), interpor agravo de admissão para insistir na submissão da matéria à corte ad quem, até porque pode ocorrer de seu caso conter distinções fáticas ou argumentos não apreciados no julgamento do recurso-piloto. Mas se o sobrestamento atingiu o próprio agravo de admissão já interposto quando da instauração do procedimento, a sua negativa de seguimento deixaria a parte sem meio para aquela insurgência.

Diante disso, é forçoso reconhecer que, negado seguimento ao agravo de admissão sobrestado (em razão do reconhecimento da ausência de repercussão geral da matéria ou da convergência entre o acórdão objeto do recurso inadmitido e o entendimento firmado pelo STF o STJ), deve-se abrir prazo para a parte eventualmente confirmar seu interesse no recurso, requerendo a remessa dos autos à instância extraordinária. Nesta oportunidade, a parte deve expor os argumentos que demonstram a distinção fática do caso ou a presença de argumentos não apreciados no julgamento do recurso-piloto.

Feito isto, o tribunal de origem deve necessariamente processar de forma normal o agravo, simplesmente o enviando ao STF ou ao STJ, sob pena de reclamação (Súmula 727 do STF). E, na instância superior, a parte poderá sofrer a aplicação de multa processual, na hipótese de se verificar que se trata de insistência meramente protelatória, ou seja, de insistência voltada à simples rediscussão das matérias já apreciadas, sem demonstração, por argumentos sólidos, da distinção do caso ou da existência de argumentos novos.

\subsection{A questão sobre a possibilidade de sobrestamento de outros recursos e processos nas instâncias inferiores}

Indaga-se, quanto a este ponto, se é possível a suspensão, além dos recursos excepcionais e agravos interpostos na forma do artigo 544 do CPC, dos processos e recursos repetitivos em tramitação nas instâncias inferiores (processos em primeiro grau, 
recursos ordinários nos tribunais de segunda instância e recursos nos demais Tribunais Superiores).

\subsubsection{Panorama normativo e a jurisprudência do STF e do STJ}

Quanto aos recursos extraordinários, o artigo 328 do RISTF dispõe que instaurado o procedimento do artigo 543-B do CPC, a Presidência do STF ou o relator poderá "sobrestar todas as demais causas com questão idêntica" (destacamos). Como se vê, a norma regimental permite, de forma ampla, o sobrestamento de processos e outros recursos, não apenas dos recursos extraordinários.

Entretanto, o artigo 543-B faz referência, em seus $\S \S 1^{\circ}$ a $3^{\circ}$, à possibilidade de sobrestamento de recursos. Como a norma regulamenta a apreciação dos recursos extraordinários repetitivos, deduz-se que apenas estes (e os respectivos agravos de admissão) poderiam ser sobrestados, não os recursos de competência das instâncias inferiores.

Ademais, o caput do artigo 543-B dispõe que "a análise da repercussão geral será processada nos termos do Regimento Interno do Supremo Tribunal Federal, observado o disposto neste artigo". Ou seja, a delegação quanto à regulamentação da matéria pelo RISTF refere-se especificamente à análise da repercussão geral ${ }^{460}$, o que, por óbvio, diz respeito ao exame de outros recursos extraordinários, e não outros recursos ou processos que tramitam em primeiro grau. Isso sem contar que o Regimento Interno não poderia ir além da regulamentação de recursos que tramitam internamente no próprio STF.

De qualquer forma, o fato é que a constitucionalidade da norma regimental não chegou até hoje a ser questionada perante o STF, que a tem aplicado normalmente para determinar, quando entende conveniente, o sobrestamento de todos os casos (inclusive

\footnotetext{
${ }^{460}$ Aliás, o sobrestamento de todos os casos repetitivos, e não apenas dos recursos extraordinário, pode ser inútil se eventualmente for determinado antes do reconhecimento da repercussão geral. É que o STF só examinará o mérito da questão constitucional controvertida se entender que está presente a repercussão. Caso se entenda que o requisto não está presente, o sobrestamento dos demais casos terá sido praticamente inútil. Por isso, apesar da redação do artigo 328 do RISTF, não se recomenda o sobrestamento dos demais casos antes do reconhecimento da repercussão geral.
} 
processos em primeiro grau e recursos nas instâncias inferiores) que versam sobre a questão constitucional a ser solucionada em caráter definitivo pela corte. ${ }^{461}$

Mais do que isso, o sentido do artigo 328 chegou a ser discutido pelo Pleno do STF no julgamento de questão de ordem no RE n. 576.155/DF, ficando clara a possibilidade, na prática, de suspensão, por decisão monocrática do relator, não só dos demais recursos extraordinários repetitivos, mas sim de toda e qualquer causa versando sobre o tema, até a definição da controvérsia pelo julgamento do caso paradigma. ${ }^{462}$

Quanto aos recursos especiais, não existe qualquer disposição nesse sentido na Resolução n. 8 e a redação do artigo 543-C parece restringir a suspensão aos recursos especiais. Tanto é assim que, segundo seu $\S 1^{\circ}$, selecionado e admitido pelo tribunal de origem o recurso especial repetitivo representativo da controvérsia, ficarão "suspensos os demais recursos especiais até o pronunciamento definitivo do Superior Tribunal de Justiça”.

Por sua vez, o $\S 2^{\circ}$ do art. 543-C, que trata do sobrestamento originado diretamente no STJ, menciona a possibilidade do relator “determinar a suspensão, nos tribunais de segunda instância, dos recursos nos quais a controvérsia esteja estabelecida”, o que levantaria dúvidas sobre a possibilidade de se permitir a extensão do sobrestamento pelo menos aos recursos ordinários que versam sobre a idêntica questão de direito. ${ }^{463}$

\footnotetext{
${ }^{461}$ Nesse sentido, ver: RE n. 626.307/SP e RE n. 591.797, rel. Min. Dias Toffoli, sobre a suspensão de processos cujo objeto era a discussão dos expurgos inflacionários e AI n. 754.745, rel. Min. Gilmar Mendes, tratando do Plano Collor II. Nesse último caso, o ministro relator proferiu, em 01.09.2010, decisão na qual - considerando-se que, reconhecida a repercussão geral da matéria, o julgamento seria aplicado a todos os casos - simplesmente decretou-se a suspensão do julgamento do mérito de todos os processos versando sobre o tema, suspensão essa limitada ao prazo máximo de cento e oitenta dias.

${ }^{462} \mathrm{Na}$ oportunidade, ficou vencido o ministro Marco Aurélio, sob o entendimento de que não se poderia sobrestar as próprias causas com base em julgamento de processo subjetivo pelo STF, mas apenas os próprios recursos extraordinários repetitivos, sob pena de afronta à garantia de acesso à justiça (STF - QO RE n. 576.155/DF, Pleno, rel. Min. Ricardo Lewandowski, j. 11.06.2008, DJe, DE 11.09.2008).

${ }^{463}$ A Resolução n. 7 chegou a prever expressamente em seu artigo $2^{\circ}, \S 3^{\circ}$ : "Poderá o presidente do tribunal, em decisão irrecorrível, estender a suspensão aos demais recursos, julgados ou não, mesmo antes da distribuição". O $\S 4^{\circ}$ ia além, e afirmava: "Determinada a suspensão prevista no parágrafo anterior, esta alcançará os processos em andamento no primeiro grau de jurisdição que apresentem igual matéria controvertida, independentemente da fase processual em que se encontrem". Mas, como já dito, a Resolução n. 7 foi imediatamente revogada logo após a sua publicação, sendo substituída pela Resolução n. 8 , atualmente em vigor.
} 
Seja como for, o fato é que, na prática, a extensão do sobrestamento até mesmo aos processos de primeiro grau tem sido admitida pela jurisprudência do STJ.

O tema foi enfrentado no julgamento do REsp n. 1.111.743/DF pela Corte Especial, em que se analisou a possibilidade de sobrestamento também das apelações, tal como fora determinado, no caso, pelo tribunal de origem. ${ }^{464}$

Contrariamente à possibilidade de suspensão dos recursos de apelação votaram, além da relatora, os ministros João Otávio de Noronha, Aldir Passarinho Junior, Laurita Vaz e Eliana Calmon. O principal argumento apresentado foi o de que, em média, aproximadamente $30 \%$ dos acórdãos que julgam apelações são impugnados por meio de recurso especial. Portanto, nada justificaria que se aguardasse o julgamento do recurso especial para, só depois, julgar-se a apelação. Considerando-se a estatística, o princípio da razoável duração do processo teria maior eficácia se julgada desde logo a apelação, resolvendo mais rapidamente um maior número de casos. A mera possibilidade de haver recurso especial não poderia justificar a paralisação do julgamento dos recursos ordinários.

Em seu voto, o ministro Aldir Passarinho Junior advertiu ainda do perigo de obstrução da prestação jurisdicional em primeiro e segundo graus, caso se admitisse a paralisação dos julgamentos, inclusive porque, como se sabe, a maioria dos recursos especiais sequer apresenta condições de admissibilidade. Nada justificaria, portanto, paralisar todos os casos, até que se aguardasse a definição da questão pelo STJ.

Por outro lado, favoravelmente à possibilidade de suspensão dos recursos de apelação, manifestaram-se, além do ministro Luiz Fux, os ministros Teori Albino Zavascki, Nilson Naves, Ari Pargendler, Fernando Gonçalves, Felix Fischer e Francisco Falcão.

O voto do ministro Luiz Fux lembrou que a ratio essendi da sistemática do artigo 543-C é evitar o confronto das decisões dos tribunais com a jurisprudência do STJ, privilegiando os princípios da isonomia e segurança jurídica, não se tratando apenas de instrumento a serviço da razoável duração do processo e da técnica de

${ }^{464}$ STJ - REsp n. 1.111.743/DF, Corte Especial, rel. Min. Nancy Andrighi, rel. para acórdão Min. Luiz Fux, j. 25.02.2010, DJe, de 21.06.2010. 
descongestionamento do STJ. De qualquer forma, se houver confronto entre a celeridade/economia e a isonomia/segurança, deveria prevalecer a letra expressa do artigo 543-C, $\S 2^{\circ}$, que fala em suspensão "dos recursos nos quais a controvérsia esteja estabelecida" (interpretação literal).

Além da interpretação literal, a interpretação teleológico-sistêmica e a ponderação dos interesses em jogo também imporiam a possibilidade de suspensão do julgamento das apelações, porque com isso se favoreceria a uniformização da jurisprudência, evitando-se novos acórdãos divergentes sobre a questão.

Pelo voto do ministro Teori Alvino Zavascki, observou-se que a técnica de julgamento de recursos repetitivos revela a tendência de acentuação da eficácia expansiva e da especial carga persuasiva dos precedentes do STJ. Suspender as apelações, que sofrerão reflexos do julgamento do recurso especial repetitivo, traria racionalidade ao sistema e se coadunaria com o significado que o atual direito positivo brasileiro atribui ao precedente $\mathrm{e}$ aos efeitos que ele acarreta nos casos análogos.

Ademais, a suspensão das apelações, ao mesmo tempo que evitaria futuro retardamento no andamento do feito, coadunando-se com os princípios da celeridade e da economia processual, preservaria os valores jurídicos que se visou implementar com o sistema dos recursos repetitivos: potencialização das funções constitucionais do STJ (nomofilaquia e uniformização) para conferir tratamento isonômico e previsibilidade das decisões judiciais. Isso porque a suspensão das apelações aumentaria a chance de aplicação, aos casos repetitivos, do entendimento firmado no julgamento do caso paradigma.

De tais considerações, decorreria a autorização para se interpretar o artigo 265, IV, "a", do CPC, que trata da suspensão do processo em caso de prejudicial externa, como norma que permite a suspensão também do julgamento dos recursos ordinários repetitivos. É que, segundo esse artigo, autoriza-se a suspensão do processo quando seu julgamento depender do julgamento de outra causa.

Em outro recurso especial afetado para julgamento segundo o procedimento do artigo 543-C do CPC, por decisão monocrática do ministro Luiz Fux, o STJ acolheu pedido 
de parte que ingressou no feito na qualidade de amicus curiae, e determinou o sobrestamento de todos os processos que tivessem por objeto controvérsia idêntica à versada em recurso representativo da controvérsia, envolvendo discussão sobre a incidência de ISS sobre operações de arrendamento mercantil ou leasing ${ }^{465}$. Confira-se a fundamentação de tal decisão:

Não obstante, é certo que o fim almejado pela novel sistemática
processual não se circunscreve à desobstrução dos tribunais superiores,
mas direciona-se, principalmente, à garantia de uma prestação
jurisdicional homogênea aos processos que versem sobre a mesma
quaestio juris, à luz do princípio da isonomia.
Sob esse enfoque, considerando-se que multifárias ações cognitivas e
executivas sobre o mesmo tema, em fases processuais diversas,
encontram-se tramitando nos tribunais pátrios, ressoa inequívoca a
necessidade de se obstar a prática de atos judiciais potencialmente lesivos
às partes e a prolatação de decisões, nas instâncias ordinárias, dissonantes
da posição a ser firmada por esta Corte Superior por ocasião do
julgamento do recurso paradigmático, de modo a assegurar a eficácia
integral desse provimento jurisdicional.
Destarte, a interpretação do citado dispositivo do Código de Processo
Civil deve ser extensiva a todos os processos que gravitem sobre o
mesmo thema judicandum, de modo que tenham o seu procedimento
paralisado, independentemente da fase em que se encontrem, até que o
recurso afetado ao regime dos recursos repetitivos seja julgado.
Ademais, a ratio essendi do sistema de julgamento por amostragem dos
recursos extraordinários repetitivos é a mesma da sistemática dos
recursos especiais repetitivos, dada a natureza similar de ambos recursos,
o que dá azo à aplicação analógica do art. 328 do Regimento Interno do
STF [...].

É interessante notar que, após a concessão de tal medida, foi ajuizada reclamação constitucional perante o STJ, na qual a parte executada em processo de execução fiscal de ISS alegou o desrespeito à decisão de sobrestamento, posto que deferido, pelo órgão judicial da instância ordinária, pedido de penhora on line formulado por Município exequente. Ao apreciar o pedido de liminar, a Primeira Seção do STJ entendeu que "a determinação de suspensão das Execuções Fiscais deveria se limitar à emissão de juízo de valor a respeito da questão de mérito (ISS sobre arrendamento mercantil)", não alcançando, portanto, atos executivos praticados nos processos de primeira instância. ${ }^{466}$

\footnotetext{
${ }^{465}$ STJ - REsp n. 1.060.210/SC, rel. Min. Luiz Fux, decisão monocrática proferida em 29.11.2010.

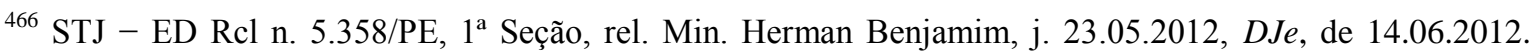
Vale observar que, em tal caso, restou consignado que a decisão determinando a suspensão de todas as execuções fiscais foi determinada monocraticamente, sem posterior análise pela Primeira Seção. Assim, por se tratar de questão inédita, não apreciada pelo órgão colegiado competente, a liminar foi concedida parcialmente, para permitir a penhora, mas sustar provisoriamente o levantamento dos valores.
} 
A mesma suspensão de todos os processos versando sobre questão idêntica foi determinada, também a pedido de amicus curiae admitido no processo, nos autos do Recurso Especial n. 1.251.331/RS, envolvendo a discussão sobre a legitimidade da cobrança das tarifas administrativas para concessão e cobrança dos créditos objetos de contratos bancários.

No caso, a extensão dos efeitos da suspensão, inicialmente determinada apenas em relação aos recursos especiais repetitivos, atingiria cerca de 285 mil ações versando sobre o mesmo tema. Assim, com base na função constitucional do STJ de definir a interpretação das normas incidentes na espécie, "de tal forma que os demais órgãos da Justiça comum possam nortear suas decisões, com aplicação harmônica e isonômica da legislação aos casos concretos", eliminando com isso a divergência jurisprudencial e favorecendo a economia processual, a relatora, ministra Isabel Gallotti, deferiu o pedido para "estender a suspensão de tramitação das correlatas ações de cognição a todas as instâncias da Justiça comum, estadual e federal, inclusive Juizados Especiais Cíveis e as respectivas Turmas ou Colégios Recursais". 467

Em outro precedente, esse deveras polêmico, o STJ chegou a conferir ao artigo 543-C do CPC interpretação tão extensiva, a ponto de se extrair dele autorização para a suspensão de todos os processos individuais, mas não em razão da afetação de recurso especial repetitivo pelo STJ, e sim da pendência de ação coletiva versando sobre a mesma matéria. ${ }^{468}$

No referido caso, o STJ apreciou a validade de acórdão do Tribunal de Justiça do Rio Grande do Sul (TJRS) que reconheceu possível a determinação de suspensão de processo individual até o julgamento de ação coletiva. Como se sabe, o Código de Defesa do Consumidor faculta ao litigante individual a suspensão de seu caso até o julgamento da ação coletiva. Porém, conforme se depreende da lei e da jurisprudência do próprio STJ, trata-se claramente de mera faculdade, nada obstando o prosseguimento da ação individual,

\footnotetext{
467 STJ - REsp n. 1.251.331/RS, rel. Min. Isabel Gallotti, DJe, de 23.05.2013. Vale informar que, em 28.08.2013, a Segunda Seção do STJ julgou o mérito do recurso representativo da controvérsia, definindo a questão de direito controvertida.

${ }^{468}$ STJ - REsp n. 1.110.549/RS, $2^{\text {a }}$ Seção, rel. Min. Sidnei Beneti, j. 28.10.2009, DJe, de 14.12.2009.
} 
caso o consumidor não se manifeste em sentido contrário. O TJRS, porém, determinou a suspensão do caso individual até a definição da matéria na ação coletiva.

No voto vencido, o desembargador convocado do Tribunal de Justiça do Amapá, Honildo Amaral de Mello Castro, consignou que a suspensão do caso individual afrontaria o direito à cidadania, o acesso à justiça (art. $5^{\circ}, \mathrm{XXXV}$, da $\mathrm{CF}$ ) e o entendimento do próprio STJ a respeito da caracterização da suspensão da ação individual, até julgamento da ação coletiva em que se discute direito individual homogêneo, como mera faculdade do litigante. Os problemas relativos à morosidade da justiça não poderiam justificar a transgressão do sistema, até porque teriam outras causas, e não exclusivamente o excesso de casos.

Prevaleceu, porém, o voto do relator, ministro Sidnei Beneti, no sentido de que “ajuizada a ação coletiva atinente à macrolide geradora de processos multitudinários, admite-se a sustação de ações individuais no aguardo do julgamento da ação coletiva", observando "que a faculdade de suspensão nos casos multitudinários abre-se ao juízo em atenção ao interesse público de preservação da efetividade da Justiça, que fica praticamente paralisada por processos individuais multitudinários, contendo a mesma lide".

O precedente propõe uma interpretação sistemática a partir da "diretriz legal resultante do disposto no art. 543-C do Código de Processo Civil, com a redação dada pela Lei dos Recursos Repetitivos". Conforme assentado no acórdão, a possibilidade de suspensão dos casos individuais "não se antagoniza, antes se harmoniza à luz da Lei dos Processos Repetitivos", pois "não bastaria, no caso, a utilização apenas parcial do sistema da Lei dos Processos Repetitivos, com o bloqueio de subida dos Recursos ao Tribunal Superior, restando a multidão de processos, contudo, a girar desgastante e inutilmente, por toda a máquina jurisdicional em $1^{\circ}$ Grau e perante o Tribunal de Justiça competente, inclusive até a interposição, no caso, do Recurso Especial”. 
Em outubro de 2010, o STJ reafirmou tal entendimento, ao decidir que "ajuizada ação coletiva atinente à macrolide geradora de processos multitudinários, suspendem-se as ações individuais, ainda que de ofício". 469

\subsubsection{Análise da conveniência e legitimidade das diversas hipóteses de extensão dos efeitos do sobrestamento}

\subsubsection{Sobrestamento dos processos e outros recursos até a definição da controvérsia}

A tendência da jurisprudência e da doutrina tem sido a de ampliar os efeitos do sobrestamento previsto nos artigos 543-B e 543-C do CPC, de forma que, na prática, $a$ suspensão de processos e outros recursos (além dos recursos excepcionais e respectivos agravos) já é uma realidade. ${ }^{470}$

Essa tendência reflete-se também na redação da versão atual do projeto de novo $\mathrm{CPC}$, cujos artigos $1.049, \S 1^{\mathrm{o}}$ e 1.050 , II preveem expressamente o sobrestamento dos processos e recursos em primeiro e segundo graus de jurisdição (ver Capítulo 12).

Realmente, a ampliação da eficácia do sobrestamento previsto nos artigos 543-B e 543-C do CPC é conveniente e deve ser positivada pelo novo CPC, por razões de racionalização da atividade jurisdicional e, principalmente, para viabilizar a aplicação de um mesmo entendimento a casos idênticos, gerenciando a divergência jurisprudencial e, com isso, favorecendo os princípios da isonomia e da segurança jurídica.

A título de ilustração, imaginemos uma situação em que, ordenado o sobrestamento de recursos repetitivos versando sobre determinada matéria, o Poder Judiciário continua a proferir milhares de sentenças, nos mais diversos sentidos, sobre aquela mesma situação

${ }^{469}$ STJ - AgR AgR AREsp n. 210.738/RS, 2a Turma rel. Min. Herman Benjamin, j. 18.10.2012, DJe, de 05.11.2012.

${ }^{470}$ Além dos precedentes do STF e STJ já citados, note-se que até mesmo no âmbito dos tribunais locais já ocorreu a determinação de sobrestamento de recursos de apelações. Vale mencionar, a título de exemplo, a Portaria n. 7.793, de 22.01.2010, por meio da qual o TJSP suspendeu "a distribuição de todas as novas apelações que chegarem à Seção envolvendo a cobrança de diferenças de cadernetas de poupança, até o julgamento, pelo Colendo Superior Tribunal de Justiça, dos Recursos Especiais ns. 1.107.201/DF e 1.147.595/RS, ambos da relatoria do eminente Ministro Sidnei Beneti”. 
jurídica. As partes terão de interpor milhares de apelações. O tribunal terá que distribuir e julgar milhares de recursos, proferindo milhares de acórdãos, possivelmente também em vários sentidos. Em seguida, as partes terão de interpor outros milhares de recursos extraordinários e especiais, que só então poderão ser sobrestados.

Ora, se a definição da matéria está sujeita ao STF ou ao STJ, com a paralisação dos recursos extraordinários e especiais repetitivos, parece não haver dúvida da conveniência de se permitir a paralisação também dos processos e recursos ordinários, o que viabilizará, a um só tempo, o julgamento uniforme dos milhares de casos idênticos, atendendo-se aos princípios da isonomia, segurança jurídica e razoável duração do processo.

O fato de que nem todos interporiam apelação e de que apenas uma minoria interporia recurso especial ou extraordinário realmente parece não afastar a conveniência do sobrestamento, pelo simples fato de que, de qualquer forma, é por meio da paralisação do julgamento dos processos e recursos que se permite a aplicação de um mesmo entendimento ao maior número de casos possível, prestigiando-se os princípios acima referidos.

Na verdade, a circunstância de que nem todos recorrem aos Tribunais Superiores apresenta-se como mais uma razão para se autorizar a suspensão de todos os processos e recursos ordinários (enfim, todos os casos repetitivos), permitindo-se a aplicação do entendimento definitivo do STF e do STJ a um maior número de casos.

Ressalte-se apenas que, tratando-se de recursos extraordinários repetitivos, não há, como já exposto acima, cabimento no sobrestamento dos demais casos antes do reconhecimento da repercussão geral. Só a apreciação do mérito da questão interessa às partes dos demais processos e recursos que ainda não chegaram na instância extraordinária, razão pela qual, em relação às mesmas, o sobrestamento seria inútil.

Por outro lado, o sobrestamento de todos os casos repetitivos não poderia atingir de forma integral a tramitação do processo, mas apenas o proferimento de decisões ou a prática de alguns atos. Não há sentido, por exemplo, suspender um processo que está em fase inicial, impedindo-se a citação do réu e o desenvolvimento das fases postulatória e de 
instrução probatória. Só as decisões que precisem levar em consideração a questão repetitiva é que devem ser suspensas.

No entanto, entendemos que a extensão do sobrestamento, para ser legítima, depende de norma legal expressa, pois a prestação jurisdicional não pode ser suspensa sem previsão legal expressa, nem com base em analogia. Ainda que os objetivos sejam nobres e visem prestigiar outros princípios constitucionais, trata-se de uma grave obstrução do acesso à justiça, que só deve ser admitida nos casos em que a lei expressamente o autoriza. $^{471}$

Também entendemos que não procede a afirmação de que a possibilidade de suspensão dos demais processos e recursos decorreria da existência de uma suposta relação de prejudicialidade entre o recurso-piloto e os demais casos repetitivos. Não se trata, aqui, de aplicação analógica do artigo 265, IV, porque no procedimento de julgamento de recursos repetitivos não há propriamente uma relação de prejudicialidade entre os processos $^{472}$. As relações jurídicas de direito material tratadas em cada processo, ainda que versem sobre a mesma questão jurídica, são distintas. A coisa julgada formada no julgamento do recurso-piloto não se estende aos demais processos repetitivos. O que há, apenas, é o sobrestamento à espera do precedente do STF e do STJ, para o fim de viabilizar julgamentos uniformes, prestigiando a igualdade, a segurança jurídica e a razoável duração do processo.

\footnotetext{
${ }^{471}$ Em sentido contrário: WAMBIER, Teresa Arruda Alvim; MEDEIROS, Maria Lúcia Lins Conceição, Recursos repetitivos: realização integral da finalidade do novo sistema impõe mais do que a paralisação dos recursos especiais que estão no $2^{\circ}$ grau, cit., p. 189.

${ }^{472}$ Conforme Cândido Rangel Dinamarco: "O efeito mais profundo da prejudicialidade é o impedimento de reapreciar a relação jurídica fundamental que haja sido objeto de julgamento no decisório de uma sentença passada em julgado. Como a decisão sobre a relação fundamental constitui pressuposto lógico do julgamento da demanda prejudicada, a declaração feita sobre ela irradia efeitos e tem a eficácia de comandar o julgamento de todas as possíveis demandas prejudicadas. A coisa julgada que se forma sobre a decisão da causa prejudicial obriga o juiz da causa prejudicada a tomar como premissa necessária e indiscutível o que a propósito daquela houver sido declarado (CPC, art. 470)." (DINAMARCO, Cândido Rangel. Instituições de direito processual civil. 6. ed. rev. e atual. São Paulo: Malheiros, 2009, v. 2, p. 161). No caso do julgamento de recursos repetitivos, nada disso ocorre. A relação jurídica julgada no recursopiloto não interfere na relação jurídica dos recursos repetitivos sobrestados. A coisa julgada formada no julgamento do recurso-piloto também não se estende de forma alguma aos recursos repetitivos sobrestados. O que ocorre é apenas a fixação do entendimento sobre a interpretação do direito federal pelo órgão superior competente, e a aplicação desse entendimento aos casos sobrestados. E, mesmo assim, não há efeito vinculante nessa aplicação.
} 
Nesse sentido, José Marcelo Magalhães Bonicio demonstra o descabimento da suspensão dos processos em grau ordinário de jurisdição com base no artigo 543-C do CPC, porque, além de não previsto pela lei, não há obrigatoriedade na adoção do entendimento firmado pela instância superior, o que pode tornar inútil a paralisação dos processos, afetando as garantias das partes. ${ }^{473}$

Realmente, os artigos 543-B e 543-C são claros em mencionar o sobrestamento apenas dos recursos, sendo evidente, pelas razões já expostas no item 8.6.1 supra, que se trata especificamente dos recursos extraordinários e especiais. Se a intenção fosse autorizar o sobrestamento também dos processos e recursos, a lei poderia muito bem ter feito referência a essa possibilidade, mas não o fez.

Assim, o sobrestamento também não pode ser aplicado com base em normas regimentais, que não podem contrariar as disposições dos artigos 543-B e 543-C, nem regulamentar a suspensão de processos que não tramitam internamente no STF ou no STJ.

De qualquer modo, repita-se que, como já demonstrado, a extensão dos efeitos do sobrestamento representa uma realidade, sendo constantemente aplicada pela jurisprudência do STF e do STJ.

Por fim, ressalva-se a possibilidade de ser eventualmente suspensa a prática de atos processuais prejudiciais às partes com base no poder geral de cautela, impedindo-se prejuízo irreparável ou de difícil reparação antes da definição da controvérsia pelo STF ou pelo $\mathrm{STJ}^{474}$, caso em que se terá, na prática, uma espécie de concessão coletiva de efeito

\footnotetext{
473 “Talvez a suspensão do julgamento da apelação tenha utilidade se o tribunal resolver seguir o mesmo entendimento adotado pelo Superior Tribunal de Justiça, no momento de julgar essa apelação, mas não há garantias para o jurisdicionado de que isso ocorrerá, nem há registros de que os tribunais brasileiros tenham preferido seguir a mesma linha da tendência da jurisprudência dos tribunais superiores nos últimos anos. Nesse caso, portanto, a potencialização da regra prevista no art. 543-C não parece razoável, porque as vantagens decorrentes da suspensão do julgamento dos recursos de apelação são remotas, o que não justifica, nem legitima, a adoção de tão drástica medida." (BONICIO, Marcelo José Magalhães. Análise da tendência jurisprudencial de potencialização dos efeitos da regra prevista no art. 543-C do CPC. (Originais cedidos pelo autor). Inédito.

${ }^{474}$ Como exposto acima, o STJ já determinou o sobrestamento dos processos em primeiro e segundo graus porque, pendente a discussão sobre a incidência de ISS, o prosseguimento das execuções fiscais poderia levar à prática de atos irreversíveis para as partes (STJ - REsp n. 1.060.210/SC, rel. Min. Luiz Fux, decisão monocrática proferida em 29.11.2010).
} 
suspensivo excepcional aos recursos sobrestados ${ }^{475}$. Aqui, não é necessária autorização legal específica, pois a medida decorre do poder geral de cautela ou de antecipação, previsto no artigo $5 .^{\circ}, \mathrm{XXXV}$ da $\mathrm{CF}$, e visa a garantir o resultado útil do procedimento dos artigos 543-B e 543-C do CPC.

\subsubsection{Sobrestamento dos processos individuais em razão da pendência de processo coletivo}

Quanto ao entendimento exposto pelo STJ no julgamento do Recurso Especial n. 1.110.549/RS, no sentido da possibilidade de suspensão dos processos individuais em face da pendência de ação coletiva, trata-se, em nosso sentir, de interpretação contra legem, eis que totalmente destoante das opções realizadas pelo legislador ao instituir o sistema de tutela coletiva, em que, bem ou mal, estabeleceu-se a mera faculdade de suspensão das demandas individuais diante da pendência da demanda coletiva, conforme previsto no artigo 104 do Código de Defesa do Consumidor (CDC).

E o artigo 543-C do CPC, não obstante a clara finalidade de prestigiar os princípios da igualdade, segurança jurídica e razoável duração do processo, tem objeto restrito (apreciação dos recursos especiais repetitivos), não autorizando a transgressão do sistema que regula a relação entre as demandas individuais e coletivas versando sobre o mesmo tema. $^{476}$

Ademais, quando os processos individuais são suspensos em razão da tramitação da ação coletiva, o que se tem é o julgamento dos próprios pedidos dos processos individuais por meio da sentença coletiva, a qual inclusive tem eficácia erga omnes. Como visto no Capítulo 5 (item 5.4), nada disso ocorre com a técnica de julgamento de recursos

\footnotetext{
475 "A regra do art. 543-C dá respaldo jurídico a que se determine, como se observou, também a suspensão da eficácia da decisão impugnada pelo recurso especial sobrestado. [...] Uma vez que a prestação jurisdicional envolve não só a declaração de um direito, mas também a sua efetiva realização, a regra do art. 543-C não apenas obsta o processamento do recurso especial, mas deve também obstar a eficácia da decisão por meio dele impugnada. Isso porque seria inócuo criarem-se meios para que o recurso especial sobrestado tenha o mesmo resultado daquele que foi afetado, se a decisão a que se refere já produziu seus efeitos, lesivos à parte, muitas vezes de forma irreversível ou de difícil reparação." (WAMBIER, Teresa Arruda Alvim; MEDEIROS, Maria Lúcia Lins Conceição, Recursos repetitivos: realização integral da finalidade do novo sistema impõe mais do que a paralisação dos recursos especiais que estão no $2^{\circ}$ grau, cit., p. 192 e 191).

${ }^{476}$ MARQUEZINI, Paulo Roberto da Silva, Técnicas de julgamento de causas repetitivas no direito brasileiro, cit., p. 33 .
} 
repetitivos, em que se tem apenas a suspensão dos recursos à espera do precedente em que serão definidas as questões de direito federal pelos órgãos constitucionalmente competentes.

Para José Marcelo Magalhães Bonicio, o sobrestamento dos casos individuais em face da pendência de ação coletiva, tal como determinado pelo STJ, pode ser bastante útil, desde que haja perfeita conformidade entre o objeto das duas espécies de demandas, de modo a permitir a posterior conversão das ações individuais suspensas em simples ações de liquidação de sentença, sem necessidade de prosseguimento do feito para apreciação de outros pedidos condenatórios. ${ }^{477}$

Observe-se, porém, que, segundo o sistema que rege a relação entre demandas individuais e coletivas, só a sentença de procedência vincula a solução dos casos individuais. Ou seja, o sistema atualmente em vigor permite a suspensão apenas para beneficiar os litigantes individuais, de modo que a suspensão dos casos individuais em face da mera pendência da ação coletiva pode ser igualmente inútil ou até prejudicial aos litigantes individuais, caso a sentença venha a ser de improcedência. ${ }^{478}$

Ademais, a suspensão forçada dos casos individuais, mesmo no caso de procedência da ação coletiva, pode não ser tão benéfica assim. Basta observar o que ocorreu no próprio caso citado acima, envolvendo os índices de reajuste dos valores depositados na poupança. O TJRS determinou a suspensão de todos os casos até o julgamento da ação coletiva, o que foi confirmado, ao menos em um dos casos individuais, por meio do julgamento do já referido Recurso Especial n. 1.110.549/RS.

\footnotetext{
477 "No caso da suspensão das ações individuais quando pendente de julgamento uma demanda coletiva com o mesmo fundamento, as vantagens não são tão poucas assim. É inegável que a possibilidade de dar uma única solução a centenas ou milhares de demandas individuais, independentemente do momento processual em que essas demandas se encontram, inclusive com a possibilidade de 'conversão automática' dessas ações em liquidação de sentença, é algo que vai ao encontro das modernas tendências processuais de relativização de regras e de valorização dos efeitos das decisões judiciais.” (BONICIO, Marcelo José Magalhães. Análise da tendência jurisprudencial de potencialização dos efeitos da regra prevista no art. 543-C do CPC. (Originais cedidos pelo autor). Inédito.

478 “Uma vez vinculado o destino da demanda individual à solução da demanda coletiva, se essa for julgada improcedente em algum momento, o autor individual - ainda que não perca o direito de pleitear individualmente seus interesses - terá perdido muito tempo." (FERNANDES, Débora Chaves Martines. Relação entre demandas individuais e coletivas: "Projeto Cadernetas de Poupança: Tribunal de Justiça do Rio Grande do Sul”: uma análise do caso. Revista de Processo, São Paulo, v. 36, n. 201, p. 345, nov. 2011).
} 
Com a procedência das ações coletivas, as ações individuais foram convertidas em liquidação de sentença. Ocorre que, entre a suspensão e o proferimento da sentença coletiva, foi firmado pelo STJ (em sede de julgamento de recurso repetitivo) o entendimento de que o prazo prescricional inerente às ações civis públicas é de cinco anos. Assim, ficou ameaçada a sentença de procedência proferida na ação civil pública do caso dos reajustes, com possibilidade de serem atingidos os processos individuais convertidos em liquidação de sentença.

Essa situação fez com que o TJRS determinasse a "desconversão" dos processos individuais, devendo prosseguir na forma como foram propostas. Como consequência, conforme exposto por Debora Chaves Martines Fernandes, “as demandas individuais voltaram a correr após cerca de quatro anos de suspensão - algumas delas, suspensas logo no momento de seu ajuizamento, antes da citação do réu -, para que finalmente pudessem ter sua pretensão individual apreciada". ${ }^{479}$

Daí porque, como bem concluído por José Marcelo Magalhães Bonicio, parece mais adequado e consentâneo com as garantias processuais considerar que, a despeito de eventual suspensão dos processos individuais, deve-se sempre conceder ao litigante individual a opção pelo prosseguimento de sua demanda, tal como, aliás, lhe faculta expressamente a lei. ${ }^{480}$

\subsection{Controle da decisão que determina o sobrestamento}

\subsubsection{Conteúdo decisório e possibilidade de impugnação da decisão de sobrestamento - crítica à jurisprudência do STJ e do STF}

Questiona-se se a decisão do tribunal de origem, do STF ou do STJ que identifica determinado recurso extraordinário ou especial como repetitivo e determina seu sobrestamento pode ser impugnada pela parte interessada.

\footnotetext{
479 FERNANDES, Débora Chaves Martines, Relação entre demandas individuais e coletivas: "Projeto Cadernetas de Poupança: Tribunal de Justiça do Rio Grande do Sul": uma análise do caso, cit., p. 346-347.

480 “Aliás, na perspectiva da tutela constitucional do processo, parece mais correto que esse litigante tenha sempre a possibilidade de continuar com sua ação individual, mesmo no caso de a decisão coletiva lhe ser absolutamente útil, porque, nessa hipótese, a lei lhe faculta a opção de não ser beneficiado pela decisão coletiva." (BONICIO, Marcelo José Magalhães. Análise da tendência jurisprudencial de potencialização dos efeitos da regra prevista no art. 543-C do CPC. (Originais cedidos pelo autor). Inédito.
} 
Advirta-se preliminarmente que não se está tratando aqui de impugnação da decisão que, negada a repercussão geral do recurso extraordinário ou julgado o mérito do recurso representativo da controvérsia pelo STF ou pelo STJ, aplica o precedente ao caso concreto, na forma dos artigos 543-B, $\S \S 3^{\circ}$ e $4^{\circ}$, e $543-\mathrm{C}, \S 7^{\circ}$, do CPC. Essa hipótese ocorre bem depois da decisão de sobrestamento e sobre ela falamos no Capítulo 6 (item 6.5), quando expusemos a imprescindibilidade do cabimento do agravo de admissão para a constitucionalidade da técnica de julgamento de recursos repetitivos.

Neste ponto, interessa-nos mais especificamente a discussão sobre a possibilidade de impugnação, não da decisão que aplica ao caso sobrestado o entendimento firmado pelo STF ou pelo STJ na apreciação do recurso paradigma, mas sim da decisão que determina o sobrestamento recurso repetitivo não selecionado.

A jurisprudência do STJ vem entendendo que a decisão de sobrestamento proferida pelo tribunal de origem não caracteriza juízo de admissibilidade nem de mérito do recurso, sendo desprovida de conteúdo decisório ${ }^{481}$, razão pela qual não está sujeita a recurso ou qualquer outro meio de impugnação. ${ }^{482}$

Essa interpretação também decorreria da finalidade do sistema de julgamento de recursos repetitivos: autorizar a impugnação representaria, na prática, impor ao STJ o dever de examinar caso a caso, bastando à parte alegar a ausência de similitude entre o caso sobrestado e o caso paradigma, o que tornaria inócua a regra do sobrestamento.

No entanto, em razão da afirmada ausência de conteúdo decisório, o STJ entende que não seria cabível nem mesmo agravo interno no âmbito do próprio tribunal de origem, muito embora se trate de decisão monocrática potencialmente lesiva às garantias processuais das partes $^{483}$. Assim, a única oportunidade para demonstração de eventual equívoco quanto à identidade entre os casos seria após a aplicação do precedente ao caso, quando então se admitiria o agravo interno (Capítulo 6, item 6.5).

\footnotetext{
${ }^{481}$ AgR Ag n. 1.277.178RJ, $1^{\text {a }}$ Turma, rel. Min. Benedito Gonçalves, DJe ,de 27.10.2010; AgR Ag n. 1.223.072SP, $2^{\mathrm{a}}$ Turma, rel. Min. Humberto Martins, DJe, de 18.03.2010; AgR Ag n. 1.268.518SP, $4^{\mathrm{a}}$ Turma, rel. Min. Luis Felipe Salomão, DJe, de 24.08.2011.

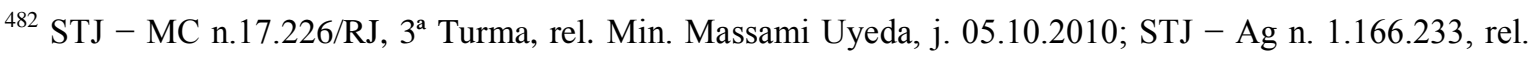
Min. Luis Felipe Salomão, decisão monocrática, j. 18.11.2010.

${ }^{483}$ STJ - RMS n. 37.013/RJ, 1ª Turma, rel. Min. Benedito Gonçalves, j. 20.03.2012, DJe, de 23.03.2012.
} 
No mesmo sentido, a jurisprudência do STF não autoriza a interposição de agravo de admissão contra a decisão do órgão de origem que determina o sobrestamento do recurso repetitivo ${ }^{484}$. Como justificativa, a corte tem feito referência aos precedentes em que se reconheceu cabível o agravo interno contra a decisão que aplica equivocadamente o instituto da repercussão geral. Isso sinaliza que, embora as hipóteses sejam diversas (sobrestamento e aplicação do precedente), o STF, diferentemente do STJ, parece sinalizar no sentido do cabimento da impugnação da decisão do tribunal local que determina o sobrestamento por meio de agravo interno.

De qualquer modo, o STF expressamente não admite agravo regimental ou interno contra as decisões monocráticas da própria Corte Suprema que determinam a devolução dos autos à origem para posterior aplicação da decisão sobre ausência de repercussão geral ou sobre o mérito da controvérsia. ${ }^{485}$

Quanto à recorribilidade das decisões monocráticas que, no âmbito do STJ, determinam o sobrestamento, a discussão praticamente não existe porque, como já demonstrado, entende-se que os recursos já remetidos à Corte Superior não devem ser sobrestados, mas sim desde logo apreciados. A recente Resolução n. 5 do STJ, posteriormente substituída pelas Resoluções ns. 16 e 17, em seu artigo $2^{\circ}$, I, passou a prever a devolução à origem dos recursos repetitivos enviados na pendência do julgamento do recurso representativo da controvérsia. Porém, segundo o seu artigo $3^{\circ}$, cabe agravo regimental contra a decisão do presidente proferida nos termos dessa Resolução.

A interpretação do STF e do STJ merece, no nosso sentir, ser criticada, pois toda decisão que determina o sobrestamento tem evidente conteúdo decisório. Por meio dela, o órgão competente deve examinar as peculiaridades do caso e, verificando tratar-se de

\footnotetext{
${ }^{484}$ Em julgado recente, restou expressamente assentado pelo STF: "Não é cabível agravo de instrumento da decisão do tribunal de origem que, em cumprimento do disposto no $\S 3^{\circ}$ do art. 543-B, do CPC, determina o sobrestamento do feito." (AgR AI n. 742.431 /PE, 1 ${ }^{\mathrm{a}}$ Turma, rel. Min. Ricardo Lewandowski, j. 31.05.2011, DJe, de 14.06.2011).

${ }^{485}$ Segundo a jurisprudência do STF, essa decisão monocrática não só é irrecorrível, como não precisa ser nem mesmo publicada, e os autos devem ser imediatamente remetidos à instância de origem! Os agravos regimentais (ou internos) interpostos pelas partes contra essas decisões monocráticas não são conhecidos, porque, para o STF, selecionado o recurso representativo da controvérsia, nenhum outro recurso repetitivo precisará voltar a ser apreciado, exceto na hipótese de, reconhecida a repercussão geral e julgado o mérito da controvérsia, haver manutenção de eventual decisão divergente pelo tribunal de origem (STF - AgR AgR AI n. 503.064 /MG, 2a Turma, rel. Min. Celso de Mello, j. 02.03.2010, DJe, de 25.03.2010).
} 
idêntica controvérsia ou questão de direito, deve determinar a suspensão do feito até que o STF ou o STJ julgue o recurso paradigma, o que na prática pode demorar meses ou até anos.

Aliás, decisão que determina o sobrestamento, como toda decisão judicial, deve ser sempre fundamentada (art. 93, IX, da CF) e formalmente certificada nos autos de cada recurso sobrestado, conforme prevê o artigo $1^{\circ}, \S 3^{\circ}$, da Resolução n. 8 do STJ, aplicável por analogia aos recursos endereçados ao STF.

Pode ocorrer de o caso individual objeto do sobrestamento não tratar exatamente da mesma questão de direito objeto do recurso paradigma e, portanto, não se sujeitar aos efeitos do precedente que será firmado pelo STF ou pelo STJ. Essa possibilidade de erro não é sequer improvável, haja vista as dificuldades de aferição da identidade em alguns $\operatorname{casos}^{486}$, sobretudo em nosso sistema de civil law, no qual, diferentemente do sistema da common law, se está pouco habituado a esse exercício de comparação dos precedentes. ${ }^{487}$

Pode ocorrer também de o recurso envolver outras questões autônomas, que não guardam relação de prejudicialidade com a questão repetitiva. Nesse caso, o sobrestamento também será indevido, merecendo ser corrigida a respectiva decisão, para a liberação do processamento do recurso.

Não é razoável entender que as partes sujeitas ao sobrestamento devam aguardar todo o trâmite previsto nos artigos 543-B e 543-C do CPC, para só depois terem a possibilidade de reconhecimento do equívoco da decisão de sobrestamento, até porque isso

\footnotetext{
${ }^{486}$ Aliás, não é tão incomum encontrar no próprio STJ decisões equivocadas sobre o sobrestamento em razão da ausência de identidade da matéria. Veja-se, por exemplo, o AgR REsp n. 911.525, 33 Turma, rel. Min. Paulo de Tarso Sanseverino, v.u., j. 02.12.2010, no qual se afirmou que "tratando o presente especial de matéria diversa daquela tratada no recurso representativo da controvérsia, reconsidera-se a decisão de sobrestamento do feito para permitir seu curso normal".

${ }^{487}$ Nos Estados Unidos, devido à maior importância dos precedentes jurisprudenciais inerente ao sistema da common law, entende-se como essencial para a adequada identificação dos casos e aplicação dos precedentes vinculantes, além da cultura jurídica na utilização dos precedentes, que o ensino jurídico seja focado na preparação dos futuros profissionais quanto a essa atividade (COLE, Charles D. Precedente judicial: a experiência americana. Revista de Processo, São Paulo, v. 23, n. 92, p. 83-84, out./dez. 1998).
} 
representaria uma violação ao seu direito de ação e de defesa, bem como ao princípio da razoável duração do processo. ${ }^{488}$

Daí porque a decisão que determina o sobrestamento tem sim cunho decisório e, podendo causar enormes prejuízos às garantias processuais das partes, deve estar sujeita a impugnação.

Ademais, se admitida essa impugnação por meio de algum recurso, isso autoriza a conclusão de que, não interposto o recurso cabível no prazo legal, ocorre a preclusão quanto à discussão sobre a identidade entre os casos, trazendo às partes sujeitas ao sobrestamento segurança jurídica. Note-se que é justamente nesse momento que, pela primeira vez, afirma-se a identidade entre o caso repetitivo e o caso relativo ao recurso representativo da controvérsia. Por outro lado, se se considerar que a decisão é irrecorrível, a inércia das partes não gerará preclusão alguma, sendo possível levantar a questão por outros meios de impugnação (por exemplo, mandado de segurança, reclamação, medida cautelar).

Esclareça-se que têm interesse na impugnação tanto a parte recorrente como a recorrida. Basta observar que esta última pode ser inclusive a parte autora da demanda, tendo evidente interesse no destrancamento indevido de recurso da parte contrária, com o fim de alcançar mais brevemente o trânsito em julgado da decisão que lhe é favorável.

Outro ponto a se esclarecer é o seguinte: mesmo quando o procedimento é instaurado pelo STF ou pelo STJ, o objeto dessa eventual impugnação, quanto aos casos que ainda não foram enviados à instância superior, é a decisão do tribunal de origem que determina a suspensão de cada caso repetitivo. Isso porque a pretensão da parte não é impugnar a decisão de instauração do procedimento (determinada pelo STF ou pelo STJ),

\footnotetext{
488 Tanto é assim que a própria Terceira Turma do STJ, na MC n.17.226/RJ, rel. Massami Uyeda, j. 05.10.2010, embora tenha afirmado que a regra é a irrecorribilidade da decisão que determina o sobrestamento, ressalvou os "casos de sobrestamento equivocado, em que a parte deve demonstrar explicitamente a diferença entre o seu caso concreto e os afetados como repetitivos", ponderando que "caso efetivamente demonstrado pela parte o equívoco da suspensão do trâmite de seu recurso especial, na hipótese acima aventada, não seria razoável que aquela fosse submetida ao mesmo procedimento dos recursos repetitivos". Daí porque o "controle direto desta augusta Corte sobre a adequação das matérias constantes no recurso especial suspenso na origem e no recurso representativo da controvérsia se afiguraria possível, em caráter excepcional".
} 
mas sim a decisão que reconhece a incidência do sobrestamento ao seu caso. Por isso, não tem cabimento o argumento de que impor ao STF e ao STJ a revisão da decisão do tribunal de origem a respeito do sobrestamento representaria a imposição de um duplo juízo da instância superior a respeito da mesma questão.

Considerando-se que o sobrestamento de todos os casos repetitivos é efeito que, conforme previsto pelos artigos 543-B e 543-C do CPC, decorre da instauração do procedimento, o interesse na impugnação da decisão que determina a suspensão de cada caso só pode estar relacionado à demonstração de eventual equívoco relativo à caracterização do caso como repetitivo, à identidade entre os casos ou à existência de outras questões não repetitivas objeto do recurso.

Por fim, eventual impugnação da decisão sobre o sobrestamento não caracteriza pedido de tutela de urgência no âmbito dos recursos extraordinário e especial (efeito suspensivo excepcional ou antecipação da tutela recursal). Quanto às tutelas de urgência no âmbito recursal, o sobrestamento não implica em praticamente qualquer mudança: a parte pode pleitear a medida excepcional ao órgão competente, o qual continua a ser, nos termos das Súmulas 634 e 635 do STF, o próprio tribunal de origem, com a única diferença de que, tratando-se de recursos sobrestados, essa competência mantém-se mesmo diante de recursos eventualmente já admitidos. ${ }^{489}$

\subsubsection{Agravo de admissão (art. 544 do CPC), pedido de reconsideração, embargos de declaração ou outros meios (mandado de segurança, reclamação ou medida cautelar)?}

Considerando-se que a decisão de sobrestamento obsta o prosseguimento normal do recurso extraordinário ou especial, boa parte da doutrina entende que contra ela se deve admitir agravo de admissão (art. 544 do CPC). ${ }^{490}$

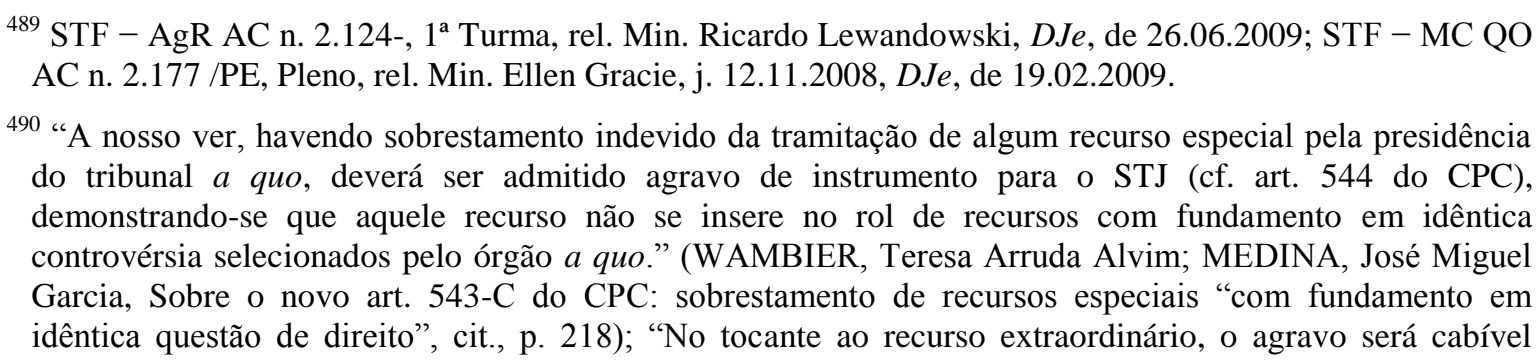


Em sentido contrário, como já adiantado no item 8.7.1 supra, tanto o $\mathrm{STF}^{491}$ como o STJ $^{492}$ entendem que não cabe agravo de admissão (art. 544 do CPC) contra a decisão que determina o sobrestamento.

O agravo de admissão realmente não parecer ser o recurso mais indicado para a impugnação da decisão de sobrestamento. Como visto nos itens anteriores deste capítulo, diante do sobrestamento, o órgão jurisdicional competente deve postergar o exame de admissibilidade para momento futuro e eventual, de modo que não seria lógico afirmar que se trata de decisão que procede, direta ou indiretamente, ao exame da admissibilidade do recurso extraordinário ou especial.

Outro argumento contrário à conveniência do agravo de admissão é o de que, conforme já exposto, tanto a parte recorrente como a recorrida podem ter interesse em impugnar a decisão que determina o sobrestamento, e não há cabimento na interposição pelo recorrido de agravo de admissão para fazer subir o recurso da parte contrária.

Ademais, com as modificações do artigo 544 do CPC, realizadas pela Lei n. 12.322/2010, o agravo de admissão não é mais interposto por instrumento, mas sim nos próprios autos, de modo que a sua mera interposição seria suficiente para justificar a

mesmo quando ocorra o sobrestamento nos termos do art. 543-B, $\S 2^{\circ}$ : com efeito, pode ter havido equívoco na suposição de que a questão controvertida no recurso sobrestado seja 'idêntica' à do(s) selecionados para remessa imediata ao Supremo Tribunal Federal.” (MOREIRA, José Carlos Barbosa, Comentários ao Código de Processo Civil: Lei n. 5.869, de 11 de janeiro de 1973, arts. 476 a 565, cit., v. 5, p. 620); "Se a parte vê o seu recurso sobrestado de maneira equivocada - porque não se refere à controvérsia a ser analisada pelo Supremo Tribunal Federal por amostragem -, cabe agravo de instrumento, demonstrando-se nas suas razões a diferença entre os casos sobrestados e pendentes de análise no Supremo e o caso do recorrente." (MARINONI, Luiz Guilherme; MITIDIERO, Daniel, Código de Processo Civil: comentado artigo por artigo, cit.., 2008, p. 572).

491 "Não é cabível agravo de instrumento da decisão do tribunal de origem que, em cumprimento do disposto no $\S 3^{\circ}$ do art. 543-B, do CPC, determina o sobrestamento do feito." (AgR AI n. 742.431 /PE, $1^{\text {a }}$ Turma, rel. Min. Ricardo Lewandowski, j. 31.05.2011, DJe, de 14.06.2011). Recentemente, esse entendimento foi confirmado por precedente da Quarta Turma, no qual se assentou: "Não cabe recurso dirigido a esta Corte Superior de Justiça com escopo de reformar decisão do Tribunal de origem que sobrestou recurso especial com base no art. 543-C do CPC, acrescido pela Lei n ${ }^{\circ}$ 11.672/2008 - Lei dos recursos especiais repetitivos. (QO no Ag 1154599/SP, Rel. Ministro César Asfor Rocha, CORTE ESPECIAL, DJe 12/05/2011), mormente quando não caracterizada, nas razões do agravo, hipótese diversa da tese a ser discutida no recurso representativo de controvérsia repetitiva." (STJ - AgR AREsp n. 214.152/SP, 4 Turma, rel. Min. Luis Felipe Salomão, j. 05.02.2013, DJe, de 14.02.2013).

${ }^{492}$ Para o STJ, a decisão que determina o sobrestamento do recurso especial não pode ser atacada pelo agravo previsto no art. 544 do CPC, inclusive porque "o juízo de admissibilidade do recurso especial sequer foi realizado" (STJ - AI n. 1.223.072/SP, 2 ${ }^{\mathrm{a}}$ Turma, rel. Min. Humberto Martins, j. 09.03.2010, DJe, de 18.03.2010). 
imediata remessa dos autos principais à instância superior, o que realmente poderia facilitar e estimular a insurgência das partes em praticamente todos os casos e, com isso, prejudicar o atingimento de algumas das finalidades do sistema de julgamento de recursos repetitivos.

Por fim, o agravo de admissão não seria cabível para o destrancamento dos próprios agravos já interpostos na origem, os quais, como visto, também são atingidos pelo sobrestamento.

Atento a essa situação, Athos Gusmão Carneiro, idealizador do projeto que culminou com a aprovação da Lei n. 11.672/2008, por meio da qual se acrescentou o artigo 543-C ao CPC, manifestou-se desde logo no sentido de que o meio adequado para revisar a decisão de sobrestamento seria o pedido de reconsideração ao próprio tribunal de origem $^{493}$. Em caso de persistência do vício, a parte teria de aguardar a definição da matéria pelo STJ para, só depois, se o caso, interpor agravo na forma do artigo 544 do CPC. ${ }^{494}$

Ocorre que essa opção, além de apresentar a inconveniência de não reconhecer a recorribilidade da decisão e de impor às partes o longo período até o julgamento da controvérsia, para só então poder demonstrar a distinção de seu caso, deixaria as partes sem qualquer meio efetivo para a demonstração do erro quanto à identidade entre os casos diretamente à instância superior, graças à jurisprudência do STF e do STJ que, como demonstrado no Capítulo 6 (item 6.5), adota o entendimento do não cabimento de agravo de admissão nem mesmo contra a decisão do tribunal de origem que, ao final, aplica o precedente ao caso para negar seguimento ao recurso repetitivo sobrestado.

Eficiente meio para a correção do equívoco quanto à verificação da identidade entre os casos - e consequentemente quanto à determinação do sobrestamento - é a interposição de embargos de declaração, sob o fundamento da ocorrência de omissão quanto à

\footnotetext{
493 Nesse sentido, o TRF4 editou a Resolução n. 62/2009, que prevê possibilidade de pedido de reconsideração em 5 dias em face da decisão que determina o sobrestamento. Acolhido o pedido, faz-se o juízo de admissibilidade do recurso especial. Rejeitado, não cabe recurso.

${ }^{494}$ CARNEIRO, Athos Gusmão, Primeiras observações sobre a lei dos recursos repetitivos, cit., p. 83.
} 
apreciação de alguma questão relevante sobre a distinção entre os casos, ou até mesmo erro evidente de fato. A conveniência desse meio está relacionada à simplicidade procedimental de tal recurso (endereçado ao próprio órgão prolator da decisão, sem dispêndio de tempo e energia com a movimentação dos autos) e à possibilidade de sua oposição pelas partes recorrente e recorrida.

Porém, é preciso reconhecer que os julgadores nem sempre analisam os embargos de declaração com o devido cuidado, e muitas vezes simplesmente o veem como uma crítica pessoal, rejeitando-os por decisões carentes da devida fundamentação. Nesse caso, o instrumento não apresentará, na prática, a efetividade que dele se espera.

Por sua vez, para os que defendem a irrecorribilidade do ato de sobrestamento, será imperioso reconhecer o cabimento do mandado de segurança, nos termos do artigo $5^{\circ}$, II, da Lei n. 12.016/2009. Porém, essa via não é conveniente às partes nem ao próprio Poder Judiciário, sobretudo por se tratar de ação autônoma, com todos os requisitos, recursos e demais desdobramentos daí decorrentes. Isso sem contar a sua reduzida eficácia no plano prático, decorrente do fato de que a jurisprudência restringe ao máximo a sua admissibilidade, abrindo poucas exceções, apenas diante de grave dano irreparável ou de decisões totalmente teratológicas.

Tem-se ainda a possibilidade de corrigir a decisão de sobrestamento pela via da medida cautelar, como já admitiu o STJ em situações excepcionais, embora sem adentrar nas justificativas para a aceitação desse meio ${ }^{495}$. Claro que, com base no poder geral de cautela, é possível o destrancamento do recurso indevidamente sobrestado pela via da medida cautelar, haja vista o dano decorrente da desnecessária espera pelo julgamento dos recursos representativos da controvérsia.

No entanto, não se trata de meio normal de impugnação das decisões de sobrestamento, e sim de medida excepcional, sujeita ao exame das peculiaridades e

${ }^{495}$ STJ - MC n. 17.542, decisão monocrática, Min. Gilson Dipp, j. 09.12.2010, DJe, de 15.12.2010. 
principalmente da urgência verificada em cada caso, tanto que pouquíssimas vezes o STJ a admitiu para essa finalidade.

Vale registrar que, também em caráter excepcional, o STJ já admitiu, no âmbito do processo penal, a revisão do ato de sobrestamento por meio de habeas corpus, em que a ordem foi concedida em face da constatação de error in procedendo, consistente na má aplicação do artigo 543-C do CPC. ${ }^{496}$

Outro caminho que se afigura possível é a aplicação análoga do entendimento da jurisprudência quanto às medidas aptas à obtenção do destrancamento do recurso excepcional indevidamente retido, nos termos do artigo 542, § $3^{\circ}$, do CPC..$^{497}$

Pode ocorrer de o recurso excepcional ser retido indevidamente, seja porque não se trata de qualquer das hipóteses do artigo 542, $\S 3^{\circ}$, do CPC, seja porque, embora se tratando de uma dessas hipóteses, a retenção equivaleria à inadmissibilidade (em razão da futura inutilidade prática) do recurso, a exemplo do que ocorre nos casos de decisões que versam sobre tutela de urgência e em todos os casos que envolvam perigo de perecimento do direito ou de dano irreparável ou de difícil reparação.

Nesses casos, atualmente não se discute que, retido indevidamente o recurso extraordinário ou especial, a parte interessada pode requerer à instância superior o seu destrancamento, a fim de que seja imediatamente processado. O que varia são os meios pelos quais esse requerimento é veiculado, quais sejam ação cautelar, reclamação, simples petição, mandado de segurança e até mesmo o agravo de admissão previsto no artigo 544

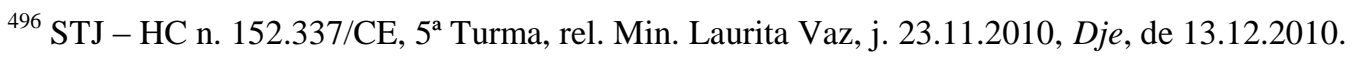

${ }^{497} \mathrm{O}$ artigo 542, § $3^{\circ}$ do CPC, conforme redação dada pela Lei n. 9.756/98, prevê a retenção dos recursos extraordinário e especial quando interpostos contra decisão interlocutória em processo de conhecimento, cautelar, ou embargos à execução. Ademais, o processamento de tais recursos só se dará "se o reiterar a parte, no prazo para a interposição do recurso contra a decisão final, ou para as contra-razões". Conforme Rodolfo de Camargo Mancuso, não há qualquer inconstitucionalidade nessa norma, pois ela implica apenas em "protrair ou sobrestar o processamento do RE ou REsp quando interpostos nas circunstâncias apontadas no $\S 3^{\circ}$, do art. 542 do CPC, deixando-os retidos". Nesse sentido, afirma-se que "o que fez o legislador ordinário - valendo-se de sua competência para legislar em matéria processual (CF, art. 22, I) foi disponibilizar um modus operandi para o RE e o REsp, agora com um efeito devolutivo diferido" (MANCUSO, Rodolfo de Camargo, Recurso extraordinário e recurso especial, cit., p. 334). 
do $\mathrm{CPC}^{498}$. Ademais, tanto a jurisprudência do $\mathrm{STJ}^{499}$ como a do $\mathrm{STF}^{500}$ aplicam o princípio da fungibilidade para admitir qualquer desses meios.

Tanto no caso de retenção indevida com base no artigo 542, $\S 3^{\circ}$, do CPC, como no sobrestamento indevido com base nos artigos 543-B e 543-C do CPC, têm-se situações semelhantes (trancamento indevido do recurso, que deve ser imediatamente processado), sendo razoável, portanto, a aceitação das mesmas medidas. ${ }^{501}$

Tanto é assim que o próprio STJ, por decisões monocráticas proferidas pela ministra Nancy Andrighi, já admitiu a aplicação, por analogia, do mesmo regime do destrancamento dos recursos especiais retidos (art. 542, $\S 3^{\circ}$, do CPC), afirmando-se a

${ }^{498}$ O STJ e o STF já manifestaram o entendimento de que até mesmo o agravo é cabível. Conforme voto
proferido pelo ministro César Asfor Rocha em precedente do STJ, seria inútil a distinção entre retenção e
não admissão do recurso especial "pois na prática o resultado que elas produzem é o mesmo, qual seja, o
não seguimento imediato do recurso especial" (STJ - liminar concedida na MC n. 2.454/RJ, rel. Min. César
Afor Rocha, DJU, de 13.03.2000). Por sua vez, o STF afirmou que a retenção indevida equivale a uma
inadmissibilidade, ainda que temporal, do recurso extraordinário. Confira-se: "É que comporta agravo de
instrumento para este Tribunal a decisão de inadmissibilidade de recurso de sua competência (art. 544,
caput, do CPC; art. 313, inc. II, do RISTF). A ordem para que o extraordinário fique retido, nos termos do
art. 542, $\S 3^{\circ}$, do CPC, não deixa de caracterizar juízo atinente à admissibilidade da impugnação,
designadamente a seu aspecto temporal. Afinal, reter o recurso equivale a reputá-lo provisoriamente
inadmissível, até que venha a ser reiterado pela parte a quem aproveite. Daí, a propriedade do agravo de
instrumento do art. 544, do CPC, nas hipóteses em que se aponte indevida a retençãa." (STF - AgR AI n. 502.333 /SP, $2^{\mathrm{a}}$ Turma, rel. Min. Cezar Peluso, DJe, de 10.10.2007).

499 “A Corte Especial já expressou entendimento de que o recurso especial, quando retido, pode ser destrancado por qualquer meio processual (mandado de segurança, cautelar, etc.)." (STJ - REsp n. 292.670RJ, rel. Min. Eliana Calmon, DJU, de 22.04.2002). E também: "O Superior Tribunal de Justiça, por sua vez, entende cabíveis medida cautelar, agravo de instrumento e reclamação, sendo que esta deve ser recebida como simples petição, com a finalidade de determinar a subida do recurso especial retido com fundamento no citado dispositivo da lei processual. Nesse sentido, há os seguintes julgados: MC 1.730/SP, Rel. p/acórdão Min. Jorge Scartezzini, Quinta Turma, DJ de 83/2000, p. 131; AgRg no Ag 436.704SP, Rel. Min. Castro Meira, Segunda Turma, DJ de 188/2003, p. 193; Rcl 686SP, Rel. Min. Fernando Gonçalves, Segunda Seção, DJ de 27/9/2004, p. 199." (STJ, AgRg na Rcl 2117/SP, Terceira Seção, rel. Min. Arnaldo Esteves Lima, DJ 14/06/2006, p. 187).

500 “A Corte ainda não firmou posição definitiva, oscilando entre considerar adequada ora a reclamação, ora medida cautelar, e até o agravo de instrumento, para que a parte prejudicada com a retenção do recurso extraordinário, com apoio no art. 543, $\S 3^{\circ}$ do Código de Processo Civil, lhe obtenha o processamento imediato [...]. Na trilha dos dois primeiros precedentes, reputo admissível qualquer das três vias. Em primeiro lugar, porque, diante da incerteza da jurisprudência do Tribunal, não seria lícito prejudicar a parte com eventual repulsa da via que, dentre todas, se entenda imprópria. Em segundo lugar, porque a pretensão de que se cuida - o desbloqueio de recurso extraordinário contra decisão interlocutória, cujo julgamento compete à Corte - parece caber no raio de admissibilidade das três medidas processuais, que, para esse efeito, devem ter-se por fungíveis." (STF - AgR AI n. 502.333/SP, 2 ${ }^{\text {a }}$ Turma, rel. Min. Cezar Peluso, DJe, de 10.10.2007).

${ }^{501}$ Nesse sentido: TALAMINI, Eduardo, Novos aspectos da jurisdição constitucional brasileira: repercussão geral, força vinculante, modulação dos efeitos do controle de constitucionalidade e alargamento do objeto do controle direto, cit., p. 69. 
possibilidade de liberação do recurso indevidamente sobrestado, com fundamento no artigo 543-C do CPC, por agravo de admissão, petição ou ação cautelar. ${ }^{502}$

Por outro lado, é lícito afirmar que, embora semelhantes, as situações não são idênticas. Quando ocorre a retenção indevida do recurso com base no artigo 542, § $3^{\circ}$, do CPC, a consequência para as partes é a imprestabilidade do recurso, caso seja processado apenas após o julgamento da ação principal - daí a equivalência com a inadmissibilidade. Ao seu turno, tratando-se de sobrestamento indevido do recurso com base nos artigos 543B e 543-C do CPC, em regra não se terá a mesma consequência, mas apenas o retardamento da prestação da tutela jurisdicional.

Por fim, quanto ao cabimento da reclamação constitucional, prevista nos artigos 102, I, “l”, e 105, I, “f”, da CF, embora seja possível afirmar que a decisão que determina o sobrestamento indevido acaba interferindo indiretamente na competência constitucional exclusiva do STF e do STJ de apreciar os recursos extraordinário e especial, não se tem um nítido caso de desobediência de decisão corte ou de usurpação de sua competência, pelo que esse instrumento também não é cabível. ${ }^{503}$

\subsubsection{Agravo interno}

O ideal seria a possibilidade de revisão de toda e qualquer decisão de sobrestamento diretamente pelo STF ou pelo STJ, que são os órgãos competentes para, em última análise, examinar a ocorrência de eventual distinção entre os casos.

\footnotetext{
${ }^{502}$ STJ - Pet n. 7.866, decisão monocrática, rel. Min. Nancy Andrighi, j. 12.08.2010, DJe, de 18.08.2010.

${ }^{503}$ Em sentido contrário, parte da doutrina entende ser cabível a reclamação, sob o argumento de que "a demonstração de que há um distinguishing ou um overruling deve ser feita perante o tribunal superior, e não perante o tribunal local". Assim, para essa mesma parte da doutrina, "manter um recurso indevidamente sobrestado equivale, em última análise, a usurpar a competência do tribunal superior, a quem cabe verificar se realmente o caso escolhido para julgamento por amostragem há ou não de se aplicar aquele que foi sobrestado pelo tribunal de origem" (DIDIER JR., Fredie; CUNHA, Leonardo José Carneiro da. Meio de impugnação contra sobrestamento indevido recurso especial repetitivo. Editorial 100. Disponível em: <http://www.frediedidier.com.br/main/noticias/detalhe.jsp?CId=417>. Acesso em: 09 set. 2013). Note-se, porém, que esse argumento vale mais para justificar a possibilidade de reclamação contra a decisão que, ao final do procedimento, aplica o precedente ao caso até então sobrestado. O sobrestamento, em si, apenas retarda o momento adequado para a realização do eventual distinguishing e overruling em relação a cada caso.
} 
Realmente, chega a ser dramática a situação das partes que têm seus recursos sobrestados indevidamente, tendo de aguardar todo o trâmite de julgamento do recursopiloto e a sua aplicação (consequentemente também indevida) ao caso individual, para, só depois, demonstrar a ausência de identidade entre as questões.

Essa é a razão pela qual, como demonstrado no item 8.7.2 supra, o STF e o STJ inicialmente concederam, ainda que em situações isoladas, e a título de exceção, o destrancamento de recursos sobrestados indevidamente.

Contudo, a ampla admissibilidade dessas impugnações de fato poderia tornar inócua a previsão legal do sobrestamento, prejudicando ao menos uma das finalidades da técnica de julgamento de recursos repetitivos, qual seja a de racionalizar a atuação da instância superior diante da multiplicidade de recursos repetitivos. Bastaria a arguição da ausência de identidade entre os casos para que a instância superior continuasse obrigada a examinar caso a caso, de modo que, nessa hipótese, seria mais econômico apreciar desde logo a admissibilidade e o mérito do recurso.

Diante disso, a hipótese da interposição de agravo interno no âmbito do tribunal que determinou o sobrestamento parece ser mais conveniente, por uma série de razões.

Primeiro, quanto à adequação desse meio, o princípio da colegialidade impõe, quando se tratar de decisão monocrática de tribunal, e à míngua da previsão legal a respeito do cabimento de outro recurso, a sua recorribilidade por meio de agravo interno, aplicando-se, com as adaptações necessárias, o disposto no artigo 557, § $1^{\circ}$, do CPC.

Por coerência, deve ser admitido agravo interno também contra a decisão do STF ou do STJ que determinar o sobrestamento do caso repetitivo (ou a sua devolução à instância inferior para que aguarde a definição da controvérsia), razão pela qual não pode prevalecer a jurisprudência do STF que afasta esse cabimento e ainda considera ser desnecessária a publicação da decisão.

Ademais, como a decisão pode ser igualmente prejudicial às partes recorrente e recorrida, há interesse recursal de ambas na interposição do recurso, o que também justifica a sua adequação para a espécie. 
Segundo, a admissão do agravo representa o reconhecimento expresso da recorribilidade imediata da decisão que determina o sobrestamento de cada caso, o que, como visto acima, traz segurança jurídica às partes, já que, não interposto o recurso, a questão fica preclusa, gerando maior aproveitamento do sobrestamento.

Terceiro, o agravo tem a vantagem de permitir o exercício do juízo de retratação, de modo que eventuais equívocos na identificação do caráter repetitivo da controvérsia podem ser corrigidos sem grande dispêndio de tempo e energia. Caso o juízo de retratação seja negativo, há ainda a apreciação do recurso pelo órgão colegiado.

Quarto, esse entendimento, ao manter no âmbito de cada tribunal de origem a revisão das decisões sobre o sobrestamento, livrando o STF e o STJ da realização desse controle individual, corrobora com a finalidade da técnica de julgamento de recursos repetitivos e com as próprias funções da instância extraordinária, por ela potencializadas. Isso sem contar que o trabalho de revisão das decisões sobre o sobrestamento será maior para os tribunais que cometerem mais erros ao determinar a suspensão de cada caso ou tiverem maior volume de recursos, o que é razoável e coerente com o princípio federativo.

Nesse sentido, a versão atual do projeto de novo CPC prevê expressamente o cabimento de agravo interno contra a decisão de relator que determina o sobrestamento, seja ela emanada da instância de origem ou da instância superior, conforme artigo 1.050, § 13 , II.

De qualquer modo, não se pode descartar o cabimento de posterior recurso especial contra o acórdão do órgão colegiado do tribunal de origem que apreciar o agravo interno interposto contra a decisão de sobrestamento, por má aplicação das normas federais infraconstitucionais previstas nos artigos 543-B e 543-C do CPC (error in procedendo). ${ }^{504}$

\footnotetext{
${ }^{504}$ Defendendo esse cabimento, embora contra a decisão que aplica equivocadamente o precedente ao caso repetitivo, ver: GARCIA, André Almeida, $O$ drama dos "sobrestados" e a utilização de um incidente autônomo de julgamento por amostragem, cit.
} 


\section{JULGAMENTO DOS RECURSOS REPRESENTATIVOS DA CONTROVÉRSIA: PREPARAÇÃO, PARTICIPAÇÃO DE TERCEIROS E ÓRGÃO COMPETENTE}

\subsection{Solicitação de informações aos Tribunais de Justiça e Tribunais Regionais Federais e concessão de vista ao Ministério Público}

Visando conferir maior qualidade e representatividade ao precedente resultante do julgamento dos recursos representativos da controvérsia, a lei prevê atos preparatórios que não ocorrem no caso de recurso não afetado para julgamento pelo rito dos artigos 543-B e 543-C do CPC.

Um desses atos é a expedição de ofício a todos os tribunais estaduais e federais (bem como turmas de juizado especial, no caso de recursos extraordinários repetitivos) do país, com solicitação de informações a respeito da controvérsia, o que ocorre na mesma oportunidade em que o STF e o STJ comunicam a instauração do procedimento e o sobrestamento dos recursos repetitivos.

Os órgãos oficiados têm o prazo de cinco dias para prestar as informações ao STF (art. 328, caput, do RISTF) e quinze dias para prestar as informações ao STJ (art. 543-C, § $3^{\circ}$, CPC c/c art. $3^{\circ}$, I, da Resolução n. 8 do STJ). A ideia é que se colham informações sobre a quantidade e qualidade de recursos e questões relacionadas à matéria repetitiva que poderão ser levadas em consideração no julgamento. ${ }^{505}$

Considerando-se a relevância do precedente a ser formado, os artigos 543-C, § $5^{\circ}$, do CPC e $3^{\circ}$, II, da Resolução n. 8 do STJ também preveem que, após vinda das informações dos tribunais e a oitiva dos terceiros interessados, será concedida vista dos autos dos recursos especiais representativos da controvérsia ao Ministério Público por quinze dias para parecer.

\footnotetext{
505 "Por essa via, o relator recolherá subsídios acerca da extensão da controvérsia, o teor do debate existente nas causas, e, principalmente, as tendências já formadas nos tribunais inferiores, inteirando-se do assunto para melhor julgá-lo.” (ASSIS, Araken de, Manual dos recursos, cit., p. 824).
} 
A atuação do Ministério Público nesses casos dá-se na condição de fiscal da lei (custos legis) e justifica-se por questões eminentemente processuais, pouco importando a natureza do direito material envolvido. Ou seja, a participação do órgão ministerial justifica-se em razão da importância do julgamento para toda a coletividade, em face dos efeitos extraprocessuais gerados pela mera instauração do procedimento (como o sobrestamento dos casos repetitivos) e pelo grau elevado de influência que o precedente gerará em relação aos demais casos.

Quanto aos recursos extraordinários repetitivos, não há no CPC qualquer disposição no sentido da participação do Ministério Público. Aliás, o artigo 325 do mesmo diploma estabelece que "uma vez definida a existência da repercussão geral, julgará o recurso ou pedirá dia para seu julgamento, após vista ao Procurador-Geral, se necessária”. Isso dá a entender que, para negar a existência de repercussão geral, não há necessidade de concessão de vista ao Ministério Público, e que, para julgar o mérito, ela é meramente facultativa.

No entanto, o artigo 52, XV, do RISTF prevê a manifestação do Procurador Geral da República "quando, pela relevância da matéria, ele a requerer, ou for determinada pelo Relator, Turma ou Plenário", podendo-se extrair dessa norma a necessidade de oitiva do Ministério Público para a apreciação da repercussão geral ou do mérito dos recursos representativos da controvérsia.

\subsection{Participação de terceiros}

\subsubsection{Amicus curiae}

A importância do precedente que será formado com a apreciação do recurso-piloto justifica a permissão para a participação de terceiros que possam contribuir para a melhor compreensão de todos os aspectos envolvidos na controvérsia.

Ao julgar o recurso representativo, o STF ou o STJ define uma questão controvertida sobre a interpretação do direito federal constitucional ou infraconstitucional (ou a questão da repercussão geral, no caso do STF) que, em geral, se faz presente em 
inúmeros casos por todo o país. A decisão servirá de parâmetro não só para a solução dos casos sobrestados e futuramente ajuizados, como também às próprias relações jurídicas não judicializadas, trazendo maior previsibilidade sobre o verdadeiro e único sentido do ordenamento jurídico.

Assim, ainda que destituídos de efeito vinculante, os precedentes formados com a apreciação dos recursos representativos da controvérsia são importantíssimos para toda a sociedade, de modo que o julgamento obviamente não interessa apenas àqueles que figuram como partes nos recursos selecionados, ou até mesmo àqueles que tiveram seu recurso sobrestado.

Isso, na verdade, já ocorre com relação a todo precedente do STF ou do STJ formado em julgamento de recurso extraordinário ou especial, haja vista suas funções específicas previstas pela Constituição Federal (ver Capítulo 3). Todavia, com o julgamento dos recursos representativos da controvérsia, em sede de procedimento de recursos repetitivos, a eficácia extraprocessual do precedente é muito maior, justamente em razão do regime dos artigos 543-B e 543-C do CPC.

Diante disso, na linha do que já ocorre com os processos objetivos (isto é, destituídos de partes, como os voltados ao controle concentrado e abstrato de constitucionalidade) e com a Súmula Vinculante ${ }^{506}$, o Código de Processo Civil e as normas regimentais que regulamentam a técnica de julgamento de recursos repetitivos preveem a realização de um contraditório coletivo ou social, por meio da participação da figura do amicus curiae.

$\mathrm{O}$ artigo 543-C, $\S 4^{\circ}$, do CPC afirma que "o relator, conforme dispuser o regimento interno do Superior Tribunal de Justiça e considerando a relevância da matéria, poderá admitir manifestação de pessoas, órgãos ou entidades com interesse na controvérsia". Por sua vez, o artigo $3^{\circ}$, I, da Resolução n. 8 do STJ, diz que o relator poderá “autorizar, ante a

\footnotetext{
${ }^{506} \mathrm{O}$ art. $7^{\mathrm{o}}, \S 2^{\mathrm{o}}$, da Lei n. 9.868/99 já previa que, nesses casos: “O relator, considerando a relevância da matéria e a representatividade dos postulantes, poderá, por despacho irrecorrível, admitir, observado o prazo fixado no parágrafo anterior, a manifestação de outros órgãos ou entidades”. Regra semelhante pode ser encontrada na Lei n. 9.882/99, que regulamenta a arguição de descumprimento de preceito fundamental (ADPF). Por sua vez, o artigo $3^{\circ}, \S 2^{\circ}$, da Lei n. 11.417/2006 também prevê a possibilidade de "participação de terceiros" no procedimento de edição, revisão ou cancelamento de súmula vinculante.
} 
relevância da matéria, a manifestação escrita de pessoas, órgãos ou entidades com interesse na controvérsia, a serem prestadas no prazo de quinze dias". 507

Já o artigo 543-A, § 6 , do CPC, dispõe que “o Relator poderá admitir, na análise da repercussão geral, a manifestação de terceiros, subscrita por procurador habilitado, nos termos do Regimento Interno do Supremo Tribunal Federal”, norma essa que foi regulamentada pelo artigo 323, $\S 3^{\circ}$, do RISTF, segundo o qual "mediante decisão irrecorrível, poderá o(a) Relator(a) admitir de ofício ou a requerimento, em prazo que fixar, a manifestação de terceiros, subscrita por procurador habilitado, sobre a questão da repercussão geral".

Como se vê, essas normas instituem a figura do amicus curiae no procedimento de julgamento de recursos extraordinários e especiais repetitivos ${ }^{508}$. Quanto ao recurso extraordinário, embora o CPC e o RISTF prevejam a intervenção apenas quanto ao exame da repercussão geral, não há dúvida de que ela deverá ser admitida também quando, reconhecida a repercussão, a corte passa ao exame do mérito da controvérsia, porque também a decisão de mérito representará precedente qualificado e dotado de alto grau de influência em relação aos casos repetitivos.

Segundo a melhor doutrina sobre o tema do amicus curiae no Brasil, trata-se de uma espécie de intervenção de terceiro "cuja finalidade última é a de ampliar, aprimorando-o, o objeto de conhecimento do juiz com informações relativas a interesses metaindividuais [...] que serão afetados, em alguma medida, pela decisão a ser proferida: uma intervenção de terceiros com finalidade instrutória, portanto". 509

Nesse sentido, o amicus curiae atua como um representante, não propriamente de uma parte ou de outra, mas sim dos interesses que existem na sociedade, e que sofrerão, em maior ou menor grau, os efeitos da decisão proferida no processo.

\footnotetext{
507 “Trata-se, sem dúvida da participação de terceiros, no julgamento do recurso especial, na qualidade de amicus curiae [...]." (ALVIM, José Eduardo Carreira, Recursos especiais repetitivos: mais uma tentativa de desobstruir os tribunais, cit., p. 178).

508 "Pessoas, órgãos ou entidades com interesse na controvérsia, isto é, eventuais amici curiae, poderão ser ouvidos, a depender da relevância da matéria, pelo Ministro-relator [...].” (BUENO, Cassio Scarpinella, Curso sistematizado de direito processual civil, cit., v. 5, p. 311).

509 BUENO, Cassio Scarpinella. Amicus curiae no projeto de novo Código de Processo Civil. Revista de Informação Legislativa, Brasília, v. 48, n. 190, t. 1, p. 114, abr./jun. 2011.
} 
Por isso, trata-se de um “inegável ponto de contato entre o 'direito processual civil individual' e o chamado 'direito processual civil coletivo' na exata medida em que as decisões jurisdicionais tendem a afetar cada vez mais pessoas ou grupos que não participam diretamente do processo no próprio plano processual" ${ }^{\text {"510 }}$, conforme ocorre com os precedentes judiciais, sobretudo os dotados de efeito vinculante e de efeito persuasivo qualificado.

Com a atuação do amicus curiae, confere-se maior legitimidade e qualidade ao precedente, porque a atuação de entes que efetivamente representam os interesses em jogo viabiliza o exercício de contraditório coletivo e social, também chamado de contraditório presumido, institucionalizado, de cooperação, coordenação e colaboração. ${ }^{511}$

A sua contribuição para o julgamento da controvérsia, a partir do fornecimento de informações detidas em razão da sua função institucional relacionada aos interesses envolvidos, atua no sentido de compensar a ausência de participação de todos aqueles que serão direta ou indiretamente afetados.

Por isso, diz-se que o amicus curiae, que tem origem no direito norte-americano, ou seja, justamente no direito em que os precedentes criam o direito e têm eficácia vinculante, é "um instituto de matiz democrático, uma vez que permite, tirando um ou outro caso de nítido interesse particular, que terceiros penetrem no mundo fechado e subjetivo do processo para discutir objetivamente teses jurídicas que vão afetar toda a sociedade". ${ }^{512}$

Não é qualquer pessoa que pode atuar como amicus curiae. Exige-se que o interveniente tenha representatividade adequada, isto é, interesse institucional na causa, o que é essencial para o sucesso da intervenção e até para justificá-la ${ }^{513}$. Quem tem mera legitimidade para ser parte ou mero interesse próprio não pode ingressar como amicus

\footnotetext{
${ }^{510}$ BUENO, Cassio Scarpinella, Amicus curiae no projeto de novo Código de Processo Civil, cit., p. 114.

${ }^{511}$ Ibidem, p. 115.

512 MACIEL, Adhemar Ferreira. "Amicus curiae": um instituto democrático. Revista de Informação Legislativa, Brasília, DF, ano 38, n. 153, p. 7, jan./mar. 2002.

513 “Se o amicus curiae não a possuir, não há razão nenhuma para ele atuar no processo. Ele deve representar interesses e representá-los adequadamente; ter representatividade perante aqueles que não têm legitimidade para atuar (e que não são, por isso mesmo, representados)." (BUENO, Cassio Scarpinella, Amicus curiae no Projeto de novo Código de Processo Civil, cit., p. 118).
} 
curiae, pois a ideia da intervenção é justamente a representação de interesses externos ao processo, e não de interesses eminentemente próprios do interveniente.

No mesmo sentido, Leonardo Greco afirma que o instituto dever ser interpretado de forma restritiva, porque "o amicus curiae não deveria ser um sujeito interessado no desfecho da causa; tem de ser um amigo da corte e, portanto, um sujeito auxiliar, imparcial e isento". 514

Isso revela a importância da atuação do amicus curiae no procedimento de julgamento de recursos repetitivos, cujo objetivo principal não é decidir o caso concreto selecionado, mas sim proferir uma decisão paradigma a respeito da interpretação do direito federal constitucional e infraconstitucional, decisão essa que servirá de parâmetro para julgamento de inúmeros outros casos idênticos que aguardam sobrestados, e também de casos futuros - formando-se um precedente que, embora não tenha efeito vinculante, é potencializado e dotado de forte carga persuasiva.

Assim, a previsão legal expressa ${ }^{515}$ no sentido da possibilidade de intervenção do amicus curiae no julgamento de recursos extraordinários e especiais repetitivos faz com que essa técnica, além de proporcionar maior racionalidade à atividade jurisdicional e maior segurança e isonomia no tratamento dos casos idênticos, viabilize a obtenção de precedentes mais legítimos e qualificados do STF e do STJ. Basta observar que, até então, a mesma jurisprudência era formada a partir do julgamento reiterado de casos individuais, porém sem possibilidade dessa participação do amicus curiae.

\subsubsection{Aspectos procedimentais da participação do amicus curiae}

Passamos a analisar os principais aspectos formais relacionados à participação do amicus curiae, quais sejam: o dever de motivação e o direito à impugnação da decisão que indefere sua participação; o direito à realização de sustentação oral; o momento da

\footnotetext{
${ }^{514}$ GRECO, Leonardo, Instituições de processo civil, cit., v. 1, p. 532.

515 Por estar ligada à garantia constitucional do contraditório, a intervenção do amicus curiae nos processos cujos julgamentos afetam direta ou indiretamente terceiros, em razão da relevância da questão e da formação do precedente jurisprudencial, pode e deve ser admitida, independentemente de previsão legal.
} 
intervenção; e, por fim, o direito à oposição de embargos de declaração contra a decisão final.

Quanto ao primeiro ponto, a legislação prevê que o relator poderá “admitir de ofício ou a requerimento, em prazo que fixar, a manifestação de terceiros" (art. $323, \S 3^{\circ}$, do RISTF c/c art. 543-A, $\S 6^{\circ}$, do CPC) e "autorizar, ante a relevância da matéria, a manifestação escrita" (art. $3^{\circ}$, I, da Resolução n. 8 do STJ c/c art. 543-C, § 4º do CPC).

Como se vê, parece que o legislador simplesmente facultou ao relator admitir a intervenção. Haveria aí uma discricionariedade do relator, que simplesmente poderia admitir ou não, sem qualquer necessidade de fundamentação, a intervenção de terceiros interessados?

A resposta mais adequada é negativa. Em primeiro lugar, o artigo 93, IX, da CF exige expressamente, sob pena de nulidade, a motivação das decisões judiciais. Por isso, a decisão sobre a intervenção ou não de terceiro em sede de julgamento de recursos repetitivos deve ser motivada.

Além disso, como visto, essa intervenção é assegurada pela garantia constitucional do contraditório (no caso, contraditório coletivo e social), cujo exercício é essencial para legitimar todos os julgamentos em que houver relevância social da matéria, de forma a produzir precedente que, direta ou indiretamente, atingirá outros setores da sociedade que não participam do julgamento. E essa relevância sempre está presente no julgamento dos recursos repetitivos pelo STF ou pelo STJ, em razão da influência do precedente nos casos sobrestados e demais casos repetitivos.

Se é assim, não há sentido em se admitir que a decisão sobre a intervenção seja meramente facultativa, conferindo-se poderes discricionários ao relator para simplesmente negar, quando melhor lhe convier, a manifestação de terceiros. Daí porque, uma vez indeferida a participação por decisão motivada, ela deve estar sujeita a recurso de agravo interno ao órgão colegiado.

Esse entendimento também decorre de interpretação analógica, posto que, segundo o artigo $7^{\circ}, \S 2^{\circ}$, da Lei n. 9.868/99, a decisão que admite a intervenção do amicus curiae 
em processo de controle abstrato de constitucionalidade é irrecorrível, do que se conclui, contrario sensu, que a decisão que indefere o pedido de intervenção poderá ser recorrida.

E, de fato, o STF admite a impugnação da decisão por meio de agravo interno dirigido ao órgão colegiado, conforme precedentes do Pleno. ${ }^{516}$

Apesar disso, o STJ vem decidindo que a intervenção de amicus curiae em sede de julgamento de recursos especiais repetitivos é mera faculdade da corte, que pode simplesmente dispensar a intervenção, se entender que ela é inconveniente. ${ }^{517}$

Claro que o STJ poderá e deverá fazer um controle da intervenção. Como já dito, deve-se levar em consideração a representatividade do interveniente e também a novidade e a relevância dos argumentos a serem apresentados, até para que não se obstrua o julgamento, prejudicando-se a razoável duração do processo. Porém, não se trata de mera faculdade do STJ, e sim de um direito daqueles que preencherem os requisitos da intervenção, de modo que, indeferida a manifestação pelo relator por qualquer motivo, a decisão poderá ser atacada por agravo interno.

Outra questão diz respeito à restrição da intervenção à mera possibilidade de manifestação escrita, ou se ela inclui o direito à sustentação oral, por ocasião do julgamento dos recursos selecionados.

Curioso notar que a Resolução n. 8 do STJ, em seu artigo $3^{\circ}$, menciona a expressão "manifestação escrita", com uma nítida pretensão de restringir a intervenção. Porém, essa limitação não consta no artigo 543-C, $\S 4^{\circ}$, do $\mathrm{CPC}$, o que suscita dúvida sobre a sua constitucionalidade.

Realmente, o direito do amicus curiae realizar sustentação oral é essencial pelas próprias características e finalidade da intervenção, no sentido de concretizar o contraditório social e trazer maior qualidade e legitimidade ao julgamento. A arguição oral (não meramente escrita) das contribuições do amicus curiae amplia o acesso da sociedade

\footnotetext{
${ }^{516}$ STF - AgR ADI n. 4.071, Tribunal Pleno, rel. Min. Menezes Direito, j. 22.04.2009, DJe, de 15.10.2009; STF - AgR ADI n. 4.067, Tribunal Pleno, rel. Min. Joaquim Barbosa, DJe, de- 23.04.2010.

${ }^{517}$ STJ - QO REsp n. 1.205.946/SP, Corte Especial, rel. Min. Benedito Gonçalves, j. 17.08.2011.
} 
às questões debatidas no processo, viabilizando maior transparência e controle sobre o tema, já que dificilmente o povo teria acesso às informações, se elas fossem meramente escritas. $^{518}$

Por isso, é comum o STF admitir a realização de sustentação oral do amicus curiae nos processos objetivos (controle abstrato de constitucionalidade). Nesse sentido, vale citar exemplificativamente a proposta do ministro Carlos Britto quanto à admissão não só do ingresso, como da sustentação oral de entidades que requereram seu ingresso como amicus curiae, na ADI n. 3.273-9/DF: “Admito, por entender que o pluralismo da nossa Constituição reconhece, desde o seu preâmbulo, é um fator de legitimação das decisões colegiadas. Se os meus Pares entenderem assim também, não vejo porque denegar o pedido de sustentação oral". 519

Por sua vez, o STJ também tem admitido a sustentação oral dos terceiros intervenientes nos julgamentos de recursos especiais repetitivos. Tanto é assim que, no julgamento do REsp n. 1061530/RS, o ministro João Otávio de Noronha propôs o indeferimento do pedido, sob o argumento de que a "a lei é taxativa: aqueles que não são partes podem se manifestar; todavia, hão de manifestar-se por escrito" ${ }^{\text {, }}$, mas, juntamente com os ministros Fernando Gonçalves e Aldir Passarinho Junior, ficou vencido pela

\footnotetext{
${ }^{518}$ Conforme o voto proferido pelo ministro Celso de Mello: "A atuação processual do amicus curiae não deve limitar-se à mera apresentação de memoriais ou à prestação eventual de informações que lhe venham a ser solicitadas. Cumpre permitir-lhe, em extensão maior [...] o exercício de determinados poderes processuais, como aquele consistente no direito de proceder à sustentação oral das razões que justificaram a sua admissão formal na causa. Tenho para mim que o Supremo Tribunal Federal, em assim agindo, não só garantirá maior efetividade e atribuirá maior legitimidade às suas decisões, mas, sobretudo, valorizará, sob uma perspectiva eminentemente pluralística, o sentido essencialmente democrático dessa participação processual, enriquecida pelos elementos de informação e pelo acervo de experiências que o amicus curiae poderá transmitir à Corte Constitucional, notadamente em um processo - como o de controle abstrato de constitucionalidade - cujas implicações políticas, sociais, econômicas, jurídicas e culturais são de irrecusável importância e de inquestionável significação.”(STF - MC ADI n. 2.223 /DF, Tribunal Pleno, rel. Min. Maurício Corrêa, j. 10.10.2002, DJ, de 05.12.2003). Na oportunidade, o ministro Celso de Mello, juntamente com os ministros Nelson Jobim e Marco Aurélio, ficaram vencidos quanto à questão preliminar, tendo o STF concluído pela impossibilidade de sustentação oral do amicus curiae.

${ }^{519}$ STF - ADI n. 3.273/DF, Tribunal Pleno, rel. Min. Carlos Britto, DJ, de 02.03.2007.

${ }^{520}$ Segundo o ministro João Otávio de Noronha: “A lei permite ao relator ouvir terceiros interessados, vale dizer, pessoas que, embora não se submetam à eficácia da coisa julgada que derivará do acórdão no caso concreto, têm legítimo interesse na defesa da tese apreciada, tendo em vista a repercussão que dela se extrairá para futuros julgamentos de outros recursos. No caso, os terceiros interessados foram ouvidos e se manifestaram por escrito. Portanto, penso que, para manter a boa ordem, deve-se cumprir o que ficou estabelecido nesta Seção em julgamento anterior: a sustentação oral deverá ficar reservada apenas para as partes".
} 
maioria dos integrantes da Segunda Seção que, apreciando a questão de ordem preliminar, admitiu a sustentação oral dos amicus curiae.

Apesar disso, decidindo questão de ordem suscitada em julgamento de recurso especial pelo rito do artigo 543-C do CPC, a Corte Especial do STJ, em agosto de 2011, "firmou a orientação de não reconhecer o direito do amicus curiae de exigir a sua sustentação oral no julgamento de recursos repetitivos, a qual deverá prevalecer em todas as Seções". Segundo o voto vencedor, o tratamento que se deve dar ao amicus curiae em relação à sustentação oral é o mesmo dos demais atos do processo: o STJ tem a faculdade de convocá-lo ou não. Se entender que deve ouvir a sustentação oral, poderá convocar um ou alguns dos amici curiae, pois não há por parte deles o direito de exigir sustentação oral. $^{521}$

Esse entendimento, embora não exclua a possibilidade de sustentação oral, enfraquece a legitimidade do julgamento de recursos especiais repetitivos, pois a Corte poderá discricionariamente afastar a manifestação oral do amicus curiae, perdendo a oportunidade de garantir maior efetividade e maior legitimidade às suas decisões, e de valorizar, sob uma perspectiva eminentemente pluralística, o sentido essencialmente democrático dessa participação processual.

Quanto ao momento da intervenção, o STF já definiu que "o amicus curiae somente pode demandar a sua intervenção até a data em que o Relator liberar o processo para pauta" e "é extemporâneo o pedido para admissão nos autos na qualidade de amicus curiae formulado após a liberação da ação direta de inconstitucionalidade para julgamento". 522

O STJ, baseado em tais precedentes, também já se manifestou no mesmo sentido ${ }^{523}$, embora tenha excepcionalmente admitido o ingresso extemporâneo, em razão do "inegável grau de representatividade da requerente" - o que revela que a regra não é tão rígida, podendo ser flexibilizada, conforme as peculiaridades de cada caso concreto.

\footnotetext{
${ }^{521}$ QO REsp n. 1.205.946/SP, rel. Min. Benedito Gonçalves, j. 17.08.2011.

${ }^{522}$ STF - AgR ADI n. 4.071, Tribunal Pleno, rel. Min. Menezes Direito, j. 22.04.2009, DJe, de 15.10.2009;

STF - AgR ADI n. 4.067, Tribunal Pleno, rel. Min. Joaquim Barbosa, DJe, de 23.04.2010.

${ }^{523}$ STJ - REsp n. 1.117.614/PR, 2 ${ }^{\text {a }}$ Seção, DJe, de 10.10.2011.
} 
Realmente, é razoável exigir que o pedido de ingresso ocorra até a liberação do processo para julgamento, seja porque pode haver obstrução da pauta e demora na apreciação da matéria (com prejuízo à razoável duração do processo), seja porque o sentido da intervenção é munir a corte de informações durante a preparação para o julgamento, contribuindo para a melhor análise da questão. Sem prejuízo, nada obsta, como visto no precedente do próprio STJ, a flexibilização dessa regra, em prol da participação do amicus curiae, conforme as peculiaridades de cada caso.

Por fim, indaga-se se o amicus curiae tem o direito de interpor recurso contra a decisão relativa ao processo no qual ele foi admitido. No caso do STF, o único recurso possível seria o de embargos de declaração ou eventuais embargos de divergência. Já no STJ, além dos embargos de declaração e eventuais embargos de divergência, o terceiro poderia, em tese, interpor até recurso extraordinário ao STF.

Em geral, não se admite a interposição de recursos pelo amicus curiae, sob o fundamento de que ele não é parte (faltando-lhe legitimidade) e não sucumbe (faltando-lhe interesse recursal). ${ }^{524}$

No julgamento da ADI n. 3.615/PB, embora o STF tenha mantido o entendimento no sentido da impossibilidade de interposição de recurso pelo amicus curiae contra a decisão de mérito que julga a causa na qual ele interveio, os ministros Carlos Britto e Gilmar Mendes manifestaram, em votos vencidos, que pelo menos a interposição de embargos de declaração deveria ser admitida ao interveniente, nos casos em que ele realiza sustentação oral. ${ }^{525}$

\footnotetext{
${ }^{524}$ O STJ recentemente se manifestou no sentido de que "a legitimidade ordinária para interpor recurso contra o Acórdão proferido em sede Recurso Especial, submetido ao rito do art. 543-C do Código de Processo Civil, é apenas das partes envolvidas no feito. No caso, O IDEC - INSTITUTO BRASILEIRO DE DEFESA DO CONSUMIDOR não é parte no processo, mas pretende intervir no feito, já julgado, na qualidade de amicus curiae para interpor recurso, o que é inviável" (STJ - ED REsp n. 1.110.549/RS, 2 ${ }^{\mathrm{a}}$ Seção, rel. Min. Sidnei Beneti, DJe, de 30.04.2010). Esse julgado do STJ faz menção ao entendimento assente do STF no sentido de que aqueles que participam do feito na qualidade de amicus curiae não possuem legitimidade para recorrer da decisão de mérito. Nesse sentido: "Carece de legitimidade recursal quem não é parte na ação direta de inconstitucionalidade, mesmo quando, eventualmente, tenha sido admitido como amicus curiae." (STF - ED ADI n. 3.582, Tribunal Pleno, rel. Min. Menezes Direito, j. 17.03.2008, DJe, de 30.04.2008).

${ }^{525}$ STF - ED ADI n. 3.615/PB, Tribunal Pleno, rel. Min. Cármen Lúcia, DJe, de 24.04.2008.
} 
De fato, entendemos que a interposição de embargos de declaração não só potencializa a atuação do amicus curiae, o que guarda consonância com a importância da sua atuação, como também é essencial para a própria eficácia da sua participação. De nada adiantaria admitir a intervenção, a manifestação por escrito e a sustentação oral se, ignoradas as razões arguidas pelo amicus curiae, ou analisadas de forma obscura ou contraditória, ele não pudesse interpor os competentes embargos de declaração.

Assim, entendemos que pelo menos essa modalidade recursal deve ser admitida ao interveniente, sob pena de risco de ineficácia da sua atuação.

\subsubsection{Intervenção dos que figuram como partes nos recursos sobrestados?}

Questiona-se se o procedimento de julgamento de recursos repetitivos também permitiria a intervenção daqueles que são parte em outros processos que ficam sobrestados até o julgamento do recurso paradigma.

Preliminarmente, deve-se descartar a possibilidade dessa intervenção na qualidade de assistente simples ou litisconsorcial, pois tal modalidade exige a existência de interesse jurídico do interveniente, o qual só está presente quando ele tem alguma relação jurídica material com alguma das partes do processo no qual se pretende intervir.

Nesse sentido, Leonardo Greco leciona que “interesse jurídico é a relação jurídica de direito material que vincula o assistente ao assistido e, às vezes, também ao seu adversário, e que pode de algum modo ser afetada pela decisão da causa na qual o assistente não é parte". 526

No procedimento de julgamento de recursos repetitivos não existe, em regra, qualquer relação jurídica de direito material entre as partes do recurso-piloto e as partes dos recursos sobrestados. Como já demonstrado no Capítulo 5 (item 5.4), não há, aqui, a extensão da coisa julgada em relação aos processos repetitivos sobrestados, mas apenas

\footnotetext{
${ }^{526} \mathrm{O}$ autor complementa explanando que "na assistência simples, o interesse jurídico do assistente está vinculado apenas à relação jurídica que ele mantém com o assistido. [...] A assistência litisconsorcial está definida no artigo 54 do Código de Processo Civil, caracterizando-se pela possibilidade de a sentença proferida no processo alheio influir na relação jurídica entre o assistente e o adversário do assistido" (GRECO, Leonardo, Instituições de processo civil, cit., v. 1, p. 498-501).
} 
sobrestamento dos recursos repetitivos à espera do precedente do STF e do STJ a respeito da definição da questão de direito federal constitucional ou infraconstitucional.

Ou seja, apesar da dimensão coletiva do procedimento (eis que a decisão importância para toda a sociedade e influenciará a definição da questão de direito objeto de todos os casos repetitivos), a instauração do procedimento não transforma o recurso-piloto em processo tipicamente coletivo, nem faz surgir entre ele e os casos repetitivos sobrestados qualquer relação de direito material.

Aliás, a questão repetitiva que enseja a instauração do procedimento não precisa sequer se referir a uma questão de direito material. Pode ocorrer, e muitas vezes ocorre, de o procedimento ser instaurado para a definição de questões meramente processuais, quando fica ainda mais clara a total ausência de relação entre as causas que pudessem autorizar uma intervenção desse tipo. $\mathrm{O}$ mesmo se diga quanto às discussões sobre matéria de direito penal.

Na verdade, o que existe é apenas uma afinidade entre as causas, o que não é relevante sequer para fins de conexão entre as demandas. ${ }^{527}$

Assim, se alguma relação existir entre as partes do recurso-piloto e as partes dos recursos sobrestados, ela decorrerá, não da circunstância de ter o procedimento de julgamento de recursos repetitivos sido instaurado, mas sim das peculiaridades da relação de direito material discutida em juízo, como ocorre, por exemplo, nos casos de direitos difusos, coletivos ou individuais homogêneos. Nessa hipótese, a possibilidade de

\footnotetext{
${ }^{527}$ Conforme Cândido Rangel Dinamarco: "A coincidência entre os elementos objetivos das demandas para determinar a conexidade juridicamente relevante, deve ser coincidência quanto aos elementos concretos da causa de pedir ou quanto aos elementos concretos do pedido. A coincidência de elementos abstratos conduz à mera afinidade entre as demandas, que não chega a ser conexidade e não tem os mesmos efeitos desta. [...] A mera coincidência dos fundamentos jurídicos não é todavia suficiente para fazer com que duas causas sejam conexas (p.ex., milhares de funcionários públicos em litígio com o Estado por um certo recálculo de vencimentos ou uma multidão de consumidores pleiteando indenização pelo defeito de dado produto). Sendo menos que a conexidade, é natural que tenha menor relevância na ordem processual: o Código de Processo Civil lhe dá o único efeito de autorizar o litisconsórcio e, assim mesmo, somente no caso em que para ambas ou todas as causas afins seja competente o mesmo foro, sem se prorrogar a competência." (DINAMARCO, Cândido Rangel, Instituições de direito processual civil, cit., p. 154-157).
} 
participação de terceiros estará sujeita às regras que regem o sistema de jurisdição coletiva, mais especificamente as Leis ns. 7.347/85 e 8.078/90. ${ }^{528}$

Enfim, para a instauração do procedimento de julgamento de recursos repetitivos, não se exige relação jurídica entre os que figuram como partes nos recursos representativos da controvérsia e os que figuram como partes nos processos repetitivos sobrestados, o que, portanto, desautoriza intervenções desses últimos como assistentes.

Pelas mesmas razões, os que figuram como partes nos processos sobrestados não podem recorrer contra a decisão proferida no julgamento do recurso-piloto. Não há que se falar aqui em recurso de terceiro prejudicado, pois não há, na forma do artigo $499, \S 1^{\circ}$, do CPC, "nexo de interdependência entre o seu interesse de intervir e a relação jurídica submetida à apreciação judicial". 529

\footnotetext{
${ }^{528}$ Nesse sentido, observa-se que, segundo o artigo 94 da Lei n. 8.078/90, proposta a ação coletiva, os interessados poderão intervir no processo como litisconsortes. Vale mencionar, porém, que, conforme comentário de Fredie Didier Jr. ao QO RE 550.769 /RJ, rel. Min. Joaquim Barbosa, j. 28.2.2008, publicada no Informativo do STF n. 496, o STF já admitiu a intervenção de legitimado extraordinário em processo individual a título de assistente simples, a fim de conferir maior legitimidade à decisão que, versando sobre relação jurídica coletiva, atingiria na prática um grande número de casos: "O STF entendeu que o interesse jurídico que autoriza a assistência simples, no caso mencionado, configurou-se pela constatação de que o julgamento do STF poderia definir a orientação da jurisprudência em torno do tema [...], que serviria para a solução de um número indefinido de casos". Segundo ele: "A relação jurídica conexa à relação discutida, aqui, é uma relação jurídica coletiva, pois envolve a proteção de direitos individuais homogêneos, cuja titularidade pertence à coletividade de vítimas (no caso, as indústrias do tabaco)." (DIDIER JR., Fredie. Intervenção de legitimado extraordinário para a defesa de direitos coletivos (lato sensu) como assistente simples em processo individual. Disponível em: <http://piauijuridico.blogspot.com.br/2008/04/intervenode-legitimado-extraordinrio.html>. Acesso em: 09 set. 2013). Aqui, porém, além da questão da formação do precedente, ocorre efetiva relação entre as demandas individuais e coletivas, pois a própria relação jurídica de direito material tem cunho coletivo. Não é isso que ocorre, ou pelo menos não necessariamente, com a técnica de julgamento de recursos repetitivos, conforme já demonstrado neste trabalho.

${ }^{529}$ Em sentido contrário, José Eduardo Carreira Alvim entende que, embora realmente não exista relação jurídica entre as relações jurídicas assentadas na mesma tese, configurando matéria repetitiva, "o terceiro sofrerá um prejuízo jurídico decorrente diretamente do acórdão que vier a ser proferido pelo STJ, em recurso especial de outrem, pelo simples fato de o seu recurso especial sobrestado se assentar na mesma tese jurídica, pelo que, pelo Código, estaria legitimado e com interesse de recorrer mediante eventual recurso especial de terceiro prejudicado (arts. 499, § 1. ${ }^{\circ}$, e 496, VI, do CPC)". Note-se, porém, que o autor parte da premissa de que o acórdão que julga os recursos representativos da controvérsia teria efeito vinculante, funcionando "como se fosse um precedente obrigatório, com maior força do que uma simples súmula" (ALVIM, José Eduardo Carreira, Recursos especiais repetitivos: mais uma tentativa de desobstruir os tribunais, cit., p. 181 e 180).
} 
Nesse sentido, o STJ vem entendendo que "o mero interesse lato sensu de que a jurisprudência desta Corte se modifique não viabiliza a intervenção e a legitimidade recursal para opor declaratórios". 530

Dessa forma, só podem interpor recurso contra tal decisão as próprias partes e o Ministério Público (que, como visto, atua como fiscal da lei). Quanto aos que intervêm na qualidade de amicus curiare, entendamos que eles também deveriam poder recorrer, mas a orientação da jurisprudência é no sentido da inexistência de legitimidade recursal (ver item 9.2.2 supra).

É justamente por essas razões que é tão importante a seleção de recursos que realmente sejam representativos da controvérsia, tanto do ponto de vista subjetivo, como objetivo, conforme demonstrado no Capítulo 7 (item 7.3.1).

$\mathrm{Na}$ verdade, tratando-se de procedimento voltado à formação de um precedente que exercerá, em maior ou menor grau, influência sobre os demais casos e sobre a sociedade em geral, a intervenção adequada para o exercício do contraditório social e, consequentemente, para a legitimação e qualificação do precedente, é, como visto, apenas do amicus curiae.

Isso posto, passamos a analisar se as partes nos processos repetitivos sobrestados podem intervir diretamente, ao menos na qualidade de amicus curiae, isto é, para ampliar o contraditório, contribuir com seus argumentos e, com isso, conferir maior legitimidade e qualificação para o precedente.

A leitura do artigo 543-C, $\S 4^{\circ}$, do CPC, parece sugerir que sim, pois admite a "manifestação de pessoas, órgãos ou entidades com interesse na controvérsia", e não menciona a exigência de qualquer requisito.

Aliás, a exposição de motivos da lei que deu origem ao artigo 543-C do CPC menciona expressamente essa possibilidade: "Para assegurar que todos os argumentos sejam levados em conta no julgamento dos recursos selecionados, a presente proposta

${ }^{530}$ STJ - ED EREsp n. 650.246PR, 1 ${ }^{\text {a }}$ Seção, rel. Min. Cesar Asfor Rocha, j. 27.06.2012, DJe, de 06.08.2012. 
permite que o relator [...] admita a manifestação de pessoas, órgãos ou entidades, inclusive daqueles que figurarem como parte nos processos suspensos. $" 531$

O mesmo se passa quanto ao artigo 543-A, § $6^{\circ}$, que, conforme já exposto, também fala apenas na possibilidade de manifestação de terceiros, sem mencionar qualquer requisito para a intervenção.

Assim, considerando-se o sobrestamento dos recursos repetitivos e a posterior influência direta do precedente, as partes teriam interesse em intervir diretamente para defender uma das posições em jogo.

A doutrina também tem respondido afirmativamente à referida questão. Comentando o artigo 543-C do CPC, Luiz Rodrigues Wambier e Rita de Cássia Corrêa de Vasconcelos entendem que "uma vez que a lei não estabeleceu - e nem mesmo a Resolução - requisitos objetivos para a participação do terceiro, pensamos que poderão intervir todos aqueles que demonstrarem ser parte nos processos cujos recursos ficaram suspensos, pois poderão contribuir com subsídios para a solução da controvérsia". 532

No mesmo sentido, Teresa Arruda Alvim Wambier e José Miguel Garcia Medina afirmam que "podem aqueles que são parte no processo em que há recurso sobrestado ter outros argumentos que justifiquem o acolhimento ou rejeição da tese veiculada, argumentos estes não levados em consideração nos recursos escolhidos e nas respectivas contra-razões". 533

Por sua vez, Humberto Theodoro Junior, Dierle Nunes e Alexandre Bahia entendem que "todos aqueles que tiveram seus processos sobrestados aguardando que o tribunal decida se há ou não repercussão geral poderão intentar seu ingresso como amicus curiae e então expor suas razões acerca da existência (ou não) de repercussão geral, no caso". Isso, na opinião dos autores, superaria as críticas às restrições trazidas pelo sistema

\footnotetext{
531 Disponível em: 〈http://www.planalto.gov.br/ccivil_03/Projetos/EXPMOTIV/MJ/2007/40.htm〉. Acesso em: 17 set. 2013. Destaques nossos.

${ }^{532}$ WAMBIER, Luiz Rodrigues; VASCONCELOS, Rita de Cássia Corrêa de, Recursos especiais repetitivos: reflexos das novas regras (Lei 11.672/2008 e Resolução 8 do STJ) nos processos coletivos, cit., p. 46.

${ }^{533}$ WAMBIER, Teresa Arruda Alvim; MEDINA, José Miguel Garcia, Sobre o novo art. 543-C do CPC: sobrestamento de recursos especiais "com fundamento em idêntica questão de direito", cit., p. 219. Ver também: ASSIS, Araken de, Manual dos recursos, cit., p. 824
} 
de julgamento por amostragem, porque "os interessados teriam a possibilidade de trazer suas razões, suas interpretações acerca da 'repercussão constitucional' do caso, fornecendo melhores elementos para que os Ministros decidam". 534

Para Leonardo Greco, essa possibilidade de intervenção, a título de amicus curiae, dos que figuram como partes nos recursos repetitivos sobrestados, justifica-se pelas garantias constitucionais do contraditório e da ampla defesa, não havendo qualquer poder discricionário do relator. ${ }^{535}$

Já para Eduardo Talamini, para ser admitido como amicus curiae, não basta que o terceiro "apenas demonstre ser parte em outro processo em que há recurso sobre a mesma questão", pois "aqueles que comprovarem essa condição de parte em outros processos podem ser admitidos como colaboradores de Corte, desde que demonstrem que têm algum argumento útil, algum subsídio relevante para acrescentar à discussão já instaurada". 536

No entanto, o STJ tem entendido que não podem intervir como amicus curiae aqueles que não têm representatividade adequada e que têm interesse direto na questão ${ }^{537}$, o que exclui, em princípio, as partes dos recursos sobrestados.

534 THEODORO JÚNIOR, Humberto; NUNES, Dierle José Coelho; BAHIA, Alexandre Gustavo Melo Franco, Litigiosidade em massa e repercussão geral no recurso extraordinário, cit., p. 42. No mesmo sentido: "Fácil é admitir, então, a intervenção aqui proposta como imposição do contraditório. Posto de outro modo, negar a intervenção no julgamento por amostragem daqueles que tiveram seus recursos sobrestados e que possuem argumentos diferentes dos aduzidos no recurso extraordinário selecionado é o mesmo que proibi-los de influenciar na convicção do magistrado e, por conseguinte, na tomada da decisão, que tem como destinatários justamente eles que não puderam se manifestar. É incontestável que tal decisão careceria de legitimidade, porque proferida sem participação das partes diretamente atingidas." (SILVA, Ticiano Alves e. Intervenção de sobrestado no julgamento por amostragem. Revista de Processo, São Paulo, v. 35, n.182, p. 247, abr. 2010).

${ }^{535}$ GRECO, Leonardo, Instituições de processo civil, cit., v. 1, p. 532.

536 TALAMINI, Eduardo, Julgamento de recursos no STJ "por amostragem”, cit.

537 "Verifico que os pedidos de intervenção dos terceiros, na qualidade de amicus curiae, foram formulados por pessoas jurídicas contribuintes do empréstimo compulsório e que, por isso, além de não contarem com a necessária representatividade, têm interesse subjetivo no resultado do julgamento. [...] Indefiro, pois, o pedido de intervenção das pessoas identificadas nas petições n. 228760/2008 e 258472/2008, na qualidade de amicus curiae e determino o desentranhamento das referidas peças processuais." (STJ - REsp n. 1.003.955/RS, 1 a Seção, DJe, de 27.11.2009). "Indefiro o pedido de intervenção do advogado Márcio Adriano Caravina, na condição de amicus curiae, pois, diferentemente de representar alguma instituição cuja finalidade esteja diretamente ligada ao objeto discutido nestes autos, apenas possui interesse subjetivo no resultado do julgamento, o que é insuficiente para a habilitação no processo. Determino, outrossim, o desentranhamento dos documentos anexados pelo citado requerente." (STJ - Rcl n. 4982/SP, 1ª Seção, rel. Min. Benedito Gonçalves, DJe, de 04.05.2011). No entanto, o STJ tem admitido a intervenção de Estados, diretamente interessados em questões relativas à incidência de ICMS, mas que têm interesse institucional na questão, como amicus curiae em recurso especial no qual se discutia a incidência de tal tributo (STJ REsp n. 1.092.206/SP, $1^{\text {a }}$ Seção, DJe, de 23.03.2009). 
No mesmo sentido, o STF tem entendido que, em razão do requisito da representatividade adequada, não podem ingressar como amici curiae "pessoas físicas ou jurídicas interessadas apenas - ou fundamentalmente - no desfecho do seu processo, como aquelas que têm recursos sobrestados na origem, aguardando o desfecho de processos com repercussão geral reconhecida por esta Corte". 538

Parte da doutrina também argumenta que se todos pudessem intervir diretamente, haveria grande tumulto processual, retardando o procedimento e prejudicando o atingimento dos escopos do sistema. ${ }^{539}$

Ocorre que, como defendido pela maior parte da doutrina, deve-se sim admitir a manifestação direta daqueles que tiveram seus recursos sobrestados, de modo a contribuir com o debate, prestigiar o contraditório e a ampla defesa e, com isso, ampliar a legitimidade e representatividade do precedente.

Por outro lado, realmente a participação de toda e qualquer pessoa com mero interesse direto e pessoal na causa desvirtuaria a figura do amicus curiae, cuja atuação deve estar justificada pela representatividade adequada, isto é, pela comprovação da existência de interesse institucional na matéria sujeita a julgamento.

Ao mesmo tempo, milhares de intervenções diretas, inclusive com sustentações orais, nos autos dos recursos representativos da controvérsia, gerariam, na prática, um tumulto processual incompatível com os escopos do sistema.

Deve-se, assim, pensar em uma participação adequada, que equilibre os interesses em jogo. É o que poderia ocorrer se fosse admitida a instauração de um incidente, na forma descrita no item 9.2.4 infra.

\footnotetext{
${ }^{538}$ STF - ADI n. 4.304/PI, rel. Min. Rosa Weber, decisão monocrática proferida em 06.05.2013, DJe, de 20.05.2013. Ver, ainda: STF - RE n. 590.415, rel. Min. Joaquim Barbosa, decisão monocrática proferida em 29.09.2011, DJe, de 04.10.2012.

${ }^{539}$ Conforme Nelson Rodrigues Netto, aqueles que figuram como recorrentes nos casos sobrestados não poderão intervir no julgamento do recurso paradigma, sob pena de se desvirtuar a finalidade do sistema, que é dar maior celeridade e segurança por meio do julgamento "por atacado" (RODRIGUES NETTO, Nelson, Análise crítica do julgamento "por atacado" no STJ: (Lei 11.672/2008 sobre recursos especiais repetitivos), cit., p. 239-240).
} 


\subsubsection{Como ampliar adequadamente a participação das partes que sofrerão a influência do julgamento?}

Embora, como já dito, o procedimento dos artigos 543-B e 543-C do CPC aproximem o julgamento dos recursos extraordinários e especiais de um processo objetivo, não se pode ignorar que ele continua a tratar do julgamento de casos concretos e, mais do que isso, gera o sobrestamento de uma multiplicidade de recursos repetitivos para que, ao final, a decisão proferida no julgamento do recurso representativo da controvérsia possa influir na solução de seu caso.

Daí a necessidade de se admitir a maior participação desses terceiros na formação do precedente, sob pena de serem privados de contribuir para a construção da decisão que definirá o seu caso, violando-se a garantia do contraditório.

Assim, diante do argumento de que a admissão da participação direta de todos os interessados, pela simples circunstância de serem partes nos processos sobrestados, tumultuaria o procedimento, e não caracterizaria o exercício do contraditório social típico da atuação do amicus curiae, deve-se buscar uma solução que equilibre os valores em jogo.

Surge, assim, a ideia de se criar um incidente nos órgãos de origem que permita às partes que não tiveram seu recurso selecionado o oferecimento de argumentos que deverão ser levados em consideração na apreciação da questão. ${ }^{540}$

Esse incidente poderia funcionar da seguinte forma: instaurado o procedimento, além do sobrestamento dos casos repetitivos, o tribunal de origem intimaria as partes para, em determinado prazo, apresentarem uma síntese dos argumentos desenvolvidos em seus recursos.

Por questões práticas relacionadas à juntada dessas peças, o tribunal poderia instaurar um procedimento autônomo, indicando os números dos autos aos quais as partes

\footnotetext{
540 GARCIA, André Almeida, O drama dos "sobrestados" e a utilização de um incidente autônomo de julgamento por amostragem, cit.
} 
deveriam direcionar o arrazoado. Todas as peças seriam juntadas nesses autos, que seriam digitalizados e disponibilizados a todos, na forma de processo eletrônico.

Feito isso, o tribunal faria uma triagem dos fundamentos apresentados pelas partes, na forma de um relatório sintético, e o publicaria para o apontamento de eventuais omissões ou incorreções por todos os interessados. Com a juntada das novas peças, o tribunal complementaria ou corrigiria o relatório, enviando todo esse material ao STF ou ao STJ, para instrução do julgamento do caso representativo da controvérsia.

O precedente que julgasse o recurso-piloto, baseando-se nos relatórios produzidos pelos tribunais de origem e, se o caso, nas próprias peças apresentadas pelas partes, teria necessariamente que relatar e enfrentar cada um dos argumentos apresentados pelas partes. Com isso, a participação de todos os interessados seria muito mais ampla, sem grande prejuízo para a funcionalidade do sistema de julgamento de recursos repetitivos.

Embora seja certo que isso tornaria o procedimento mais demorado e complexo, as características do julgamento por amostragem seriam mantidas. E, tratando-se de decisão com alta eficácia extraprocessual, é natural que o procedimento seja um pouco mais longo.

O importante é que, no fim, o precedente seria muito mais legítimo, democrático e qualificado. A ampliação da participação absorveria o inconformismo das partes que têm seu recurso sobrestado, aumentando a aceitação da decisão e, consequentemente, diminuindo a sua recorribilidade. Até a hipótese de aplicação de multa por recurso protelatório seria mais legítima e fácil de ser identificada, eis que não teria o menor cabimento a mera repetição do questionamento já apresentado no recurso e nos memoriais, sobretudo se consta no acórdão que julga o recurso-piloto a menção a ele.

\subsection{Competência do órgão mais complexo e quorum qualificado}

Considerando-se que o precedente que será formado pelo julgamento dos recursos representativos da controvérsia representará, por si só, precedente dotado dos mesmos efeitos da jurisprudência dominante do STF ou do STJ sobre a questão, justificando a retratação de decisões contrárias e a negativa de seguimento dos recursos sobrestados na origem, bem como sinalizando a toda a sociedade a interpretação definitiva do direito 
federal a respeito do tema, é conveniente que esse julgamento seja realizado pelo órgão fracionário mais complexo do STF e do STJ, e também por quorum qualificado.

De fato, embora a divisão interna do STF e do STJ em órgãos fracionários seja importante e conveniente por uma série de razões ${ }^{541}$, é importante que o julgamento do recurso-piloto ocorra pelo Pleno do STF e pela Corte Especial ou pela competente Seção especializada do STJ, a fim de que o entendimento dele resultante realmente represente a orientação majoritária da instância superior sobre o tema.

Tratando-se de apelação ou agravo, a regra que faculta esse deslocamento da competência para o órgão fracionário mais complexo do tribunal é prevista pelo artigo 555 do CPC (assunção de competência), nada obstando que seja aplicada por analogia aos demais recursos.

No âmbito do STJ, o artigo $2^{\circ}$ da Resolução n. 8 dispõe, especificamente quanto à apreciação do recurso especial representativo da controvérsia, que "o Relator submeterá o seu julgamento à Seção ou à Corte Especial, desde que, nesta última hipótese, exista questão de competência de mais de uma Seção".

Conforme Luiz Guilherme Aidar Bondioli, isso significa que "sempre o órgão com máxima competência no Superior Tribunal de Justiça para o exame do tema repetido nos recursos é que será o responsável pelo julgamento", com o que se "confere maior autoridade, legitimidade e representatividade para um julgamento programado para orientar outros atos decisórios". 542

Nas palavras de Athos Gusmão Carneiro, essa alteração da competência justifica-se porque "se trata de 'recurso-piloto', e considerada a finalidade de unificação da jurisprudência no STJ e de orientação aos tribunais de segundo grau". ${ }^{543}$

\footnotetext{
541 BENETI, Sidnei Agostinho. Assunção de competência e fast track recursal. Revista de Processo, São Paulo, v. 34, n. 171, p. 9-23, maio 2009.

${ }^{542}$ BONDIOLI, Luiz Guilherme Aidar, A nova técnica de julgamento dos recursos extraordinário e especial repetitivos, cit., p. 19.

${ }^{543}$ CARNEIRO, Athos Gusmão, Recurso especial, agravos e agravo interno, cit., p. 110.
} 
No âmbito do STF não existe norma no mesmo sentido. Mas o artigo 11 do RISTF prevê a submissão do feito pela Turma ao Plenário, quando: tratar-se de matéria relevante ainda não submetida ao Plenário; houver proposta de reexame da matéria já decidida pelo Plenário; ou houver proposta de revisão da jurisprudência compendiada em súmula. Assim, embora em tese seja possível o julgamento do recurso-piloto por uma das duas Turmas dos STF, trata-se de prática que não deve ser adotada, pelo risco de se ameaçar a "autoridade, legitimidade e representatividade que se espera de um julgamento pensado para nortear decisões acerca da mesma controvérsia". 544

Quanto ao quorum qualificado, não há na lei nem nas normas regimentais qualquer previsão nesse sentido, o que é preocupante. De nada adiante o julgamento pelo órgão mais complexo se, pela não exigência do quorum qualificado, o resultado não espelhar o entendimento efetivamente majoritário deste mesmo órgão. Isso pode levar à formação de um precedente definitivo sobre determinado tema, com grande influência sobre inúmeros casos, sem que o entendimento realmente esteja consolidado no tribunal.

Nesse sentido, José Ignácio Botelho de Mesquita e outros afirmam que “o art. 479 do CPC exigia que o julgamento fosse tomado pelo voto da maioria absoluta dos membros do tribunal, exigência que não é repetida pelo art. 543-C do CPC". Concluem, assim, que disso pode resultar na qualificação do precedente a partir do "voto da maioria simples da Seção ou do Órgão Especial, como já acontece quanto aos embargos de divergência, o que é pouco razoável". 545

É por isso que o sistema exige quorum de dois terços para que o STF delibere sobre rejeição de repercussão geral, concessão de modulação de efeitos de decisões proferidas em sede de controle abstrato de constitucionalidade e sobre aprovação das súmulas vinculantes, ou seja, justamente em face da importância e projeção dessas decisões. Pelas mesmas razões, esse deve ser o quorum para o julgamento dos recursos extraordinários e especiais repetitivos.

\footnotetext{
${ }^{544}$ BONDIOLI, Luiz Guilherme Aidar, op. cit., p. 19.

545 MESQUITA, José Ignácio Botelho de et al., A repercussão geral e os recursos repetitivos: economia, direito e política, cit., p. 24.
} 
Embora não haja qualquer norma nesse sentido, recentemente o STJ decidiu conter o julgamento de recursos submetidos à sistemática do artigo 543-C do CPC, a fim de evitar a formação de precedente por meio de votação apertada sobre a questão do direito à reincorporação da gratificação de horas extras, sem a presença do mínimo de dois terços dos integrantes da Primeira Seção. A votação estava em 5 a 4, com o que o entendimento da jurisprudência dominante até então seria alterado. ${ }^{546}$

Assim, o ministro Napoleão Maia interrompeu o julgamento, para questionar a modificação da jurisprudência por meio da técnica de recursos repetitivos, fazendo com o que o ministro Castro Meira, que presidia a sessão, suscitasse a questão de saber se, em razão da alteração jurisprudencial e também da maioria apertada, era o caso de se afastar a prerrogativa dos recursos repetitivos e se valer somente do precedente simples. O ministro Napoleão Maia chegou a propor o quorum de dois terços como exigência para que o precedente tivesse os efeitos previstos no artigo 543-C do CPC, de modo que, não sendo ele atingido, o precedente seria simples.

Após alguma discussão, a Primeira Seção decidiu, por unanimidade, acolher a proposta do ministro Castro Meira, de modo que o caso não foi julgado nos termos do artigo 543-C do CPC, e sim pelo procedimento normal, formando precedente simples.

546 Conforme notícia publicada em 11.09.2013 no Valor Econômico (Disponível em: <http://professormedina.com/2013/09/15/stj-comecaa-a-conter-julgamento-de-recursos-repetitivos>. Acesso em: 15 set. 2013). 


\section{EFEITOS DO JULGAMENTO DOS RECURSOS REPRESENTATIVOS DA CONTROVÉRSIA}

\subsection{Momento de eficácia do acórdão que julga os recursos representativos da controvérsia}

Questiona-se em que momento o acórdão do STF ou STJ (que julga os recursos selecionados) passa a produzir efeitos em relação aos recursos repetitivos sobrestados: a partir do julgamento, da publicação ou do seu trânsito em julgado?

$\mathrm{O}$ artigo 543-B do CPC e as normas regimentais que regulamentam o julgamento de recursos extraordinários repetitivos nada dispõem a esse respeito.

Por sua vez, o artigo 543-C, $\S 7^{\circ}$, do CPC prevê expressamente que a negativa de seguimento dos recursos contrários e o juízo de retratação provocado pelos recursos favoráveis ao entendimento firmado pela instância superior ocorrerá depois que "publicado o acórdão do Superior Tribunal de Justiça". Mas o $\S 1^{\circ}$ do referido artigo também fala que os recursos repetitivos ficarão suspensos "até o pronunciamento definitivo do Superior Tribunal de Justiça", transmitindo-se a ideia de que a aplicação do acórdão aos casos sobrestados só se dará após o seu trânsito em julgado.

Antes mesmo da positivação da técnica de julgamento de recursos repetitivos, já vinha prevalecendo no $\mathrm{STF}^{547}$ e no $\mathrm{STJ}^{548}$ o entendimento de que não é necessária a publicação do acórdão relativo ao precedente que se invoca em posterior julgamento de caso sucessivo.

\footnotetext{
547 “A circunstância de não haver sido publicado o precedente referido na decisão agravada não impede que o relator negue seguimento ao recurso extraordinário, com maior razão se constar a síntese dos respectivos fundamentos, permitindo-se o exercício de defesa à parte agravante." (STF - AgR AI n. 329.967/DF, 2a Turma, rel. Min. Maurício Corrêa, v.u., DJU, de 31.10.2001).

${ }^{548}$ STJ - AgR REsp n. 522.342MG, $3^{\text {a }}$ Turma, rel. Min. Antônio de Pádua Ribeiro, v.u., DJU, de 17.12.2004; AgR AG n. 947.181/RS, 4 ${ }^{\text {a }}$ Turma, Rel. Min. Aldir Passarinho Junior, v.u., DJU, de 07.04.2008; AgR REsp. n. 505.696MG, 4a Turma, rel. Min.Barros Monteiro, v.u., DJU, de 06.09.2004; AgR ED AG n. 964.292RS, $4^{\text {a }}$ Turma, rel. Min. Massami Uyeda, v.u., DJU, de 10.06.2008; AgR REsp n. 853.887/RS, $3^{\text {a }}$ Turma, rel. Min. CarlosAlberto Menezes Direito, DJ, de 30.4.2007.
} 
Especificamente sobre o precedente qualificado, formado nos termos do artigo 543C do CPC, o STJ reafirmou a orientação de que "nada impede que o entendimento adotado no julgamento do recurso especial representativo de controvérsia, ou de qualquer outro recurso especial, seja adotado como razão de decidir de outros recursos, mesmo antes da publicação de seu acórdão". 549

Esse, porém, não é o melhor entendimento, pois é imprescindível que, antes de se aplicar o entendimento fixado pela instância superior, as partes e os próprios órgãos judiciais tenham acesso ao inteiro teor do respectivo acórdão, o que só costuma ocorrer no momento da publicação.

Sem o inteiro teor, os demais órgãos judiciais e as próprias partes não poderão compreender exatamente qual entendimento foi fixado a respeito da questão, o que, obviamente, é crucial para o julgamento do caso de forma semelhante à que ocorreu no precedente.

Se a ideia da ampliação da eficácia extraprocessual dos precedentes dos Tribunais Superiores está relacionada à influência da ratio decidendi sobre a solução das mesmas questões nos casos repetitivos, é claro que se deve, antes de tudo, conhecer a fundamentação completa do precedente.

Buscando transmitir esse conhecimento aos tribunais de origem, a própria Resolução n. 8 do STJ dispõe em seu artigo $6^{\circ}$ que "a coordenadoria do órgão julgador expedirá ofício aos tribunais de origem com cópia do acórdão relativo ao recurso especial julgado na forma desta Resolução".

Além disso, é fato que, contra o acórdão que julga o recurso especial representativo da controvérsia, cabem embargos de declaração, eventuais embargos de divergência e até recurso extraordinário ao STF. Por sua vez, tratando-se de recurso extraordinário representativo da controvérsia, cabem embargos de declaração e eventuais de divergência.

${ }^{549}$ STJ -, AgR AI n. 1.146.958, rel. Min. Teori Albino Zavascky, j. 01.03.2011. 
A interposição de recursos pode, embora seja pouco provável, gerar a modificação substancial do acórdão paradigma, de modo que a aplicação prematura do entendimento a inúmeros outros casos repetitivos seria desastrosa, gerando tumulto e extrema insegurança jurídica. ${ }^{550}$

Por isso, mesmo em se tratando de precedente simples, exige-se que, para sua aplicação a outros casos, o entendimento por ele externado seja realmente definitivo, o que pressupõe a ausência de recursos que, em tese, possam gerar a sua modificação. Tratandose de precedente qualificado, eis que formado a partir da aplicação das regras dos artigos 543-B e 543-C do CPC, a importância da definitividade do entendimento é ainda maior, em face da amplitude da sua eficácia extraprocessual, em relação aos casos repetitivos sobrestados.

Assim, se os recursos disserem respeito a alguma circunstância limitada ao caso individual, não interferindo, nem em tese, no entendimento firmado a respeito da questão constitucional ou infraconstitucional, então o precedente poderá ser aplicado.

O problema dessa interpretação é que, na prática, pode demorar bastante tempo para a liberação da eficácia do precedente, prejudicando as partes cujos recursos estão sobrestados. Mas justamente por isso é tão importante a fixação de prazo para o julgamento dos recursos selecionados e para o sobrestamento dos recursos repetitivos (conforme Capítulo 8, item 8.2).

Assim, a eficácia do acórdão do STF ou do STJ está condicionada não só à disponibilização do inteiro teor do acórdão, como também à definitividade do entendimento a respeito da questão constitucional ou infraconstitucional, o que poderá ser verificado pela constatação da ausência de pendência de recurso com potencial para modificação, em tese, do referido entendimento.

\footnotetext{
550 “Na verdade, a simples publicação (intimação) do acórdão do STJ ainda não afeta os recursos especiais sobrestados (ou suspensos) nos tribunais de origem, pois as medidas impostas pelo art. 543-C, § $7^{\circ}$, do CPC dependem do trânsito em julgado do acórdão, pois enquanto couber recurso interno (embargos de declaração, embargos de divergência) ou externo (recurso extraordinário), o acórdão (que o art. 543-C, § 1º, do CPC chama de 'pronunciamento') não será ainda definitivo." (ALVIM, José Eduardo Carreira, Recursos especiais repetitivos: mais uma tentativa de desobstruir os tribunais, cit., p. 179-180).
} 


\subsection{Efeitos do julgamento dos recursos extraordinários representativos da controvérsia, quando o STF nega a existência de repercussão geral}

Julgados os recursos extraordinários representativos da controvérsia pelo STF, no sentido da ausência de repercussão geral da questão constitucional, "os recursos sobrestados considerar-se-ão automaticamente não admitidos” (art. 543-B, § $2^{\circ}$, do CPC).

Ou seja, o julgamento, nesse caso, produz o efeito de gerar a inadmissibilidade automática dos recursos extraordinários repetitivos e respectivos agravos de admissão sobrestados na origem, o que corresponde, na prática, a uma espécie de efeito vinculante do acórdão que afirma que determinada matéria não apresenta repercussão geral (ver Capítulo 6, itens 6.4 e 6.5).

Como esses recursos repetitivos sobrestados estarão fisicamente nos órgãos de origem, caberá a estes a declaração da incidência, ao caso concreto, do precedente que negou a repercussão geral, sem a necessidade de apreciação dos demais requisitos de admissibilidade dos recursos repetitivos sobrestados (art. 328-A do RISTF), posto que se a questão constitucional não apresenta repercussão geral, fica prejudicado (em razão da sua inutilidade) o exame dos demais pressupostos. Sem prejuízo, é claro que o eventual reconhecimento e declaração da ausência de outros requisitos (preparo, prequestionamento, pretensão do reexame de provas etc.) amplia a força da decisão, desestimulando ainda mais a interposição de eventuais insurgências.

Ademais, embora a lei preveja a eficácia vinculante de decisão que reconhece a ausência de repercussão geral, entendemos, pelas razões já expostas no Capítulo 6 (itens 6.4 e 6.5), que o órgão a quo pode e deve excepcionalmente admitir o recurso extraordinário por decisão fundamentada e enviá-lo ao STF para a realização de eventual distinguishing ou overruling em relação ao precedente que afastou a repercussão geral. Caso contrário, o STF dificilmente teria a oportunidade de revisar a tese.

Tratando-se de agravo de admissão, o órgão a quo deve simplesmente determinar o seu processamento, enviando os autos à instância superior. 
Pelas mesmas razões, e a despeito do entendimento contrário da jurisprudência do STF, entendemos que, contra a decisão do órgão de origem que reconhece a incidência do precedente do STF ao recurso extraordinário repetitivo sobrestado, deve caber agravo de admissão, a fim de que a parte possa provocar e realização de eventual distinguishing ou overruling. E, tratando-se de agravo de admissão sobrestado, a parte deve ter a oportunidade de manifestar-se no sentido da remessa dos autos à instância superior.

Os efeitos previstos no artigo 543-B, $\S 2^{\circ}$, do CPC só poderão incidir em relação aos recursos sobrestados para fins de reconhecimento de ausência da repercussão geral. Isso significa que não serão automaticamente inadmitidos os recursos repetitivos sobrestados se o recurso-piloto for inadmitido por outro fundamento, que não a ausência de repercussão geral. ${ }^{551}$

Entretanto, o RISTF prevê, em seu artigo 324, § $2^{\circ}$, que a inadmissibilidade do recurso extraordinário sob o fundamento de que a matéria é infraconstitucional "será considerada como manifestação de inexistência de repercussão geral”. Ou seja, o Regimento Interno criou novo caso de presunção de ausência de repercussão geral, o que, nos termos do artigo 102, $\S 3^{\circ}$, da $\mathrm{CF}$, deveria ser feito pela própria lei (art. 543-A do $\mathrm{CPC})$.

Assim, entendemos que os recursos repetitivos sobrestados não serão automaticamente inadmitidos nessa hipótese, embora possam, como sempre puderam, ser inadmitidos na origem por ausência de questão constitucional. A diferença é que, aqui, deve-se aplicar o regime normal, e não o do artigo 543-B.

Em relação aos casos que ainda não estão em fase da interposição de recurso extraordinário, embora em tese o seu sobrestamento seja possível, o reconhecimento da ausência de repercussão geral não gerará praticamente efeito algum, exceto o de sinalizar que o caso provavelmente não chegará ao STF no futuro, em face da ausência de

\footnotetext{
551 “Obviamente, se o motivo da inadmissão for circunstancial, específico do recurso-amostra (p. ex., intempestividade, deserção, falta de prequestionamento etc.), a negativa de conhecimento não gerará nenhum reflexo sobre o destino dos recursos sobrestados. Caberá apenas ao STF solicitar a seleção e encaminhamento de outro recurso representativo (se já não existirem no Tribunal outros recursosamostra)." (TALAMINI, Eduardo, Novos aspectos da jurisdição constitucional brasileira: repercussão geral, força vinculante, modulação dos efeitos do controle de constitucionalidade e alargamento do objeto do controle direto, cit., p. 79).
} 
transcendência da questão constitucional objeto de discussão no processo. Daí porque, como expusemos no Capítulo 8 (item 8.6), a ampliação da eficácia do sobrestamento aos demais casos, tratando-se de recursos extraordinários repetitivos, só se justifica após o reconhecimento da repercussão geral.

Por fim, quanto aos recursos extraordinários interpostos após o encerramento do procedimento do artigo 543-B do CPC, isto é, após ser proferido o acórdão que reconhece a ausência de repercussão geral da matéria constitucional, os efeitos são os mesmos, até por força do artigo 543-A, § 5º do CPC. Assim, o órgão de origem deverá negar seguimento a esses recursos, com base na ausência de repercussão geral já reconhecida pelo STF. Mas, também nesse caso, existe a possibilidade de processamento excepcional do recurso para eventual distinguishing ou overruling, e justifica-se, com razão ainda maior, a possibilidade de interposição de agravo de admissão (conforme Capítulo 6, item 6.5), porque as partes desses recursos não puderam, de forma alguma, participar do julgamento dos recursos representativos da controvérsia.

\subsection{Efeitos do julgamento de mérito dos recursos representativos da controvérsia, em relação aos recursos repetitivos sobrestados}

Julgado o mérito dos recursos extraordinários (com repercussão geral) ou especiais representativos da controvérsia, duas hipóteses podem ocorrer em relação aos recursos repetitivos sobrestados: (a) têm por objeto decisões que convergem com a tese fixada pela instância superior no acórdão paradigma; ou (b) têm por objeto decisões que divergem da tese fixada pela instância superior no acórdão paradigma.

\subsubsection{Recursos repetitivos interpostos contra decisões que convergem com a tese fixada pela instância superior}

Se as decisões dos órgãos inferiores, contra as quais os recursos repetitivos sobrestados foram interpostos, adotaram o mesmo entendimento que veio a ser fixado pela instância superior na apreciação dos recursos representativos da controvérsia, isso significa que tais recursos repetitivos defendem tese contrária a essa mesma tese. 
Nesse caso, o sistema prevê que os recursos repetitivos ficarão "prejudicados" (art. 543-B, $\S 3^{\circ}$ ) ou terão "seguimento denegado" (art. 543-C, § $7^{\circ}$, I). Isso, conforme exposto no Capítulo 6 (item 6.3), só pode representar o reconhecimento, pelo órgão ou tribunal de origem, da inadmissibilidade dos recursos repetitivos diante da sua manifesta contrariedade à jurisprudência dominante do STF ou STJ, considerada pela lei como autorizadora da presunção de ausência de violação ao direito federal.

Esse efeito previsto na lei demonstra que a técnica de julgamento de recursos repetitivos atua para a construção de um precedente qualificado, o qual, por si só, produz os mesmos efeitos gerados pela jurisprudência dominante do STF ou do STJ sobre o tema decidido, sem necessidade de reiteração de julgados e de sumulação da matéria. Conforme José Ignácio Botelho de Mesquita e outros, "o efeito do julgamento do recurso especial repetitivo consiste em conferir à tese vitoriosa o status oficial de jurisprudência dominante, à feição do precedente nos sistemas que adotam o princípio do stare decisis". 552

No mesmo sentido, André Almeida Garcia observa que a técnica do julgamento por amostragem e suas consequências processuais - o sobrestamento dos recursos repetitivos, essa possibilidade de denegação dos recursos contrários à tese consolidada e a imposição do reexame pelo órgão julgador da decisão que se mostrar divergente em relação a essa tese - "prestigiam sobremaneira a figura do precedente, que tem assumido papel de maior destaque no sistema processual brasileiro, especialmente no que diz respeito às decisões do Supremo Tribunal Federal e do Superior Tribunal de Justiça". 553

Daí a importância da representatividade dos casos selecionados (conforme Capítulo 7, item 7.3) e da adequada interpretação e observância das regras sobre a preparação para o julgamento (participação de terceiros, competência, quorum - conforme Capítulo 9).

\footnotetext{
552 Os autores também observam o seguinte: "Está claro que se está diante de um precedente ao qual se pretendeu atribuir a força necessária para servir como ratio decidendi para o juiz subsequente." (MESQUITA, José Ignácio Botelho de et al., A repercussão geral e os recursos repetitivos: economia, direito e política, cit., p. 29).

553 GARCIA, André Almeida, O drama dos "sobrestados" e a utilização de um incidente autônomo de julgamento por amostragem, cit.
} 
E esse, talvez, seja o maior mérito da técnica de julgamento de recursos repetitivos, eis que, com a formação desse precedente qualificado, as funções do STF e do STJ são eficientemente potencializadas, prestigiando-se os princípios da igualdade, da segurança jurídica e da razoável duração do processo.

Sobre a competência do órgão a quo para o pronunciamento dessa inadmissibilidade, deve-se observar a regra do artigo 541, caput, do CPC, que se refere ao "presidente ou o vice-presidente do tribunal recorrido", bem como as regras do regimento interno de cada tribunal.

Questiona-se se, além da contrariedade à tese fixada pela instância superior, o recurso excepcional for inadmissível por outro motivo, caberá ao tribunal de origem evidenciar a ausência do requisito, tal como a tempestividade, o preparo, a regularidade formal etc.? Em princípio, a lei parece apontar para a desnecessidade de pronunciamento sobre a inadmissibilidade por outros $\operatorname{motivos}^{554}$, mas, sendo isso feito, fica ainda mais desestimulada a interposição de recursos contra a decisão denegatória de seguimento.

Como o precedente qualificado não tem aquela força que a Proposta de Emenda Constitucional 358/2005 pretende atribuir à súmula impeditiva de recurso ${ }^{555}$, não se pode dizer que o órgão ou tribunal de origem necessariamente terá de negar seguimento ao recurso repetitivo contrário ao entendimento firmado no julgamento dos recursos representativos da controvérsia. Assim, vislumbrando-se, por exemplo, a presença dos elementos necessários para a realização de eventual distinguishing ou overruling, o recurso poderá e deverá ser processado. Sendo admitido, os autos deverão ser enviados à instância superior.

Note-se que, quanto aos recursos excepcionais eventualmente admitidos na origem, e em seguida suspensos em razão da instauração do procedimento, o tribunal local terá de reapreciar a sua admissibilidade, podendo agora negar-lhes seguimento, com base nos artigos 543-B e 543-C do CPC. Ou seja, em princípio, os recursos eram admissíveis, mas,

${ }^{554}$ CARNEIRO, Athos Gusmão, Recurso especial, agravos e agravo interno, cit., p. 110.

${ }^{555} \mathrm{Na}$ referida PEC, simplesmente não se admite recurso contrário à súmula. Pretende-se, por meio dela, incluir o art. 105-A à Constituição Federal, cujo $\S 3^{\circ}$ prevê o seguinte: " $\S 3^{\circ}$ - São insuscetíveis de recurso e de quaisquer meios de impugnação e incidentes as decisões judiciais, em qualquer instância, que deem a tratado ou lei federal a interpretação determinada pela súmula impeditiva de recurso.” 
com a formação do precedente qualificado em sentido contrário, o tribunal de origem poderá negar-lhes seguimento.

Por sua vez, quanto aos recursos já enviados à instância superior antes da instauração do procedimento, não há dúvida da possibilidade de serem julgados monocraticamente (arts. 544 e 557 do CPC e Lei n. 8.038/90) ${ }^{556}$. Se o precedente qualificado produz, por si só, os mesmos efeitos gerados pela jurisprudência dominante da Corte a respeito do tema, não há, quanto a esse ponto, praticamente qualquer novidade em relação ao que já ocorria antes da sistemática dos artigos 543-B e 543-C do CPC: possibilidade de julgamento monocrático, inclusive do mérito dos recursos excepcionais, com base na jurisprudência dominante ou sumulada da própria corte.

Acrescente-se apenas que, nesse caso, como a decisão é emanada do STF ou do STJ, e não do tribunal de origem, o julgamento, mesmo sendo monocrático, é de mérito, e portanto substitui a decisão recorrida.

\subsubsection{Recursos repetitivos interpostos contra decisões que divergem da tese fixada pela instância superior}

\subsubsection{Juízo positivo de retratação}

Se os recursos repetitivos sobrestados foram interpostos contra decisões que divergem da tese que veio a ser firmada pelo STF ou pelo STJ, isso significa que referidos recursos defendem entendimento contrário a essa mesma tese. Em tal caso, tanto o artigo 543-B como o artigo 543-C do CPC preveem a realização de juízo de retratação pelo tribunal de origem, para que o acórdão recorrido divergente possa ser ajustado ao entendimento definitivo sobre a questão de direito federal.

\footnotetext{
$556 \mathrm{Na}$ prática, esse julgamento monocrático, no âmbito do STF, não deve teoricamente ocorrer com frequência, pois, como visto no Capítulo 8, a regra é a de que, instaurado o procedimento, todos os recursos repetitivos sejam devolvidos à instância de origem, a fim de que ali permaneçam sobrestados, aguardando a formação do precedente. Quanto ao STJ, até há pouco tempo atrás, os recursos especiais já enviados ao STJ não só não eram devolvidos, como podiam ser desde logo julgados. Nesse sentido, a Resolução n. 8 do STJ prevê em seu artigo $5^{\circ}$, incisos I e II, que os recursos já distribuídos são julgados pelo relator nos termos do artigo 557 do CPC, enquanto que os recursos ainda não distribuídos serão julgados pela Presidência, nos termos da Resolução n. 3/2008. Porém, com a recente Resolução n. 17/2013 do STJ, os recursos especiais e agravos de admissão repetitivos passam, na linha do que já ocorre no STF, a ser devolvidos à instância de origem, até a formação do precedente.
} 
$\mathrm{O} \S 3^{\circ}$ do artigo 543-B menciona a possibilidade de o tribunal de origem "retratarse", enquanto o artigo 543-C, $\S 7^{\circ}$, afirma que "os recursos especiais sobrestados na origem [...] II - serão novamente examinados pelo tribunal de origem". Quanto a esse último, como já exposto anteriormente, verifica-se um erro de redação: serão novamente examinados pelo tribunal de origem não "os recursos especiais sobrestados", mas sim os acórdãos impugnados pelos recursos especiais repetitivos sobrestados. ${ }^{557}$

Como exposto nos Capítulos 5 (item 5.4) e 6 (item 6.3), o sentido da lei não é autorizar que o próprio tribunal de origem aprecie e julgue o mérito dos recursos extraordinários ou especiais repetitivos sobrestados, nem emprestar à decisão do STF ou do STJ sobre o recurso representativo da controvérsia uma espécie de eficácia coletiva, de modo a fazer com que ela represente por si só o julgamento automático desses recursos repetitivos ou a própria cassação dos acórdãos contrários.

Tanto é assim que o próprio sistema exige que os acórdãos recorridos, eventualmente divergentes da tese vencedora na instância superior, sejam reapreciados pelo órgão julgador. Se o acórdão paradigma julgasse o próprio recurso repetitivo sobrestado, o tribunal de origem teria de considerá-lo provido, bem como anulada ou reformada, pela própria instância superior, a decisão ou o acórdão contra o qual ele foi interposto.

Observe-se que, aparentemente, o julgamento do recurso-piloto gera, pelo menos, a cassação automática (ou coletiva) das decisões contrárias impugnadas por recursos repetitivos sobrestados. Mas nem essa cassação efetivamente ocorre, porque, se assim fosse, não teria cabimento a possibilidade de manutenção da decisão recorrida, em juízo negativo de retratação.

\footnotetext{
557 "Nota-se, no art. 543-C, $\S 7^{\circ}$, um equívoco de ordem técnica: o texto menciona que os recursos especiais sobrestados na origem (...) II - serão novamente examinados pelo tribunal de origem na hipótese de o acórdão recorrido divergir da orientação do Superior Tribunal de Justiça. Ora, os próprios 'recursos especiais' não podem, por evidentes motivos, ser 'novamente examinados' pelo tribunal de origem (que os não examinou...) e que, aliás, para tanto seria constitucionalmente incompetente." (CARNEIRO, Athos Gusmão, Recurso especial, agravos e agravo interno, cit., p. 111).
} 
Assim, o que a lei prevê é uma espécie de efeito regressivo ulterior do recurso excepcional repetitivo sobrestado ${ }^{558}$, efeito esse que surge apenas na hipótese de divergência entre a decisão ou o acórdão recorrido e o acórdão do STF ou do STJ que julga os recursos representativos da controvérsia (daí ser adjetivado de ulterior).

Trata-se, pois, como vem sendo amplamente reconhecido pela doutrina, de impor ao órgão prolator da decisão divergente o exercício do juízo de retratação, em virtude da interposição de recurso endereçado a outro órgão. ${ }^{559}$

Em trabalho específico sobre o pedido de reconsideração e o juízo de retratação, Fabiano Carvalho ressalta que, apesar de as duas figuras levarem a resultados semelhantes, há distinções técnicas entre elas ${ }^{560}$. O juízo de retratação, que ocorre na hipótese ora analisada, já há muito tempo é previsto pelo CPC para os casos de interposição de recursos de agravo de instrumento e retido (art. 522, $\S 2^{\circ}$ ), de agravo interno (art. 557, $\S 1^{\circ}$ ) e de apelação, este último apenas quando interposto contra sentença de improcedência prima facie (art. 285-A, $\S 1^{\circ}$ ) e de indeferimento da petição inicial (art. 296).

O juízo de retratação pode ser positivo ou negativo. Sendo reconsiderada a decisão, para ajustá-la ao sentido pretendido pelo recurso, o juízo é positivo. Observe-se que, nesse

\footnotetext{
558 “A retratação aqui prevista, para se ajustar ao sistema processual civil, precisa ser interpretada como sendo o efeito regressivo, ínsito aos agravos em geral." (BUENO, Cassio Scarpinella, Curso sistematizado de direito processual civil, cit., v. 5, p. 300).

559 “O mandamento legal é, em verdade, no sentido de que o tribunal prolator do acórdão divergente da orientação do STJ proceda a um 'juízo de retratação', novamente examinando o recurso ordinário e podendo, visto que livre a vontade do juiz, operar ou não a reconsideração do julgado." (CARNEIRO, Athos Gusmão, Recurso especial, agravos e agravo interno, cit., p. 111). "Por meio da retratação, fica autorizada uma reviravolta no resultado do processo, a fim de que ele seja adaptado ao entendimento dos tribunais de superposição. Há assim um novo pronunciamento acerca do meritum causae, que cassa e substitui o acórdão recorrido e passa a regular a situação da vida trazida ao Poder Judiciário." (BONDIOLI, Luiz Guilherme Aidar, A nova técnica de julgamento dos recursos extraordinário e especial repetitivos, cit., p. 27). "A norma comentada permite ao tribunal a quo, em nome da economia e celeridade processual (CF $5^{\circ}$ LXXVIII), pelo órgão que proferiu a decisão impugnada por RE, retratar-se e modificar o acórdão recorrido, quando o STF tiver conhecido e provido o RE representativo da tese jurídica por ele acolhida." (NERY JUNIOR, Nelson; NERY, Rosa Maria Andrade, Código de Processo Civil comentado e legislação extravagante, cit., p. 983). "A diretriz do art. 543-C, § 7º, II, institui a possibilidade de retratação do acórdão do tribunal a quo." (ASSIS, Araken de, Manual dos recursos, cit., p. 826). "Institui-se assim mais uma nova hipótese de juízo de retratação (presente em geral nos recursos de agravo - CPC, art. 523, $\S 2^{\circ}-$ e excepcionalmente nas apelações - CPC, art. 285-A, § $1^{\circ}$, e art. 296), e que já havia também sido prevista pela Lei 11.418/2006 para os recursos extraordinários." (TALAMINI, Eduardo, Julgamento de recursos no STJ "por amostragem", cit.).

${ }^{560}$ CARVALHO, Fabiano. Pedido de reconsideração e juízo de retratação. Revista de Processo, São Paulo, v. 37, n. 212, p. 421, out. 2012.
} 
caso, o recurso que o ensejou perde o objeto, ficando prejudicado, sendo esse um efeito específico do juízo de retratação, não observado quando se trata de mero pedido de reconsideração. Por outro lado, mantida a decisão recorrida, diz-se que ocorreu o juízo negativo de retratação.

Como se vê, trata-se de uma nítida exceção à regra do artigo 463 do $\mathrm{CPC}^{561}$, que veda a alteração da decisão pelo órgão que a prolatou, após a sua publicação em cartório, para autorizar ao órgão recorrido, em nome da economia e da eficiência processual, o reexame da matéria, à luz do recurso endereçado a órgão diverso, recurso esse que, no caso da técnica de julgamento de recursos repetitivos, veiculará razões coincidentes com os fundamentos do acórdão paradigma do STF ou do STJ.

Assim, o sistema prevê que, pendente o recurso extraordinário ou especial repetitivo, e formado o precedente qualificado divergente do acórdão recorrido, o órgão prolator desse acórdão deverá rever sua decisão em juízo de retratação ${ }^{562}$, devendo, em princípio, ajustá-la ao entendimento defendido pelo recorrente em seu recurso excepcional e firmado pelo STF ou pelo STJ. Ou seja, a ideia é que o acórdão recorrido seja reexaminado, a fim de que a interpretação sobre o direito federal seja ajustada à interpretação definitiva fixada pelo STF ou pelo STJ.

Note-se que o juízo de retratação não ficará condicionado ao exame de admissibilidade do recurso extraordinário ou especial que estava sobrestado. Como demonstrado no Capítulo 8, a apreciação da admissibilidade também fica sobrestada (com exceção da tempestividade, que deve ser desde logo aferida) e só ocorrerá se o órgão de origem mantiver a decisão divergente. Isso porque o sistema visa prestigiar os princípios

\footnotetext{
561 “Caso, diversamente, o STF conheça do recurso e julgue no mérito, o órgão a quo poderá: a) retratar-se, revendo a decisão recorrida em conformidade com o que tiver decidido o STF no recurso representativo da controvérsia. Constata-se que, neste caso, está-se diante de exceção à regra do art. 463 (na redação da Lei 11.232/2005), hipótese em que o recurso extraordinário sobrestado restará prejudicado [...].” (WAMBIER, Teresa Arruda Alvim, Recurso especial, recurso extraordinário e ação rescisória, cit., p. 306).

${ }^{562}$ Fala-se na ocorrência de um efeito expansivo subjetivo indireto do julgamento do recurso representativo da controvérsia, que passará a ensejar "um novo modelo de recurso com juízo de retratação de mérito: o recurso especial de matéria repetitiva e sobrestado na origem, onde o julgamento da tese pelo STJ foi favorável ao recorrente. Tal recurso irá devolver ao órgão fracionário do tribunal a possibilidade de decidir, novamente, a questão federal apreciada pelo STJ se dela for contrária" (ARAÚJO JÚNIOR, Pedro Dias de. Os efeitos do recurso especial representativo de controvérsia, a participação do indivíduo no julgamento coletivizado e a inegável inserção de elementos da Common Law no processo brasileiro. Jus Navigandi, Teresina, ano 17, n. 3249, 24 maio 2012. Disponível em: <http://jus.com.br/artigos/21844>. Acesso em: 03 out. 2013.
} 
da igualdade e da segurança jurídica, atuando em prol da aplicação de soluções iguais para casos iguais.

Se a aplicação do precedente estivesse condicionada à admissibilidade do recurso excepcional, esta deveria, então, ser desde logo apreciada, sob pena de o sobrestamento ser totalmente inútil. Por isso, não há sentido em condicionar o juízo de retratação ao reconhecimento da admissibilidade do recurso que aguardava sobrestado. ${ }^{563}$

Parte da doutrina critica essa possibilidade de retratação, sob os argumentos de que o processo poderá caminhar para trás (em face da possibilidade de interposição de novos recursos extraordinário e especial contra a nova decisão), da incerteza gerada pela possibilidade de modificação da decisão (mesmo quando esteja em conformidade com a jurisprudência dominante do órgão superior, em face da sua modificação pelo julgamento dos recursos representativos da controvérsia) e da possibilidade de modificação de uma decisão gerada por recurso que sequer precisa reunir os pressupostos de admissibilidade. ${ }^{564}$

Porém, a possibilidade de modificação da decisão, devidamente prevista pela lei, representa uma opção do sistema, e se justifica em face da necessidade de decisões uniformes sobre a mesma questão de direito federal, para dar concretude aos princípios constitucionais da igualdade e segurança jurídica, que no caso preponderam.

Até mesmo o princípio da razoável duração do processo será prestigiado, porque, apesar do risco de interposição de novos recursos contra a decisão de retratação, a tendência é a de que as novas insurgências só sejam manejadas para o apontamento de distinções entre os casos e fundamentos não apreciados - o que, então, será saudável para o sistema, em face da contribuição para a evolução do direito.

Dessa forma, embora não se tenha efeito vinculante (em face da possibilidade de manutenção da divergência), esse sistema aumenta a probabilidade de decisões uniformes

\footnotetext{
${ }^{563}$ Em sentido contrário: TALAMINI, Eduardo, Novos aspectos da jurisdição constitucional brasileira: repercussão geral, força vinculante, modulação dos efeitos do controle de constitucionalidade e alargamento do objeto do controle direto, cit., p. 76 .

${ }^{564}$ MONTEIRO, Vítor José de Mello. Julgamento por amostragem do recurso especial (Lei n. 11.672/08). In: GIANNICO, Maurício; MONTEIRO, Vítor José de Mello (Coords.). As novas reformas do CPC e de outras normas processuais. São Paulo: Saraiva, 2009. p. 414.
} 
sobre o mesmo tema. Espera-se que a divergência seja efetivamente eliminada pela modificação da decisão, primeiro porque o precedente paradigmático é qualificado, aumentando-se o seu poder de persuasão; segundo porque, ciente da pacificação do tema repetitivo pela instância extraordinária, e da pendência do recurso excepcional, o órgão jurisdicional sabe que não há sentido na simples manutenção do entendimento contrário, destinado a ser reformado pelo futuro provimento do recurso excepcional. ${ }^{565}$

Quanto à competência para esse juízo de retratação, ela não é da presidência ou da vice-presidência do tribunal de origem. Esses órgãos, competentes para aferir a admissibilidade dos recursos, não foram os prolatores da decisão divergente. Quem deve reapreciar o recurso anterior e rever a decisão divergente é exclusivamente o mesmo órgão que a proferiu. ${ }^{566}$

Exercido o juízo positivo de retratação, e alterado o acórdão recorrido, o recurso excepcional da parte antes vencida e agora vencedora ficará obviamente prejudicado, posto que, com a modificação do julgamento, terá desaparecido o interesse recursal.

Porém, nesse caso surgirá para a parte contrária, antes vencedora e agora vencida, o interesse em interpor novos recursos excepcionais contra o novo acórdão, que lhe será desfavorável. Caso a reforma ocorra por maioria, e estiverem presentes os demais pressupostos do artigo 530 do CPC, a admissibilidade desses novos recursos ficará

\footnotetext{
565 “O acórdão resultante do julgamento por amostragem presta-se à orientação de futuras decisões. Todavia, não se trata de uma orientação qualquer. Fala-se de uma orientação emanada dos mais representativos tribunais do país, acerca de matérias nas quais a última palavra é dada por eles. Assim, malgrado os tribunais locais não fiquem atados pelos precedentes firmados no julgamento por amostragem, eles devem em regra seguir tal orientação e somente passar por cima dela quando houver relevantes. fundamentos para tanto (p. ex., existência de elementos novos ou não levados em conta no julgamento da controvérsia pelo STF ou STJ). Agindo dessa forma, os tribunais contribuem concomitantemente para o bom funcionamento do sistema e para o não engessamento da jurisprudência." (BONDIOLI, Luiz Guilherme Aidar, A nova técnica de julgamento dos recursos extraordinário e especial repetitivos, cit., p. 24-25). No mesmo sentido, Rodrigo Valente Giublin Teixeira afirma, em comentário ao art. 543-C do CPC, que "o caráter do efeito do acórdão que julgou o recurso repetitivo com idêntica questão de direito detém apenas um efeito persuasivo". Mas, analisando os efeitos do julgamento do primeiro recurso repetitivo pelo STJ (REsp n. 760.246/PR), o autor observa que "todos os TRFs, mesmo com acórdãos divergentes, adotaram a mesma orientação que o STJ adotou", pelo que se poderia falar em "efeito vinculativo indireto" (TEIXEIRA, Rodrigo Valente Giublin, Recursos especiais repetitivos fundados em idêntica questão de direito no âmbito do Superior Tribunal de Justiça, cit., p. 180).

${ }^{566}$ RODRIGUES NETTO, Nelson, Análise crítica do julgamento "por atacado" no STJ: (Lei 11.672/2008 sobre recursos especiais repetitivos), cit., p. 242. Em sentido contrário, sob o argumento de que permitir ao próprio órgão rever sua decisão representaria violação ao art. 463 do CPC: OLIVEIRA, Guilherme José Braz de, Repercussão geral das questões constitucionais e suas consequências para o julgamento do recurso extraordinário, cit., p. 300.
} 
condicionada à prévia interposição de embargos infringentes, com o fim de esgotar a instância ordinária.

Não se argumente que, por estar a nova decisão em conformidade com o entendimento dominante do STF ou do STJ, fixado no julgamento dos recursos representativos da controvérsia, seria vedada, nesse caso, a interposição de novo recurso, até porque a parte inicialmente vencedora e agora vencida pode interpor recurso extraordinário ou especial arguindo fundamentos novos, não apreciados pelo STF ou pelo STJ no julgamento do recurso representativo da controvérsia. ${ }^{567}$

Questiona-se se, ao realizar o reexame da matéria, o órgão julgador pode apreciar também outras questões, não relacionadas à matéria repetitiva atingida pelos efeitos do precedente qualificado. Incidem aqui, no nosso sentir, as mesmas regras que regem o efeito devolutivo nos planos vertical e horizontal (art. 515, caput, $\S \S 1^{\circ}$ e $2^{\circ}$, do CPC), aliadas à regra, que se deduz a partir das finalidades do rito dos repetitivos, de que só as questões repetitivas, objeto do precedente qualificado, podem, via de regra, ser reapreciadas.

Dessa forma, no plano horizontal, a devolutividade deverá observar os seguintes critérios: a questão deve, obviamente, ser objeto do recurso excepcional, até porque, caso contrário, terá transitado em julgado (hipótese em que a própria coisa julgada material impede o seu reexame); além disso, a questão deve identificar-se com o tema repetitivo que deu causa à instauração do procedimento e ao consequente sobrestamento do caso, de modo que as questões não repetitivas nem relacionadas ao objeto da afetação devem ser normalmente processadas; por fim, também serão devolvidas as questões que guardarem, com a questão repetitiva, alguma relação de prejudicialidade.

No plano vertical, porém, a devolutividade é ampla. Caberá, assim, ao órgão julgador reapreciar a questão a partir de todos os elementos dos autos e à luz de todos os argumentos jurídicos incidentes, com a única ressalva de que o precedente qualificado (que foi justamente o que causou o efeito regressivo) deve ser levado em consideração na

\footnotetext{
567 "Se, entretanto, o tribunal de origem reformar o acórdão e adotar a posição firmada pelo Superior Tribunal de Justiça, então a parte antes vencedora, e agora sucumbente, terá, por sua vez, oportunidade de manifestar seu recurso especial; poderá, v.g., negar a incidência do acórdão-padrão porque a questão de direito julgada naquela lide não seria idêntica à julgada pelo STJ, ou suscitar a incidência de lei posterior, ou poderá até tentar que o STJ reconsidere a posição adotada no acórdão-padrão." (CARNEIRO, Athos Gusmão, Recurso especial, agravos e agravo interno, cit., p. 111).
} 
fundamentação. O mesmo se diga quanto às questões de ordem pública que, segundo o artigo $267, \S 3^{\circ}$, do CPC podem ser apreciadas a qualquer tempo e grau ordinário de jurisdição.

\subsubsection{Juízo negativo de retratação (manutenção da divergência)}

Apesar de conspirar para a modificação das decisões divergentes, o sistema prevê claramente a possibilidade de manutenção da divergência, o que revela de forma inequívoca a ausência de efeito vinculante do precedente qualificado (conforme Capítulo 6, item 6.4).

Quanto aos recursos extraordinários, o artigo 543-B, § 4º , prevê essa possibilidade de manutenção da divergência, ao dispor que "mantida a decisão e admitido o recurso, poderá o Supremo Tribunal Federal, nos termos do Regimento Interno, cassar ou reformar, liminarmente, o acórdão contrário à orientação firmada".

Ou seja, a norma prevê que o tribunal de origem poderá manter a decisão, mesmo diante do precedente qualificado do STF. Nesse caso, o recurso extraordinário deve ser normalmente processado, realizando-se o juízo de admissibilidade. Positivo o juízo, os autos serão enviados ao STF, que poderá cassar ou reformar liminarmente o acórdão divergente. A respeito dessa possibilidade de cassação ou reforma liminar do acórdão, note-se que, mais uma vez, o sistema confirma que os efeitos do precedente qualificado são os mesmos da jurisprudência dominante, qual seja, o julgamento monocrático do recurso excepcional (arts. 544 e 557 do CPC e Lei n. 8.038/90). ${ }^{568}$

\footnotetext{
${ }^{568}$ Parte da doutrina enxerga nesse dispositivo a criação de nova hipótese de julgamento monocrático do recurso extraordinário, pois até então se exigia "súmula ou jurisprudência dominante" (art. 557 do CPC), o que pressuporia a reiteração de julgados do STF no mesmo sentido, sendo insuficiente a existência de apenas um julgado (como pode ocorrer com o art. 543-B do CPC) (ABBUD, André de Albuquerque Cavalcanti, A repercussão geral dos recursos extraordinários e o julgamento por amostragem no âmbito do Supremo Tribunal Federal (CPC, arts. 543-A e 543-B), in As novas reformas do CPC e de outras normas processuais, cit., p. 314). No entanto, parece mais adequado à realidade do sistema de julgamento de recursos repetitivos o entendimento de que, tal como vimos defendendo ao longo deste trabalho, o acórdão paradigma, formado pelo julgamento dos recursos representativos da controvérsia, exprime por si só a jurisprudência dominante da Corte. Conforme demonstrado no Capítulo 2, embora tecnicamente um único julgado não represente "jurisprudência", ele pode representar precedente e gerar os mesmos efeitos extraprocessuais normalmente gerados pela jurisprudência dominante, desde que isso seja previsto pela lei.
} 
Além do artigo 543-B, $\S 4^{\circ}$, do CPC, tem-se o artigo 318-A, $\S 2^{\circ}$, do RISTF, segundo o qual, "julgado o mérito do recurso extraordinário em sentido contrário ao dos acórdãos recorridos, o Tribunal de origem remeterá ao Supremo Tribunal Federal os agravos em que não se retratar". Ou seja, tratando-se de agravo de admissão, e não de recurso extraordinário, o tribunal de origem também poderá se retratar. Sendo negativo o juízo de retratação, e consequentemente mantida a divergência, o recurso deve ser remetido ao STF, que também nessa hipótese poderá julgá-lo liminar e monocraticamente. Aplica-se normalmente, nesse caso, a Súmula 727 do STF.

Quanto aos recursos especiais, passa-se o mesmo: o artigo 543-C, § $8^{\circ}$, prevê que, após o novo exame da questão pelo órgão julgador, "mantida a decisão divergente pelo tribunal de origem, far-se-á o exame de admissibilidade do recurso especial”. E, segundo o artigo $7^{\circ}$ da Resolução n. 8 do STJ, o procedimento aplica-se, no que couber, aos agravos de admissão. Nessa hipótese, os recursos repetitivos também poderão ser monocraticamente providos e, por decisão do próprio presidente, conforme o artigo $1^{\circ}$, II, “b”, da Resolução n. 17, de 04.09.2013.

Embora não haja efeito vinculante, isso não significa que a existência do precedente qualificado possa ser ignorada, o que tornaria o sistema totalmente inócuo, e até o sobrestamento do caso seria totalmente inútil e injustificado. Assim, se o tribunal de origem, mesmo ciente do precedente, exerce o juízo negativo de retratação para manter a decisão, pode-se afirmar que a sujeição do caso ao rito dos artigos 543-B e 543-C do CPC impõe a fundamentação expressa da nova decisão, sob pena de nulidade.

Trata-se de um dever que decorre diretamente do próprio princípio constitucional da motivação das decisões judiciais, o qual impõe que se levem em consideração as decisões oficialmente dotadas de alto poder de influência no sistema, eis que emanadas dos órgãos criados pela Constituição Federal justamente para estabelecer a exata e uniforme interpretação do direito positivo no território nacional (ver Capítulos 2 e 3). ${ }^{569}$

\footnotetext{
${ }^{569}$ A esse respeito, aliás, merece aplauso a disposição prevista na versão atual do projeto de CPC, prevendo que não se considera fundamentada a decisão que não leva em consideração o teor do precedente, seja para aplicá-lo, seja para abandoná-lo por distinguishing ou overruling. Neste sentido, ver os artigos 499, $\S 1^{\circ}$, VI, e 521, $\S 6^{\circ}$.
} 
Nesse sentido, o dever de fundamentação da decisão à luz do precedente qualificado já levou o STJ a anular decisões dos órgãos de origem que simplesmente se recusaram a seguir a orientação dos precedentes sem exposição dos motivos dessa decisão. ${ }^{570}$

Com isso, a possibilidade de manutenção da divergência deixa saudavelmente aberto o caminho da revisão dos precedentes pela instância superior, deixando espaço para a oxigenação da jurisprudência e, por consequência, para a evolução do direito.

Se o precedente não tem efeito vinculante no plano horizontal, com maior razão não poderá tê-lo no plano vertical. Assim, em relação ao julgamento de recursos repetitivos eventualmente não devolvidos ao tribunal de origem, o STF e o STJ não precisarão necessariamente se sujeitar ao precedente qualificado. Nesse caso, porém, a decisão também tem de ser fundamentada, levando-se expressamente em consideração a existência do precedente, sob pena de total ineficácia do sistema.

Em respeito ao princípio do contraditório e da ampla defesa, a complementação da decisão que mantém a divergência por novos fundamentos apresentados à luz do precedente qualificado deverá gerar a concessão de oportunidade para que o recorrente e o recorrido igualmente aditem suas razões e contrarrazões recursais, processando-se, em seguida, o recurso na forma já exposta acima. ${ }^{571}$

\subsection{Efeitos do julgamento de mérito dos recursos representativos da controvérsia, em relação aos novos recursos extraordinários e especiais (e respectivos agravos de admissão ou interno)}

Apesar da ausência de eficácia vinculante, a ideia do sistema é efetivamente diminuir o número de decisões divergentes, contribuindo para a uniformidade do direito federal. Espera-se, assim, que, com a definição da questão pelo precedente qualificado, as

\footnotetext{
${ }^{570}$ STJ - QO REsp n. 1.148.726/RS; REsp n. 1.146.696/RS; REsp n. 1.153.937/RS; REsp n. 1.154.288/RS, REsp n. 1.155.480/RS e REsp n. 1.158.872/RS, rel. Min. Aldir Passarinho Junior, j. 10.12.2009.

571 "Nesta contingência, os fundamentos do recurso especial pendente, a que alude o art. 543-C, § 8', conforme se infere da sua redação, talvez já não se mostrem congruentes com tais fundamentos. É óbvio que, então, mostrar-se-á imprescindível incorporar tais fundamentos a um novo acórdão, substituindo ao primeiro, e, intimando-se a parte vencida, admitir a complementação das razões do recurso especial anteriormente interposto, com base no princípio da complementariedade." (ASSIS, Araken de, Manual dos recursos, cit., p. 827).
} 
subsequentes decisões proferidas pelas instâncias inferiores, pelo STF e pelo STJ passem a efetivamente adotar o entendimento definitivo sobre a interpretação do direito federal, salvo quando houver novos fundamentos de fato ou de direito a justificar novos precedentes.

Diante de decisões no mesmo sentido do precedente qualificado, as partes sabem da reduzida chance de êxito de novas insurgências ao STF e ao STJ, sobretudo daquelas que se limitem a repetir fundamentos já profundamente analisados e rejeitados pela instância superior no procedimento diferenciado de julgamento de recursos repetitivos. Assim, também se espera que diminua o número de novos recursos extraordinários e especiais nos quais eventualmente se busque a mera reiteração da matéria.

Apesar de ser essa a intenção do sistema, é certo que, na prática, mesmo após a definição da controvérsia, continuarão a ser interpostos, espera-se que com menor intensidade, novos recursos extraordinários e especiais contra as decisões colegiadas ou monocráticas que apliquem o precedente qualificado.

Surge então a questão de se saber os efeitos do precedente, previstos pelos artigos 543-B e 543-C do CPC, aplicam-se também a esses novos recursos, contrários à tese pacificada pelo STF e pelo STJ.

Embora não se possa falar em sobrestamento dos recursos repetitivos, nem em possibilidade de retratação em caso de acórdãos divergentes, os órgãos e tribunais de origem deverão, ao apreciar a admissibilidade desses novos recursos, negar-lhes seguimento, tal como previsto pelos artigos 543-B e 543-C do CPC, em face da presunção de inocorrência de violação ao direito federal, caracterizada pela preexistência de precedente qualificado sobre a questão. ${ }^{572}$

\footnotetext{
572 "Recursos interpostos posteriormente deverão ser processados sem a alternativa de aplicação de juízo de retratação da decisão recorrida, mas, apenas, a declaração de juízo negativo de admissibilidade (art. 543-C, $\S 7^{\circ}$ ), o que não representa uma novidade, ao menos não uma novidade completa, haja vista a regra contida no art. 557 do CPC." (RODRIGUES NETTO, Nelson, Análise crítica do julgamento "por atacado" no STJ: (Lei 11.672/2008 sobre recursos especiais repetitivos), cit., p. 245). "Proferido o acórdão no processo 'piloto', os recursos especiais, que vierem a ser interpostos com base naquela questão de direito, não mais serão sobrestados; todavia, é evidente que o respectivo juízo primeiro de admissibilidade tomará em conta a orientação firmada pelo STJ." (CARNEIRO, Athos Gusmão, Recurso especial, agravos e agravo interno, cit., p. 114). No mesmo sentido: TALAMINI, Eduardo, Novos aspectos da jurisdição constitucional brasileira: repercussão geral, força vinculante, modulação dos efeitos do controle de constitucionalidade e alargamento do objeto do controle direto, cit., p. 80.
} 
Porém, também aqui não se descarta a possibilidade de admissão do recurso em face de distinções fáticas ou novos fundamentos apresentados pela parte recorrente, assim como não se descarta a possibilidade de interposição de agravo de admissão contra a decisão denegatória de seguimento, conforme já demonstrado no Capítulo 6 (item 6.5).

O mesmo se diga quanto às decisões do STF ou do STJ que julguem monocraticamente, com base no precedente qualificado, recursos extraordinários ou especiais (ou os respectivos agravos de admissão) eventualmente enviados à instância superior. Nesse caso, a parte prejudicada continua podendo interpor agravo regimental ou interno ao colegiado.

Aliás, no STJ, após o julgamento do recurso-piloto, os recursos repetitivos contrários à tese poderão ser apreciados pela própria Presidência, conforme o artigo $1^{\circ}, \mathrm{I}$, “b”, da Resolução n. 17, de 04.09.2013, do STJ.

Por outro lado, entendemos que, em relação a esses novos recursos, a preexistência do precedente qualificado pode e deve justificar a imposição de multas processuais, em face do caráter protelatório da impugnação. Não que todo e qualquer novo recurso contrário ao precedente deva ser considerado, por si só, protelatório. Mas os recursos que se limitem a repetir argumentos já analisados no julgamento dos recursos selecionados, sem apresentar qualquer novidade, devem sim ser considerados protelatórios, com a aplicação das sanções processuais previstas no CPC.

Nesse sentido, o STJ tem entendido que, embora o agravo interno contra a decisão monocrática que julga recurso com base no precedente qualificado (art. 543-C) deva ser improvido, e não inadmitido por uma eventual falta de interesse recursal, deve-se aplicar a multa do artigo 557, $\S 2^{\circ}$, do CPC, em virtude da caracterização de recurso protelatório. ${ }^{573}$

\footnotetext{
${ }^{573} \mathrm{Na}$ oportunidade, a ministra Eliana Calmon defendeu que o agravo interno não poderia ser conhecido por falta de interesse recursal, haja vista a manifesta ausência de utilidade do recurso simplesmente interposto para rediscutir a questão já pacificada. Foi vencedor, porém, o entendimento de que se deve, no caso, negar provimento ao agravo interno, confirmando quanto ao mérito da decisão monocrática que julgou o recurso anterior com base no acórdão paradigma do STJ, podendo-se, entretanto, aplicar a multa do artigo 557, § $2^{\circ}$, do CPC (STJ - AgR REsp n. 1.025.220/RS, $1^{\text {a }}$ Seção, rel. Min. Eliana Calmon, j. 25.03.2009, DJe, de 20.04.2009). Em julgado mais recente, entendeu-se que "a interposição de agravo regimental para debater questão já apreciada em recurso submetido ao rito do art. 543-C do CPC atrai a aplicação da multa prevista no art. 557, $\S 2^{\circ}$, CPC" (STJ - AgR AREsp n. 313.928/RN, $2^{\mathrm{a}}$ Turma, rel. Min. Humberto Martins, j. 15.08.2013, DJe, de 26.08.2013).
} 
Vale mencionar também a decisão monocrática do ministro Herman Benjamin, que deu provimento monocraticamente a recurso especial com base em precedente qualificado e consignou, ao final, "a advertência de que a interposição de recurso contra decisão fundada em precedente julgado sob o rito do art. 543-C será considerada manifestamente inadmissível e protelatória”. De fato, não foi interposto agravo contra tal decisão, que logo em seguida transitou em julgado. ${ }^{574}$

Não obstante, fazemos referência ao entendimento do STF e do STJ, no sentido de não admitir o envio à instância superior de novos recursos extraordinário e especial interpostos contra decisões que, mesmo posteriores ao procedimento dos artigos 543-B e 543-C, adotam o entendimento firmado pelo acórdão que julgou os recursos selecionados como representativos da controvérsia. E as decisões denegatórias de seguimento desses recursos sequer podem ser contrastadas por agravo de admissão, devendo eventuais equívocos quanto à identidade entre os casos ser resolvidos no âmbito do próprio tribunal de origem, por meio de agravo interno.

Aliás, em 01.02.2013, foi publicada a Resolução n. 5 do STJ, posteriormente substituída pelas Resoluções ns. 16, de 20.08.2013, e 17, de 04.09.2013, cujo artigo 2º II, prevê expressamente que "se já proferido o julgamento do mérito do recurso representativo da controvérsia", os novos recursos poderão, por decisão do presidente, ser devolvidos "ao tribunal de origem para os efeitos dos incisos I e II do $\S 7^{\circ}$ do art. 543-C do Código de Processo Civil, ressalvada a hipótese do $\S 8^{\circ}$ do referido artigo". 575

Com esse entendimento, a nosso ver inconstitucional, tanto o STF como o STJ passam, do ponto de vista teórico, a não mais apreciar recursos extraordinários e especiais repetitivos que defendem tese contrária ao acórdão que julga os recursos representativos da controvérsia, trancando indevidamente o acesso dessas partes à instância superior, e impondo a revisão da jurisprudência da instância superior apenas na hipótese de decisões divergentes.

\footnotetext{
${ }^{574}$ STJ - AI 1.366.010, rel. Min. Herman Benjamin, decisão monocrática, DJe, de 14.02.2011.

${ }^{575}$ Diferentemente do entendimento do STF (segundo o qual não cabe agravo regimental contra a decisão monocrática que determina a devolução dos autos ao tribunal de origem para observância do art. 543-B do CPC), a própria Resolução do STJ prevê, em seu artigo $3^{\circ}$, a possibilidade de interposição de agravo regimental contra a decisão do presidente.
} 


\subsection{A questão da impugnação da decisão que nega seguimento aos recursos repetitivos contrários ao acórdão paradigma}

A polêmica questão sobre a possibilidade de interposição de agravo de admissão contra a decisão que nega seguimento ao recurso extraordinário ou especial com base no precedente qualificado foi examinada no Capítulo 6 (item 6.5), quando se demonstrou que o entendimento da jurisprudência do STF e do STJ, no sentido de não admitir a interposição daquele recurso, torna o sistema de julgamento de recursos repetitivos inconstitucional.

Assim, o presente item justifica-se apenas para recordar que, segundo a jurisprudência pacificada do STF e do STJ, firmadas respectivamente pelo julgamento da QO AI n. $760.358 / \mathrm{SE}^{576}$, da Rcl n. $7.569^{577}$ e da QO AI n. 1.154.599/SP ${ }^{578}$, não cabe agravo de instrumento ou de admissão (art. 544 do CPC) nem reclamação contra decisões denegatórias de seguimento, proferidas pelos tribunais de origem, com base em precedente qualificado sobre questão repetitiva.

Os agravos e reclamações endereçados ao STF e protocolados antes de 19.11.2009 (data do precedente do STF que definiu ser incabível a insurgência direcionada à instância superior) serão convertidos em agravo interno e remetidos às instância de origem para apreciação. A partir da referida data, considera-se erro grosseiro a utilização de outro meio que não o agravo interno no âmbito do próprio tribunal de origem.

Quanto às decisões monocráticas do STF que determinam a devolução de recursos extraordinários ou agravos de admissão porventura enviados à Corte Suprema, o entendimento da jurisprudência é de que não cabe agravo regimental ou interno, sendo dispensável até mesmo a publicação da decisão.

Já quanto ao STJ, em virtude da sua jurisprudência, que entende pela desnecessidade de sobrestamento dos recursos especiais e agravos de admissão

\footnotetext{
${ }^{576}$ STF - QO AI n. 760.358 /SE, rel. Min. Gilmar Mendes, DJe, de 11.02.2010.

${ }^{577}$ STF - Rcl n. 7.569, Pleno, rel. Min. Ellen Gracie, DJe, de 10.12.2009.

578 STJ - QO AI n. 1.154.599/SP, Corte Especial, rel. para acórdão Min. César Asfor Rocha, DJe, de 12.05.2011.
} 
eventualmente enviados à Corte Superior, bem como pela possibilidade de sua apreciação independentemente do julgamento dos recursos selecionados, é comum o julgamento monocrático de recursos com base no entendimento firmado anteriormente em sede de recursos representativos da controvérsia. E, contra essas decisões, o STJ admite a interposição de agravo interno, muito embora isso possa gerar a aplicação da multa do artigo 557, $\S 2^{\circ}$, do CPC.

A situação pode mudar em virtude da recente Resolução n. 17, de 04.09.2013, cujo artigo $2^{\circ}$ prevê, tal como ocorre com o STF, a devolução à origem de recursos repetitivos enviados ao STJ na pendência do julgamento dos recursos selecionados, ou após esse julgamento, sendo que, nesse último caso, só devem ser enviados os recursos contra decisões divergentes. Mesmo assim, diferentemente do que ocorre no STF, a própria Resolução admite, em seu artigo $3^{\circ}$, a interposição de agravo interno contra a decisão que determina a devolução.

\subsection{Efeitos do julgamento de mérito dos recursos representativos da controvérsia, em relação às causas e recursos nas demais instâncias}

Diante do exposto até aqui, fica claro que o julgamento dos recursos representativos da controvérsia dá origem a precedente que, por si só, e independentemente da sua conversão em súmula, gera os mesmos efeitos da jurisprudência dominante do STF ou do STJ a respeito da questão decidida.

Dessa forma, mesmo em relação às causas e recursos nas demais instâncias que não foram sobrestados, o acórdão paradigma resultante do procedimento dos artigos 543-B e 543-C do CPC gera, a partir de uma interpretação sistemática, efeitos processuais concretos, pela aplicação combinada com outros dispositivos do ordenamento processual.

Nesse sentido, o precedente justificará, por exemplo, o julgamento monocrático de conflitos de competência em que se apresente a questão repetitiva (art. 120, parágrafo único), a sentença de improcedência prima facie de ações repetitivas (art. 285-A) ${ }^{579}$, a

\footnotetext{
579 Interpretando o artigo 285-A do CPC, o STJ recentemente manifestou o entendimento de que "é necessário, para que o objetivo visado pelo legislador seja alcançado, que o entendimento do Juiz de $1^{\circ}$ grau esteja em consonância com o entendimento do Tribunal local e dos Tribunais Superiores (dupla conforme)" (STJ - REsp n. 1.225.227/MS, 3 ${ }^{\text {a }}$ Turma, rel. Min. Nancy Andrighi, j. 28.05.2013, DJe, de 12.06.2013).
} 
dispensa do reexame necessário de sentença baseada no entendimento firmado pelo precedente (art. $475, \S 3^{\circ}$ ) e o julgamento monocrático de recursos nos tribunais (arts. 544 e 557).

No nosso entendimento, as apelações contra sentenças fundadas no precedente formado em sede de julgamento de recursos repetitivos (arts. 543-B e 543-C do CPC) também podem, por interpretação sistemática, ser inadmitidas, na forma do artigo 518, § $1^{\circ}$.

Além disso, a definição da questão pelo julgamento dos recursos repetitivos selecionados também propicia todas as vantagens da jurisprudência estável, a qual contribui para a concretização dos princípios da igualdade, segurança jurídica e razoável duração do processo (conforme Capítulo 2, item 2.4.3).

Vejamos as conclusões de José Ignácio Botelho de Mesquita e outros sobre a amplitude e importância que essa técnica tem no direito brasileiro:

Em razão disto, é preciso estar atento ao fato de não ser impossível que a tese vencedora venha a ter um alcance bem maior do que o de limitar simplesmente o número de recursos relativos a uma mesma questão; pode chegar até mesmo a obstar a propositura de ações novas em primeiro grau de jurisdição.

Com efeito, no juízo em que já houver sido pronunciada alguma sentença sobre a questão de direito controvertida, decidindo-a com base no precedente do STJ, poderá o juiz da causa, com fundamento no art. 285-A do CPC, julgar improcedente a ação sem ter que mandar citar o réu. Se o autor recorrer não caberá, diante da eventual falta de súmula dispondo a respeito, aplicar o art. 518, $\S 1^{\circ}$, do CPC, mas o relator, no tribunal, poderá aplicar o disposto no art. 557 e indeferir o processamento da apelação, selando definitivamente a sorte do litígio.

Visto sob este aspecto, o alcance desse novo sistema parece ser bem mais amplo que o da "repercussão geral", posto que, enquanto esta se limita a questões de natureza constitucional, a jurisprudência qualificada como dominante irá influir no julgamento de qualquer das questões que componham o mérito da causa.

Assim, a despeito de não se tratar de julgamento objetivo, ou abstrato, nem estar explicitamente provido de eficácia erga omnes, é enorme a importância que a este instituto está reservada no direito brasileiro. ${ }^{50}$

${ }^{580}$ MESQUITA, José Ignácio Botelho de et al., A repercussão geral e os recursos repetitivos: economia, direito e política, cit., p. 25-26. 
A previsibilidade proporcionada pelo prévio conhecimento do entendimento definitivo sobre a questão contribui para o desestímulo à litigiosidade e à interposição de recursos protelatórios, e influi nas decisões a serem proferidas em todas as instâncias e fases do processo.

Também por isso é tão importante a ampla divulgação a toda a sociedade do inteiro teor das decisões que julgam os recursos selecionados, como já ocorre no âmbito do STF e do STJ, que disponibilizam em seus sites setores específicos aos recursos repetitivos, com informações detalhadas sobre os casos julgados e em andamento. ${ }^{581}$

\subsection{Possibilidade de modulação dos efeitos do julgamento de mérito dos recursos representativos da controvérsia}

Quando o Poder Judiciário, no exercício do controle concentrado e abstrato da constitucionalidade das normas, reconhece a sua inconstitucionalidade, sua decisão tem, em regra, eficácia retroativa (ex tunc), atingindo, com a eficácia vinculante prevista expressamente na Constituição Federal, os atos jurídicos praticados com base naquela norma.

Pode ocorrer, porém, de a segurança jurídica ser seriamente comprometida, eis que os atos foram praticados com base em normas jurídicas até então consideradas válidas, podendo ter produzido modificações drásticas no mundo sensível. Daí porque o sistema admite, excepcionalmente, a limitação temporal dos efeitos da decisão declaratória de inconstitucionalidade.

Nesse sentido, dispõe o artigo 27 da Lei n. 9.868/99, inserido no capítulo que trata "Da decisão na ação direta de inconstitucionalidade e na ação declaratória de constitucionalidade", que o STF poderá, ao declarar a inconstitucionalidade de lei ou ato normativo, e com base no princípio da segurança jurídica ou razões de excepcional interesse social, "restringir os efeitos daquela declaração ou decidir que ela só tenha eficácia a partir de seu trânsito em julgado ou de outro momento que venha a ser fixado",

\footnotetext{
581 Conforme prevê o artigo 329 do RISTF: “A Presidência do Tribunal promoverá ampla e específica divulgação do teor das decisões sobre repercussão geral, bem como formação e atualização de banco eletrônico de dados a respeito."
} 
desde que a decisão sobre essa modulação seja tomada por maioria de dois terços de seus membros.

Como se vê, a própria Lei n. 9.868/99 trata essa hipótese como uma verdadeira exceção, sujeitando-a a rígidos critérios formais: pode ser adotada apenas em sede de controle concentrado e abstrato de constitucionalidade pelo STF, e mesmo assim somente na hipótese de declaração de inconstitucionalidade, por "razões de segurança jurídica ou de excepcional interesse social" e com a observância do quorum qualificado de dois terços da maioria dos integrantes da corte.

Os efeitos extraprocessuais da jurisprudência ou dos precedentes também podem atingir situações pretéritas. A atividade jurisprudencial não consiste na criação de normas jurídicas regulamentadoras de situações futuras, mas sim no estabelecimento do sentido das normas no julgamento dos casos concretos submetidos ao Poder Judiciário. Assim, não obstante a sua importância para a integração do sistema jurídico (Capítulo 2), a jurisprudência representa a interpretação de uma norma preexistente, de modo que o entendimento por ela externado pode e deve ser aplicado para orientar a forma de julgamento das situações anteriores, já concretizadas.

Nesse sentido, as decisões judiciais que formam a jurisprudência ou os precedentes, ainda que proferidas no julgamento de casos concretos, com a coisa julgada restrita às partes litigantes, e ainda que não sejam dotadas de eficácia vinculante, influenciam, em maior ou menor grau, o julgamento dos casos sucessivos, os quais podem se referir a situações pretéritas.

No entanto, em face das funções constitucionais exercidas pelo STF e pelo STJ em sede de recursos extraordinários e especiais, eventuais decisões que representem uma alteração brusca no entendimento jurisprudencial desses órgãos de cúpula gera igualmente prejuízo à segurança jurídica, pois frustra a previsibilidade e a confiança legitimamente depositada pelas pessoas em geral na orientação adotada pelos seus precedentes.

Como demonstrado nos Capítulos 2 e 3, essa confiança gerada pelos precedentes não depende do seu caráter eventualmente vinculante. Tratando-se de jurisprudência formada pelos Tribunais Superiores, justamente os órgãos constitucionalmente incumbidos 
de unificar o direito federal no país por meio do julgamento de recursos excepcionais, é legítimo acreditar que a orientação fixada em suas decisões consolidadas exprime o verdadeiro sentido das normas. Assim, a alteração da jurisprudência, que passará a imediatamente orientar o julgamento dos casos em curso, não pode atingir as situações consolidadas à luz do entendimento dominante anterior, sob pena de violação da segurança jurídica, em seus sentidos de previsibilidade e de proteção da confiança.

Para Luiz Guilherme Marinoni, “a proteção da confiança justificada nos precedentes judiciais constitui dever dos Tribunais Superiores”, não havendo dúvida da possibilidade e, mais do que isso, do dever de modulação dos efeitos dos precedentes que revogam a jurisprudência consolidada dos Tribunais Superiores, porque a alteração do entendimento a respeito do direito federal manifestada por esses órgãos tem grande impacto sobre as situações levadas a efeito sob o império do precedente revogado. Porém, para o autor, a modulação está sujeita a rígidos requisitos, de modo que se deve exigir do tribunal "em primeiro lugar, a análise acerca da existência de 'confiança justificada', uma vez que nem todo precedente gera confiança capaz de legitimar a conduta praticada. Depois, há que se verificar se o ato ou a conduta realmente deriva da confiança que se depositou no precedente". 582

E, tratando-se de julgamento de recursos extraordinários e especiais repetitivos selecionados como representativos da controvérsia, a eficácia do precedente é ainda maior, por todas as razões já expostas ao longo deste trabalho.

Diante disso, entendemos que o STF e o STJ podem e devem, em nome da segurança jurídica, modular os efeitos do precedente paradigmático, para estabelecer que determinada orientação, por ser considerada nova e por contrariar precedentes anteriores sobre o mesmo tema, deve ser observada apenas em relação aos julgamentos futuros, na linha do que ocorre com o prospective overruling do sistema de common law vigente nos Estados Unidos. ${ }^{583}$

\footnotetext{
${ }^{582}$ MARINONI, Luiz Guilherme. Eficácia temporal da revogação da jurisprudência consolidada dos tribunais superiores. Revista de Informação Legislativa, Brasília, v. 48, n. 190 t. 2, p. 33, abr./jun. 2011.

${ }^{583}$ Caso em que a Suprema Corte dos Estados Unidos revoga o precedente com eficácia ex nunc, de forma que sua revogação produza efeitos apenas para casos futuros.
} 
No entanto, por coerência com o sistema, é imprescindível que essa modulação seja determinada pela maioria qualificada dos integrantes da corte com competência para a análise da matéria, nos termos do que já exige, hoje, o artigo 27 da Lei n. 9.86899.

No âmbito do STF, mesmo antes da exigência da repercussão geral e da possibilidade de julgamento de recursos extraordinários repetitivos pela técnica do artigo 543-B do CPC, a jurisprudência já vinha considerando a possibilidade dessa modulação em sede de julgamento de recurso extraordinário, com base no princípio constitucional da segurança jurídica e em interpretação analógica da regra do artigo 27 da Lei n. 9.868/99, mesmo quando se confirma a constitucionalidade de normas jurídicas, desde que se caracterize a alteração do entendimento jurisprudencial até então dominante e para evitar prejuízo às situações jurídicas consolidadas, diante da confiança do jurisdicionado na interpretação dominante anteriormente adotada. ${ }^{584}$

Apesar disso, só em situações muito excepcionais o STF adota essa modulação, valendo citar, por exemplo, o caso relativo ao RE n. $377.457 / \mathrm{PR}^{585}$, em que a corte negou provimento ao recurso, para confirmar a constitucionalidade da Lei ordinária n. 9.430/96, que revogou isenção antes prevista pela Lei Complementar n. 70/91. A jurisprudência do STJ era majoritária no sentido da manutenção da isenção, tendo inclusive editado, no ano de 2003, a Súmula 276, confirmando essa isenção.

Com o julgamento desse recurso extraordinário pelo STF, que foi concluído em 17.09.2008, o entendimento sobre a isenção até então adotado pelo STJ foi alterado, mas ficou vencida a proposta de modulação dos efeitos, por se considerar que, apesar daquela Súmula do STJ, no âmbito do Supremo não houve alteração de jurisprudência a respeito da matéria constitucional - pelo contrário, precedentes sobre matéria análoga já sinalizavam, desde 2006, que a interpretação da corte era no sentido da possibilidade de revogação de

\footnotetext{
${ }^{584}$ Conforme ocorreu, por exemplo, na Reclamação n. 2.391(Informativo STF, Brasília, n. 334, 15-19, de. 2003), quando "prosseguindo em seu voto, o Min. Gilmar Mendes - tendo em conta o fato de que, na espécie, estar-se-ia revisando jurisprudência firmada pelo STF, amplamente divulgada e com inegáveis repercussões no plano material e processual -, admitindo a possibilidade da limitação dos efeitos da declaração de inconstitucionalidade prevista no art. 27 da Lei 9.868/99, em sede de controle difuso, emprestou à sua decisão efeitos ex nunc (...)". Mais recentemente, constou em emenda de precedente da Segunda Turma que "a orientação do Supremo Tribunal Federal admite, em situações extremas, o reconhecimento de efeitos meramente prospectivos à declaração incidental de inconstitucionalidade". (STF - AgR AI n. 627.770 /RJ, 2a Turma, rel. Min. Joaquim Barbosa, j. 04.10.2011, DJe, de 20.10.2011).

${ }^{585}$ STF - RE n. 377.457/PR, rel. Min. Gilmar Mendes, j. 17.09.2008, DJe, de 18.12.2008.
} 
lei complementar por lei ordinária, se a Constituição Federal não prevê, sobre a matéria, a competência exclusiva da lei complementar.

Apesar de não ter prevalecido no caso a proposta de modulação dos efeitos, vale citar o voto vencido do ministro Celso de Mello, o qual registrou que o princípio da segurança jurídica exige que se proteja "sob pena de se ignorar, com grave lesão aos cidadãos, o atributo da previsibilidade das ações estatais, que norteia e estimula a adoção de padrões de comportamento por parte das pessoas em geral (e dos contribuintes em particular)". Exigir-se-ia, portanto, a projeção dos efeitos do precedente para o futuro, sob pena de frustrar as justas expectativas dos contribuintes que, apoiados na Súmula do STJ, acreditavam na vigência da isenção antes previstas por lei complementar. ${ }^{586}$

Por sua vez, no âmbito do STJ, o entendimento da jurisprudência dominante é no sentido de que não existe base legal para a modulação dos efeitos de seus precedentes ${ }^{587}$. A questão foi amplamente discutida no julgamento do EREsp n. 738.689/PR, em que

\footnotetext{
${ }^{586}$ Em outro trecho do voto, afirma-se: “A instabilidade das decisões estatais, motivada pela ruptura abrupta de critérios jurisprudenciais, que, até então, pautavam o comportamento dos contribuintes [...] não pode nem deve afetar ou comprometer a esfera jurídica daqueles que, confiando em diretriz firmada pelos Tribunais e agindo de acordo com esse entendimento, ajustaram, de boa-fé, a sua conduta aos pronunciamentos reiterados do Superior Tribunal de Justiça a propósito da subsistência, no caso, da isenção do Cofins."

587 Apesar disso, o STJ já acolheu excepcionalmente a tese de que o precedente que fixa situação nova deve ter efeitos ex nunc, isto é, voltados exclusivamente para os casos futuros. Mas se tratou de caso totalmente excepcional, em que se deu provimento ao recurso especial para reconhecer a suspeição de determinado juiz, autor de inúmeras sentenças em processos repetitivos de massa no Estado do Rio Grande do Sul. O provimento do recurso especial, interposto contra acórdão proferido em "Assunção de Competência" (CPC, art. 555, $\S 1^{\circ}$ ) acarretaria o reconhecimento da suspeição em inúmeras situações idênticas, todas envolvendo o mesmo réu. Entendeu-se, então, que "os efeitos da declaração de suspeição, em caráter transcendental, valem somente para o futuro, ex nunc, a partir do julgamento da Sessão de 1404/2010, preservados, portanto, todos os atos anteriormente praticados pelo Magistrado", evitando-se com isso a nulidade dos processos já julgados. O fundamento, porém, foi o de que "válidas as decisões e sentenças, preservadas da mácula da suspeição, porque atacáveis pelos recursos pertinentes, que as devolvem, por inteiro, ao conhecimento dos Tribunais - não suspeitos, estes" (STJ - REsp n. 1.165.623/RS, 2ª Seção, rel. Min. Vasco Della Giustina, j. 14.04.2010, DJe, de 17.08.2010). Entretanto, em outro caso, reconheceu-se excepcionalmente a possibilidade de modulação dos efeitos do precedente, ficando consignada a projeção para o futuro da nova orientação então firmada pelo STJ. Trata-se do julgamento do HC n. 83.255/SP, $5^{\mathrm{a}}$ Turma, rel. Min. Laurita Vaz, DJ, de 01.05.2005, em cuja ementa constou o seguinte: "1. De fato, o Supremo Tribunal Federal, a partir do julgamento plenário do Habeas Corpus $\mathrm{n}^{\circ}$ 83.255/SP (informativo $\mathrm{n}^{\circ}$ 328), decidiu que o prazo recursal para o Ministério Público conta-se a partir da entrada do processo nas dependências da Instituição. O Superior Tribunal de Justiça, por seu turno, aderiu à nova orientação da Suprema Corte. 2. Não se pode olvidar, todavia, que o entendimento jurisprudencial, até então, há muito sedimentado no STF e no STJ, era justamente no sentido inverso, ou seja, entendia-se que a intimação pessoal do Ministério Público se dava com o 'ciente' lançado nos autos, quando efetivamente entregues ao órgão ministerial. 3. Dessa maneira, constata-se que o Procurador de Justiça, nos idos anos de 2000, tendo em conta a então sedimentada jurisprudência das Cortes Superiores, valendo-se dela, interpôs o recurso dentro do prazo legal. 4. Não se poderia, agora, exigir que o órgão ministerial recorrente se pautasse de modo diverso, como se pudesse antever a mudança do entendimento jurisprudência [...].”
} 
prevaleceu o voto do ministro Teori Albino Zavascki, no sentido de que "salvo nas hipóteses excepcionais previstas no art. 27 da Lei 9.86899, é incabível ao Judiciário, sob pena de usurpação da atividade legislativa, promover a 'modulação temporal' de suas decisões, para o efeito de dar eficácia prospectiva a preceitos normativos reconhecidamente revogados". 588

Mesmo diante de precedentes originados do julgamento de recursos submetidos ao procedimento do artigo 543-C do CPC, continua-se entendendo que só pode haver a modulação nas hipóteses excepcionais previstas no artigo 27 da Lei n. 9.86899 (controle abstrato de constitucionalidade pelo STF).

Nesse sentido, ao julgar o REsp n. 1.105.442/RJ, a Corte Superior assentou que "a eventual modificação de entendimento jurisprudencial não dá ensejo à atribuição de eficácia prospectiva a julgado, à absoluta falta de amparo legal e constitucional" ${ }^{589}$. Na oportunidade, apreciou-se recurso especial representativo da controvérsia nos termos do artigo 543-C do CPC, sendo definida a orientação de que os créditos fiscais não tributários prescrevem em cinco anos a contar da sua constituição, ficando vencida a tese da aplicação da prescrição vintenária prevista no Código Civil. Afastou-se, assim, a possibilidade de aplicar esse entendimento apenas em relação aos casos futuros, o que significaria a manutenção do prazo de vinte anos em relação às execuções fiscais em curso.

Da mesma forma, a Corte já entendeu que, "diante da inexistência de autorização legal e da manifesta distinção entre as técnicas de julgamento de ação direta de inconstitucionalidade e da atividade jurisdicional constitucionalmente atribuída a este STJ, reputa-se descabida a modulação de efeitos de decisão levada a efeito pela Seção de Direito Privado, ainda que em sede de recurso representativo da controvérsia". 590

\footnotetext{
${ }^{588}$ STJ - EREsp n. 738.689/PR, 2 ${ }^{\text {a }}$ Seção, rel. Min. Teori Albino Zavascki, DJ, de 22.10.2007.

${ }^{589}$ STJ - REsp n. 1.105.442/RJ, $1^{\text {a }}$ Seção, rel. Min. Hamilton Carvalhido, j. 09.12.2009, DJe, de 22.02.2011.

${ }^{590}$ STJ - ED REsp n. 1.202.151/RS, 4a Turma, rel. Min. Marco Buzzi, j. 16.10.2012, DJe, de 12.11.2012. No mesmo sentido: "O STJ possui orientação no sentido de que a modulação dos efeitos da decisão judicial está disciplinada no art. 27 da Lei 9.868/1999, ou seja, somente o STF detém competência para análise da matéria, quando a controvérsia tiver por objeto questão constitucional.”(STJ - AgR REsp n. 1.353.699/CE, $2^{\mathrm{a}}$ Turma, rel. Min. Herman Benjamin, j. 19.02.2013, DJe, de 07.03.2013). "No tocante à questão referente à não aplicação retroativa da nova orientação desta Corte, a Primeira SeçãoSTJ, ao apreciar os EREsp 738.689/PR (Rel. Min. Teori Albino Zavascki, DJ de 22.10.2007), firmou orientação no sentido de que, 'salvo nas hipóteses excepcionais previstas no art. 27 da Lei 9.86899, é incabível ao Judiciário, sob pena de usurpação da atividade legislativa, promover a 'modulação temporal' de suas decisões, para o efeito de dar
} 
Espera-se que, com a constante utilização prática da técnica de julgamento de recursos especiais repetitivos, o entendimento do STJ venha a mudar, para admitir, ainda que em situações excepcionais, a modulação dos efeitos de seus precedentes, pelo menos aqueles formados nos termos do artigo 543-C do CPC, até porque, como bem sintetizado por Luiz Guilherme Marinoni, essa corte, "para dar cumprimento a sua missão constitucional de dar unidade ao direito federal, tem o dever de utilizar a técnica da limitação dos efeitos retroativos, como todo tribunal que, ao decidir, fixa normas que orientam a conduta dos jurisdicionados, dando-lhes previsibilidade para trabalhar e viver". 591

\subsection{Cabimento de ação rescisória (art. 485, inc. V, do CPC) em face de decisões contrárias ao acórdão que define a controvérsia}

$\mathrm{O}$ artigo 485, V do CPC prevê a possibilidade de rescisão da sentença de mérito transitada em julgado quando, entre outras hipóteses, ocorrer violação à "literal disposição de lei".

Buscando atribuir um significado à literal disposição de lei, a Súmula 343 do STF dispõe que "não cabe ação rescisória por ofensa a literal dispositivo de lei, quando a decisão rescindenda se tiver baseado em texto legal de interpretação controvertida nos tribunais" ${ }^{592}$. Ou seja, se a lei vem sendo interpretada de várias formas pela própria

eficácia prospectiva a preceitos normativos reconhecidamente revogados'. Agravo regimental desprovido." (STJ - AgR REsp n. 1.089.940BA, $1^{\mathrm{a}}$ Turma, rel. Min. Denise Arruda, DJe, de 04.05.2009). "Esta Corte, ao interpretar o art. 27 da Lei 9.86899, entendeu que compete exclusivamente ao Supremo Tribunal Federal a modulação dos efeitos da declaração de inconstitucionalidade de ato normativo." (STJ - REsp n.1.184.895/MG, 2 2 Turma, rel. Min. Eliana Calmon, DJe, de 11.05.2010).

${ }^{591}$ MARINONI, Luiz Guilherme, Eficácia temporal da revogação da jurisprudência consolidada dos tribunais superiores, cit., p. 33.

${ }^{592}$ Essa Súmula veicula entendimento semelhante àquele previsto na Súmula 400, também do STF, segundo a qual: "Decisão que deu razoável interpretação à lei, ainda que não seja a melhor, não autoriza recurso extraordinário pela letra 'a' do art. 101, III, da Constituição Federal'. Admitir-se-ia, assim, a existência de mais de uma interpretação da lei federal, não cabendo recurso excepcional contra as respectivas decisões, nem, consequentemente, ação rescisória. Essa Súmula, cuja aplicação é voltada a matéria infraconstitucional, "tem sido objeto das mais acerbas críticas por prestigiar a possibilidade de remanescerem decisões variadas, oriundas da aplicação do mesmo texto de lei a situações idênticas" (WAMBIER, Teresa Arruda Alvim, Recurso especial, recurso extraordinário e ação rescisória, cit., p. 534). De fato, definir o sentido exato da lei federal representa nada menos que a principal função constitucional do STJ (Capítulo 3). Daí porque a aplicação dessa Súmula tem sido constantemente abandonada pela própria jurisprudência. 
jurisprudência, a decisão que acolhe uma dessas formas ao julgar o caso concreto não viola a disposição literal de lei, sendo incabível, portanto, a ação rescisória.

Pouco importa que a jurisprudência tenha posteriormente sido pacificada nos tribunais, pois o que vale é a existência de divergência no momento da decisão. Inversamente, quando não há divergência jurisprudencial a respeito do sentido da lei e a decisão adota interpretação diversa, caracteriza-se a violação à disposição literal, sendo cabível a ação rescisória, com fundamento no artigo 485, V, do CPC, para desconstituir a coisa julgada e permitir o rejulgamento da causa para aplicação da interpretação correta da norma.

É tranquilo o entendimento de que a Súmula 343 não se aplica quando a discussão refere-se à interpretação de normas constitucionais, caso em que pouco importa a existência de divergência jurisprudencial à época da decisão, sobretudo quando, posteriormente, o STF declara, no controle difuso ou concentrado, a inconstitucionalidade de determinada norma ${ }^{593}$. Nessa hipótese, a rescisória poderá ser manejada para ajustar a decisão à correta interpretação da Constituição Federal, cuja última palavra compete sempre ao STF. ${ }^{594}$

O mesmo não se passa em relação às questões sobre a interpretação da lei federal. A Súmula 343 continua a ser aplicada para vedar ações rescisórias contra decisões que adotam interpretação controvertida, pouco importando a posterior pacificação da matéria pelo STJ. Nesse sentido, em precedente datado de 2007, o STF deixou consignado que "não cabe ação rescisória, por ofensa a literal disposição de lei, quando a decisão rescindenda se tiver baseado em texto legal de interpretação controvertida (Súmula 343 do STF)". 595

\footnotetext{
${ }^{593}$ STF - ED RE n. 328.812/AM, Pleno, rel. Min. Gilmar Mendes, DJe, de 24.03.2008; STJ - EREsp n. 608.122/RJ, rel. Min. Teori Albino Zavascki, DJ, de 28.05.2007.
${ }^{594}$ Nesse sentido, a Súmula 27 do TRF3 dispõe: "É inaplicável a Súmula 343 do Supremo Tribunal Federal em ação rescisória de competência da Segunda Seção, quando implicar exclusivamente em interpretação do texto constitucional."

595 STF - AgR AI n. 625053 /SP, 1 ${ }^{\text {a }}$ Turma, rel. Min. Ricardo Lewandowski, j. 23.10.2007, DJe, de 13.11.2007. Na mesma linha, ver o seguinte precedente: STF - AgR AR n. 663.589 /DF, $1^{\mathrm{a}}$ Turma, rel. Min. Luiz Fux, j. 05.03.2013, DJe, de 18.03.2013.
} 
No mesmo sentido, o STJ vem entendendo que a Súmula 343 do STF continua a afastar o cabimento da ação rescisória com base no art. 485, V: "é firme a jurisprudência desta Corte no sentido de que a mera existência de divergência interpretativa sobre um determinado tema jurídico não é suficiente para ensejar o provimento de uma ação rescisória com base no art. 485, V, do CPC". 596

Ocorre que, como também demonstrado nos Capítulo 2 e 3, diante dos princípios da igualdade e da segurança jurídica, não há como conceber um sistema jurídico que compactue com decisões judiciais simultâneas e divergentes sobre a interpretação da mesma lei federal à luz de situações idênticas. Daí a função do Superior Tribunal de Justiça, que consiste justamente em unificar a interpretação do direito federal infraconstitucional no país, definindo a última e única interpretação possível a respeito dessas normas jurídicas, à luz de determinadas situações fáticas.

Nessa linha, Teresa Arruda Alvim Wambier defende veementemente a inconstitucionalidade da Súmula 343 do STF, também quanto às questões infraconstitucionais, com fundamento principalmente no princípio da igualdade. Se a jurisprudência, inicialmente vacilante, amadurece e se consolida com o tempo, isso significa que se alcançou o verdadeiro e único sentido da lei, que pode e deve ser aplicado ao caso concreto em sede de ação rescisória, a qual representa mais um instrumento de concretização da igualdade. ${ }^{597}$

Por tais razões, também entendemos que a existência da interpretação divergente à época da decisão não pode servir de fundamento para a manutenção de decisões que, baseadas na mesma lei, tratem desigualmente situações idênticas, ferindo o princípio da igualdade.

Apesar de ainda prevalecer o entendimento de que decisões proferidas em ambiente de divergência jurisprudencial não podem ser rescindidas com base no artigo 485, V, do

\footnotetext{
${ }^{596}$ STJ - AgR AREsp n. 109.474/DF, $1^{\text {a }}$ Turma, rel. Min. Arnaldo Esteves Lima, j. 05.09.2013, DJe, de 12.09.2013. E mais: "Ocorrência de divergência interpretativa acerca do assunto em causa, atraindo, ao caso sub examine, o enunciado da Súmula 343 do STF.” (STJ - AgR REsp n. 1.370.559RJ, 2ª Turma, rel. Min. Muro Campbell Marques, DJe, de 13.08.2013).

597 WAMBIER, Teresa Arruda Alvim, Recurso especial, recurso extraordinário e ação rescisória, cit., p. 521-543. No mesmo sentido: BUENO, Cassio Scarpinella, Curso sistematizado de direito processual civil, cit., v. 5, p. 381.
} 
CPC, verifica-se que, aos poucos, a aplicação da Súmula 343 em matéria de lei federal vai sendo flexibilizada.

No próprio STJ, por mais de uma vez, decidiu-se que a Súmula 343 deve em alguns casos ser aplicada com temperamento, sobretudo quando a jurisprudência da Corte Superior já se pacificou em sentido contrário ao adotado pela decisão rescindenda. ${ }^{598}$

Em precedente do ano de 2008, a partir de voto muito bem fundamentado do ministro Teori Albino Zavascki, a Primeira Turma do STJ afastou a aplicação da Súmula 343, justamente com base no princípio da igualdade e das funções constitucionais de nomofilaquia e uniformização da Corte Superior ${ }^{599}$, mas o acórdão foi objeto de embargos de divergência, os quais foram providos pela Primeira Seção do STJ, para se reconhecer a incidência da Súmula 343 ao caso. ${ }^{600}$

Como se vê, o tema é polêmico e extenso, de modo que, em respeito aos limites deste trabalho, levanta-se unicamente a seguinte questão: o acórdão paradigma do STF e do STJ, que julga os recursos representativos da controvérsia nos termos dos artigos 543-B e 543-C do CPC, gera algum efeito em relação ao cabimento da ação rescisória contra decisões contrárias à interpretação então definida por esses órgãos superiores?

\footnotetext{
598 "O dispositivo da Súmula 343 do Supremo Tribunal Federal deve ser interpretado com temperamentos." (STJ - EAR n. 368/BA, 1 a Seção, rel. Min. Francisco Peçanha Martins, j. 12.09.1995, DJ, de 23.10.1995). No mesmo sentido: STJ - AR n. 429/BA, 1 a Seção, rel. Min. Humberto Gomes de Barros, j. 13.12.1994, DJ, de 06.03.1995. Recentemente, a Quarta Turma do STJ anulou acórdão do TJRS que, com base na Súmula 343, impediu o prosseguimento de ação rescisória contra decisão baseada em antiga jurisprudência da Corte Superior. Conforme constou na notícia sobre o julgamento veiculada pelo próprio STJ, o voto do relator, ministro Luis Felipe Salomão, ressaltou que "a solução oposta, a pretexto de não eternizar litígios, perpetuaria injustiças [...] Definitivamente, não constitui propósito da Súmula 343 do Supremo Tribunal Federal (STF) a chancela da rebeldia judiciária" (Disponível em: <http:// www.stj.jus.br/ portal_stj/publicacao/ engine.wsp?tmp.area=398\&tmp.texto=111390>. Acesso em: 24 set. 2013).

599 “[...] a exemplo do que ocorreu no STF em matéria constitucional, justifica-se a mudança de orientação em relação à súmula 343/STF, para o efeito de considerar como ofensiva a literal disposição de lei federal, em ação rescisória, qualquer interpretação contrária à que lhe atribui o STJ, seu intérprete institucional. A existência de interpretações divergentes da norma federal, antes de inibir a intervenção do STJ (como recomenda a súmula), deve, na verdade, ser o móvel propulsor para o exercício do seu papel de uniformização. Se a divergência interpretativa é no âmbito de tribunais locais, não pode o STJ se furtar à oportunidade, propiciada pela ação rescisória, de dirimi-la, dando à norma a interpretação adequada e firmando o precedente a ser observado; se a divergência for no âmbito do próprio STJ, a ação rescisória será o oportuno instrumento para uniformização interna; e se a divergência for entre tribunal local e o STJ, o afastamento da súmula 343 será a via para fazer prevalecer a interpretação assentada nos precedentes da Corte Superior, reafirmando, desse modo, a sua função constitucional de guardião da lei federal." (STJ REsp n. 1.026.234DF, $1^{\text {a }}$ Turma, rel. Min. Teori Albino Zavascki, j. 27.05.2008, DJe, de 11.06.2008).
}

${ }^{600}$ STJ - EREsp n. 1.026.234/DF, $1^{\text {a }}$ Seção, rel. Min. Herman Benjamin, j. 13.05.2009, , de 25.05.2009. 
José Henrique Mouta Araújo defende que o sistema de repercussão geral e julgamento de recursos repetitivos, justamente por dar lugar a precedentes qualificados do STF e do STJ, justifica o abandono da Súmula 343 para, em nome da uniformização da jurisprudência e da concretização do princípio da isonomia, permitir o cabimento de ação rescisória por violação a literal disposição de lei contra os acórdãos contrários à jurisprudência da instância superior. ${ }^{601}$

Em relação ao STF, como já dito, é pacífico o entendimento de que a Súmula 343 não se aplica à interpretação das normas constitucionais. Logicamente, portanto, a formação do precedente (art. 543-B do CPC) sobre a interpretação da questão constitucional só confirmará a caracterização da hipótese do artigo 485, V, do CPC, em relação às decisões contrárias ao entendimento então consolidado, inclusive e sobretudo aquelas que, ao exercerem o juízo de retratação em sede de recursos extraordinários repetitivos sobrestados, mantiverem a divergência.

Por sua vez, quanto ao do STJ, entendemos que, de modo geral, o precedente formado nos termos do artigo 543-C do CPC justifica com maior força a flexibilização da Súmula 343, nos termos do entendimento da doutrina que defende ser inconstitucional a sua aplicação. É que aquele precedente gerará os mesmos efeitos da jurisprudência dominante do STJ sobre a questão, assim como ocorre quando determinada orientação vem a ser sumulada. Diante disso, ficará evidente a caracterização da hipótese do artigo 485, V, do CPC em relação às decisões contrárias a essa orientação, pouco importando se, na época em que proferidas, havia ou não divergência jurisprudencial.

Até aí, porém, a técnica de julgamento de recursos repetitivos não representa grande novidade em relação ao cabimento da ação rescisória, exceto no que diz respeito ao fato de que o julgamento dos recursos representativos da controvérsia gera, por si só, a jurisprudência dominante da corte.

De outro lado, na hipótese de recursos especiais repetitivos sobrestados, o acórdão do STJ que julga os recursos representativos da controvérsia, para formar precedente qualificado que seja inédito ou que supere o entendimento da jurisprudência até então dominante, pode representar uma novidade, em termos de cabimento da ação rescisória.

\footnotetext{
601 ARAÚJO, José Henrique Mouta, Processos repetitivos e o desafio do Judiciário: rescisória contra interpretação de Lei Federal, cit., p. 155.
} 
Isso porque, quanto aos recursos repetitivos sobrestados que veicularem tese favorável à que veio a ser firmada pelo STJ, embora o órgão julgador competente do tribunal de origem possa rever a decisão recorrida para eventualmente ajustá-la à orientação da instância superior, o próprio sistema admite a manutenção da divergência.

Nesse caso, de manutenção da divergência, embora a ação rescisória pudesse ser inadmissível num primeiro momento (em razão da conformidade da decisão com o entendimento até então dominante, ou da existência, até então, de divergência jurisprudencial, incidindo a Súmula 343), ela passará a ser perfeitamente cabível num segundo momento, diante da manutenção da divergência, à luz do entendimento consolidado do STJ a partir do julgamento do recurso-piloto.

De fato, na hipótese de juízo negativo de retratação, a manutenção da divergência pelo tribunal de origem representará o proferimento de nova decisão, já sob a vigência do precedente qualificado da instância superior. E essa nova decisão, se eventualmente transitar em julgado, será rescindível, por ter violado o sentido da lei federal fixado previamente (ou seja, no julgamento dos recursos representativos) pela jurisprudência dominante do STJ.

Essa é mais uma razão para que os tribunais locais apliquem o entendimento consolidado do STF e do STJ sobre a interpretação do direito federal: a manutenção da divergência gerará a possibilidade de cassação ou rescisão da decisão, contribuindo para um processo natural de descrédito dos órgãos que, sem razões relevantes, insistam em contrariar a jurisprudência dominante dos órgãos constitucionais encarregados de realizar a sua uniformização.

Com isso, fica claro, mais uma vez, que a técnica de julgamento de recursos repetitivos fortalece a jurisprudência do STF e do STJ e, com isso, atua para desestimular e corrigir a divergência jurisprudencial, contribuindo não só para a racionalização da atuação dos órgãos superiores frente à multiplicidade de recursos repetitivos, mas também para que os princípios da igualdade e da segurança jurídica (no sentido de previsibilidade) tenham maior efetividade no sistema jurídico pátrio. 


\section{RESULTADOS PRÁTICOS}

\subsection{Os números no Supremo Tribunal Federal e no Superior Tribunal de Justiça, após a aplicação da técnica de julgamento de recursos repetitivos}

Neste item, analisaremos, a partir dos dados estatísticos divulgados pelo STF e pelo STJ, se os números de recursos extraordinários e agravos de instrumento ou de admissão (art. 544, CPC) distribuídos e julgados por essas cortes, após a implementação da técnica de julgamento de recursos repetitivos, tem produzido efetivos resultados práticos em relação à almejada redução de processos. Advirta-se, desde já, que foram levados em consideração apenas os dados relativos a essas espécies de recursos, que são atingidas pela técnica sob estudo.

Diante da falta de dados estatísticos mais completos, não foram considerados outros fatores que eventualmente possam ter exercido influência sobre esses números de processos distribuídos e julgados. A análise baseou-se apenas nos números relativos aos anos anteriores e posteriores à positivação da técnica de julgamento por amostragem.

Iniciando pelo STF, a maior parte de processos distribuídos nessa Corte é composta pelos recursos extraordinários e agravos (agravos de instrumento até a Lei n. 12.322/2010 e agravo de admissão, a partir de então). Entre 1990 e 2013, esse grupo representou 90\% de todos os processos distribuídos, de forma que todas as demais classes são responsáveis por apenas $10 \% .^{602}$

Em 2006, foram distribuídos no STF 110.716 recursos extraordinários e agravos de instrumento, correspondendo a $95,27 \%$ de todos os processos que entraram na corte. Em 2007, ano em que entrou em vigor a sistemática da repercussão geral e do julgamento de recursos repetitivos pelo STF, esse número foi para 106.617, correspondendo a 94,40\% do total de feitos distribuídos.

\footnotetext{
602 Dados disponibilizados pelo STF em seu site na internet. Disponível em: <http://www.stf.jus.br/portal/cms/verTexto.asp?servico=estatistica\&pagina=REAIProcessoDistribuidoAno sAnteriores >. Acesso em: 07 out. 2013.
} 
Porém, a partir de 2008, o cenário começou a mudar sensivelmente. O total de recursos extraordinários e agravos caiu para 59.314, representando 88,70\% do total. E, de uma forma geral, os números vêm sendo constantemente reduzidos:

Tabela 1 - Recursos extraordinários e agravos de admissão distribuídos no STF e sua porcentagem em relação ao total de processos distribuídos (2009 a 2013)

\begin{tabular}{|c|c|c|}
\hline Ano & $\begin{array}{c}\text { Recursos } \\
\text { Extraordinários e } \\
\text { Agravos Distribuídos }\end{array}$ & \% do Total \\
\hline 2009 & 32.644 & 76,41 \\
\hline 2010 & 31.536 & 76,89 \\
\hline 2011 & 29.579 & 77,62 \\
\hline 2012 & 38.075 & 82,07 \\
\hline 2013 (até 12.09 .2013$)$ & 21.896 & 79,54 \\
\hline
\end{tabular}

Além da redução do número de recursos, tem também aumentado a produtividade, ou seja, a relação entre o número de julgados e distribuídos ${ }^{603}$. Em 2006, foram julgados 102.740 e distribuídos 110.716 recursos extraordinários e agravos de instrumento. Desde 2008, a produtividade vem aumentando sensivelmente:

Tabela 2 - Recursos extraordinários e agravos de admissão distribuídos e julgados pelo STF (2008 a 2013)

\begin{tabular}{|c|c|c|}
\hline Ano & Distribuídos & Julgados \\
\hline 2008 & 59.314 & 98.332 \\
\hline 2009 & 32.644 & 79.830 \\
\hline 2010 & 31.536 & 88.912 \\
\hline 2011 & 29.579 & 84.140 \\
\hline 2012 & 38.075 & 74.756 \\
\hline 2013 (até 02.09.2013) & 21.896 & 44.939 \\
\hline
\end{tabular}

${ }^{603}$ Estatísticas do STF - Processos protocolados, distribuídos e julgados por classe processual (Disponível em:

$<$ http://www.stf.jus.br/portal/cms/verTexto.asp?servico=estatistica\&pagina=pesquisaClasseAnosAnteriores >. Acesso em: 07 out. 2013). 
No âmbito do STJ, apesar da ausência de repercussão geral, os resultados também foram expressivos ${ }^{604}$. Vejamos inicialmente a relação entre os números de recursos especiais e agravos de instrumento distribuídos e julgados de 2002 a 2007 :

Tabela 3 - Recursos especiais e agravos de admissão distribuídos e julgados pelo STJ (2002 a 2007)

\begin{tabular}{|c|c|c|c|c|}
\hline \multirow{2}{*}{ Ano } & \multicolumn{2}{|c|}{ Recursos Especiais } & \multicolumn{2}{c|}{ Agravos de admissão } \\
\cline { 2 - 5 } & Distribuídos & Julgados & Distribuídos & Julgados \\
\hline 2002 & 82.782 & 80.555 & 55.820 & 53.537 \\
\hline 2003 & 126.473 & 100.096 & 80.062 & 72.968 \\
\hline 2004 & 105.716 & 90.944 & 84.490 & 86.908 \\
\hline 2005 & 93.353 & 104.918 & 82.500 & 86.294 \\
\hline 2006 & 97.835 & 85.659 & 100.279 & 91.897 \\
\hline 2007 & 104.219 & 91.851 & 153.619 & 133.443 \\
\hline
\end{tabular}

A partir de 2008, lembrando que o artigo 543-C do CPC entrou em vigor em agosto, foram distribuídos 85.612 recursos especiais e julgados outros 106.984, dos quais 49,31\% foram providos. Quanto aos agravos de instrumento, foram distribuídos 135.983 e julgados outros 121.106 , dos quais $20,52 \%$ foram providos.

Note-se que já nesse primeiro ano de vigência do artigo 543-C, o número de recursos especiais e agravos de instrumento começou a cair. A redução foi de 17,8\% para os recursos especiais e $11,4 \%$ para os agravos.

Além disso, a produtividade também aumentou em relação ao ano anterior: diferentemente de 2007, o número de julgamentos superou significativamente o de distribuídos.

Vejamos agora o quadro relativo aos anos de 2008 a 2012:

\footnotetext{
604 Boletim Estatístico do Superior Tribunal de Justiça (Disponível em: <http://www.stj.jus.br/webstj/Processo/Boletim/Default.asp?ano=2001\&submit=Ok>. Acesso em: 09 out. 2013).
} 
Tabela 4 - Recursos especiais e agravos de admissão distribuídos e julgados pelo STJ (2008 a 2012)

\begin{tabular}{|c|c|c|c|c|}
\hline \multirow{2}{*}{ Ano } & \multicolumn{2}{|c|}{ Recursos Especiais } & \multicolumn{2}{c|}{ Agravos de Admissão } \\
\cline { 2 - 5 } & Distribuídos & Julgados & Distribuídos & Julgados \\
\hline 2008 & 85.612 & 106.984 & 135.983 & 121.106 \\
\hline 2009 & 75.600 & 71.470 & 162.836 & 137.583 \\
\hline 2010 & 54.596 & 69.797 & 119.517 & 131.379 \\
\hline 2011 & 70.422 & 62.488 & 160.684 & 128.040 \\
\hline 2012 & 55.672 & 65.556 & 175.571 & 160.883 \\
\hline
\end{tabular}

Note-se que o número de recursos especiais distribuídos em 2012 foi muito menor do que em 2002, dez anos antes. E, em relação a 2003, esse número chega a ser mais do que duas vezes menor. ${ }^{605}$

Quanto ao número de agravos de instrumento, embora ele ainda seja grande, isso pode se dever ao fato de que o STJ, até há bem pouco tempo, não devolvia aos tribunais de origem os recursos repetitivos (recursos especiais e agravos) enviados à instância superior após a instauração do procedimento do artigo 543-C do CPC, diferentemente, portanto, do que faz o STF desde 2007, por força do artigo 328, parágrafo único, do RISTF. Talvez esse quadro mude em razão da atual Resolução n. 17, de 04.09.2013, do STJ, cujo artigo $2^{\circ}$ prevê a devolução à origem de recursos repetitivos enviados ao STJ na pendência do julgamento dos recursos selecionados ou após esse julgamento.

De qualquer forma, observe-se que, comparando-se os dois períodos, de uma forma geral a produtividade aumentou, mesmo em relação ao julgamento de agravos de instrumento.

\footnotetext{
${ }^{605}$ A mesma tendência foi observada no primeiro semestre de 2013. Conforme notícia divulgada pelo STJ, em relação à Terceira Turma, "o número de processos decididos foi muito superior aos 17.489 novos casos distribuídos aos cinco ministros da Turma. Sanseverino cumprimentou os ministros e servidores pelo resultado alcançado, 'superando muitas vezes os limites das próprias forças"'. Por sua vez, também quanto ao primeiro semestre de 2013, o presidente da Quarta Turma afirmou o seguinte: "Presume-se que os filtros e triagens realizados pelo STJ estejam funcionando, bem como os recursos repetitivos. Baixamos mais decisões do que recebemos: 22.045." (Mais de 60 mil decisões de direito privado foram proferidas no primeiro semestre. Disponível em: <http://www.stj.jus.br/portal_stj/publicacao/engine.wsp?tmp.area=398\&tmp.texto=110205>. Acesso em: 26 jun. 2013).
} 
Outro dado interessante é a mudança no percentual de recursos especiais e agravos de instrumento ou admissão providos. Em 2006, foram providos 56,53\% dos recursos especiais e 19,51\% dos agravos. Em 2007, 54,37\% dos recursos especiais e 18,73\% dos agravos. Mas, a partir de 2008, embora ainda permaneçam altos, esses números começaram a reduzir. Em 2008, foram providos 49,31\% dos recursos especiais e 20,52\% dos agravos; em 2009, 38,60\% dos recursos especiais e 15,04\% dos agravos; em 2010, $39,37 \%$ dos recursos especiais e 14,77\% dos agravos; em 2011, 41,05\% dos recursos especiais e 21,93\% dos agravos em recurso especial; por fim, em 2012, 38,71\% dos recursos especiais e $8,79 \%$ dos agravos em recurso especial.

Isso talvez reflita a maior adesão, pelos órgãos de origem, ao entendimento consolidado pelo STJ no julgamento dos recursos representativos da controvérsia.

Obviamente, os números de recursos extraordinários e especiais, bem como de agravos de instrumento ou admissão, distribuídos e julgados, ainda são muito altos para órgãos de cúpula de dimensões reduzidas e compostos por tão poucos membros. ${ }^{606}$

No entanto, deve-se considerar que, do ponto de vista prático, e sob o aspecto do pretendido desafogamento do STF e do STJ, os resultados não são desprezíveis. O número de recursos vinha crescendo muito e, com a implementação da técnica, passaram a cair e produziram reflexos em relação à produtividade. Basta imaginar qual seria o número de recursos atualmente, se considerássemos a tendência de crescimento observada nos anos anteriores à implementação da técnica de julgamento por amostragem.

\subsection{O problema do tempo de duração do procedimento de julgamento de recursos repetitivos}

Apesar da relativa redução do número de recursos no STF e no STJ e do aumento da produtividade, não se pode deixar de apontar o problema da demora excessiva no julgamento dos recursos repetitivos, o que compromete, conforme exposto no Capítulo 8

\footnotetext{
${ }^{606}$ Conforme notícia publicada no Valor Econômico, edição de 24.08.2012, a técnica dos recursos repetitivos "ajudou a reduzir o volume de processos, mas ainda não se mostrou suficiente, como avalia o ministro Felix Fischer, de 65 anos, que assume a presidência do STJ daqui uma semana para um mandato de dois anos" (Disponível em: <http://www.aasp.org.br/aasp/imprensa/clipping/cli_noticia.asp?idnot=12764>. Acesso em: 10 dez. 2013).
} 
(item 8.2), a aptidão da técnica dos artigos 543-B e 543-C do CPC para dar efetividade ao princípio constitucional da razoável duração do processo.

Conforme dados obtidos a partir da realização do II Seminário Repercussão Geral em Evolução ${ }^{607}$, quando alguns tribunais forneceram material para a elaboração de estatísticas, do total de processos que aguardam sobrestados nos tribunais de origem, em razão da instauração do procedimento de julgamento de recursos extraordinários repetitivos (art. 543-B do CPC), 378 permanecem sobrestados por menos de seis meses; 1.698, de seis meses a um ano; 6.382, de um a dois anos; 5.024, de dois a três anos; e 22, mais de três anos. ${ }^{608}$

Ou seja, mais de $80 \%$ dos processos permanecem sobrestados por um período que varia de um a três anos.

Além disso, conforme artigo publicado em junho de 2013, cerca de $70 \%$ dos processos que tiveram repercussão geral conhecida ainda não foram julgados, acumulando 425.199 processos pendentes de julgamento. Fala-se, assim, na criação de um novo "gargalo processual", relativo aos inúmeros processos sobrestados aguardando o julgamento do mérito dos recursos extraordinários representativos da controvérsia, de modo que "é indispensável, para o aperfeiçoamento do instituto, a existência de outros mecanismos de aceleração processual, como a necessidade de imposição de prazos para julgamento, com trancamento da pauta, caso o processo não venha a ser julgado" ${ }^{609}$

Esse problema é apontado por José Miguel Garcia Medina, para quem "é grave, também, a situação decorrente da demora do julgamento de recursos especiais e extraordinários que observem tais técnicas". Segundo o autor, milhares de processos têm aguardado sobrestados por muitos anos a decisão da instância superior. Cita-se, como exemplo, o caso das diferenças de correção monetária de depósitos em caderneta de poupança, não bloqueados pelo Banco Central, por alegados expurgos inflacionários

\footnotetext{
${ }^{607}$ II Seminário Repercussão Geral em evolução. Disponível em: <http:// www.stf.jus.br/ arquivo/cms/ jurisprudenciaRepercussaoGeralRelatorio/anexo/Resultados_apresentados.pdf>. Acesso em: 12 out. 2013.

${ }^{608}$ Em percentuais, esses números equivalem, respectivamente a 2,8\%, 12,57\%, 47,26\%, 37,2\% e 0,16\% (CAMBI, Eduardo; NEVES, Aline Regina das, Repercussão geral e PEC 209/2012, cit., p. 193).

${ }^{609}$ Ibidem, p. 194.
} 
decorrentes do Plano Collor II, o qual acumula mais de 178 mil recursos aguardando decisão. ${ }^{610}$

Admitir que o julgamento leve anos para ocorrer, e que enquanto isso os processos repetitivos permaneçam sobrestados, representa utilizar a técnica de julgamento de recursos repetitivos como instrumento de paralisação institucionalizada da jurisdição, em afronta aos princípios do acesso à justiça e da razoável duração do processo.

É urgente, assim, que se crie prazo máximo para o julgamento, liberando-se o processamento normal dos recursos e processos sobrestados, caso ele não seja respeitado, tal como previsto no projeto de novo CPC (Capítulo 12).

\subsection{Quadro geral em relação aos procedimentos instaurados}

Até 13.10.2013, o site do STF indicava a instauração de 693 temas relativos a procedimentos de reconhecimento de repercussão geral. ${ }^{611}$

Desse total, 199 temas referiam-se a alguma questão relacionada a "direito tributário"; 227 temas, a "direito administrativo e outras matérias de direito público"; 32, a "direito civil"; 85, a "direito processual civil e do trabalho"; 36, a "direito do trabalho"; 16 temas, a "direito penal"; 27, a "direito processual penal"; 10, a "direito eleitoral e processo eleitoral"; 26, a "direito do consumidor"; e 31, a "direito previdenciário".

Note-se como a grande maioria dos temas refere-se a processos repetitivos envolvendo o próprio Estado (direito tributário, direito administrativo, direito público em geral), e parte significativa ( 85 temas, ou $12 \%$ ) a direito processual civil ou do trabalho.

\footnotetext{
${ }^{610}$ MEDINA, José Miguel Garcia, Justiça não pode ser medida apenas em números, cit.

611 Estatísticas do STF - Competência recursal e repercussão geral. Disponível em: $<$ http://www.stf.jus.br/portal/cms/verTexto.asp?servico=estatistica\&pagina=competenciarecursal $>$. Acesso em: 14 out. 2013 .
} 
Em 197 temas, reconheceu-se a inexistência de repercussão geral; 328 temas tiveram a repercussão geral reconhecida, mas se encontra pendente a apreciação do mérito; e apenas 152 tiveram seu mérito julgado.

O site do STF também informa o impacto da repercussão geral em relação aos processos repetitivos, por órgãos de origem. Ou seja, essa informação refere-se ao número de processos que foram atingidos pelos julgamentos definitivos de repercussão geral (decisões pela inexistência de repercussão geral e julgamentos de mérito proferidos em temas com repercussão geral reconhecida). Só no Tribunal de Justiça do Rio Grande do Sul foram impactados 44.530 processos, até 17.06.2013. Não há informações sobre todos os órgãos de origem, nem estão todas atualizadas, mas pelo total de informações prestadas até 24.09.2013, 119.994 processos tinham sido impactados nos tribunais de origem.

Por sua vez, quando aos feitos sobrestados, só no Tribunal de Justiça do Rio Grande do Sul, até 16.06.2013, eram 31.616 processos. E no Tribunal Regional Federal da $4^{\text {a }}$ Região, até 16.08.2012, outros 31.752 processos. Com a mesma ressalva do parágrafo anterior (ausência de informações atualizadas e sobre todos os órgãos de origem), o número total de processos sobrestados é de 385.487.

No âmbito do STJ, até 17.12.2012 haviam sido instaurados 527 procedimentos de julgamento de recursos repetitivos, sendo 430 julgados e 97 em tramitação. A grande maioria (336 instaurados, 284 julgados e 52 em tramitação) de competência da Primeira Seção, especializada em matérias de direito público. Em seguida, acumulava naquela data mais procedimentos a Segunda Seção (direito privado), com 82 instaurados, 57 julgados e 25 em tramitação e, por fim, a Terceira Seção (direito penal), com 47 instaurados, 40 julgados e 7 em tramitação. Por sua vez, os números relativos à Corte Especial eram os seguintes: 62 instaurados, 49 julgados e 13 em tramitação. ${ }^{612}$

Vale destacar ainda que o STJ disponibiliza em seu site um link intitulado "Recursos Repetitivos", com informações atualizadas sobre a situação dos procedimentos de recursos repetitivos. Além da descrição da questão federal objeto de discussão em cada

612 Boletim estatístico do Superior Tribunal de Justiça. Disponível em: < http:// www.stj.jus.br/webstj/Processo/ Boletim/?vPortalAreaPai=183\&vPortalArea=584>. Acesso em: 14 out. 2013. 
caso, esse quadro informa, entre outros, dados como quais são os recursos representativos da controvérsia selecionados, a data da "afetação", a eventual ocorrência de cancelamento da "afetação", o órgão fracionário julgador, o acesso ao acórdão paradigma e a data do seu trânsito em julgado. ${ }^{613}$

O sistema informa que 883 procedimentos já foram instaurados até hoje, mas 277 tiveram a afetação cancelada por diversas questões como, por exemplo, a verificação de a questão estar pendente de apreciação pelo STF (art. 543-B), com possibilidade de tornar prejudicado o recurso especial, e a alteração da competência interna do STJ por emenda regimental.

Os temas são variados, mas os relacionados a questões de direito tributário, direito previdenciário, direito administrativo e direito do consumidor (principalmente bancário e relacionados a serviços públicos concedidos pelo Poder Público, como energia elétrica e telecomunicações) representam a grande maioria. Questões de direito processual, civil e penal também justificaram a instauração de vários procedimentos.

Essa nova realidade do STF e do STJ revela que a técnica de julgamento de recursos repetitivos contribui para valorizar a função paradigmática desempenhada pelos recursos extraordinários e especiais. Basta notar que muitos desses temas e questões, embora já fizessem parte da jurisprudência dominante das Cortes Suprema e Superior, não tinham a projeção que hoje têm em razão do sistema previsto pelos artigos 543-B e 543-C do CPC, nem eram disponibilizados da forma organizada como se expôs acima.

A partir da consulta aos sites do STF e do STJ, é possível verificar facilmente se determinada questão já foi enfrentada em sede de recursos repetitivos. Em caso positivo, tem-se acesso ao inteiro teor de um acórdão que, pelo menos do ponto de vista teórico, deve ter qualidade superior aos precedentes que, até então, recebiam a qualificação de jurisprudência dominante da Corte.

Antes, a jurisprudência dominante sobre esses temas repetitivos era formada simplesmente a partir da repetição reiterada de inúmeras decisões no mesmo sentido, todas formadas em casos individuais, sem preocupação com a representatividade do caso, sem a

\footnotetext{
613 Superior Tribunal de Justiça - Recursos Repetitivos. Disponível em: <http://www.stj.jus.br/webstj/Processo/Repetitivo/relatorio_retorno.asp>. Acesso em: 14 out. 2013.
} 
possibilidade de participação de terceiros e sem a dedicação de maior tempo à apreciação das questões envolvidas.

Muitas vezes, as decisões não faziam mais do que copiar a anterior, sem uma devida reflexão sobre o tema e sua importância, prestigiando-se, de certa forma, a quantidade de decisões uniformes, mais do que a própria qualidade do enfrentamento da questão.

Isso dificultava até mesmo a pesquisa sobre a jurisprudência dominante, condicionada à reunião de inúmeros precedentes no mesmo sentido, não sendo incomum encontrar algum precedente em sentido contrário, fruto de julgamentos isolados, sem atenção aos precedentes anteriores.

Hoje, com a técnica de julgamento por amostragem, a jurisprudência dominante sobre as questões repetitivas decorrem de um único precedente, proferido de forma presumidamente mais cuidadosa e aprofundada, eis que oficialmente destinado a resolver grande quantidade de feitos versando sobre idêntica questão de direito. Esse precedente é formado a partir da seleção de casos representativos da controvérsia e conta com a participação do Ministério Público e de terceiros (na qualidade de amicus curiae). Além disso, por se tratar de um julgamento único, os próprios ministros têm mais tempo para se dedicar à questão.

Formado o precedente, ele é disponibilizado a toda a sociedade como um indicador único, objetivo e qualificado do entendimento consolidado do STF e do STJ sobre a questão de direito federal constitucional e infraconstitucional. Aumenta-se, com isso, a previsibilidade e a possibilidade de julgamentos efetivamente iguais de questões iguais.

Poder-se-ia argumentar que, mesmo antes da técnica de julgamento de recursos repetitivos, já existia (como ainda existe) a possibilidade de sumulação do entendimento consolidado da corte. Ainda que meramente persuasiva, as súmulas têm essa virtude de compilar em um breve enunciado o entendimento sobre determinada questão, trazendo objetividade para a qualificação da jurisprudência como dominante. 
Ocorre que o critério para a formação das súmulas também é meramente quantitativo e, pior do que isso, elas têm a desvantagem de abstrair excessivamente o significado dos acórdãos relativos ao julgamento dos casos concretos que lhes deram origem. Com seus enunciados sintéticos, elas muitas vezes escondem as peculiaridades e os verdadeiros fundamentos desses julgamentos, cujos inteiros teores normalmente não são consultados, o que, conforme a experiência do sistema de common law, é essencial para fins da adequada aplicação de precedentes aos casos sucessivos (Capítulo 2).

Já os precedentes formados a partir do julgamento de recursos repetitivos são representados pelo inteiro teor dos respectivos acórdãos, o que, em princípio, deve contribuir para o desenvolvimento de uma cultura mais adequada de consulta aos precedentes.

Desse modo, vê-se que a técnica sob estudo contribui não só para a racionalização dos trabalhos desenvolvidos pelos integrantes do STF e do STJ, mas também para a efetiva ampliação da função uniformizadora ou paradigmática exercida por esses órgãos, prestigiando-se, com isso, também os princípios constitucionais da igualdade e da segurança jurídica.

\subsection{Consequências práticas em relação ao funcionamento dos Tribunais de origem e a criação dos Núcleos de Repercussão Geral e Recursos Repetitivos (NURER)}

Com a técnica de julgamento de recursos repetitivos, o papel dos órgãos e tribunais de origem mudou significativamente em relação ao processamento dos recursos extraordinários e especiais. Não basta, como antes, processar o recurso, apreciar sua admissibilidade e eventualmente enviar os autos ao STF ou ao STJ.

Fazem parte das atribuições desses órgãos a identificação da multiplicidade de recursos com idêntica controvérsia constitucional ou infraconstitucional (ainda que de forma concorrente com a instância superior - conforme Capítulo 7, item 7.2), a seleção adequada dos casos representativos e o sobrestamento de inúmeros casos repetitivos, até a definição da controvérsia. 
Além disso, com a instauração do procedimento pelo STF (e agora também pelo STJ, em razão da Resolução n. 17, de 04.09.2013), ou então por outro tribunal de origem, com a subsequente confirmação pela instância superior, inúmeros feitos repetitivos são devolvidos à origem para que permaneçam sobrestados, gerando um imenso contrafluxo de processos.

Depois, com o julgamento dos recursos representativos pelo STF ou pelo STJ, o tribunal de origem passa a ter que gerenciar a aplicação do precedente aos casos sobrestados, na forma dos artigos 543-B e 543-C do CPC, inclusive com a remessa dos recursos interpostos contra decisões divergentes às Câmaras ou Turmas competentes para o julgamento do recurso anterior, a fim de que seja realizado o juízo de retratação, gerando novo contrafluxo de processos.

Diante disso, por meio da Resolução n. 160, de 19 de outubro de 2012, o Conselho Nacional de Justiça (CNJ) disciplinou a criação do Núcleo de Repercussão Geral e Recursos Repetitivos (NURER) no Superior Tribunal de Justiça, Tribunal Superior do Trabalho, Tribunal Superior Eleitoral, Superior Tribunal Militar, Tribunais de Justiça dos Estados e do Distrito Federal e nos Tribunais Regionais Federais.

Entre suas atribuições, enumeradas no artigo $2^{\circ}$ da Resolução, estão a de uniformizar o gerenciamento dos processos submetidos à sistemática da repercussão geral e dos recursos repetitivos; monitorar os recursos dirigidos ao STF ou ao STJ, a fim de identificar controvérsias e subsidiar a seleção, pelo órgão competente, de um ou mais recursos representativos da controvérsia; manter e disponibilizar dados atualizados sobre os recursos sobrestados no tribunal; auxiliar os órgãos julgadores na gestão do acervo sobrestado; informar a publicação dos acórdãos dos recursos paradigmas e assegurar o encaminhamento dos processos sobrestados ao órgão julgador competente, para as providências previstas no $\S 3^{\circ}$ do artigo 543-B e nos incisos I e II do $\S 7^{\circ}$ do artigo 543-C do CPC; e elaborar, trimestralmente, relatório quantitativo dos recursos sobrestados.

Em suma, a ideia é que o órgão contribua para melhorar a gestão dos tribunais de origem em relação à aplicação da repercussão geral e da técnica de recursos repetitivos, monitorando os enviados ao STF ou ao STJ, identificando as controvérsias passíveis de dar ensejo à instauração do procedimento, auxiliando os órgãos competentes a selecionar 
adequadamente os recursos representativos das controvérsias, bem como mantendo e disponibilizando dados atualizados sobre os recursos sobrestados à espera da definição da controvérsia pela instância superior.

Conforme notícia divulgada em março de 2013 pelo site do $\mathrm{CNJ}$, dos trinta e sete tribunais (Tribunais Superiores, Tribunais Regionais Federais e Tribunais de Justiça) incumbidos da criação do Núcleo, onze haviam cumprido o prazo de 90 dias estipulado pelo artigo $1^{\circ}$ da Resolução ${ }^{614}$. Em setembro desse mesmo ano, trinta e um tribunais já haviam criado o NURER. ${ }^{615}$

No STJ, o NURER foi criado pela Resolução n. 2, de 14 de janeiro de 2013, sem qualquer regulamentação adicional diferente das que já constam na Resolução n. 160 do CNJ.

Por sua vez, a título de exemplo, o Tribunal de Justiça do Estado de São Paulo criou, por meio do Provimento n. 2.019/2012 do Conselho Superior da Magistratura, cinco Núcleos, vinculados à Presidência, à Vice-Presidência e a cada uma das três Seções especializadas (Direito Público, Direito Privado e Direito Criminal). A justificativa para a criação de cinco Núcleos, segundo o próprio Provimento, refere-se à "expressiva quantidade de processos, em especial nas Seções de Direito Público e de Direito Privado deste Tribunal, sobrestados ante repercussão geral já reconhecida pelo Supremo Tribunal Federal" e "expressiva quantidade de processos sobrestados devido a recursos repetitivos em trâmite no Superior Tribunal de Justiça".

Como resultado da instalação dos Núcleos no TJSP, pode-se citar a elaboração de dois relatórios trimestrais referentes a 2013, contendo tabela com o "quantitativo de

\footnotetext{
${ }^{614}$ Superior Tribunal de Justiça, Tribunal de Justiça do Estado do Amapá (TJAP), Tribunal de Justiça do Estado da Bahia (TJBA), Tribunal de Justiça do Estado do Espírito Santo (TJES), Tribunal de Justiça do Estado de Goiás (TJGO), Tribunal de Justiça do Estado de Minas Gerais (TJMG), Tribunal de Justiça do Estado de Mato Grosso (TJMT), Tribunal de Justiça do Estado do Rio de Janeiro (TJRJ), Tribunal de Justiça do Estado do Rio Grande do Sul (TJRS), Tribunal de Justiça do Estado de São Paulo (TJSP) e Tribunal Regional Eleitoral de Rondônia (TRE/RO) (Tribunais comunicam criação de núcleo para acompanhar recursos repetitivos. Disponível em: <http://www.cnj.jus.br/noticias/cnj/23789-maioria-dostribunais-ainda-nao-tem-nucleos-para-acompanhar-recursos-repetitivos>. Acesso em: 10 out. 2013).
}

615 Tribunais brasileiros criam núcleos de recursos repetitivos. Disponível em: <http://www.cnj.jus.br/noticias/cnj/26150-tribunais-brasileiros-criam-nucleos-de-recursos-repetitivos>.

Acesso em: 10 out. 2013. 
processos suspensos, sobrestados, baixados ou enviados para retratação correspondentes a cada tese, de matéria repetitiva, nos termos do artigo 543-C do CPC", 616

O quadro resumo do relatório relativo ao segundo trimestre demonstra que, em julho de 2013, em virtude da aplicação da sistemática de recursos repetitivos, existiam no TJSP mais de cem mil processos sobrestados ou suspensos (incluindo-se as suspensões em primeiro grau), e mais de dois mil processos com retratação realizada. Já quanto à aplicação da sistemática de repercussão geral, na mesma data havia mais de duzentos mil processos sobrestados ou suspensos, com retratação exercida em 166 casos.

As informações relativas à quantidade de processos sobrestados no TJSP, mencionadas exemplificativamente no item anterior, revela o impacto da técnica de julgamento de recursos repetitivos também em relação à atuação dos tribunais de origem, exigindo novas atividades dos órgãos julgadores incumbidos da apreciação da admissibilidade dos recursos excepcionais e posterior juízo de retratação, bem como a criação de novas unidades administrativas para o gerenciamento da seleção, do sobrestamento e, por fim, da aplicação do acórdão paradigma, nos termos dos artigos 543B e 543-C do CPC.

\footnotetext{
616 Superior Tribunal de Justiça $\quad-$ Recursos Repetitivos. Disponível em: <http://www.tjsp.jus.br/Download/pdf/Nurer/RecursosRepetitivos/STJEstatisticaSegundoTrimestre.pdf>. Acesso em: 10 out. 2013.
} 


\section{O PROJETO DE NOVO CÓDIGO DE PROCESSO CIVIL}

\subsection{O estágio atual do projeto}

Pelo Ato n. 379, de 30 de setembro de 2009, o Senado Federal criou uma Comissão de Juristas para Elaboração de um Novo Código de Processo Civil. Além de outros dez integrantes, a Comissão teve como presidente o atual ministro do STF Luiz Fux e como relatora a professora Teresa Arruda Alvim Wambier.

O anteprojeto criado pela referida Comissão tramitou no Senado Federal como Projeto de Lei do Senado (PLS) n. 166/2010 e, após sua aprovação com modificações, foi enviado à Câmara dos Deputados, sendo autuado como Projeto de Lei (PL) n. 8.046/2010.

Na Câmara, instaurou-se Comissão Especial presidida pelo deputado Fábio Trad e que teve como relator geral o deputado Paulo Teixeira. Após inúmeras audiências e contribuições de todos os setores de sociedade ${ }^{617}$, foram inseridas modificações aprovadas pela referida Comissão em 17 de julho de 2013. Esse texto recebeu, ainda, modificações oriundas das chamadas emendas aglutinativas, resultando em texto final que foi aprovado no final de 2013, mas que ainda aguarda discussão e aprovação de destaques. Esta é a última versão do projeto, e na qual nos baseamos para a realização dos comentários inseridos ao longo deste trabalho e, em especial, no presente capítulo. ${ }^{618}$

Caso seja aprovada pelo Plenário da Câmara, o PL n. 8.046/2010 ainda terá de retornar ao Senado Federal para aprovação, em virtude das modificações realizadas.

\footnotetext{
617 “Todavia, não se poderá questionar o caráter democrático desse projeto, pois, ao longo destes quatro anos de intensos e profícuos debates, foram ouvidas instituições do sistema de Justiça, acadêmicos, operadores do Direito e a sociedade civil como um todo. Por exemplo, apenas na Câmara dos Deputados, foram realizadas 15 audiências públicas, 13 conferências estaduais, foram ouvidos mais de 140 palestrantes, o portal e-democracia registrou 25.300 acessos, 282 sugestões, 143 comentários e 90 emails. Ou seja: todos participaram ou tiveram ampla oportunidade de participação.” (WAMBIER, Teresa Arruda Alvim et al. O novo CPC dará maior racionalidade ao sistema de Justiça. Por Teresa Arruda Alvim Wambier, Alexandre Freire, Bruno Dantas e Marcelo Guedes Nunes. Migalhas, jul. 2013. Disponível em: <http://www.migalhas.com.br/dePeso/16,MI182384,41046-

O+novo+CPC+dara+maior+racionalidade+ao+sistema+de+Justica>. Acesso em: 14 out. 2013). 618 


\subsection{Valorização da jurisprudência}

Um dos principais aspectos do CPC projetado diz respeito à positivação de regras voltadas à valorização da jurisprudência ${ }^{619}$. Na verdade, pode-se afirmar que o texto institui e regulamenta um novo sistema de precedentes no nosso direito processual, estabelecendo de forma expressa uma série de princípios e regras cujo objetivo é disciplinar a formação e a aplicação de precedentes judiciais no julgamento de casos sucessivos.

Tanto é assim que os artigos 520 a 522 estão reunidos em capítulo intitulado "Do precedente judicial", estabelecendo-se, logo no primeiro dispositivo, que "os tribunais devem uniformizar sua jurisprudência e mantê-la estável, íntegra e coerente".

O artigo 521 estabelece as regras que, segundo seu caput, devem ser observadas para a uniformização da jurisprudência e efetivação dos "princípios da legalidade, da segurança jurídica, da duração razoável do processo, da proteção da confiança e da isonomia", ou seja, todos aqueles relacionados à valorização da jurisprudência que mencionamos no Capítulo 2.

Em resumo, essas regras exprimem o dever de observância da jurisprudência ou dos precedentes do STF, do STJ e dos demais tribunais, conforme o caso. Isso significa, segundo o $\S 7^{\circ}$, a necessidade de observância "dos fundamentos determinantes adotados pela maioria dos membros do colegiado, cujo entendimento tenha ou não sido sumulado", pelo que fica claro que a vinculação refere-se a algo equivalente à ratio decidendi, e não ao dispositivo ou a qualquer fundamento mencionado pelo precedente a ser observado. Assim, o $\S 8^{\circ}$ exclui da vinculação os fundamentos prescindíveis para o alcance do resultado fixado no dispositivo e "não adotados ou referendados pela maioria dos membros do órgão julgador, ainda que relevantes e contidos no acórdão".

\footnotetext{
619 "Merece destaque a disciplina que o projeto do novo CPC conferiu à regra do precedente judicial. Percebe-se que o texto se preocupou em detalhar pormenores a respeito do procedimento para alteração dos julgados consolidados pelas cortes, assim como prescreveu a necessidade de orientação dos juízos inferiores pelas decisões proferidas pelos tribunais de superposição.” (WAMBIER, Teresa Arruda Alvim et al., O novo CPC dará maior racionalidade ao sistema de Justiça, cit.).
} 
Conforme os incisos do artigo 521, além do grau hierárquico do órgão do qual emanou o precedente, a sua natureza também influi no seu grau de vinculação: primeiro, "as decisões e os precedentes do Supremo Tribunal Federal em controle concentrado de constitucionalidade"; depois, "os enunciados de súmula vinculante, os acórdãos e os precedentes em incidente de assunção de competência ou de resolução de demandas repetitivas e em julgamento de recursos extraordinário e especial repetitivos" (destaque nosso); em seguida, "os enunciados das súmulas do Supremo Tribunal Federal em matéria constitucional, do Superior Tribunal de Justiça em matéria infraconstitucional, e dos tribunais aos quais estiverem vinculados, nesta ordem"; por fim, os precedentes "do plenário do Supremo Tribunal Federal em controle difuso de constitucionalidade" e "da Corte Especial do Superior Tribunal de Justiça, em matéria infraconstitucional”.

$\mathrm{O} \S 1^{\mathrm{o}}$ do artigo 521 estabelece a forma de modificação do entendimento jurisprudencial sedimentado (equivalente ao overruling do common law): procedimento de revisão ou cancelamento de súmula vinculante (Lei n. 11.417/2006), procedimento regulamentado em cada regimento interno, quanto às súmulas da jurisprudência dominante (súmulas persuasivas) e incidentalmente, no julgamento de recursos ou remessas necessárias, nas demais hipóteses.

Como prevê o $\S 2^{\circ}$, essa modificação da jurisprudência pode fundar-se, entre outros argumentos, "na revogação ou modificação de norma em que se fundou a tese ou em alteração econômica, política ou social referente à matéria decidida”. Ou seja, basicamente nas mesmas razões que autorizam, no common law, a realização do overruling.

Estabelece-se, ainda, a possibilidade de "audiências públicas e da participação de pessoas, órgãos ou entidades que possam contribuir para a rediscussão da tese" no procedimento de modificação $\left(\S 3^{\circ}\right)$, bem como a competência do órgão responsável pela superação do precedente, quando este emanar de julgamento em incidente de assunção de competência ou resolução de demandas repetitivas, e em julgamento de recursos extraordinários e especiais repetitivos: preferencialmente o mesmo órgão que tiver firmado a tese a ser rediscutida $\left(\S 4^{\circ}\right)$. 
$\mathrm{O} \S 5^{\circ}$ prevê expressamente a possibilidade de modulação dos "efeitos da decisão que supera o entendimento anterior, limitando a sua retroatividade ou lhe atribuindo efeitos prospectivos", na linha do que defendemos no Capítulo 10 (item 10.7).

Por sua vez, o artigo 521, § $9^{\circ}$, também regulamenta a hipótese de distinguishing, facultando a não observância do precedente ou da jurisprudência "quando o órgão jurisdicional distinguir o caso sob julgamento, demonstrando fundamentadamente se tratar de situação particularizada por hipótese fática distinta ou questão jurídica não examinada, a impor solução jurídica diversa".

Por fim, o artigo 522 esclarece que o "julgamento de casos repetitivos", referente a decisão proferida em incidente de resolução de demandas repetitivas ou recursos especial ou extraordinário repetitivo, pode ter por objeto questão de direito material ou processual.

Apesar de sugerir o efeito vinculante de todas as decisões judiciais em relação aos órgãos inferiores, a previsão do cabimento de reclamação para "garantir a observância de súmula vinculante e de tese firmada em julgamento de casos repetitivos ou de incidente de assunção de competência” (art. 1.000, IV), mas não para garantir a observância de outros precedentes, parece indicar que só nessas hipóteses haverá verdadeira vinculação. Note-se, a esse respeito, que o novo CPC institui o efeito vinculante da "tese firmada em julgamento de casos repetitivos", o que suscitará questões a respeito da sua constitucionalidade (ver Capítulos 2 e 6).

Nem por isso a previsão da necessidade de observância dos precedentes e da jurisprudência nas demais hipóteses mencionadas pelo artigo 521 será inútil. É que, segundo o artigo 499, § $1^{\circ}$, V e VI, não se considera fundamentada a decisão que "se limitar a invocar precedente ou enunciado de súmula, sem identificar seus fundamentos determinantes nem demonstrar que o caso sob julgamento se ajusta àqueles fundamentos" e que deixar de seguir "enunciado de súmula, jurisprudência ou precedente invocado pela parte, sem demonstrar a existência de distinção no caso em julgamento ou a superação do entendimento". Na mesma linha, para o CPC projetado, considera-se omissa a decisão que "deixe de se manifestar sobre tese firmada em julgamento de casos repetitivos ou em incidente de assunção de competência aplicável ao caso sob julgamento", hipótese em que será cabível a oposição de embargos de declaração (art. 1.035, parágrafo único, I). 
Ou seja, caso seja mal aplicado ou ignorado o precedente ou a jurisprudência, a decisão será nula por efeito ou falta de fundamentação, ficando claro, com isso, a maior valorização que efetivamente se pretende dar a esses institutos.

\subsection{Manutenção e aperfeiçoamento do sistema de julgamento de recursos repetitivos}

Especificamente quanto ao sistema de julgamento de recursos extraordinários e especiais repetitivos, a versão atual do projeto deixa clara a intenção de sua manutenção e aperfeiçoamento, o que, aliado à grande aceitação dessa técnica pela jurisprudência do STF e do STJ, parece indicar a sua consolidação no direito processual brasileiro.

Nesse sentido, além dos comentários já realizados no decorrer de cada capítulo, em relação às alterações previstas para cada fase do procedimento de julgamento de recursos repetitivos, passamos a analisar de forma geral como a técnica está regulamentada na versão atual do projeto de novo CPC.

O capítulo destinado aos "Recursos para o Supremo Tribunal Federal e para o Superior Tribunal de Justiça" está dividido em quatro seções, que tratam, nesta ordem, "Do recurso ordinário", "Do recurso extraordinário e do recurso especial", "Do agravo de admissão" e "Dos embargos de divergência".

A Seção II abarca duas subseções, uma para regulamentar as "disposições gerais" sobre os recursos extraordinários e especiais e a outra para tratar, de forma também unificada, "Do julgamento dos recursos extraordinário e especial repetitivos" (arts. 1.049 a 1.054).

A primeira novidade, portanto, é a unificação das regras sobre o processamento e julgamento do mérito dos recursos extraordinário e especiais repetitivos, mantendo-se apartada a regulamentação da tramitação dos recursos extraordinários repetitivos antes de definida a repercussão geral, matéria que é objeto do artigo $1.048, \S \S 5^{\circ}$ a 11.

O artigo 1.049 prevê que "sempre que houver multiplicidade de recursos com fundamento em idêntica questão de direito, o recurso extraordinário ou especial será 
afetado para julgamento de acordo com os termos desta Subseção, observado o disposto no regimento interno do Supremo Tribunal Federal e do Superior Tribunal de Justiça". Buscando evitar confusões a respeito da verdadeira questão objeto do julgamento, o artigo 1.050 , I e $\S 2^{\circ}$ estabelece que a decisão de afetação "identificará com precisão a questão a ser submetida a julgamento", e veda ao órgão colegiado decidir questão não delimitada.

$\mathrm{O}$ artigo $1.049, \S \S 1^{\circ}$ e $5^{\circ}$, mantém a sistemática atual quanto à competência concorrente do órgão a quo e do próprio STF ou STJ para a instauração do procedimento (Capítulo 7). Corrigiu-se a impropriedade do atual artigo 543-C, $\S 1^{\circ}$, (que especifica a Presidência do Tribunal de origem, quando a Vice-presidência também é competente para a admissibilidade dos recursos excepcionais - art. 541), mencionando-se o "presidente ou vice-presidente", mas manteve-se a referência a "Tribunal de Justiça ou Tribunal Regional Federal" e ao "tribunal de origem", que são equivocadas, porque no caso de recurso extraordinário a decisão pode não ser de "tribunal" (melhor seria, aqui, falar em órgão de origem).

A respeito da seleção dos recursos representativos da controvérsia (Capítulo 7), a serem enviados ao STF ou STJ, o artigo 1.049, $\S \S 1^{\circ}$ e $5^{\circ}$, abandona a atual expressão "um ou mais recursos" (arts. 543-B, $\S 1^{\circ}$, e $543-\mathrm{C}, \S 1^{\circ}$ ), e passa a impor a escolha de mais de um, ao se referir a "dois ou mais recursos representativos da controvérsia".

Alguns requisitos para a seleção do recurso representativo, que já são atualmente exigidos pela jurisprudência, passam a ser expressamente mencionados pelo artigo 1.049, § $6^{\text {o: }}$ "Somente podem ser selecionados recursos admissíveis que contenham abrangente argumentação e discussão a respeito da questão a ser decidida”.

Sobre o sobrestamento, as novas regras passam a estabelecer o que hoje já é admitido pela jurisprudência: o sobrestamento dos processos em primeiro e segundo grau, e no tribunal superior (Capítulo 8).

Considerando-se que, independentemente de previsão, essa ampliação da eficácia do sobrestamento já representa uma realidade, a disciplina da matéria pelos artigos 1.049, § $1^{\circ}$, e 1.050, II, que preveem a suspensão de todos os processos pendentes, merece aplausos, 
inclusive porque: limita-se a suspensão ao prazo máximo de um ano, devendo prosseguir normalmente o feito após esse período (art. 1.050, $\S \S 3^{\circ}$ e $4^{\circ}$ ); e prevê-se a necessidade de intimação das partes que têm seu processo sobrestado em qualquer instância, com a possibilidade de interposição, conforme o caso, de agravo de instrumento ou agravo interno para apontar a distinção da controvérsia (arts. 1.050, $\S 8^{\circ}, 9^{\circ}$ e 13 ).

Ou seja, fixa-se prazo máximo para o sobrestamento e regulamenta-se a possibilidade de interposição de recurso (agravo de instrumento ou interno, conforme se esteja em primeiro grau, ou então em grau de recurso), combatendo-se a interpretação restritiva atualmente empregada pelo STF e STJ sobre essas questões.

Ainda sobre o sobrestamento, o artigo 1.049, § $2^{\circ}$, deixa claro que os recursos intempestivos não poderão ser suspensos, devendo ser desde logo inadmitidos, permitindose, inclusive, que a parte interessada impugne por "agravo extraordinário" eventual decisão que, ignorando a intempestividade, determine o sobrestamento. Ao mesmo tempo, depreende-se dessa regra que, excetuando-se a tempestividade, a aferição dos demais requisitos de admissibilidade dos recursos sobrestados só ocorrerá na hipótese de manutenção da divergência, pelo que se deduz que a determinação de suspensão impede a negativa de seguimento ao recurso antes do julgamento dos recursos representativos da controvérsia.

Sobre a participação de terceiros (Capítulo 9), fica mantida a regra sentido de que “considerando a relevância da matéria e consoante dispuser o regimento interno, o relator poderá solicitar ou admitir manifestação de pessoas, órgãos ou entidades com interesse na controvérsia" (art. 1.051, § $2^{\circ}$ ).

Infelizmente, não se previu qualquer procedimento ou incidente prévio voltado à efetiva ampliação da participação dos que tiveram seu recurso sobrestado, na forma sugerida por nós no Capítulo 9 (item 9.2.4). Em contrapartida, o $§ 4^{\circ}$ do artigo 1.051 prevê que "para instruir o procedimento, pode o relator fixar data para, em audiência pública, ouvir depoimentos de pessoas com experiência e conhecimento na matéria", com o que se pretende ampliar a realização do contraditório coletivo e aumentar a legitimidade e representatividade do precedente a ser formado. 
Outra regra que amplia a legitimidade e representatividade do acórdão que julga os recursos representativos da controvérsia é a do artigo $1.051, \S 5^{\circ}$, que é imperativo ao estipular que "o conteúdo do acórdão abrangerá a análise de todos os fundamentos suscitados à tese jurídica discutida, favoráveis ou contrários”. Não bastam, portanto, os fundamentos suficientes, o que condiz com a finalidade do precedente, de não apenas resolver o caso concreto, mas sim de fixar tese que influenciará o julgamento de inúmeros casos repetitivos.

Também é inovadora a regra do $\S 6^{\circ}$ do mesmo artigo, segundo a qual "se o recurso tiver por objeto questão relativa a prestação de serviço concedido, permitido ou autorizado, o resultado do julgamento será comunicado ao órgão ou à agência reguladora competente para fiscalização do efetivo cumprimento da decisão por parte dos entes sujeitos a regulação". Visa-se, com isso, estimular o próprio Estado, maior responsável pelos processos repetitivos (conforme Capítulo 4, item 4.6), a respeitar a interpretação definitiva da norma de direito federal, com isso reduzindo a quantidade de recursos e de casos futuros envolvendo a mesma controvérsia.

Sobre os efeitos do precedente, os artigos 1.052 e 1.053 praticamente mantêm as regras atualmente em vigor, estudadas no Capítulo 10.

Nesse sentido, fica estabelecido o seguinte: “os órgãos colegiados declararão prejudicados os demais recursos versando sobre idêntica controvérsia ou os decidirão aplicando a tese" (art. 1.052 caput); "negada a existência de repercussão geral no recurso extraordinário afetado e no representativo da controvérsia, considerar-se-ão automaticamente inadmitidos os recursos extraordinários cujo processamento tenha sido sobrestado (art. 1.052, parágrafo único); “o presidente ou vice-presidente do tribunal de origem negará seguimento aos recursos especiais ou extraordinários sobrestados na origem não terão seguimento, se o acórdão recorrido coincidir com a orientação do tribunal superior” (art. 1.053, I); “o órgão que proferiu o acórdão recorrido, na origem, reexaminará a causa de competência originária, a remessa necessária ou o recurso anteriormente julgado, na hipótese de o acórdão recorrido contrariar a orientação do tribunal superior" (art. 1.053, II).

Note-se que, além da sistematização mais adequada da matéria, foi corrigido o erro de redação constante no atual artigo 543-C, $\S 7^{\circ}$, II, segundo o qual caberia ao tribunal de 
origem novamente examinar "os recursos especiais sobrestados na origem”. Fica claro, assim que, em caso de divergência entre o acórdão recorrido e a orientação do tribunal superior, o que será reexaminado pelo tribunal de origem é "a causa de competência originária, a remessa necessária ou o recurso anteriormente julgado”.

A título de novidade quanto a esse ponto, tem-se que, considerando-se o sobrestamento também dos processos em primeiro e segundo graus, a publicação do acórdão paradigma implica a sua retomada, para julgamento e aplicação da tese firmada (art. 1.053, III).

Além disso, o tribunal de origem só pode manter a divergência "quando o órgão jurisdicional distinguir o caso sob julgamento, demonstrando fundamentadamente se tratar de situação particularizada por hipótese fática distinta ou questão jurídica não examinada, a impor solução jurídica diversa" (art. 1.053, § $1^{\circ} \mathrm{c} / \mathrm{c}$ art. 521, § $9^{\circ}$ ), ou seja, apenas em caso de distinguishing, sugerindo vinculação do precedente qualificado formado pelo julgamento dos recursos representativos da controvérsia (o que é confirmado pela previsão de cabimento de reclamação contra as decisões que desrespeitem tese firmada em julgamento de casos repetitivos, conforme o art. 1.000, IV).

Por sua vez, o artigo 1.053, § $3^{\circ}$, prevê que "realizado o juízo de retratação, com alteração do acórdão divergente, o tribunal de origem, se for o caso, decidirá as demais questões antes não decididas cujo enfrentamento se tornou necessário em decorrência da alteração". Isso confirma, conforme expusemos no Capítulo 10, que ocorre aqui a devolução ao órgão originário da apreciação das questões repetitivas na extensão e profundidade regulamentadas pelo atual artigo $515, \S \S 1^{\circ}$ e $2^{\circ}$ do CPC.

Segundo o artigo 1.054 e seus parágrafos, as partes que tiveram seus processos sobrestados em primeiro grau poderão, desde que o façam antes da sentença, desistir da ação, independentemente do consentimento do réu. E, se o fizerem antes da contestação, ficarão isentas de custas e honorários advocatícios.

Importante novidade é a prevista no artigo $1.055, \S 1^{\circ}$, II, inserido na Seção III, que trata do "agravo extraordinário". Segundo essa norma, as partes poderão interpor agravo contra a decisão que negar seguimento aos seus recursos com base em decisão do STF que 
reconhece a inexistência de repercussão geral ou em decisão do STF ou STJ que julgar recursos representativos da controvérsia em sede de procedimento de apreciação de recursos repetitivos.

A norma apenas condiciona o conhecimento do agravo de admissão à demonstração expressa da existência de distinção entre o caso em análise e o precedente invocado (distinguishing) ou superação da tese (overruling), o que é saudável, pois do contrário essa insurgência tenderia a ser meramente protelatória.

Note-se que, ao regulamentar o cabimento do agravo nessa hipótese, o dispositivo também passa a deixar claro que a decisão que nega seguimento ao recurso extraordinário ou especial com base em "entendimento firmado em julgamento de casos repetitivos por tribunal superior" tem, para os efeitos da lei, natureza de juízo de admissibilidade, como defendemos no Capítulo 6 (item 6.3).

Quanto à desistência dos recursos selecionados, o projeto também inova, ao estabelecer em seu artigo 1.011, parágrafo único, que "a desistência do recurso não impede a análise de questão cuja repercussão geral já tenha sido reconhecida e daquela objeto de julgamento de recursos extraordinários ou especiais repetitivos". Ou seja, admite-se a desistência e permite-se o prosseguimento do procedimento destinado à fixação da tese, tal como sugerido pela maior parte da doutrina (ver Capítulo 7, item 7.4).

Por fim, deve-se destacar que o projeto prevê uma série de regras que ampliam expressamente a eficácia do precedente formado pelo julgamento dos recursos representativos da controvérsia em relação a outros processos, com o fim de acelerar o procedimento e trazer maior uniformidade de decisões versando sobre questões idênticas.

Assim, o artigo $12, \S 2^{\circ}$, II, permite que se quebre a ordem cronológica de conclusão para proferimento de sentença e acórdão no caso de "julgamento de processos em bloco para aplicação da tese jurídica firmada em julgamento de casos repetitivos"; o artigo 306, II, permite a concessão de tutela antecipada de evidência quando "houver tese firmada em julgamento de casos repetitivos"; o artigo 333, II, viabiliza a declaração da improcedência prima facie de ação repetitiva contendo pedido que "contrariar acórdão proferido pelo Supremo Tribunal Federal ou pelo Superior Tribunal de Justiça em 
julgamento de recursos repetitivos"; o artigo 507, § $3^{\circ}$, II, dispensa a remessa necessária quando a sentença estiver fundada em "acórdão proferido pelo Supremo Tribunal Federal ou pelo Superior Tribunal de Justiça em julgamento de recursos repetitivos"; o artigo 535, III, dispensa a caução em execução provisória quando "a sentença a ser provisoriamente cumprida estiver em consonância com a súmula da jurisprudência do Supremo Tribunal Federal ou do Superior Tribunal de Justiça ou em conformidade com acórdão proferido no julgamento de casos repetitivos"; os artigos 945, IV, “b”, e V, “b”, e 967, II, autorizam o julgamento monocrático de recursos e conflitos de competência para aplicação de tese firmada no julgamento de recursos repetitivos.

\subsection{A proposta de instituição de um novo "incidente de resolução de demandas repetitivas"}

O projeto de novo CPC não só mantém a técnica de julgamento por amostragem de recursos repetitivos pelo STF e pelo STJ, como pretende ampliá-la, para permitir a aplicação de técnica semelhante em relação aos processos em primeiro grau.

Trata-se do "incidente de resolução de demandas repetitivas" regulamentado pelos artigos 988 a 1.000 da versão atual do projeto $^{620}$, cuja instauração será admitida quando “estando presente o risco de ofensa à isonomia e à segurança jurídica, houver efetiva repetição de processos que contenham controvérsia sobre a mesma questão unicamente de direito".

Embora a instauração do incidente esteja condicionada à existência de processos com questões repetitivas "unicamente de direito", o artigo 988, § 9º prevê que ele "pode ser instaurado quando houver decisões conflitantes sobre mesma questão de fato". Ou seja, considerando-se que o tribunal, ao apreciar o incidente, terá de resolver também a questão fática controvertida (premissa menor), para só então definir a tese jurídica, isto é, a regra de direito aplicável ao caso (premissa maior), prevê-se a extensão dos efeitos da decisão sobre as questões fáticas aos casos repetitivos sobrestados.

\footnotetext{
${ }^{620}$ A regulamentação prevista na versão inicial do projeto era mais polêmica. Por exemplo, permitia-se a instauração quando houvesse mero risco de multiplicação de processos fundados em idêntica questão de direito; não só o tribunal, mas também o próprio juiz, de ofício, poderia instaurar o incidente.
} 
Isso justifica a afirmação de que o incidente de resolução de demandas repetitivas está, ao menos nessas hipóteses em que for utilizado também para a solução de questões fáticas comuns (as quais não são observadas quando se trata de técnica de julgamento de recursos repetitivos pelo STF e pelo STJ, exclusivamente voltada à potencialização dos precedentes dos órgãos superiores), mais próximo do procedimento-modelo do direito alemão e de outras técnicas de julgamento por amostragem voltadas à solução de litígios que versam sobre interesses individuais homogêneos, em resposta à ineficácia dos processos coletivos de modo representativo (ver Capítulo 5, itens 5.2 e 5.3).

Conforme a disciplina dos mencionados artigos, o incidente pode ser instaurado quando alguma causa estiver pendente de julgamento no competente Tribunal de Justiça ou Tribunal Regional Federal, por petição endereçada ao presidente e a pedido do relator, do colegiado, de qualquer das partes, do Ministério Público, da Defensoria Pública, da pessoa jurídica de direito público ou de associação.

Em relação à instauração do procedimento, aplicam-se regras semelhantes às que regulam o julgamento de recursos repetitivos: a desistência ou abandono da causa não impede o reexame do mérito do incidente; o Ministério Público, quando não for requerente, atuará como fiscal da lei e poderá até assumir a titularidade do caso; poderão ser pedidas informações aos órgãos inferiores, em que a controvérsia esteja instaurada; a instauração e o julgamento do incidente serão sucedidos da mais ampla e específica divulgação e publicidade, por meio de registros eletrônicos no $\mathrm{CNJ}$ e nos tribunais.

Segundo o artigo 990, $\S 1^{\circ}$ a $5^{\circ}$, a admissão do incidente gera a suspensão dos processos pendentes, individuais ou coletivos, que versem sobre a questão de direito repetitiva, e que tramitam no Estado ou na região. Certificada a suspensão nos autos, a parte poderá interpor agravo de instrumento demonstrando a distinção de seu caso. Além disso, a extensão estende-se à prescrição das pretensões nos casos em que se repete a questão de direito.

O artigo 996 estabelece que o incidente deverá ser julgado no prazo de um ano, além da preferência no julgamento do incidente, ressalvados os casos em que envolvam réus presos e pedidos de habeas corpus. Ultrapassado o prazo de julgamento, cessa a suspensão, salvo decisão fundamentada do relator. 
Qualquer das partes legitimadas para requerer a instauração do incidente, independentemente dos limites da competência territorial, poderá requerer ao tribunal competente para conhecer de recurso extraordinário ou recurso especial a suspensão de todos os processos individuais ou coletivos em curso no território (art. 997), suspensão essa que cessará se não for interposto recurso extraordinário ou especial contra a decisão que julgar o incidente.

O julgamento, que será de competência do órgão que cada regimento indicar (respeitados os critérios do art. 991), ocorrerá depois de ouvidas "as partes e os demais interessados, inclusive pessoas, órgãos e entidades com interesse na controvérsia, que, no prazo comum de quinze dias, poderão requerer a juntada de documentos, bem como as diligências necessárias para a elucidação da questão de direito controvertida", sem prejuízo da designação de "data para, em audiência pública, ouvir depoimentos de pessoas com experiência e conhecimento na matéria".

Ao que parece, fica estabelecida aqui uma regra semelhante à que mencionamos no Capítulo 9, no sentido de ampliação da participação das partes que tiveram seus recursos sobrestados, regra essa que deveria ser aplicada também para o julgamento de recursos repetitivos pelo STF e pelo STJ.

De qualquer forma, ainda no sentido da ampliação da participação das partes, o artigo 994, § $2^{\circ}$, prevê que, após a possibilidade de sustentação oral pelas partes do processo originário e pelo Ministério Público, "em seguida, os demais interessados poderão manifestar-se no prazo de trinta minutos, divididos entre todos, sendo exigida inscrição com dois dias de antecedência. Havendo muitos interessados, o prazo poderá ser ampliado, a critério do órgão julgador". Ademais, nos termos do $\S 3^{\circ}$, "todos os fundamentos suscitados à tese jurídica discutida, sejam favoráveis ou contrários”, deverão integrar o acórdão que julgar o incidente. Por último, os terceiros admitidos como amicus curiae poderão recorrer (art. 138, $\S 3^{\circ}$ ).

Em contrapartida, o incidente não prevê qualquer critério para a seleção do processo-piloto, nem permite a escolha de um líder ou a participação direta e ativa, em todas as suas fases, das partes que tiveram seu processo sobrestado. 
Por sua vez, o artigo 995 estabelece o efeito vinculante da tese jurídica firmada no incidente, a qual "será aplicada a todos os processos individuais ou coletivos que versem sobre idêntica questão de direito e que tramitem na área de jurisdição do respectivo tribunal", bem como aos casos futuros, salvo revisão da tese pelo tribunal que a fixou, a ser realizada de ofício ou a requerimento dos legitimados. A confirmar a existência de verdadeiro efeito vinculante - suscitando, consequentemente, dúvidas sobre a sua constitucionalidade (conforme Capítulos 2 e 6) - o artigo 1.000 prevê o cabimento de reclamação contra a decisão que não observar a tese.

Segundo o artigo 995, $\S 4^{\circ}$, contra a decisão que julgar o incidente, caberá recurso especial ou extraordinário, presumindo-se, nesse último caso, a repercussão geral da questão constitucional discutida. A novidade é que o recurso terá efeito suspensivo (art. 998) e sua admissibilidade não será apreciada pelo tribunal de origem (art. 999). Além disso, julgado o mérito do recurso especial ou extraordinário, a tese terá efeito vinculante em relação "a todos os processos individuais ou coletivos que versem sobre idêntica questão de direito e que tramitem no território nacional”.

Caso seja efetivamente implementado e funcione na prática, esse novo incidente poderá reduzir bastante a utilização da técnica de julgamento de recursos repetitivos pelo STF e pelo STJ, pois sequer haverá oportunidade para a interposição de uma multiplicidade de recursos extraordinários e especiais fundados em idêntica questão de direito: os processos repetitivos ficarão sobrestados aguardando a definição da tese pelo Tribunal de Justiça ou Regional, e em seguida pelo STF e pelo STJ, pois é previsível que, nesses casos de grande projeção, sempre serão interposto recursos excepcionais. 


\section{CONCLUSÃO}

Como exposto na parte introdutória deste trabalho, os extensos temas correlatos relativos à tendência de valorização da jurisprudência e às funções, importância e admissibilidade dos recursos extraordinários e especiais - foram desenvolvidos na Primeira Parte desta dissertação, apenas para estabelecimento de conceitos e algumas das premissas necessárias à abordagem do tema principal.

Em relação ao tema da valorização da jurisprudência, verificou-se que a busca de soluções para os diversos problemas que afligem a Justiça nos países filiados ao civil law e ao common law tem justificado uma constante aproximação, ainda que parcial e pontual, entre esses dois sistemas. Um desses pontos de contato é justamente a valorização dos precedentes judiciais, tradicionalmente dotados de eficácia vinculante e utilizados como fonte do direito no common law, mas cada vez mais utilizados para o julgamento de casos também no civil law.

No Brasil, país filiado ao civil law, o movimento de valorização da jurisprudência e dos precedentes judiciais é, a despeito de críticas, uma realidade, conforme revela o exame das diversas reformas constitucionais e infraconstitucionais levadas a cabo nas últimas décadas, as quais vêm constantemente ampliando a eficácia extraprocessual dos precedentes, para permitir, ou até impor (como ocorreu, em 2004, pela criação das chamadas súmulas vinculantes), que as questões repetitivas sejam julgadas tal como definido pela jurisprudência ou pelos precedentes.

Essas reformas têm sido justificadas pela necessidade de se gerenciar a divergência jurisprudencial (gravemente ampliada pelo problema dos processos repetitivos) e de se buscar uma prestação jurisdicional que cada vez mais prestigie os princípios constitucionais da igualdade, da segurança jurídica e da razoável duração do processo. E, de fato, o julgamento de casos com base na jurisprudência ou nos precedentes (não importa se em razão da ampliação ou qualificação da sua eficácia persuasiva, ou da previsão de uma eficácia vinculantes propriamente dita) é uma das ferramentas teoricamente adequadas para a obtenção, num mesmo momento histórico, de decisões iguais para casos iguais, contribuindo, assim, para que aqueles ditames constitucionais sejam efetivamente concretizados. 
Ainda que conveniente e adequado para as finalidades referidas acima, o modelo constitucional brasileiro impõe uma clara limitação à eficácia da jurisprudência e dos precedentes: ela só pode ser efetivamente vinculante ou obrigatória quando e se especificamente autorizada pela competente norma constitucional específica. A essa conclusão, que é defendida por parte da doutrina e combatida por outra (que defende a desnecessidade de autorização constitucional específica), pode-se chegar, entre outros fundamentos, pela observância do próprio texto constitucional brasileiro, que prevê e regulamenta, de forma direta, os casos específicos em que a jurisprudência ou os precedentes judiciais têm eficácia vinculante.

Assim, no sistema brasileiro convivem técnicas que atribuem aos precedentes eficácia meramente persuasiva (jurisprudência), eficácia persuasiva ampliada ou qualificada (jurisprudência dominante, súmulas persuasivas, precedentes emanados de julgamento de recursos repetitivos etc.) e, por fim, eficácia vinculante propriamente dita (súmulas vinculantes, decisões proferidas em sede de controle abstrato de constitucionalidade), estas últimas só admissíveis diante de previsão constitucional específica.

Além disso, para que se possam aproveitar efetivamente os pontos positivos dessa experiência de valorização da jurisprudência, é necessário observar também os cuidados relacionados à sua aplicação aos casos sucessivos, a fim de, entre outros pontos: impor a adequada verificação prévia da identidade entre os pressupostos fáticos do precedente e do caso sucessivo; garantir que só as questões efetivamente julgadas tenham maior força (identificação da ratio decidendi ou motivos determinantes); exigir a fundamentação adequada da decisão que aplica o precedente; viabilizar a flexibilidade na sua aplicação e os caminhos adequados para a sua eventual revisão, por meio de técnicas como o distinguishing e o overruling. E, nesse sentido, merecem destaque as previsões constantes no projeto de novo CPC, conforme demonstrado no Capítulo 12.

Ainda na Primeira Parte, tratamos também do tema relativo às funções, importância e admissibilidade dos recursos extraordinários e especiais.

Viu-se que os recursos extraordinários ou excepcionais (extraordinário e especial) do direito processual civil brasileiro são o instrumento adequado para o controle da 
jurisprudência, ou seja, o controle da atuação dos demais órgãos jurisdicionais, protegendo-se e unificando-se a interpretação e aplicação do direito federal constitucional e infraconstitucional (funções nomofilácica e de uniformização ou paradigmática). Daí a grande importância da jurisprudência e dos precedentes do STF e do STJ, órgãos responsáveis por julgar tais recursos e, com isso, estabelecer o sentido único do direito federal constitucional e infraconstitucional à luz das diversas hipóteses fáticas submetidas à sua apreciação.

Essas finalidades atingem-se por meio de regras que fazem da interposição desses recursos um direito subjetivo de as partes impugnarem, em seus casos concretos, as decisões contrárias aos seus interesses, desde que observadas as hipóteses de cabimento previstas nos artigos 102, III, e 105, III, da Constituição.

Desde as lições de Piero Calamandrei sobre a cassação civil, percebeu-se que essa é a melhor forma de se fixar o sentido único das normas jurídicas e controlar a uniformidade da sua aplicação a casos semelhantes, viabilizando-se, com isso, a observância da igualdade e segurança inerentes a qualquer Estado de Direito. Ou seja, a finalidade pública especial dos recursos excepcionais, embora de fato prepondere sobre outras finalidades públicas (como a de simplesmente aplicar a lei ao caso concreto) e sobre o interesse particular das partes (para cuja satisfação o sistema se contentaria com a instância ordinária), desenvolve-se necessariamente por meio de uma atuação conjunta e colaborativa das partes litigantes, de forma que este impulso sempre vivo e atual não pode ser ignorado.

Por estarem esses recursos voltados àquelas finalidades públicas especiais, a sua admissibilidade está sujeita, além dos requisitos gerais, a requisitos específicos, que decorrem das próprias hipóteses de cabimento previstas nos artigos 102, III, e 105, III, da Constituição Federal. Além disso, como o STF e do STJ são órgãos de dimensões reduzidas, e considerando a grande quantidade de recursos excepcionais naturalmente interpostos pelas partes, o sistema prevê a realização de uma filtragem dos recursos por meio da aferição prévia da sua admissibilidade pelos órgãos de origem, perante os quais os recursos são interpostos. Essa filtragem não viola a garantia constitucional de interposição desses recursos porque o próprio sistema permite o contraste da decisão pelo recurso de agravo de admissão (art. 544 do CPC). 
Por serem recursos de fundamentação vinculada, é natural que a aferição do seu cabimento tangencie o mérito. Mas o juízo prévio de admissibilidade a cargo dos órgãos de origem encontra limites na própria Constituição, que impõe a realização do juízo de mérito exclusivamente pelo STF e pelo STJ.

É necessário, porém, compreender que, nesse caso, juízo de mérito significa, à luz das próprias funções especiais dos recursos excepcionais, e consequentemente das suas hipóteses de cabimento previstas na Constituição, a interpretação e fixação do sentido único do direito federal. Não atuando nesse sentido, os órgãos de origem não estarão decidindo o mérito dos recursos excepcionais.

Na Segunda Parte do trabalho, tratamos das questões relacionadas às justificativas para a criação da técnica de julgamento de recursos repetitivos, aos seus aspectos gerais, bem como à sua constitucionalidade.

Como demonstrado no Capítulo 4, a técnica de julgamento de recursos repetitivos foi criada sob a justificativa de atender ao princípio da razoável duração do processo, em razão da atuação adequada do STF e STJ estar obstaculizada pelo excessivo número de casos, incompatível com as dimensões reduzidas e com a própria finalidade constitucional dos Tribunais Superiores.

O estudo da doutrina sobre a histórica "crise do Supremo" revela que o STJ foi criado pela Constituição de 1988 justamente na tentativa de desafogar o STF, diante do enorme número de processos (a maioria recursos extraordinários) que inviabilizava o seu adequado funcionamento, bem como dos consequentes óbices regimentais e jurisprudenciais que, embora criados para tentar equacionar a crise, criaram uma distância excessiva entre as partes e a instância superior.

Depois, porém, o próprio STJ entrou em crise, devido ao enorme número de recursos especiais e respectivos agravos de admissão submetidos à apreciação de seus apenas trinta e três ministros.

Entre as alternativas para a racionalização da atuação do STF e do STJ, e considerando-se que o excessivo número de recursos tem a peculiaridade de envolver 
questões repetitivas, o legislador optou, entre outros mecanismos, pela instituição da técnica de julgamento por amostragem, por meio da qual basicamente cria-se apenas um precedente qualificado sobre questões repetitivas, para que o mesmo possa ser aplicado aos demais recursos, que devem aguardar sobrestados.

Não constam, entre os motivos oficiais da positivação de tal técnica, referências à necessidade de ampliação da eficácia dos precedentes do STF e STJ para concretização dos princípios da igualdade ou segurança jurídica, embora estes últimos também façam parte, e até com maior razão, da conveniência de toda técnica de valorização dos precedentes judiciais.

De qualquer modo, a legitimidade da busca pela racionalização do trabalho do STF e do STJ não pode ser desprezada, diante do quadro realmente preocupante do número de processos (a maioria recursos extraordinários e especiais, e respectivos agravos de admissão) em tramitação nessas cortes e, principalmente, do percentual de crescimento desses recursos a que se vinha assistindo nos anos anteriores à positivação da técnica de julgamento de recursos repetitivos. Afinal, como observado por alguns autores, nossos Tribunais Superiores são os que mais julgam em todo o mundo.

Conforme salientado pela doutrina, a técnica de julgamento por amostragem inspirou-se no Musterverfahren do direito alemão. Trata-se de uma forma de julgamento por amostragem, baseada na seleção de um processo-modelo ou processo-piloto, no qual as questões fáticas e jurídicas comuns serão resolvidas para, ao final, serem utilizadas nos processos repetitivos.

Mas, além de inúmeras diferenças procedimentais, a técnica de julgamento de recursos repetitivos dos artigos 543-B e 543-C do CPC é, antes de tudo, técnica de potencialização dos precedentes do STF e do STJ (ou seja, técnica que lhes atribui eficácia persuasiva qualificada ou especial), distanciando-se um pouco das técnicas de julgamento por amostragem que visam a dar trato adequado a interesses coletivos.

Tanto isso é verdade que, diferentemente do que ocorre no Musterverfahren e em outras técnicas de julgamento por amostragem do direito estrangeiro, o julgamento de recursos repetitivos não gera decisão coletiva dotada de coisa julgada erga omnes - e se o 
gerasse seria inconstitucional, por violação ao contraditório, em face da inexigência de representatividade da parte do processo-modelo, da impossibilidade de participação ampla dos que não tiveram seu processo selecionado e da inexistência de faculdade de não sujeição dos casos individuais ao precedente.

Ainda quanto aos aspectos gerais da técnica de julgamento de recursos repetitivos, demonstramos que ela foi instituída, de início, no contexto de regulamentação do instituto da repercussão geral - requisito de admissibilidade dos recursos extraordinários, na forma de qualificadora de suas hipóteses de cabimento, criado pela Emenda Constitucional n. ${ }^{\circ}$ 45/2004. Entretanto, ela não se confunde com esse instituto, tanto que poderia existir - e existia, na forma de relevância da questão federal - repercussão geral sem técnica de julgamento de recursos repetitivos, assim como existe essa técnica sem repercussão geral (em relação aos recursos especiais).

Finalizando a Segunda Parte, tratamos do delicado tema relativo à constitucionalidade da técnica de julgamento de recursos repetitivos. O tema é polêmico e difícil, na medida em que a técnica, na prática, dificulta o acesso direto das partes ao STF e ao STJ, forçando, de certa forma, a solução das questões repetitivas pelos próprios órgãos de origem, sem envio dos autos à instância extraordinária. Entretanto, o exame dos vários aspectos relacionados à função pública especial dos recursos excepcionais, às dificuldades práticas de acesso que já existem em razão do excesso de recursos e à própria interpretação dos artigos 543-B e 543-C do CPC, permitiu-nos concluir que a técnica não é, em si, inconstitucional, basicamente porque:

1) Ao invés de afastar as partes da ordem jurídica justa, a técnica amplia a possibilidade de solução das questões jurídicas à luz do sentido único do direito federal, independentemente da submissão de cada caso ao STF e ao STJ, razão pela qual amplia, e não mitiga, a concretização do princípio do acesso à justiça.

2) A decisão do órgão de origem que, com base no precedente qualificado, nega seguimento ao recurso repetitivo sobrestado não é de mérito, tanto que não representa a interpretação e a aplicação, pelo órgão de origem, do direito federal no caso concreto, nem substitui a decisão anterior. Por não caracterizar uma decisão de mérito, não há violação à 
competência constitucional do STF e STJ para negar provimento a recursos extraordinários e especiais.

3) A mencionada decisão representa o juízo negativo de admissibilidade do recurso excepcional, e não se pode dizer que, por isso, a lei teria criado, sem a necessária previsão constitucional, um novo requisito de admissibilidade para os recursos extraordinários e especiais. Primeiro, porque é possível interpretar que essa negativa de admissibilidade baseia-se na falta de interesse recursal (utilidade) do recurso contrário ao precedente. Segundo, porque a contrariedade do recurso à jurisprudência consolidada do STF ou STJ, representada objetivamente por precedente qualificado sobre a questão, caracteriza, no fim, a não ocorrência das hipóteses de cabimento previstas no art. 102, III e 105, III da Constituição Federal. Ou seja, trata-se de uma presunção da inadmissibilidade do recurso por não ocorrência de sua hipótese de cabimento, presunção esta que não é inconstitucional, por se basear justamente no atendimento das finalidades públicas especiais dos recursos extraordinários e especiais.

4) Não se pode falar em efeito vinculante, tanto que a própria sistemática dos artigos 543-B e 543-C do CPC preveem a possibilidade de o órgão de origem manter sua decisão contrária ao precedente qualificado do STF ou do STJ.

Apesar dessas conclusões, é imperioso considerar que a técnica de julgamento de recursos repetitivos vem sendo interpretada e aplicada pelo próprio STF e STJ de forma inconstitucional, em razão da vedação à interposição de agravo de admissão contra a decisão que aplica o precedente qualificado. A possibilidade de interposição de tal recurso, ao menos para discussão de eventuais distinções entre os casos (distinguisguing) e para revisão da questão à luz de novos pressupostos fáticos ou jurídicos não levados em consideração pelo precedente (overruling) é o que poderia salvaguardar a legitimidade de todos os aspectos restritivos da técnica, e é justamente isso que prevê o projeto de novo CPC, pela sua redação atual.

Exposta a síntese conclusiva sobre os principais pontos da primeira e segunda partes do trabalho, iniciamos a exposição de algumas das principais conclusões sobre os aspectos procedimentais da técnica de julgamento de recursos repetitivos pelo STF e STJ, detalhadamente estudados na Terceira Parte desta dissertação. 
Iniciando pela questão da instauração do procedimento (Capítulo 7), vale destacar, entre os inúmeros aspectos ali tratados, a importância da adequada seleção dos casos representativos da controvérsia e o problema da desistência do recurso selecionado para julgamento.

Sobre o primeiro ponto, como não existe na técnica dos artigos 543-B e 543-C tutela coletiva propriamente dita, mas sim sobrestamento dos casos repetitivos à espera do precedente, a ausência de preocupação com a representatividade adequada dos que figuram como partes nos processos selecionados não implica a sua inconstitucionalidade.

Porém, em razão da alta influência do precedente que será formado com o julgamento dos casos selecionados, e em atenção ao princípio do contraditório, o sistema não se contenta com a escolha de qualquer caso, pelo contrário, exige a escolha de casos que sejam efetivamente representativos da controvérsia. E isso, como demonstrado, obtém-se pela observância de requisitos objetivos e subjetivos que podem ser extraídos da interpretação sistemática das normas legais e regimentais que regulamentam o procedimento.

Sobre a problemática questão da desistência do recurso selecionado, entendemos que a técnica dos artigos 543-B e 543-C do CPC não excepciona o direito previsto expressamente no artigo 501 do mesmo diploma. Apesar das funções públicas nomofilácia e paradigmática dos recursos excepcionais, eles continuam sujeitos a todas as regras e princípios inerentes à teoria geral dos recursos, inclusive a voluntariedade, até porque é por meio desse impulso das partes, na busca de seus interesses particulares, que funciona o sistema de controle exercido pelo STF e pelo STJ por meio da via recursal extraordinária.

Ademais, não parece adequado admitir a desistência em relação ao caso concreto, mas prosseguir no julgamento da questão controvertida (tese defendida por parte da doutrina e encampada pelo projeto de novo CPC). Mais uma vez deve-se fazer referência à atuação das partes na busca de seus interesses particulares como elemento necessário ao adequado funcionamento do sistema de controle exercido pelo STF e pelo STJ: com a desistência, perde-se o interesse daquele que figura como parte no recurso selecionado, sendo inadequado, portanto, prosseguir com o procedimento voltado justamente à 
construção de precedente qualificado, que influenciará diretamente o julgamento de inúmeros casos repetitivos.

Por isso, ocorrendo a desistência do recurso selecionado, cabe ao STF ou ao STJ selecionar novos recursos representativos da controvérsia, entre toda a multiplicidade de casos repetitivos, dando prosseguimento ao rito dos artigos 543-B e 543-C.

Quanto à técnica do sobrestamento, tratada no Capítulo 8, vale destacar a sua conveniência para, à luz das limitações do sistema brasileiro, ampliar a eficácia dos precedentes do STF e do STJ, racionalizando a atuação da instância extraordinária e, ao mesmo tempo, contribuindo para a concretização dos princípios da igualdade e da segurança jurídica.

Isso porque, com o sobrestamento, viabiliza-se a maior eficácia do precedente, independentemente de vinculação. Com a paralisação dos casos repetitivos, um só precedente qualificado sobre a questão será formado. Depois, permite-se aos órgãos inferiores a mera aplicação desse precedente, de modo que o sistema força, de certa forma, a solução igual para os casos iguais, salvo a identificação de peculiaridades de cada caso e a presença de elementos novos, que viabilizem a eventual revisão da tese.

Porém, o sobrestamento encontra algumas limitações. O próprio princípio da razoável duração do processo, embora por um lado justifique a técnica de julgamento de recursos repetitivos, por outro lado impõe a fixação de um prazo máximo de sobrestamento. Por sua vez, não se pode admitir a extensão do sobrestamento sem previsão legal, porque ele paralisa a prestação jurisdicional, obstando o acesso à justiça. Se a lei diz que os recursos extraordinários e especiais serão sobrestados (incluindo-se os respectivos agravos de admissão), entendemos que a suspensão de outros recursos, e até do processo em primeiro grau, não poderia ser autorizada, sob pena de obstrução ilegítima da prestação jurisdicional.

Quanto à impugnação da decisão do órgão de origem que determina a incidência do sobrestamento em cada caso concreto, faz-se aqui referência às considerações expostas no Capítulo 8 (item 8.7), em que ressaltamos a importância do controle de tal decisão por meio de recurso (apesar da jurisprudência do STF e do STJ, que defendem o não 
cabimento, em regra, de qualquer meio de impugnação) e defendemos ser mais adequado e conveniente admitir-se a interposição de agravo interno.

No Capítulo 9, tratamos dos aspectos relativos ao julgamento dos recursos representativos da controvérsia, incluindo os atos preparatórios, a questão da participação de terceiros e o órgão competente. Nesta síntese conclusiva, vale destacar três pontos: a atuação de terceiros na qualidade de amicus curiae, a questão da intervenção dos que figuram como partes nos recursos sobrestados, bem como a importância de que o julgamento seja realizado pelo órgão mais complexo da corte competente, com a observância de quorum qualificado.

Em razão da maior influência do precedente a ser formado com o julgamento dos recursos representativos da controvérsia, e a despeito da ausência de eficácia vinculante propriamente dita, o sistema prevê a possibilidade de atuação de terceiros na qualidade de amicus curiae, de forma semelhante à que ocorre nos chamados processos objetivos, voltados ao controle abstrato de constitucionalidade. Essa participação confere maior legitimidade e qualidade ao precedente, porque a atuação de entes que efetivamente representam os interesses em jogo viabiliza o exercício de contraditório coletivo e social.

Por outro lado, questiona-se se aqueles que figuram como partes nos processos não selecionados e sobrestados poderiam intervir, de alguma forma, no julgamento.

Descartada a possibilidade de intervenção na qualidade de assistente - em razão da ausência, em tese, de relação jurídica material com alguma das partes do processo selecionado para julgamento -, e consequentemente de interposição de recurso de terceiro, defendemos, com apoio da maior parte da doutrina, e de forma contrária à jurisprudência do STF e do STJ, a possibilidade dessa intervenção ao menos na qualidade de amicus curiae.

Por outro lado, diante das dificuldades práticas que poderiam ser causadas pela intervenção de milhares de partes que tiveram seus recursos sobrestados, defendemos, de forma alternativa, a instauração, na forma descrita no item 9.4.2, de um incidente prévio perante os órgãos de origem, a fim de permitir àqueles que não tiveram seu recurso 
selecionado o oferecimento de argumentos por escrito, os quais devem necessariamente ser levados em consideração na apreciação da questão pelo STF e pelo STJ.

Em relação à competência para o julgamento, defendemos que ele deve se dar necessariamente pelo órgão mais complexo do STF (Plenário) e do STJ (Corte Especial ou Seção), bem como respeitar o quorum qualificado de dois terços, a fim de que o julgamento efetivamente exprima a posição da maioria dos integrantes dessas cortes. Com isso, fica relativizada a importância do argumento de que a técnica de julgamento de recursos repetitivos só deveria ser aplicada para confirmar a jurisprudência já existente do STF e do STJ, mas nunca para criar novos precedentes ou revogar precedentes anteriores.

No Capítulo 10, à luz das premissas estabelecidas ao longo do trabalho, estudamos os efeitos do julgamento dos recursos representativos da controvérsia, em relação a todos os demais processos e recursos repetitivos em tramitação nos diversos órgãos judiciais do país.

Definido pelo STF que a questão constitucional repetitiva é desprovida de repercussão geral, os órgãos de origem devem negar seguimento, por inadmissibilidade, aos recursos sobrestados. Porém, no nosso entendimento, o precedente do STF não tem eficácia vinculante propriamente dita, razão pela qual os órgãos de origem podem excepcionalmente, e de forma fundamentada, admitir o recurso extraordinário e enviá-lo ao STF para confirmação ou revisão do precedente. Ademais, a parte pode interpor agravo de admissão contra a decisão que nega seguimento ao recurso repetitivo com base no precedente qualificado do STF.

É preciso consignar, entretanto, que esse não é o entendimento da jurisprudência do STF, segundo a qual, negada a repercussão geral, o precedente gera eficácia vinculante, não existindo sequer competência da instância extraordinária para a apreciação de novos recursos repetitivos sobre a questão.

Julgado o mérito dos recursos extraordinário ou especiais, duas situações podem ocorrer em relação aos recursos repetitivos que estavam sobrestados. 
Primeiro, se a decisão recorrida, objeto do recurso repetitivo sobrestado, tiver adotado a mesma tese definida pela instância superior, o órgão de origem poderá negar seguimento ao recurso extraordinário ou especial. Trata-se, nesse caso, de juízo negativo de admissibilidade.

Segundo, se a decisão recorrida, objeto do recurso repetitivo sobrestado, tiver adotado tese divergente da definida pela instância superior, então o órgão de origem deverá exercer juízo de retratação em relação ao seu julgamento divergente, juízo esse que, nos termos da lei, pode ser positivo ou negativo, e deverá ser proferido sempre de forma fundamentada.

A possibilidade de juízo negativo de retratação, expressamente prevista em lei, revela a ausência de efeito vinculante do precedente qualificado e garante a constitucionalidade do sistema. Além disso, ela é conveniente para evitar o congelamento da jurisprudência e contribuir para a evolução do direito.

Por sua vez, a possibilidade de juízo positivo de retratação não significa o julgamento, pelo órgão de origem, do mérito do recurso excepcional, mas sim o reexame do recurso anterior, de competência desse mesmo órgão, à luz do precedente. Essa possibilidade, que representa, como todo juízo de retratação, uma exceção à regra do artigo 463 do CPC, justifica-se por razões de eficiência processual, além de prestigiar a obtenção de soluções iguais para casos iguais, favorecendo a concretização dos princípios da igualdade e da segurança jurídica. Nesse caso, a parte vencedora, e agora sucumbente, passa a poder interpor novos recursos excepcionais contra o novo acórdão proferido pelo órgão de origem.

Além de exercer influência em relação aos recursos repetitivos sobrestados, o precedente qualificado também influencia a admissibilidade de novos recursos excepcionais versando sobre a mesma questão, que venham a ser interpostos após o julgamento dos recursos representativos da controvérsia. Ou seja, os órgãos de origem poderão inadmitir esses novos recursos por contrariedade ao precedente qualificado.

Em todos os casos, o cabimento de agravo de admissão não fica prejudicado, merecendo ser criticada, como já exposto, a jurisprudência do STF e do STJ que veda a 
interposição de agravo de admissão contra a decisão que nega seguimento ao recurso repetitivo (facultada tão somente a interposição de agravo interno).

A interpretação sistemática das normas que regulamentam a técnica em questão também autoriza a conclusão de que o precedente qualificado tem status de jurisprudência dominante ou sumulada (súmula persuasiva), exercendo, assim, influência sobre todas as causas e recursos repetitivos em tramitação nas demais instâncias.

No Capítulo 11, analisamos as estatísticas divulgadas pelo STF e pelo STJ a respeito dos recursos extraordinários e especiais (e respectivos agravos de admissão), a fim de avaliar os resultados práticos da técnica de julgamento de recursos repetitivos.

Analisamos, assim, os números relativos aos períodos anterior e posterior à positivação da técnica de julgamento de recursos repetitivos, pelo que foi possível concluir que houve uma diminuição significativa em relação à quantidade de processos distribuídos a essas cortes. É conveniente destacar que o número de processos distribuídos ao STF e ao STJ vinha aumentando drasticamente e, depois dos artigos 543-B e 543-C do CPC, não só se conteve o crescimento, como também os números começaram a diminuir.

Além disso, especificamente em relação a recursos excepcionais e respectivos agravos de admissão, houve uma melhora na produtividade do STF e do STJ, caracterizada pela relação entre o número de feitos julgados e distribuídos.

É verdade que o número de recursos distribuídos ao STF e ao STJ ainda é muito grande, e que o tempo médio de duração do procedimento também precisa diminuir (conforme Capítulo 11, item 11.2).

Mas não se pode ignorar que a técnica dos artigos 543-B e 543-C do CPC tem de fato contribuído para racionalizar, em certa medida, a atuação dessas cortes, em relação aos casos repetitivos.

E isso não significa que ela atua para resolver um problema exclusivo do Poder Judiciário, e não dos jurisdicionados. Na verdade, a dificuldade de prestar uma jurisdição de qualidade e no menor tempo possível (elementos tão caros a todos os órgãos judiciais, mas ainda mais importantes quando se trata da instância extraordinária), dificuldade essa 
que é inerente a um cenário de centenas de milhares de recursos para poucas dezenas de julgadores, não é um problema que interessa apenas aos ministros do STF e do STJ, mas também, e principalmente, aos próprios jurisdicionados.

De qualquer modo, ainda mais importante do que a diminuição do número de recursos e o aumento da produtividade, é a ampliação da eficácia, importância, projeção, qualidade e respeitabilidade dos precedentes qualificados do STF e do STJ, gerados pelo julgamento dos casos representativos da controvérsia.

Todos os aspectos procedimentais descritos nos Capítulo 7 a 10 revelam que o precedente tem tudo para efetivamente exprimir, em um só julgado, constituído do inteiro teor do acórdão que aprecia os recursos selecionados (e não de mero enunciado sintético, que poderia pecar por desprezar os elementos fáticos da causa), o entendimento da instância extraordinária sobre a interpretação do direito federal constitucional e infraconstitucional do país, contribuindo, com isso, para o gerenciamento da divergência jurisprudencial e para a concretização dos princípios da igualdade e da segurança jurídica.

A criação de sistemas que divulgam todas as informações sobre os recursos repetitivos já julgados e em tramitação (Capítulo 11, item 11.3), a instituição de órgãos criados nos tribunais de origem para o gerenciamento das questões atinentes ao procedimento dos artigos 543-B e 543-C do CPC (Capítulo 11, item 11.4) e a ampliação da divulgação dos julgamentos de muitos recursos representativos da controvérsia relativos são, entre outros, fatores que fortalecem os precedentes do STF e do STJ e, consequentemente, contribuem para a maior uniformidade da jurisprudência e um sistema jurídico mais eficiente, isonômico e previsível.

Apesar de necessários aperfeiçoamentos - dos quais, muitos estão previstos na versão atual do projeto de novo $\mathrm{CPC}$-, e da necessidade de revisão do entendimento da jurisprudência do STF e do STJ (que, no nosso sentir, vêm interpretando os artigos 543-B e 543-C do CPC de forma excessivamente restritiva ao direito das partes), entendemos que a técnica em questão é adequada - embora possa não ser suficiente - para lidar inteligentemente com o problema dos recursos repetitivos e contribui efetivamente para a maior concretização dos princípios da igualdade, segurança jurídica e razoável duração do processo, sendo correta a decisão de mantê-la e aperfeiçoá-la no projeto de novo CPC. 


\section{REFERÊNCIAS}

ABBUD, André de Albuquerque Cavalcanti. A repercussão geral dos recursos extraordinários e o julgamento por amostragem no âmbito do Supremo Tribunal Federal (CPC, arts. 543-A e 543-B). In: GIANNICO, Maurício; MONTEIRO, Vítor José de Mello (Coords.). As novas reformas do CPC e de outras normas processuais. São Paulo: Saraiva, 2009. p. 291-317.

ALVES, José Carlos Moreira. O Supremo Tribunal Federal em face da nova Constituição: questões e perspectivas. Arquivos do Ministério da Justiça, Brasília, DF, v. 41, n. 173, p. 35-47, jul./set. 1988.

ALVIM, José Eduardo Carreira. Recursos especiais repetitivos: mais uma tentativa de desobstruir os tribunais. Revista de Processo, São Paulo, v. 33, n. 162, p. 168-185, ago. 2008.

AMARAL, Guilherme Rizzo. Efetividade, segurança, massificação e a proposta de um "incidente de resolução de demandas repetitivas". Revista de Processo, São Paulo, v. 36, n. 196, p. 237-276, jun. 2011.

ANDRADE, Fábio Martins. Procedimento para o julgamento de recursos repetitivos no âmbito do STJ: anotações à Lei no 11.672/2008: acréscimo do art. 543-C no CPC. Revista Dialética de Direito Processual, São Paulo, n 65, p. 17-27, ago. 2008.

ANDREWS, Neil. O moderno processo civil: formas judiciais e alternativas de resolução dos conflitos na Inglaterra. Orientação e revisão da tradução de Teresa Arruda Alvim Wambier. São Paulo: Revista dos Tribunais, 2009.

Multi-party proceedings in England: representative and group actions. Duke Journal of Comparative and International Law, Durhan, NC, v. 11, n. 2, p. 249-268, Spring 2001. Disponível em:

$<$ http://scholarship.law.duke.edu/cgi/viewcontent.cgi?article=1199\&context=djcil $>$. Acesso em: 10 nov. 2013.

. A Suprema Corte do Reino Unido: reflexões sobre o papel da mais alta Corte Britânica. Revista de Processo, São Paulo, v. 35, n. 186, p. 299-312, ago. 2010.

ANDRIGHI, Fátima Nancy. Recursos repetitivos. Revista de Processo, São Paulo, v. 35, n. 185, p. 265-281, jul. 2010.

ARAÚJO, José Henrique Mouta. Processos repetitivos e o desafio do Judiciário: rescisória contra interpretação de Lei Federal. Revista de Processo, São Paulo, v. 35, n. 183, p. 145164, maio 2010.

. A verticalização das decisões do STF como instrumento de diminuição do tempo do processo: uma reengenharia necessária. Revista de Processo, São Paulo, v. 33, n. 164, p. 342-359, out. 2008. 
ARAÚJO JÚNIOR, Pedro Dias de. Os efeitos do recurso especial representativo de controvérsia, a participação do indivíduo no julgamento coletivizado e a inegável inserção de elementos da Common Law no processo brasileiro. Jus Navigandi, Teresina, ano 17, n. 3249, 24 maio 2012. Disponível em: <http://jus.com.br/artigos/21844>. Acesso em: 03 out. 2013.

ARMELIN, Donaldo. Uma visão da crise atual do Poder Judiciário. In: MACHADO, Fábio; MACHADO, Rafael Bicca (Coords.). A reforma do Poder Judiciário. São Paulo: Quartier Latin, 2006. p. 119-140.

ARRUDA ALVIM, José Manoel de. A alta função jurisdicional do Superior Tribunal de Justiça no âmbito do recurso especial e a relevância das questões. Revista de Processo, São Paulo, v. 24, n. 96, p. 37-44, out./dez. 1999.

. O antigo recurso extraordinário e o recurso especial: na Constituição Federal de 1988. Revista de Processo, São Paulo, v. 15, n. 58, p. 62-74, abr./jun. 1990.

. Arguição de relevância no recurso extraordinário. São Paulo: Revista dos Tribunais, 1988.

A EC n. 45 e o instituto da repercussão geral. In: WAMBIER, Teresa Arruda Alvim et al. (Coords.). Reforma do judiciário: primeiros ensaios críticos sobre a EC $\mathrm{n}$. 45/2004. São Paulo: Revista dos Tribunais, 2005. p. 63-99.

. Notas sobre o projeto de novo Código de Processo Civil. Revista de Processo, São Paulo, v. 36, n. 191, p. 299-318, jan. 2011.

ASSIS, Araken de. Manual dos recursos. 2. ed. rev., atual. e ampl. São Paulo: Revista dos Tribunais, 2008.

ATAIIDE JÚNIOR, Vicente de Paula. O sistema judiciário e a administração da justiça dos Estados Unidos da América. Revista CEJ, Brasília, v. 10, n. 33, p. 36-42, abr./jun. 2006.

AZEM, Guilherme Beux Nassif. A instrumentalidade objetiva do recurso extraordinário. Revista de Informação Legislativa, Brasília, DF, v. 48, n. 190 t. 1, p. 205-210, abr./jun. 2011.

BAHIA, Alexandre Gustavo Melo Franco; VECCHIATTI, Paulo Roberto Iotti. Inconstitucionalidade do requisito da repercussão geral do recurso extraordinário e da técnica do julgamento por pinçamento. Revista dos Tribunais, São Paulo, v. 100, n. 911, p. 243-258, set. 2011.

BARROS, Humberto Gomes de. Carta de Alforria: Lei 11.672/08 vai resgatar o STJ da inviabilidade. Revista Consultor Jurídico, maio, 2008. Disponível em:

<http://www.conjur.com.br/2008-mai-16/lei_1167208_resgatar_stj_inviabilidade>. Acesso em: 04.07.2012.

BASTOS, Antonio Adonias Aguiar. Situações jurídicas homogêneas: um conceito necessário para o processamento das demandas de massa. Revista de Processo, São Paulo, v. 35, n. 186, p. 87-107, jul. 2010. 
BEDAQUE, José Roberto dos Santos. Efetividade do processo e técnica processual. 3. ed. São Paulo: Malheiros, 2010.

. Legitimidade processual e legitimidade política. In: SALLES, Carlos Alberto de (Org.). Processo civil e interesse público: o processo como instrumento de defesa social. São Paulo: Revisa dos Tribunais, 2003. p. 101-111.

Tutela cautelar e tutela antecipada: tutelas sumárias e de urgência (tentativa de sistematização). 5. ed. rev. e ampl. São Paulo: Malheiros, 2009.

BENETI, Sidnei Agostinho. Assunção de competência e fast track recursal. Revista de Processo, São Paulo, v. 34, n. 171, p. 9-23, maio 2009.

. Doutrina de precedentes e organização judiciária. BDJur, Brasília, DF, 8 maio 2008. Disponível em:

<http://bdjur.stj.gov.br/xmlui/bitstream/handle/2011/17006/Doutrina_Precedentes_Organiz a\%c3\%a7\%c3\%a3o.pdf?sequence=1>. Acesso em: 10 nov. 2013.

O processo na Suprema Corte dos Estados Unidos. Revisa dos Tribunais, São Paulo, v. 82, n. 695, p. 270-274, set. 1993.

A reforma do Código de Processo Civil e os recursos para os tribunais superiores. Revista de Informação Legislativa, Brasília, v. 48, n. 190 t. 2, p. 243-250, abr.jun. 2011.

BONAVIDES, Paulo. Curso de direito constitucional. 8. ed. São Paulo: Malheiros, 1999.

BONDIOLI, Luiz Guilherme Aidar. A nova técnica de julgamento dos recursos extraordinário e especial repetitivos. Disponível em: <http://www.dinamarco.com.br/wpcontent/uploads/NovaTecnica.pdf>. Acesso em: 14 nov. 2013.

BONICIO, Marcelo José Magalhães. Análise da tendência jurisprudencial de potencialização dos efeitos da regra prevista no art. 543-C do CPC. (Originais cedidos pelo autor). Inédito.

BUENO, Cassio Scarpinella. Amicus curiae no processo civil brasileiro: um terceiro enigmático. 2. ed. rev., atual. e ampl. São Paulo: Saraiva, 2008.

. Amicus curiae no projeto de novo Código de Processo Civil. Revista de Informação Legislativa, Brasília, v. 48, n. 190, t. 1, p. 111-121, abr./jun. 2011.

. Curso sistematizado de direito processual civil. 3. ed. São Paulo: Saraiva, 2011. v.

5.

O "modelo constitucional do direito processual civil": um paradigma necessário de estudo do direito processual civil e algumas de suas aplicações. Disponível em: <http://www.scarpinellabueno.com.br/text15.htm>. Acesso em: 14 nov. 2013.

BUZAID, Alfredo. A crise do Supremo Tribunal Federal. In: . Estudos de direito I.

São Paulo: Saraiva, 1972. p. 121-177. 
Uniformização da jurisprudência. Ajuris, Revista da Associação dos juízes do Rio Grande do Sul, Porto Alegre, v. 12, n. 34, p. 189-217, jul. 1985.

CABRAL, Antonio do Passo. O novo procedimento-modelo (Musterverfahren) alemão: uma alternativa às ações coletivas. Revista de Processo, São Paulo, v. 32, n. 147, p. 123146, maio 2007.

CALAMANDREI, Piero. La casación civil: bosquejo general del instituto. Traducción de Santiago Sentís Melendo. Buenos Aires, Argentina: Editorial Bibliográfica Argentina, 1945. v. 2.

CALMON DE PASSOS, José Joaquim. Função social do processo. Revista Forense, Rio de Janeiro, v. 94, n. 343, p. 85-93, jul./set. 1998.

. O recurso extraordinário e a Emenda n. 3 do Regimento Interno do Supremo Tribunal Federal. Revista de Processo, São Paulo, v. 2, n. 5, p. 43-60, jan./mar. 1977.

CAMBI, Eduardo. Jurisprudência lotérica. Revista dos Tribunais, São Paulo, v. 90, n. 786, p. 108-128, abr. 2001.

CAMBI, Eduardo; NEVES, Aline Regina das. Repercussão geral e PEC 209/2012. Revista de Processo, São Paulo, v. 38, n. 220, p. 183-206, jun. 2013.

CAPONI, Remo. Modelli europei di tutela collettiva nel processo civile: esperienze tedesca e italiana a confronto. Rivista Trimestrale di Diritto Processuale Civile, 2007, p. 1229-1256. Disponível em:

<http://www.academia.edu/205454/R._Caponi_Modelli_europei_di_tutela_collettiva_nel_ processo_civile_esperienze_tedesca_e_italiana_a_confronto_2007>. Acesso em: 08 nov. 2013.

. Overruling in materia processuale e garanzie costituzionali (in margine a Cass. $\mathrm{n}$. 19246 del 2010). Disponível em <http://unifi.academia.edu/remocaponi/Papers/309288/2010_R._Caponi_Overruling_in_m ateria_processuale_e_garanzie_costituzionali_in_margine_a_Cass._n._19246_del_2010_>. Acesso em 08 nov.2013.

CAPPELLETTI, Mauro. O acesso à justiça e a função do jurista em nossa época. Revista de Processo, São Paulo, v. 16, n. 61, p. 144-160, jan./mar. 1991.

. Juízes legisladores? Tradução Carlos Alberto Alvaro de Oliveira. Porto Alegre: Sergio Antonio Fabris, 1993.

. Problemas de reforma do processo civil nas sociedades contemporâneas. Revista de Processo, São Paulo, v. 17, n. 65, p. 127-143, jan./mar. 1992.

CAPPELLETTI, Mauro; BRYANT, Garth. Acesso à justiça. Tradução de Ellen Gracie Northfleet. Porto Alegre: Sergio Antonio Fabris, 1988. 
CARMONA, Carlos Alberto. O sistema recursal brasileiro: breve análise crítica. In: ALVIM, Eduardo Pellegrini de Arruda; NERY JUNIOR, Nelson; WAMBIER, Teresa Arruda Alvim (Coords.). Aspectos polêmicos e atuais dos recursos. São Paulo: Revista dos Tribunais, 2000. p. 34-51.

CARNEIRO, Athos Gusmão. Anotações sobre o recurso especial. In: TEIXEIRA, Sálvio Figueiredo (Coord.). Recursos no Superior Tribunal de Justiça. São Paulo: Saraiva, 1991. p. 109-123.

. O novo Código de Processo Civil: breve análise do projeto revisado do Senado. Revista de Processo, São Paulo, v. 36, n. 194, p. 141-172, abr. 2011.

Primeiras observações sobre a lei dos recursos repetitivos no STJ. Revista de Processo, São Paulo, v. 33, n. 160, p. 83-86, jun. 2008.

Recurso especial, agravos e agravo interno. 7. ed. atual. e ampl., inclusive com anotações relativas ao projeto de novo Código de Processo Civil. Rio de Janeiro: Forense, 2011.

CARVALHO, Fabiano. Pedido de reconsideração e juízo de retratação. Revista de Processo, São Paulo, v. 37, n. 212, p. 421-444, out. 2012.

CARVALHO, Ivan Lira de. Decisões vinculantes. Revista dos Tribunais, São Paulo, v. 86, n. 745 , p. 48-58, nov. 1997.

CASTRO, Daniel Penteado de. Questões polêmicas sobre o julgamento por amostragem do recurso especial repetitivo. Revista de Processo, São Paulo, v. 37, n. 206, p. 79-119, abr. 2012.

CAVALCANTE, Mantovanni Colares. A Lei 11.672/2008 e o novo processamento de recursos especiais com identidade de matérias, em confronto com a feição transindividual do recurso extraordinário. Revista de Processo, São Paulo, v. 33, n. 163, p. 179-189, set. 2008.

CHIOVENDA, Giuseppe. Instituições de direito processual civil. Saraiva: São Paulo, 1965. v. 2-3.

CINTRA, Antonio Carlos de Araújo; GRINOVER, Ada Pellegrini; DINAMARCO, Cândido Rangel. Teoria geral do processo. 24. ed. rev. e atual. Malheiros: São Paulo, 2008.

COLE, Charles D. Precedente judicial: a experiência americana. Revista de Processo, São Paulo, v. 23, n. 92, p. 71-86, out./dez. 1998.

. Stare decisis na cultura jurídica dos Estados Unidos: o sistema de precedente vinculante do common law. Revista dos Tribunais, São Paulo, v. 87, n. 752, p. 11-21, jun. 1998. 
COMOGLIO, Luigi Paolo. Accesso alle corti e garanzie costituzionali. In: YARSHELL, Flávio Luiz; MORAES, Maurício Zanóide de (Coords.). Estudos em homenagem à Professora Ada Pellegrini Grinover. São Paulo: DPJ, 2005. p. 259-289.

. Etica e tecnica del "giusto processo". Torino: Giappichelli, 2004.

COMPARATO, Fábio Konder. Novas funções judiciais no Estado moderno. Revista dos Tribunais, São Paulo, v. 75, n. 614, p. 14-22, dez. 1986.

CONCEIÇÃO, Marcelo Moura da. Julgamento por amostragem de recursos excepcionais: denegação de justiça? Revista de Processo, São Paulo, v. 35, n. 181, p. 231-257, mar. 2010 .

CONSOLO, Claudio; RIZZARDO, Dora. Due modi di mettere le azione colletive alla prova: Inghilterra e Germania. Rivista Trimestrale di Diritto e Procedura Civile, Milano, Giuffrè, v. 60, n. 3, p. 891-914, set. 2006.

CORTE SUPREMA DI CASSAZIONE. Ufficio del Massimario. Le Corti Supreme in Europa: le regole per l'accesso. A cura di Giovanni Canzio; redattori: Ersilia Calvanese, Carmelo Celentano, Gaetano De Amicis. Roma, giugno 2008. Disponível em:

<http://www.cortedicassazione.it/Documenti/Relazione\%20Corti\%20Supreme_08.pdf>. Acesso em: 08 nov. 2013.

CÔRTES, Osmar Mendes Paixão. A nova recorribilidade extraordinária: considerações sobre o prequestionamento e o cabimento dos recursos extraordinário e especial no novo CPC. Revista de informação legislativa, Brasília, v. 48, n. 190 t. 2, p. 129-135, abr./jun. 2011.

. A "objetivação" no processo civil: as características do processo objetivo no procedimento recursal. Revista de Processo, São Paulo, v. 34, n. 178, p. 220-226, dez. 2009.

Recurso extraordinário: origem e desenvolvimento no direito brasileiro. 2. ed. Rio de Janeiro: Forense, 2006.

CÔRTES, Osmar Mendes Paixão; MAGALHÃES, Ana Luiza de Carvalho M. O acesso à justiça e a efetividade da prestação jurisdicional: o inciso LXXVIII do art. $5^{\circ}$ da Constituição Federal inserido pela EC 45/2004. Revista de Processo, São Paulo, v. 31, n. 138, p. 79-91, ago. 2006.

COSTA E SILVA, Paula. A ordem do juízo de D. João III e o regime processual experimental. Revista de Processo, São Paulo, v. 33, n. 156, p. 237-250, fev. 2008.

CUNHA, Leonardo José Carneiro da. Anotações sobre o incidente de resolução de demandas repetitivas previsto no Projeto do novo Código de Processo Civil. Revista de Processo, São Paulo, v. 36, n. 193, p. 255-279, mar. 2011.

. O regime processual das causas repetitivas. Revista de Processo, São Paulo, v. 35, n. 179, p. 139-174, jan. 2010. 
DANTAS, Bruno. A jurisprudência dos tribunais e o dever de velar por sua uniformização e estabilidade. Revista de Informação Legislativa, Brasília, v. 48, n. 190 t. 1, p. 61-73, abr./jun. 2011.

Súmula vinculante: o STF entre a função uniformizadora e o reclamo por legitimidade democrática. Revista de Informação Legislativa, Brasília, v. 45, n. 179, p. 179-190, jul./set. 2008.

DIDIER JR., Fredie. Intervenção de legitimado extraordinário para a defesa de direitos coletivos (lato sensu) como assistente simples em processo individual. Disponível em: <http://piauijuridico.blogspot.com.br/2008/04/interveno-de-legitimadoextraordinrio.html>. Acesso em: 09 set. 2013.

DIDIER JR., Fredie; CUNHA, Leonardo José Carneiro da. Curso de direito processual civil. 7. ed. Salvador, BA: Juspodivm, 2009. v. 3.

. Meio de impugnação contra sobrestamento indevido recurso especial repetitivo. Editorial 100. Disponível em:

<http://cadernodeestudosjuridicos.blogspot.com.br/2010/07/meio-de-impugnacao-contrasobrestamento.html>. Acesso em: 09 set. 2013.

DINAMARCO, Cândido Rangel. O conceito de mérito em processo civil. Revista de Processo, São Paulo, v. 9, n. 34, p. 20-46, abr./jun. 1984.

. Decisões vinculantes. Revista de Processo, São Paulo, v. 25, n. 100, p. 166-185, out./dez. 2000.

. A função das cortes supremas na América Latina. Revista Forense, Rio de Janeiro, v. 94, n. 342, p. 3-12, abr./jun. 1998.

Fundamentos do processo civil moderno. 4. ed. São Paulo: Malheiros, 2001. 2009. v. 2.

Instituições de direito processual civil. 6. ed. rev. e atual. São Paulo: Malheiros,

. A instrumentalidade do processo. 14. ed. rev. e atual. São Paulo: Malheiros, 2009.

A reforma da reforma. São Paulo: Malheiros, 2002.

. Nova era do processo civil. São Paulo: Malheiros, 2003.

. O relator, a jurisprudência e os recursos. In: WAMBIER, Teresa Arruda Alvim; NERY JUNIOR, Nelson (Coords.). Aspectos polêmicos e atuais dos recursos cíveis de acordo com a Lei 9.756/98. São Paulo: Revista dos Tribunais, 1999. p. 127-144.

. Superior Tribunal de Justiça e acesso à ordem jurídica justa. In: TEIXEIRA, Sálvio Figueiredo (Coord.). Recursos no Superior Tribunal de Justiça. São Paulo: Saraiva, 1991. p. 249-258. 
FERNANDES, Débora Chaves Martines. Relação entre demandas individuais e coletivas: "Projeto Cadernetas de Poupança: Tribunal de Justiça do Rio Grande do Sul": uma análise do caso. Revista de Processo, São Paulo, v. 36, n. 201, p. 315-355, nov. 2011.

FERREIRA, William Santos. Princípios fundamentais da prova cível. São Paulo: Revista dos Tribunais, 2014.

Sistema recursal brasileiro: de onde viemos, onde estamos e para onde (talvez) iremos. In: COSTA, Hélio Rubens Batista Ribeiro; RIBEIRO, José Horácio Halfed Rezende; DINAMARCO, Pedro da Silva (Orgs.). Linhas mestras do processo civil: Comemoração dos 30 anos de vigência do CPC. São Paulo: Atlas, 2004. p. 657-770.

FREIRE, Alexandre Reis Siqueira. O recurso especial no novo Código de Processo Civil. Revista de Informação Legislativa, Brasília, v. 48, n. 190 t. 1, p. 17-26, abr./jun. 2011.

FUNKEN, Katja. "The best of both worlds": the trend towards convergence of the civil law and the common law system. Disponível em:

<www.jurawelt.com/sunrise/media/mediafiles/13598/convergence.pdf >. Acesso em: 08 jun. 2012.

FUX, Luiz. 50 anos de Brasília. Por uma justiça ágil. Revista de Informação Legislativa, Brasília, v. 47, n. 187, p. 161-171, jul./set. 2010.

A desistência recursal e os recursos repetitivos. Revista de Direito Renovar, Rio de Janeiro, n. 42, p. 1-11, set./dez. 2008.

GAIO JÚNIOR, Antônio Pereira. Considerações sobre a idéia da repercussão geral e a multiplicidade dos recursos repetitivos no STF e STJ. Revista de Processo, São Paulo, v. 34, n. 170, p. 140-155, abr. 2009.

GALVÃO, Ilmar Nascimento. Poder Judiciário: reforma de 1988: o recurso especial no Superior Tribunal de Justiça. In: TEIXEIRA, Sálvio Figueiredo (Coord.). Recursos no Superior Tribunal de Justiça. São Paulo: Saraiva, 1991. p. 83-89.

GARCIA, André Almeida. O drama dos "sobrestados" e a utilização de um incidente autônomo de julgamento por amostragem. Disponível em:

<http://www.lex.com.br/doutrina_23260023_O_DRAMA_DOS_SOBRESTADOS_E_A_ UTILIZACAO_DE_UM_INCIDENTE_AUTONOMO_DE_JULGAMENTO_POR_AMO STRAGEM.aspx>. Acesso em: 09 set. 2013.

GARCIA, Dínio de Santis. Efeito vinculante dos julgados da Corte Suprema e dos Tribunais Superiores. Revista dos Tribunais, São Paulo, v. 85, n. 734, p. 40-47, dez. 1996.

GOÉS, Gisele Santos Fernandes. Razoável duração do processo. In: WAMBIER, Teresa Arruda Alvim et al. (Coords.). Reforma do judiciário: primeiros ensaios críticos sobre a EC n. 45/2004. São Paulo: Revista dos Tribunais, 2005. p. 261-268.

GOMES JUNIOR, Luiz Manoel. A repercussão geral da questão constitucional no recurso extraordinário. Revista de Processo, São Paulo, v. 30, n. 119, p. 91-116, jan. 2005. 
GOMES, Luiz Flávio. Súmulas vinculantes e independência judicial. Revista dos Tribunais, São Paulo, v. 86, n. 739, p. 11-42, maio 1997.

GOTTWALD, Peter. About the extension of collective legal protection in Germany. Revista de Processo, São Paulo, v. 32, n. 154, p. 81-93, dez. 2007.

GRECO, Leonardo. Instituições de processo civil. 2. ed. Rio de Janeiro: Forense, 2010. v. 1.

. Princípios de uma teoria geral dos recursos. Revista Eletrônica de Direito Processual, REDP, Rio de Janeiro, ano 4, v. 5, p. 5-62, jan./jun. 2010. Disponível em: <http://www.redp.com.br/arquivos/redp_5a_edicao.pdf>. Acesso em: 10 nov. 2013.

Suspensão do processo. Revista de Processo, São Paulo, v. 20, n. 80, p. 90-102, out./dez. 1995.

GRINOVER, Ada Pellegrini. Direito processual coletivo. In: GRINOVER, Ada Pellegrini; MENDES, Aluisio Gonçalves de Castro; WATANABE, Kazuo (Coords.). Direito processual coletivo e o anteprojeto de Código Brasileiro de Processos Coletivos. São Paulo: Revista dos Tribunais, 2007. p. 11-15.

. Efficienza e garanzie: i nuovi instituti processuali in America Latina. Revista de Processo, São Paulo, v. 37, n. 203, p. 267-292, jan. 2012.

O tratamento dos processos repetitivos. In: JAYME, Fernando Gonzaga; FARIA, Juliana Cordeiro de; LAUAR, Maira Terra (Orgs.). Processo civil: novas tendências: homenagem a Humberto Theodoro Junior. Belo Horizonte: Del Rey, 2008. p. 1-9.

HOFFMAN, Paulo. Princípio da razoável duração do processo. In: OLIVEIRA NETO, Olavo de; LOPES, Maria Elizabeth de Castro (Orgs.). Princípios processuais civis na Constituição. Rio de Janeiro: Elsevier, 2008. p. 321-346.

JORGE, Flávio Cheim. Recurso especial com fundamento na divergência jurisprudencial. In: NERY JUNIOR, Nelson; WAMBIER, Teresa arruda Alvim (Coords.). Aspectos polêmicos e atuais dos recursos cíveis e de outras formas de impugnação às decisões judiciais. São Paulo: Revista dos Tribunais, 2001. p. 370-406.

. Requisitos de admissibilidade dos recursos: entre a relativização e as restrições indevidas (jurisprudência defensiva). Revista de Processo, São Paulo, v. 38, n. 217, p. 13 38, mar. 2013.

LAMY, Eduardo de Avelar. Repercussão geral no recurso extraordinário: a volta da argüição de relevância? In: WAMBIER, Teresa Arruda Alvim et al. (Coords.). Reforma do judiciário: primeiros ensaios críticos sobre a EC n. 45/2004. São Paulo: Revista dos Tribunais, 2005. p. 167-180.

LEAL, Victor Nunes. Aspectos da reforma judiciária. Revista de Informação Legislativa, Brasília, DF, v. 2, n. 7, p. 15-46, set. 1965. Disponível em: <http://www2.senado.leg.br/bdsf/bitstream/handle/id/180663/000347537.pdf?sequence=1> . Acesso em: 08 out. 2013. 
. Atualidade do Supremo Tribunal Federal. Revista Forense, Rio de Janeiro, v. 61, n. 208, p. 15-18, out./dez. 1964.

LEITE, Evandro Gueiros. A Emenda 2/85 (RISTF) e a boa razão. Revista dos Tribunais, São Paulo, v. 76, n. 615, p. 7-31, jan. 1987.

LIEBMAN, Enrico Tullio. A força criativa da jurisprudência e os limites impostos pelo texto da lei. Revista de Processo, São Paulo, v. 11, n. 43, p. 57-60, jul./set. 1986.

LIMA, Alcides de Mendonça. Introdução aos recursos cíveis. 2. ed. rev. e atual. São Paulo: Revista dos Tribunais, 1976.

Recurso extraordinário e recurso especial. In: TEIXEIRA, Sálvio Figueiredo (Coord.). Recursos no Superior Tribunal de Justiça. São Paulo: Saraiva, 1991. p. 135-144.

LIMA, Tiago Asfor Rocha. Primeiras impressões sobre os precedentes judiciais no Projeto de Novo Código de Processo Civil. Revista de Informação Legislativa, Brasília, DF, v. 48, n. 190 t. 2, p. 279-291, abr./jun. 2011.

LOBO, Arthur Mendes. Reflexões sobre o incidente de resoluções de demandas repetitivas. Revista de Processo, São Paulo, v. 35, n. 185, p. 233-244, jul. 2010.

LOPES, João Batista. Efetividade da tutela jurisdicional à luz da constitucionalização do processo civil. Revista de Processo, São Paulo, v. 29, n. 116, p. 29-38, jul./ago. 2004.

MACHADO, Fábio Cardoso. A uniformização jurídico-decisória por vinculação às súmulas de jurisprudência: objeções de ordem metodológica, sócio-cultural e políticojurídica. In: MACHADO, Fábio Cardoso; MACHADO, Rafael Bicca (Coords.). A reforma do Poder Judiciário. São Paulo: Quartier Latin, 2006. p. 244-274.

MACIEL, Adhemar Ferreira. "Amicus curiae": um instituto democrático, Revista de Informação Legislativa, Brasília, DF, ano 38, n. 153, p. 7-10, jan./mar. 2002.

. Restrição à admissibilidade de recursos na Suprema Corte dos Estados Unidos e no Supremo Tribunal Federal no Brasil, Revista CEJ, Brasília, DF, n. 33, p. 30-35, abr./jun. 2006.

MANCUSO, Rodolfo de Camargo. A jurisprudência, dominante ou sumulada, e sua eficácia contemporânea. In: WAMBIER, Teresa Arruda Alvim; NERY JUNIOR, Nelson (Coords.). Aspectos polêmicos e atuais dos recursos cíveis de acordo com a Lei 9.756/98. São Paulo: Revista dos Tribunais, 1999. p. 518-532.

Divergência jurisprudencial e súmula vinculante. 4. ed. rev., atual. e ampl. São Paulo: Revista dos Tribunais, 2010.

Recurso extraordinário e recurso especial. 11. ed. rev., atual. e ampl. São Paulo: Revista dos Tribunais, 2010. 
MARCATO, Antonio Carlos. Considerações sobre o julgamento de causas repetitivas. Carta Forense, São Paulo, 03 ago. 2009. Disponível em:

<http://www.cartaforense.com.br/conteudo/artigos/consideracoes-sobre-o-julgamento-decausas-repetitivas/4509>. Acesso em: 16 nov. 2011.

. Crise da justiça e influência dos precedentes judiciais no direito processual civil brasileiro. 2008. 265 p. Tese (Professor Titular - Direito Processual Civil) - Faculdade de Direito da Universidade de São Paulo, 2008. Confere?

MARINONI, Luiz Guilherme. Ações repetitivas e julgamento liminar. Revista dos Tribunais, São Paulo, v. 96, n. 858, p. 11-19, abr. 2007.

Aproximação crítica entre as jurisdições de civil law e de common law e a necessidade de respeito aos precedentes no Brasil. Revista de Processo, São Paulo, v. 34, n. 172, p. 175-232, jun. 2009.

. Eficácia temporal da revogação da jurisprudência consolidada dos tribunais superiores. Revista de Informação Legislativa, Brasília, v. 48, n. 190 t. 2, p. 15-33, abr./jun. 2011. 2011.

Precedentes obrigatórios. 2. ed. rev. e atual. São Paulo: Revista dos Tribunais,

MARINONI, Luiz Guilherme; MITIDIERO, Daniel. Código de Processo Civil: comentado artigo por artigo. São Paulo: Revista dos Tribunais, 2008. 2007. Repercussão geral no recurso extraordinário. São Paulo: Revista dos Tribunais,

MARQUEZINI, Paulo Roberto da Silva. Técnicas de julgamento de causas repetitivas no direito brasileiro. 2012. 172 f. Dissertação (Mestrado em Direito Processual). Faculdade de Direito, Universidade de São Paulo, São Paulo, 2012.

MARTINS FILHO, Ives Gandra da Silva. O critério de transcendência no recurso de revista: Projeto de Lei no 3.267/00. Revista Jurídica Virtual, v. 2, n. 20, jan. 2001. Disponível em:

<http://www.planalto.gov.br/ccivil_03/revista/rev_20/artigos/IvesGandra_rev20.htm>. Acesso em: 10 nov. 2013.

MARTINS, Samir José Caetano. O julgamento de recursos especiais repetitivos. Revista Dialética de Direito Processual (RDDP), São Paulo, n. 64, p. 114-120, jul. 2008.

MEDINA, José Miguel Garcia. Código de Processo Civil comentado: com remissões e notas comparativas ao Projeto do novo CPC. São Paulo: Revista dos Tribunais, 2011.

. Fundamentação das decisões e precedentes no novo CPC. Grupo de pesquisas Prof. Medina. Disponível em: <http://professormedina.com/2013/08/05/fundamentacaodas-decisoes-e-precedentes-no-novo-cpc/>. Acesso em: 05 ago. 2013. 
Jurisprudência não está, nem pode estar, acima da lei. Consultor Jurídico, set. 2013. Disponível em: <http://www.conjur.com.br/2013-set-09/processo-jurisprudencianao-nem-fonte-direito\#_ftn1>. Acesso em: 15 set 2013.

Justiça não pode ser medida apenas em números. Consultor Jurídico, set. 2013. Disponível em: <http://www.conjur.com.br/2013-set-16/processo-justica-nao-medidaapenas-numeros $>$. Acesso em: 16 set. 2013.

. Pelo fim da jurisprudência defensiva: uma utopia? Consultor Jurídico, jul. 2013. Disponível em: <http://www.conjur.com.br/2013-jul-29/processo-fim-jurisprudenciadefensiva-utopia>. Acesso em: 29 jul. 2013.

. Sobre a PEC n. 209/2012, que pretende instituir o requisito da "relevância" da

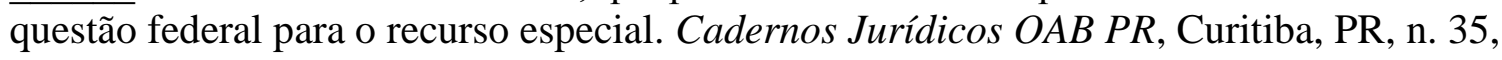
p. 2-4, nov. 2012. Disponível em:

<http://www.professormedina.com.br/arquivos/Cadernos.pdf>. Acesso em: 10 nov. 2013.

MEDINA, José Miguel Garcia; WAMBIER, Luiz Rodrigues; WAMBIER, Teresa Arruda Alvim. A súmula vinculante, vista como meio legítimo para diminuir a sobrecarga de trabalho dos tribunais brasileiros. Revista do Advogado, São Paulo, v. 27, n. 92, p. 7-22, jul. 2007.

MEDINA, Paulo Roberto de Gouvêa. Os valores celeridade processual e segurança jurídica no projeto de novo Código de Processo Civil. Revista de Informação Legislativa, Brasília, DF, v. 48, n. 190, t. 2, p. 169-177, abr./jun. 2011.

MELLO, Celso Antonio Bandeira de. O conteúdo jurídico do princípio da igualdade. 3. ed., 8. tiragem. Malheiros: São Paulo, 2000.

MELLO, Rogério Licastro Torres de. Recursos especiais repetitivos: problemas de constitucionalidade da Resolução 8/2008, do STJ. Revista de Processo, São Paulo, v. 33, n. 163, p. 190-195, set. 2008.

MENCHINI, Sergio. Azioni seriali e tutela giurisdizionale: aspetti critici e prospettive ricostruttive. In: Atti del Incontro di Studi: le azioni Seriali do Centro Interuniversitario di Studi e Ricerche sulla Giustiza Civile Giovani Fabbrini, junto da Università di Pisa, 04 e 05 de maio 2007

MENDONÇA, Luís Correia de. O pensamento de Franco Cipriani sobre a justiça civil. Revista de Processo, São Paulo, v. 34, n. 172, p. 55-120, jun. 2009.

Processo civil líquido e garantias: o regime processual experimental português. Revista de Processo, São Paulo, v. 34, n. 170, p. 214-250, abr. 2009.

MESQUITA, José Ignácio Botelho de et al. A repercussão geral e os recursos repetitivos: economia, direito e política. Revista de Processo, São Paulo, v. 38, n. 220, p. 13-31, jun. 2013. 
MONTEIRO, Vítor José de Mello. Julgamento por amostragem do recurso especial (Lei n. 11.672/08). In: GIANNICO, Maurício; MONTEIRO, Vítor José de Mello (Coords.). As novas reformas do CPC e de outras normas processuais. São Paulo: Saraiva, 2009.

MONTORO, André Franco. Introdução à ciência do direito. 23. ed. São Paulo: Revista dos Tribunais, 1995.

MOREIRA, Fernando Mil Homens; NOVAIS, Fabrício Muraro. Reflexões sobre o cabimento do recurso extraordinário e do papel do recurso especial na ordem constitucional brasileira: premissas para uma discussão séria. Revista de Processo, São Paulo, v. 36, n. 192, p. 291-297, fev. 2011.

MOREIRA, José Carlos Barbosa. Algumas inovações da Lei 9.756 em matéria de recursos cíveis. In: WAMBIER, Teresa Arruda Alvim; NERY JUNIOR, Nelson (Coords.). Aspectos polêmicos e atuais dos recursos cíveis de acordo com a Lei 9.756/98. São Paulo: Revista dos Tribunais, 1999. p. 320-329

Comentários ao Código de Processo Civil: Lei n. 5.869, de 11 de janeiro de 1973, arts. 476 a 565. 16. ed. rev., atual. e ampl. Rio de Janeiro: Forense, 2012. v. 5.

Correntes e contracorrentes no processo civil contemporâneo. In: . Temas de direito processual: nona série, São Paulo: Saraiva, 2007. p. 55-67.

A efetividade do processo de conhecimento. Revista de Processo, São Paulo, v. 19, n. 74, p. 126-137, abr./jun. 1994.

. O futuro da justiça: alguns mitos. Revista de Processo, São Paulo, v. 25, n. 99, p. 141-150, jul./set. 2000.

. Juízo de admissibilidade e juízo de mérito no julgamento do recurso especial. In: TEIXEIRA, Sálvio Figueiredo (Coord.). Recursos no Superior Tribunal de Justiça. São Paulo: Saraiva, 1991. p. 163-170.

O neoprivatismo no processo civil. Revista de Processo, São Paulo, v. 30, n. 122, p. $9-21$, abr. 2005.

. Notas sobre o problema da 'efetividade' do processo. In: Temas de direito processual: terceira série. São Paulo: Saraiva, 1984. p. 27-42.

Restrições ilegítimas ao conhecimento de recursos. In: Temas de direito processual: nona série, São Paulo: Saraiva, 2007. p. 271-272.

Súmula, jurisprudência, precedente: uma escalada e seus riscos. In: Temas de direito processual: nona série, São Paulo: Saraiva, 2007. p. 299-313.

NAVES, Nilson Vital. Panorama dos problemas no Poder Judiciário e suas causas: o Supremo, o Superior Tribunal e a reforma. Revista CEJ, Brasília, n. 13, p. 7-19, jan./abr. 2001. Disponível em: <http://www2.cjf.jus.br/ojs2/index.php/revcej/article/viewFile/372/553>. Acesso em: 30 out. 2013. 
NEGRÃO, Theotonio. Uma nova estrutura para o Judiciário. Revista dos Tribunais, São Paulo, v. 639, p. 242-247, jan. 1989.

NERY JUNIOR, Nelson. Princípios do Processo Civil na Constituição Federal. 11. ed. rev., atual. e ampl. com as novas súmulas do STF (simples e vinculantes) e com análise sobre a relativização da coisa julgada. São Paulo: Revista dos Tribunais, 2013.

Teoria geral dos recursos. São Paulo: Revista dos Tribunais, 2004.

NERY JUNIOR, Nelson; NERY, Rosa Maria de Andrade. Código de Processo Civil comentado e legislação extravagante. 11. ed. rev., ampl., e atual. até 17.02.2010. São Paulo: Revista dos Tribunais, 2010.

NIEVA-FENOLL, Jordi. El modelo anglosajón en las Cortes Supremas: ¿solución o elusión del problema de la casación? Revista de Processo, São Paulo, v. 38, n. 219, p. 185204, maio 2013.

NOBRE JUNIOR, Edílson Pereira. O direito processual brasileiro e o efeito vinculante das decisões dos Tribunais Superiores. Revista de Processo, São Paulo, v. 27, n. 105, p. 64-95, jan./mar. 2002.

NOGUEIRA, Daniel. Moura. A nova sistemática do processamento e julgamento do recurso especial repetitivo, art. 543-C do CPC. Revista de Processo, São Paulo, v. 33, n. 164, p. 235-244, out. 2008.

NORTHFLEET, Ellen Gracie. Ainda sobre o efeito vinculante. Revista de Informação Legislativa, Brasília, v. 33, n. 131, p. 133-134, jul./set. 1996.

NOTARIANO JUNIOR, Antônio de Pádua. Garantia da razoável duração do processo. In: WAMBIER, Teresa Arruda Alvim et al. (Coords.). Reforma do judiciário: primeiros ensaios críticos sobre a EC n. 45/2004. São Paulo: Revista dos Tribunais, 2005. p. 59-62.

NOTARIANO JUNIOR, Antônio de Pádua et al. Sobre a criação dos “julgamentos virtuais" no âmbito do Tribunal de Justiça de São Paulo: parecer da Comissão de Direito Processual Civil do IASP. Revista do Instituto dos Advogados de São Paulo, Nova Série, v. 14, n. 28, p. 351-369, jul./dez. 2011.

NUNES, Dierle José Coelho. Comentários acerca da súmula impeditiva de recursos (Lei 11.276/2006) e do julgamento liminar de ações repetitivas (Lei 11.277/2006). Revista de Processo, São Paulo, v. 31, n. 137, p. 171-186, jul. 2006.

NUNES, Dierle José Coelho; BAHIA, Alexandre Gustavo Melo Franco. Eficiência processual: algumas questões. Revista de Processo, São Paulo, v. 34, n. 169, p. 116-139, mar. 2009.

NUNES, Dierle José Coelho; BAHIA, Alexandre Gustavo Melo Franco. Processo constitucional: uma abordagem a partir dos desafios do Estado Democrático de Direito. Revista Eletrônica de Direito Processual, REDP, Rio de Janeiro, ano 3, v. 4, jul./dez. 2009. Disponível em: <http://www.arcos.org.br/periodicos/revista-eletronica-de-direitoprocessual/volume-iv/processo-constitucional-uma-abordagem-a-partir-dos-desafios-doestado-democratico-de-direito>. Acesso em: 30 nov. 2013. 
OLIVEIRA, Guilherme José Braz de. Repercussão geral das questões constitucionais e suas consequências para o julgamento do recurso extraordinário. 2009. 383 p. Dissertação (Mestrado em Direito Processual) - Faculdade de Direito da Universidade de São Paulo, São Paulo, 2009.

ORESTANO, Andréa. Interessi seriali, diffusi e collettivi: profili civilistici di tutela. In: Menchini, S. (Dir.). Le azioni seriali. Napoli: ESI, 2008.

PARENTE, Eduardo de Albuquerque. Jurisprudência: da divergência à uniformização. São Paulo: Atlas, 2006.

PATTO, Belmiro Jorge. Aspetos da dimensão temporal do processo civil nas alterações advindas da EC n. 45, de 8 de dezembro de 2004. In: WAMBIER, Teresa Arruda Alvim et al. (Coords.). Reforma do judiciário: primeiros ensaios críticos sobre a EC n. 45/2004. São Paulo: Revista dos Tribunais, 2005. p. 101-120.

PEÑA, Eduardo Chemale Selistre. Breve contribuição à Reforma do Judiciário: a inclusão do requisito da relevância para a redução do volume de processos no Supremo Tribunal Federal e no Superior Tribunal de Justiça. In: MACHADO, Fábio Cardoso; MACHADO, Rafael Bicca (Coords.). A reforma do Poder Judiciário. São Paulo: Quartier Latin, 2006.

PICKER, Colin B. International law's mixed heritage: a common/civil law jurisdiction. Vanderbilt Journal of Transnational Law, v. 41, 2008. Disponível em: <http://ssrn.com/abstract=1125044>. Acesso em 30 nov. 2013.

PINTO, Junior Alexandre Moreira. O regime processual experimental português. Revista de Processo, São Paulo, v. 32, n. 148, p. 169-180, jun. 2007.

PINTO, Luis Filipe Marques Porto Sá. Técnicas de tratamento macromolecular dos litígios: tendência de coletivização da tutela processual civil. Revista de Processo, São Paulo, v. 35, n. 185, p. 117-144, jul. 2010.

PINTO, Nelson Luiz. Recurso especial para o STJ: teoria geral e admissibilidade. 2. ed. rev., atual. e ampl. São Paulo: Malheiros, 1996.

PISANI, Andrea Proto. Principio d'eguaglianza e ricorso per cassazione. Revista de Processo, São Paulo, v. 36, n. 191, p. 201-210, jan. 2011.

Crisi della cassazione: la (non più rinviabile) necessita di una scelta. Revista de Processo, São Paulo, v. 33, n. 157, p. 261-268, mar. 2008.

POMBO, Rodrigo Goulart de Freitas. A desistência de recurso especial repetitivo representativo da controvérsia: o entendimento do STJ. Informativo Justen, Pereira, Oliveira e Talamini, Curitiba, n. 43, set. 2010. Disponível em:

$<$ http://www.justen.com.br//informativo.php?1=pt\&informativo=43\&artigo=1037> . Acesso em: 30 nov. 2013.

PONTES DE MIRANDA, Francisco Cavalcanti. Comentários à Constituição de 1967: com a Emenda n. 1, de 1969: arts. 118 a 153, § 1º. 2. ed. rev. São Paulo: Revista dos Tribunais, 1970. v. 4. 
POZZA, Pedro Luiz. Considerações sobre a súmula vinculante. In: MACHADO, Fábio Cardoso; MACHADO, Rafael Bicca (Coords.). A reforma do Poder Judiciário. São Paulo: Quartier Latin, 2006. p. 486-512.

RAMOS, Saulo. Questões do efeito vinculante. Revista de Direito Constitucional e Internacional, São Paulo, n. 16, 1996.

RÁO, Vicente. O direito e a vida dos direitos. 5. ed. anotada e atual. por Ovídio Rocha Barros Sandoval. São Paulo: Revista dos Tribunais, 1999.

RE, Edward D. "Stare decisis”. Revista dos Tribunais, São Paulo, v. 83, n. 702, p. 7-13, abr. 1994.

REICHELT, Luis Alberto. A duração do processo: o julgamento do recurso extraordinário dotado de repercussão geral e a modulação dos efeitos da declaração de inconstitucionalidade. Revista de Processo, São Paulo, v. 36, n. 193, p. 131-150, mar. 2011.

RIBEIRO, Antônio de Pádua. Do recurso especial para o Superior Tribunal de Justiça. In: TEIXEIRA, Sálvio de Figueiredo (Coord.). Recursos no Superior Tribunal de Justiça. São Paulo: Saraiva, 1991. p. 135-136.

ROCHA, Cármen Lúcia Antunes. O princípio constitucional da igualdade. Belo Horizonte: Lê, 1990.

. Sobre a súmula vinculante. Revista de Informação Legislativa, Brasília, DF, v. 34, n. 133, p. 51-64, jan./mar. 1997.

RODRIGUES NETTO, Nelson. Análise crítica do julgamento "por atacado" no STJ: (Lei 11.672/2008 sobre recursos especiais repetitivos). Revista de Processo, São Paulo, v. Revista de Processo, São Paulo, v. 33, n. 163, p. 234-247, set. 2008.

RODRIGUES, Ruy Zoch. Ações repetitivas: casos de antecipação de tutela sem o requisito de urgência. São Paulo: Revista dos Tribunais, 2010.

ROSSI, Júlio César. Recursos repetitivos: meios processuais hábeis a impugnar o indevido sobrestamento dos recursos excepcionais pelo Tribunal de Origem. Revista Dialética de Direito Processual Civil, n. 95, p. 42-51, fev. 2011.

SANTOS, Francisco Cláudio de Almeida. Recurso especial: visão geral. In: TEIXEIRA, Sálvio Figueiredo (Coord.). Recursos no Superior Tribunal de Justiça. São Paulo: Saraiva, 1991. p. 91-107.

SALOMÃO, Luis Felipe. Breves anotações sobre a admissibilidade do recurso especial. Revista de Processo, São Paulo, v. 34, n. 172, p. 233-255, jun. 2009.

SANTANA NOGUEIRA, Gustavo. Jurisprudência vinculante no direito norte-americano e no direito brasileiro. Revista de Processo, São Paulo, v. 33, n. 161, p. 101-114, jul. 2008. 
SERAU JUNIOR, Marco Aurélio; REIS, Silas Mendes dos. Recursos especiais repetitivos no STJ. São Paulo: Método, 2009.

SICA, Heitor Vitor Mendonça. Direito processual civil espanhol. In. TUCCI, José Rogério Cruz e (Coord.) Direito processual civil europeu contemporâneo. São Paulo: Lex Editora, 2010. p. 71-112.

SILVA, Carla Mendonça Dias Alves da. Efeitos vinculantes das decisões dos Tribunais Superiores: uma realidade. Revista de Processo, São Paulo, v. 29, n. 115, p. 164-177, maio/jun. 2004.

SILVA, José Afonso da. Curso de direito constitucional positivo. 24. ed. rev. e atual. São Paulo: Malheiros, 2005.

SILVA, Evandro Lins e. O recurso extraordinário e a relevância da questão federal. In: CLÈVE, Clèmerson Merlin; BARROSO, Luís Roberto (Coords.). Doutrinas essenciais de direito constitucional. São Paulo: Revista dos Tribunais, 2011. v. 5, capítulo 2.

SILVA, Ovídio Araújo Baptista da. A função dos Tribunais Superiores. In: MACHADO, Fábio Cardoso; MACHADO, Rafael Bicca (Coords.). A reforma do Poder Judiciário. São Paulo: Quartier Latin, 2006.

Os recursos: viés autoritário da jurisdição. In: SILVA, Ovídio Araújo Baptista da. Processo e ideologia: o paradigma racionalista. Rio de Janeiro: Forense, 2004. p. 239-263.

SILVA, Ticiano Alves e. Intervenção de sobrestado no julgamento por amostragem. Revista de Processo. São Paulo, v. 35, n.182, p. 234-257, abr. 2010.

SIQUEIRA, Julio Pinheiro Faro Homem de. Breve estudo sobre as decisões de efeito vinculante no sistema processual brasileiro. Revista de Processo, São Paulo, v. 33, n. 160, p. 115-141, jun. 2008.

SOARES, Guido Fernando Silva. O que é a "Common Law", em particular, a dos EUA. Disponível em:

<http://www.migalhas.com.br/arquivo_artigo/O_\%20que_\%20e_\%20a_\%20Common.htm >. Acesso em: 08 jun. 2012.

SOUZA, Carlos Aurélio Mota de. Direito judicial, jurisprudencial e sumular. Revista de Processo, São Paulo, v. 20, n. 80, p. 208-214, out./dez. 1995.

STREK, Lenio Luiz. O efeito vinculante das súmulas e o mito da efetividade: uma crítica hermenêutica. In: BONAVIDES, Paulo; LIMA, Francisco Gérson Marques de; BEDÊ, Fayga Silveira (Coords.). Constituição e democracia: estudos em homenagem ao Prof. J. J. Gomes Canotilho. São Paulo: Malheiros, 2006. p. 395-433.

. O STJ e a desistência de recurso. Jus Navigandi, Teresina, ano 14, n. 2016, 7 jan. 2009. Disponível em: <http://jus.com.br/artigos/12173>. Acesso em: 10 nov. 2013. 
TALAMINI, Eduardo. Julgamento de recursos no STJ “por amostragem”. Informativo Justen, Pereira, Oliveira e Talamini, Curitiba, n. 14, abr. 2008. Disponível em: <http://www.justen.com.br//informativo.php?\&informativo=14\&artigo=796\&l=pt\#>. Acesso em: 11 nov. 2013.

Novos aspectos da jurisdição constitucional brasileira: repercussão geral, força vinculante, modulação dos efeitos do controle de constitucionalidade e alargamento do objeto do controle direto. 2008. 332 p. Tese (Livre Docência) - Departamento de Direito Processual, Área de Direito Processual Civil, Faculdade de Direito da Universidade de São Paulo, São Paulo, 2008.

TARUFFO, Michele. Dimensiones del precedente judicial. In: . Páginas sobre justicia civil. Traducción de Maximiliano Aramburo Calle. Madrid: Marcial Pons, 2009. p. 543-555.

. Observações sobre os modelos processuais de civil law e de common law. Revista de Processo, São Paulo, v. 28, v. 110, p. 141-158, abr./jun. 2003.

. Precedente e jurisprudência. Revista de Processo, São Paulo, v. 36, n. 199, p. 139155, set. 2011.

TAVARES JUNIOR, Homero Francisco. Recursos especiais repetitivos: aspectos da Lei 11.672/2008 e da Res. 8/2008 do STJ. Revista de Processo, São Paulo, v. 33, n. 166, p. 190-202, dez. 2008.

TEDESCO, Paulo Camargo. Jurisprudência defensiva de segunda geração. Revista de Processo, São Paulo, v. 35, n. 182, p. 259-290, abr. 2010.

TEIXEIRA, Rodrigo Valente Giublin. Recursos especiais repetitivos fundados em idêntica questão de direito no âmbito do Superior Tribunal de Justiça. Revista de Processo, São Paulo, v. 36, n. 191, p. 161-186, jan. 2011.

TEIXEIRA, Sálvio Figueiredo. O recurso especial e o Superior Tribunal de Justiça. In: TEIXEIRA, Sálvio Figueiredo (Coord.). Recursos no Superior Tribunal de Justiça. São Paulo: Saraiva, 1991. p. 67-81.

TEIXEIRA, Sálvio Figueiredo (Coord.). Recursos no Superior Tribunal de Justiça. São Paulo: Saraiva, 1991.

THEODORO JÚNIOR, Humberto. O novo art. 543-C do Código de Processo Civil (Lei ${ }^{\circ}$ 11.672, de 8.5.2008). Revista Forense, Rio de Janeiro, v. 104, n. 397, p. 193-198, maio/jun. 2008.

THEODORO JÚNIOR, Humberto; NUNES, Dierle José Coelho; BAHIA, Alexandre Gustavo Melo Franco. Breves considerações sobre a politização do Judiciário e sobre o panorama de aplicação no direito brasileiro: análise de convergência entre o civil law e o common law e dos problemas da padronização decisória. Revista de Processo, São Paulo, v. 35, n. 189, p. 9-52, nov. 2010. 
. Litigiosidade em massa e repercussão geral no recurso extraordinário. Revista de Processo, São Paulo, v. 34, n. 177, p. 9-46, nov. 2009.

TIMM, Luciano Benetti; TRINDADE, Manoel Gustavo Neubarth. As recentes alterações legislativas sobre recursos aos Tribunais Superiores: a repercussão geral e os processos repetitivos sob a ótica da law and economics. Revista de Processo, São Paulo, v. 34, n. 178, p. 153-179, dez. 2009.

TUCCI, José Rogério Cruz e. Anotações sobre a repercussão geral como pressuposto de admissibilidade do recurso extraordinário (Lei 11.418/2006). Revista de Processo, São Paulo, v. 32, n. 145, p. 151-162, mar. 2007.

2004.

Precedente judicial como fonte do direito. São Paulo: Revista dos Tribunais,

VELLOSO, Carlos Mário da Silva. Do Poder Judiciário: como torná-lo mais ágil e dinâmico: efeito vinculante e outros temas. Revista de Informação Legislativa, Brasília, v. 35, n. 138, p. 75-87, abr./jun. 1998. Disponível em:

<http://www2.senado.leg.br/bdsf/bitstream/handle/id/368/r138-08.pdf?sequence=4>. Acesso em: 10 nov. 2013.

. O Superior Tribunal de Justiça na Constituição de 1988. Revista dos Tribunais, São Paulo, v. 77, n. 638, p. 15-29, dez. 1988.

VERBIC, Francisco. El incidente de resolución de demandas repetitivas em el proyecto de nuevo Codigo Procesal Civil Brasileño. Revista de Informação Legislativa, Brasília, DF, v. 48, n. 190 t. 1, p. 189-201, abr./jun. 2011.

VILLELA, José Guilherme. Recurso extraordinário. Revista de Processo, São Paulo, v. 11, n. 41, p. 137-150, jan./mar. 1986.

VITA, Jonathan Barros. Repercussão geral: um novo caminho entre civil law e common law através da semiótica e da teoria dos sistemas. Revista Tributária das Américas, São Paulo, v. 1, n. 2, p. 207-239, jul./dez. 2010.

WALD, Arnoldo. Eficiência judiciária e segurança jurídica: a racionalização da legislação brasileira e reforma do Poder Judiciário. In: MACHADO, Fábio Cardoso; MACHADO, Rafael Bicca (Coords.). A reforma do Poder Judiciário. São Paulo: Quartier Latin, 2006.

WALD, Arnoldo; GAENSLY, Marina. Um caso exemplar de aplicação da Lei dos Recursos Repetitivos. Revista de Direito Bancário e do Mercado de Capitais, São Paulo, v. 12, n. 46, p. 317-319, out./dez. 2009.

WAMBIER, Luiz Rodrigues; VASCONCELOS, Rita de Cássia Corrêa de. Recursos especiais repetitivos: reflexos das novas regras (Lei 11.672/2008 e Resolução 8 do STJ) nos processos coletivos. Revista de Processo, São Paulo, v. 33, n. 163, p. 28-49, set. 2008.

Sobre a repercussão geral e os recursos especiais repetitivos, e seus reflexos nos processos coletivos. Revista dos Tribunais, São Paulo, v. 98, n. 882, p. 25-44, abr. 2009. 
WAMBIER, Teresa Arruda Alvim. Estabilidade e adaptabilidade como objetivos do direito: civil law e common law. Revista de Processo, São Paulo, v. 34, n. 172, p. 121-174, jun. 2009.

. A função das súmulas do Supremo Tribunal Federal em face da teoria geral do direito. Revista de Processo, São Paulo, v. 10, n. 40, p 224-235, out./dez. 1985.

Interpretação da lei e de precedentes: civil law e common law. Revista dos Tribunais, São Paulo, v. 99, n. 893, p. 33-45, mar. 2010. 2005 .

Omissão judicial e embargos de declaração. São Paulo: Revista dos Tribunais,

Recurso especial, recurso extraordinário e ação rescisória. 2. ed. São Paulo: Revista dos Tribunais, 2008.

. Recursos como uma forma de fazer "render" o processo no Projeto 166/2010. Revista de Processo, São Paulo, v. 35, n. 189, p. 275-283, nov. 2010.

Sobre a Súmula 343. Revista de Processo, São Paulo, v. 22, n. 86, p. 148-157, abr./jun. 1997.

WAMBIER, Teresa Arruda Alvim et al. O novo CPC dará maior racionalidade ao sistema de Justiça. Por Teresa Arruda Alvim Wambier, Alexandre Freire, Bruno Dantas e Marcelo Guedes Nunes. Migalhas, jul. 2013. Disponível em:

<http://www.migalhas.com.br/dePeso/16,MI182384,41046-

$\mathrm{O}+$ novo+CPC+dara+maior+racionalidade+ao+sistema+de+Justica $>$. Acesso em: 14 out. 2013.

WAMBIER, Teresa Arruda Alvim; MEDEIROS, Maria Lúcia Lins Conceição. Recursos repetitivos: realização integral da finalidade do novo sistema impõe mais do que a paralisação dos recursos especiais que estão no $2^{\circ}$ grau. Revista de Processo, São Paulo, v. 36, n. 191, p. 187-197, jan. 2011.

WAMBIER, Teresa Arruda Alvim; MEDINA, José Miguel Garcia. Sobre o novo art. 543C do CPC: sobrestamento de recursos especiais "com fundamento em idêntica questão de direito”. Revista de Processo, São Paulo, v. 33, n. 159, p. 215-221, maio 2008.

WATANABE, Kazuo. Política pública do Poder Judiciário nacional para tratamento adequado dos conflitos de interesses. Revista de Processo, São Paulo, v. 36, n. 195, p. 381389, maio 2011.

Relação entre demandas coletivas e demandas individuais. In: GRINOVER, Ada Pellegrini; MENDES, Aluisio Gonçalves de Castro; WATANABE, Kazuo (Coords.). Direito processual coletivo e o anteprojeto de Código Brasileiro de Processos Coletivos. São Paulo: Revista dos Tribunais, 2007.

WHITTAKER, Simon. El precedente en el derecho inglés: una visión desde la ciudadela. Revista Chilena de Derecho, v. 35 n. 1, p. 37-83, 2008. Disponível em: $<$ http://www.scielo.cl/scielo.php?pid=S071834372008000100003\&script=sci_abstract\&tlng=en>. Acesso em: 30 nov. 2013. 
WITTMAN, Ralf-Thomas. Il "contenzioso di massa" in Germânia. In: GIORGETTI, Alessandro; VALLEFUOCO, Valério. Il contenzioso di massa in Itália, in Europa e nel mondo. Milano: Giuffrè, 2008.

YOSHICAWA, Eduardo Henrique de Oliveira. Julgamento por amostragem e desistência do recurso especial. Revista Dialética de Direito Processual, São Paulo, v. 76, p. 33-39, jul. 2009.

ZAVASKI, Teori Albino. Reforma do processo coletivo: indispensabilidade de disciplina diferenciada para direitos individuais homogêneos e para direitos transindividuais. In: GRINOVER, Ada Pellegrini; MENDES, Aluisio Gonçalves de Castro; WATANABE, Kazuo (Coords.). Direito processual coletivo e o anteprojeto de Código Brasileiro de Processos Coletivos. São Paulo: Revista dos Tribunais, 2007. p. 33-38. 